M. ${ }^{a}$ ROSARIO SEVILLA SOLER

\title{
Santo Domingo Tierra de Frontera (1750-1800)
}

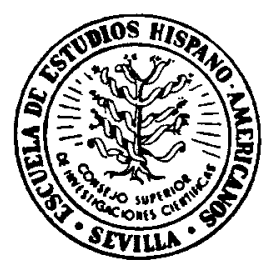

SEVILLA， 1980 
Edición de 1.000 ejemplares

ISSN $0210-5802$

Depósito legal SE - 42 - 1981

I. S. B. N. $84-00-04742-7$

Imprerta E.E.H.A., Alfonso XII, 16.-Sevilla, 1981 
A Javier 


\section{INDICE GENERAL}

Páginas

INDICE DE ILUSTRACIONES Y GRAFICOS ................ XIII

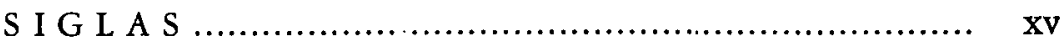

PROLOGO, del Dr. D. Francisco Morales Padrón .............. XVII

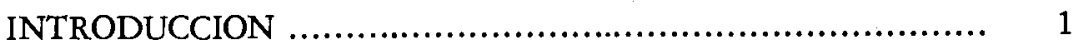

\section{Capítulo I}

EL MARCO GEOGRAFICO. DESCRIPCIONES DE LOS CONTEMPORANEOS

\section{CAPítrulo II}

POBLACION

El crecimiento demográfico del siglo XVIII (25) - Fundación de nuevas poblaciones. Inmigración canaria (47) - Sociedad y costumbres (63) - Intentos de reducción de los negros libres a población (75).

\section{CAPÍtULO III}

Principales cultivos y producciones (97) - Auge y decadencia del tabaco (104) - Intentos dé fomentar la agricultura (117). 


\section{Capítulo IV}

GANADERIA

El problema del abastecimiento de carne a la capital (143) - La saca de ganado a la colonia francesa (151).

\section{Capítulo V}

EL COMERCIO

La Compañía de Comercio de Barcelona (174) - El Libre Comercio. Cédulas de 1765 y 1778 (182) - El comercio con la metrópoli (189) - El comercio con las colonias españolas de América (203) - El comercio con las colonias extranjeras y el contrabando (209).

\section{Capítulo VI}

Estado de las Cajas Reales de Santo Domingo (221) - Movimiento de las Cajas Reales. A) Entradas! (230): 1 Entradas reales (235). 2. Entradas no efectivas (268). B) Salidas (Datas) (269). 1. Datas reales (273). 2. Datas no efectivas (281) - Conclusiones (283).

\section{Capítulo VII}

EL GOBIER̃NO

Los gobernadores de Fernando VI (291) - Los gobernadores de Carios III (298) - Los gobiernos interinos. Los problemas sobre la sucesión del mando por muerte del gobernador (313) - El último gobernador del siglo (317). 


\section{Capítulo VIII}

El batallón fijo de infantería (326) - La Compañía de artillería (329) - Compañías de caballería (330) - Compañías de milicias de infantería (332) - La compañía de fieles prácticos y las milicias urbanas (333) - Los soldados (334).

\section{Capítulo IX}

RELACIONES CON LA COLONIA FRANCESA

De la llegada de los franceses a la segunda mitad del siglo XVIII (341) - El pacto de familia de 1761 y la intervención en la guerra de los siete años (348) - Los tratados de 1773 a 1775 (361) - El tratado de Aranjuez de 1777 y la guerra contra Inglaterra (366).

\section{Capítulo $\mathrm{X}$}

LA REVOLUCION FRANCESA Y LA CESION DE LA ISLA ...

La revolución francesa en la isla de Santo Domingo (377) La guerra contra la República Francesa (388) - El tratado de Basilea y los problemas surgidos con los ingleses (395) - Consecuencias del tratado de Basilea (399) - La entrega (404).

\section{APENDICES}

I. MOVIMIENTO COMERCIAL DESDE 1754 a 1775 ....... 409

II. MOVIMIENTO DE LAS CAJAS REALES DESDE 1754 a 1775.459 


\section{INDICE DE ILUSTRACIONES Y GRAFICOS}

1 División de la isla en partidos

$42-43$

2 Plano de la ciudad de Santo Domingo .................. 44-45

3 Plano de la bahía de Manzanillo ..................... 56-57

4 Plano de San Fernando de Montecristi ................ 56-57

5 Plano de Santa Bárbara de Samaná y bahía de Samaná. 58-59

6 Poblaciones fundadas en el siglo XVIII ............. 62-63

7 Importaciones de las colonias expañolas ............... 206-207

8 Exportaciones a las colonias españolas ............... 206-207

9 Importaciones de las colonias extranjeras ............. 214-215

10 Exportaciones a las colonias extranjeras ............... 214-215

11 Plano de las labranzas hachas por los franceses en terreno español ............................................. 354-355

12 Plano de los límites provisionales según el acuerdo

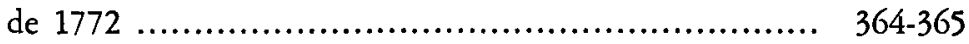

13 Mapa de la parte de la isla en disputa ................. 364-365

14 Mapa de límites realizado en 1784 .................... 368-369

15 Retrato de Vicente Ogé ............................. 382-383 


\section{SIGLAS}

A.G.I.: Archivo General de Indias de Sevilla.

A.G.N.: Archivo General de la Nación de la República Dominicana.

A.G.S.: Archivo General de Simancas.

A.H.N.: Archivo Histórico Nacional de Madrid. 


\section{$P R O L O G O$}

Las relaciones entre un doctorando y su mentor o director por lo general, y en función del trabajo, discurren por tres caminos. Dos son vías extremas: el director se olvida del alumno que lucha solitariamente; o el director participa tan activamente que es casi un coautor. Un tercer caso, y' es el habitual, el mentor, tras unas iniciales indicaciones temáticas, de fuentes y hasta de técnica investigadora, sigue muy de cerca la investigación y posterior elaboración e interpretación del material de acuerdo con el doctorando y, por lo mismo, constituyéndose en responsable parcialmente de los fallos del trabajo. El caso de este libro, presentado en su dia como Tesis Doctoral en la Facultad de Filosofía y Letras de Sevilla, se encuadra dentro del tercer ejemplo, como acontece con todas las investigaciones que dirigimos. Pero en esta Tesis o mejor, con su autora, ocurre algo que deseo resaltar.

Quiero subrayar la piersonalidad de Rosario Sevilla Soler; sus condiciones como investigadora, nada corrientes. Es algo puesto en evidencia desde sus años como alumna en la especialidad de Historia de América. Algo que solemos denominar vocación. La doctora Sevilla Soler no ha dado vida a una obra para, simplemente, lograr el titulo de doctor. O no solo por y para eso. Tampoco lo ha hecho por vanidad. Lo ha realizado vocacionalmente. Ha trabajado, viene trabajando, de modo intenso y casi sin pausa, desde que seguia el último año de carrera. Entonces, como quehacer de clase en la materia de "Historiografía indiana y técnica de la investigación", que cursó con nosotros, hizo algo que, posteriormente, le sirvió como trabajo de Licenciatura. Ba- 
sándose en los ricos fondos de la Hemeroteca Municipal de Sevilla, redactó un trabajo que tituló La Revolución Mejicana en la prensa sevillana. Fue esta una iniciación que le sirvió para demostrar, especialmente, su tenacidad y perseverancia. No era aquello un trabajo para publicar, pero reelaborado le sirvió como ponencia en la $V$ Reunión de Americanistas Europeos celebrada en Torún (Polonia, I978) y publicada en los "Estudios Latinoamericanos" 6, II Par te, de la Polska Akademia Nauk Institut Historii (Varsovia, Ig80).

Sin solución de continuidad, y con la ayuda de una beca lograda en función de su expediente académico, nuestra doctorando emprendió una nueva tarea investigadora. Ningún acontecimiento fue capaz de entorpecer o empañar sus tareas como investigadora y sus ilusiones académicas. Ni el matrimonio, ni la maternidad, ni marginaciones en el cuerpo universitario hacia donde su vocación le llama. Nada ha implicado una detención o demora en su marcha. Sevilla, Madrid, Simancas, Santo Domingo fueron escenarios de sus buisquedas e indagaciones para hallar el enlace entre los hechos, las causas y los porqués en los temas que se planteó. Consideramos que ha sabido honestamente indagar en el pasado dominicano claves para sucesos posteriores, alumbrando hechos $y$ situaciones que afectaron a un gran numero de hombres marcando sus vidas y decidiendo sus destinos. Después de este libro estamos en condiciones de entender mejor la historia dominicana, gracias a esa averiguación del funcionamiento de un pasado hasta donde las fuentes lo han permitido. La preparación y la vocación de Rosario Sevilla Soler, ingredientes del oficio de historiador han permitido tales logros.

Pero nuestra autora, junto a estas notas de preparación, vocación, tenacidad y perseveración, ha hecho gala de una disciplina con respecto al mentor que no ha de interpretarse como subordinación, inconcebible en una personalidad como la suya. Por eso subrayo tal nota. Porque siendo un 
fuerte temperamento, una definida personalidad, a la hora de escuchar $y$ de atender sugerencias no ha dudado en leer $y$ releer, hacer y rehacer, escribir y reescribir, lo leido, hecho y escrito. Hubo una total compenetración con su maestro.

Fiel a esa manera de ser y de concebir la investigación o la Historia, Rosario Sevilla Soler se embarcó en un nuevo tema sin salirse del área antillana. Tema dotado de enorme importancia y de gran novedad: Las Antillas durante la Guerra de Emancipación. ¿Cómo se vió el fenómeno emancipador desde las Antillas? ¿Cuál fue el papel de las Antillas durante la guerra? ¿Qué repercusiones tuvo la lucha y' su final en las islas? Son tres de las muchas interrogantes que el tema planteaba y que la doctora Sevilla Soler ha sabido llevar ya a buen término, aunque las fuentes no se han mostrado todo lo generosas que se esperaba. Apenas ls tórculos pongan el punto y final a esta obra que prologamos, volverán a ponerse en marcha para estampar esa nueva aportación, inserta también en el programa de investigaciones que nuestra Cátedra viene desarrollando hace años. Porque este trabajo que el lector tiene en sus manos, no es una contribución aislada. Otras personas indagan el pasado dominicano en los siglos XVII y XVIII de acuerdo con nuestro programa o plan de alumbrar la historia antillana en esas centurias. Después, y en el caso dominicano, quizá merezcan una aclaración los años decimonónicos de la Patria Boba. Porque nos encontramos con una nacionalidad singular, nacida entre equivocos o dudas, y que desgajada de España volverá a su seno en la década de I860 en su lucha por mantener sus esencias hispánicas.

El papel del historiador es el de dar sentido al pasado. Un pasado que muchas veces, quierase o no, dicta grandes lecciones. Estimamos que Rosario Sevilla Soler ha cumplido ampliamente con este objetivo exhibiendo, quizá -ïPorqué no decirlo? - los conocidos fallos de las primeras investigaciones. Nuestra esperanza en ella tras esta primera experiencia, se ha visto satisfecha cuando aún su tesis doctoral no 
había visto la luz pública. Por eso es doble nuestra satisfacción al pergeñar estas líneas prologales. Lineas que no sólo pretenden ser la presentación de un autor, sino también la expresión parcial del homenaje que nos merecen tantos $y$ tantos nombres femeninos que vienen silenciosamente -nota muy femenina - enalteciendo al americanismo español y, en nuestro caso, al sevillano.

Francisco Moraless Padrón Octubre de Ig80 


\section{INTRODUCCION}

El tema tratado en este libro, Santo Domingo en la segunda mitad del siglo XVIII, que en su día presentamos como Tesis Doctoral, obedece a un programa general de investigación sobre las Antillas.

Este programa está siendo dirigido por el doctor don Francisco Morales Padrón, en el Departamento de Historia de América de la Facultad de Filosofía y Letras de la Universidad de Sevilla. En él se han elaborado varias monografías, algunas de las cuales han sido ya publicadas por la E.E.H.A. de Sevilla, o el Instituto de Cultura Puertorriqueña, y con ello se pretende efectuar un estudio completo sobre las mencionadas islas.

Dentro de este plan de investigación histórica, nuestro trabajo se ha centrado en el conocimiento de la historia de la isla Española, en un período tan poco estudiado como es la segunda mitad del siglo XVIII. En él tienen lugar fenómenos tan interesantes como las reformas de los Borbones, la cesión de toda la colonia a los franceses por la paz de Basilea, así como la influencia de las ideas de la Revolución Francesa sobre la población esclava, a través de sus vecinos.

Hemos de señalar que la elección de este período no se ha hecho de forma arbitraria. No hemos iniciado nuestra investigación en los últimos cincuenta años del siglo dejando inéditos los primeros, pues éstos, constituyen el tema de otra Tesis Doctoral, dirigida también por el profesor Morales Padrón en el Departamento citado, y que próximamente se presentará en esta Facultad.

Y la razón de escoger la segunda mitad del siglo 
XVIII, se encuentra en la personalidad y propia entidad de esta etapa, determinadas por las reformas borbónicas y los sucesos de la colonia vecina. Desde comienzos del siglo XVIII se asentó una nueva dinastía de origen francés en el trono de España. Con su llegada se inician una serie de innovaciones y cambios en la administración peninsular y de las colonias, tímidamente al principio. Será en la segunda mitad cuando estas reformas empiecen a manifestarse en Santo Domingo, coincidiendo con el reinado de Fernando VI que se inicia en I746, y en especial con Carlos III. Es entonces cuando los monarcas se preocupan del fomento de su agricultura y ganaderia, así como del comercio, que siguiendo nuevas líneas liberalizadoras adquirirá mayor importancia.

El otro factor fundamental, el de la presencia de los franceses en la parte occidental de la Española, había sido tolerado anteriormente, pero no fue reconocido oficialmente hasta la época que nos ocupa. Por otra parte, se produce también en estos años la Revolución Francesa, que tan ta trascendencia tuvo en Saint Domingue, y como consecuencia de ello en la parte española de Santo Domingo. Por último, todo el proceso desembocó en la cesión de la isla a la República Francesa. Termina así pues en estos años la dominación de España en Santo Domingo, porque aunque posteriormente se recupere la colonia por algunos años, la dependencia de la antigua Metrópoli será efímera, al ser ya un hecho irreversible la idependencia de las colonias americanas.

El primer paso seguido para la realización de esie estudio ha sido, como es lógico, el examen de la bibliografía existente sobre el tema, y posteriormente, de la documentación perteneciente a distintos archivos.

Las fuentes básicas han sido, sobre todo, las documentales. En esta indagación hemos visitado el Archivo General de Indias de Sevilla, el Archivo Histórico Nacional de Madrid, el Archivo General de Simancas, y el Archivo Ge. neral de la Nación de la República Dominicana. Veamos 
someramente las fuentes encontradas y vistas en cada uno de estos depósitos.

Por lo que respecta al Archivo General de Indias, fueron consultadas las siguientes secciones: Indiferente General, Contaduría, Contratación, Escribanía de Cámara, Secretaría del Juzgado de Arribadas, Correos, Estado, y sobre todo la subsección de la Audiencia de Santo Domingc, incluida en la sección de Gobernación. En él desde luego, es donde hemos encontrado más datos sobre el asunto a tratar.

Cuando visitamos el Archivo General de Simancas, pudimos ponernos en contacto con la documentación conservada dentro de las secciones de Secretaría de Guerra, y en la de Hacienda, en el apartado denominado Dirección General de Rentas.

Por lo que respecta al Archivo Histórico Nacional de Madrid, el estudio se centró en los documentos conservados en las secciones de Consejos y Estado.

Por último, hemos de señalar nuestra presencia en el Archivo General de la Nación de la República Dominicana. Los documentos contenidos en dicho repositorio sobre nuestro tema son muy escasos. En su mayor parte son fotocopias procedentes del Archivo General de Cuba, que el gobierno cubano regaló al dominicano.

A partir de la documentación señalada, y basándonos en ella, hemos dividido el trabajo en diez apartados o capítulos: El marco geográfico ; Población y sociedad ; Agricultura; Ganadería; Comercio; Real Hacienda; Gobierno ; Ejército; Relaciones con la colonia francesa; y, el último, sobre los efectos de la Revolución Francesa en la isla, y la cesión de toda ella a los franceses.

Para el primer capítulo nos hemos basado fundamentalmente en las descripciones de los contemporáneos, Moreau de Saint-Mery, Antonio Sánchez Valverde, Luís Josep Peguero, y Antonio de Alcedo, así como en la correspondencia de las autoridades isleñas. Intentamos de este modo presentar el medio en que se desarrollan los hechos 
narrados a continuación, pero no sólo en su entorno real, sino como lo vieron y sintieron los protagonistas.

Por lo que se refiere a la población, las fuentes nos hablan de la fundación de nuevos establecimientos a base de familias canarias, y del crecimiento demográfico experimentado en la segunda mitad del siglo XVIII. A comienzos del siglo la isla se encontraba despoblada por varios motivos que exponemos en este capítulo. Pero la presencia de los franceses en la zona occidental, hacía necesaria una barrera de contención que impidiera su avance. $\mathrm{Y}$ el único medio de conseguirlo, consistía en la creación de núcleos de población cercanos a la frontera. Esto, unido al deseo de la Corona de levantar la decadente economía dominicana, para lo cual era fundamental la existencia de una población suficiente, determinaron una importante política de repoblación, que como más tarde veremos tuvo algunos logros. Hemos querido analizar también en este apartado la distribución de la población en las distintas zonas, así como su estratificación en clases sociales y los aspectos de la vida cotidiana, aunque la pobreza de fuentes to hacen casi imposible.

En el capítulo dedicado a la agricultura nuestra atención ha recaído, especialmente, en las causas determinantes del poco interés que los dominicanos parecían sentir por las labores del campo, así como en hacer una relación de los distintos cultivos, para pasar, por último, a analizar la política de fomento agrícola preconizada por los Borbones en estos años. Con la llegada al trono de esta nueva dinastía, el interés por la isla, que en el siglo anterior había sido casi nulo, parece despertar. Las teorías fisiocráticas, que valoraban los productos de la tierra como la principal fuente de riqueza de un país, señalarán las directrices económicas de la España de la época. En consecuencia, se dictan toda una serie de medidas importantes, dedicadas a proteger la agricultura y a fomentarla, iniciándose en el caso de Santo Domingo nuevos cultivos, a la par que se procuró mejorar los antiguos. 
En el apartado relativo a la ganadería, nos ocupamos de la que durante mucho tiempo fue la principal fuente de ingresos de los colonos de la Española. El tráfico de reses a través de la frontera con los franceses, produjo en todo momento pingües beneficios a los habitantes de la zona española. De este modo, uno de los principales problemas a que tuvieron que enfrentarse las autoridades, fue el contrabando ganadero. El comercio con el Guarico, donde los hateros conseguian mejores precios, hizo que la capital quedase en muchas ocasiones desabastecida de carne. Por ello, cada ganadero estaba obligado a entregar un número de reses proporcional al total de que era dueño, para el mantenimiento de la ciudad de Santo Domingo. Pero esta medida resultaba inútil, desde el momento en que los dueños de ganado falseaban las relaciones del número de cabezas que poseían, con el fin de vender la mayor cantidad posible a la colonia francesa. Con todo ello, según las quejas de las autoridades isleñas, se desatendía incluso a la procreación de los animales, de manera que el estado de la crianza llegó a ser alarmante en algunos hatos.

E1 capítulo quinto está dedicado al comercio. La vida comercial de la Española era mínima, reduciéndose al contacto con algunas posesiones españolas del Caribe, y unas cuantas colonias extranjeras de la misma zona. En este apartado intentamos analizar las causas de tal estado de cosas, así como los medios puestos por la Corona para acabar con él, que culminarán con la promulgación del Real Decreto e Instrucción de Libre Comercio con las Antillas de 1765 , y del Reglamento de Libre Comercio de i778. Analizamos también aquí, el volumen del tráfico comercial de Santo Domingo con la Península, con otras zonas españolas de América, y con las colonias extranjeras. Así mismo, dejamos constancia de los productos que fueron objeto de este tráfico, y de su intensificación a partir de la promulgación del ya mencionado decreto de 1765 .

En el sexto capítulo, que se refiere a la Real Hacienda, presentamos el movimiento de las Cajas Reales de Santo 
Domingo, los diversos conceptos por los que entraba dinero en la Real Contaduria, y en que se gastaba, así como los problemas acasionados por la falta de dinero en efectivo en la isla, y la consiguiente emisión de papel moneda. Hemos de señalar en este punto, que únicamente contamos con las cuentas de aquellas Reales Cajas desde I754 a I775. Por ello, sólo ha sido factible ofrecer una visión parcial sobre el asunto, aunque desde luego puede servirnos de índice de lo que fue la economía pública dominicana en la segunda mitad del siglo XVIII.

Respecto al capítulo séptimo, sobre el gobierno y administración, los legajos estudiados nos facilitan algunas noticias sobre los distintos gobernadores que tuvo el Santo Domingo español en la época de nuestro estudio. Se abre el período con el nombramiento de don Francisco Rubio y Peñaranda, designado en I 75I por muerte del anterior don José Colomo, y concluye con don Joaquín García Moreno, último mandatario antes de la entrega de la parte española de la isla a las autoridades de la colonia francesa. Dentro de los renglones de este apartado, exponemos también los problemas surgidos entre la Audiencia y los gobernadores, con motivo de la sucesión del cargo por muerte del titular, así como las decisiones de la Corte sobre el tema.

El capítulo octavo está dedicado al ejército. La documentación nos ofrece poco material sobre este punto, constriñéndonos a la exposición de los distintos cuerpos militares radicados en la isla, así como a la creación de otros nuevos, siguiendo la política de reorganización del ejército llevada a cabo por Carlos III. Hemos tratado de estudiar también la procedencia de los soldados y su situación en la sociedad dominicana, aunque la falta de fuentes ha dificultado considerablemente esta tarea.

En lo tocante a las relaciones del Santo Domingo español con la colonia francesa, diremos que, desde nuestro punto de vista, constituye uno de los aspectos más interesantes e importantes de esta investigación, ya que los contactos entre los ciudadanos franceses y españoles fueron continuos. 
El comercio entre las dos zonas era muy intenso, en especial por medio del contrabando, y aunque las autoridades españolas se mostraban recelosas de las pretensiones territoriales de sus vecinos, los habitantes de las zonas fronterizas debieron entenderse bastante bien.

Tanto Francia como España, aunque esta última un poco tarde, se dieron cuenta de la importancia estratégica de la isla. Por ello, hay una tirantez constante entre sus gobernadores, intentando mantener o extender sus fronteras. De este modo, hemos examinado en este apartado las relaciones a nivel oficial y a nivel popular, que a nuestro parecer fueron diferentes, así como los tratados que se estipularon entre las dos colonias, para conseguir la convivencia de ambas.

Atención aparte merecen los fenómenos producidos en la isla con motivo de la Revolución Francesa, y que constituyen el décimo capítulo de nuestro trabajo. La correspondencia del capitán general español con su Corte, evidencia la grave preocupación que sentía porque las ideas revolucionarias pudieran pasar a la colonia española.

No tratamos desde luego en este apartado del fenómeno revolucionario en sí, ya que queda al margen de lo pretendido en este estudio, sino de las consecuencias que tuvo en la Española desde los primeros levantamientos de esclavos en la parte francesa, hasta la cesión de toda la isla a la República francesa por la paz de Basilea. En él pretendemos exponer el choque producido en el Santo Domingo español por las nuevas ideas, el temor experimentado ante ellas, y al mismo tiempo, el apoyo concedido por las autoridades españolas a los negros sublevados, intentando aprovechar la ocasión para arrojar a los franceses al mar.

Nos importa subrayar, que en el conjunto de los temas abordados figuran como más interesantes, desde nuestro punto de vista, la política reformista de la Corona española en esta etapa y la presencia de los colonos franceses en la parte occidental de la isla.

Por lo que se refiere al primer aspecto, parece eviden- 
te que las directrices de la monarquía proporcionaron al Santo Domingo español un cierto florecimiento, tras la decadencia en que se encontraba en el siglo anterior. Las órdenes que se dictaron sobre la repoblación de la isla, produjeron la creación de nuevas poblaciones como San Fernando de Montecristi, San Felipe de Puerto Plata, Sabana de la Mar, etc.

Las medidas encaminadas a favorecer la agricultura y el comercio tuvieron también consecuencias inmediatas. Cultivos que hasta entonces habían sido minoritarios como el del tabaco, adquieren ahora una importancia considerable. Al mismo tiempo, surgen otros nuevos como el del café, que proporcionará importantes beneficios a los colonos.

En lo tocante a la presencia de los franceses, este hecho condiciona toda la historia dominicana de la etapa. Dentro de la política de fundación de nuevas poblaciones de que ya hemos hablado, una causa alegada constantemente por los gobernadores para su realización, será la existencia de la colonia francesa en la isla. Los deseos de expansión de los galos, hacían necesaria la existencia de una serie de establecimientos españoles en la frontera que los frenara. Surgen así, en la segunda mitad del siglo XVIII, San Gabriel de las Caobas, San Rafael de la Angostura, San Miguel de la Atalaya, etc. La economía se ve también afectada por el mismo fenómeno. Los españoles vendían sus ganados a los franceses con grandes ganancias, por lo que no tenían ningún interés en el fomento de la agricultura preconizado por la Corona. De ahí que el contrabando entre ambas zonas se convirtiera en una de las principales actividades económicas del país, de manera que las dos partes se surtían mutuamente de lo que les era más necesario. Y como consecuencia de todo ello, resultaba que la principal preocupación de casi todos los gobernadores de la época será la presencia de los franceses en la Española, preocupación que intentará siempre limitar el comercio ilícito entre ambas colonias, y contener a los franceses dentro de los terrenos que ya habían ocupado, evitando su progresivo avance. 
En este panorama que hemos esbozado, es obvio que algunos aspectos no han sido aclarados. Tales son por ejemplo: el papel desempeñado por la Iglesia en la sociedad dominicana, la vida cultural, etc. Esto se debe a que la ivestigación ha tenido que hacer frente a problemas graves, derivados del contenido de las fuentes documentales. Hay puntos sobre los que no aparece ningún dato en los documentos examinados, que puedan servirnos para este trabajo. Esto es lo que ocurre en el caso ya señalado de la Iglesia. Para otros las fuentes son incompletas, por lo que sólo podemos ofrecer una visión limitada de ellos. Así, por lo que respecta a las cuentas de las Cajas Reales, no aparecen antes de I754 y se pierden después de r775. A causa de ello, en el capítulo del comercio y en el de la Real Hacienda, hemos intentado dar una visión de lo que fueron cincuenta años, a través del material correspondiente a $2 \mathrm{I}$ solamente.

De lo expuesto se deduce, que el primer y principal problema al que hemos tenido que hacer frente ha sido la limitación de las fuentes documentales, al que hemos de sumar la pobreza de bibliografía existente sobre el tema, lo cual ha dificultado aún más nuestra labor.

Con todo, nos parece que el lapsus de tiempo escogido queda ya bastante iluminado, teniendo en cuenta las fuentes con que hemos podido contar, y que se trata de un tema hasta ahora poco estudiado.

Como final de esta introducción, queremos dar las gracias al director de este trabajo, el doctor don Francisco Morales Padrón, catedrático de Historia de los Descubrimientos Geográficos de la Facultad de Filosofía y Letras de Sevilla, por el apoyo y ayuda que nos brindó en todo momențo merced a lo cual este trabajo ha sido posible, así como a todos los profesores de la citada cátedra.

Nuestro agradecimiento va dirigido también al doctor don Antonio Acosta, por la colaboración que nos prestó en la elaboración del apartado dedicado a la demografía, y al doctor don Emilio Rodríguez Demorizi, que tan amablemente nos guió en nuestra búsqueda de documentos en la República Dominicana. 

Capítulo I

\section{EL MARCO GEOGRAFICO. DESCRIPCIONES DE LOS CONTEMPORANEOS}

Aunque la geografía de la isla Española es de sobra conocida por todos, hemos querido en este primer capítulo hacer una especie de introducción geográfica, que pueda darnos una idea más completa del marco en que se desarrollan los acontecimientos que vamos a estudiar a continuación, ya que podría considerarse fundamental para la compresión de muchos de ellos.

Algunos de los fenómenos de la segunda mitad del siglo XVIII en Santo Domingo, no podríamos explicárnoslos si no tuviésemos en cuenta su situación geográfica y su clima, pues todo es en cierto modo producto del medio físico en que se desarrolla, y el caso de la historia de la Española no podía ser una excepción.

La geografía determina los tipos de cultivo, y cualquiera otra modalidad de explotación económica, lo que a su vez se refleja en la estructura social y en las formas de vida en general.

Políticamente, la situación geográfica dominicana la lleva a ser en un principio, el foco colonizador de España en América, la "llave" del continente recién descubierto, y aunque los fenómenos económicos hacen que la isla pierda interés posteriormente en este sentido, es también su situación, en medio de las otras Antillas, lo que le permite seguir siendo el centro de la Audiencia, el núcleo político-administrativo de una zona, que abarca territorios de mayor importancia y desarrollo económico como la isla de Cuba. 
$\mathrm{Y}$ al exponer el medio geográfico en el que vamos a movernos, lo hemos hecho a través de los autores del siglo XVIII y algunas cartas de los gobernadores dominicanos de aquellos años, pues a pesar de los errores que puedan ofrecernos, nos describen la isla tal y como la vieron en esa época sus habitantes, lo que fue para éstos su tierra, como medio para entender mejor su historia, e incluso a ellos mismos.

Para esta labor contamos con cuatro relatos de gran interés, unos más detallados que otros, pero todos con una característica común: fueron escritos en el siglio XVIII o en los años posteriores a él, y tres de ellos nos están narrando algo que vieron, o incluso vivieron sus autores. Estas cuatro obras son:

I." "Diccionario geográfico-histórico de las Indias Occidentales", de Antonio Alcedo, publicado en Madrid en I787. No tenemos noticias de que Alcedo conociese la isla de Santo Domingo, pero para su descripción se basa desde luego, en testimonios de gentes que si la habían visitado, pues coincide, a veces casi exactamente, con las de autores criollos.

Aunque en este caso se pierda la espontaneidad del que cuenta lo que ve, pues su intento fue hacer una obra erudita de toda la América hispana, nos ofrece datos de gran interés para el conocimiento de lo que fue la primera colonia de España en América.

2." "Descripción de la parte española de Santo Domingo", de Moreau de Saint-Mery, que aunque fue escrita a principios del siglo XIX, el mismo autor confiesa que quiere hablar de la isla en la época en que él la conoció, antes de que se produjeran allí los fenómenos derivados de la Revolución Francesa de I789, y la cesión de toda la isla a Francia. Moreau vivió en la colonia francesa de Santo Domingo y recorrió la parte española con un interés propio de los ilustrados del siglo XVIII. Fruto de ello fue su obra, 
en la que nos habla desde la geografía y el clima, a los fenómenos políticos y económicos, e incluso de las formas de vida y costumbres de los españoles de aquellos años.

Aunque en toda ella se ve un cierto desprecio por los colonos españoles, que mantenían su país en un estado miserable, que él compara continuamente con el florecimiento de la parte francesa, su obra es quizás la más rica de las que hemos utilizado para este trabajo, por la gran cantidad de aspectos tratados y su exposición clara y sencilla.

3." "Historia de la conquista de la isla Española de Santo Domingo, trasumptada el año de I $762 "$, de Luís Josep Peguero.

Era éste un criollo dominicano, un hatero de la villa de Bani, que en los ratos de ocio se dedicó a escribir esta historia, no con grandes pretensiones, sino para la gente de su ambiente. Aunque empieza su narración en el descubrimiento y conquista de la isla, lo interesante en ella es lo que se refiere al siglo XVIII. Fue la época que él vivió, y la mayor parte de lo que nos dice o lo vio personalmente, o le fue contado por testigos cercanos, y por lo que respecta a los fenómenos geográficos y climáticos, nos ofrece una gran exposición, sobre todo por lo que se refiere a las calamidades y huracanes -frecuentes en aquellas tierras.

Esta obra ha sido publicada en I975, permaneciendo hasta entonces los dos manuscritos originales que la componen, en la Biblioteca Nacional de Madrid.

4." "Idea del valor de la isla Española", de Antonio Sánchez Valverde, que fue publicada en Madrid en 1785.

Sánchez Valverde conoció a fondo los territorios que nos describe, y en este aspecto su valor es indudable. Pero su obra no está movida por un interés científico, sino por el deseo de que la Corona preste un mayor interés a su colonia. Este deseo lo hace caer en algunas exageraciones por lo que se refiere a las riquezas naturales de la isla, para llevar allí la atención de la Metrópoli. Nos habla de Santo 
Domingo como de un verdadero paraíso terrenal, de modo que tomando las medidas adecuadas, se podría convertir en el establecimiento más importante de España en América.

En este sentido, su narración carece absolutamente de objetividad, pero interesa también ya que, en cierto modo, es representativa del sentir de muchos dominicanos, que se consideraban abandonados por el gobierno central, y achacaban a este hecho la decadencia de su tierra.

La isla de Santo Domingo fue descubierta por Cristóbal Colón, en su primer viaje a lo que luego se llamaría América, el I2 de Octubre de 1492. Era conocida entonces entre los indios con el nombre de "haytí". Colón fundó la capital del nuevo territorio en el sur, y la llamó Santo Domingo, que pronto pasó a denominar a toda la isla, a la que en un principio se le dio el nombre de Isabela, en honor de la reina de Castilla Isabel la Católica. ${ }^{1}$

Se encuentra situada en el centro del Archipiélago de las Antillas, limitando al norte con el océano Atlántico, al este con el canal de la Mona que la separa de Puerto Rico, al sur con el mar de las Antillas, y al oeste con el canal del Viento que la separa de Cuba. Esta situación privilegiada respecto a las demás islas del Archipiélago Antillano, así como respecto al continente, hace afirmar a Antonio Sánchez Valverde que "Está casi rodeada de ellas, y podría decirse que fue colocada en el centro de aquel gran archipiélago para darles la ley. Las otras tres grandes Antillas, de Sotavento, Cuba, Puerto Rico y Jamaica, parecen sobre todo dispuestas a aceptar la superioridad de aquella y su dependencia, porque cada una de ellas se avanza con tres cabos o puntas...

Su colocación a Barlovento, la multitud y capacidad de sus puertos a los cuatro vientos principales, la hacen el centro de la navegación y la llave de la Nueva España...

Sobre estas indisputables ventajas, tiene la Española

1 Alcedo, Antonio đe: Diccionario geográfico-histórico de las Indias Occidentales. Imprenta de Manuel González. Madrid, 1787. Tomo II, pág. 24. 
otra muy apreciable, que es la de estar cercada con mucha inmediación de varias islas pequeñas, de las que puede sacar, y en otros tiempos ha sacado, grandes auxilios".

Antonio Alcedo nos dice que se extiende desde los $17^{\circ}$ $37^{\prime}$ hasta los $20^{\circ}$ de latitud, y desde los $67^{\circ} 35^{\prime}$ hasta los $75^{\circ}$ i $5^{\prime}$ de longitud. ${ }^{3}$

Moreau de Saint-Mery por su parte nos da una situación muy aproximada a la anterior, entre los $17^{\circ} 55^{\prime}$ y los $20^{\circ}$ de latitud septentrional, y entre los $7 \mathrm{I}^{0}$ y $77^{\circ}$ de longitud occidental. ${ }^{4}$

En realidad, se encuentra entre $\operatorname{los} 17^{\circ} 36^{\prime} 50^{\prime \prime}$ y $19^{\circ}$ $56^{\prime} 40^{\prime \prime}$ de latitud norte, y entre $\operatorname{los} 68^{\circ}$ I $8^{\prime}$ i 2 " y $\operatorname{los} 74^{\circ}$ $30^{\prime} 50^{\prime \prime}$ de longitud oeste.

Es la segunda isla en extensión del Archipiélago Antillano, después de la de Cuba, con 76.286 kilómetros cuadrados. En este punto, los autores de la época exageran considerablemente la realidad, pues refiriéndose sólo a la parte que en el siglo XVIII ocupaban los españoles, Sánchez Valverde nos da una extensión de 3.175 leguas cuadradas (96.046,75 Kms. cuadradios) ${ }^{\mathbf{5}}$, y Moreau de Saint-Mery 3.200 (96.800 Kms. cuadrados), ${ }^{6}$ cuando una tercera parte de la isla aproximadamente fue ocupada desde el siglo XVII por los franceses, que se establecieron en la parte occidental de ella.

$\mathrm{Su}$ clima es tropical, aunque suavizado considerablemente por las brisas y corrientes marinas.

Su situación en el trópico de Cáncer, hace pensar en las altas temperaturas de la zona tórrida, que en realidad no se alcanzan nunca en la isla, pues hay varios factores que ayudan a paliarla como pueden ser:

2 Sánchez Valverde, Antonio: Idea del valor de la isla española de Santo Domingo. Editora Montalvo. Ciudad Trujillo, 1947, págs. 28-29.

3 Ibídem, nota 1.

4 Moreau de Saint-Mery, M. L.: Descripción de la parte española de Santo Domingo. Editora Montalvo. Ciudad Trujillo, 1944, pág. 50.

5 Sánchez Valverde, Antonio: Op. cit., pág. 154.

6 Moreau de Saint-Mery, M. L.: Op. cit., pág. 78. 
- Los vientos que soplan del mar.

- Su orografía montañosa, que hace que gran parte de la isla por su altitud, no sufra nunca temperaturas demasiado elevadas.

- Las frecuentes lluvias que se producen en todo el país.

A este respecto, Alcedo nos dice que " $\mathrm{El}$ clima es muy cálido, pero se templa mucho con los vientos y abundancia de lluvias, que lo hacen tan húmedo que todo se pierde en poco tiempo, y sin embargo de ser contrario a los europeos, se acostumbran a él y no sólo gozan de buena salud, sino que muchos llegan a los 80 años, y algunos se han visto pasar de cien". ${ }^{7}$

Predomina en Santo Domingo el viento del este, "Cuyos efectos saludables debilitan los del sol...

A la influencia bienhechora del viento se reune, la de casi la igualdad de los días y de las noches y de las lluvias abundantes, que traen sin cesar al aire una fluidez siempre deseable, y que al bañar con profusión la superficie de la isla, producen, ayudadas por la evaporación causada por el mismo calor, una especie de enfriamiento...

Las lluvias de la zona tórrida son extremadamente abundantes, y en Santo Domingo caen con una profusión tal, que producen el doble efecto de temperar el calor, y distribuir en los numerosos ríos un enorme volumen de agua...

El contraste de un calor violento y de lluvias considerables, hacen el clima de Santo Domingo esencialmente húmedo". 8

Debido a su situación geográfica, la isla de Santo Domingo ha sufrido constantemente una serie de borrascas y huracanes, que han influido de forma decisiva en su desarrollo. Desde mediados del mes de julio hasta el de octubre, es cuando estos fenómenos se producen normalmente en las Antillas, aunque a veces se prolonguen hasta el de

7 Ibídem nota 1.

8 Moreau de Saint-Mery, M. L.: Op. cit., págs. 60-66. 
noviembre. "Es viento que asola, unido casi siempre a temblores de tierra durante cinco a seis horas". ${ }^{9}$

A lo largo de toda la historia de la isla, observamos repetidamente los efectos destructivos de estos huracanes, que acompañados de fuertes lluvias asolan el país, arrastrando casas y plantaciones. Así, nada más empezar la segunda mitad del siglo XVIII, en I75I, nos encontramos con una serie de ellos, que nos han sido descritos con todo detalle por Luís Josep Peguero en la siguiente forma:

"La primera vez que visitó la Divina Justicia nuestra iniquidad, visitans iniquitatem, fue miércoles que se contaron dos del mes de Junio, que desde las diez y media de la noche comensaron las nubes a sudar tanta agua, que un solo aguacero sin interpolación de tiempo, duró hasta las siete de la noche del día domingo día seis, maravillosa lluvia, y qué de temores causó, y quántas memorias del general dilubio se hisieron, que desaforadas cresientes hisieron Ríos y Arroyos, pues de dies y nuebe embarcaciones que estavan en el puerto bien ancladas, sólo una se libró, porque su dueño, antes que tomara mucho cuerpo el agua, la varó en tierra y amarró fortísimamente a la muralla: no pedía una buena cordura tanta prevención, que por eso las 18 restantes no escaparon; pero no alcanza el prudente lo que el prudentísimo previene.

Quedó la ciudad, con bastantes pérdidas en las tapiserías de las Casas principales, donde las espejerías cayhan descuadernadas al suelo con la fuerza. de la humedad; pues siendo las Casas de esta Ciudad fuertísimas, sus techumbres se calaron con la continuación de la lluvia, en los campos no ubo menos pérdidas, con los cresientes de Ríos ahogando muchos ganados que pastavan en sus riberas, quedando las yervas de las savanas, como si les hubiera pasado fuego...

fue la segunda visita día 21 de agosto, en el qual dava el mar Oceano por quatro días horrorosos bramidos, empollándose y obscuresiendo sus salitrosas aguas, levantan-

9 Ibídem, págs. 70-72. 
do en glovos sus espumosas olas que querían tocar las Estrellas, pues desde partes muy distantes del mar, se beyhan las olas por ensima de los Montes, dejando sus márgenes, y sin atender al precepto de que no saliera de sus límites. (ne transirent fines suos) salió en la vahía de Ocoa, y se tragó la punta de los Dátiles, que era de más de treinta pasos entre el mar. Fue esta alteración del mar, no tan solamente en la banda del sur de la isla Española, sólo circularmente en toda la isla, secando los salitres los árboles de su contorno, dejando sus playas infectas con la pudrición de los peses que arroja en ellas el mar...

fue la tercera visita de la justicia divina en esta isla Española, día 18 del mes de octubre del año dicho... Entre las dos y las tres de la tarde se oyó un espantoso ruido, semejante al que hace un resio viento dentro de un Monte, que no se podía distinguir si era en la región del Ayre, o si tenía por las entrañas de la tierra, y con él un temblor de la tierra, tan grande como espantoso, en continuo movimiento de balanzes dados del norte al sur, aunque muchos disen observaron fueron de oriente a poniente...

Bino este temblor acompañado con un llubia que corrieron las calles, pero no impidió ésta los rosarios; y estuvieron continuando los temblores hasta el día $\mathbf{2 8}$ del mismo mes...

Pero llegado el día 21 del mes de Noviembre, aquí fue que desató Dios su ira entre las nueve y las dies del día, duraría un cuarto de ora los repetidos baybenes que dio la tierra, tan grande que los vivientes ni parados, ni de rodillas, se podían mantener sobre la tierra: mucha fue la confusión, pero como ya estavan apartadas las culpas, y resignados a morir, por cumplir la voluntad del Altísimo, no parece fue aunque tan grande, tan temeroso como el primero por lo que aquél tuvo de inesperado". ${ }^{10}$

Por su parte don Francisco Rubio y Peñaranda, que

10 Peguero, Luís Josep: Historia de la conquista de la isla Española de Santo Domingo, trasumptada el año de 1762. Publicaciones del Museo de las Casas Reales. Santo Domingo, 1975. Tomo II, págs. 31-34. 
había tomado posesión como gobernador, capitán general, y presidente de la Audiencia de Santo Domingo en agosto de I75I, en carta de I9 de octubre del mismo año, comunicaba a la Corte que el día anterior, "poco después de las tres, acometió por espacio de seis minutos, sin zesar, un tan fuerte terremoto que ninguno de los nacidos aquí, se acuerdan haver experimentado otro igual, y por eso fue tan considerable el pavor que generalmente concibieron sus moradores, que todos o los más consintieron su total exterminio, a impulso del estruendo subterráneo que sentía, y conmovía con suma violencia todos los templos y edificios, de los muchos de piedra que hai en esta ciudad, amenazando todos su última ruina; y se hubiera visto este extrago, si no han cedido a menos, hasta ocho temblores que después prosiguieron;

Pero aunque por lo sólido y fuerte de su construcción no ha llegado este lastimoso caso, quedan tan sumamente maltratados, que será muy costosa su reparación, siendo rara la casa que haun las paredes maestras y más fuertes, no estén abiertas por muchas partes.

La yglesia cathedral lo quedó, y quarteada por distintos parajes, lastimadas sus bóvedas, siendo una fábrica sumamente sólida, y la torre que sirve de campanario será preciso derribarla". ${ }^{11}$

Posteriormente, el 30 de diciembre del mismo año, don Francisco Rubio informaba al Consejo de la continuación de estos fenómenos, pues tras el terremoto del 18 de octubre volvieron a repetirse, y aunque los que siguieron no fueron tan fuertes como aquél, "Llegó el día I9 y 2 I de Noviembre, en que bolbieron con más ímpetu, y en especial este último día, a cosa de las ocho de la mañana, con tanta duración, que generalmente o los más contestan pasó de ocho minutos, y de modo que si los estrechones hubieran si-

11 Carta del gobernador don Francisco Rubio y Peñaranda de 19 de octubre de 1751, dando cuenta a la Corte de los estragos causados en la isla por los terremotos. A.G.I. Santo Domingo, 942. 
do encontrados como los del primero, no hubiera quedado en pie ninguno de los edificios...

De las poblaciones o lugares de esta isla por la parte del sur, se han sentido los mismos temblores en los expresados días y horas, en las villas de Hincha, Banica y Azúa, $y$ en la primera con tanta violencia, que todos los maízes sembrados y otros árboles grandes del campo, fueron desprendidos del centro de la tierra con sus raízes, y al mismo tiempo, se oyeron tantos truenos con relámpagos y aguazeros el día del primer temblor, que esperaron sería el último de su fin, haviendo quedado por el suelo la iglesia de piedra. De la de Banica han sido también conformes las noticias, pero como su pobreza la tiene reducida a la maior infelizidad, sólo han sido compañeras en el susto.

La de Azúa, que dista tres días de camino de esta capital, se halló en el maior conflicto, y quedó totalmente arruinada... De ésta son los inmediatos valles de Neyba y San Juan, donde por barias partes se abrió la tierra y tragó algunos animales, y haviendo caido un hombre en una abertura, se le sacó muy maltratado...

Por la banda del norte, se ha experimentado igualmente en la ciudad de Santiago, Vega, y villa de Cotuy...". Como consecuencia de ello, la mayoría de los edificios se encontraban en ruinas, y según el gobernador, la mayor parte de la población, incluido él mismo, se veía obligada a vivir en barracas. ${ }^{\mathbf{1 2}}$

Aunque este año de I75I fue quizás el más trágico para la isla, por lo que se refiere a los temporales, éstos continúan durante toda la segunda mitad del siglo XVIII, de modo que el I 3 de noviembre de 1780 , el entonces gobernador don Isidro de Peralta y Rojas, daba cuenta a la Corte del gran temporal que sufrió la isla desde el i4 hasta el i7 del mes de octubre anterior, a consecuencia del cual los bojíos se derrumbaron, y las haciendas perdieron los po-

12 Carta del gobernador don Francisco Rubio y Peñaranda de 30 de diciembre de 1751, dando cuenta al Consejo de Inđias de los efectos de los temporales. A.G.I. Santo Domingo, 942. 
cos frutos que había dejado una fuerte sequía sufrida en los meses anteriores. Este temporal se sintió sobre todo en los pueblos del norte, donde los ríos produjeron grandes inundaciones que arrastraron ganados y personas, quedando cortados todos los cäminos. ${ }^{13}$

En I798, cuando quedaba poco tiempo para la entrega de Santo Domingo a los franceses, y los españoles se encontraban ya practicamente abandonados por la Metrópoli, el gobernador don Joaquín García escribía al Consejo, con fecha de ro de octubre del citado año, que tras las torrenciales lluvias sufridas en la capital en los meses de marzo y abril, y para mayor calamidad de la isla, la noche del i9 al 20 de septiembre se produjo un fuerte huracán que arrancó los techos de los bojios, de modo que "se hizo la ciudad un espectáculo de compasión, mucho más por haberse sentido este temporal acompañado de la lluvia, de la lobreguez, de los bramidos del mar, con que se aumentaba la congoja. Quedó el campo como si el fuego hubiera pasado por él". ${ }^{14}$

De este modo, hasta los últimos momentos de la presencia española en la isla (por lo que se refiere al siglo XVIII), tuvieron que enfrentarse sus moradores a los efectos desoladores de los huracanes, que a menudo destrozaron sus hogares y cosechas.

Respecto a la orografía, la isla de Santo Domingo es en general montañosa, con algunas regiones llanas al sur. Todo el territorio, de noroeste a sureste, se encuentra cruzado por la Cordillera Central, con las alturas máximas de las Antillas en los picos Duarte (3.175ms.), La Pelona (3.168 ms.) y Yaque (2.995 ms.).

Por el norte corre la llamada Cordillera Septentrional, menos elevada, y en el suroeste se alza la sierra del Bahoruco.

13 Carta del gobernador don Isidro de Peralta y Rojas de 13 de noviembre de 1780 , dando cuenta a la Corte de varios asuntos. A.G.I. Santo Domingo, 945.

14 Representación del gobernador don Joaquín García a la Corte, de 10 de octubre de 1798. A.G.I. Santo Domingo, 960. 
$\mathrm{Y}$ entre estos macizos montañosos, se encuentran expléndidos valles como la famosa Vega Real, la zona más fértil de la isla.

Sobre ello, Moreau de Saint-Mery nos dice que Santo Domingo posee dos grandes cadenas montañosas que van de oeste a este, y de las que salen otras secundarias. Sus cimas "no tienen una gran elevación sobre el nivel del mar, y esta elevación puede estimarse en cuatrocientas toesas perpendiculares ( $780 \mathrm{~ms}$.), en la mayor parte de las del interior; pero las del Cibao, de la Selle, y de la Motte, tienen una altura doble". ${ }^{15}$

En estas montañas nacen gran cantidad de ríos, entre los que hay que destacar el Yaque del norte, Yaque del sur, Artibonito, Ozama, Nizao, Nigua, etc. Estos ríos, con las intensas lluvias que son propias de la zona tropical producen a veces graves inundaciones; pero al mismo tiempo, son la base de la vegetación rica y exuberante del país.

"Riegan y fertilizan la isla muchos ríos, de que son los principales Ozama, Hayna, Nigua, Villegas, Nissao, Ocoa y Yane, de modo que apenas se encontrará país tan beneficiado por las aguas, que al mismo tiempo produce muchísimo pescado y tortugas". ${ }^{16}$

$\mathrm{Y}$ en este conjunto de montañas, valles y ríos, se encuentra el fundamento de la fertilidad de la isla:

"Para el observador que contempla las largas cadenas de montañas, y todas las estribaciones que de ella salen como de un tronco principal, para ir a extender sus sinuosas ramificaciones sobre toda la superficie de la isla, ve allí en cuanto a ella la causa de su fertilidad, el inmenso depósito en que se acumulan las aguas, que los innumerables ríos van en seguida a derramar por todas partes". ${ }^{17}$

De como vieron esta fertilidad, y la riqueza de la fauna de Santo Domingo los autores del siglo XVIII, es significa-

15 Moreau de Saint-Mery, M. L.: Op. cit., págs. 51 y 57.

16 Alcedo, Antonio de: Op. cit., pág. 25.

17 Moreau de Saint-Mery, M. L.: Op. cit., pág .52. 
tivo el siguiente texto: Esta isla respecto a las demás de América, es "la más fértil y deliciosa, poblada de dilatados bosques de exquisitas maderas como caobas, futetes, robles, hacanas, guayacanes, candelones, capaes, laureles, cedros, naranjos, espinos, carimas, sabinos, marías, pinos, ceibas, mameyes, copeyes, higuillos, jobos, almacigos, higueros, ávanos, granadillos, cateis, nazarenos, guaconejos y cuernos de buey y mucha variedad de palmas, y otros que producen hermosas y delicadas frutas como ananás, bananas, uvas, cidras, limones, toronjas, dátiles y otras infinitas, que son de mejor calidad que en las demás islas. Abunda así mismo de variedad de aves y pájaros de canto y de hermosas plumas, y en los prados o sabanas que llaman allí, es increible el número de ganado que se cría". ${ }^{18}$

Además según nos dice el mismo autor, la isla tiene "muchas minas de oro, plata, cobre, cristal y talco, que a los principios produjeron grandes riquezas, especialmente las del Cibao, las primeras, y de una se sacó un grano o pepita de oro, que pesaban tres mil y seiscientos castellanos, y se perdió en la desgraciada flota que naufragó; el año de I645, se descubrió una mina muy abundante de azogue...". ${ }^{19}$

Sin embargo en la época tratada en esta ocasión, la segunda mitad del siglo XVIII, la minería carece de importancia, pues sólo tenemos noticias de la explotación de una mina de oro en la villa de Hincha, en la banda fronteriza del sur. ${ }^{20}$

Es indudable que todo estos autores, exageran considerablemente las riquezas que podían obtenerse de la Española; pero los textos que hemos señalado no hacen más que reflejar los sentimientos de los dominicanos de la época. Nos presentan el medio físico en que se desenvolvieron tal y como ellos lo vieron.

\footnotetext{
18 Alcedo, Antonio de: Op. cit., págs. 24-25.

19 Ibídem, pág. 25.

20 Representación del gobernador don Francisco Rubio y Peñaranda, dirigida a la Corte y fechada el 14 de junio de 1754. A.G.I. Santo Domingo, 1.010.
} 



\section{Cpítulo II}

\section{P O B L A C I O N}

El CRECIMIENTO DEMOGRÁFICO DEL SIGLO XVIII

La isla de Santo Domingo, que fue la base de los dominios españoles en el Nuevo Mundo, la primera Audiencia americana, con el paso de los años decayó profundamente; este declive se manifiesta claramente, en la casi despoblación en que se encontraba en los comienzos del siglo XVIII por varios y conocidos motivos. Tales fueron entre otros, las nuevas conquistas y los nuevos establecimientos continentales, que desviaron la atención general hacia Tierra Firme, donde se suponían mayores riquezas. Así mismo, y en relación con lo anterior, el hecho de que las primitivas minas de oro insulares mostrasen pronto la limitación en su producción, indujo a muchos al abandono de las Antillas, las cuales se vieron afectadas además por el descenso de su comercio con España, debido a que los comerciantes obtenían un mayor beneficio dirigiéndose a Tierra Firme, de donde podían sacar mayor variedad y cantidad de frutos. Finalmente, la despoblación y las epidemias.

Un factor fundamental en la decadencia dominicana fue, desde luego, la despoblación de las ciudades del norte de la isla llevada a cabo a principios del siglo XVII por orden real. Las ciudades de Montecristi, San Felipe de Puerto de Plata, Bayajá, La Yaguana y otras de la parte norte y oeste de Santo Domingo, eran quizás las más prósperas de la isla, debido en parte al intenso contrabando realizado por sus 
habitantes con todos los extranjeros que se acercaban a sus costas, principalmente holandeses y portugueses. ${ }^{1}$ Para acabar con este contrabando, el Consejo de Indias proyectó el traslado de los habitantes y los ganados de estas ciudades a las cercanías de la capital. Pero las nuevas poblaciones a que se trasladaron no llegaron a prosperar. La mayor parte del ganado o murió en el viaje o se hizo cimarrón, mientras que muchos de sus dueños optaron por macharse a la isla de Cuba. ${ }^{2}$ En cuanto a "Las epidemias, de viruela, de sarampión, especie de fiebre eruptiva muy contagiosa y grave; la disentería, particularmente en $\mathbf{1 7 6 6 , ~ l l a m a d o ~ e l ~ a n ̃ o ~ c r u e l ~}$ de los seises, concluyeron la despoblación, y redujeron la colonia a no ser más que una esjecie de desierto al comienzo del siglo actual... un censo efectuado en 1737 , demuestra claramente que la población total no llegaba más que a seis mil almas, y la capital contaba apenas quinientas...". ${ }^{3}$

De este modo la isla decaía poco a poco en todos los aspectos, y pronto los dominicanos se dieron cuenta de que el único medio que tenían para la recuperación económica era repoblarla. Así, en carta de 26 de noviembre de 1695 , el arzobispo de Santo Domingo escribía al Rey:

"Señor; por real zédula de nuebe de febrero de noventa y quatro, me manda $\mathrm{V} . \mathrm{M}$. que pida y anime a vuestro presidente, para el efecto de un donativo para iuda de las guerras en que se ve su corona, y los empeños con que se alla. A que respondo que toda esta isla es vn agregado de pobres, assí los de vno como los de otro brazo ellos le piden a V.M. y yo en su nombre, que les remedie poblando esta ysla toda, echando de una vez al francés, les de continuo comercio, que assí ni V. M. tendrá necesidad ni ellos, pues obrándose justicia y tratando a los vasallos como mereces zesa-

1 Mac Lean, J. y T. Pina Chevalier: Datos históricos sobre la frontera dominicohaitiana Santo Domingo, S. I. 1921, pág. 5.

2 Hernánđez Tapia, Concepción: Despoblaciones de la isla de Santo Domingo en el siglo XVII. Separata del Tomo XVII del "Anuario de Estudios Americanos". Sevilla, 1970, pág. 15.

3 Moreau de Saint-Mery, M. L.: Loc. cit., págs, 157-158. 
rán los enojos de dios, abundará a V. M. y no tendrá guerra". ${ }^{4}$

Casi un siglo más tarde el problema continuaba, y en I767, el gobernador de Santo Domingo, don Manuel de Azlor, hacía hincapié sobre el tema escribiendo al Consejo, y dándole cuenta de una representación que le hizo el Cabildo de la capital, manifestando que, al igual que hacían los franceses, podrían llegar a lograr una gran producción de café, cacao, tabaco y otros frutos, si se les concedían determinadas libertades en el comercio. El Cabildo proponía además otra solución para el fomento de la Española, que va a ser patrocinada por el gobernador en su carta. Ese otro remedio, que era el que don Manuel de Azlor consideraba más conveniente y menos costoso para la Real Hacienda, consistía en que la isla se repoblase mucho más, como realmente lo necesitaba, y de este modo contar con el número de brazos suficiente para la explotación de sus tierras. El gobernador creía firmemente, que la solución de todos los males que padecía Santo Domingo se encontraba en este incremento de la población, y en la fundación de nuevas ciudades, especialmente en la zona de la frontera con la colonia francesa vecina, que hasta entonces estaba casi desierta, y en algunos ríos y puertos de sus costas, que servían de base para el comercio ilícito con los extranjeros. ${ }^{5}$

Un poco antes de iniciarse el período que nos interesa en esta ocasión, en I739, al entrar a tomar posesión del gobierno de Santo Domingo don Pedro Zorrilla de San Martín, la isla se encontraba en un estado miserable, y con una población escasa, que algunos historiadores estiman en seis mil almas, diseminadas por la parte oriental del territorio. ${ }^{6}$

4 Rodríguez Demorizi, Emilio: Relaciones historicas de Santo Domingo. Editora Montalvo. Ciudad Trujillo, 1957. Vol. III, págs. 348-349.

5 Carta de don Manuel de Azlor de 18 de enero de 1767, dirigida, a la Corte, apoyando una instancia del Cabildo de la capital, proponiendo los medios necesarios para el fomento de la isla. A.G.I. Santo Domingo, 978.

6 García, José Gabriel: Compendio de la historia de Santo Domingo. Imprenta Hermanos García. Santo Domingo, 1893, tomo I, pág. 202. 
Pero a partir de entonces se iniciará una rápida recuperación, que sólo se verá frenada por la cesión de la isla a los franceses por el tratado de Basilea de r795.

La Ilustración trae consigo la idea del gobierno como un medio de cambio social con una finalidad esencial: el incremento de la riqueza del estado y, al mismo tiempo, de la individual, de la que en aquellos momentos se consideraba dependía el engrandecimiento de la monarquía. Como consecuencia de ello, los monarcas borbónicos van a iniciar una serie de reformas políticas, administrativas y económicas, que traerán a España un nuevo florecimiento, tras la decadencia a que había llegado en el siglo anterior. Este florecimiento se hace desde luego extensivo a las colonias americanas, y aunque no fue Santo Domingo una de las más favorecidas por la fortuna, inició a pesar de ello un levantamiento en cierto inodo espectacular, que se manifiesta sobre todo en el aumento de la población que se produjo en la segunda mitad del siglo XVIII.

"Los resultados, aunque insuficientes en relación con otras colonias (Cuba, Puerto Rico, Río de la Plata) fueron importantes, ya que de unos seis mil habitantes que había en $\mathrm{r} 737$, en 1785 se pasó de IOO a I 25.000 , de los cuales de doce a catorce mil eran negros". ${ }^{7}$

Estas estimaciones nos parecen sin embargo un tanto exageradas, a juzgar por los estados de población existentes en el A.G.I. de Sevilla. Hay que señalar a este respecto, que las seis mil almas que indican algunos autores pueden ser en realidad vecinos. Pero son una muestra de algo en lo que todos se muestran de acuerdo, de lo que significó la segunda mitad del siglo XVIII por lo que se refiere al desarrollo de la población de la isla.

Desde finales del siglo XVII se venía intentando la repoblación de Santo Domingo, enviando anualmente cincuenta familias desde las islas Canarias, pero ningún año

7 Santiago, Pedro J.: Estudio preliminar a la Historia de la conquista de la isla Española de Santo Domingo..., de Luís Josep Peguero. Tomo I, pág. XXIII. 
se alcanzaba este número. Además, muchas de ellas desertaron o perecieron, bien víctimas de enfermedades, bien por efectos del cambio de medio, o por los duros trabajos de los "desmontes" realizados para el establecimiento de sus nuevos hogares.

Pero al fin, la colonia española de Santo Domingo inició su recuperación en la segunda mitad del siglo XVIII. Aparecieron nuevos pueblos y ciudades en distintos lugares de la isla, incrementándose considerablemente el número de habitantes, al tiempo que surgían nuevos cultivos como el del café, que dieron a la agricultura mayor importancia de la que había tenido hasta entonces. ${ }^{8}$

Este crecimiento demográfico tuvo dos causas fundamentales :

La ya señalada de las ideas propias del despotismo ilustrado. Como ya hemos dicho anteriormente, la monarquía ve como único medio de hacerse fuerte la riqueza del país. $\mathrm{Y}$ en el caso de Santo Domingo, el aumento de la población era requisito indispensable para lograr una explotación total del territorio, por lo que los reyes españoles van a sentir una gran preocupación por este asunto.

$\mathrm{El}$ avance que los franceses realizaban en la parte occidental de la isla. Tras el abandono de las ciudades de Montecristi, Puerto Plata, Bayajá, La Yaguana y San Juan de la Maguana, quedaron desiertos el norte y el oeste de la isla, que se convirtieron en fácil presa para los piratas y naciones enemigas, y junto con la Tortuga, la cuna del imperio colonial francés en América. ${ }^{9}$

De este modo se fueron estableciendo en lo que luego sería la República de Haití, un grupo cada vez más numeroso de franceses procedentes en su mayor parte de la isla de San Cristóbal, de donde habían sido expulsados por

8 Moreau de Saint-Mery, M. L.: Loc. cit., pág. 158.

9 Vid. Utrera, Fray Cripriano de: Historia militar de Santo Domingo (Documentos y noticias). Ciudad Trujillo, 1943. 
los españoles. ${ }^{10}$ Poco a poco fueron avanzando en los terrenos que habían sido despoblados por los dominicanos, y el único medio de frenarlos era aumentar la población, y colocarla a modo de barrera de contención en los territorios entonces vacíos.

Conocer el volumen de la población de Santo Domingo en el siglo XVIII es bastante complicado, ya que sólo contamos para ello con una relación de las parroquias de la isla de $1782-83$ que no es completa, un estadillo de la población de I772, y otro de I8I2, aparte de las noticias que nos proporciona el arzobispo de Santo Domingo Alvarez de Abreu para I740, que recoge Emilio Rodríguez Demorizi en las Relaciones Históricas, y algunas referencias aisladas que aparecen en la correspondencia de los gobernadores de la época.

El valor de las Relaciones del mencionado arzobispo es desde luego relativo. Se trata de una somera descripción de los pueblos de la isla con sus pobladores. No debe estar basada en los padrones parroquiales, pues en unos lugares nos habla del número total de habitantes, en otros del de vecinos o familias, en otros de hombres de armas y vecinos, que en este caso son casi equivalentes, y por último en algunos, sólo de hombres de armas. Por todo ello no podemos tomar sus datos como algo fidedigno, pero a falta de censos completos, sirven para darnos una idea de la despoblación dominicana en esa fecha y su evolución posterior.

El segundo documento que citamos, y que hemos utilizado en este estudio, es un estadillo elaborado en I772 sobre el ganado y la población de la isla en aquellos momentos. No sabemos el origen de este estadillo, y lo único que podemos decir de él es que desde luego no está realizado meticulosamente, sino a base de meras aproximaciones, con los errores lógicos de este tipo de documentos, pero como fecha intermedia nos da ya un índice, del incremento que 
estaba sufriendo la población dominicana en la segunda mitad del siglo XVIII.

El tercero es un padrón de $1782-83$, y es el más completo de los documentos con que contamos para este tema. Aparecen en él las poblaciones que había en aquellos momentos en la isla, a excepción de una que se acababa de fundar: San Gabriel de las Caobas. En muchos de los pueblos cita incluso los nombres de los cabezas de familia con el número de personas que se encuentran a su cargo, así como si son adultos o párvulos, e incluso la distancia a que se encontraban las distintas haciendas de la población. Se realizó obedeciendo una real orden de $2 \mathrm{I}$ de enero de I772, en la que se prevenía al gobernador de Santo Domingo que, deseando el rey conocer las rentas que percibían los curas de aquel país, debía nombrar comisionados que, junto con otros designados por el arzobispo, hiciesen un informe completo de cada parroquia con un padrón exacto del número de feligreses de cada una, y con separación de los de "comunión y párvulos", así como el número de entierros, matrimonios, bautismos, derechos que los sacerdotes cobraban por ellos, congrua que gozaban, etc.

Pero el arzobispo se negó a nombrar los delegados que se le encargaron para esta labor, por lo que fueron sólo los comisionados por el gobernador los que la llevaron a cabo, interrogando directamente a los religiosos y examinando los libros de las distintas parroquias, basándose desde luego en los padrones parroquiales para la elaboración del censo, siendo muy difícil para los sacerdotes falsear los datos con objeto de ocultar los beneficios que obtenían. ${ }^{11}$

Por último, el cuarto documento es un estado general de la población de la parte española de la isla en I8I2, realizado con el fin de elegir a los diputados que deberían representar a la provincia en las Cortes españolas, y aunque no sea exacto parece bastante completo. Se refiere a una

11 Relación de las parroquias de la isla de Santo Domingo, realizada en 1782-83, obedeciendo la Real Cédula de 21 de enero de 1772. A.G.I. Santo Domingo, 988. 
época que queda fuera del objeto de nuestro estudio, pero al no tener datos sobre el número de habitantes del Santo Domingo español en el siglo XVIII, después de I782-83, nos interesa en gran forma para darnos una idea de la influencia que la Revolución Francesa y su reflejo en la isla, tuvieron para la evolución de la población dominicana.

Por su parte, los autores que han escrito sobre el tema nos dan cifras muy diferentes entre sí y respecto a las que nos proporcionan las fuentes documentales citadas, quizás por la confusión que pueda haber, según hemos señalado ya, entre los términos "almas" y "vecinos".

Así, Moreau de Saint-Mery nos dice que un censo efectuado en I737 demostraba claramente "que la población total no llegaba a seis mil almas, y la capital contaba apenas quinientas". ${ }^{12}$ Esta misma cifra nos da Pedro J. Santiago, ${ }^{13}$ pero resulta excesivamente baja para creer en el desarrollo posterior.

Por el contrario, Moya Pons nos da para I739, basándose según nos dice en los datos recogidos en el mencionado año por el arzobispo Alvarez de Abreu, una población de 30.058 habitantes. ${ }^{14}$ Sin embargo, del informe de Alvarez de Abreu señalado por Moya Pons, y recogido por Emilio Rodríguez Demorizi como hemos dicho anteriormente, se deduce que en 1740 había en toda la isla unas 25.806 almas, de las que unas 8.384 corresponderían a la capital. ${ }^{15}$

Para I769, Moya Pons afirma que había en la isla 73.3 I9 habitantes, según los padrones parroquiales de ese año. ${ }^{18}$ Pero un estadillo de población de 1772 , nos da un total de 50.000 para esa fecha, ${ }^{17}$ cifra que probablemente

12 Moreau de Saint-Mery, M. L,: Loc. cit., pág. 158.

13 Ibídem, nota 7.

14 Moya Pons, Frank: Historia colonial de Santo Domingo. Universidad Católica

Madre y Maestra. Santiago (República Dominicana), 1974, pág. 306.

15 Rodríguez Demorizi, Emilio: Op. cit., vol. III, págs. 259-271.

16 Moya Pons, Frank: Op. cit., pág. 307.

17 Estado general de la población y el ganado de la isla de Santo Domingo en 1772. A.G.I. Santo Domingo, 1.059. 
será exagerada, si tenemos en cuenta que sólo para Santo Domingo señala unas I 5.000 almas, número que no alcanza en los estados posteriores, a no ser agregándole la población de todo el territorio de su jurisdicción, pues tanto el padrón de $1782-83^{18}$ como el estado de población de I8I $2,{ }^{19}$ nos dan para la capital en sí misma, sin tener en cuenta las demás habitaciones que entonces eran consideradas de su distrito, de ocho a once mil almas.

A partir de 1780 , las diferencias entre los autores mencionados y la documentación que hemos examinado en el Archivo General de Indias de Sevilla se agudiza aún más. Así, para esta época, Moreau de Saint-Mery ${ }^{20}$ y Pedro J. Santiago ${ }^{21}$ nos dan una cifra de 125.000 habitantes aproximadamente, Carlos Federico Pérez y Pérez para I785 llega a señalar $152.000,{ }^{22}$ y Moya Pons, que a nuestro juicio se aproxima más a la realidad, unas 80.000 en $1783 .{ }^{23}$

Contrastando con estas cifras, en el Código que se intentó formar en Santo Domingo para el gobierno político y moral de los negros, se nos da un total para toda la isla, alrededor del año 1785 , de 54.000 personas. ${ }^{24}$

Por su parte, en el censo realizado entre i782-83, figuran exactamente 60.962 habitantes para toda la zona de la isla ocupada por los españoles, aunque faltan en él los vecinos de la nueva población fronteriza de San Gabriel de las Caobas. Pero a juzgar por este padrón, que es el documen-

18 Ibídem, nota 11.

19 Estado de la población de la isla de Santo Domingo en 1812, según los padrones y certificados presentados a la Junta Preparatoria para la elección de diputados para las Cortes Españolas. A.G.I. Indiferente General, 1.525.

20 Moreau de Saint-Mery, M. L.: Op. cit., pág. 82.

21 Ibídem, nota 7.

22 Pérez y Pérez, Carlos Federico: Historia diplomática de Santo Domingo (1492-1861). Universidad Nacional Pedro Henríquez Ureña. Santo Domingo, 1973, pág. 80.

23 Moya Pons, Frank: Op. cit., pág. 307.

24 Código formado en 1785 para el gobierno económico, político y moral de los negros de la Española. A.G.I. Santo Domingo, 1.034.

Ha sido editado con un estudio previo de Malagón Barcelo, J., con el título de $U n$ documento del siglo XVIII para la historia de la esclavitud en las Antillas. Sejarata de "Imago Mundi". Año III, núm. 9. Buenos Aires, 1955. 
to más completo con que contamos por lo que se refiere a este asunto, la población del Santo Domingo español no debía sobrepasar en esta fecha los 65.000 habitantes, siendo las ciudades más pobladas la capital, con I4.059 en toda su jurisdicción, Santiago de los Caballeros con r2.024, y Concepción de la Vega con I I.839. ${ }^{25}$

De todos modos, hay un punto en el que todos los autores se muestran de acuerdo: el crecimiento demográfico de la segunda mitad del siglo XVIII, aunque algunos de ellos lo exageran considerablemente.

El siguiente cuadro, para el que hemos utilizado los datos más completos que tenenos sobre este tema, nos muestra de manera clara el gran aumento que se produjo en la población de la isla en la época mencionada, a pesar de que lógicamente adolezca de errores y no sea completo. Para su elaboración tomamos como punto de partida cuatro fechas: I740, I772, I782-83 y I812, por ser las únicas de que tenemos noticias sobre la demografía de Santo Domingo a través de las fuentes citadas.

A este respecto hemos de señalar, que la relación del arzobispo Alvarez de Abreu recogida en las mencionadas Relaciones Históricas, nos da el número de vecinos para algunas localidades, de almas para otras, y para unas pocas de almas y vecinos. $Y$ utilizando la misma proporción que hemos observado en estas últimas de cuatro personas por cada vecino aproximadamente, hemos deducido el número de habitantes de aquellas en que sólo se habla de vecinos, a pesar de que normalmente se calcule un promedio de cinco personas por familia. 
Evolución DE LA POBLACIÓN DOMINICANA DESDE I740 A I8I2

Poblaciones

Santo Domingo

Los Llanos

El Ozama

Los Ingenios

S. Lorenzo de Minas

Haina

San Carlos

Bani

Seibo

Higuey

Samaná

Sabana de la Mar

Bayaguaná

Boyá

Monte Plata

Santiago

La Vega

Cotui

Puerto Plata

Montecristi

Azúa

La Maguana

Neiba

Banica

Hincha

San Rafael

Dajabón

San Miguel

Las Caobas

$$
\begin{aligned}
& 1740^{26} \quad 177^{27} \quad 1782-83^{28} \quad 1812^{29} \\
& \begin{array}{llll}
8.384 & \text { I } 5.000 & \text { I0.702 } & 8.000
\end{array} \\
& \text { I.600 } 1.350 \\
& 2.215 \\
& \text { I.8OO } \quad 952 \quad 3.428 \\
& \begin{array}{lll}
105200 & 1.445
\end{array} \\
& \begin{array}{llll}
1.030 & 1.000 & 340 & \text { I.1 } 26
\end{array} \\
& \begin{array}{llll}
822 & 2.000 & \mathrm{I} .024 & 68 \mathrm{O}
\end{array} \\
& \begin{array}{llll}
525 & 1.000 & \text { I.04I } & 2.132
\end{array} \\
& \text { I.II3 } 2.500 \quad 2.209 \quad 4.332 \\
& \begin{array}{llll}
318 & 600 & 508 & 1.442
\end{array} \\
& 150 \quad 215 \quad 710 \\
& 100 \quad 151 \quad 205 \\
& \begin{array}{llll}
380 & 1.200 & 679 & 875
\end{array} \\
& 65 \quad \text { I00 } \quad 95 \quad \text { I72 } \\
& 220 \quad 600 \quad 521 \quad 719 \\
& \begin{array}{llll}
5.200 & \text { I0.000 } & \text { I } 2.024 & 9.549
\end{array} \\
& \begin{array}{llll}
3.000 & 2.000 & \text { II } .839 & 9.366
\end{array} \\
& \begin{array}{llll}
584 & 1.500 & 1.542 & 2.625
\end{array} \\
& \begin{array}{llll}
400 & 800 & 1.804 & 2.989
\end{array} \\
& 600 \quad 1.646 \quad 557 \\
& \begin{array}{llll}
500 & \text { I.700 } & \text { I.43I } & 2.204
\end{array} \\
& \begin{array}{llll}
440 & \mathrm{I} .600 & \mathrm{I} .45 \mathrm{I} & \mathrm{I} .975
\end{array} \\
& \begin{array}{llll}
320 & 800 & 1.427 & 2.000
\end{array} \\
& \begin{array}{ll}
400 \quad 2.689 \\
2.000
\end{array} \\
& \left.\begin{array}{rrr}
2.000 & 3.000 & 2.993 \\
150 & 1.079
\end{array}\right\} \\
& \text { I. } 469\} 2.000 \\
& \text { I.I } 3 \text { I }
\end{aligned}
$$

Totales

26 Ibídem, nota 15.

27 Tbídem, nota 17.

28 Ibídem, nota 11.

29 Ibídem, nota 19. 
Como podemos apreciar, desde 1740 a r $782-83$ el aumento fue constante y muy elevado, produciéndose después un estancamiento, pues desde $1782-83$ hasta 1812,30 años, la población sufre un incremento no superior a 2.000 almas según los documentos que citamos. Desde i 740 a I772, la población sufrió una elevación de 24.I94 personas, es decir, de un 93 ' $75 \%$ en 32 años, con una media de un 2 '92\% anual.

Desde 1772 a $1782-83$, se pasó de 50.000 a 60.962 habitantes (incremento de ro.962), con un alza anual del 2'r $9 \%$.

A partir de esta última fecha es probable que la población siguiese su ascensión. Aunque no tenemos más estados de población sobre el siglo XVIII que puedan confirmar esta teoría, el 15 de noviembre de 1788 don Pedro Catani, entonces gobernador interino de Santo Domingo, en un informe que hace a la Corte sobre la situación económica en que se encontraba la isla, nos dice que había entonces en ella unas 70.000 personas. ${ }^{30}$

Pero la cesión de la isla a los franceses por la paz de Basilea de I795, significó no sólo un frenazo en la evolución demográfica del Santo Domingo español, sino que nos atreveríamos a decir que fue un retroceso.

El único dato que poseemos sobre el número de pobladores de la Española en el siglo XVIII después de I782-83, es el mencionado informe de don Pedro Catani. Pero es significativo el hecho de que, a pesar del ritmo de crecimiento continuado que se experimentó desde I740 hasta esa fecha, según el estado de población realizado en $\mathrm{r} 8 \mathrm{r} 2$ sólo hay un aumento de I.I34 almas en 30 años. Es decir, la población sufrió un incremento del o'o6 $2 \%$ al año. $\mathrm{Y}$ la única explicación para que una población de más de 60.000 habitantes, que por otra parte venía aumentando de forma constante en los años anteriores, creciese solamente un r'860\% en esos treinta años, es la emigración producida tras la cesión de to-

30 Informe del oidor decano de la Audiencia de Santo Domingo, don Pedro Catani de 15 de noviembre de 1788, sobre el estado en que se encontraba la isla. A.G.I. Santo Domingo, 1.012. 
da la isla a la República Francesa por el tratado ya mencionado

Probablemente cuando tuvo lugar la citada cesión, y a juzgar por el desarrollo demográfico de la etapa anterior, la población podía haber llegado a alcanzar los 65.000 ó 70.000 habitantes, para disminuir a partir de 1795 .

Según algunos autores, los criollos españoles no aceptaban el dominio francés. "Muchos fueron los que prefirieron acogerse a la aventurada alternativa de trasladarse a otras posesiones españolas, con abandono y pérdida de bienes casi siempre, para encontrar que donde llegaban no eran bien recibidos, o que las condiciones de hospitalidad eran insostenibles". ${ }^{31}$

Pero la realidad es que la mayor parte de la población no se atrevió a abandonar sus bienes para marchar a tierras que le eran desconocidas, al tiempo que la demora en la entrega de Santo Domingo a los franceses, hizo pensar a muchos que el asunto aún podía ser solucionado. Esto hizo posible la recuperación posterior de la colonia en I8og, al surgir entre los criollos que permanecieron en el país un movimiento de oposición al gobierno francés, que tuvo que salir de la capital en el mencionado año, pasando de nuevo el territorio a la Corona española. ${ }^{32}$

De este modo, cuando en i812 se lleva a cabo la elaboración de un estado general de la población, para organizar la elección de los diputados que representarían en las Cortes españolas a la provincia, aún permanecían en Santo Domingo aproximadamente unos 62.000 habitantes. ${ }^{33}$

Pero a pesar de este gran desarrollo demográfico producido en la segunda mitad del siglo XVIII, la despoblación de la isla seguía siendo un hecho. Si tenemos en cuenta que la extensión total de Santo Domingo es de 76.286 kilómetros

31 Pérez y Pérez, Carlos Feđerico: Op. cit., pág. 87.

32 Peña Batlle, Manuel Arturo: Historia de la cuestión fronteriza dominico-haitiana.

L. Sánchez Andújar. Ciudad Trujillo, 1946, págs. 111-112.

33 Ibídem, nota 19. 
cuadrados y la colonia francesa ocupaba en esta época aproximadamente un tercio de ella, nos queda una extensión de 50.857 kilómetros cuadrados poco más o menos para la parte española, en los que se repartieron como máximo unas 65 ó 70 mil almas. Sin embargo, la densidad de población varía según el momento de que se trate, ya que mientras en I740 nos encontramos con unos o' 50 habitantes por kilómetro cuadrado, ${ }^{34}$ y en 1772 con unos o'98, ${ }^{35}$ en $1782-83$ se pasó a I'I9 habitantes por kilómetro cuadrado. ${ }^{36}$

Así pues, aunque la población se incrementó en más de un $100 \%$ desde la primera mitad del siglo hasta la cesión de la isla a Francia, según los datos que poseemos al respecto, la despoblación continuaba, aunque considerablemente paliada por la política llevada a cabo en este aspecto por las autoridades españolas e isleñas.

El interior sin embargo permanecía deshabitado casi por completo. Las haciendas se agrupaban en los alrededores de las ciudades y villas, dejando abandonadas grandes extensiones de terreno. ${ }^{37}$

Por lo que se refiere a la edad de la población es muy difícil precisar. En el padrón de $1782-83$ nos encontramos con una distinción clara. Por una parte están las almas "de confesión y comunión", y por otra los párvulos, cuyo límite de edad es imposible señalar. Por eso hemos tenido que simplificar considerablemente, catalogando adultos a los primeros y niños a los segundos. La proporción entre ambos podemos situarla en $1782-83$, única fecha en la que tenemos noticias sobre el asunto, en un 73 ó $74 \%$ de adultos y un 26 ó $27 \%$ de niños, aunque su distribución es muy irregular en las distintas poblaciones de la isla, tal y como observamos en el siguiente cuadro: ${ }^{38}$ 
Santo Domingo (catedral)

Parroquia de Sta. Bárbara ${ }^{39}$

Los Llanos

$79^{\prime} 5^{\circ} \quad 20^{\prime} 5^{\circ}$

Los Ingenios

Curato del Haina

San Carlos

Bani

Seibo

Higuey

Samaná

Sabana de la Mar

Bayaguaná

Boyá

Monte de Plata

92'05

8o'37

7'94

$67 ' 25$

I9'62

8o'26

32'75

$79 ' 33$

I9'73

80 '93

20'66

69'53

I9'06

$75^{\prime} 69$

30'46

76,84

24 '30

79 '07

23'I 5

Santiago

$73^{\prime} 85$

20'92

La Vega

Cotui

Puerto Plata

$72^{\prime} 5^{\circ}$

$26 ' 24$

Montecristi

75 '16

$27^{\prime} 50$

Azúa

La Maguana

$79^{\prime} 5^{8}$

24,83

$63^{\prime} 5^{2}$

20 '4I

$77 ' 73$

$36^{\prime} 47$

74 '70

22 ' 26

Neiba

$66^{\prime} 56$

$25 ' 29$

Banica

69'50

33 '43

Hincha

74 '79

30'50

San Rafael

$79 ' 57$

$25^{\prime} 20$

Dajabón

6I'09

$20 ' 42$

San Miguel

Las Caobas

San Lorenzo de Minas

$38^{\prime} 90$

Hemos de señalar desde luego, que en este esquema no aparece la proporción entre niños y adultos por lo que se refiere a algunas poblaciones, entre ellas la correspondiente a

39 Esta parroquia se encontraba dentro đe la capital dominicana, pero su jurisdicción era distinta a la de la catedral. 
la catedral de Santo Domingo, aunque sí en la parroquia de Santa Bárbara de la misma ciudad. En la capital existían dos parroquias, la de Santa Bárbara y la de la catedral, esta última con una población en la fecha señalada de 8.654 personas, siendo muy difícil por ello of recer como seguros los porcentajes medios que hemos indicado, cuando de ellos están excluidos más de un $14 \%$ de los habitantes de la isla, pero a falta de datos más completos, pueden darnos siquiera un índice de la distribución de la población por edades.

A este respecto hemos de dejar constancia, de que el número de niños y adultos de cada población debió estar íntimamente ligado al tipo de economía de cada una de ellas, ya que por ejemplo los curatos del río Haina, zona azucarera por excelencia, y por tanto con necesidad de esclavos, nos dan el número más bajo de población infantil, 7'94 \%, mientras que en lugares donde descienda la esclavitud lógicamente aumentará aquella.

Por lo que se refiere al tamaño de las familias varía considerablemente, ya que más que familias son unidades de vivienda, en las que se encuentran incluidos los esclavos. Así, en I782 en Santa Bárbara de Samaná, población creada a base de familias canarias que en teoría tenían que estar formadas por cinco personas y $\sin _{\text {i }}$ esclavos, por no poder permitírselos su economía, nos encontramos con 2 I 5 almas y $5 \mathrm{I}$. familias, es decir, unas 4'2I personas por unidad de vivienda. Por el contrario, en otros lugares como por ejemplo Hincha, apreciamos un término medio de $63^{8}$ personas por unidad, ${ }^{40}$ siendo lógico pensar que este número se vería incrementado en lugares como Santiago, La Vega y Los Ingenios, por requerir la agricultura y la industria azucarera un mayor número de esclavos, aunque no tenemos ningún dato que pueda confirmar esta teoría.

Por lo que respecta a la forma de vida de esta población, se puede afirmar en general que en el siglo XVIII era casi toda rural, pues la mayor parte de las ciudades y villas no merecían siquiera ese nombre dado el corto número de

40 Ibídem, nota 11. 
sus habitantes. Pero prescindiendo de esto podemos hacer una distinción entre población rural y urbana, aunque desde luego no corresponda a los conceptos actuales. Llamaremos pues en este caso población urbana, a aquella que reside en las villas y ciudades por muy pequeñas que éstas sean, y rural, a la que habita en las haciendas o hatos de sus respectivas jurisdicciones.

Son muy pocos los núcleos para los que tenemos datos sobre este asunto, apenas 12 , y según ellos en $1782-83$ el $58 ' 27 \%$ de la población era rural y el 4I'72 \% urbano, como se observa en el siguiente cuadro, aunque dado su carácter incompleto no puede ser tomada esta cifra como real, sino sólo como una mera aproximación: ${ }^{41}$

\section{Poblaciones Población urbana Población rural}

Sto. Domingo (Catedral) 8.654 (I00\%)

San Carlos

Curatos del Haina

Ingenios

Bayaguaná

Seibo

Higuey

Samaná

Sabana de la Mar

Puerto Plata

Montecristi

Cotui

La Vega

Santiago
$1.024(100 \%)$

$$
\begin{aligned}
& 340(100 \%) \\
& 952(100 \%) \\
& 679(100 \%) \\
& \text { I } 85(837 \%) \quad 2.024\left(9 I^{\prime} 62 \%\right) \\
& 70\left(\text { I } 3 \text { '77\%) } 438\left(86{ }^{\prime} 22 \%\right)\right. \\
& 2 \mathrm{r} 5(100 \%) \\
& \text { I } 51 \text { ( } 100 \%) \\
& \text { I.I } 54\left(63^{\prime} 96 \%\right) \quad 650\left(36^{\prime} \circ 3 \%\right) \\
& \text { I.032 (79'1о\%) } 344(20 \text { ' } 89 \%) \\
& \text { I.542 (100\%) } \\
& 3.189(26,93 \%) \quad 8.650(73 \text { '06\%) } \\
& \text { I.598 (I ' } 29 \%) \quad \text { I0.426 (86'70\%) }
\end{aligned}
$$

Hemos de aclarar, que aunque en este esquema aparece el número de habitantes de la capital, que constituye desde luego la mayor parte de la población urbana de la isla, no ocurre lo mismo con el de una serie de villas como Dajabón, San Rafael, Hincha, Neiba, Azúa y San Juan de la Magua- 
na por desconocerse la proporción señalada. Dado el carácter ganadero de estos centros debieron ser desde luego eminentemente rurales, por la distribución de los hatos en todo el territorio de sus respectivas jurisdicciones, sumando en total un $25 \%$ de la población de Santo Domingo en esta época. Por todo ello hemos de tener en cuenta, que la proporción entre ambos tipos de población que hemos señalado se refiere sólo a algunos lugares, siendo lógico pensar que el porcentaje de rurales sea bastante superior al que hemos indicado.

En cuanto a la distribución de la población en los distintos lugares de la isla, hay variaciones importantes a lo largo de la segunda mitad del siglo XVIII. Para estudiar esta evolución hemos dividido todo el territorio en varias zonas, ayudándonos del esquema seguido en el estado de la población de 1812 antes mencionado, con alguna variación necesaria para la mejor comprensión del problema:

Partido de la capital. - Comprende Santo Domingo, el curato de los Llanos, el del río Ozama, la villa de San Carlos, y las parroquias de San Lorenzo de Minas, los Ingenios, el río Haina, $\mathrm{y}^{\prime}$ el valle de Bani.

Partido del este.-Comprende las poblaciones del Seibo, Higuey, Santa Bárbara de Samaná, Sabana de la Mar, San Juan Bautista de Bayaguaná y Monte de Plata, con el anejo de la villa de Boyá.

Región de la Vega Real.-Contiene tres poblaciones: Santiago de los Caballeros, Concepción de la Vega y Cotui.

Partido del sur.-Se encuentran en él las villas de Azúa, San Juan de la Maguana y Neiba.

Costa norte.-Comprende las ciudades de San Felipe de Puerto de Plata y Montecristi.

Zona occidental.-Abarca las poblaciones de Banica, Hincha, San Rafael de la Angostura, Dajabón, San Miguel de la Atalaya y las Caobas. 
La situación de estas seis regiones en las cuatro fechas de que poseemos noticias sobre la población era la siguiente:

P. de la Capital

P. del Este

La Vega Real

P. del Sur

C. Norte

Z. Occidental

Totales

$$
1740^{48} \quad 1772^{45} \quad 1782-83^{44} \quad I 812^{45}
$$

\begin{tabular}{rrrr} 
I0.866 & 22.600 & 14.059 & 20.376 \\
2.096 & 5.250 & 4.378 & 8.455 \\
8.784 & 13.500 & 25.405 & 21.540 \\
1.260 & 4.100 & 4.309 & 6.179 \\
400 & 1.400 & 3.450 & 3.546 \\
2.400 & 3.150 & $9.36 \mathrm{I}$ & 2.000 \\
\hline 25.806 & 50.000 & 60.962 & 62.096
\end{tabular}

Si observamos este estadillo, veremos que hay una constante clara en toda esta época: el mayor volumen demográfico se encuentra en la capital y sus alrededores, y en la zona de la Vega Real, sobre todo en las ciudades de Santiago de los Caballeros y Concepción de la Vega, por ser la parte más fértil de la isla.

Pero si en I740 tiene lugar la casi concentración de la población en esas zonas, al tiempo que el llamado partido del sur (el suroeste) y la parte occidental permanecen casi despoblados, teniendo en cuenta su extensión, y la costa norte totalmente desierta, si exceptuamos las 400 almas señaladas para Puerto de Plata, en I772 se produce un cambio significativo: la aparición de un volumen importante de habitantes en las regiones mencionadas, sobre todo en la costa norte $y$ en el sur.

Así el partido del sur, que contaba en 1740 con 1.260 almas, pasa a 4.100 en 1772 , incrementándose en un $22539 \%$ a lo largo de los 32 años señalados.

La costa norte por su parte, es el territorio que sufre

42 Ibídem, nota 15.

43 Ibídem, nota 17.

44 Ibídem, nota 11.

45 Ibídem, nota 19. 
proporcionalmente un mayor crecimiento demográfico desde I 740 a I772, elevándose de 400 a 1.400 personas, con una subida del $250 \%$.

En el decenio transcurrido desde I772 a I782-83, aún es más significativo el aumento de población en los lugares antes despoblados, en este caso sobre todo en la parte occidental que pasa de 3. 50 a 9.36r habitantes, con un aumento del I97' $7 \%$ en estos diez años. De este modo, mientras que en r 772 significaba un 6'3\% de la población total de Santo Domingo, en I $782-83$ representará un I 5'357 \% del volumen total de la isla.

En esta misma etapa la costa norte continúa su desarro11 , elevándose su población en un $1_{4} 6^{\prime} 42 \%$.

En el mismo decenio, y según los mismos documentos, la Vega Real pasa de 13.500 a 25.405 almas, con un alza de un 88 ' I I \% ; el sur de 4 . IoO a 4.309 (incremento del 5'o9 \%), mientras que el partido del este desciende de 5.250 a 4.378 personas (descenso del $16,60 \%$ ), y el de la capital de 22.600 a I4.059, con un descenso del 37 '79 \% .

Por muchos errores que puedan contener los distintos estados de población cotejados, es evidente que las regiones de Santo Domingo con un mayor crecimiento demográfico desde I740 a I782-83, son las que antes estaban más despobladas, según podemos observar en el siguiente esquema, aunque la mayoría absoluta de la población siga correspondiendo a Santo Domingo y la Vega Real.

INCREMENTO DEMOGRÁFICO POR REGIONES DESDE I 740 A $1782-83$

Regiones

Costa Norte

Zona Occidental

Partido del Sur

La Vega Real

Partido del Este

Partido de la Capital
Incremento total Idem. anual

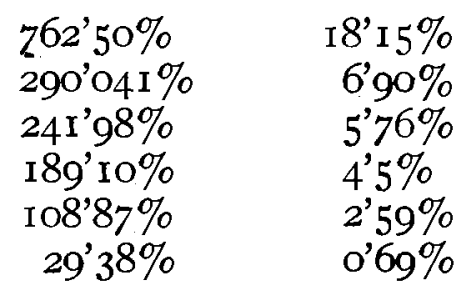



Las causas de este fenómeno son muy claras, y ya hemos hablado de ellas al tratar del desarrollo demográfico en general. Las ciudades de la costa del norte, que fueron abandonadas a principios del siglo XVII, vuelven a fundarse ahora con familias canarias siguiendo la politica de fomento que se intenta durante todo el siglo XVIII. Reaparecen así Puerto de Plata en $\mathrm{I} 736,{ }^{46}$ y Montecristi en $175 \mathrm{I} .{ }^{47}$ Estas poblaciones pronto adquirieron gran auge, y siendo las únicas establecidas en la costa septentrional de la isla, llegaron a tener entre las dos 3.450 habitantes. ${ }^{48}$

La parte occidental de Santo Domingo es, por su parte, la segunda por lo que se refiere al incremento proporcional de la población, y lo es por un motivo fundamental: la presencia francesa en lo que más tarde sería la República de Haití. La necesidad de contener a los franceses en los terrenos que ya habían ocupado evitando un avance mayor, hace surgir un buen número de nuevas poblaciones en las que se reunieron los ganaderos que hasta entonces vivían en hatos dispersos, y acogieron a nuevos pobladores del resto de la isla, ante la perspectiva de un lucrativo comercio con la colonia vecina.

Este es el origen de Dajabón, en un principio simple puesto fronterizo, San Rafael de la Angostura, San Miguel de la Atalaya y Las Caobas, ${ }^{49}$ que irán desarrollándose al amparo del tráfico de ganado con la colonia francesa, hasta que los fenómenos revolucionarios que tienen lugar en ésta como consecuencia de la Revolución Francesa, interrumpe este activo comercio.

Pero a partir de aquí hay un nuevo cambio en la evolución de la población. La Revolución Francesa tuvo un gran impacto en su colonia de Santo Domingo. Por una parte las

46 Rodríguez Demorizi, Emilio: Nueva fundación de Puerto Plata Sociedad Dominicana de Geografia. Vol. VII. Santo Domingo, 1975, pág. 6.

47 Carta de don Francisco Rubio y Peñaranda de 16 de enero de 1752, dando cuenta a la Corte de la fundación de San Fernando de Montecristi, en obedecimiento de la Real Cédula de 18 de mayo de 1749. A.G.I. Santo Domingo, 1.020.

48 Ibídem, nota 11 .

49 Moreau de Saint-Mery, M. L.: Op. cit., págs. 242-245. 
revueltas de los negros haitianos, y por otra la declaración de guerra de la Corona Española a la República Francesa, ocasionaron un movimiento migratorio de los habitantes de las regiones fronterizas hacia lugares más seguros.

Por último, el anuncio de la cesión de toda la isla a los franceses por la $\mathrm{Paz}$ de Basilea, hace que se origine una concentración considerable de personas en la capital, producida por los que se trasladaron a ella a la espera de una embarcación que los transportase a Cuba, según se les había prometido en el mencionado tratado. ${ }^{50}$

De este modo, en I8I2 la población de la capital y sus alrededores había pasado de 14.059 almas con que contaba en $1782-83,{ }^{51}$ a $20.376,{ }^{52}$ con un incremento del 44 '93\%. Mientras la zona fronteriza, que había alcanzado un gran desarrollo demográfico en los años anteriores, vio reducirse los 9.36I habitantes que poseía en $1782-83^{53}$ a 2.000 aproximadamente en $1812,{ }^{54}$ con un descenso del $78^{\prime} 63 \%$.

La variación en la distribución de la población por zonas en los cuatro momentos que hemos podido cotejar sería la siguiente:

\begin{tabular}{|c|c|c|c|c|}
\hline & $I 740$ & $177^{2}$ & $I 782-83$ & $I 8 I 2$ \\
\hline P. de la Capital & $42^{\prime} 10 \%$ & $45^{\prime} 2 \%$ & 23 '06\% & $32^{\prime} 81 \%$ \\
\hline P. de la Vega & $34^{\prime} \mathrm{O} 3 \%$ & $27 \%$ & $4 I^{\prime} 67 \%$ & $34^{\prime} 68 \%$ \\
\hline P. del Este & $8 ' 12 \%$ & I0' $5 \%$ & $7 \times 18 \%$ & I3'6 $\%$ \\
\hline P. del Sur & 4'88\% & $8 ' 2 \%$ & $7 ' 06 \%$ & 9'95\% \\
\hline Costa Norte & I'55\% & $28 \%$ & $5 ' 65 \%$ & $57>1 \%$ \\
\hline P. Occidental & $930 \%$ & $6{ }^{\prime} 3 \%$ & $15 ' 35 \%$ & $3,22 \%$ \\
\hline
\end{tabular}

50 Carta del gobernador don Joaquín García de 29 de junio de 1799 , dando cuenta a la Corte de la estancia del barón de la Atalaya en la capital, al igual que otros muchos habitantes de la zona fronteriza. A.H.N. Estado, 3.394.

51 Ibídem, nota 11.

52 Ibídem, nota 19.

53 Ibídem, nota 11.

54 Ibídem, nota 19. 
Según esto, en cifras absolutas, las zonas más pobladas fueron siempre las antes mencionadas de Santo Domingo y la Vega Real, ya que ambas poseían en todos los años estudiados más del $60 \%$ de la población total de la isla, repartiéndose irregularmente el resto y según los años entre las otras cuatro regiones. La causa de este fenómeno es muy clara, pues son los centros económicos de la Española. Pero mientras que al principio estas dos zonas llegan a contener al $75 \%$ del número total de habitantes de la colonia, en 1782 este porcentaje había descendido al $64 \%$, mientras aumentaba en otras regiones como la fronteriza y la costa norte, para volver más tarde a la situación inicial, con motivo de la guerra con los franceses y la cesión a éstos de Santo Domingo.

\section{Fundación de NUEVAS POBlaciones:}

\section{INMIGRACIÓN CANARIA}

Un factor fundamental para el desarrollo demográfico que tuvo lugar en Santo Domingo en la segunda mitad del siglo XVIII, fue la fundación de nuevas poblaciones, y el restablecimiento de otras que habían sido despobladas con anterioridad.

A lo largo de todo el siglo XVII la isla había ido precipitándose en una profunda decadencia, a la que no fue ajena la real orden de abandonar las ciudades de Montecristi, Puerto de Plata, Bayajá, La Yaguana y San Juan de la Maguana. ${ }^{55}$

Estas poblaciones habían adquirido gran auge a lo largo del siglo XVI, en parte como embarcaderos de los productos procedentes de la Vega Real, y en parte, por el contrabando realizado con cuantas embarcaciones se acercaban a sus costas, especialmente con los holandeses y los portugue-

55 Vid. Utrera, Fray Cripriano de: Op. cit. 
ses. ${ }^{56}$ Este contrabando perjudicaba notablemente a la Real Hacienda, y la única manera que vio el gobierno para acabar con él, fue la despoblación de la costa norte y el este de la isla.

La desacertada orden del abandono de estas poblaciones, tuvo su origen en dos memoriales presentados al Consejo de Indias por un criollo dominicano, Baltasar López de Castro, en el que se proponían los medios para acabar con "los rescates que en la isla española se hacen con los herejes". ${ }^{57}$

En el primero de estos memoriales, fechado en Madrid el 20 de noviembre de 1598, López de Castro pedía el traslado y confinamiento de todo el ganado de la costa norte, en los alrededores de Santo Domingo. En el segundo, insistiendo en su propuesta, abogaba por la despoblación de los terrenos de la llamada banda del norte; es decir, traer los ganados y sus dueños a las cercanías de Santo Domingo, como remedio para el comercio ilícito con los extranjeros. ${ }^{53}$

Cuando Baltasar López de Castro envió sus memoriales al Consejo de Indias, no fueron objeto de la menor atención. Pero más tarde, siendo presidente del mismo don Pedro López de Castro, conde de Lemos, el 23 de abril de I603, emitió un dictamen favorable al proyecto presentado por López de Castro. ${ }^{59}$ La resolución del Rey sobre el asunto, fue que se actuase como mejor pareciera al Consejo, que determinó en sus resoluciones de 22 y 24 de septiembre del mismo año, la puesta en práctica de los citados memoriales. ${ }^{60}$

Para llevar a cabo la despoblación de la Banda del Norte de la isla, "fueron menester fuego y sangre, quemar hogares y haciendas, y ahorcar más de setenta personas. De las I 10.000 cabezas de ganado vacuno manso que habían en ciento veinte hatos, cuando la despoblación comenzó, no se sa-

56 Mac Lean, J. y T. Pina Chevalier: Op. cit., pág. 5.

57 Lugo, Américo: Baltasar López de Castro y la despoblación del norte de la Española. Publicaciones de la Secretaria de Educación. Santo Domingo, 1974, pág. 281.

58 Ibídem, pág. 287.

59 Ibídem, pág. 284.

60 Vid. Utrera, Fray Cipriano de: Op. cit. 
caron más de 8.000 , porque el resto se alzó con el ganado montés; en el camino hacia los nuevos sitios murieron 6.000, y sólo quedaron dos mil..." Por su parte el ganado bravo se perdió por completo. ${ }^{61}$

Las nuevas poblaciones a que se pretendió trasladar a los habitantes de las ciudades abandonadas no prosperaron, ya que muchos de sus pobladores optaron por salir hacia $\mathrm{Cu}-$ ba, ${ }^{62}$ mientras que "abandonadas de esta suerte las costas del norte de la isla de Santo Domingo, los bucaneros, compañeros y afines de los filibusteros, se establecieron y construyeron sus viviendas en aquella costa arrasada". ${ }^{63}$

De este modo, fueron llegando a ella un grupo cada vez más numeroso de franceses, procedentes de la isla de la Tortuga y otras cercanas, que lograron adueñarse del tercio occidental de Santo Domingo, y al mismo tiempo ser reconocidos como vasallos por la Corona francesa.

Esta colonia de franceses adquirió pronto un gran desarrollo, haciendo temer a los españoles por la posesión de sus terrenos. La expansión de este nuevo establecimiento extranjero y las noticias de las fortificaciones que los franceses estaban realizando en él, hizo comprender al gobierno que el único medio de detenerlos era oponerles un fuerte contingente de pobladores, en aquellas zonas que, por estar entonces abandonadas, podían ocupar con mayor facilidad. Con motivo de ello, se sucedieron las representaciones a la Corte por parte de los gobernadores y la Audiencia, solicitando se tomaran las medidas oportunas para la repoblación de la isla.

La repoblación americana a base de canarios era algo frecuente ya desde el siglo XVI, dado el exceso de población de estas islas. Pero la emigración canaria continúa además en los siglos XVII y XVIII, aunque el número de sus habitantes se encontrase ya muy mermado, forzada por el

\footnotetext{
61 Lugo, Américo: Op. cit., pág. 288.

62 Hernández Tapia, Concepción: Op. cit, pág. 15.

63 Mac Lean, J. y T. Pina Chevalier: Op. cit., pág. 6.
} 
Estado. Así, y a pesar de que había medidas anteriores obligando a las Canarias a enviar pobladores a las islas de Barlovento, una real cédula de $\mathbf{1} 697$ permitirá a los canarios embarcar mercancías con destino a América, por un peso de I.0oo toneladas al año. A cambio, debían llevar expresamente a Santo Domingo cinco familias por cada Ioo toneladas, es decir, cincuenta familias al año. ${ }^{64}$

Las peticiones de los dominicanos, tuvieron en esta ocasión como resultado un real decreto de I74r, dirigido a don Domingo de la Guerra, juez del comercio de las islas Canarias, en el que se le manifestaba que:

"Siendo muy notable la falta que hay en la isla española, de familias que la pueblen y beneficien sus tierras, como se reconoce de las varias representaciones de algunos gobernadores de aquella isla, me lo hizo presente el referido mi Consejo de las Indias, en consulta de I 5 de julio del año de mil setecientos y treinta $y$ nueve; en cuya inteligencia he resuelto ordenaros y mandaros (como lo executo), que indispensablemente todos los años y desde el día en que recibiéreis este despacho en adelante, y hasta que otra cosa se os prevenga, embieis a la isla Española y ciudad de Santo Domingo, las cincuenta familias de a cinco personas cada una a que están obligadas esas islas, llevando precisamente los registros que fueren a la Havana o Campeche, las correspondientes al de Caracas y Maracaybo, y al que debe despacharse a Puerto Rico, pagándoles su contingente, para que no se malogre la conducrión íntegra de las cincuenta familias, por quedar Puerto Rico de veinte a veintidós leguas más a Barlovento de la isla Española. Que no concedais ni despacheis licencia a puerto alguno de los del permiso, sin que los dueños de los navíos se obliguen a llevar y entregar a San-

64 Morales Padrón, Francisco: El comercio canario americano. E.E.H.A. Sevilla, 1955, pág. 198. 
to Domingo al presidente y oficiales reales, el número de familias correspondientes al número de sus registros, sin permitir con pretexto alguno que se permute a dinero el transporte de las familias, a excepción de los registros de Puerto Rico, Caracas y Maracaibo como queda previsto..."

Se le ordenaba también al mencionado juez, que se encargase de que se diese "a cada persona un doblón de quatro escudos de plata, y a cada familia dos hazadas, dos hachas, una barra de hierro y quatro cors, y en lugar de los dos machetes que se acostumbran a dar, remitais para cada cincuenta familias doscientas libras de hierro y cincuenta de acero, para que allí se hagan los cien machetes o cuchillos de monte correspondientes a ellas... Y que así mismo se les hagan los gastos menores que causan estas familias en su colección y manutención y en su conducción, y en la de sus herramientas, caxas y colchones hasta ponerlas a bordo de los navíos, cuyos gastos no excederán por cada cincuenta familias de 1.602 pesos...

Encontrarán las familias que fueren todo lo que necesitaren por el primer año, o más tiempo si fuere menester, y que serán bien aloxadas a su llegada, que se las establecerá en terrenos a propósito para las labranzas y cría de ganados, para lo qual se les repartirán las tierras necesarias para solares y peonías, y se les darán por primera vez las semillas y ganados de vientre correspondientes a ambos fines..." 65

Los I.602 pesos que se mencionan en el anterior real decreto debían emplearse en la forma siguiente:

65 Real Decreto de uno de diciembre de 1741, ordenando al juez de Indias de las islas Canarias la remisión de familias pobladoras a Santo Domingo. A.G.I. Santo Domingo, 1.020 . 
Pesos

- Cuatro pesos para cada una de las personas a su salida de Canarias para ropa y preparación de sus equipajes. Para un total de 250 personas que forman las cincuenta familias .............. I.000

- Dos hazadas que se dan a cada familia a 8 reales. IOO

- Dos hachas que se dan a cada familia a io reales.

- Una barra de hierro que se da a cada familia a 20 reales cada una ........................... I25

- Cuatro "cors o tacis" a cada familia a 4 reales. IOO

- Doscientas libras de hierro y 50 de acero .......

- Para los gastos menores al reclutarlas hasta el embarque

Pero esta inmigración canaria costaba mucho más dinero, y las Cajas Reales de Santo Domingo no estaban en condiciones de poder correr con los gastos. Para solucionar este problema, se envió otra real cédula al virrey de México, duque de la Conquista, fechada en Madrid el seis de diciembre del citado afío de I74I, manifestándole la decisión del Rey de enviar a la Española 50 familias de las islas Canarias cada año. Había que asistir a estos nuevos pobladores desde su llegada a la ciudad de Santo Domingo hasta un año después, tiempo que se consideraba suficiente para que establecidos en sus nuevos hogares, pudiesen obtener frutos de la tierra. Era necesario también darles semillas y ganado para la cría, y en fin, todo lo que precisaban para la vida que iban a comenzar. Por ello se ordenaba al mencionado virrey, que enviase al gobernador y a los oficiales reales de Santo Domingo I6.000 pesos anuales, además del situado ordinario correspondiente a la isla. ${ }^{67}$

66 Relación del costo que ha de ocasionar la recolección, manutención y conducción de 50 familias de las islas Canarias a Santo Domingo. Madtid, 1741. A.G.I. Santo Domingo, 1.020 .

67 Real Cédula de reis de diciembre de 1741 dirigida al virrey de Nueva España, ordenándole enviase dinero a Santo Domingo con el situado ordinario, para mantener allí a 50 familias canarias cada año. A.G.I. Indiferente General, 3.093. 
Estos I6.000 pesos debían ser empleados en la siguiente forma:

- Para la manutención de las $25^{\circ}$ personas de las 50 familias durante un año a un real de plata por persona y día .........

- Para su curación si la necesitasen y algún otro gasto extraordinario ............

- Para su transporte desde la capital a su punto de destino a I2 pesos por familia ...

Pesos Reales

- Para la congrua de dos curas para dos poblaciones de 25 familias .................

- Para dos vacas de vientre para cada familia .................................... 200

- Para 5 puercas de vientre por familia ... 75

- Para cinco gallinas y un pollo que se deben dar a cada cinco personas ............

- Para una yegua y un caballo para cada familia ...................................

- Para una fanega de maíz para sembrar a cada una ............................... 75

- Para una arroba de arroz a cada familia. $\quad$ I50

- Para la manufactura de 100 machetes ... $\quad 50$

- Para costear 50 casas y dos iglesias ... I.700

- Para los ornamentos de esas dos iglesias. $\quad$ I 50

- Para mantener a IOO hombres que habrán de emplearse en el desmonte y la tala de los sitios elegidos para las nuevas fundaciones

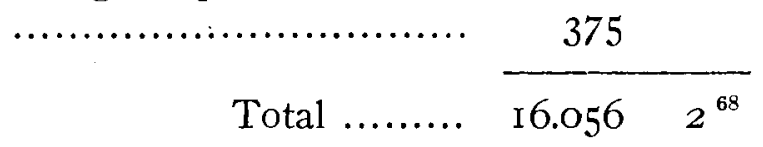

68 Madrid, 1741. Relación de la distribución que ha de hacerse del dinero que debe mandar a Santo Doningo el virrey de Nueva España para la manutención de los nuevos pobladores. A.G.I. Santo Domingo, 1.020. 
A pesar de estas facilidades que se pretendieron dar a los nuevos pobladores, la inmigración canaria a Santo Domingo no fue tan numerosa como se pretendía en las reales órdenes expedidas sobre el asunto. A1 parecer, casi ningún año se consiguió enviar allí las 50 familias que se establecían en ellas.

En carta de 3 de febrero de I775, don Bartolomé de Casabuena, juez de Indias de las Islas Canarias, en cumplimiento de lo que se le había ordenado por real cédula de I9 de mayo de I774, envió a la Corte un informe de las familias de aquellas islas, que habían salido de ellas con destino a los distintos puertos americanos desde 17 I 8 a 1764.

Según esta certificación, desde I748 a I764, marcharon desde Canarias a Santo Domingo unas I.640 personas, en lugar de las 4.000 que debían haberlo hecho en cumplimiento de las reales órdenes (250 al año), tal y como observamos en el siguiente cuadro:

Total

Años Embarcaciones Familias personas

I749 $\left\{\begin{array}{lll}\text { B. Sta. Bárbara } & 2 & \text { IO } \\ \text { F. N. Sra. del Rosario } & 4 & \text { 2O }\end{array}\right.$

I750 F. N. Sra. de la Soledad 5 y 3 personas 28

I75 I $\left\{\begin{array}{lll}\text { B. Sta. Bárbara } & 2 \text { y I persona } & \text { I I } \\ \text { N. Sacramento } & 8 & 40 \\ \text { N. N. Sra de los Remedios } & 4 & 20\end{array}\right.$

F. N. Sra. del Rosario $\quad 4 \quad 20$

r752 F. N. Sra. de la Estrella 4 y I persona 2I

F. Corazón de Jesús 4 y 2 personas 22

P. S. Antonio de Padua 2

IO

N. N. Sra. de las Angustias 22 y 2 personas $\quad$ I 12

I753 F. S. Corazón de Jesús 4 y 2 " 22

F. N. Sra. del Rosario 3 I5

I754 $\left\{\begin{array}{llr}\text { B. N. Sra. del Rosario } & \text { I } \\ \text { F. San Xinés } & 7 \text { y I persona } & 56\end{array}\right.$ 


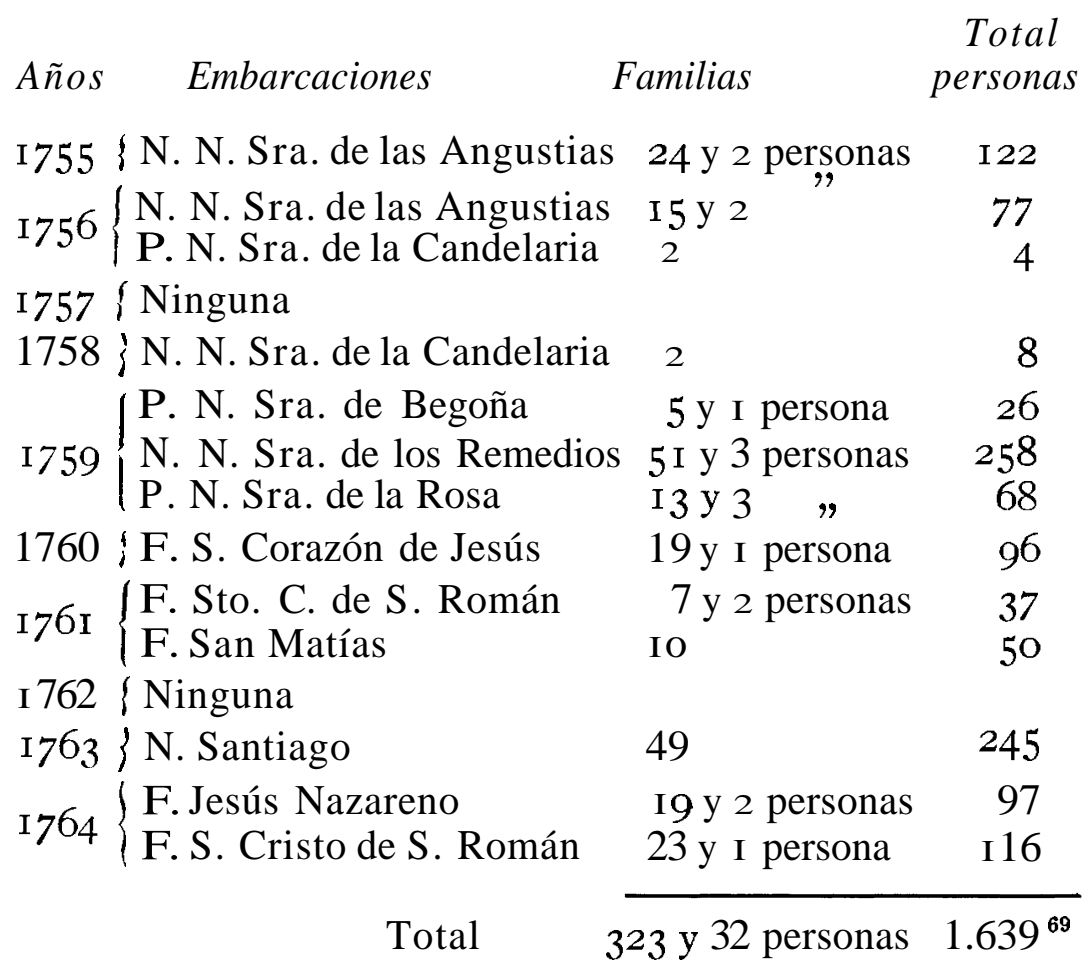

Según esto, en 1759 se sobrepasaron las $25^{\circ}$ personas que debían embarcarse para Santo Domingo (352 nuevos pobladores), y en 1763 casi se alcanza la cifra propuesta, con 245 ; pero el resto de los años ofrece un número muy inferior, y en dos de ellos no emigró ningún canario a aquel lugar.

Se aprecia también que no sólo se enviaron familias de cinco personas como se había ordenado expresamente, sino también otras sueltas, sin ninguna relación entre sí. A este respecto, el gobernador don Pedro Zorrilla de San Martín escribía a la Corte, con fecha de 3 de marzo de I750, sobre lo importante que era para la repoblación de la isla y la fundación de las nuevas poblaciones que se pretendían,

\footnotetext{
69 Certificación del juez de Indias de las Islas Canarias, sobre familias de aquellas islas que marcharon a América desde 1718 a 1764. A.G.I. Santo Domingo, 1.020.
} 
que se enviasen sólo grupos que formasen verdaderas familias, "sin incluirse ninguna otra volante o accidental, porque de éstas es muy rara la que subsiste, y apenas alguna que se dedique a las labores de su destino".

A partir de 1764 el problema se agudiza, pues el virrey de México dejó de enviar a Santo Domingo los 10.000 pesos consignados en el ramo de familias canarias, arguyendo que, del dinero enviado hasta entonces con ese fin, había un excedente importante, por no haber llegado a Santo Domingo las familias que establecían las reales órdenes. Con motivo de ello, el entonces gobernador don Manuel de Azlor y Urríes, pidió al Consejo se terminasen los envíos de pobladores canarios, afirmando que se encontraba sin fondos para su atención. ${ }^{71}$

La Corte entre tanto sigue insistiendo ante el juez de Indias de Canarias, previniéndole de nuevo por una real orden de 31 de agosto de 1765, que ante los desajustes producidos por la falta de remisión de pobladores a Santo Domingo, haga que se envíen las $5^{\circ}$ familias establecidas en el reglamento de 1718 y posteriores reales órdenes. ${ }^{72}$

Aunque la inmigración canaria no supuso para Santo Domingo el incremento de pobladores que los gobernantes esperaban de ella, fue la base de la creación de una serie de nuevas poblaciones, y de la reedificación de algunas de la costa del norte y la parte occidental que habían sido abandonadas a principios del siglo XVII. Surgen así de nuevo San Felipe de Puerto Plata, San Juan de la Maguana, San Fernando de Montecristi, y otras nuevas como Santa Bárbara de Samaná y Sabana de la Mar.

El primer establecimiento que se repuebla con las nuevas familias fue la villa de San Carlos, formada por los primeros labradores canarios que llegaron a Santo Domingo

70 Carta del gobernador don Pedro Zorrilla de San Martín de seis de marzo de 1750, solicitando a la Corte que sólo se envíen a Santo Domingo familias de cinco personas, y no pobladores sueltos. A.G.I. Santo Domingo, 1.020.

71 Moya Pons, Frank: Op. cit., pág. 290.

72 R. O. de 31 de agosto de 1765 dirigida al juez de Indias de las Islas Canarias. A.G.I. Santo Domingo, 1.020. 


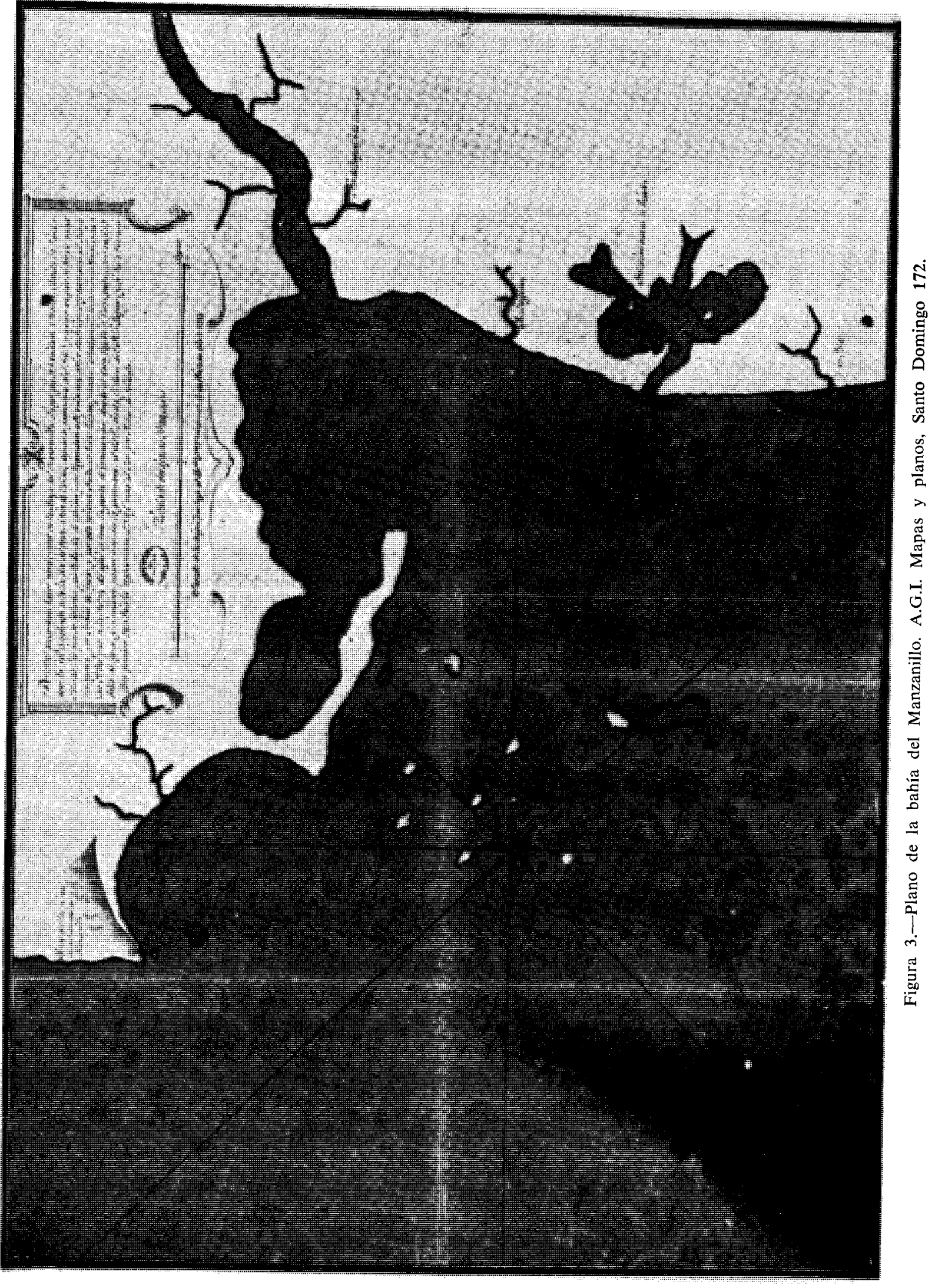




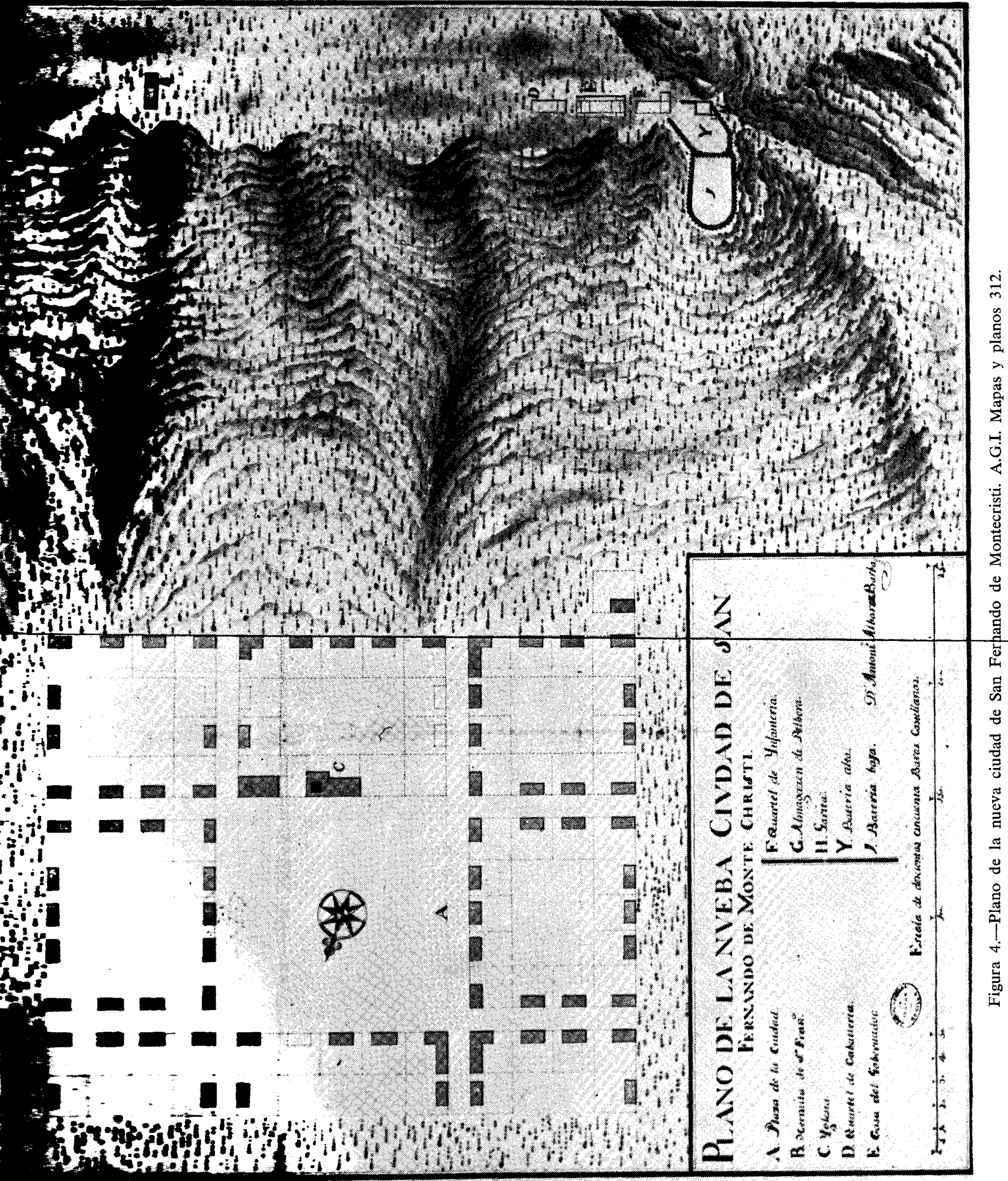


para iniciar la repoblación, por lo que se la conoció también con el nombre de villa de los isleños. ${ }^{73}$

Mucho tiempo después, el 22 de julio de 1736 , se inicia la nueva fundación de San Felipe de Puerto de Plata por el gobernador don Alfonso de Castro y Mazo, a base de familias canarias llegadas exclusivamente con ese fin. ${ }^{74}$

E1 I8 de mayo de I749, siguiendo esta política de fundaciones, el Rey ordenaba al gobernado de Santo Domingo el incremento de San Felipe de Puerto de Plata, y la creación de dos nuevas poblaciones, una en la bahía de Manzanillo, y otra en el golfo de Guanábano. En respuesta a estas reales órdenes, durante el gobierno interino de don José Sunyer y Basteros se inició el desmonte de la bahía del Manzanillo. ${ }^{75}$

El gobierno de don Francisco Rubio y Peñaranda, supuso un gran impulso por lo que se refiere a la fundación de poblaciones. Nada más tomar posesión de sus cargos, inició la de San Fernando de Montecristi. El lugar elegido para ella había sido la bahía del Manzanillo, pero no se consideraron buenos aquellos terrenos y se estableció un poco más al norte, también al lado del mar. Sobre esta población, el propio gobernador, en carta de 16 de enero de I752, manifestaba a la Corte haberse hecho cargo "de la importancia de su fomento, no sólo por la de que se pueble esta isla, sino también que servirá a que cesen y cedan las continuas pretensiones de los franceses a su extensión por aquella costa". ${ }^{76}$ La nueva población fue por algún tiempo la más occidental de las del norte de la isla, y por consiguiente la más

73 Carta del gobernador don Pedro Zorrilla de San Martín de seis de marzo de 1750, dando cuenta a la Corte de haber establecido transitoriamente cn la villa de San Carlos a las nuevas familias pobladoras. A.G.I. Santo Domingo, 1.020.

74 Ibídem, nota 46 , pág. 6.

75 Carta del gobernador interino de Santo Domingo, don José Sunyer, de cinco de mayo de 1751, dando cuenta a la Corte de la fundación de nuevas poblaciones. A.G.l. Santo Domingo, 942.

76 Carta del gobernador don Francisco Rubio de 16 de enero de 1752, informando a la Corte de la fundación de San Fernando de Montecristi. A. G,I., Santo Domingo, 1.020 . 
cercana a los franceses, que durante mucho tiempo habían intentado avanzar sobre aquellos terrenos.

También se comenzó la fundación de Santa Bárbara de Samaná. Esta población se había proyectado en un principio para el golfo de Guanábano, y con este fin, don Francisco Rubio envió a reconocer la bahía de Samaná al ingeniero Lorenzo de Córdoba. Tras un estudio del terreno, el ingeniero eligió el lugar que consideró más apropiado, y levantó un plano de lo que sería el nuevo establecimiento, que fue enviado a la Corte. Y según este proyecto, se aprobó por el Consejo que se fundase la mencionada ciudad de Santa Bárbara de Samaná en el puerto del Carenero Grande, en lugar de donde se pensó en un principio. Se inició así la fundación en $1756^{77}$ a base de 48 familias procedentes de las Canarias, que se desarrollaron rápidamente. ${ }^{78}$

Por último, se fundó durante su gobierno la villa de San Juan de la Maguana, con vecinos de la cercana villa de Azúa y otros que vivían en el valle de San Juan, pero sin formar un establecimiento firme. El lugar elegido para esta nueva población se encontraba muy cerca de donde estuvo la antigua ciudad del mismo nombre.

$\mathrm{Su}$ sucesor en el cargo, don Manuel de Azlor y Urríes, se dedicó a fomentar las fundaciones del gobierno anterior y a emprender otras nuevas como la de Sabana de la Mar, en la bahía de Samaná.

En carta de I 5 de enero de 1760, Azlor daba cuenta a la Corte, de que habiéndose destinado Ioo familias canarias para la nueva fundación de Santa Bárbara de Samaná, según una real orden de 18 de mayo de I749, encontró a su llegada a la isla 48 familias ya establecidas en ella; y habiendo llegado dos embarcaciones más de Puerto Rico con nuevas familias pobladoras, había separado 40 de ellas con

77 Rodríguez Demorizi, Emilio: Samaná pasado y porvenir. Sociedad Dominicana de Geografía. Santo Domingo, 1973. Vol. III, pág. 16.

78 Carta de! gobernador don Manuel de Azlor de 15 de marzo de 1760 dando cuenta a la Corte del estado de las nuevas fundaciones. A.G.I. Santo! Domingo, 1.011. 79 Peguero, Luis Josep: Op. cit., tomo II, págs. 13-14. 


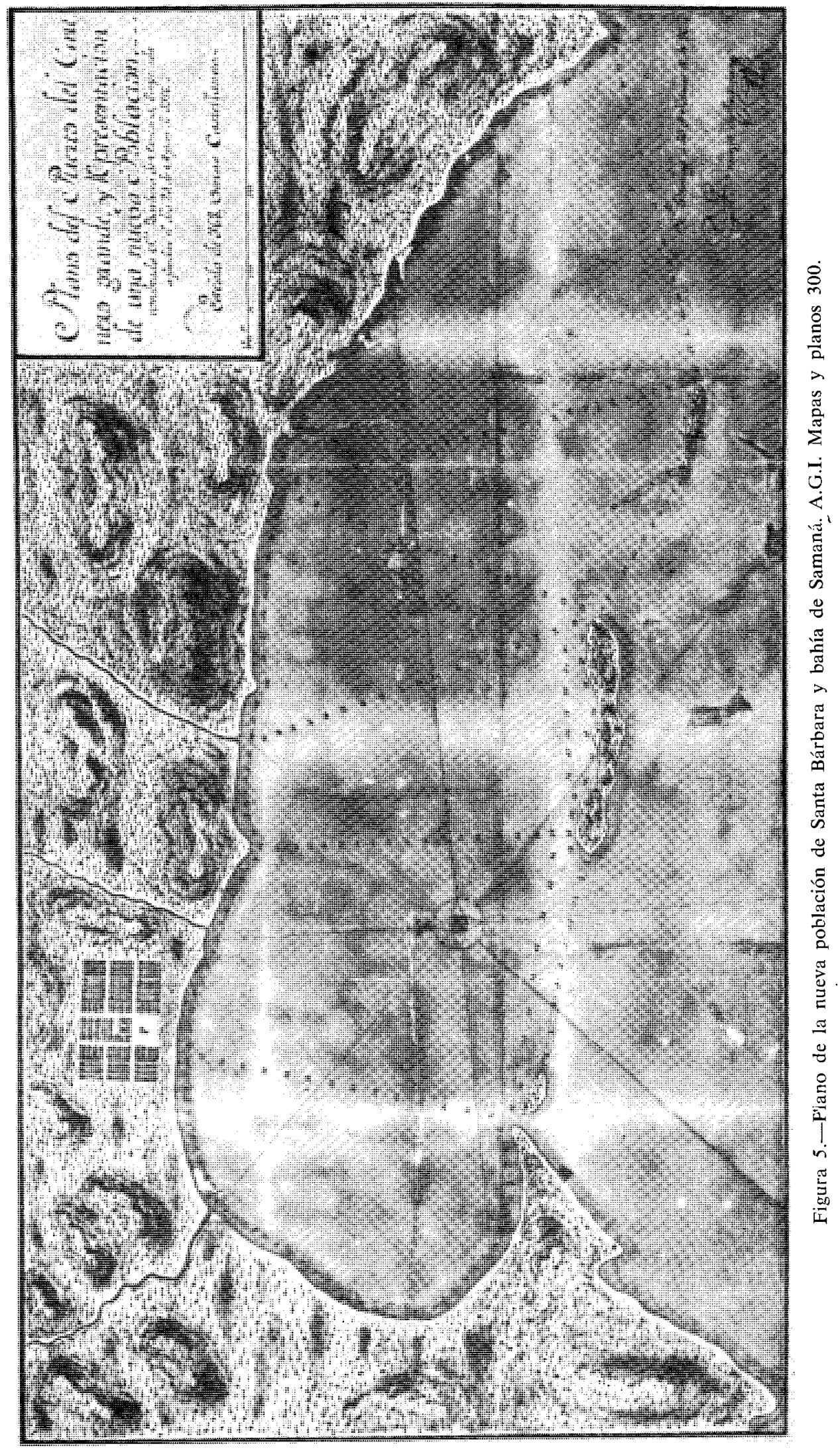


destino a la creación de una nueva población, en el lugar denominado Sabana de la Mar. Se encontraba este paraje frente a Santa Bárbara, al otro lado de la bahía, y según el gobernador, debía servir de auxilio a aquella, "Siendo éste el lugar más inmediato a esta plaza, para que se tenga con ella prompta comunicación, con algunas canoas para el comercio y transporte de víveres, respecto de no aver camino avierto que lo facilite con la parte opuesta de la villa de Cotuy, y ser grandes y difíciles las providencias que se pudieran tomar para dársele..." 80

Poco tiempo después, el 2 I de febrero de I761, don Manuel Azlor informaba al Consejo, que al poco tiempo de tomar posesión del gobierno de Santo Domingo pasó a reconocer la boca del río Haina, a tres leguas de la capital, considerando la importancia de fundar una población en aquel territorio. Para ello, el gobernador pensaba trasladar a aquel lugar 50 familias canarias de las destinadas a Puerto de Plata, por pensar que allí no eran tan necesarias. A su juicio, debía establecerse en la Boca del mencionado río un destacamento de tropa, que junto con los pobladores señalados contribuirían a la mejor defensa de la capital, y a la lucha contra el contrabando. La respuesta a este plan no salió del Consejo hasta iz64. En ella se comunicaba a don Manuel Azlor que, aunque su propuesta podía tener grandes ventajas, adolecía también de graves defectos que era preciso evitar, por lo que debía suspender la fundación y hacer un nuevo reconocimento en aquel lugar, para que el Consejo, tras un detenido examen, llegara a un dictamen definitivo. ${ }^{81}$

A esto respondió el gobernador que habían sido muchos los reconocimientos hechos, y cada día se convencía más de la necesidad de esa fundación, aparte de haberse empleado ya

80 Carta del gobernador don Manuel de Azlor de 15 de enero de 1760, dando cuenta a la Corte de la fundación del pueblo de Sabana de la Mar. A.G.I., Santo Domingo, 1.011.

81 Carta del gobernador don Manuel de Azlor de 21 de febrero de 1761, informando a la Corte de la necesidad de crear una población en la boca del Haina y resolución real sobre e! asunto de 28 de enero de 1764. A.G.I. Santo Domingo, 1.018. 
en sus obras I 5.745 pesos, que resultarían tirados si el proyecto se abandonaba. ${ }^{82}$

Pero a pesar de su insitencia no tuvo éxito en su empresa. Se construyó en la boca del río Haina una batería de defensa, pero la población que el gobernador pretendía no prosperó.

No ocurrió lo mismo con sus intentos de creación de nuevas poblaciones en la frontera occidental. Allí, lindando con la zona ocupada por los franceses, se fundó San Rafael de la Angostura con familias procedentes de las islas Canarias, y la villa de Neiba, con varios vecinos de la de Azúa y los pobladores de aquel valle, que hasta entonces vivían en hatos dispersos sin tener una población propiamente dicha. ${ }^{83}$

Otra fundación importante de esta época fue la de Las Caobas, también en la zona fronteriza, y que en un principio fue un anejo de la villa de Banica. En 1768, don Fernando de Espinosa, capitán de caballería de la costa del sur. envió un memorial al gobernador solicitando se le permitiese fundar un pueblo en el paraje conocido como Las Caobas. Don Manuel de Azlor, tenaz en su idea de poblar toda la frontera con la colonia francesa, concedió inmediatamente la licencia correspondiente para ello y la fundación se inició. A continuación informó a la Corte sobre el asunto, rogando se aprobase su determinación y se concediese al nuevo pueblo el título de villa con el nombre de Nuestra Señora de la Anunciación y San Gabriel de las Caobas. El Consejo no puso ningún reparo al proyecto y el nuevo establecimiento prosiguió.

También durante los años del gobierno de don Manuel de Azlor se pobló Dajabón, en el extremo norte de la frontera, aunque no consiguió para sus vecinos el título de vi1la. Dajabón era el centro de la llamada guardia del norte, encargada de la vigilancia de aquella parte de la frontera

\footnotetext{
82 Rodríguez Demorizi, Emilio: Relaciones históricas..., vol. III, págs. 331-333.

83 Peguero, Luís Josep: Op. cit., tomo II, pág. 14.

84 Carta de don Manuel de Azlor de 31 de mayo de 1768 sobre una petición de don Fernando de Espinosa para fundar una nueva población, e informe del Consejo de Indias de 17 de noviembre del mismo año. A.G.I. Santo Domingo, 979.
} 
y su capitán, el teniente coronel don Gaspar de Leoz y Echalas, envió un memorial al gobernador solicitando se le concediese el grado y sueldo de coronel de caballería y la comandancia de la frontera del norte. Iba acompañado de otro de los habitantes de aquel distrito, pidiendo que se crease un pueblo en el mencionado paraje, encargándose el mando de él a don Gaspar de Leoz y Echalas. El gobernador los envió a la Corte con un informe favorable al proyecto, por considerar que la nueva villa, que se erigiría con el nombre de San Joaquín de Dajabón, significaría una fuerte barrera contra los intentos de los franceses de extender sus territorios.

Después de estudiar el asunto, el fiscal del Consejo se manifestó partidario de que se concediese a Leoz el grado de coronel y la comandancia de la frontera del norte. Pero respecto a la villa que pretendía el gobernador que se fundase, afirmó que lo que los vecinos habían solicitado en su memorial no era su constitución en población civil, sino "en plaza fronteriza con los franceses, y a sus vecinos, el privilegio militar que como a tales soldados fronterizos les corresponde, declarándolos exentos de toda jurisdicción ordinaria", y éto, a su juicio, era impracticable. Sin embargo, antes de tomar una decisión definitiva, aconsejó que era conveniente solicitar nuevos informes sobre el tema al gobernador, para determinar a favor o en contra del proyecto con un mayor conocimiento de causa. A los informes que se le pedían contestó don Manuel de Azlor el i3 de octubre de 1769, que el mencionado pueblo, por estar separado de los franceses sólo por el río Dajabón, serviría para contener las continuas tentativas de éstos para extender sus posesiones. Pero la Audiencia, en carta fechada en noviembre del mismo año, se mostraba contraria a ello, por considerar que lo único que pretendía el vecindario, era una mayor facilidad en el contrabando que continuamente realizaban con los franceses. ${ }^{85}$

85 Carta del gobernador don Manuel de Azlor de 31 de mayo de 1768, apoyando una instancia para la funđación de una nueva población en Dajabón, y expediente promovido con este motivo. A.G.I. Santo Domingo, 979. 
Es difícil saber si tenía razón el gobernador o la Audiencia, aunque lo probabable es que ambos tuvieran parte de ella. La nueva población evitaría por una parte que los franceses avanzasen por aquella zona, pero al mismo tiempo, significaba un nuevo foco de contrabando, y quizás más importante que los existentes en aquellos momentos. Pero independientemente de la decisión del Consejo de Indias y del Rey, la nueva población se creó. No fue una fundación oficial, pero los numerosos habitantes de aquella zona, dedicados en su mayor parte a la ganadería, fueron dando forma y cada vez mayor auge a su establecimiento, al amparo del intenso tráfico de ganado que realizaban con la colonia francesa. Sin embargo, no es hasta I776 cuando Dajabón, que por el intenso comercio que ya hemos señalado había prosperado considerablemente, es erigida en parroquia y separada de la jurisdicción de la de Santiago, a la que hasta entonces había pertenecido su territorio. ${ }^{86}$

La última fundación de la etapa de don Manuel de Azlor y del siglo XVIII, fue la de San Miguel de la Atalaya, también en la frontera occidental, que fue la población española más cercana a los establecimientos franceses. La creación de este nuevo pueblo tuvo lugar gracias a don José Guzmán, teniente coronel de milicias, quien dentro de sus tierras y a costa de su dinero, creó la mencionada población con el apoyo del gobernador. Por esta fundación se le concedería poco después a don José Guzmán el título de Barón de la Atalaya, mientras que el pueblo lograría en $1778 \mathrm{su}$ reconocimiento como villa. ${ }^{87}$

Así pues, los esfuerzos realizados por lo que se refiere a la fundación de nuevas poblaciones dieron su fruto. En I736 había solamente I I poblaciones propiamente dichas en toda la parte española de la isla: Santo Domingo, Monte de Plata, San Juan Bautista de Bayaguaná, Seibo, Higuey,

86 García, José Gabriel: Op. cit., tomo I, pág. 229 .

87 Carta del gobernador don Manuel de Azlor de 31 de mayo de 1768 sobre la fundación del pueblo de San Miguel de la Atalaya y expeđiente originado con este motivo (1768-78). A.G.I. Santo Domingo, 1.005 . 


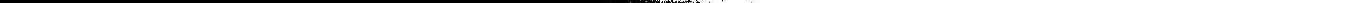


Cotui, La Vega, Santiago, Hincha, Banica y Azúa, algunas de ellas escasamente pobladas. De ellas dependían algunos curatos que no eran sino poblados dispersos, como la villa de Boyá, el valle de San Juan, etc.

Cuando se realizó la entrega de la colonia española a los franceses, habían pasado a ser 21, incrementándose pues su número casi en un IoO \%, con las io nuevas fundaciones que hemos señalado.

\section{Sociedad y COSTUMBRES}

Es muy poco lo que sabemos de la estructura social y las costumbres de los dominicanos del siglo XVIII, y en su mayor parte, la noticias que sobre ello tenemos proceden del testimonio de un francés de aquella época, Moreau de SaintMery, que ya hemos citado anteriormente, y que vivió durante algún tiempo en la isla, y visitó con gran atención la parte española.

Desde luego la población de Santo Domingo, como en general la del resto de América, constituía una sociedad heterogénea, formada por una serie de estratos claramente diferenciados.

A su cabeza se encontraba una aristocracia formada por el gobernador, los altos funcionarios y oficiales de la tropa, y las antiguas familias de la isla, junto con el alto clero.

En un segundo grupo se encontrarían los comerciantes, profesionales libres, y los pequeños propietarios de tierra.

Un poco más abajo, los pequeños comerciantes y todos aquellos que ejercían oficios mecánicos, los artesanos.

A continuación, una serie de vendedores a pequeña escala conocidos con el nombre de regatones, en su mayoría negros y pardos libres, y en último lugar los esclavos. ${ }^{88}$

Dentro del primer grupo hay que distinguir entre la aristocracia peninsular por un lado y la criolla por otro. 
Los primeros fueron en todo momento los representantes del poder político en la isla, pero el hecho de vivir del sueldo correspondiente a su empleos, aunque éste en algunos casos fuese muy elevado, impidió a muchos de ellos que ese poder político fuese acompañado por el económico. Otros, sin embargo, se convirtieron en propietarios de tierras, pasando de este modo a formar parte de los hacendados. ${ }^{89}$

Respecto a los criollos, eran en su mayoría los descendientes de las primeras familias que llegaron a Santo Domingo. En sus manos se concentraban las mayores extensiones de terrenos, que dedicaron casi siempre a la ganadería.

Respecto a la propiedad de la tierra, en principio ésta pertenecía a la Corona, que hizo concesiones a sus súbditos. El gobierno estableció una serie de normas sobre la extensión que debían tener estas concesiones; pero dentro de los límites marcados, se hicieron repartos según el prestigio o dinero de los pobladores. Esto, unido a algunas usurpaciones ilegales, produjo en toda América un estrato social integrado por dueños de latifundios más o menos extensos, una aristocracia criolla descendiente de los primitivos conquistadores y pobladores. $^{90}$

Este grupo tenía el poder económico y compartía al mismo tiempo con los peninsulares el político, a través de los cargos de los distintos Cabildos de la isla, algunos de los cuales llegaron a ser verdaderos feudos de determinadas familias. Dentro de los Cabildos había dos tipos de cargos: los que se obtenían por elección y los que se conseguían a través de una subasta pública, como por ejemplo el de regidor, que de este modo eran otorgados al mejor postor. Así, y aunque la ley $5 .^{\mathrm{a}}$, título Io, del libro $4 .^{\circ}$ de la Recopilación de Leyes de Indias, prohibía que dentro de un Ayuntamiento ocupasen puestos personas de la misma familia, esto sólo se observaba por lo que se refiere a los cargos electivos, ad-

89 Expediente formado sobre la fundación de una población en Dajabón, 1768-1771. A.G.I. Santo Domingo, 979.

90 Konetzke, Richard: Colección de documentos para la historia de la formación social de Hispano-América, 1493-1810. C.S.I.C., Madrid, 1953, vol. I, págs. X-XII. 
judicándose los otros a los que hicieran una oferta mejor, que debieron ser siempre los mismos, los miembros de las familias acautialadas. ${ }^{91}$ De este modo cada población tuvo sus familias principales, de las que salieron alcaldes y regidores repetidas veces, y que en ningún momento consintieron que nadie extraño a ellas formase parte de los Concejos. ${ }^{92}$

Es imposible con la documentación con que contamos, conocer el monto de las fortunas de la aristocracia. Tenemos algunas noticias de los salarios de algunos altos funcionarios del Rey, dentro de los cuales hay gran variedad. Así, el gobernador tenía asignados 55.147 reales y dos maravedíes al año en I768; seguía a éste en la cuantía de los salarios el teniente del Rey, con 24.000 reales anuales, seguido de los oidores de la Audiencia con I7.647 y del fiscal de la misma con $14.847 \cdot{ }^{93}$

Pero por lo que se refiere a las familias propietarias, ya hemos dicho que su riqueza se basaba en la posesión de tierras, dedicadas a la agricultura o a la ganadería según las zonas, y en la posesión de esclavos, pero no hemos podido comprobar la extensićn de esas propiedades ni su valor real.

Por lo que respecta al clero, el problema se hace aún más difícil. Su poder económico era en teoría escaso por lo que se refiere a sus rentas. Pero al margen de ellas, la Iglesia recibía importantes cantidades por bautizos (unos Io reales cada uno), matrimonios (43 reales), etc. ${ }^{94}$

El segundo grupo lo podríamos considerar como una elevada clase media actual. Estaría formada por los comerciantes importantes, los miembros de las profesiones liberales y los pequeños propietarios de tierras, como ya hemos señalado. Los comerciantes de cierta importancia no debie-

91 Informe del Cabildo de la ciudad de Santo Domingo de 27 de enero de 1771, sobre la acumulación de los cargos en determinadas familias y resolución del Consejo de Indias de agosto del mismo añc. A.G.I. Santo Domingo, 983.

92 Informe del Cabildo de la ciudad de San Fernando de Montecristi de nueve de julio de 1776. A.G.I. Santo Domingo, 989.

93 Entrada y salida de caudales en las Cajas Reales de Santo Domingo en 1768. A.G.I. Santo Domingo, 1.048 .

94 Ibídem, nota 11. 
ron ser muy numerosos en Santo Domingo, a juzgar por su escasa vida mercantil, y en su mayoría se debían encontrar en la capital, el único puerto legal de la isla durante muchos años. Los miembros de las profesiones liberales fueron también muy escasos: los ingenieros, que eran siempre militares, escribanos, médicos y una serie de funcionarios de la Audiencia y los Cabildos. Su situación social debió ser importante, pero su poder adquisitivo era considerablemente inferior al del primer grupo, aun dentro de una gran variedad. Así el ingeniero de la plaza de Santo Domingo tenía un sueldo de 8.000 reales al año en I 768 , el oficial mayor de la Contaduría 2.400, el tesorero de la Real Hacienda 8.823, etc. ${ }^{95}$

Seguiría a éstos una clase media baja, formada por pequeños comerciantes y artesanos. Social y políticamente la representación de este grupo era nula, al igual que su poder económico, aunque sus salarios en algunos casos casi se acercaban a los del estrato anterior. Así, un maestro carpintero cobraba hacia I 758 unos 120 reales al mes (I.I 52 al año), sueldo desde luego cercano al de algunos profesionales libres, y que en algunos casos lo superan como al del juez de media annata, que percibía sólo i.096 reales anuales. ${ }^{96}$

El cuarto grupo, integrado en su mayor parte por los llamados "regatones", debió tener un nivel de vida netamente inferior a los anteriores. Eran vendedores al por menor de productos de primera necesidad como pan, frutas, etc., así como los llamados "pulperos". Este grupo al parecer era muy numeroso, hasta el punto de que los Ayuntamientos intentáron reducirlos restringiendo la expedición de licencias, sin las cuales no podrían dedicarse a estos menesteres.

Por último nos encontramos con los esclavos, la mayoría de ellos dedicados a los trabajos del campo, y que constituyeron un grupo importante en cuanto a su número, aun-

\footnotetext{
95 Cuentas de Jas Cajas Reales de Santo Domingo en 1768. A.G.I. Santo Domingo, 1.048 .

96 Entrada y salida de caudales en las Cajas Reales de Santo Domingo desde 1754 a 1760. A.G.I. Contaduría, 1.069-A y B.
} 
que mucho menos que en otras partes del Caribe y desde luego que en la colonia francesa vecina.

Hay que señalar, que la estratificación social en Santo Domingo estuvo siempre unida al pigmento. La población blanca fue la que integró las clases más elevadas y retuvo en todo momento tanto el poder político como el económico.

Por debajo de ellos estaban los mestizos, muchos de los cuales llegaron a ser comerciantes y propietarios e incluso considerados como blancos. "Es también rigurosamente cierto, que la mayoría de los colonos españoles son mestizos, que tienen todavía más de un rasgo africano que los traiciona". ${ }^{97}$

A este respecto hemos de decir, que aunque tradicionalmente se consideran mestizos al producto de la mezcla de blanco e india o viceversa, ${ }^{98}$ en Santo Domingo se aplicaba este nombre en el siglo XVIII a todo el que no era blanco por completo. En la Española del siglo XVIII no quedaban indios ni mestizos de este origen, y el nombre se empleó para designar al fruto de la unión de blancos y negras, aunque en un grado ya lejano.

Los mulatos, en sus distintos grados, debieron constituir pues el grupo más numeroso de la población dominicana y los blancos llegaron a temer por la importancia que estaba adquiriendo, de modo que en las ordenanzas que se formaron por orden del Rey en I784 para el "gobierno político y moral de los negros", las antiguas familias blancas decidieron poner una serie de cortapisas para frenar su desarrollo. Hacemos referencia desde luego al Código formado para el gobierno económico, político y moral de los negros creado en $1784 .{ }^{99}$

En este Código, que no llegó nunca a ponerse en práctica, se establecía la división de los negros en libres y esclavos. Los libres a su vez estarían integrados por los negros,

97 Moreau de Saint-Mery, M. L.: Op. cit., págs. 93-94.

98 Pêrez de Barradas, José: Los mestizos de América. Cultura Clásica y Moderna. Madrid, 1948, pág. 174.

99 Vid. Malagón Barceló, J.: Op. cit., nota 24. 
mulatos, pardos, cuarterones y mestizos. Para evitar la rápida incorporación a determinados puestos de la sociedad de estos mulatos libres, se pretendió que se implantara como ley que sólo en el sexto grado de generación legítima, los pardos, cuarterones y mestizos pudiesen ser considerados como blancos a todos los efectos. Del mismo modo, se intentaba prohibir que todo pardo tercerón pudiese ejercer las denominadas profesiones mecánicas, que quedarían reservadas a los blancos, cuarterones y mestizos. Tampoco podrían dedicar a sus hijos a las ciencias y empleos públicos, sino que debían continuar la profesión de sus padres hasta la sexta generación de color. ${ }^{\text {too }}$

Por debajo de este grupo de "mestizos" con toda su variedad, se encontraban los mulatos y negros libres, dedicados a la venta de productos de primera necesidad en las ciudades, los negros jornaleros del campo y los sirvientes. Estos mulatos y negros debieron ser muy numerosos sobre todo en las ciudades, y concretamente en la capital, al amparo de este tráfico a pequeña escala, abandonando al finalizar su esclavitud el trabajo de los campos, que significaba para ellos una vida más dura.

En el postrero escalón, según decíamos, se encontraban los negros esclavos, que según la legislación vigente en aquellos momentos, debían dedicarse a las labores de las haciendas, y sólo en algunos casos y pagando a la Real Hacienda una determinada cantidad, al servicio doméstico. ${ }^{101}$ Este grupo constituía según algunos autores, la octava parte de la población total del Santo Domingo español, ${ }^{102}$ aunque las noticias que tenemos por los documentos de esta época nos dan una cifra considerablemente inferior. El Código Negro por ejemplo, nos habla de la existencia de unos i 5.000 negros en la isla, pero entre libres y esclavos. ${ }^{\mathbf{1 0 3}}$

Esta escasez de esclavos se debería, al parecer, a "un

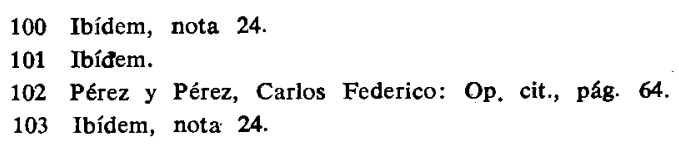


principio de religión propio de los españoles de Santo Domingo: ellos miran como un acto de piedad, el legado de la libertad que hace un amo. Los confesores mantienen esta opinión, de manera que es muy común ver testamentos que conceden la libertad a varios esclavos a la vez". ${ }^{104}$ Pero no debió ser ajena a ello la falta de dinero en efectivo, común a la mayor parte de los colonos, para poder comprar esos esclavos en las colonias extranjeras.

Así pues, la etnia fue fundamental para el encaje en uno $\mathrm{u}$ otro sector de la estratificación social dominicana, de modo que si los negros estaban en la escala más baja, los mestizos en la práctica, y ante la oposición de los blancos, no alcanzaban lugares que oficialmente les estaban permitidos. Observamos claramente este fenómeno, por una carta que el fiscal de la Audiencia de Santo Domingo envió al Consejo de Indias, con fecha de 12 de noviembre de i 768 , en la que - solicitaba que, puesto que Solórzano Pereira no encontraba razón para excluir a los mulatos y mestizos de los cargos y dignidades públicas, siendo de legítimo matrimonio, se terminase con "la injusticia que se ha pretendido, de hacer privativos estos cargos de ciertas casas y sangre, con exclusión de hombres virtuosos, pérdida del Real Erario y servicio de la patria". ${ }^{105} \mathrm{La}$ realidad era que los negros libres no consiguieron nunca la igualdad jurídica con los criollos. Quedaban sujetos a un estatus jurídico particular, siendo excluidos de ciertas profesiones y ocupaciones. ${ }^{106}$

Pero aunque estas discriminaciones existieron, los prejuicios raciales tan fuertes en otros lugares de América, no se dieron con tanta intensidad en el Santo Domingo español, aunque hubiese desde luego segregación, reflejándose este fenómeno en el trato dispensado a los esclavos, que generalmente eran alimentados como sus dueños y con una servidumbre bastante moderada, quizás como resultado de que

104 Moreau de Saint-Mery, M. L.: Op. cit., pág. 92.

105 Carta del fiscal de la Audiencia de Santo Domingo de 12 de noviembre de 1768, informando a la Corte đe las injusticias que se cometían contra los mulatos. A.G.!., Santo Domingo, 979.

106 Konetzke, Richard: Op. cit., págs. XXIII-XXIV. 
la mayor parte de la población tuviera sangre negra, y de la facilidad que tenían los esclavos para ser liberados. ${ }^{107}$

Los medios de lograr la liberación eran fundamentalmente tres: ser hijo de blanco, pagar por sí mismo el precio que se considerase que valía trabajando a cambio de un jornal en sus horas libres, y las disposiciones testamentarias en pago a la fidelidad o buenos servicios respecto al amo. ${ }^{108}$

Por otra parte, la legislación española y las ordenes remitidas por los monarcas españoles de la segunda mitad del siglo XVIII, ayudaban a este trato moderado de que fueron objeto los hombres de color. Así, por real cédula fechada en Aranjuez el 14 de noviembre de 1784, se prevenía a las autoridades de América que quedaba abolida la práctica establecida por antiguas reales disposiciones de marcarlos a su entrada en los puertos de dominio español, para distinguir los que entraban legalmente de los que lo hacían de contrabando, por ser un medio "opuesto a la humanidad". ${ }^{109}$ Gobernaba entonces en Santo Domingo don Isidro de Peralta y Rojas, que el 25 de marzo del año siguiente, respondía haber recogido los carimbos o marcas utilizadas con aquel fin y que las remitiría al Ministerio de Indias en la primera ocasión. ${ }^{110}$

Posteriormente, el 31 de mayo de 1789, y aunque se hallaba establecido por el Código de las Leyes de Partida y otras leyes del reino el trato que debía darse a los esclavos, conociendo el Rey que quizás por ignorancia de ellas, se habían cometido graves abusos contra los negros, envió una instrucción sobre el asunto a las autoridades americanas, en las que se establecían los siguientes puntos:

107 Moreau de Saint-Mery, M. L.: Op. cit., págs. 93-94.

108 Díaz Soler, Luís M.: Historia de la esclavitud negra en Puerto Rico. Universidad de Puerto Rico, Río Piedras, 1965, págs. 225-228.

109 R. C. de 14 de noviembre de 1784 aboliendo el derecho de marca de los esclavos americanos. A.G.I. Indiferente General, 660.

110 Caria del gobernador don Isidro de Peralta y Rojas de 25 de marzo de 1785, acusando el recibo, de la R. C. de 14 de noviembre de 1784. A.G.I., Santo Domingo, 947. 
I. - - Todo poseedor de esclavos debía instruirlos en la religión católica los días de precepto, en que bajo ningún concepto se les permitiría trabajar.

2. - Las justicias de los distritos de las haciendas, con acuerdo de los Ayuntamientos y audiencia del procurador śndico, señalarían la cantidad y calidad de los alimentos y vestidos que debían suministrarse a los esclavos, según lo que fuese costumbre en el país para los trabajadores libres.

$3 .^{\circ}$ - Los esclavos deberían ser empleados en los trabajos del campo, dejándoles dos horas libres para ocuparlas en su propio beneficio, pagándose dos pesos anuales por cada esclavo dedicado al servicio doméstico.

$4 .^{\circ}$ - En las fiestas de precepto, después de oir misa, debían procurar los dueños que sus esclavos se ocupasen en diversiones sencillas, evitando todos los excesos.

$5 .^{\circ-D e b i ́ a n ~ t e n e r ~ l o s ~ e s c l a v o s ~ c a m a s ~ " e n ~ a l t o ", ~ c o n ~}$ mantas y toda la ropa necesaria, y con separación para cada uno, y como mucho un cuarto para cada dos, destinando una pieza como enfermería.

$6^{\circ}$ - Los ancianos o enfermos deberían ser alimentados por sus dueños.

7. - Los dueños evitarán los tratos ilícitos entre los dos sexos fomentando los matrimonios.

8. - En caso de no respetar a sus dueños, los esclavos podrían ser castigados por éstos, pero sólo "con instrumento suave que no les cause contusión grave o efusión de sangre".

9. - Si el delito fuese grave, el dueño debería recurrir a la justicia para que se procesase al esclavo como a cualquier delincuente libre.

IO. ${ }^{\circ-L o s}$ dueños o mayordomos de las haciendas que no cumpliesen su obligación de educar a los esclavos, o cansasen a éstos efusión de sangre, contusiones graves o mutilaciones, serían multados y procesados por el delito cometido.

I I. - Ninguna persona que no fuera su dueño podría castigar a los esclavos, y el que lo hiciese sería procesado como si la injuria la hubiese hecho a un hombre libre. 
12."-Los dueños deberían presentar todos los años a las justicias de su jurisdicción una lista de sus esclavos, y dar cuenta de la muerte o desaparición de cualquiera de ellos en el término de tres días, justificando su ausencia o muerte natural, so pena del procesamiento correspondiente.

13." - Para averiguar los excesos cometidos por los dueños, los esclavos presentarán sus quejas al sacerdote que los asista, que debe dar cuenta al procurador síndico para que éste solicite la investigación correspondiente.

I4. - - En los respectivos Ayuntamientos, habrá una caja especial para recoger el dinero procedente de las multas impuestas a los dueños de esclavos, empleándose su producto en los medios necesarios para la observancia de esta instrucción. ${ }^{111}$

Así, la protección legal de los esclavos, unida al sentimiento religioso de que nos habla Moreau de Saint-Mery, debió suavizar considerablemente la esclavitud en la parte española de Santo Domingo, de manera que fue frecuente la llegada de nuevos esclavos fugitivos de otras naciones con la esperanza de un mejor trato, e incluso de conseguir su libertad. ${ }^{112}$ Por su parte, su poco número favoreció también ese trato moderado del que hemos hablado, ante el temor de perder un trabajador difícil de reemplazar. ${ }^{113}$

Independientemente del factor racial, hay que destacar en la estructura social dominicana la ausencia de una burguesía urbana, que impulsara la economía de la isla. La sociedad de Santo Domingo en la segunda mitad del siglo XVIII fue eminentemente rural, y en gran parte ganadera. La mayor parte de los propietarios de la isla dedicó sus tierras a la ganadería, el medio que les resultaba más fácil para

111 Instrucción de 31 de mayo de 1789 dirigida a todas las autoridades americanas, sobre el trato y educación que debe darse a los esclavos. A.G.I., Indiferente General, 802 .

112 R.C. de 10 de enero de 1764 dirigida al gobernador de Santo Domingo, sobre la restitución de los negros fugitivos esclavos de los franceses. A.G.I. Santo Domingo, 889.

113 Díaz Soler, Luís M.: Op. cit., pág. 149. 
la obtención de rápidos beneficios. "Los productos comerciales como el azúcar, el añil, el algodón, las maderas preciosas, etc., apenas si eran explotadas y su exportación era mínima. El hatero impidió el desarrollo de una burguesía agrícola-industrial, que en contacto relacional con la burguesía urbana, crearía una corriente comercial campo-ciudad-exportación de productos manufacturados, mano de obra esclava y bienes de equipo, para desarrollar y perfeccionar la industria". ${ }^{114} \mathrm{Y}$ este fenómeno es fundamental para comprender la situación socio-económica de la isla.

La ausencia de una burguesía dedicada a la industria y al comercio, que proporcionase puestos de trabajo y sirviese de eslabón entre la aristocracia y el pueblo llano, trae consigo al mismo tiempo que una mayor diferenciación entre los distintos grupos, un escaso desarrollo económico, que se manifiesta claramente en las formas de vida, modestas incluso entre las consideradas clases elevadas.

Así, Moreau de Saint-Mery nos dice, que el criollo español tenía en general pocas necesidades. A menudo iba descalzo y vistiendo una chaqueta, una camisa y un calzón de tela corriente. Algunos vestían levitones entallados que llamaban capotes, y otros, muy pocos, trajes de seda o camelote. Pero esto sólo ocurría entre los más destacados socialmente, y exclusivamente en la capital y ciudades importantes.

En cuanto a las mujeres, vestían normalmente una saya de color negro, una camisa y una especie de corpiño. "Sus hermosos cabellos sin polvo, van trenzados; a veces van anudados con una cinta en forma de venda y un lujo verdadero es, porque no se usa sino en las grandes ciudades, el llevar una cofia o redecilla, o sujetar los cabellos con gruesos alfileres blancos adornados con piedras falsas y de colores". ${ }^{115}$

Por lo que se refiere a la comida, vivían sobre todo de carne de vaca o cerdo, la mayor parte de las veces dejada

114 Santiago, Pedro J.: Op. cit., tomo $l$, pág. $X X X$.

115 Moreau de Saint-Mery, M. L.: Op. cit., pág. 83. 
secar al sol; tomaban también gran cantidad de dulces. sobre todo de coco y de guayaba, así como plátanos y cazabe, que utilizaban a modo de pan ante la escasez de harina. Consumían además pescado y tortugas terrestres, muy abundantes en la isla. La cena consistía para muchos en una taza de chocolate, del que hacían gran consumo por ser uno de sus alimentos favoritos, y en otros tiempos, el principal cultivo de la isla, aunque algunos empezaron a sustituirlo por el café, introducido por los franceses en la época que estamos estudiando.

"La sobriedad de esos insulares se hace notar en sus bebidas, que es generalmente agua, de la que normalmente no beben más que un trago al acabar de comer", ya que el aguardiente, al que al parecer eran muy aficionados, resultaba excesivamente caro, "pues cuesta treinta centavos torneses la pinta".

Las viviendas variaban según se tratase del campo o de la ciudad. En la capital, la mayor parte de las casas antiguas eran de una especie de piedra de mármol extraído de las cercanías, y las más modernas de "tapia”, es decir, de una tierra arcillosa rojiza apisonada, que adquiría gran dureza; eran casas sencillas y casi uniformes. Ya en el siglo XVIII, se construyeron bastantes de madera con techo de palmas.

En el campo, la mayoría eran simples cabañas de madera, a veces sin más sillas que troneos de árboles. Algunas tenían una sola habitación, donde se encontraba el hogar, y en el centro una gran mesa de caoba. Sus moradores se acostaban sobre cueros de buey o de caballo, siendo el colchón un verdadero artículo de lujo.

Estas viviendas eran las normales incluso en los grandes hatos, a pesar de que su dueño poseyera gran número de reses. "El albergue en que se abriga tanto él como su familia, es una choza construida de estacas y tablas mal unidas, y cubiertas de paja, con una sala de doce a diez y ocho pies en cuadro, en la cual hay una mesa, dos o tres tabure-

116 Ibídem, pág. 88. 
tes y una hamaca. Para acostarse hay una segunda pieza, menos grande que la primera, y con uno o varios lechos". ${ }^{117}$

Así pues, como consecuencia de esa falta de desarrollo económico que hemos señalado, hay una cierta uniformidad en cuanto a las formas de vida de las distintas clases sociales, con excepción de las grandes ciudades, que podía haberse visto alterada a finales del siglo XVIII.

Los intentos realizados en la segunda mitad de ese siglo por los gobernadores y la propia monarquía para fomentar la agricultura y la industria de sus derivados, como los ingenios de azúcar, y de los que hablaremos más adelante, podían haber dado lugar a una burguesía emprendedora, que diese a la economía dominicana el impulso que estaba necesitando con tanta urgencia, y alterase el rígido esquema social y las formas de vida; pero la cesión de la parte española a los franceses en I795 impidió que pudieran recogerse los frutos de esos intentos de fomento, que los Borbones reformistas habían preconizado.

\section{INTENTOS DE REDUCCIÓN DE LOS NEGROS}

\section{LIBRES A POBLACION}

Como ya hemos visto en el apartado anterior, la monarquía española en la segunda mitad del siglo XVIII sintió gran preocupación por la situación de los negros de sus colonias americanas, ya fuesen libres o esclavos.

Consecuencia de ello fue una comunicación de don José de Gálvez, fechada en Madrid el 23 de diciembre de I783, y dirigida al gobernador de Santo Domingo, en la que se le prevenía de orden del Rey, que junto con la Audiencia, y oyendo a todas las personas que pudieran representar alguna ayuda, como los propios hacendados, además de otras que también pudieran ver el asunto con más imparcialidad, formase unas ordenanzas para el gobierno político y moral de los negros, "al modo de las que tienen los franceses que

117 Ibídem, págs. 137-138 y 90-102. 
denominan Código negro", y las enviase al Consejo de Indias para su estudio y posterior aprobación por parte del Rey. ${ }^{118}$

El entonces gobernador de Santo Domingo, don Isidro de Peralta y Rojas, puso manos a la obra con gran rapidez, y al año siguiente, remitía a la Corte los resultados obtenidos al respecto. Las ordenanzas formadas de este modo, se ocupaban del buen trato que deberían recibir los esclavos por parte de sus dueños, de la obligación de éstos de educarlos y bautizarlos, de la forma en que debían trabajar los negros y mulatos libres y otros muchos temas de gran interés.

Esta especie de Código no llegó sin embargo a ponerse en práctica, pues el Consejo retardó demasiado tiempo su estudio, y se llegó a la cesión de toda la Española a los franceses sin que hubiese sido aún aprobado por el Rey. Pero hay que señalar que en su capítulo cuarto, que trata de la ocupación útil de los negros, establece en su apartado segundo, la necesidad de reducir a los negros y mulatos libres a poblaciones donde pudiesen ser bien vigilados, para evitar el vagabundeo y los robos a que estos hombres sometían a los colonos para poder subsistir. ${ }^{119}$

En este sentido, el mencionado Código no hace sino recoger las aspiraciones de muchos habitantes del Santo Domingo español, que veían un gran peligro en la existencia de un grupo cada vez más numeroso de gentes de color, sin ninguna ocupación que no fuese el robo de sus ganados, que utilizaban como alimento.

La facilidad que tuvieron los esclavos dominicanos para su liberación, y la llegada de otros procedentes de las colonias extranjeras, principalmente de la parte francesa de Santo Domingo, que conseguían su libertad al acogerse a la protección de la Corona española, originaron el rápido aumento de estos negros libres, que sin recursos económi-

118 R. C. de 23 de diciembre de 1783 dirigida al gobernador de la isla de Santo Domingo, ordenándole la creación de un Código negro semejante al de los franceses de aquella isla. A.G.I. Santo Domingo, 1.034.

119 Ibídem, nota 24. 
$\cos$ de ningún tipo se refugiaban en las montañas, viviendo en la mayor parte de los casos al margen de la ley en los llamados "palenques".

A este respecto son varias las reales cédulas enviadas a los gobernadores de Santo Domingo, declaratorias de la libertad que debían obtener todos los esclavos fugitivos de las colonias extranjeras al refugiarse en el territorio español, de acuerdo con el llamado "derecho de gentes". ${ }^{120}$

Estas cédulas estuvieron vigentes en Santo Domingo hasta 1790, con excepción de algunos periodos por lo que se refiere a los procedentes de la colonia francesa de la isla, a causa de los tratados existentes entre las dos naciones sobre la mutua devolución de los negros fugitivos. Sin embargo, y a pesar de estos acuerdos, los esclavos franceses continuaban a menudo cruzando la frontera, acusando a sus amos de malos tratos, y sólo en contadas ocasiones eran reintegrados a sus dueños.

De este modo, el problema de los negros vagabundos se fue agudizando de tal modo, que por real orden de I7 de mayo de 1790 se suspendieron las reales cédulas anteriores sobre el asunto, y se mandó interrumpir las costumbre de liberar a los esclavos procedentes de las colonias extranjeras, por no haber en qué ocuparlos. ${ }^{121}$

Pero antes de llegar a esta determinación, se trató por encima de todo reducir a estos negros libres a poblaciones, proporcionándoles tierras que pudiesen cultivar para su sustento, de modo que no necesitasen del robo para vivir.

El primer intento en este sentido tuvo lugar ya en el siglo XVII. Los negros fugitivos de la colonia francesa, fueron establecidos por las autoridades españolas junto al río Ozama, a media legua de la capital, llegando a formar un pueblo que se llamó San Lorenzo de los Minas, al ser la

120 R. C. de 24 de septiembre de 1750 (A.G.I. Santo Domingo, 982), idem - de 21 de octubre de 1764 (A.G.I. Santo Domingo, 889), y R. C. de 14 de abril de 1789 (A.G.I. Indiferente General, 2.770).

121 R. O. de 17 de mayo de 1790 suspendiendo todas las anteriores disposiciones sobre el mismo asunto. A.G.I. Santo Domingo, 953. 
mayoría de los que lo integraron de la casta de negros denominados "minas".

La nueva población se desarrollaba normalmente, cuando en I746 el gobernador de Santo Domingo informó a la Corte, que el mencionado establecimiento se encontraba en unos terrenos pertenecientes a la Compañía de Jesús de Santo Domingo; el colegio pleiteó por la propiedad de sus tierras, fallándose el consiguiente juicio a su favor. Al poco tiempo, con el dictamen del juez reconociendo a la Compañía la propiedad de los terrenos en litigio, ésta pidió que el pueblo de negros fuese demolido. Basaba su solicitud en que sus vecinos destruían sus montes, al tiempo que no pagaban el arrendamiento que se les había señalado en el anterior juicio.

Pero la junta que se formó para determinar sobre el asunto, resolvió que la existencia de San Lorenzo de Minas era fundamental para evitar el vagabundeo de los negros libres, siendo sobre todo patente, que durante el tiempo que llevaban habitando allí no habían representado el menor problema, limitándose a vivir como lo haría cualquier colono español.

El Rey vino a ratificar esta decisión por real cédula, fechada en el Buen Retiro el 21 de agosto de 1748 , en la que se prevenía no sólo que el pueblo de negros debía subsistir, sino que se debía procurar su mayor fomento, nombrando para él un gobernador y justicias, y procurando que volviesen a él los que se habían marchado, así como todos los que hasta entonces vivían en los montes sin domicilio conocido. ${ }^{122}$

No obstante, cuando el brigadier don Manuel de Azlor y Urríes tomó posesión de su cargo como gobernador, capitán general, y presidente de la Audiencia de la Española, en I759, aún no se había llegado a un acuerdo definitivo con la Compañía de Jesús.

$\mathrm{Su}$ antecesor, don Francisco Rubio, intentó poner en práctica la real cédula de $2 \mathrm{I}$ de agosto de 1748 , pero la

122 R. C. de 21 de agosto de 1748. A.G.I. Santo Domingo, 985. 
necesidad de nuevos terrenos para el establecimiento de todos los negros representaba una grave dificultad, por la oposición de los jesuitas. Por fin, don Manuel de Azlor puso todo su empeño en terminar con un asunto que amenazaba con hacerse eterno, determinando que se asignasen a la población 4'5 caballerías más de tierra, pagando al colegio todo su valor, 3.107 pesos y 3 reales, por cuenta de la Real Hacienda. Al mismo tiempo expidió una serie de bandos y órdenes, para que se presentasen allí todos los antiguos vecinos y sus descendientes, y les nombró un gobernador y un sacerdote. Las medidas tomadas por el gobernador fueron aprobadas por el Rey, cediendo así la amenaza que podían representar las bandas de negros vagabundos y hambrientos. ${ }^{123}$

Pero los fugitivos seguían llegando cada vez en mayor número, y el temor a ser entregados a sus antiguos amos a causa de los tratados concertados entre ambas naciones, les hizo establecerse en los llamados Montes del Maniel, en las cercanías de la villa de Neiba, donde se unían a los esclavos de la colonia española escapados de sus dueños.

Se trata de las montañas del Bahoruco, en la frontera entre las dos colonias, donde por su geografía agreste, con las consiguientes facilidades para permanecer ocultos, vivían fuera de la ley en palenques, bajando de ellos sólo para robar en los pueblos cercanos, tanto españoles como franceses.

Para acabar con ello, se llevaron a cabo expediciones armadas entre las dos colonias que no obtuvieron ningún resultado. Durante el curso de una de estas campañas, en I 768, fueron quemados los dos poblados que los negros cimarrones mantenían en aquellas montañas, pero no lograron acabar con ellos, ya que formaron rápidamente nuevos establecimientos. ${ }^{\mathbf{1 2 4}}$

123 Expediente sobre la subsistencia del pueblo de negros de San Lorenzo de los Minas, 1760-1761. A.G.I. Santo Domingo, 920.

124 Carta del gobernador de Santo Domingo don Manuel de Azlor de 26 de marzo de 1768 sobre los esclavos fugitivos del Maniel de Neiba. A.G.I., Santo Domingo, 1.101. 
A partir de r780 la situación parecía que iba a cambiar, y así, el i6 de mayo de 1783 , el Cabildo, Justicia y Regimiento de la Villa de San Bartolomé de Neiba escribía al gobernador, que "En consideración a las aflixiones que con los insultos, abances, muertes, y demás de que V.S. estará cerciorado, han causado a este pobre vecindario los negros de su Maniel, gastos que a nuestro augusto y soberano monarca (que Dios guarde) ha causado, con las expediciones que para cogerlos se han mandado a esta villa, de cuyas resultas ha quedado en el deplorable estado en que ahora se halla, que para que vuelva a lo que era han de mediar algunos años, hace a $\mathrm{V}$. S. la más reverente súplica, que en atención que el actual comandante don Felipe Fromesta, tiene a dichos negros casi manzos y reducidos, hasta tanto se logre salir todos, según lo determinare la superioridad de V.S. se dirige la súplica que hase el cavildo, a que aunque se mude la tropa quede el dicho comandante, porque como están los negros ya hechos con él, los contempla, engaña, y ellos lo celebran; si viene otro, consideran que como ellos están todavía medio temerosos, pueden retirarse y no volver más, y volver a hacer lo que antes hacían".

El mencionado don Felipe de Fromesta, había llevado a cabo una interesante labor de captación entre los negros rebeldes, de modo que logró hacer bajar a la villa de Neiba a cuarenta y seis de ellos, de los que 42 fueron bautizados. Al mismo tiempo, trató de conseguir que les fuese concedida la libertad, y unas tierras cercanas a la mencionada población para establecerlos en ellas.

A este respecto, el gobernador don Isidro de Peralta se mostraba en todo acorde con él. El concederles legalmente la libertad, no era sino reconocer el estado en que en la práctica se encontraban, y el hecho de cederles algunos terrenos para su establecimiento en una población, evitaría el peligro de nuevos asaltos, al tiempo que los negros así

125 Carta del Cabildo de la villa de Neiba de 16 de Mayo de 1783 sobre los negros cimarrones del Maniel. A.G.I., Santo Domingo, 1.102. 
atraídos, por el agradecimiento al gobierno a causa del trato recibido, ayudarían a la captura de los pocos que prefirieran seguir rebeldes.

Considerando todos estos motivos, Peralta se puso en contacto con el gobernador francés Bellecombe, para la realización conjunta del proyecto. ${ }^{126}$

El Rey aprobó la decisión del gobernador por real orden de 28 de noviembre de 1783, y en su consecuencia, don Isidro de Peralta nombró comisionado para la fundación del nuevo pueblo al oidor decano de la Audiencia, don Luís de Chávez y Mendoza, enviando al ingeniero don Lorenzo Núñez para reconocer aquellos terrenos, y así poder elegir el más adecuado para tal fin.

El oidor comisionado se trasladó a Neiba en marzo de 1785 , pero el delegado francés nombrado para este asunto no se reunió con él hasta el mes de mayo.

Entre tanto don Luís de Chávez había comprobado, que sólo dos de las familias refugiadas en el Maniel procedían de la parte española de la isla. Por eso, al llegar el comisionado francés, ambos, en nombre de sus respectivos monarcas, decidieron conceder la libertad y asilo a todos los negros "arrochelados" en aquelias montañas, y que la nueva población se levantara en territorio francés, ante el escaso número de españoles existente entre ellos. De este modo, se concedería la libertad a I 3 I negros que entonces se hallaban refugiados en las cercanías de Neiba, 74 varones y 57 hembras. De estos, 86 eran mayores de 13 años, 60 de ellos casados, y 45 , menores de ambos sexos.

Los dos delegados firmaron un acuerdo al respecto el 28 de mayo de aquel año, en el que, al mismo tiempo que se les concedía la libertad, se estipulaba la entrega de los antiguos esclavos franceses a aquel gobierno, para su esta-

126 Carta del gobernador de Santo Domingo don Isidro de Peralta de 23 de marzo de 1784 dando cuenta a la Corte de haber iniciado contactos con el gobernador francés para el establecimiento en población de los negros cimarrones. A.G.I. Santo Domingo, 946.

127 R. C. de 28 de noviembre de 1783 y expediente sobre el establecimiento en población de los negros del Maniel de Neiba A.G.I., Santo Domingo, 1.102. 
blecimiento en población en su propia colonia. Pero los negros se negaron rotundamente a ello, manifiestando que sólo vivirían en una población que estuviese en territorio español. ${ }^{128}$

El comisionado francés no aceptó bajo ningún concepto esta pretensión, y al año siguiente, el gobernador general de la colonia francesa escribía al nuevo capitán general de la Española, don Manuel González, que puesto que los negros habían faltado a su acuerdo de restituirse a su colonia, quedaban excluidos del perdón que a consecuencia de ello se les había otorgado. De este modo, y según los tratados de policía firmados entre ambas naciones, los dos gobiernos debían perseguirlos para entregarlos a sus antiguos dueños.

Estos inconvenientes diplomáticos, y las repetidas instancias del arzobispo de Santo Domingo, fray Isidoro Rodríguez, que manifestaba desconfiar por completo de los comisionados, hicieron que el Rey lo autorizase para que, por medio del cura de Neiba don Juan de Bobadilla, prosiguiese los intentos de establecer en una población propia a los negros del Maniel. ${ }^{129}$ Con este fin, envió una real cédula al mencionado arzobispo en 1787 , en la que le manifestaba que, puesto que era don Juan de Bobadilla la única persona que al parecer contaba con la contianza de los negros, debía continuar la reducción de éstos, aunque de acuerdo con él y con el presidente de la Audiencia, ya que consideraba que no había fuerza capaz de devolver los antiguos esclavos a sus dueños. ${ }^{130}$

Pero la aplicación de estas órdenes pronto ocasionaría graves diferencias entre fray Isidoro Rodríguez y don Manuel González. Aconsejados por Bobadilla, los negros nom-

128 Carta del gobernador de Santo Domingo de 20 de febrero de 1786 sobre la reducción de los negros del Maniel. A.G.I. Santo Domingo, 1.102.

129 Carta del gobernador de Santo Domingo don Manuel González de 25 de diciembre đe 1786 sobre el establecimiento en población de los negros 'del Maniel y respuesta de la Corte de 23 de abril de 1787. A.G.I. Santo Domingo ,1.015.

130 R. C. de 23 de mayo de 1787 dirigida al arzobispo de Santo Domingo sobre el establecimiento en población de los negros cimarrones. A.G.I. Santo Domingo, 1.102. 
braron cuatro representantes con plenos poderes, para tratar con las autoridades españolas sobre su libertad y asentamiento en una población.

El sacerdote marchó entonces a Santo Domingo con los cuatro delegados de color, con el fin de entrevistarse con el capitán general de la isla. Pero éste no parecía estar satisfecho con el asunto; pensaba que no se podía tratar sobre el pueblo en cuestión y el lugar de su emplazamiento hasta recibir la confirmación real, pues el hacerlo equivaldría al incumplimiento del tratado de policía firmado con los franceses, que como ya hemos señalado, reclamaban a estos negros como prófugos.

A esto respondía el arozbispo, que la real cédula que había recibido era lo bastante clara y no necesitaba de más confirmación; lo urgente era conceder cuanto antes a los negros las tierras para su pueblo, ante el riesgo de que la demora los hiciese desconfiar y volver a su anterior estado.

No lograron ponerse de acuerdo en este punto y el arzobispo cedió entonces, a cambio de que mientras se esperaba la confirmación del Rey, se hiciese algo que pudiera mantener la esperanza de los negros. Por ello decidieron construir varios bohíos cerca de Neiba, uno como hospital, y otros para que algunos de ellos fueran estableciéndose. Mientras, fray Isidoro enviaba amargas cartas al Consejo de Indias pidiendo una rápida solución al problema. ${ }^{131}$

Don Manuel González por su parte, manifestaba las dificultades existentes para la realización del proyecto, por su incompatibilidad con los tratados firmados con los franceses; al mismo tiempo, afirmaba que sería mucho mejor repartir a los negros cimarrones en diversos pueblos, pues mientras siguieran juntos se sentirían fuertes, y observarían el mismo comportamiento que hasta entonces. Basaba su afirmación, en el hecho de que, contra lo que se había estipulado en el acuerdo por el que se les concedió la libertad, ha-

131 Testimonio de las disputas surgidas entre el gobernador $y$ el arzobispo de Santo Domingo con motivo de la reducción de los negros del Maniel de Neiba, y carta del arzobispo de 25 de octubre de 1787 dirigida a la Corte. A.G.I. Santo Domingo, 1.102. 
bían admitido entre ellos a nuevos fugitivos de la colonia francesa. ${ }^{132}$

A esto respondía el arzobispo, "Que aquellos pactos habían sido recíprocos entre nosotros y ellos, y que no haviendo nosotros por nuestra parte cumplido, no estaban obligados ellos al cumplimiento de los suyos; y que además tuvieron muy justas causas para admitir a aquellos fugitivos, que por fin entregaron cuando el cura lo mandó".

Por fin, el 12 de diciembre de 1788, se expidieron las reales cédulas que el arzobispo esperaba con tanta ansiedad. En ellas quedaba bien claro que la reducción de los negros debía hacerse, aun cuando el gobierno francés protestara, y se haría en una sola población y cerca de Neiba, en terrenos realengos o comunales, para que pudiese estar cerca de ellos don Juan de Bobadilla, sin perjuicio de que más adelante, cuando estuviesen totalmente pacificados, se les fuese separando destinándolos a distinto lugares. ${ }^{134}$

No se acabaron con esto los problemas, pues enseguida surgió la disputa sobre el lugar en que debía emplazarse el nuevo establecimiento. Según una certificación del Cabildo de Neiba de 8 de junio de 1789, no había en su jurisdicción tierras comunales o de realengos, y en virtud de ello, don Juan de Bobadilla se mostró favorable a que se hiciese un poco más lejos, en el lugar conocido como Las Aullamas, a lo que se negaba el fiscal de la Audiencia, basándose en que la decisión real era que se levantase la poblacibn cerca de Neiba.

Entre tanto, don Manuel González y fray Isidoro Rodríguez habían sido sustituidos en sus cargos por don Joaquín García y fray Fernando Portillo respectivamente. Las

132 Carta del gobernador de Santo Domingo don Manuel González de 25 de diciembre de 1787, dando cuenta a la Corte de las dificultades existentes para el establecimiento de los negros cimarrones. A.G.I. Santo Domingo, 947.

133 Carta del arzobispo de Santo Domingo de 24 de diciembre de 1787; sobre el estado de la reducción de los negros cimarrones. A.G.I. Santo Domingo; 1.102 .

134 Resolución del Consejo de Indias 'y R. C. de 12 de diciembre de 1788, ordenando a las autoridades dominicanas se procediese a la fundación de: un pueblo de negros sin contar con los franceses. A.G.I. Santo Domingo, 1.102. 
nuevas autoridades política y eclesiástica lograron llegar en principio sin dificultades a un acuerdo. Consistía éste en no fundar la nueva población ni en la jurisdicción de Neiba, por la inexistencia de tierras, ni en el lugar preconizado por Bobadilla, por considerarlo peligroso el gobernador dada su cercanía al Maniel.

Eligieron entonces un nuevo paraje conocido como Arroyo Naranjo, a ocho leguas de la villa, aunque con eso se tuviera que nombrar un teniente de cura que atendiese a los nuevos pobladores.

Los negros se mostraron conformes y todo parecía solucionado. Pero al poco tiempo, en enero de I79o, fray Fernando Portillo informaba al Consejo de Indias que el tiempo pasaba sin que se diese comienzo a las construcciones. ${ }^{135}$ Don Joaquín García achacaba este retraso a la poca salud del prelado que, según él, le impedía atender a todas sus tareas, y al mal tiempo, que hizo imposible hacer llegar a don Juan de Bobadilla a la capital con el fin de darle las instrucciones y ayudas necesarias al caso. ${ }^{136}$

Sin embargo, la única ayuda que se dio al párroco de Santa Cruz de Neiba a su llegada a Santo Domingo, fueron 50 hachas con que iniciar los trabajos y varios ornamentos con destino a la iglesia que se habría de erigir. Pero los negros reclamaban que se cumpliesen las promesas que se les hicieron en tiempos del gobernador don Manuel González: darles el pueblo construido y junto a él, las tierras suficientes con el fin de poder dedicarse a la agricultura, y el dinero necesario para mantenerse durante el primer año, hasta recoger los frutos que sembrasen.

Intentando evitar que el asunto se malograse, el Consejo de Indias se dirigió al gobernador recordándole que,

135 Certificación del Cabildo de la villa de Neiba de ocho de mayo de 1789, carta del cura de Neiba al gobernador de 25 de septiembre del mismo año y autos obrados en 1790 sobre la elección del lugar para la fundación, y carta de la Corte al arzobispo de 24 de enero de 1790. A.G.I. Santo Domingo, 1.102.

136 Carta del gobernador de Santo Domingo de 25 de enero de 1790, dando cuenta a la Corte de las causas del retraso del establecimiento de los negros cimarrones. A.G.I. Santo Domingo, 953. 
por una real cédula de I788, estaba autorizado a sufragar por cuenta de la Real Hacienda los gastos necesarios en la nueva fundación, tal y como se había prometido a los negros, por lo que debía actuar con la mayor rapidez. ${ }^{137}$

Ante estas órdenes taxativas de la Corte, el gobernador García no se dio aún por vencido, y en carta de 25 de abril de I79I, informaba a aquella que los negros indultados no cumplían tampoco sus promesas, dedicándose al contrabando y al robo y viviendo en el más absoluto libertinaje, sin acceder a presentarse en el lugar que se pensaba dedicar a su establecimiento, y negándose "a todo partido que no sea situarlos en sus mismas sierras", siendo imposible con ello la realización de lo que habían proyectado. ${ }^{138}$

No debía ser ajena a la idea de don Joaquín García, la situación en que se encontraba la colonia francesa vecina. La Revolución Francesa produjo en lo que sería el futuro Haití importantes revueltas de negros. El gobernador preveía el paso de estos fenómenos a la parte española con el mantenimiento de estos negros, en su mayoría procedentes de aquellas tierras.

Lo cierto era que los negros se negaban a abandonar sus montañas, desconfiando del indulto que se les había prometido por sus delitos anteriores, y de nuevo el Rey, deseando acabar con aquel asunto cuanto antes, les concedió por real cédula de 18 de diciembre de I793, un nuevo indulto general de todos los delitos que hubieran cometido hasta el día en que fuese publicado en la isla. ${ }^{139}$

Poco después y a consecuencia de este indulto, se habían construído ya en Árroyo Naranjo 50 bohíos y algunos más estaban levantándose; muchos de los refugiados antes en el

137 Carta del cura de Neiba de 11 de mayo de 1790 sobre la escasez de medios para la fundación del pueblo de negros y orđen de 17 de septiembre del mismo, año dirigida al gobernador de la isla. A.G.I. Santo Domingo, 1.015.

138 Carta del gobernador don Joaquín García de 25 de abril de 1791 informando a la Corte del comportamiento de los negros cimarrones. A.G.I. Santo Domingo, 954.

139 R. C. de 18 de diciembre de 1793 concediendo a los negros del Maniel de Ne1ba un indulto general. A.G.I. Santo Domingo, 898. 
palenque del Maniel se radicaron en ellos, esperándose como segura la llegada del resto. ${ }^{140}$

Es difícil saber si esta nueva población hubiese progresado, de no ocurrir los sucesos revolucionarios en la parte francesa. De hecho los revolucionarios franceses cruzaban a menudo la frontera, atacando muchas veces a los negros que ya se hallaban en territorio español, y eso produjo en algunos un sentimiento de odio hacia aquéllos. Pero al mismo tiempo, la declaración de la abolición de la esclavitud y de la igualdad de derechos para los hombres de todas las razas en todas las colonias de la República Francesa, hizo cambiar de actitud a otros, que se unieron a los "brigantes".

Por último, la cesión de toda la isla Española a Francia en I795, puso fin a este proyecto en el que se habían consumido bastantes años, no ya para realizarlo, sino para comenzarlo. Los acontecimientos posteriores no permitieron que se llevase a buen término.

La empresa, como ya hemos visto, tuvo que superar graves obstáculos. Por una parte las autoridades religiosas intentaron por todos los medios acelerar el proceso; por otra los gobernadores fueron aplazándolo, bien para evitar los problemas con los de la colonia vecina, bien por el deseo de que esos negros cimarrones volvieran a sus primitivos lugares, y quitarse así de encima la amenaza que podían representar en territorio español estos negros de la colonia francesa.

A nuestro juicio, el verdadero motivo de que tanto don Manuel González como don Joaquín García demorasen continuamente el proyecto, a pesar de recibir contundentes reales órdenes al respecto, estaba en este temor ya apuntado.

140 Carta del arzobispo de Santo Domingo de 11 de junio de 1794, sobre el estado en que se encontraba la fundación del pueblo de negros. A.G.I. Santo Domingo, 1.102. 



\section{Capítulo III}

\section{A G R I C U L T U R A}

Los habitantes de la isla de Santo Domingo se dedicaron principalmente, durante toda la época colonial, a la ganadería y a la caza de reses montesas. Su economía fue fundamentalmente ganadera, con el consiguiente detrimento de la agricultura.

Sin embargo, en el siglo XVIII todo el mundo era consciente de la fertilidad de aquella tierra, de modo que los autores de la época, como ya hemos señalado en el primer capítulo, la alaban continuamente. La frecuencia de las 1luvias y las numerosas corrientes que regaban la isla, hacían que tuviese el aspecto de un gran jardín en el que crecía cualquier cosa que se plantara con gran rapidez, y que, según uno de sus gobernadores, don Manuel de Azlor, "produce regularmente dos cosechas cada año". ${ }^{1}$

Una prueba de ello, fue la prosperidad agrícola que alcanzó en seguida la colonia francesa que se estableció en su tercio occidental. Los franceses no contaron con la abundancia de ganados de la parte española, El único recurso que tenían para desarrollarse era la agricultura y el comercio, e industrias derivadas de aquélla. A ello se dedicaron con gran empeño y al poco tiempo, a pesar de poseer los peores terrenos de la isla, su colonia se había convertido en la más próspera de todas las francesas gracias a su producción de azúcar, cacao y café.

1 Representación del gobernador de Santo Domingo don Manuel Azlor de 18 de enero de 1767, proponiendo a la Corte los medios que consideraba necesarios para el fomento de la isla. A.G.I. Santo Domingo, 978. 
Hay varias causas que ayudan a explicar el escaso desarrollo agrícola del Santo Domingo español. Una de ellas puede ser, la existencia en la isla de una fuente de riqueza que necesitaba menos atenciones y producía mayores ingresos en menos tiempo: la ganadería. Mientras los productos de la tierra exigían una mano de obra considerable y un determinado tiempo para fructificar, el ganado, desde los inicios de la colonización, se había multiplicado de forma exuberante en estas tierras, y su crianza no exigía grandes esfuerzos.

Así mismo hay que apuntar como motivo, que en el siglo XVIII la parte francesa proveía a los españoles de los productos agrícolas que pudiesen necesitar a cambio de sus reses. $^{2}$

Este comercio estuvo prohibido salvo en momentos excepcionales por las leyes españolas. La Corona había permitido la venta de ganados a la colonia francesa del oeste, pero siempre a cambio de dinero, ya que los demás productos que necesitasen los habitantes de Santo Domingo debían ser llevados desde la Península. Pero no eran muchas las embarcaciones españolas que llegaban a aquel puerto, y la legalización del trueque con los franceses fue una aspiración constante de los colonos españoles.

De este modo, en I779 el cura rector de Santiago de los Caballeros escribía a la Corte, para solicitar, debido a los escasos frutos que los terrenos españoles producían, que "así como S.M. se sirvió hacer lícito el ingreso de animales en las colonias vecinas, pagando los derechos, del mismo modo pedimos haga lícito el regreso de harinas, azeyte y demás víveres, pagándole también sus derechos". ${ }^{3} \mathrm{El}$ Consejo de Indias sin embargo no cedió en este punto, permitiendo la compra de víveres en las colonias cercanas sólo en caso de extrema

2 Carta del gobernador de Santo Domingo don José Solano y Bote de ocho de octubre de 1772, solicitando una serie de gracias para el fomento de la agricultura de la isla. A.G.I. Santo Domingo, 969.

3 Representación del cura rector de la ciudad de Santiago de los Caballeros de 25 de junio de 1779, dirigida a Ia Corte. A.G.I. Santo Domingo, 1.059. 
necesidad, y previo informe del procurador síndico, vista del fiscal de la Audiencia, y licencia del gobernador.

La colonia francesa de Santo Domingo, a pesar de la fertilidad de su suelo, proporcionaba en sus comienzos pocos recursos económicos. Sólo se cultivaba al principio el tabaco, y serán las necesidades del comercio metropolitano las que hagan introducir nuevos cultivos como el café, el cacao, o el algodón. ${ }^{4}$

De este modo, en el siglo XVIII se llega a un desarrollo extraordinario de la agricultura gracias a dos factores fundamentales: a la "fertilidad del suelo y a los numerosos esclavos", 5 convirtiéndose en la más rica colonia de Francia

Los productos que se cultivaban en ella se producían también en la parte española, pero en cantidades muy inferiores. Y a veces, los españoles tenían que recurrir a Saint Domingue para abastecerse. Una muestra de este tráfico agrícola, es la introducción en Santo Domingo de un nuevo cultivo procedente de allí como el café.

Así pues, aunque este comercio quedase prohibido, fue constante en la época que estamos estudiando, de modo que durante los ocho años en que gobernó la isla don Francisco Rubio y Peñaranda, entraron en Santo Domingo diez embarcaciones procedentes de las posesiones extranjeras, ${ }^{6}$ mientras que don Manuel de Azlor, en los I I años y medio en que ocupó el mando supremo de la isla, concedió 97 licencias a distintos navíos para traer víveres de las colonias amigas. $^{7}$

$\mathrm{Y}$ al margen de estas licencias concedidas estaba el contrabando, que en la zona fronteriza con los franceses fue muy intenso en todo momento, y que permitió la continua

4 Franco, José Luciano: Historia de la revolución de Haiti. 2a edición. Eđitora Nacional. Santo Domingo, 1971, págs. 117-118.

5 Córdova-Bello, Eleazar: La independencia de Haití y su influencia en HispanoAmérica. Instituto Panamericano de Geografia e Historia. Caracas, 1967, pág. 10.

6 Juicio de residencia del gobernador don Francisco Rubio y Peñaranda realizado en Santo Domingo en 1759. A.G.I. Escribanía de Cámara, 16-A.

7 Documentos del juicio de residencia del gobernador don Manuel de Azlor y Urríes, Santo Domingo, 1771. A.H.N. Consejos, 21.465. 
traída de víveres y otros efectos, contra todas las leyes y prevenciones que se hacían para evitarlo.

Otra razón estuvo, en la falta de mano de obra y utensilios apropiados para las labores de la tierra.

La despoblación de Santo Domingo, hizo necesaria la existencia de un mayor número de cultivadores. Si tenemos en cuenta que solamente hacia I780 llegó a tener Santo Domingo un habitante por kilómetro cuadrado, veremos claramente el alcance de este hecho. Muchas de las tierras estaban desocupadas, y si tenían un dueño, éste no podía por sí solo atender en ellas una verdadera explotación agrícola en un territorio demasiado extenso. Por eso, las grandes haciendas se dedicaron casi en su totalidad a la ganadería. ${ }^{8}$ Este problema se vio agravado además por el establecimiento en Santo Domingo del batallón fijo, "pues los naturales, para acogerse al fuero militar, toman la carrera de las armas dejando en total abandono sus haciendas". 9

Por otra parte, no había apenas jornaleros libres, y los pocos con que se podía contar eran muy costosos. Era pues necesario recurrir a los esclavos, y ya hemos señalado que éstos fueron siempre muy escasos, en contraposición a lo que estaba ocurriendo en la colonia francesa, que basó su economía en el sistema esclavista. ${ }^{10}$

Los siervos eran liberados con facilidad, y entonces escapaban rápidamente de las haciendas. Unos marchaban a las ciudades malviviendo en ellas con la venta de algunos frutos silvestres; otros se dedicaban a la montería de vacas y cerdos monteses para poder subsistir.

Teniendo en cuenta esta escasez, se trató que todos los esclavos de la isla fuesen empleados en los trabajos del campo y no en ninguna otra actividad, pero, así y todo, su número seguía siendo insuficiente. ${ }^{11}$

\footnotetext{
8 Moreau de Saint-Mery, M. L.: Loc. cit., pág. 100.

9 Carta de don José Osorio de 25 de noviembre de 1778, informando a la Corte de las causas de la decadencia en que se encontraba la isla. A.G.I. Santo Domingo, 1.045.

10 Franco, José Luciano: Op. cit., pág. 122.

11 Resolución del Consejo de Indias en sesión de ocho de junio đe 1785. Sacado del expediente causado para el fomento de la isla Española. A.G.I. Santo Domingo, 1.034.
} 
A la penuria de cultivadores y de mano de obra, hay que añadir la falta de utensilios apropiados. No hubo industria en Santo Domingo y las manufacturas debían venir de la Península. España no tiene en aquellos momentos tecnología alguna, comparada con otros países de Europa como por ejemplo los Países Bajos. A consecuencia de ello los utensilios que produce no son de buena calidad, y si procedían de otros lugares, su paso por la Metrópoli era causa de que al llegar a Santo Domingo se hubiesen encarecido considerablemente, sumándose a ello la cuantía de los impuestos. Por ello, una petición constante de los agricultores dominicanos a la Corona, va a ser que les permita la compra de herramientas para las labores de la tierra, y utensilios para la fabricación de azúcar y añil, en las colonias extranjeras, donde las lograban a un precio muy inferior al de España, y al mismo tiempo, que no tuviesen que pagar derechos por ellos a la Real Hacienda. ${ }^{12}$

Pesaba también el clima. Si las abundantes lluvias y la gran cantidad de ríos que fertilizaban la isla hacían de ella una tierra excelente para determinados cultivos, las borrascas y huracanes que tienen lugar a menudo en ella, sirven de contrapartida a esa fertilidad. Algunos de sus productos agrícolas tradicionales, como por ejemplo el cacao, aparte de exigir muchos cuidados eran sumamente delicados. Cualquier. temporal acababa con ellos, y en ese caso la pérdida no se reducía a la cosecha de ese año, sino también a los inmediatamente posteriores, pues los árboles recién plantados tardaban bastante en dar sus frutos.

"La continuación de las tormentas que llaman huracanes, terremotos, y pestilencias que con frecuencia ha padesío esta isla, an cido mucha parte de su decadencia, en que padecieron no tan sólo los edificios de la ciudad, quanto los de los ingenios, como lo demuestran sus desastrosos bestigios en los montes ; con que sesó el comersio de azúcar y cacao". ${ }^{13}$ Y a lo largo de toda la época estudiada se repitieron

12 Ibídem, nota 2.

13 Peguero, Luís Josep: Op. cit., tomo II, pág. 14. 
estos fenómenos, frenando el posible desarrollo agrícola que hubiera podido originarse, al amparo de las medidas tomadas para ello por la Corona española. Así, como ya hemos dicho, en I75I los temporales se produjeron continuamente desde julio hasta noviembre, con la consiguiente destrucción de las labranzas. ${ }^{14}$. Nuevamente tenemos noticias de ellos en I780, por una carta del entonces gobernador don Isidro de Peralta y Rojas. En este caso habían sido precedidos por una pertinaz sequía, con lo que se malograron los pocos frutos que dejó aquella. ${ }^{15}$

El mismo Peralta en I784 informaba al Consejo de Indias, que durante los meses de mayo y junio, los temporales ocasionaron tal cantidad de lluvias que impidieron los trabajos del campo, causando además estragos considerables en las labranzas ya hechas. ${ }^{16}$ Posteriormente, en 1798 , durante el gobierno de don Joaquín García, volvieron à desencadenarse lluvias torrenciales durante los meses de marzo y abril que arrasaron los cultivos, viéndose agravado el problema por un fuerte huracán en el mes de octubre, con lo que el panorama de la isla no podía ser más desolador. ${ }^{17}$

Así pues, es fácilmente comprensible que los hacendados, ante el temor de perder sus cosechas con tanta facilidad, prefiriesen dedicar sus tierras a la ganadería, que significaba unas ganancias seguras, sin los riesgos a que estaban sometidas las explotaciones agrícolas.

Hay que señalar además, las escasas perspectivas que se presentaban a los cultivadores para la exportación de sus productos. ${ }^{18}$ Como ya es sabido, las Leyes de Indias vedaban el comercio con los extranjeros. El único mercado para los

14 Ibídem.

15 Carta del gobernador de Santo Domingo don Isidro de Peralta y Rojas de 13 de noviembre de 1780, informando a la Corte de los estragos causados en la isla por los temporales. A.G.I. Santo Domingo, 945.

16 Informe del gobernador de Santo Domingo don Isidro de Peralta de 23 de junio de 1784 sobre los temporales sufridos en la isla. A.G.I. Santo Domingo, 946.

17 Carta del teniente del rey don Joaquín García a la Corte, de 10 de octubre de 1768. A.G.I. Santo Domingo, 960.

18 Informe del oidor decano de la Audiencia de Santo Domingo don Pedro Catani, de 15 de noviembre de 1788, sobre el estado en que se encontraba la isla, A.G.I., Santo Domingo, 1.012 . 
frutos del país era la Península. Pero el tráfico con aquella había decaído profundamente, por el mayor interés que representaba para los comerciantes el Continente.

A pesar de la creación de la Compañía de Barcelona, dedicada al comercio de las Antillas, eran muy pocas las embarcaciones españolas que llegaban a la isla. Los frutos que ésta producía, los lograba la Metrópoli con mayor facilidad y en mayores cantidades en otros lugares de América. Así, el principal producto durante todo el siglo XVI fue la caña de azúcar. Pero su exportación se vio pronto comprometida por la competencia de la de México y Brasil, al parecer de mejor calidad. ${ }^{19}$

Fue entonces sustituida por el cacao, como fruto principal de Santo Domingo en el siglo XVII. Pero la facilidad de este árbol para perderse hizo disminuir su producción, y con el tiempo se encontró suplantado por el de Venezuela en el mercado español, e incluso en el interior de la isla, como se deduce de los registros de los navíos que procedentes de aquel lugar desembarcaban mercancías en Santo Domingo.

Ante esto, se iniciaron en la Española nuevos cultivos en el siglo XVIII como el añil o el café, y se incrementó el del tabaco, aunque este último tuvo que hacer frente en todo momento a la competencia del cubano.

De este modo, la agricultura dominicana fue de subsistencia y se limitó a la necesaria para el consumo interior, siendo muy reducidas sus exportaciones, lo que contribuyó al escaso desarrollo agrícola de la isla en todas las épocas.

Finalmente, otro motivo podría ser el sistema de propiedad de la tierra. Es difícil hablar con certeza del régimen de posesión de las tierras en Santo Domingo en el siglo XVIII, dada la falta de documentación existente sobre el tema. En principio, y según la legislación promulgada

19 Moya Pons, Frank: Loc. cit., pág. 202.

20 Relación del Real Derecho de Armada de entrada cobrado en Santo Domingo en 1761. Sacado de las cuentas de las Cajas Reales de Santo Domingo. A.G.I. Santo Domingo, 1.048 . 
sobre el asunto, todas las tierras descubiertas pasaron a ser propiedad de la Corona. Los monarcas hicieron concesiones a los particulares, bien como compensación a unos servicios prestados, bien para conseguir la colonización y población, que se consideraba fundamental para la posesión real de los nuevos territorios.

Las concesiones se hacían a cambio de que los terrenos otorgados fueran explotados y habitados, bajo la pena de perder los derechos adquiridos. Y este tipo de mercedes se concedieron tanto a personas particulares, como a las nuevas poblaciones para su explotación en régimen comunal.

En los primeros momentos, el reparto de las tierras realengas lo hicieron los conquistadores, a los que las capitulaciones firmadas con la Corona daban autoridad para ello. ${ }^{21}$ Posteriormente, la tarea de esta distribución recayó en los virreyes y Audiencias, que debían señalar las personas encargadas de este asunto. En el caso de Santo Domingo, y por lo que se refiere a la segunda mitad del siglo XVIII, conocemos la existencia de un oidor juez de realengos, que se ocupó de la expedición de los títulos de propiedad y de la llamada composición de terrenos, o adquisición de un territorio por el que entonces lo ocupaba a cambio de una determinada cantidad. ${ }^{22}$

Muchas de estas concesiones habían pasado a ser de forma efectiva posesión de los que las explotaban. Una prueba de ello la hemos visto, en la fundación del pueblo de San Lorenzo de Minas. Parte de las tierras que se pretendía dar a los negros, hubo que comprarlas al colegio de la Compañía de Jesús de la capital. ${ }^{\mathbf{2 3}}$

Pero otras seguían siendo aún de realengos, que había

21 Ots Capdequí, José María: España en América. El régimen de tierras en la época colonial. Fondo de Cultura Económica. México, 1959, pág. 12.

22 Relación de los caudales que entraron en las Reales Cajas de Santo Domingo procedentes del beneficio de Realengos en los años 1768 y 1769. A.G.I., Santo Domingo, 1.050 .

23 Testimonio de los autos obrados sobre la compra de las tierras del Tablado, pertenecientes al Colegio de la Compañía de Jesús de la ciudad de Santo Domingo, para la subsistencia del pueblo de San Lorenzo de los Minas. Santo Domingo, 10 de abril de 1760. A.G.I. Santo Domingo, 974. 
que explotar de un modo $\mathrm{u}$ otro so pena de perderlas, y el remedio para evitarlo era fácil: poblarla de ganado. Los colonos no contaban con brazos suficientes para explotar agrícolamente el total de sus tierras como ya hemos indicado, y las dedicaban a la ganadería, de forma que aunque no estuviesen cultivadas, no estaban tampoco abandonadas. Quizás como consecuencia de ello, y para que parte de esas tierras fuesen abiertas al cultivo sin temor a perderlas, la Corona envió a Santo Domingo un real despacho, fechado en Aranjuez el i7 de abril de I74I, en el que se concedía a los vecinos de la isla que pudiesen obtener la propiedad de los terrenos de realengos, con la única condición de haberlos explotado durante treinta años, y previo el pago correspondiente, sin correr el riesgo de que a partir de entonces se les pudieran declarar por realengos. ${ }^{24}$

\section{Principales cultivos y PRoducciones}

La situación de Santo Domingo, en el trópico, le permitió en todo momento la producción de una gran variedad de frutos propios de la zona. Unos eran originarios de la isla; otros fueron introducidos a lo largo de la colonización, y se adaptaron rápidamente a aquellas tierras, llegándose a conseguir en algunos, como en el café, una calidad extraordinaria.

En la segunda mitad del siglo XVIII, se cultivaba en la Española azúcar, cacao, tabaco, cafó, algodón, maíz, arroz, batatas, plátanos, yuca, bija o achiote y jenjibre.

Producía además la isla gran cantidad de frutas como toronjas, cocos, guayabas, dátiles y otros frutos tropicales, además de una gran variedad de maderas excelentes como la caoba, cedros, robles, etc.

El principal cultivo de la isla de Santo Domingo des-

24 Carta del Cabildo de la ciudad de Santo Domingo de 16 de septiembre de 1741, acusando el recibo de un Real Despacho fechado en Aranjuez el 17 de abril de 1741 . A.G.I. Santo Domingo, 983. 
de los primeros tiempos de la conquista española, fue la caña de azúcar. Al parecer se llevó allí desde las islas Canarias, ${ }^{25}$ donde se cultivaba en aquella época, y pronto adquirió gran desarrollo. Su cultivo estaba centrado en los alrededores de la capital y en las márgenes del río Ozama, es decir, en la zona del sureste. Pero la falta de mano de obra y utensilios apropiados hizo decaer la economía azucarera, al tener que sufrir la competencia del azúcar mexicana y brasileña, ${ }^{26}$ cuyo proceso de fabricación se llevaba a cabo con mayor perfección.

A lo largo del siglo XVII disminuyó considerablemente su producción, que resurgió tímidamente en la segunda mitad del XVIII, al amparo del impulso que se pretendió dar a la agricultura en esta época. Se volvieron a poner en explotación las antiguas haciendas de caña de los alrededores de Santo Domingo y otras zonas del sur del país, sobre todo entre los ríos Ozama y Nizao. ${ }^{27}$

De este modo, el gobernador don Manuel de Azlor transmitía a la Corte, con fecha de 18 de enero de 1767 , una representación del Cabildo de Santo Domingo, en la que se proponían los medios que habrían de tomarse para el fomento de la isla. Y en ella, se decía que la producción de azúcar ascendía a más de 22.000 arrobas anuales, pudiendo llegar a las 70.000 si se protegían las labranzas. ${ }^{28}$

El azúcar era fabricado en las mismas haciendas en que se cultivaba la caña, en los llamados ingenios o trapiches, así como el aguardiente o jarabe.

Según Moya Pons, funcionaban entonces en Santo Domingo II ingenios entre los ríos Ozama y Nizao, y 20 de ellos en los alrededores de la capital. ${ }^{29}$ Moreau de Saint-Mery es más parco en sus apreciaciones, y nos habla de la exis-

25 Fernández de Oviedo, Gonzalo: Historia natural y general de las Indias. Biblioteca de autores españoles. Madrid, 1959. Libro IV, Capítulo VIII, y Libro VIII, Capítulo I.

26 Ibídem, nota 19.

27 Idem. pág. 308.

28 ibídem, nota 1.

29 ibídem, nota 27. 
tencia de 22 de ellos, "pues los otros que hay no merece la pena ni citarlos aquí". En estas 22 fábricas trabajaban un total de 600 negros, produciendo azúcar y aguardiente. Había además otros establecimientos menores que no producían azúcar, sino exclusivamente jarabe, extrayendo la miel de la caña. ${ }^{30}$

$\mathrm{Y}$ estos ingenios eran, en su mayor parte, industrias de poca monta. En esta época, toda la cosecha azucarera de la colonia española de Santo Domingo se consumía en la isla. Por una parte, la producción era en aquellos momentos limitada y no daba para más. Por otra, los defectos de su fabricación la hacían muy inferior a la de Cuba y poco estimada en el comercio exterior, de modo que aun en los años de cosechas abundantes, los hacendados se encontraban en la necesidad de despreciar parte de ella, por no poderla colocar en el mercado. ${ }^{31}$

Esta imposibilidad de exportación y los elevados costes de producción, que no eran compensados en la mayoría de los casos por los precios, explican claramente la limitación de su cultivo, a pesar de todos los intentos que se realizaron en esta época para fomentarlo.

En el siglo XVII, a causa de la decadencia que había experimentado la producción azucarera, se incrementó considerablemente el cultivo del cacao. Siendo un fruto propio de Santo Domingo, se producía en gran parte de la isla, sobre todo en los alrededores de la capital y en la zona de la Vega Real. ${ }^{32}$ Durante mucho tiempo significó una considerable fuente de ingresos para los labradores, y según Moreau de Saint-Mery, ya en el siglo XVI el cacao dominicano era el mejor considerado comercialmente por su gran calidad, y proveía a toda España, a la propia colonia, e incluso después quedaba algún excedente. ${ }^{33}$

Pero el cacao tuvo que enfrentarse a los mismos pro-

30 Moreau de Saint-Mery, M. L.: Loc. cit., págs. 96-97.

31 Ibídem, nota 18.

32 Expediente sobre el fomento de la isla Española. A.G.I. Santo Domingo, 1.034.

33 Moreau de Saint-Mery, M. L.: Op. cit., pág. 98. 
blemas que el azúcar: la falta de mano de obra, agravada por los temporales. Mientras que aquella explotación se recuperaba fácilmente tras uno de estos fenómenos, los árboles de cacao destrozados por ellos necesitaban varios años para volver a dar frutos. Esto hizo que, a pesar del gran consumo que los colonos hacían de él en forma de chocolate, y los beneficios que su exportación traía consigo, fuese disminuyendo paulatinamente su producción y quedase sustituido en el comercio exterior por el de Venezuela y otros lugares de América.

De este modo, apenas fue quedando cacao para las propias necesidades de la colonia española de Santo Domingo. Hubo en el siglo XVIII una cierta recuperación que permitió, hacia I764, la exportación a la Península de pequeñas cantidades. Pero de nuevo los temporales cortaron este desarrollo, al destruir en esta época gran cantidad de árboles de este fruto, ${ }^{34}$ permaneciendo su cultivo sólo en unas pocas haciendas. ${ }^{35}$

Respecto al café, no comenzó a cultivarse en Santo Domingo hasta el siglo XVIII. Los colonos españoles recibieron las primeras semillas de la parte francesa de la isla, y al parecer concretamente del Dondón. En un principio se sembró sólo una pequeña cantidad que apenas bastaba para el consumo interior, en un lugar donde la mayoría de las personas preferían el chocolate. ${ }^{36}$

Pero el café dominicano se reveló pronto como de una gran calidad, especialmente la variedad conocida con el nombre de Moca, produciéndose incluso dos cosechas al año. Este factor, unido a los intentos que se realizan en esta época para el incremento agrícola de la isla, trajo como consecuencia la real cédula de 8 de junio de 1768 , por la que se prevenía al gobernador de Santo Domingo, que había decidido el Rey extender a aquel territorio el proyecto de siembra del café, al tiempo que se relevaba de todos los derechos

34 Idem, pág. 99.

35 Ibíđem, nota 18.

36 Moreau de Saint-Mery, M. L.: Op. cit., pág. 97. 
a este fruto durante cinco años. Esta disposición ordenaba además al gobernador, la realización de un informe sobre si su cultivo podía perjudicar las siembras de caña de azúcar y tabaco, y el envío de varias muestras de café, especificando los lugares en que se recolectaba. ${ }^{37}$

Obedeciendo estas órdenes, el gobernador don $\mathrm{Ma}$ nuel de Azlor envió en I77I las muestras del nuevo fruto, en dos paquebotes de la Real Compañía de Comercio de Barcelona, el "San Esteban" y el "Santa María del Socos". Estas muestras habían sido recogidas en los siguientes lugares:

A. De la jurisdicción de la capital

- Un saquito de la hacienda "Cambita", de Nicolás Guridi, a 6 ó 7 leguas de Santo Domingo.

- Otro de la hacienda de "San Isidoro de Cambita", de Nicolás Esterlín, a igual distancia que la anterior.

- Otro de la hacienda de Lorenzo Daniel, a 3 ó 4 leguas.

- Otro de la hacienda de "Caucino", de Julián Fernández, a 2 ó 3 .

B. De la jurisdicción de Santiago

- Uno del partido de Gurabo, de la hacienda de Juan Antonio Méndez, a o's leguas de la ciudad.

- Otro del partido de Licey, de la hacienda de Juan Monte, a igual distancia.

- Otro del partido de Canca, de la hacienda de Juan Acevedo, a igual distancia.

- Otro del partido de Exido, de la hacienda de Francisco Reina, a igual distancia.

- Otro del partido de Jacagua, de la hacienda de Francisco Pichardo.

37 Carta de don Manuel de Azlor y Urries de 11 de febrero de 1771, respendiendo a la R. C. de ocho de junio de 1768, sobre el proyecto de extensión a la isla de Santo Domingo de las siembras de café. A.G.I. Santo Domingo, 981. 
El gobernador informó además al Consejo de Indias, que en estos mismos partidos había otras muchas haciendas en las que se había sembrado cafetales, pero que los granos enviados a la Corte fueron sólo una muestra para que allí se examinase su calidad.

Al mismo tiempo, señalaba que el cultivo del café no perjudicaría al azúcar ni al tabaco, a no ser por falta de mano de obra, ya que "los terrenos están combinados a que los cultiven, sin que el que ocuparen con café haga falta para tabacos, ni el que se ocupa para tabaco haga falta para la caña o cacao". ${ }^{38}$

Tras la llegada a España de las muestras de café enviadas desde Santo Domingo, el Consejo de Indias pidió parecer a su fiscal, sobre si se debía incrementar o no este cultivo en aquella isla. $Y$ el fiscal respondió que debía ordenarse al gobernador, se adelantasen cuanto antes las nuevas siembras sin perjuicio de las otras, amparando a sus cosecheros en las gracias concedidas en la real cédula de junio de $1768 .{ }^{39}$

Es lógico pensar, que a cosecuencia de ello se incrementasen las siembras de cafetales en el Santo Domingo español, aunque no tenemos noticias sobre la producción alcanzada.

Este nuevo fruto se cultivó, como ya hemos visto en la nota de las muestras enviadas a la Corte, en algunas haciendas de la jurisdicción de la capital, y sobre todo en la de Santiago de los Caballeros, de donde se obtenía el de mejor calidad, y en general en toda la zona de la Vega Real, en los mismos lugares en que se sembraba el tabaco.

El algodón que se producía en Santo Domingo era de gran calidad, aunque los colonos españoles dieron poca importancia a este fruto. Según Moreau de Saint-Mery, crecía en la isla de forma natural, en terrenos áridos y pedregosos, e incluso en los intersticios de las rocas. ${ }^{40}$

\footnotetext{
38 Idem.

39 Informe del fiscal del Consejo de Indias favorable al fomento de las siembras d’e café en la islá de Santo Domingo. 1771. A.G.I. Santo Domingo, 981.

40 Moreau de Saint-Mery, M. L.: Op. cit., pág. 97.
} 
Se cultivaba el algodón al oeste del río Nizao, donde terminaban las haciendas de caña de azúcar. ${ }^{41}$

El intento de fomentar la industria textil catalana en la segunda mitad del siglo XVIII, llevó a la Corona a declarar libre de derechos todo el algodón americano que estuviese destinado a las fábricas españolas. ${ }^{42}$ Con ello, los beneficios para los cosecheros serían mayores. Pero esta medida no tuvo ningún reflejo en Santo Domingo, por lo que se refiere al incremento de su cultivo. La producción algodonera siguió siendo mínima, llegando escasamente a la necesaria para el consumo interno.

En el siglo XVI, habían tenido gran importancia las cosechas de achiote o bija, así como de cañafístola y jenjibre, del que se enviaban cargamentos considerables a la Península; pero en el siglo XVIII sólo quedaban vestigios de estas producciones.

En el siglo XVIII, además del café, comenzó a cultivarse en Santo Domingo el añil, en las mismas zonas poco más o menos que el algodón, ${ }^{44}$ pero su producción fue pequeña en esta época. En casi todas las zonas de la isla se encontraban además una serie de frutos como el maíz, arroz, batatas, plátanos, yucas y otras "raíces", que constituían los alimentos básicos de gran parte de la población dominicana. $\mathrm{Su}$ producción se reducía a las necesidades del abastecimiento interior en las épocas normales. Pero en cuanto se producía algún temporal, o alguna sequía, no bastaba para este consumo. ${ }^{45}$

Una de las producciones naturales más importantes de la isla fue siempre la madera. La riqueza forestal de Santo Domingo era enorme, y de una gran variedad. Se podía encontrar por toda la isla gran cantidad de árboles, sobre

41 lbídem, nota 27.

42 Representación del gobernador de Santo Domingo don Manuel de Azlor de 20 de febrero de 1767, en respuesta al Real Despacho de 24 de octubre de 1766, en que se declaraba la libertad de derechos para el algodón americano destinado a las fábricas españolas. A.G.I. Santo Domingo, 944.

43 Moreau de Saint-Mery, M. L.: Op. cit., pág. 99.

44 Ibídem, nota 27.

45 Ibídem, nota 18. 
todo en los montes de Azúa. Había robles, guayacanes, y otros muchos, destacando por encima de todos la caoba, cuya exportación fue durante muchos años, el principal recurso económico de Santo Domingo. Se producía en toda la isla, especialmente en su mitad oriental, destacando por su calidad la de la zona de Azúa. ${ }^{46}$

La longitud y el grosor de sus palos, así como su extraordinaria calidad, hacían este árbol muy estimado en el comercio internacional.

En todas las épocas, la caoba había salido de Santo Domingo por medio del contrabando. Las medidas tomadas para evitarlo no daban resultado alguno, y la Corona no podía dejar de darse cuenta, de los beneficios que la Real Hacienda perdía con este comercio ilícito. Con este motivo, una real cédula de II de abril de I786, permitió la libre extracción de esta madera pagando los impuestos correspondientes. Esta medida tuvo sus consecuencias beneficiosas para los dueños de las tierras en que la caoba se producía. Pero al mismo tiempo trajo consigo un excesivo número de talas, sin que se llevase a cabo un plan de repoblación, que hacía preveer una desaparición casi total de este árbol en algunas zonas, al tiempo que continuaba el comercio ilícito para eludir los aranceles establecidos. ${ }^{47}$

\section{Auge y deCADENCIA DEL TABaco}

El tabaco comenzó a cultivarse en Santo Domingo en el siglo XVII. Al parecer era de buena calidad para la fabricación de cigarros, y sobre todo convertido en rapé. Era muy estimado por los franceses de la colonia vecina cuando se preparaba en "rollos", pues mezclado con otros inferiores, elevaba la calidad de éstos.

A pesar de ello sólo se sembraba una pequeña cantidad, en las zonas de Santiago y la Vega, para el consumo interno y exportación a la parte francesa y otras islas vecinas. ${ }^{48}$

46 Sánchez Valverde, Antonio: Op. cit., pág. 50.

47 Ibídem, nota 18.

48 Moreau de Saint-Mery, M. L.: Op. cit., pág. 98. 
En I753, el gobernador de Santo Domingo don Francisco Rubio y Peñaranda solicitaba de la Corte, que puesto que los registros procedentes de la Península tenían que volver a ésta vacíos por la falta de frutos de la isla, y se estaba extendiendo en ella el cultivo del tabaco, que adquiría cada vez mayor importancia, se permitiera a aquellas embarcaciones cargar cuanto pudiesen de este fruto con destino a España. Su propuesta no tuvo éxito, pues las Reales Fábricas de Sevilla se abastecían por aquel entonces del tabaco de la isla de Cuba, con el que les bastaba para su producción y que, en general, era de mejor calidad que el dominicano.

Pero en 1762 La Habana cayó en poder de los ingleses y el entonces gobernador de Santo Domingo, don Manuel de Azlor, siguiendo las líneas de su antecesor en su intento de colocar el tabacc dominicano en el mercado español, envió a Cádiz en la balandra "San Carlos" un cargamento de este futo, con un total de unas I5O arrobas y con el siguiente costo:

Pesos Reales

- 3 cargas de tabaco de primera calidad, con un peso de nueve a diez arrobas cada una, a 32 pesos la carga .........

- I I'5 cargas de tabaco de segunda calidad, de ocho a nueve arrobas cada una,

a 28 pesos la carga .................... 322

- 3'5 cargas de tercera calidad de 8 arro-

bas cada una, a 26 pesos la carga ... 79

- Por la conducción del tabaco al embarcadero

\section{6}

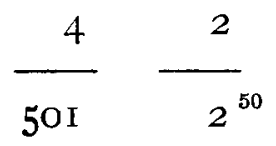

49 Carta de! gobernador de Santo Domingo don Francisco Rubio y Peñaranda a la Corte con fecha de 24 de junio de 1753, y respuesta de aquella de 15 de septiembre del mismo año. A.G.I. Santo Domingo, 1.010.

50 Relación del tabaco embarcado en la balandra del Rey San Carlos, por orden del gobernador don Manuel de Azlor y Urríes en 1762. A.G.I., Indiferente General, 1.745. 
Respecto a este envío, en carta de 6 de febrero de 1763 don Manuel de Azlor informó a la Corte, que no sabiendo lo que podía durar la guerra con Inglaterra, y antes de recibir la real orden en que se le comunicaba el cese de las hostilidades, había ordenado la compra de algún tabaco de la isla para remitirlo a España, ante la imposibilidad de recibir allí el que debía ser enviado desde Cuba. El gobernador aprovechaba esta situación, para solicitar al Rey se permitiese remitir desde Santo Domingo nuevas cargas de este fruto, al igual que se hacía desde La Habana, enviando la Corona el dinero necesario para su compra y para el fomento de su cultivo, evitando así que un suceso parecido al de la toma de La Habana por los ingleses, produjera el cese de las remesas a la Península. ${ }^{51}$

A consecuencia de ello, y en el mismo año, el Consejo de Indias acordó con la aprobación real, la creación de una Factoría de Tabacos en Santo Domingo, que debía estar a cargo de un factor y un oficial contador interventor.

Esta factoría tendría como fin la compra y remisión del tabaco dominicano, a excepción del necesario para el consumo interno, y fomentar las labranzas, sobre todo del de las mejores calidades. ${ }^{52} \mathrm{Al}$ mismo tieinpo se ordenó al virrey de México que, junto con el situado, enviase anualmente a Santo Domingo 25.000 pesos, que estarían dedicados a la compra del tabaco del país. El virrey, tanto en 1765 como en I766, envió los 25.000 pesos que se le ordenaban, y que el gobernador recibió. Sin embargo, no habían llegado a manos de don Manuel de Azlor las instrucciones formadas en 1763 para la creación de la factoría, y así daba cuenta al Consejo, con fecha de 7 de enero de 1768, de hallarse en posesión de los 50.000 pesos que le habían sido remitidos desde México, y que esperaba otros 25.000 con el siguiente situado,

51 Carta del gobernador don Manuel de Azlor a la Corte con fecha de seis de febrero de 1762, explicando los motivos de enviar remesas de tabaco a España y solicitando se fomentase su cultivo. A.G.I. Indiferente General 1.745 .

52 Instrucciones dadas para la creación de una factoría de tabacos en Santo Domingo. 11 de octubre de 1763. A.G.I. Santo Domingo, 1.055. 
pero que se encontraba sin instrucciones sobre su empleo y sin factores $\mathfrak{u}$ otras personas que se encargasen de la compra. Al mismo tiempo, proponía que se ocupara de este asunto el entonces guarda almacén de la plaza, don Andrés de Lecanda. ${ }^{53}$

Poco después, el 22 de agosto del mismo año, se ordenaba al gobernador de Santo Domingo que de los 50.000 pesos que había recibido, gastase de 25 a 30 en la compra de tabaco de las mejores calidades remitiéndolos cuanto antes a Cádiz, con una nota en la que se indicasen los lugares de que procedía. Debía informar además de los costos detallados de los envíos, y de las siembras que pudieran hacerse en la isla. ${ }^{54}$

El gobernador entonces escogió tabacos de las mejores calidades, y los envió en r 770 a Cádiz en el navío "San Antonio", alias el "Culiacán". Constaba este cargamento de 3.757 arrobas de tabaco en rama, y 15 barriles con 307 arrobas y 18 libras, en 172.788 cigarrillos labrados. Así pues, el peso total era de 4.064 arrobas, 18 libras, y su coste de 315.068 reales, 6 maravedíes, distribuidos en la forma siguiente:

\section{Reales Maravedies}

- Para la compra del tabaco ...... I 77.082 30

- Por los salarios y los gastos de las personas empleadas en ello.

- Por los fletes del tabaco ..... 53.337

- Por su traslado de Cádiz a Sevilla

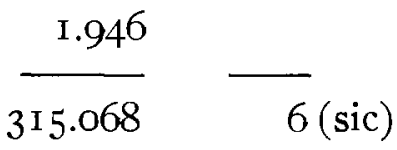

53 Carta del gobernador de Santo Domingo don Manuel de Azlor y Urríes a la Corte, fechada en Sarı Juan de la Maguana a siete de enero de 1768, sobre los envíos de caudales desde Méjico para la compra de tabaco. A.G.I. Santo Domingo ,1.055.

54 Carta del gobernador don Manuel de Azlor de 29 de abril de 1770, acusando el recibo de la Real Orden de 22 de agosto de 1768. A.G.I. Indiferenter General, 1.745. 
De este modo, cada libra de tabaco había venido a costar a la Real Hacienda por término medio, independientemente de su calidad, unos 3 reales y 19 maravedíes de ve1lón. ${ }^{55}$

Hasta entonces, los españoles se habían limitado a cultivar este producto en las haciendas de Santiago y la Vega, recogiéndose unas 10.000 arrobas al año, y ocupándose en su labor unos 247 vecinos, ayudados por 202 esclavos. Pero había otros terrenos muy apropiados para este cultivo, y su producción podría incrementarse considerablemente, de contar con la mano de obra suficiente para ello. ${ }^{\mathbf{5 6}}$

La creación de la Factoría de Tabacos en Santo Domingo, que significó la compra por parte de la Corona del tabaco dominicano, hizo que su producción aumentara bastante, extendiéndose por toda la Vega Real hasta Cotui. ${ }^{57}$

En mayo de I77I, llegó a Cádiz un nuevo cargamento de tabaco procedente de Santo Domingo, en el paquebote "San Esteban". Había sido recogido en los partidos de Licey, Limonal, Gurabo, Guazimal, Guayabal, Sabana Grande, Hato Mayor, Canca, Quinigua, Moca, Jacagua, Exido y Papayo, todos ellos en los alrededores de Santiago. Su peso total era de 37.452 libras, I 7.653 de ellas del conocido en Santo Domingo con el nombre de Tienda o de primera calidad, y 19.799 del de Rescogido o de segunda calidad.

Tras su llegada a la Península, este tabaco fue reconocido en las Reales Fábricas de Sevilla. El dictamen de los prácticos fue que los de calidad T. (tienda) eran los mejores, de hoja limpia y sana, con "buen olor, fuerza, y gusto para los consumidores". Respecto a los de calidad R. (rescogido), los de Licey, Limonal, Quinigua, Guayabal, Sabana Grande, Jacagua y Gurabo eran malos, y los procedentes de

55 Liquidación del costo que han tenido para la Real Hacienda las 88.531 libras de tabaco embarcadas en el navío San Antonio hacia España. Santo Domingo, 8 de octubre de 1770. A.G.I., Santo Domingo, 1.055 .

56 Representación del gobernador de la isla don Manuel de Azlor de 28 de junio de 1770 , sobre el fomento del cultivo del tabaco en Santo Domingo. A.G.I. Santo Domingo, 1.055 .

57 Moreau de Saint-Mery, M. L.: Op. cit., pág. 98. 
los otros seis partidos señalados eran mejores aunque "les falta más cuidado en que fermenten sus ojas". ${ }^{58}$

En octubre del mismo año llegó a Cádiz desde Santo Domingo el bergantín "San Antonio", con una nueva carga de tabaco. En esta ocasión aparecían ya tres calidades: T (tienda), R (rescogido), y L (libra). Procedía este tabaco de los mismos lugares que el cargamento anterior, y su peso era de 67.186 libras distribuidas en la siguiente forma:

- De calidad T ........................ 8.569 libras

- De calidad R ......................... 31.109 libras

- De calidad L .......................... 27.508 libras

En esta ocasión los prácticos de las reales fábricas informaron, que los tabacos marcados como de tienda eran de muy buena calidad y bien tratados, pudiendo igualarse con los de La Habana. Los de rescogido, aunque peores, estaban en el grado de madurez que debían, mientras que los de libra eran bastante peores, conteniendo hojas bastante dañadas por haber estado las matas "más cerca de la tierra". Señalaban al mismo tiempo, que los dos primeros eran ya de mejor calidad que los de Virginia para la elaboración de cigarros. ${ }^{59}$

Las tres denominaciones empleadas en su clasificación no representaban al parecer un tipo diferente de hoja, sino tres calidades distintas.

Con este motivo, el 23 de noviembre de I 77 I se remitieron a Santo Domingo estos informes, ordenando al gobernador de la isla fomentase en lo posible el cultivo del tabaco.

Las ideas mercantilistas imperantes aún en la economía española, llevaban a reducir en lo posible las importaciones, $y$, en este caso, las cosechas del tabaco dominicano podían sus-

58 Sevilla, 22 de mayo de 1771 . Nota del reconocimiento que hicieron los prácticos de las Reales Fábricas de Sevilla, del tabaco llegado a España en el paquebote San Esteban procedente de Santo Domingo. A.G.I., Santo Domingo, 1.055.

59 Sevilla, 24 de octubre de 1771. Nota del reconocimiento que hicieron los prácticos de las Reales Fábricas de Sevilla, del tabaco llegado a España en el bergantín San Antonio procedente de Santo Domingo. A.G.I. Santo Domingo, 1.055. 
tituir al que entonces se compraba en Norte América, concretamente al de Virginia. Por ello, se ordenaba al gobernador que enviase la mayor cantidad posible para poder prescindir totalmente de aquél. ${ }^{60}$

Así pues, la segunda mitad del siglo XVIII supuso el incremento de este cultivo, ya antiguo en la isla, y que irá adquiriendo cada vez mayor importancia. Alcanzó pronto una producción regular en toda la Vega, siendo los mejores los de los alrededores de la ciudad de Santiago de los Caballeros, y concretamente los de los partidos de Gurabo, Licey, Limonal, Jacagua y Sabana Grande.

En 1772 el gobernador de Santo Domingo escribía a la Corte, que había tomado todas las medidas oportunas para el incremento de las siembras, consiguiendo que aumentasen respecto a las del año anterior, de modo que en aquel momento tenía almacenadas 12.000 arrobas para remitir a las fábricas de Sevilla, pensando que al año siguiente la carga podía ascender a 18.000 arrobas. ${ }^{61}$

Pero si en un principio la creación de la Factoría de Tabacos significó el incremento de la producción de este fruto, las ideas económicas imperantes en España van a ocasionar pronto graves problemas por lo que se refiere a este cultivo. El estanco del tabaco establecido originó serios descontentos entre los cosecheros, que vendían su producto a un precio tope establecido que en nada les beneficiaba. A causa de ello, los de Santiago dirigieron una instancia a la Corte en I772, apoyada por el gobernador don José Solano y Bote, en la que solicitaban se igualasen los precios de los diferentes tipos de tabaco con los que se pagaban por los similares que se compraban en Cuba. Al mismo tiempo, pidieron que se les facilitasen los medios para conseguir negros esclavos

60 Orden dirigida al gobernador de Santo Domingo con fecha de 23 de noviembre de 1771, para que intentase fomentar por todos los medios el cultivo del tabaco en la isla. A.G.I. Santo Domingo, 1.055 .

61 Carta del gobernador de Santo Domingo don José Solano y Bote de 24 de diciembre de 1772, informando a la Corte de los resultados obtenidos con el fomento del cultivo del tabaco. A.G.Y. Santo Domingo, 1.055. 
con destino a las labores de este cultivo, pagados por la Real Hacienda, a la que ellos retribuirían con tabaco.

Con este motivo, los prácticos de las Reales Fábricas de Sevilla realizaron un informe sobre los cargamentos que llegaban de Santo Domingo, manifestando que los de calidad T eran equivalentes a la hoja regular procedente del partido de Santiago de Govea en Cuba; los de calidad R a los del partido de Santiago de Cuba, y los de calidad L a los del partido de Bayamo Largo en la misma isla.

A la vista de este informe se comunicó al gobernador de Santo Domingo, que el Rey autorizaba la subida de cuatro reales de plata en cada arroba de tabaco de las tres clases, que hasta entonces se pagaban a 18,16 y 12 reales respectivamente, con tal de que el tabaco de Tienda o calidad $\mathrm{T}$ que se enviase fuera de la mejor calidad, para que pudiera equipararse en realidad al cubano. ${ }^{62}$

Esta orden no decía nada sobre la compra de los negros que los cosecheros necesitaban, y don José Solano actuó por su cuenta, amparándose en la real orden de i 8 de octubre de I 770 en que se le prevenía fomentase el cultivo del tabaco y la creación de la Factoría, proporcionando esclavos a los estancieros por cuenta de la Real Hacienda. Así, en carta de 25 de mayo de 1774 comunicaba a la Corte, que había hecho traer I 50 negros de las colonias vecinas, pagándolos del ramo de tabacos, por un precio de 33.000 pesos. Repartió los negros entre los cultivadores, que se comprometieron a retribuirlos con la cosecha de aquel año y las de los dos siguientes. ${ }^{63}$

Salvados estos escollos, continuó el auge tabaquero. En

62 Carta del gobernador don José Solano de 24 de agosto de 1772, apoyando una instancia de los cosecheros de Santiago de los Caballeros, en la que solicitaban la elevación de los precios del tabaco y algunas otras gracias; informe de los prácticos de las Reales Fábricas de Sevilla de 17 de marzo de 1773 sobre la calida del tabaco dominicano y comunicación del Consejo de Indias a don José Solano autorizando la subida. A.G.I. Santo Domingo, 1.055 .

63 Carta del gobernađor don José Solano y Bote a la Corte, con fecha de 25 de mayo de 1774, dando cuenta de haber proporcionado esclavos a los estancieros para fomentar el cultivo del tabaco. A.G.I. Santo Domingo, 1.055. 
I773, el tabaco escogido para las Reales Fábricas ascendió a 3.I3 I quintales, y en I774 a unos 6.000.

Este aumento en la producción hacía cada vez más difícil y costoso el traslado desde la Vega Real a la capital, siendo necesario para este fin, hacer navegables los ríos Yuma y Camú a costa de las ciudades de Santiago, La Vega y Cotui, encargándose de su transporte por río la Compañía de Barcelona.

El futuro se presentaba próspero para los cosecheros, la producción aumentaba considerablemente, de modo que en I 772 ascendió a 13.989 arrobas, cifra que se igualó poco más o menos en 1773 a pesar de la grave sequía sufrida ese año, mientras que se estimaba que la de I774 alcanzaría las 24.000.

Pero la alegría iba a durar poco, ya que en esa misma fecha, concretamente el 16 de septiembre, el Consejo de Indias remitió al gobernador de Santo Domingo una real orden, en la que se le prevenía que los prácticos de las Reales Fábricas habían estimado en unas $\mathbf{1 2 . 0 0 0}$ arrobas aproximadamente, la cantidad de tabaco de aquella isla que se necesitaba en ellas para la fabricación de cigarros, y que éstas debían ser recogidas en el partido de Licey, de donde procedía el de mejor calidad. Se aconsejaba al gobernador por tanto, procurase se redujesen las siembras a los lugares donde se cosechaban los mejores, y que esta reducción se hiciera de modo que no fuese "sensible" a los labradores, que con el tiempo podrían dedicar sus tierras a otros cultivos.

Para pagar la cosecha de aquel año, se ordenó al virrey de México que remitiera a Santo Domingo el dinero necesario. Pero en lo sucesivo la compra debía limitarse a esas I 2.000 arrobas poco más o menos. ${ }^{65}$

De este modo, la concepción mercantilista de la econo-

64 Carta del gobernador don José Solano dirigida a la Corte, con fecha de 25 de septiembre de 1774, informando a aquélla de las dificultades existentes para transportar el tabaco a la capital. A.G.I. Santo Domingo, 1.055.

65 Real Orden dirigida al gobernador de Santo Domingo wn fecha de 16 de septiembre de 1774, previniéndole la reducción de las siembras de tabaco en aquella isla. A.G.I. Santo Domingo, 1.055 . 
mía, en la que lo que importaba era el beneficio exclusivo de la Metrópoli, cortará el desarrollo de una nueva fuente de riqueza en Santo Domingo. La economía de las colonias se encontraba al servicio de la Península. Mientras las manufacturas nacionales necesitasen materias primas, habia que fomentar su prodúcción en las colonias y evitar su importación del extranjero; pero en el momento en que sus necesidades estuviesen cubiertas tenían que reducirla. Y esto es lo que ocurrió en Santo Domingo con el tabaco. La real orden citada, significó que los agricultores vieran desperdiciadas sus cosechas sin mercado para ellas, con la consiguiente ruina para muchos. Las Reales Fábricas se abastecían esencialmente del tabaco cubano, cuya producción acauaró por completo desde I7I8 hasta principios del siglo XIX, ${ }^{66}$ recurriendo sólo al dominicano para cubrir la diferencia entre los suministros de Cuba y las necesidades de su ritmo normal de fabricación.

Intentando evitar el grave error que esta medida representaba, el gobernador don José Solano respondió a ella que haría lo que se le ordenaba, pero, al mismo tiempo, solicitaba que el tabaco dominicano pudiera ser exportado "sea para las reales fábricas de Sevilla u otros estancos de estos reynos", por ser el medio más eficaz de levantar la desastrosa economía insular, que se vería arruinada por completo de persistir en la idea de limitar las siembras.

Pero poco importaba al gobierno central la economía de Santo Domingo a no ser en función de la de la Metrópoli, y la respuesta a don José Solano ratificaba la decisión anterior, de no dar salida a más de 12.000 arrobas del tabaco cultivado en la isla. ${ }^{67}$

Los cosecheros se encontraron así con que el mercado

66 Vid. Rodríguez Ferrer, Miguel: El tabaco habano. Su historia, sus cultivos, sus vicisitudes, sus más afamadas vegas. Imprenta del Colegio Nacional de Sordomudos. Madrid, 1851.

67 Carta del gobernador de Santo Domingo don José Solano y Bote de 24 de diciembre de 1774, informando a la Corte de lo desacertado de la reducción de las siembras de tabaco, y respuesta ce aquella de 21 de abril del año siguiente. A.G.I., Santo Domingo, 1.055 . 
español les era limitado, y al tener cerrado cualquier otro por el sistema monopolista de la Corona, decayó rápidamente la producción, aurique ni el gobernador ni los cosecheros se resignasen a ello.

Los envíos regulares de tabaco a Cádiz con todo esto, sólo duraron unos 6 años: desde I77 I a i776 ambos inclusive, con un volumen total de 52.864 arrobas y 15 libras de las tres calidades, distribuidas en la siguiente forma:

Tabaco de $\mathrm{T}$. Tabaco de $R$. Tabaco de $L$. años arrobas libras arrobas libras arrobas libras

\begin{tabular}{lrlrrrr}
\hline I77 I & I.805 & I9'5 & 2.479 & IO'5 & I.100 & 8 \\
I772 & 690 & II & 1.817 & 8 '5 & 759 & 3 \\
I773 & 2.505 & I8 & 5.086 & 9 & 3.812 & 0 \\
I774 & I.123 & I7 & 4.469 & 20 & 7.903 & I3 \\
I775 & 1.040 & O & 3.216 & 0 & 4.336 & 0 \\
I776 & 712 & O & 5.199 & 3 & 4.808 & 0 \\
\hline Total: & 7.877 & I5'5 & 22.268 & I & 22.718 & 24
\end{tabular}

A partir de este año, y a causa de la decadencia producida por la real orden de I6 de septiembre de 1774 , los envíos se hicieron poco frecuentes, de manera que en algunos años, como en I777, no llegó a Cádiz ningún cargamento de este fruto procedente de Santo Domingo.

En 1777, un tal don Miguel Calvo envió una instancia a la Corte, en la que manifestaba que al ser el factor del ramo de tabacos al mismo tiempo guarda almacén de la plaza de Santo Domingo, no podía atender el fomento de este fruto, por lo que las cosechas eran cada vez más bajas. El Consejo de Indias pidió informe al gobernador sobre este asunto, quien rápidamente aprovechó la ocasión para manifestar, su creencia de que el incremento de este cultivo era el único

68 Nota de las embarcaciones que transportaron tabaco de Santo Domingo a España. A.G.I. Santo Domingo, 1.055 . 
medio de levantar a la isla de la miseria en que se encontraba. Desmentía rotundamente las afirmaciones de don $\mathrm{Mi}$ guel Calvo, ya que la decadencia en la producción de tabaco se debía desde luego, a la real orden de 16 de septiembre de I774 que mandaba reducirla, insistiendo de nuevo en que se permitiera, al menos, la extracción del que no podía ser comprado por parte de la Corona para las Reales Fábricas. ${ }^{69}$

En el mismo sentido se manifestaba el cura rector de Santiago de los Caballeros, en una representación que hizo a la Corte, solicitando la compra por parte del Rey de todo el tabaco que la isla podía producir. ${ }^{70}$

En esta ocasión, las súplicas de los dominicanos fueron por fin escuchadas, merced al cambio de las ideas sobre el comercio producido en estos años, y que culminó con la promulgación del Reglamento del Libre Comercio en 1778.

Al mismo tiempo, el consumo de tabaco era cada vez mayor en España, y la producción acaparada por entonces por las Reales Fábricas se mostraba insuficiente. Con motivo de ello, el 17 de noviembre de 1778 se envió una real orden al gobernador de Santo Domingo, en aquellos años don Isidro de Peralta y Rojas, previniéndole que facilitase las siembras para poder surtir convenientemente a aquéllas con las I2.000 arrobas estipuladas, ya que la decadencia en que había caído aquel fruto hizo disminuir los envíos. Se autorizaba asimismo a los labradores, en virtud del Reglamento del Comercio Libre del mismo año, a exportar los tabacos sobrantes a la colonia francesa de la isla, tomando a cambio de él dinero o. esclavos.

El tabaco era de nuevo solicitado por España con urgencia; en virtud de ello, el gobernador envió en 1780 la cosecha de I778, unas II.692 arrobas. Pero manifestaba don Isidro de Peralta no poder remitir una cantidad mayor,

69 Carta del gobernađor don José Solano con fecha 20 de febrero de 1778, dando cuenta a la Corte de la decadencia del cultivo tabaquero. A.G.I. Santo Domingo, 1.055.

70 Representación del cura rector de la ciudad de Santiago de los Caballeros de 25 de junio de 1779 sobre las dificultades que atravesaban los cosecheros. A.Gr.I. Santo Domingo, 1.059 . 
ya que sólo contaba para su compra con 25.000 pesos anuales, que por otra parte hacía tiempo que no llegaban de México.

Sin embargo no se trataba sólo de problemas de dinero. Era difícil entonces un incremento de esta producción, y los cargamentos con destino a la Península escaseaban cada vez más, de modo que en julio de 1785 el Consejo de Indias apremiaba al gobernador, para que sin la menor dilación y en la primera ocasión que se presentase, enviara la mayor cantidad de tabaco que pudiera recoger, continuando a partir de entonces las remisiones acostumbradas. A ello respondió el gobernador expidiendo $21 \mathrm{I} .700$ libras. Pero al mismo tiempo afirmaba, que la siguiente remesa no podría alcanzar el peso que se le pidió por la decadencia en que se encontraba aquel fruto, con motivo de la reducción obligada de sus siembras y de las sequías. ${ }^{72}$

Con todo ello, y como ya hemos señalado, al iniciarse estas peticiones en I778, el gobernador de Santo Domingo envió para las Reales Fábricas de Sevilla 1.508 arrobas de tabaco de tienda, 4.372 de rescogido, y 7.872 de libra. ${ }^{73}$

De nuevo cesaron estos cargamentos en 1779, reanudándose en $\mathbf{I 7 8 0}$ ante las apremiantes órdenes recibidas. Pero desde entonces hasta la cesión de toda la isla a la República Francesa en 1795, y concretamente hasta 1796, ambos inclusive, fueron embarcadas en Santo Domingo con destino a Cádiz un total de 99.679 arrobas solamente, es decir unas 5.864 anuales, cesando por completo las remesas de este fruto a partir de ese año. ${ }^{74}$

71 Carta del gobernador de Santo Domingo don Isidro de Peralta y Rojas de 24 de febrero de 1779, acusando el recibo de la Real Orden de 17 de noviembre de 1778 sobre el fomento de las siembras de tabaco en aquella isla, y otra de 18 de mayo del mismo año, informando a la Corte de la falta de dinero para la compra del tabaco. A.G.I. Santo Domingo, 1.055 .

72 Orden dirigida al gobernador de Santo Domingo de nueve de julio de 1785 para que enviase tabaco a España y respuesta de aquél de 29 de septiembre del mismo año. A.G.I. Santo Domingo, 1.055 .

73 Factura del tabaco enviado a España desde Santo Domingo en 1778. A.G.I. Santo Domingo, 945 y $\mathbf{1 . 0 5 5 .}$

74 Factura del tabaco enviado a España desde Santo Domingo desde 1779 a 1796. A.G.T. Santo Domingo, 947, 954 ,955, 959, 1.055 y 2.677. 
De este modo, y como había ocurrido con el azúcar y el cacao, la expansión de la economía tabaquera se vio obstaculizada por una política económica a la que sólo importaba los intereses de la Metrópoli, sin tener en cuenta que en ocasiones se perjudicaba con ello a las propias colonias.

El estanco primero y la limitación de la producción después, fueron dos barreras con las que tuvieron que enfrentarse los labradores dominicanos, con el consiguiente perjuicio para un producto de gran calidad, que se había convertido en unos años en el más importante de la isla, y que probablemente, si el esquema económico de la época se hubiera basado en el libre cambio que caracteriza los últimos años del siglo, hubiera significado una importante fuente de ingresos para el Santo Domingo español, y al mismo tiempo, la base de un desarrollo que tan urgentemente estaba necesitando.

\section{INTENTOS DE FOMENTAR LA AGRICULTURA}

El siglo XVIII, como ya hemos señalado anteriormente, fue un siglo de reformas en toda Europa, y desde luego en España, con la llegada al trono de una nueva dinastía procedente de Francia, que traerá imbuidas las ideas entonces imperantes allí. El llamado despotismo ilustrado, sistema que triunfa en Europa en el siglo XVIII, va a ser encarnado en España por los Borbones, sobre todo en la segunda mitad del siglo, aunque como vemos, con algo de retraso respecto al resto de Europa.

Políticamente se persigue el absolutismo monárquico, con la supresión de los fueros regionales y la centralización de la administración, produciéndose al mismo tiempo el robustecimiento del poder real. Económicamente se intenta también el fortalecimiento del tesoro. Pero para ello era necesaria la revitalización de los medios de producción, para al mismo tiempo que se enriquecía el país enriquecerse la 
monarquía, y así consolidar aún más su autoridad. Y el único medio que en un principio se vio como posible para conseguirlo, fue la intervención estatal en los asuntos económicos.

Esta intervención se centró sobre todo en fomentar la industria nacional, para lo cual era necesario favorecer la producción de materias primas en las colonias, con el fin de obtenerlas al precio más bajo posible.

De este modo, las colonias americanas se van a ver beneficiadas en general, aunque indirectamente, por estos intentos de los monarcas de incrementar la riqueza nacional.

Pero si este sistema intervencionista dio algunos resultados en un principio, pronto se mostró insuficiente para el gran impulso que los Borbones pretendieron dar a la economía del país. El monopolio evitó el desarrollo de algunos productos como ocurrió por ejemplo con el tabaco dominicano, por la competencia sufrida en el mercado español con el de otros lugares. La imposibilidad de colocarlos en otros hizo decaer la producción, de modo que, cuando la industria nacional por escasez de su fuente de aprovisionamiento habitual necesitaba de ellos en un momento determinado, no encontraba donde surtirse.

Al mismo tiempo en el resto de Europa se iba sustituyendo el mercantilismo, triunfante en los siglos anteriores, por las teorías del liberalismo económico.

Estos dos factores debieron ser decisivos, para el cambio que se produjo en la política seguida hasta entonces por la Corona española. Poco a poco se fueron reduciendo algunos impuestos y concediendo determinadas libertades al comercio, que culminaron en 1778 con la promulgación del Reglamento del Comercio Libre.

E1 reflejo que todo esto va a tener en Santo Domingo se centra fundamentalmente en un punto: el incremento agrícola, de manera que la isla sirviese como fuente de abastecimiento a la Península. Contribuye a ello el auge que entonces alcanzaban las teorías fisiocráticas, que valoraban como primera fuente de riqueza de un país su producción 
agrícola. Una nación es más rica, cuanto mayor es la producción agrícola.

De este modo, y por una real cédula fechada en Aranjuez el i6 de octubre de I765, se declaraba la abolición de los derechos que hasta entonces se cobraban por el azúcar de Cuba, Puerto Rico, Santo Domingo, Margarita y Trinidad, reduciéndose todos ellos a un $6 \%$ de alcabala en el momento de la venta, o bien a su salida de las islas.

Al mismo tiempo, y también para fomentar la producción azucarera de aquellos lugares, se establecía la abolición del real derecho de marca de los esclavos introducidos en ellos, que ascendía a 40 pesos por cada negro o negra adultos, 26 por cada mulecón, y 20 por cada muleque, para de este modo, facilitar la entrada de los negros que los hacendados necesitaban para sus labranzas, sustituyendo este impuesto por uno anual de 3 pesos por cada varón, I'5 por cada mujer, y I por cada muleque.

Poco tiempo después, era el añil el que se veía beneficiado por las reformas arancelarias. En I767, el fiscal de la Audiencia de Santo Domingo daba cuenta al Consejo, de que había comenzado a cultivarse el añil en aquella isla, y que al ser un fruto "industrial", al igual que el azúcar y otros que no pagaban los derechos regulares, se había dudado sobre la cantidad que se debía cobrar por sus diezmos. $\mathrm{Y}$ teniendo en cuenta que era un fruto de nuevo cultivo, y que al parecer se había adaptado perfectamente a aquellas tierras, y que convenía extender, el gobierno estableció que se pagara sólo un I por 20 en espera de la aprobación real. El Consejo de Indias y el Rey con él, aceptaron esta decisión tanto por el motivo expuesto, como por ser un fruto con destino a la industria que con tanto empeño querían impulsar. ${ }^{76}$

También el algodón quedó libre de derechos descle

75 Real Cédula fechada en San Lorenzo el 16 de octubre de 1765 reduciendo 1is cierechos cobrados por el azúcar americano exportado a España, y la abolición del que se pagaba por la marca de esclavos. A.G.I. Santo Domingo, 2.410.

76 Carta del fiscal de la Audiencia de Santo Domingo de 10 de febrero de 1757 dirigida a la Corte y expediente formado en el Consejo de Indias del mismo año. A.G.I. Santo Domingo, 978. 
I766, ${ }^{77}$ y en 1768 se tomó la misma medida con el café, que quedaría libre de todos los impuestos por cinco años. ${ }^{78}$

$\mathrm{Y}$ estas libertades fueron extendiéndose y haciéndose cada vez más numerosas, sobre todo en los años en que gobernaba en España Carlos III, el verdadero monarca ilustrado, cuyo reinado fue ejemplo de esas reformas, que aunque venían produciéndose poco a poco en la época de sus antecesores, casi desde principios del siglo, adquieren con él pleno desarrollo, gracias a la labor llevada a cabo por los excelentes ministros de que supo rodearse.

Así en I783, don Juan Bautista de Oyarzábal solicitó a la Corte varias gracias, para el fomento de un ingenio de azúcar que poseía en las cercanías de la capital. ${ }^{79} \mathrm{El}$ Rey, después de que el Consejo estudiase el asunto, envió una real orden al gobernador de Santo Domingo con fecha de 23 de diciembre de $I 783$, en la que se le prevenía haber concedido al mencionado solicitante lo siguiente:

- Que pudiese remitir a aquella capital desde Cádiz todos los utensilios que allí tenía, que habían sido comprados a varias presas inglesas.

- Que pudiera llevar todos los demás que necesitase de los países extranjeros, embarcándolos en cualquier puerto de los habilitados en la Península, sin pagar derechos a su salida de ellos ni a su llegada a Santo Domingo, con la facultad de poderlos vender o arrendar a cualquier otro hacendado que los necesitase sin devengar aranceles tampoco, pues estando dirigida esta medida al incremento de la fabricación de azúcar, era indiferente que aprovechase al solicitante o a cualquier otro.

77 Carta del gobernador de Santo Domingo don Manuel de Azlor de 20 de febrero de 1767, acusando el recibo de la Real Orden de 24 de octubre de 1766, que declaraba libre de derechos el algodón. A.G.I. Santo Domingo, 944.

78 Carta del gobernador don José Solano y Bote dirigida a la Corte con fecha de 11 de diciembre de 1771, acusando el recibo de la Real Orden de ocho de junio de 1768 , en la que se le pedía informase sobre el cultivo del café, y se declaraba libre de derechos por cinco años a este fruto. A.G.I. Santo Domingo, 981.

79 A este respecto hemos de señalar que si bien al hacer esta solicitud don Juan Bautista de Oyarzábal aparece como dueño de un ingenio de azúcar, posteriormente nos 10 encontramos como administrador. 
- Que pudiese introducir en la isla 400 negros libres de todos los impuestos para el cultivo de su hacienda, pudiéndolos también ceder o vender a otros, siempre que estuvieran destinados a las mismas labores, sin pagar contribución alguna.

- Que no se le exigiese el diezmo durante diez años, contados desde que comenzara a dar fruto su hacienda. ${ }^{80}$

Con este motivo, en 1784 el gobernador don Isidro de Peralta y Rojas apoyaba ante el Consejo de Indias una instancia de don José de la Vegła y don Ignacio Caro de Oviedo, dueños de dos ingenios de azúcar en la jurisdicción de la capital, en la que solicitaban se les permitiese introducir 200 negros a cada uno de ellos de las colonias extranjeras, 40 fondos de pailas, cuatro juegos de molino completos y 500 azadas, todo libre de los reales derechos, y en los mismos términos en que antes se concedió a Oyarzábal. El Rey accedió, extendiendo de este modo a dos nuevos hacendados las libertades que había otorgado a aquél. ${ }^{81}$

Sin embargo, en I 788 don Juan Bautista de Oyarzábal expuso en un memorial dirigido a la Corte, que pese a las gracias de que le hicieron merced por la real orden de 23 de diciembre de 1783 , todavía no había podido cumplir con una de ellas: la introducción de los cuatrocientos negros. Manifestaba que, a pesar de todos sus intentos, sólo logró adquirir 60 , a causa de la escasez de embarcaciones propias de este tráfico que se acercaban a Santo Domingo, y que si se le permitía salir a él mismo a comprarlos a los barcos ingleses que desde Africa se dirigían a las colonias cercanas, conseguiría los que le faltaban con mayor facilidad.

De nuevo el Rey cedió a las peticiones de Oyarzábal, ampliando el permiso que le concedió anteriormente para

80 Carta del gobernador don Isidro de Peralta y Rojas de 21 de abril de 1784, acusando el recibo de la Real Orden de 23 de diciembre de 1783 concediendo diversas gracias a un azucarero dominicano. A.G.I. Santo Domingo, $94 \hat{6}$.

81 Carta del gobernador don Isidro de Peralta y Rojas de 21 de julio de 1784, apoyando una instancia de dos propietarios de ingenios dominicanos, y resolución real fechada en San Lorenzo el 30 de octubre del mismo año. A.G.I. Santo Domingo, 1.012 . 
que pudiera obtener los negros directamente en los navíos que los llevaban a América, que aunque no recalaban en aquel puerto, pasaban cerca de las costas dominicanas. ${ }^{82}$

Pero independientemente de estas concesiones, que afectaban solamente a unos cuantos particulares que las solicitaron, y a unos sectores determinados de la economía, se otorgaron en los años que estamos estudiando una serie de gracias, que afectarán por igual a todos los vecinos de la isla, y que irán dirigidas al incremento de todas las fuentes de riqueza, y en especial de la agricultura y la industria de sus derivados.

Gobernaba en Santo Domingo desde I759 el brigadier don Manuel de Azlor y Urríes a quien, a pesar de algunas graves acusaciones que se le hicieron con motivo de su juicio de residencia, hay algo que nadie podría negar: su constante esfuerzo por sacar a Santo Domingo de la postración en que se encontraba, utilizando para ello todos los medios a su alcance, y a veces en abierta desobediencia con la órdenes del poder central.

En I766, con motivo de una visita que estaba realizando por la isla, el gobernador escribió a la Corte exaltando su fertilidad y las grandes riquezas que la Corona podía sacar de allí, si se atendía a sus problemas y se tomaban tres medidas que él consideraba fundamentales:

- La libertad de derechos en España para todos los frutos procedentes de Santo Domingo.

- Prestar dinero a los hacendados para la compra de esclavos, con la obligación de pagar a la Real Hacienda un $3 \%$ al año del total de la deuda, mientras no pagasen su importe completo.

- Poblar toda la isla y en especial la zona de la frontera francesa. ${ }^{83}$

82 Aranjuez, 21 de junio de 1788. Orden dirigida al gobernador de Santo Domingo sobre unas solicitudes hechas por don Juan Bautista de Oyarzábal. A.G.I. Indiferente General, 2.821 .

83 Carta del gobernador de Santo Domingo don Manuel de Azlor dirigida a la Corte con fecha de 27 de abril de 1766, proponiendo los medios necesarios para el fomento de la isla. A.G.I. Santo Domingo, 944. 
No obtuvo respuesta a su carta, y al año siguiente se dirigió de nuevo a la Corte, haciendo hincapié en el asunto. En esta ocasión, apoyaba una instancia que le había dirigido el Cabildo de la capital, en la que se manifestaba que la decadencia en que la isla se encontraba era causa de su despoblación y la consiguiente escasez de mano de obra; que "puede esta isla sola, quizás en cincuenta años, dar tanto cacao como la provincia de Caracas, tanto tabaco y azúcar como la isla de La Habana, y tanto café y algodón como les produce a los franceses". Para que esto pudiera ser una realidad, solicitaba se les permitiese enviar sus frutos a Españia y traer de vuelta los géneros que necesitasen de ella, sin que la Real Compañía de Barcelona les proveyese, e igualmente, que se les autorizara el libre comercio por lo menos con la colonia francesa vecina, así como la repoblación de todo el territorio. ${ }^{84}$

El asunto fue estudiado por el Consejo, con los correspondientes informes enviados al respecto por su fiscal y la Contaduría general, y tras largas deliberaciones, acordó desechar por el momento las peticiones del Cabildo y del gobernador de Santo Domingo, teniendo por conveniente que, cuando llegara el nuevo gobernador que había de nombrarse para aquella isla por expirar el tiempo para el que don Manuel de Azlor había sido designado, se formase una junta compuesta de dos o tres oidores, el fiscal de la Audiencia, el teniente del rey, los oficiales reales, dos capitulares del Ayuntamiento, los prácticos, y algunos labradores. Esta junta debería formar los planes para el fomento adecuado de la isla, con el fin de incrementar las cosechas de azúcar, añil, cacao, algodón, tabaco, comercio de cueros, y demás productos que en ella se produjesen. ${ }^{85}$

Sin embargo, no hubo en principio nuevo gobernador

84 Carta del gobernador de Santo Domingo don Manuel de Azlor dirigida a la Corte, con fecha 18 de enero de 1767, apoyando una instancia del Cabildo de la ciudad de Santo Domingo, en que hace hincapié en los medios necesarios para el fomento de la isla. A.G.I. Santo Domingo, 978.

85 Resolución del Consejo de Indias de octubre de 1769, sacada del expediente sobre el fomento de la isla Española. A.G.I. Santo Domingo, 1.034. 
para la Española, pues gracias a una representación del $\mathrm{Ca}$ bildo de la capital elogiando la labor llevada a cabo por don Manuel de Azlor, éste fue prorrogado en sus cargos por ocho años más. ${ }^{86} \mathrm{Y}$ a él fue dirigida la real cédula de 29 de octubre de 1769 , en la que se le ordenaba la creación de la citada junta. ${ }^{87}$ Pero ésta no se llevó a cabo bajo su tutela, ya que ante las continuas solicitudes que hizo a la Corte para que se le relevase de aquel gobierno, fue sustituido en I77 r por don José Solano y Bote, ${ }^{88}$ que tuvo que encargarse de la reunión de la junta.

El cambio de gobernadores la atrasó sin embargo considerablemente, y no es hasta $I 772$ cuando se reune. En ella se acordó casi por unanimidad, como único medio para mejorar la situación económica de Santo Domingo, solicitar del Rey la concesión de las siguientes gracias:

- Que la Real Hacienda prestase mil pesos a los particulares, destinados a la compra de I.500 negros que trabajasen en las labranzas, y se concediera la entrada libre de otros cuatro mil en los cinco años siguientes.

- Que los frutos de la isla transportados a España, no pagasen derecho alguno ni a su salida de Santo Domingo ni a su entrada en la Península en el plazo de diez años, aunque el oro y la plata siguiesen pagando los establecidos.

- Que los registros de España no pagaran impuestos a su salida y a su llegada a Santo Domingo, sino sólo el $6 \%$ los de fábrica española, y el $7 \%$ los extranjeros, tal y como se establecía en el reglamento del Libre Comercio.

- Que el comercio con España se hiciera con las exen-

\footnotetext{
86 Representación del Cabildo, Justicia y Regimiento de la ciudad de Santo Domingo de nueve de enero de 1767. A.G.I. Santo Domingo, 944.

87 Carta de! gobernador don Manuel de Azlor de 3 de marzo de 1770 acusando el recibo de la Real Cédula de 29 de octubre de 1769. A.G.I. Santo Domingo, 981. 88 Carta del gobernador de Santo Domingo don José Solano dirigida a la Corte con fecha de 24 de abril de 1771, dando cuenta de haberse hecho cargo del gobierno de la isla. A.G.I. Santo Domingo, 940.
} 
ciones de los artículos primero y segundo del Reglamento de Comercio Libre.

- Que los intrumentos para la labor de la tierra y la fábrica, fueran libres por completo de derechos.

- Que se reuniese en pueblos a los monteros.

- Que se rebajara del 5 al $3 \%$ el rédito de los censos.

- Que en las ordenanzas que debían hacerse para el Ayuntamiento de la capital, se tuviese en cuenta todo lo acordado en la junta. ${ }^{89}$

El fiscal del Consejo de Indias, después de examinar el expediente, se mostró partidario de aprobar las peticiones de la junta, con excepción de la $7 .^{\mathrm{a}}$ Pero el Consejo no fue del mismo parecer, y tras nuevas y largas deliberaciones, acordó en I 785 desechar algunas de ellas, informando al Rey sobre las solicitudes a que le parecía conveniente acceder. ${ }^{90}$

Consecuencia de ello fue una real cédula de 12 de abril de 1786 , por la que se establecían con exclusividad en Santo Domingo, las normas siguientes:

- La libertad absoluta de introducir negros sin limitación de número, ni pagar derechos de entrada ni por las ventas o reventas, siempre que fuesen destinados a las labores del campo, dándose además una gratificación a los que los trajesen con ese objeto.

- Que sobre cada esclavo empleado en el servicio doméstico, para moderar su exceso, se pagara un tributo anual que se emplearía en las gratificaciones señaladas.

- Que se creara un código para el gobierno político y moral de los negros de Santo Domingo, a semejanza del que tenían los franceses.

89 Carta de don José Solano y Bote fechada el ocho de octubre de 1772, informando a la Corte de las decisiones tomadas en la Junta de Auxilio y Fomento de la Española. A.G.I. Santo Domingo, 969.

90 Expediente formado en el Consejo de Indias sobre el fomento de la isla de Santo Domingo y resoluciones del Consejo sobre el asunto de 1785. A.G.I. Santo Domingo, 1.034. 
- Que fuesen reducidos a población los monteros y hombres vagos.

- Que la entrada en la isla de utensilios con destino a las labranzas e industrias fuesen libres de derechos de cualquier parte de que procedieran.

- Que el comercio de la isla gozase de todas las libertades que ya se habían establecido en los puertos menores.

- Que manteniéndose al $5 \%$ el rédito de los censos de los efectos ya impuestos, corrieran al 3 los que se impusiesen en lo sucesivo.

- Que la ciudad formara sus ordenanzas sin perder de vista la protección de la agricultura y la ganadería.

- Que estuviesen libres de pagar diezmos durante diez años, los hacendados que roturasen y labrasen tierras eriales e hiciesen plantíos de caña, cacao, añil, café, tabaco, algodón, y cualquier otro fruto, así como los que creasen nuevos ingenios.

- Que se eximiera de derechos al aguardiente de caña producido en la isla.

- Que se liberase a los ganaderos de la obligación de entregar un número determinado de reses con destino al abastecimiento de la capital.

- Que con el fin de facilitar el comercio interior se enviaran a la isla 40.000 pesos en moneda menor de cordoncillo, ${ }^{91}$ es decir, de circunferencia más o menos perfecta y con el borde labrado para evitar los cortes, y cuyo valor no dependía del peso como el de las macuquinas, sino simplemente de lo que se les asignase. ${ }^{\mathbf{9 2}}$

Tal y como se ordenaba en esta real cédula, las ordenanzas que se formaron para el gobierno del Cabildo de Santo Domingo, aunque se llevaron a cabo unos meses an-

91 Real Cédula de 12 de abril de 1786 conceđiendo diversas gracias a los habitantes de Santo Domingo para el fomento de su economía. A.G.I. Santo Domingo, 969 y 1.012 .

92 Burzio, Humberto F.: Diccionarlo de la moneda hispanoamertcana. Fondo Histórico y Bibliográfico José Toribio Medina. Santiago de Chile, 1958. Tomo I, pág. 94. 
tes de la recepción de aquélla, se ocuparon desde luego de la protección de la agricultura.

En su capítulo IV, dedicado a los labradores, y considerando las repetidas quejas de éstos por los daños que les causaban los ganados que se criaban en terrenos propios de labranzas, se estableció que en las tierras que fuesen únicamente de labor no podrían criarse animales a no ser dentro de cercados, y si alguno salía de ellos penetrando en las zonas sembradas, los agricultores podrían matarlos libremente y cobrar a sus dueños el daño ocasionado.

Pero esta medida era desde luego insuficiente, y el Consejo de Indias, en su reunión del 5 de octubre del mismo año, decidió que se comunicara a la Audiencia que el capítulo $4^{\circ}$ de las ordenanzas del Cabildo debía ajustarse a lo dispuesto por real cédula de 12 de abril, sobre la atención y protección de los principales ramos de la agricultura.

No quedaron los dominicanos contentos con todo esto, y en 1788 don Pedro Catani, oidor decano de la Audiencia de Santo Domingo, y en aquellos momentos gobernador interino de la isla, envió un informe al Consejo de Indias sobre el estado en que se encontraba el territorio y los medios que consideraba fundamentales para su fomento. En él, Catani manifestaba que la colonia, a pesar de todos los esfuerzos realizados por evitarlo, seguía totalmente despoblada en cuanto se dejaban atrás los alrededores de las ciudades. La agricultura se encontraba reducida a unas cuantas plantaciones de azúcar, cacao y tabaco, resultando a su juicio insuficientes las gracias concedidas por la real cédula de 12 de abril de 1786. La compra de I.5O0 negros por cuenta de la Real Hacienda a precios y plazos que resultasen cómodos a los hacendados, y la libertad de los derechos de su entrada, así como la de utensilios dedicados a las labranzas, era un medio que podía tener resultados en otros lugares, pero no en Santo Domingo, por no haber allí dine-

93 Ordenanzas formadas por el Cabildo de Santo Domingo para el gobierno público de aquella ciudad Santo Domingo, 25 de febrero de 1786. A.G I. Santo Domingo, 989. 
ro con que pagarlos, ni aun en la forma que se estableció de aportar para ello una cantidad anual.

Por otra parte, serían necesarios unos 40 ó 50.000 pesos para la construcción de fábricas y la obtención de los utensilios precisos, y los dominicanos no tenian de donde sacar esta cantidad. ${ }^{94}$

Sin embargo, el Consejo estimaba que sobre este punto no había nada que hacer aparte de las gracias ya concedidas, y aunque posteriormente se tomarán otras medidas importantes para el fomento de la agricultura, éstas irán dirigidas también a otros lugares de América, dejando a un lado el problema concreto de Santo Domingo, que se consideraba ya suficientemente atendido por la citada real cédula de I786, cuyas medidas afectaban sólo a esta colonia.

De este modo, el 28 de febrero de 1789 se expidió una real cédula por la que, tratando el Rey por todos los medios el fomento de la agricultura de Santo Domingo, Puerto Rico, Cuba y Caracas, y ante la necesidad de mano de obra para los cultivos que se experimentaba en estos lugares, se establecieron los siguientes puntos:

- Todos los particulares podrán comprar negros en cualquier lugar sin pagar derecho alguno por su introducción.

- Para los que hagan este comercio saliendo de la Península quedará permitido, con el fin de que no lleven vacíos sus navíos, cargar frutos y géneros para venderlos en los lugares en que compren los negros.

- Se autorizará a los extranjeros durante dos años a conducir negros a los puertos mencionados, gozando también de libertad de contribuciones a su llegada a aquéllos.

- El precio de los esclavos será concertado directamente entre vendedores y compradores, sin que se les imponga tasa alguna.

94 Ibídem, nota 18. 
- Los funcionarios reales no podrán hacerse cargo de los negros que se lleven ni comprarlos para venderlos después.

- Cada cargamento estará formado por un tercio de hembras y dos de varones, vedándose la entrada a enfermos o inútiles.

- Se premiará con cuatro pesos por negro, a los españoles que hagan este comercio en embarcaciones nacionales.

- Por cada negro no dedicado a la agricultura o a los ingenios se pagarán dos pesos a la Real Hacienda.

- Los puertos de Puerto Cabello, Santo Domingo, San Juan y La Habana quedaban abiertos para la introducción de esclavos por todo el que quisiera, excepto el de Cuba, limitado a los españoles.

- A la llegada a ellos se examinarán los barcos para evitar el contrabando de cualquier otro efecto y que el peso de los extranjeros no exceda de 300 toneladas.

- Los navíos extranjeros solo permanecerán fondeados el tiempo necesario para el desembarco.

- Los gobernadores e intendentes quedarán encargados de nombrar las personas adecuadas que vigilen este tráfico y darán las órdenes precisas con el fin de evitar los abusos. ${ }^{95}$

El permiso a los extranjeros para realizar este comercio fue posteriormente ampliado por dos años más en I79I, al mismo tiempo que se autorizaba también que sus embarcaciones pudieran alcanzar 500 toneladas, en lugar de las 300 señaladas en un principio. ${ }^{96}$

Poco después fue ampliada de nuevo la real cédula de I789, con otra expedida el 24 de noviembre de I79I en la que se aprobaba lo establecido en aquélla, además de ex-

95 Real Cédula de 28 de febrero de 1789 concediendo una serie de gracias para la introducción de negros en varios países de Améria. A.G.I. Santo Domingo, 953.

96 Cartas del gobernador de Santo Domingo de 25 de abril de 1791 y 9 de junio del mismo año, respondiendo a la Real Orden de ocho de marzo de 1791. A.G.I. Santo Domingo, 954. 
tender a seis años el periodo permitido a los extranjeros, al igual que los españoles, por lo que se refiere a la realización de este tráfico. En ellos se incluían los dos que se concedieron en febrero de aquel año, con lo que la autorización no finalizaba hasta diciembre de I797.

Se dejaba en esta ocasión al arbitrio de los comerciantes la proporción de varones o hembras que debían llevar, anulándose el tributo de dos pesos anuales, que hasta entonces se pagaba por cada esclavo dedicado al servicio doméstico. Por último, en esta ocasión se ampliaba la libre entrada de negros a otros lugares de América, y pasados los seis años fijados, se suspendería o prorrogaría la licencia según las circunstancias de cada provincia. ${ }^{97}$

Todas estas medidas fueron tomadas con un único fin: el incremento de la mano de obra necesaria para el fomento de la agricultura. Pero sus resultados por lo que respecta a Santo Domingo nos son desconocidos por completo. No sabemos el número de negros que entraron en la isla merced a la concesión de estas libertades, así como su reflejo en el aumento de los cultivos.

La Revolución Francesa, factor decisivo en la historia dominicana, la guerra declarada por la Corona española a la República Francesa con motivo de aquella, -que la colonia española de Santo Domingo sufrió mucho más de cerca que cualquier otra-, y por último, la cesión de toda la isla a Francia, nos impiden ver los efectos que los intentos hechos para su fomento podian haber producido.

La falta de dinero por un lado, y la inestabilidad reinante en la isla por las continuas revueltas de los negros franceses y la guerra entre ambas colonias por otro, debieron impedir a los vecinos del Santo Domingo español beneficiarse de los nuevos planes económicos, que poco después se verían frustrados por completo, con el abandono de La Española por parte de la Metrópoli.

97 Real Cédula de 24 de noviembre de 1791 sobre el libre comercio de negros A.G.I. Indiferente General, 622 . 


\section{Capítulo IV}

\section{G A N A D E R I A}

Ya hemos dicho al hablar de la agricultura, que durante toda la época colonial de Santo Domingo su principal fuente de riqueza fue la ganadería. La mayor parte de las haciendas dominicanas eran hatos dedicados a la crianza de animales. ${ }^{1}$

E1 ganado, llevado a la isla por los colonizadores españoles desde su descubrimiento, proliferó con gran rapidez en aquellas tierras por la riqueza y abundancia de sus pastos, viviendo muchas de las reses por los montes en estado salvaje o "cimarrón".

Abunda tanto el ganado vacuno como el caballar y el de cerda, siendo también numerosas las ovejas y cabras.

El ganado, con excepción desde luego del cimarrón, se concentraba en grandes haciendas o hatos, "una especie de yeguada destinada para la cría de animales". La extensión de estas fincas era de una gran variedad, pero en general fueron excesivamente grandes en proporción al número de reses que contenían. ${ }^{2}$

La mayoría de estás haciendas se mantuvieron en régimen familiar. El propietario era casi siempre el mayoral y sus hijos los peones o laceros, aunque algunos disponían de esclavos negros que ejercieron estas tareas. ${ }^{3}$

1 Informe del oidor decano de la Audiencia de Santo Domingo don Pedro Catani con fecha 15 de noviembre de 1788, sobre el estado en que se encontraba la isla. A.G.I. Santo Domingo, 1.012.

2 Moreau de Saint-Mery, M. L.: Loc, cit., págs. 100-101.

3 Santiago, Pedro J.: Loc. cit., tomo I, pâg. XXIX. 
Desconocemos por completo el número total de hatos existentes en la segunda mitad del siglo XVIII en Santo Domingo, a excepción de los de la jurisdicción de la villa de Hincha: I 37, y los de Santiago de los Caballeros: $239 .{ }^{4} \mathrm{Pe}-$ ro lo que sí podemos afirmar, es que éstos se extendieron por toda la isla en detrimento de las explotaciones agrícolas.

Nos encontramos con ellos ya en territorios propios de la jurisdicción de la capital, junto a las haciendas de caña, en las villas de San Carlos, San Lorenzo de Minas, Los Ingenios, y sobre todo en Los Llanos. Y desde el partido de la capital y por todo el país, las haciendas eran en su mayor parte ganaderas, dedicándose a la crianza casi toda la población, a excepción de algunos vecinos de la Vega Real, que tenían terrenos en los que se cultivaba sobre todo tabaco y café, y de los pobladores de Samaná, cuya principal riqueza fue siempre la madera. ${ }^{5}$

El ganado más numeroso y el que produjo a los habitantes del Santo Domingo español una mayor fuente de ingresos fue el vacuno, tanto por lo que se refiere a su carne, principal alimento en toda la isla, como a sus cueros, que exportaron no sólo lícitamente, sino además, y sobre todo, por el contrabando. ${ }^{6}$

Es muy difícil determinar el número de reses vacunas existentes en esta época, pues son pocas las noticias que tenemos al respecto, al tiempo que presentan importantes diferencias entre ellas. Así, en I743, por orden del gobernador don Pedro Zorrilla, se hizo una especie de censo del ganado vacuno de todos los hatos de la isla, y el resultado arrojó una cifra de II 2.098 cabezas distribuidas en los siguientes lugares:

4 Extracto del número de reses de la isla de Santo Domingo de 21 de octubre de 1744, sacado del expediente originado con motivo del paso del ganado dominicano a la colonia francesa. A.G.Y. Santo Domingo, 314.

5 Informe del gobernador de Santo Domingo don Manuel de Azior, fechado el 16 de octubre de 1760 , sobre la situación ganadera de Santo Domingo. A.G.I., Santo Domingo, 1.059 .

6 Ibídem, nota 1. 
- Ciudad de Santiago de los Caballeros. 26.467

- Villa de Hincha.

- Villa del Seibo.

- Ciudad de Concepción de la Vega.

- Villa de Cotui. I 2.685

- Valle de San Juan de la Maguana (Azúa). IO. 187

- Villa de Banica.

- Valle de Neiba (jurisdicción de Azúa).

- Ciudad de Bayaguaná.

- Villa de Higuey.

- Ciudad de Monte de Plata.

En I 772, según un estadillo en el que se señala el número de habitantes y reses con que contaba el Santo Domingo español, se habían alcanzado 271.00o, distribuidas como sigue:

- Villa de Hincha.

30.000

- Villa del Seibo. 28.000

- Villa de San Juan de la Maguana.

25.000

- Ciudad de Puerto de Plata.

25.000

- Curato de Los Llanos.

23.000

- Villa de Bani.

20.000

- Villa de Cotui.

I 8.000

- Ciudad de Bayaguaná.

I 6.000

- Ciudad de Santiago.

I 5.000

- Villa de Azúa.

I 4.000

- Ciudad de la Vega.

I 2.000

- Curato del río Haina

I I .OOO

- Villa de Neiba.

9.000

- Curato de los Ingenios.

8.000

- Villa de Higuey.

6.000

- Ciudad de San Fernando de Montecristi. 
- Idem de Monte de Plata.

3.000

- Pueblo de San Rafael de la Angostura.

- Villa de San Carlos.

- Población de Sabana de la Mar.

- Villa de Boyá.

500

- Pueblo de San Lorenzo de los Minas.

500

Total: 27 I.000 8

La diferencia entre los dos estados presentados es lo suficientemente clara, como para hacernos pensar que lo que ocurrió no fue simplemente un incremento del número de cabezas de ganado por un crecimiento natural. Independientemente de que la cifra dada en I 772 se haya exagerado o no, hemos de tener en cuenta para explicarnos este contraste varios factores.

El recuento hecho en $\mathbf{I 7 4 4}$, tuvo como fin señalar el número de reses con que cada hacendado debía contribuir al abastecimiento de la parte española, y concretamente a la capital, que era casi el único lugar de la isla que no producía ganado.

De lo que se consideraba que aumentaba al año el número total de reses, después de pagar el diezmo correspondiente, se había de deducir un tercio para el incremento de los hatos, y el resto se dividía en tres partes: una para sustento de los propios ganaderos, otra para el abastecimiento de la parte española, y la tercera se podría vender a los franceses pagando los derechos correspondientes. ${ }^{9}$ Pero los ganados llevados a la capital eran vendidos a un precio fijo, considerablemente inferior al que conseguían los hateros en la parte francesa, por muy bajo que este fuera, por lo que preferían la introducción clandestina en ella antes que venderlos a los españoles. ${ }^{10}$

\footnotetext{
8 Estado general del número de habitantes y cabezas de ganado vacuno del Santo Domingo español en 1772. A.G.I. Santo Domingo, 1.059.

9 Santo Domingo, 1744. Expediente sobre el paso de ganado desde el Santo Domingo español a la colonia francesa de la isla. A.G.I. Santo Domingo, 314.

10 Ibídem, nota 5.
} 
De ahí, que los criadores declarasen probablemente un número de reses bastante más bajo del que disfrutaban en realidad, para, disminuida su obligación con la colonia española, poder extraer a la francesa un mayor número de cabezas aunque fuese mediante el contrabando. Ayudaron desde luego a esta falsificación, las medidas tomadas en algunos lugares para la realización de este censo. Así, en la villa de Hincha existía una relación anterior del ganado vacuno de toda la jurisdicción, y los capitulares encargados de hacer la nueva, decidieron que, puesto "que por otra antecedente justificación que en virtud de otra orden de su señoría se hizo con los mismos criadores, en que tienen declarado el número de ganado bacuno con que cada uno se hallava, y que por ello se hallarían aora temerosos de ser cojidos en variedad, y que para que se consiguiese el fin de haserse la más justa sin el predicho reselo, se rompiese y chanselase la zitada antecedente justificazion, como se hiso en presenzia y conosimiento de todos...". ${ }^{11}$

En el primero de los estados mencionados, y tal como en él mismo se hace constar, no aparecen los hatos de la jurisdicción de la capital, por no haberse tomado hasta entonces razón del ganado que se criaba en ellos. ${ }^{12} \mathrm{Y}$ en algunos de estos lugares se contaba con un importante número de reses según el de 1772 , como por ejemplo en el curato de los Llanos, con 23.000 cabezas, el del río Haina con I I.000, y el de los Ingenios con 8.000. ${ }^{13}$

Por otra parte, en el recuento de 1744 no aparecen una serie de poblaciones como Montecristi, Sabana la Mar, y San Rafael, que se fundan con posterioridad, y en las que entonces el ganado era en su mayor parte cimarrón. Al mismo tiempo, algunos lugares como los valles de Neiba y San Juan, experimentaron en la segunda mitad del siglo un desarrollo considerable, con el consiguiente incremento del ganado domesticado a costa del cimarrón.

11 Ibídem, nota 4

12 Nota del escribano real de Santo Domingo al extracto del número de reses vacunas existentes en la isla, de 21 de octubre de 1744. A.G.I. Santo Domingo, 314 13 Ibiđem, nota 8. 
Por último, no aparecen tampoco en el primero de los estados las villas de Azúa y Bani, eminentemente ganaderas, y aunque a este respecto hemos de señalar que en el estado de 1772 no figura por su parte la de Banica, que reunía en su jurisdicción un importante número de hatos, su ganado no podía equivaler en ningún momento al de todos los otros lugares citados.

Así pues, parece ser que el estado de 1772 es más digno de crédito, aunque desde luego puede ser bastante inexacto, a causa de los defectos propios de todas las estadísticas elaboradas en esta época.

Sin embargo, todos los indicios hacen pensar que en la etapa que estudiamos, la ganadería había entrado en un importante declive. El Ayuntamiento de Santo Domingo, en un informe que envió al gobernador en I783, manifestaba que los criadores de la isla no podían contribuir al abastecimiento de la capital con el número de reses que tenían señalados, "con motivo del atrazo y decadencia a que por razón de las secas continuas y otros diversos accidentes adversos a la crianza, han venido generalmente los hatos de esta isla", siendo necesario relevar a muchos de ellos de la obligación de contribuir al mantenimiento de Santo Domingo, debido a la ruina en que se había comprobado se encontraban sus haciendas. ${ }^{14}$

Los autores contemporáneos por su parte corroboran también esta afirmación. Así, Sánchez Valverde nos dice que en toda la isla, sobre todo en la zona fronteriza, había sufrido un importante deterioro, que no bastaba a solucionar la prohibición de matar a las hembras, ya que el consumo de machos había reducido a éstos "a menos del número necesario de toros para fecundar las hembras". ${ }^{15}$

En general, todas las noticias que tenemos al respecto parecen confirmar esta decadencia, y don Pedro Catani, en un informe enviado a la Corte en I 788 sobre la situación

14 Informe del Ayuntamiento de la capital dominicana fechado el 25 de enero de 1783, sobre el insuficiente abastecimiento de carnes en la ciudad de Santo Domingo. A.G.I. Indiferente General, 1.579.

15 Sánchez Valverde, Antonio: Loc. cit., pág. 85. 
económica en que se encontraba la colonia española, y del que ya hemos hablado en el capítulo anterior, señala la necesidad de atender convenientemente a la crianza de ganado por la mala situación en que se hallaba, con un total de 2 I 3.5 I 5 cabezas, ${ }^{18}$ casi 60.000 menos de las que aparecen en el estado de 1772 .

Esta disminución de reses debió desde luego ser exagerada por los propios hateros, para conseguir una rebaja en el número de animales con que debían contribuir al abastecimiento de la capital. No hay que olvidar nunca que el precio que en ella obtenían era mínimo, y ni siquiera les servía para cubrir gastos.

Un informe realizado en las distintas villas de la isla sobre el precio que en ellas tenían las reses, dio un resultado de Io pesos por cabeza como mínimo. ${ }^{17} \mathrm{El}$ precio que los ganaderos conseguían en Santo Domingo, aunque nos es desconocido, sí podemos afirmar que era considerablemente inferior, ya que por real cédula de $\mathrm{i} 2$ de abril de $\mathbf{1} 786$, se ordenaba cesar en el cobro de los derechos que se recaudaban por este ganado y el establecimiento de un precio más justo, "para que al provehedor le salga cada res poco más o menos al valor que tiene vendida en la dehesa, aunque ni aun así se eximirán de las pérdidas que experimentan a causa de las muchas cabezas que mueren o se les estrabian en el camino hasta la ciudad". ${ }^{18}$

Por el contrario, en la parte francesa las ganancias eran muy superiores, pues mucho antes de I786 se obtenían como mínimo is pesos por cada res en el comercio ilegal, mientras que en un tratado firmado por ambas colonias en tiempos del gobernador don Pedro Zorrilla en $\mathbf{1 7 4 3}$, se fijó un precio de 35 pesos la mancuerna, que fue ratificado en I 762 en el nuevo convenio que se acordó entre

\footnotetext{
16 Ibídem, nota 1.

17 Informe del gobernador de Santo Domingo don Manuel de Azlor, con fecha de diez de noviembre de 1763 , sobre el precio que alcanzaba el ganado vacuno en las distintas poblaciones de la isla. A.G.I. Santo Domingo, 1.020.

18 R. C. đe 12 de abril de 1786, concediendo una serie de gracias a los habitantes de Santo Domingo para el fomento de su economía. A.G.I., Santo Domingo, 969 y 1.012.
} 
los respectivos gobernadores, a consecuencia del pacto de familia estipulado entre España y Francia. ${ }^{19}$

Algunos autores afirman que el beneficio que los dominicanos obtenían con este comercio llegó hacia 1780 a unos 30 e incluso a 40 pesos la cabeza. ${ }^{20}$ Pero no hemos podido encontrar ningún dato que pueda llevarnos a confirmar esta teoría, pues los únicos con que contamos son los mencionados tratados de I743 y I762, y en ambos se habla literalmente de "35 pesos la mancuerna" o pareja de reses. ${ }^{21}$

A pesar de ello hay una cosa clara. Eran superiores las ganancias que los ganaderos obtenían en la colonia fancesa, y como es lógico sus aspiraciones se centraban en dirigir a ella su comercio, disminuyendo su aportación a la capital.

Ahora bien, independientemente de las exageraciones que pudieran cometerse al hablar de la decadencia de los hatos por los motivos que hemos expuesto, son demasiadas las noticias que tenemos de ella como para ignorarla.

El descenso en el número de reses debió ser cierto, y a él probablemente contribuyeron varias causas:

- Los factores climatológicos. Las sequías producidas en los años anteriores a 1780 que afectaron a las zonas ganaderas, y las consecuencias de las fuertes tormentas que tuvieron lugar entre 1780 y $178 \mathrm{I}$ : las inundaciones, que unidas a los huracanes destruyeron una parte importante del ganado. ${ }^{22}$

19 Tratado firmado el 21 de julio de 1762, entre don León de Fontenelle y don Ignacio Caro de Oviedo, como representantes de los gobernađores francés y español de la isla de Santo Domingo. A.G.I., Santo Domingo, 1.059.

20 Moya Pons, Frank: Loc, cit., pág. 303.

21 Acuerdo de 1743 entre las autoridades francesas y españolas de la isla de Santo Domingo, para la venta de ganado de la parte española a los franceses y tratado firmado en 1762 entre los representantes de ambas colonias. A.G.I. Santo Domingo, 1.059 .

22 Carta de don Bernardo de Gálvez al gobernador de Santo Domingo don Isidro de Peralta y Rojas, acusando recibo de la suya fechada el ochb de noviembre de 1781, en que daba cuenta de las dificultades existentes para abastecer de carne a los soldados del ejército de operaciones. A.G.I., Indiferente General, 1.579. 
- La necesidad de surtir de carne a las escuadras francesa y española y al ejército de operaciones, con motivo de la intervención de ambas naciones en la guerra de la idependencia de los Estados Unidos contra Inglaterra, hizo que el consumo fuese excesivo en relación con el crecimiento natural de los hatos. ${ }^{23}$

- El consumo de la parte francesa, que cada vez era mayor. Esta colonia proseguía su desarrollo extraordinario con el consiguiente incremento de la población, por lo que tenía cada vez más necesidad del ganado español por carecer ella de hatos. Las ganancias obtenidas por los criadores españoles con esta venta, y de las que ya hemos hablado, hizo que se dedicaran intensivamente a la extracción sin tener en cuenta la procreación de las reses, llegando a sacar al parecer hasta 20.000 cabezas al año, ${ }^{24}$ a pesar de todas las prohibiciones existentes en este sentido. Además, algunas de ellas eran de las llamadas vacas de vientre, aunque legalmente sólo podian exportarse los machos. ${ }^{25}$

- Las enfermedades como la epizootia causaron también importantes bajas a los ganados. ${ }^{26}$

- El contrabando de cueros realizado sobre todo con los holandeses. Era éste un lucrativo comercio, que llevaba a muchos a la matanza de reses que no eran aprovechadas luego como alimento. Para perseguir a los animales se criaban unos perros de gran tamaño, que ocasionaban la muerte sobre todo a los más jóvenes. ${ }^{27}$

Ya en I774, se habían oído voces que intentaban poner remedio a la disminución del ganado vacuno en la isla, co-

23 Cartas del gobernador don Isidro de Peralta fechadas el ocho de noviembre de 1781 y 28 de febrero de 1782, dirigidas a don Bernardo de Gálvez, sobre las dificultades que tenía para abastecer de carne al ejercito de operaciones. A.G.I., Indiferente General, 1.579 .

24 Ibídem, nota 5.

25 Carta del gobernador de Santo Domingo don Isidro de Peralta de tres de diciembre de 1783, sobre la escasez de ganado sufriđa en la isla. A.G.I., Indiferente General, 1.579 .

26 Moreau de Saint-Mery, M. L.: Op. cit., págs. 106-107.

27 Idem, pág. 107. 
mo la del fiscal de la Audiencia, que ese mismo año escribió a la Corte sobre la conveniencia de establecer en Santo Domingo la "Hermandad de la Mesta", como único medio para que se incrementase el número de reses. ${ }^{28}$ Pero aunque esta medida estuviera fuera de lugar en una época en que en España se abolían los privilegios de que gozaba aquella institución, a favor de una intensificación de las explotaciones agrícolas preconizada por las teorías fisiocráticas, no por eso dejó la Corona de prestar atención al asunto. Así, la real cédula de 1786 de la que ya hemos hablado, teniendo en cuenta que la ganadería era la principal fuente de riqueza de los dominicanos, concedió determinadas libertades a los criadores para evitar, en lo posible, la extracción clandestina que tantos perjuicios ocasionaba. ${ }^{29}$

Pero no pareció suficiente a los habitantes del Santo Domingo español, y en las ordenanzas formadas en el mismo año por el Cabildo de la capital para su gobierno, y en las que se le había ordenado tuviese en cuenta lo establecido en la anterior real cédula, los capitulares acordaron que en terrenos que se consideraban de crianza, no pudiese culparse a los dueños si las reses invadían tierras de labranza. Por el contrario, si alguna res entraba en terrenos considerados como de labor, el agricultor podía matarla y su dueño debía reparar los daños causados.

En teoría la medida puede parecer justa respecto a ambos aspectos de la economía, pero hemos de señalar que las únicas tierras que estas ordenanzas reconocían como de labor, eran extrictamente las de los alrededores de la capital.

La Corona, que como ya hemos dicho intentaba sobre todo el incremento agrícola, no pudo estar de acuerdo con ello, ordenando que a pesar de lo establecido por el Cabildo, se observase lo dispuesto por la real cédula, protegiendo

28 Informe del fiscal de la Audiencia de Santo Domingo de 25 de septiembre de 1774, sobre la decadencia en que se encontraba la isla. A.G.I., Santo Domingo, 1.034.

29 Ibídem, nota 18. 
desde luego a la ganadería, pero siempre que con ello no se perjudicasen los cultivos. ${ }^{30}$

Aunque el ganado vacuno fue el más importante en Santo Domingo, por ser la principal fuente de ingresos para los hateros, era también considerable el número de cerdos y caballos que se criaban en la isla.

Desconocemos por completo la cuantía de los primeros, aunque debieron ser abundantes si tenemos en cuenta que sólo en el abastecimiento de la capital se consumían anualmente más de 5.000 cabezas. ${ }^{31}$

Respecto al caballar, el estado de población y ganado de 1772 señala que casi alcanza el número de reses vacunas, ${ }^{32}$ y Sánchez Valverde por su parte, nos dice que su número era muy crecido ya que su multiplicación fue rapidísima, no perdiendo nada de la raza primitiva, pues "vemos todavía, especialmente en ciertos distritos como los de Vani, Azúa, Maguana y Banica, una entera semejanza con los mejores de acá". ${ }^{33}$

Independientemente del ganado que se criaba en los hatos existía un gran número de cabezas que vivían en estado silvestre, sin que sea posible contabilizarlos. Era el ganado conocido con el nombre de cimarrón, de cuya caza y venta de sus cueros vivía una parte importante de la población.

Una preocupación constante de los gobernadores de Santo Domingo, fue acabar con las frecuentes monterías de reses y cerdos silvestres que contribuían a la disminución de la cabaña, al tiempo que restaban mano de obra a la agricultura y la industria. En este sentido, don Manuel de Azlor solicitó al Rey en I770 que se prohibiese esta actividad por completo, bajo la pena de confiscación de bienes, un mínimo de cuatro años de cárcel y otras más graves a los rein-

30 Ordenanzas formadas por el Cabildo de la ciudad de Santo Domingo el 25 de febrero de 1786, para el gobierno de la capital. A.G.I., Santo Domingo, 989.

31 Cargo de la sisa de la vaca en los años 1773 y 1774, sacada del las cuentas de los propios de la ciudad de Santo Domingo. A.G.I., Santo Domingo, 1.055 y 1.056,

32 Tbídem, nota 8.

33 Sánchez Valverde, Antonio: Op. cit., págs. 86-87. 
cidentes, haciéndose para su detención una o dos batidas al año en las jurisdicciones de cada población.

El Consejo de Indias no se mostró sin embargo tan radical como el gobernador, ordenando a éste, que el tema se tratara en la junta que habria de formarse para estudiar los medios de fomentar la economía de la isla, indicándole al mismo tiempo, que las penas que proponía le parecían exageradas y debían modificarse. ${ }^{34}$

Por su parte, la junta reunida para estudiar los planes de auxilio y fomento de la Española en I772, acordó pedir ocho gracias al Rey. La sexta de ellas, consistía en que se ordenase agrupar en pueblos a los monteros, es decir, a los que dedicados a la caza del ganado cimarrón vivían dispersos por los montes. La respuesta a esta petición vino en la ya citada cédula de 1786 , por la que se mandaba a la junta que ella misma propusiese los medios que considerase más oportunos para llevar a cabo estas reducciones, comunicándolos después al Consejo. ${ }^{35}$

También las ordenanzas del Cabildo de Santo Domingo formadas en I786, se ocuparon de este asunto. En su capítulo segundo, dedicado al fomento de pueblos de negros libres que andaban vagando por los campos viviendo de la montería, y contra los que se producían constantes quejas en toda la isla, se trató este tema. ${ }^{36}$

Pero todo lo que se intentó en este sentido fue inútil. Los negros que conseguían su libertad abandonaban normalmente las haciendas, y el deseo de no depender de ningún amo, limitaba su actuación a dos campos: la venta de productos de primera necesidad en las ciudades, y la cacería de reses montaraces.

De este modo, los llamados monteros proliferaron siem-

34 Carta del gobernador de Santo Domingo don Manuel de Azlor de 30 de marzo de 1770 , dando cuenta a la Corte de los medios de acabar con las monterías y dictamen del Consejo de Indias sobre el asunto, de 17 de abril de 1771. A.G.I., Santo Domingo, 1.034 .

35 Ibídem, nota 18.

36 Ibídem, nota 30 . 
pre en toda la isla sin que el gobierno pudiera hacer nada para evitarlo, contribuyendo en gran forma al descenso del ganado vacuno.

EL PROBlema DEL ABASTECIMIENTo

DE CARNE A LA CAPITAL

A pesar del elevado número de cabezas de ganado existente en Santo Domingo, un problema que atraerá la atención de los gobernantes durante todo el siglo XVIII, será el deficiente abastecimiento de carne a la capital.

Ya hemos dicho que la ganadería era común a casi toda la isla, produciéndose especialmente en las zonas norte y oeste. Pero la ciudad de Santo Domingo carecía por completo de ganados, por lo que se hallaba establecida legalmente para los criadores, la obligación de aprovisionarla de la carne necesaria para su consumo, práctica que se conocía con el nombre de "pesas".

Sin embargo, la lejanía de los principales centros ganaderos como Santiago, Hicha, Azúa, y los valles de San Juan y Neiba respecto a la capital, hizo que sus hateros, por las graves pérdidas que experimentaban en los traslados, quedasen liberados de esta obligación desde "tiempos inmemoriales". Con ello, la ciudad sólo podía proveerse de los pueblos inmediatos, y la carne que éstos le proporcionaban no era suficiente. ${ }^{37}$

En I742 don Pedro Zorrilla de San Martín, entonces gobernador de Santo Domingo, acordó conceder una serie de permisos para la exportación de ganado a la colonia francesa vecina, siempre que no se perjudicara la procreación y el abastecimiento de la parte española. ${ }^{38}$ Para ello, ordenó que se elaborase un censo de toda la ganadería que se criaba en la isla, en el que debía constar el número total

\footnotetext{
37 Ibídem, nota 5.

38 Decreto del gobernador de Santo Domingo don Pedro Zorrilla de San Martín de siete de mayo de 1742, sobre la exportación de ganado a la colonia francesa de aquella isla. A.G.I., Santo Domingo, 314.
} 
de reses de cada hato, y el aumento que experimentaban al año. Del incremento anual de cabezas de cada ganadero, debía deducirse el diezmo que tenían que pagar a la iglesia, y el resto se dividiría en tres partes. La primera de ellas estaría dedicada al fomento de los hatos. Las otras dos se dividirían a su vez conjuntamente en tres tercios, uno dedicado al consumo de cada criador, otro al abastecimiento de la parte española, y el otro, que se consideraba sobrante, podría enviarse a la colonia francesa.

El resultado de este censo, del que ya hemos hablado en el apartado anterior, y en el que como hemos señalado no figuran los hatos de la jurisdicción de la capital, fue el siguiente

\section{Poblaciones}

Villa de Hincha

Villa de Banica

Valle de Neiba

Valle de San Juan

Villa de Couti

Ciudad de la Vega

Ciudad de Santiago

Ciudad de Monte de Plata

Ciudad de Bayaguaná

Villa del Seibo

Villa de Higuey

\section{Total}

cabezas de ganado Incremento anual

19.335

6.674

$5 \cdot 550$

8.687

I0. 187

I 2.685

26.467

2.076

4. I7 I

I 3.750

$2.5 \mathrm{I} 6$

Totales :
I 12.098
$3 \cdot 353$

I. 590

I. 446

2. 104

2.731

$2.79 \mathrm{I}$

6.530 418 765

$2.7 \mathrm{IO}$

537

$\mathrm{Y}$ este incremento anual de 24.975 cabezas, se debía distribuir siguiendo las órdenes del gobernador en la siguiente forma:

39 Ibídem, nota 4. 
Hincha

Banica

Neiba

San Juan

Cotui

La Vega

Santiago

Monte Plata

Bayaguaná

Seibo

Higuey

$\begin{array}{rrc}292 & \text { I.044 } & 694 \\ \text { I37 } & 495 & 333 \\ \text { I32 } & 448 & 297 \\ \text { I9I } & 648 & 436 \\ 232 & 852 & 576 \\ 256 & 855 & 57 \text { I } \\ 566 & 2.043 & \text { y hateros } \\ 36 & \text { I31 } & 85 \\ 67 & 238 & \text { I } 54 \\ 232 & 844 & 558 \\ 46 & \text { I69 } & \text { I } 08\end{array}$

652

671

312

3 I 3

286

283

$4 \mathrm{I} 8$

4 I I

536

535

553

$55^{6}$

2.OOI

83

I.920

I 53

538

IO7

\section{Totales \\ $2.187 \quad 7.767 \quad 3.812$ \\ 5.639 \\ $5 \cdot 570^{40}$}

Con ello, quedaba establecido el suministro obligatorio de todas estas poblaciones a la capital con 5.639 reses al año, aunque en este esquema no se respeten las divisiones exactas que se habían ordenado, como es fácil de comprobar.

Pero esta cantidad no era suficiente para una población que alcanzaba en esta época los 8.000 habitantes, ${ }^{41} \mathrm{y}$ por eso en 1748 don Felipe de Fromesta, regidor, fiel ejecutor, y procurador general de la ciudad de Santo Domingo, daba cuenta al Rey de que la falta de carnes para el consumo de la capital era constante, debido al desorden de la remisión a la colonia francesa que había sido permitida por el gobernador. Esta exportación a su juicio hacía decaer la crianza, dificultando con ello el abastecimiento de Santo Domingo. ${ }^{42}$

Los hateros tenían que superar graves dificultades para llevar sus ganados a la capital. Cerca de ella, y en su parte oriental, se encontraban las ciudades de Monte de Plata y

40 Idem.

41 Rodriguez Demorizi, Emilio: Relaciones Historicas..., Vol. III, págs. 259-271.

42 Garta de don Manuel Felipe de Fromesta, fiel ejecutor y procurador general de la ciudad de Santo Domingo, sobre la extracción de ganado a la colonia francesa de la isla, fechada el tres de abril de 1748. A.G.I., Santo Domingo, 314. 
Bayaguaná, las villas de Boyá, Seibo e Higuey, además del curato de los Llanos, que aunque de escasa población, poseían gran cantidad de hatos que eran los que surtían con mayor facilidad a la ciudad. Pero el ganado de estos lugares tenía que cruzar el río Ozama para llegar a su destino, con las consiguientes pérdidas de reses que se ahogaban en sus aguas. Intentando solucionar este problema, el gobernador don Francisco Rubio y Peñaranda propuso en I753, la construcción de un puente de barcas que asegurase el paso de las reses, realizando la obra a base de un impuesto de dos reales que fijaría el Cabildo, sobre cada fanega de sal que se vendiera en la ciudad.

La propuesta fue aprobada por la Corona, aunque las noticias que tenemos sobre el asunto nos dicen que el puente no llegó a levantarse, ya que en r769, el Cabildo, Justicia y Regimiento de la ciudad de Santo Domingo informaba al Consejo, que había proyectado la creación de un cercado destinado al ganado que llegaba a la capital para su consumo, y había tenido que contraer por ello una deuda de 3.800 reales con las Cajas Reales.

En su consecuencia, y dado que se hallaba en depósito una importante cantidad, procedente del cobro de los dos reales por fanega de sal establecidos en tiempos de don Fran cisco Rubio, y que todavía se seguía cobrando, y como el puente de barcas, motivo por el cual se impuso esta tasa no se había comenzado, solicitaba se dedicase este dinero a la construcción del cercado. ${ }^{43}$

Con todo ello, la escasez de carne era cada vez más patente en la ciudad, estando de nuevo libres del abastecimiento a ella los lugares antes señalados, por haber desaprobado la Corte las medidas que había tomado el gobernador don Pedro Zorrilla en cuanto al reparto de las reses. ${ }^{44}$

43 Solicitud del gobernador de Santo Domingo don Francisco Rubio y Peñaranda de 16 de diciembre de 1753, aceptación de la Corte con fecha de uno de enero de 1754, y solicitud del Cabildo de la ciudad de Santo Domingo de 29 de julio de 1769. A.G.I., Santo Domingo, 980.

44 Ibídem, nota 5. 
Así, son frecuentes las representaciones llegadas a la Corte informando sobre este asunto, tanto por parte de la Audiencia como del Cabildo. Todos ellos hablaban en sus cartas de la gran cantidad de ganado que se criaba en la isla, y lo fácil que debía ser por ello el abastecimiento a la capital, si se tomaban severas medidas sobre la extracción a la colonia francesa vecina. ${ }^{45}$

Las causas de esta escasez en Santo Domingo ya han quedado indicadas en el apartado anterior.

Por una parte, el precio estipulado para la venta en la capital era muy inferior al que los ganaderos obtenían, no ya negociándolas en la parte francesa legal o clandestinamente, sino incluso vendiéndolas a cualquiera en sus propios hatos.

Por otra parte, la mayoría de los grandes centros ganaderos estaban muy lejos de Santo Domingo. El transporte era caro y los hateros sufrían graves pérdidas en el camino. Las reses que por fin conseguían llegar a su destino, lo hacían con un peso bastante inferior al que tenían al salir de sus haciendas, no compensando con ello la venta.

Por último, a estos gastos había que añadir el pago de un real de plata por cada cabeza de las que llegaban a la ciudad. Teniendo en cuenta todo esto, es comprensible que los dueños de ganado hicieran lo imposible por verse libres de la obligación que se les había impuesto, y vender su ganado a mejores precios.

No contamos con muchos datos sobre el número de reses que realmente llegaban a la capital para su consumo. Se reducen a dos relaciones de la sisa de la carne cobrada por el Ayuntamiento de Santo Domingo en I773 y I774, sacadas de las cuentas de los propios de la ciudad, y otra de 1782 sobre el número de cabezas que se consumieron aquel año.

45 Carta de la Audiencia de Santo Domingo de 13 de febrero de 1760. A.G.I., Santo Domingo, 976, y otra del Cabildo de aquella ciudad de 28 de agosto de 1758 . A.G.I., Santo Domingo, 1.010. 
De ellas resulta que en I773 entraron en la capital para su abastecimiento $4.8 \mathrm{a} 5$ reses vacunas, ${ }^{46}$ y 4.686 en $1774 .{ }^{47}$

En I782 hay un ligero incremento con un total de 5.476 cabezas, número al parecer sensiblemente superior al de los cinco años inmediatamente antecedentes. ${ }^{48}$

Pero en ninguno de los tres años señalados se alcanzaron las 5.639 que se habían establecido en el decreto de don Pedro Zorrilla de I743, a pesar de que en él no estaba incluido el ganado de los lugares cercanos a Santo Domingo, que lógicamente eran los que lo proveían más asiduamente.

Si tenemos en cuenta que la población de la ciudad osciló entre los 8 y los I 0.000 habitantes, veremos que la carne para su consumo era en realidad escasa tal y como sus vecinos señalaban. La importancia del asunto hizo que una junta de abastos que se reunió en Santo Domingo en julio de 1775 , determinara que se exigiese rotundamente a los criadores el abastecimiento a la ciudad, siempre que el número de reses señaladas para este fin no excediese el tercio de lo que cada año se multiplicaban sus cabañas.

El Ayuntamiento hacía anualmente el repartimiento de las pesas, pero nunca se conseguía el número de reses establecido en el reparto. Esta circunstancia se debía, según el Cabildo, al bajo precio que se veían obligados a cobrar los ganaderos y a la decadencia en que se encontraban los hatos.

Pero a causa de ello, se rebajó para algunos tal contribución obligatoria, a cambio de pagar cinco pesos por cada res con que dejaban de concurrir al abasto público, cantidad que posteriormente se aumentó hasta los siete $\mathfrak{u}$ ocho.

El sistema empleado era el siguiente: los hateros del interior celebraban una contrata con los de las cercanías de la capital, por la que éstos se comprometían al suministro

46 Cargo de la sisa de la vaca en 1773, sacado de las cuentas de los propios de la ciudad de Santo Domingo. A.G.I. Santo Domingo, 1.055.

47 Cargo de la sisa de la vaca en 1774, sacado de las cuentas de los propios de la ciudad de Santo Domingo. A.G.I., Santo Domingo, 1.056.

48 Estado que manifiesta el número de reses que se han consumido en el abasto público de la ciudad de Santo Domingo en 1782. A.G.I., Indiferente General, 1.579. 
de la carne que correspondía a aquellos a cambio del dinero indicado.

Pero la decadencia de los hatos de la jurisdicción de Santo Domingo, hizo que el Cabildo permitiese hacer los contratos con cualquier persona que quisiera comprometerse a ello. ${ }^{49}$ Todo fue inútil. La escasez de ganado para el abastecimiento de la ciudad continuaba, e incluso se hacía cada vez más grave al incrementarse la población.

Para remediar en lo posible el problema, la real cédula de 1786 , por la que se concedían determinadas libertades a los habitantes de la Española para el fomento de las riquezas de la isla, establecía que se liberase a los ganaderos de la obligación de llevar sus reses a la capital, y "determinar que las carnicerías, abastos del común, se surtan bien sea por lo mismos ganaderos, o por los traficantes de reses, obligándose en pública subasta a proveer al mismo común a precios equitativos, sin imponerles derecho o gravamen alguno, para que no recaiga en el consumidor, en cuyo alivio y en el de la tropa, se pretende mantener inalterable el precio de 2 I quartos por cada cinco libras, hasta la cantidad de 42 cuartos, para que al provehedor le salga cada res poco más o menos, al valor que tiene vendida en la dehesa..." so

Pero: esta medida no tuvo los resultados que se pretendían pues, aunque se señalaba que el ganadero cobrase por cada cabeza su valor real, y cesaba la recaudación de la sisa de un real de plata por cada una que se pagaba entonces, no compensaba la venta por las graves pérdidas que se sufrían en los transportes.

Así pues, la liberación del sistema de las "pesas" y de la sisa, sólo debió afectar al incremento del número de cabezas de ganado procedente de las cercanías, dando carta blanca a los hateros del resto de la isla para hacer legalmen-

49 Informe del Cabildo de la ciudad de Santo Domingo de 25 de enero de 1783, sobre la falta de ganados existentes para el abastecimiento de la capital. A.G.I., Indiferente General, 1.579 .

50 Ibídem, nota 18. 
te lo que ya venían practicando desde hacía tiempo: su inhibición por lo que se refiere al mantenimiento de carne de la capital.

E1 problema del abastecimiento se extendía también al ganado de cerda, con los mismos problemas que el vacuno, aunque las noticias a este respecto son casi inexistentes, pues el interés se centró fundamentalmente en aquél por ser la carne más preciada para el consumo.

En 1773 entraron en la ciudad 5.2 I I cerdos, ${ }^{51}$ y en I $774,5.474,{ }^{52}$ número a todas luces insuficiente para la alimentación de los vecinos, si tenemos en cuenta el número de reses vacunas de que ya hemos hablado.

Según hemos señalado en el capítulo relativo a la población, Santo Domingo contaba con unos Io.00o habitantes aproximadamente en el periodo que va de 1772 a 1783 .

Si partiendo de las noticias que tenemos de I773, I774 y 1782 , establecemos una media de 5.000 reses anuales que entraban en la ciudad, media ya de por sí elevada si pensamos que sólo en I 782 se superan las 5.000 , y se dice claramente en el estado en que figuran que en los cinco años anteriores este número era considerablemente inferior, y una media de 5.500 cerdos destinados al mismo fin, nos encontraríamos con que a cada uno de los moradores de la capital le correspondía media res vacuna y algo más de medio cerdo al año.

Pero este reparto a su vez tampoco sería cierto, ya que la junta de abastos de I775, estableció que las reses llegadas a la ciudad tendrían como primer destino la guarnición de la plaza, que no figura en los censos entre el número de habitantes, "ministerios, cuerpos de distinción asi seculares como eclesiásticos y regulares", y lo que sobrase sería para el consumo de la población, ${ }^{53}$ a la que poco debió alcanzar,

51 Sisa del cerdo en 1773, sacada de las cuentas de los propios de la ciudad de Santo Domingo. A.G.I., Santo Domingo, 1.055.

52 Sisa del cerdo en 1774, sacada de las cuentas de los propios de la ciudad de Santo Domingo. A.G.I., Santo Domingo, 1.056.

53 Ibidem, nota 49. 
con las consiguientes protestas por parte del Cabildo que, en sus representaciones al Consejo de Indias solicitando se tomasen las medidas necesarias para solucionar este asunto, señalaba que era tan escaso el ganado que entraba a la capital para su abastecimiento, que alcanzaba sólo a la tropa, el Cabildo, las comunidades religiosas, y "otras personas distinguidas, con lo que el resto del vencidario sólo podía consumirla uno u otro día al año". ${ }^{54}$

LA SACA DE GANADo a LA COLONIA FRANCESA

Aunque el establecimiento de la colonia francesa en la parte occidental de Santo Domingo produjo graves disputas entre los vecinos de una y otra parte de la isla, y aunque las relaciones a nivel oficial fueron tirantes en muchos casos, pronto se hizo patente que ambas podían vivir relativamente en paz, cubriéndose mutuamente las necesidades de cada una.

Los colonos franceses dedicaron sus tierras a la agricultura, mientras que la mayor parte de las haciendas españolas eran hatos ganaderos.

Los franceses carecían de ganado, tanto para el consumo de carne como para las labores del campo. Los españoles a su vez carecían de manufacturas, pues la Península se las proporcionaba en pequeñas cantidades y a precios muy elevados. De este modo, ya desde finales del siglo XVII se inició un intenso comercio entre ambas zonas. El ganado español era cambiado en la colonia francesa por manufacturas europeas, que llegaban a Puerto Príncipe procedentes de Francia, ${ }^{55}$ o por dinero en efectivo, tan escaso en todo momento en la zona española.

\footnotetext{
54 Carta del Cabildo de la ciudad de Santo Domingo de 28 de agosto de 1757, informando a la Corte sobre la escasez de ganados para el abastecimiento del vecindario de aquella capital. A.G.I., Santo Domingo, 1.010.

55 Moya Pons, Frank: Op. cit., pág. 248.
} 
Así pues, poco a poco se fueron haciendo necesaria una a otra, de manera que, al margen de la política llevada a cabo por las autoridades respectivas, el contacto entre los vecinos fue continuo y muy lucrativo para algunos.

En la segunda mitad del siglo XVIII, la venta de ganados a la colonia francesa era la más importante fuente de ingresos para los colonos españoles, pues las necesidades de aquella se mostraban cada vez mayores por el incremento demográfico, que al parecer fue muy intenso en esta época. ${ }^{58}$

Los principales centros ganaderos del Santo Domingo espñol se encontraban lejos de la capital, y algunos muy cerca de la colonia francesa. Los habitantes de Santiago de los Caballeros, Concepción de la Vega, Cotui, Hicha, Banica y Azúa, con sus respectivas jurisdicciones, comenzaron muy pronto a vender sus reses a los franceses, a pesar de estar prohibido por las leyes, y de las severas medidas tomadas a este respecto por los distintos gobernadores.

La despoblación de la zona fronteriza y lo agreste del terreno, hacían imposible impedir esta extracción, con el perjuicio consiguiente para el abastecimiento de la parte española, e incluso del aumento de las crianzas.

Los ganaderos, después de la introducción clandestina de su ganado en la colonia francesa, se veían obligados sin embargo a vender al precio que sus moradores ofrecían, aunque fuese inferior al que ellos pretendían, por no correr el riesgo de volver a sacar las reses por la frontera. ${ }^{57} \mathrm{De}$ este modo en I74I, el gobernador don Pedro Zorrilla de San Martín daba cuenta al Consejo de Indias, de la escasez de ganados experimentada en la isla, debido fundamentalmente al paso clandestino que se hacía de él a la colonia vecina. Como único medio para evitar esta sangría desordenada, proponía la creación de dos aduanas en la frontera, una en la llamada banda del norte y otra en la del sur, en

\footnotetext{
56 Carta del gobernador de Santo Domingo don Isidro de Peralta y Rojas de tres de diciembre de 1783 y dirigida a don Bernardo de Gálvez, sobre la situación ganadera de la isla. A.G.I., Indiferente General, 1.579.

57 Ibídem, nota 5.
} 
los lugares por los que se haría la exportación de las reses que no fueran necesarias para el mantenimiento de la parte española. ${ }^{\text {s }}$

Mientras el Consejo decidía si se aprobaba o no la propuesta de don Pedro Zorrilla, de que los españoles pudiesen vender legalmente a los franceses el excedente de sus ganados, el gobernador intentaba acabar por todos los medios con el contrabando de este género.

Pero la guerra de sucesión de Austria, en la que Francia y España actuaban como aliadas apoyando la candidatura de María Teresa, hija del recién fallecido emperador Carlos VI, llevó a ambas potencias a la firma del segundo pacto de familia en I743. Sus respectivas colonias de Santo Domingo habían llegado también a un acuerdo con anterioridad. La parte francesa facilitaría a la española todos los auxilios que necesitase, "especialmente con las harinas". Y ante las representaciones del gobernador francés sobre la escasez de carne que sufrían sus vecinos y soldados, en justa correspondencia a aquél, don Pedro Zorrilla de San Martín publicó un decreto en marzo de I742, en el que se ordenaba que, desde el siguiente mes de abril, se asistiese a la colonia francesa con 200 reses mensuales. Cien de ellas deberían ser de Santiago, La Vega y Cotui, y las otras cien de Hincha, Banica y Azúa. Estas doscientas reses deberían ser la mitad de toros hechos y la otra de novillos, sin que en ningún momento se permitiera el paso de hembras, por ser fudamentales para el incremento de la especie.

Para que todos los ganaderos gozasen por igual de este beneficio se haría un reparto justo, de modo que la aportación fuese proporcional al número de cabezas de cada uno.

Las justicias de cada pueblo, junto con su Cabildo y

58 Cartas del gobernador de Santo Domingo don Pedro Zorrilla de San Martín de uno de septiembre y 14 de diciembre de 1741, proponiendo a la Corte los medios necesarios para acabar con la escasez de ganados. Expediente sobre el paso de ganados a la colonia francesa. A.G.I., Santo Domingo, 314. 
los gạaderos, debían establecer el precio que los franceses tendrían que pagar por cada res, pago que se haría exclusivamente en dinero, del que la Real Hacienda cobraría una quinta parte. Pero desde el principio se intentó dejar claro, que cuando los ganaderos no tuvieran excedente bastante para abastecerlos cesaría la extracción, pues ésta sólo tendría efecto si "pudiesen y no necesitaren para sus obligaciones". ${ }^{59}$

A causa de este decreto, en cada una de las villas mencionadas, Hincha, Azúa, etc., se celebró Cabildo abierto en el que cada ganadero declaró el número de cabezas que poseía de ganado vacuno, y lo que éste se incrementaba cada año. Se pretendía mantener intacto el llamado "principal", es decir, lo que tenía cada uno en aquellos momentos, haciéndose el reparto a base del "multíplico", o incremento anual.

$\mathrm{Ya}$ hemos señalado en el apartado anterior como se hizo esta distribución, cuyo resultado fue que los mencionados lugares, después de atender a las necesidades de los propios criadores, el aumento de la especie, y el abastecimiento de la parte española, aparte de pagar el diezmo correspondiente, tenían un excedente de 5.570 reses al año, con lo que fácilmente podían suministrar doscientas cabezas mensuales a la colonia francesa y aun sobrar.

El precio que se estipuló fue de 35 pesos el par o mancuerna, con tal de que ésta estuviese formada por un animal de menos de dos años y otro de más de cuatro. ${ }^{60}$

De este modo, desde el mes de abril de I742 en que se inició la extracción hasta el mismo mes del año siguiente, pasaron por las aduanas unas 2.400 reses, cobrando la Real Hacienda por el quinto establecido cerca de 9.000 pesos, de los que quedaron líquidos 8.000 en las Reales Cajas. El gobernador escribió a la Corte a este respecto, que de continuarse esta providencia, y aumentando el número de cabezas,

\footnotetext{
59 Ibídem, nota 38.

60 Acuerdo firmađto en 1743 entre los representantes de las colonias francesa y española de Santo Domingo, sobre el paso de ganado. A.G.I., Santo Domingo, 314.
} 
las Reales Cajas podrían beneficiarse con más de 25.000 pesos anuales. ${ }^{61}$

Independientemente de que don Pedro Zorrilla de San Martín pudiese o no gozar de algunos intereses en esta ex. tracción, cosa que ignoramos por completo, hay que tener en cuenta que el paso de ganado se realizaba aunque no fuese legal. El precio que los ganaderos españoles obtenían en la colonia francesa, ya hemos dicho que fue siempre muy superior al conseguido con la venta en la parte española, por lo que les compensaba el riesgo, en realidad escaso, de que su contrabando fuese descubierto y sus reses declaradas de comiso. Zorrilla era consciente de que, dada la extensión de la frontera y la escasez de pueblos y guardias en ella, sería imposible acabar con este comercio; y ya que el gobierno no podía impedir el paso del ganado, podía beneficiarse de él legalizándolo, y cobrando por ello los derechos correspondientes.

Pero el Consejo de Indias no aprobó la determinación del gobernador, y así lo manifestó a éste en carta de 2 de abril de r743. En ella, se le ordenaba que se atuviese a las antiguas órdenes existentes sobre el asunto sin imponer ninguna novedad, aunque sus propuestas serían estudiadas entre tanto detenidamente. ${ }^{\text {2 }}$

Al parecer el gobernador recibió esta càrta en I743, pero continuó permitiendo la exportación por la banda del norte, mientras insistía a la Corte para que su proposición fuese aprobada, en vista de los importantes beneficios que representaba para la Real Hacienda. De nuevo se le respondió que cesase la extracción hasta que el Consejo determinase sobre el asunto, suspendiéndose por ello en 1745 .

Desde el mes de abril de 1742 hasta el de junio de I745, ambos inclusive, tiempo durante el que se permitió el paso

\footnotetext{
61 Carta del gubernador de Santo Domingo don Pedro Zorrilla de San Martín, de cinco de abril de 1743, informando a la Corte de los beneficios obtenioos con la venta de ganado a los franceses. A.G.I., Santo Domingo, 314.

62 Carta del Consejo de Indias al gobernador don Peđro Zorrilla de dos de abril de 1743, desaprobando la exportación ganadera a la colonia vecina. A.G.I., Santo Domingo, 314.
} 
legal de ganado a la colonia francesa por la banda del norte, habían ingresado en las Reales Cajas procedentes del derecho cobrado por ello, I3.977 pesos, mientras que en la banda del sur, donde sólo se realizó desde el citado mes de abril de 1742 hasta el de noviembre del 43 , habían ingresado $7.464{ }^{\prime}{ }^{63}$

Así pues, el decreto de don Pedro Zorrilla quedó en suspenso, mientras el Consejo de Indias sometía el asunto a largas deliberaciones.

En esta situación, el procurador general de la ciudad de Santo Domingo escribía al Consejo en I748, sobre el deplorable estado en que se hallaba el abastecimiento de carnes a aquella capital, "por la frecuente extracción de ganados a las colonias francesas". Manifestaba que aunque el tráfico legal había cesado, el gobernador había permitido que el ganado siguiera pasando la frontera, no castigando a ninguno de los contrabandistas, a pesar de haber publicado algunos bandos amenazando con ello.

Afirmaba además, que Zorrilla destinaba a las guardias a oficiales del batallón fijo de aquella plaza, algunos de los cuales daban pasaportes y licencias a los ganaderos sin que el gobernador tomase las medidas pertinentes. ${ }^{64}$

En virtud de ello, y pensando el Consejo que la falta de carne en la colonia francesa dificultaría su mantenimiento en la isla, ordenó al sucesor de Zorrilla, don Juan José Colomo, en agosto de I749, prestase la mayor atención a este asunto, no permitiendo en ningún momento la exportación de reses a sus vecinos. ${ }^{65}$

Pero abolido el comercio legal, el contrabando se hacía cada vez más intenso. Y en I755 Tomás de la Cruz, al-

63 Carta del gobernador de Santo Domingo don Pedro Zorrilla de 30 de junio de 1745, remitiendo a la Corte una certificación de los oficiales reales de las Cajas de Santo Domingo, sobre los derechos cobrados por el paso de ganado a la colonia francesa, y comunicando haber suspendido esta providencia. A.G.I., Santo Domingo, 314. 64 Ibídem, nota 42.

65 Carta del gobernador interino de Santo Domingo don Juan José Colomo de 18 de mayo de 1749, sobre los medios necesarios para evitar el paso clandestino de ganados a la colonia francesa. A.G.I., Santo Domingo, 1.059. 
calde ordinario de la villa de Hincha, enviaba un informe a la Corte, en el que daba cuenta de que tanto el gobernador como sus tropas tenían abandonada por completo la frontera, adelantando los franceses sus posesiones, y dando los guardias paso franco a todo el que quería introducir ganado en la colonia francesa, "solicitando sólo que se les pague aquel estipendio que han establecido", y permitiéndolo el gobernador por sus intereses particulares.

Gobernaba entonces en Santo Domingo don Francisco Rubio y Peñaranda, que se defendió inmediatamente de estas acusaciones manifestando que, nada más tomar posesión de sus cargos, había publicado un bando prohibiendo la saca de ganado, y que conociendo lo poco que por ello velaban los alcaldes ordinarios, había dado facultades al gobernador de las armas de la villa de Hincha para "conocer a prevención y substanciar las causas de comisos", con lo que se había conseguido que el contrabando disminuyera considerablemente.

Así pues, los alcaldes ordinarios acusaban al gobernador de permitir y aun de beneficiarse de la extracción de ganado, y éste a su vez acusaba a aquellos de no intentar terminar con ella. Es difícil saber quien tenía razón, y si alguno de ellos estaba involucrado o no en este comercio. La carta de Tomás de la Cruz es fácil que pudiese estar dictada, por el descontento causado con el establecimiento de una autoridad superior a la de los alcaldes, por lo que se refería a las causas de contrabando. Pero el Consejo pareció prestar más atención a su informe que a la autodefensa de Rubio, previniendo a éste rápidamente, que ordenase al gobernador de las armas no inmiscuirse en las causas de comisos, y no embarazar las medidas tomadas en este punto por los alcaldes ordinarios.

Pero lo cierto es que ese contrabando existía, independientemente de que fuese favorecido o no por los goberna-

66 Informe de Tomás Ortiz de Landauri, alcalde ordinario de la villa de Hinha dando cuenta a la Corte del abandono en que el gobierno tenía la frontera, fechado el 11 de junio de 1775. A.G.I., Santo Domingo, 283. 
dores o los guardias y autoridades de la frontera, de manera que, si en un principio abastecían a la colonia francesa sólo los hatos españoles cercanos a ella, hacia I757 el ganado procedía incluso de zonas cercanas a la capital, en detrimento del suministro necesario para ésta. ${ }^{67}$

A don Francisco Rubio le sucedió como gobernador, capitán general, y presidente de la Audiencia de Santo Domingo, don Manuel de Azlor y Urríes. Azlor se dio cuenta, rápidamente, de que al abolir la medida que había tomado don Pedro Zorrilla por lo que se refería al comercio ganadero con sus vecinos, sólo se había logrado que éste continuase, pero desordenadamente y sin beneficio alguno para la Real Hacienda. En vista de ello, escribió a la Corte en I760 informando sobre la intensidad de este tráfico, que llegaba a alcanzar las 20.000 cabezas anuales, con los consiguientes perjuicios para las haciendas de los propios hateros. Al no estar regulado el paso de las reses, éste se hacía en exceso, y la abundancia abarataba considerablemente los precios.

Señalaba el nuevo gobernador, que las precauciones tomadas para acabar con el comercio ilícito no habían dado resultado alguno, ya que la frontera era extensa y poco poblada, y era imposible vigilarla por completo. "La disposición del terreno, la distancia considerable de unas a otras guardias con tan corto número de gente para su servicio, imposibilita el que se crucen y comuniquen, y siendo todos los parajes a propósito, arriesgados y propios para facilitar la introducción, no hay quien la impida".

Don Manuel de Azlor encontraba dos soluciones al problema. La primera consistía en trasladar los hatos a la parte oriental de la isla, lo que acarrearía la despoblación total de la frontera como había ocurrido antes con la zona norte, con el consiguiente avance de los franceses. La segunda era, que se permitiera a los criadores la venta a la

67 Ibídem, nota 54. 
colonia francesa de las reses que se considerasen sobrantes, pagando a la Real Hacienda un quinto de su valor. ${ }^{68}$

E1 Consejo de Indias, después de estudiar todos los antecedentes del asunto, que databan de la época del gobernador Zorrilla, comunicó a don Manuel de Azlor en I76I, que mientras se tomaban las providencias oportunas "usase del medio término menos perjudicial del disimulo, en el modo en que lo practicó don Pedro Zorrilla, no obstante que le fue desaprobado". Se autorizaba de este modo al gobernador, a conceder licencias para el tráfico ganadero entre las dos colonias, pero de forma que no pudiese considerarse a partir de entonces, como una obligación de los españoles respecto a sus vecinos.

Meses más tarde Azlor recibía una nueva comunicación de la Corte, en la que se le prevenía que autorizase la franca extracción de ganados, sin exigir por ello a los hacendados ninguna contribución extraordinaria, con la única limitación de fijar el número de reses que podían utilizarse con este fin, para que la parte española no sufriese escasez por ello. ${ }^{69}$

Estas órdenes se debieron a la firma de un nuevo pacto de familia entre España y Francia, y en virtud de ello, el $2 \mathrm{I}$ de julio de I762, don León de Fontenelle y don Ignacio Caro de Oviedo, con poderes otorgados por los gobernadores de la parte francesa y española respectivamente, firmaron un convenio de mutua ayuda entre ambas colonias durante el tiempo que durasen las hostilidades con Inglaterra. Se trataba desde luego de la guerra de los siete años, en la que España intervendría ahora, ya casi en su final, con motivo de la firma del mencionado pacto.

El capítulo cuarto del convenio que se hizo en Santo Domingo, y que fue ratificado por las dos primeras autoridades de la isla, estipulaba que, debiendo procurarse ambas

68 Ibídem, nota 5.

69 R. O. de 23 de mayo de 1761, autorizando al gobernador de Santo Domingo a permitir el paso de ganado a la colonia francesa vecina, aunque no de forma clara. R. O. de 30 de octubre del mismo año, autorizando ya la libre extracción, siempre que no se perjudicase el abastecimiento de la parte espafiola. A.G.I., Indiferente General, 1.661 . 
naciones la subsistencia para la defensa común, y careciendo los franceses de la carne necesaria con que mantener a sus tropas, los españoles les proporcionarían 800 reses al mes, y más si les fuera posible, sin que esto representase que una vez terminada la contienda tuviese que continuar la extracción.

De estas 800 cabezas de ganado vacuno, que deberían ser todos machos, 600 pasarían por la zona de Dajabón y San Rafael (norte) con destino al abastecimiento de las tropas del Guarico o cabo francés, y las otras doscientas por la frontera del sur. El precio al que debía pagarse esta carne era el mismo que se había fijado en tiempos del gobernador Zorrilla: 35 pesos la mancuerna, aunque en este caso debían ser todos los animales mayores de tres años.

La guerra terminó pronto, pero la colonia francesa parecía dispuesta a que el artículo expuesto siguiera en vigor. Así, en marzo del siguiente año, el señor Bertrand, comisario de guerra de la Corona francesa, envió una representación a don Manuel de Azlor, en la que manifestaba que la entrega de las 800 reses que se habían acordado no se había efectuado hasta aquel momento, por lo que debía permitir que en lugar de las 800 pasaran 1.000 al mes, y que puesto que a pesar de haberse firmado la paz las tropas continuaban en aquel territorio, debían ser enviados además I.000 caballos para su uso.

El gobernador español, aunque el convenio de 1762 quedaba en suspenso tras la firma de la paz, dando "testimonio de buena vecindad", respondió que daría las licencias necesarias para la extracción del ganado. Pero el número de reses sería el establecido en un principio, y no ı.Ooo como pedía el comisario, por haber escasez en la propia colonia española. En cuanto al precio sería ajustado libremente por los hateros y los comisarios franceses, que tendrían que pasar

70 Tratado firmado entre los representantes de las colonias francesa y española de la isla de Santo Domingo el 21 de julio de 1762, en el que se estipulaba el abastecimiento de carnes para la primera por parte de la segunda mientras durase la guerra contra Inglaterra. A.G.I., Santo Domingo, 1.059. 
a la parte española a realizar directamente la compra. El paso del ganado debería realizarse por las guardias de Dajabón, San Rafael, las Caobas o Neiba, donde pagarían un impuesto de dos pesos y medio por cabeza.

Respecto a los caballos que se le solicitaban, don Manuel de Azlor manifestó que no se hallaba en condiciones de proporcionar sino unos pocos, en cuya compra se seguirían las mismas reglas que regían la de las reses vacunas, pues en aquellos momentos eran muy necesarios en la colonia española. ${ }^{71}$

Entre tanto, el embajador francés en España había solicitado a la Corona española, que se mantuviera en vigor el permiso para la extracción de ganados que se concedió durante la guerra. El resultado de esta petición fue una real orden fechada en octubre de 1763 , en la que se prevenía al gobernador de Santo Domingo, que continuase permitiendo el paso de las reses que no fuesen necesarias al incremento de los hatos y al abastecimiento interno. A este fin, debía tratar de nuevo con el general del Guarico el número de cabezas que se exportarían y la forma de realizar la extracción.

A ello respondió don Manuel de Azlor, que se había hecho ya el reparto de las reses que se podían exportar, pero que el paso no se había realizado por continuar la introducción clandestina, pues "es constante que todas las colonias están provehidas de carne con sobrada abundancia", interviniendo en este contrabando el comisario francés. A pesar de ello, y tal y como se le ordenaba, intentaría lograr un nuevo acuerdo, comisionando para este fin al tesorero de las Reales Cajas, don Francisco Pepín González, continuándose mientras el normal abastecimiento, según las normas fijadas en el convenio de $1762 .{ }^{72}$

El nuevo acuerdo no se logró hasta agosto de I766. En

71 Carta del señor Bertrand al gobernador de Santo Domingo don Manuel Azlor de 24 de marzo de 1763 , y respuesta' de éste fechađa el siete de mayo del mismo año sobre el paso de ganados. A.G.I., Santo Domingo, 1.059.

72 R. O. de cinco de octubre de 1763 , previniendo al gobernador de Santo Domingo que se continuase la franca extracción de las reses necesarias a los franceses y la firma de un nuevo acuerdo, y carta de don Manuel de Azlor de 17 de marzo de 1764 acusando su recibo. A.G.I., Santo Domingo, 1.059. 
su artículo quinto se trataba este asunto, revalidando lo establecido en el ya mencionado de 1762 , con la única novedad de rebajar los derechos a sólo 24 reales por cada mancuerna, en lugar de los 40 fijados en aquél. Esta disminución de impuestos no fue aceptada por el Consejo de Indias, pero no tenemos noticias de que, a pesar de ello, se alterasen. ${ }^{73}$

Por otro lado, las peticiones de los franceses no se limitaban ya al abastecimiento de carne, solicitando también la compra de caballos para las tropas. En este sentido se produjeron algunas irregularidades, pues un comisionado del príncipe de Rohan se presentó en la frontera del sur con este objeto, y el comandante de ella autorizó la venta sin permiso del gobierno. Como ya no podía remediarse lo hecho, Azlor escribió al gobenador francés manifestándole su aprobación para la compra de 50 caballos, pagando cinco pesos de derechos por cada uno y sin que el suceso sirviese de precedente. La Corona desaprobó todo lo realizado, ordenando al capitán general, que en lo sucesivo no accediese a semejantes pretensiones, pues en los tratados se había acordado el paso de ganado vacuno para el abastecimiento de carne, pero nunca de caballos. ${ }^{74}$

Al margen de este comercio más o menos legal el contrabando continuaba. En I769, el gobernador don Manuel de Azlor realizó una visita general de la isla, en la que se informó del número de reses que había en los hatos, y en su consecuencia, del incremento que debía tener anualmente, deduciendo de ello "que se hace una extracción clandestina de la maior consideración a las colonias francesas, por caminos y sendas extraviadas". De ello se seguía no sólo un fraude a la Real Hacienda, sino lo que era aún más grave,

73 Tratado firmado el 26 de agosto de 1766 entre los representantes de las colonias francesa y española de Santo Domingo, y resolución del Consejo de Indias sobre él de tres de julio de 1767. A.G.I., Santo Domingo, 1.101.

74 Carta del gobernador de Santo Domingo don Manuel de Azlor de 21 de febrero de 1769, sobre algunas irregularidades ocurridas en la extracción de ganado, y R. O. de siete de agosto del mismo año, desaprobando lo sucedido. A.G.I., Santo Domingo, 1.059 . 
una exportación tan exorbitante que amenazaba la perviviencia de las haciendas. ${ }^{75}$

Intentando acabar con este comercio ilícito, la Audiencia y el gobernador redactaron unas instrucciones a las que debía ajustarse la actuación de las justicias y las guardias, en lo que respecta al paso de ganados a la colonia francesa. Según ellas, las licencias sólo podían ser concedidas por el gobernador, tomándose razón de todas en la Contaduría. Para su concesión, las justicias y Cabildos formarían todos los años un estado general de los hatos de su término, y el ganado que se encontrara fuera de su jurisdicción sin la correspondiente licencia sería confiscado. ${ }^{76}$

También el comercio legal presentaba serios problemas. La saca de ganados continuaba. El cobro de los derechos de este ramo era privativo de la capitanía general, sin conocimiento alguno por parte de los oficiales reales, ya que el gobierno había confiado este asunto a los oficiales militares de las fronteras.

Don Francisco Gelabert, contador del tribunal de cuentas de Barlovento, que se había trasladado a Santo Domingo para revisar las cuentas de sus Cajas Reales, informaba al Consejo que desde primeros de enero de I765 hasta el $3 \mathrm{I}$ de diciembre de I768, sólo produjo este impuesto I0.030 pesos, cuando según las declaraciones que tomó en la frontera sobre el tráfico de ganados, la cantidad debía ascender a 47.550 .

A causa de ello Gelabert convocó una junta de Real Hacienda, en la que se acordó que, para esta cobranza, se nombrasen cuatro oficiales que recibirían i2 reales por cada res vacuna, tres pesos por cada caballo o mulo y seis reales por cada cerdo, carnero, oveja y cabra. Pero a este respecto la respuesta de la Corte fue contundente, preguntando en

75 Carta del gobernador de Santo Domingo don Manuel de Azlor dirigida a la Corte y fechada el 30 de junio de 1769, sobre el paso de ganado a la colonia francesa de la isla. A.G.I., Santo Domingo, 1.059.

76 Santo Domingo, 25 de marzo de 1769; "Instrucciones que con arreglo al dictamen del superior tribunal de la Audiencia de ocho de noviembre de 1768 y de lo que en consecuencia deberán obrar las justicias para la extracción de ganado a la colonia francesa". A.G.I., Santo Domingo, 930. 
qué disposición se habían basado para ampliar este comercio a otros animales que no fuesen reses vacunas, y ordenando taxativamente que en lo sucesivo se ajustasen a lo prevenido el 7 de agosto de I 769 , cuando se desaprobó claramente el paso de caballos a la colonia vecina. ${ }^{77}$

En esta situación, llegó a la colonia francesa un nuevo gobernador, el conde de Nolivos, que inmediatamente propuso a su colega español la firma de un nuevo tratado, dos de cuyos puntos - el tercero y el sexto- hacían referencia al comercio ganadero. El tercero establecía, que se concedería permiso al conde de Nolivos para enviar uno o más hombres a la parte española, con el fin de comprar trescientos caballos con destino a las compañías de dragones. El sexto hacía referencia, a la inviolabilidad del derecho que tenía que pagarse por cada cabeza de ganado que pasara la frontera, y que debía recaer sobre los comerciantes franceses que realizasen la compra en el territorio español.

Don Manuel de Azlor se mostró conforme con algunos de los puntos del acuerdo que se le proponía, pero en lo relativo a la venta de caballos, informó a la Corte del asunto esperando la real determinación, haciendo saber al francés que no tenía autoridad para su aceptación.

En esta ocasión sin embargo, y en contra de lo que anteriormente se le había ordenado, se permitió al gobernador francés la compra de los trescientos caballos que solicitaba, "en atención a ser para el servicio de la tropa del rey Christianísimo". ${ }^{78}$

Dos años después, en I772, intentaron los franceses nuevamente firmar otro acuerdo sobre el asunto. En esta ocasión solicitaban que el precio no se pagara en dinero en efectivo, como se hallaba estipulado, sino en frutos de la co-

77 Carta del contador del tribunal de cuentas de las islas de Barlovento don Francisco Gelabert fechada el 11 de septiembre de 1769, informando a la Corte de las irregularidades existentes en el cobro del derecho del paso de ganado a la colonia francesa. A.G.I., Santo Domingo, 1.059.

78 Tratado propuesto por el gobernador general de la colonia francesa de Santo Domingo conde de Nolivos al español don Manuel de Azlor, con fecha de seis de mayo de 1770. Carta de éste a la Corte sobre el asunto de 20 de junio del mismo año. y respuesta de aquella de 12 de octubre d'e 1770 .A.G.I., Santo Domingo, 1.059 
lonia o en cualquier útil que necesitasen los españoles. Don José Solano, nuevo gobernador de la colonia española, no accedió a ello, pero informó a la Corte que le parecía bien que a cambio del ganado pudieran importarse esclavos, tan necesarios en los cultivos. ${ }^{79}$

Al mismo tiempo, el embajador francés en España presentó un oficio al Rey, en el que manifestaba que aunque tradicionalmente la colonia francesa de Santo Domingo se abasteció de carne en su vecina española, en aquellos momentos los colonos sufrían gran escasez, por las dificultades puestas por el gobernador español con el fin de que el pago se hiciera en dinero.

En vista de ello, se pidió al gobernador que informase sobre la base que tenían los franceses para pretender pagar en especies, cuando se hallaba legalmente establecido que se hiciera exclusivamente en moneda, y si a este respecto se efectuaba alguna novedad en contra de las órdenes reales.

Don José Solano respondió, que en el poco tiempo que llevaba al frente de la isla no puso embarazo alguno al paso de ganados, pues en sólo dos años cruzaron la frontera con las correspondientes licencias 15.860 reses. $Y$ por lo que se refiere a la forma de pago siempre se hizo en dinero, no permitiéndose nunca a los españoles traer a cambio ninguna otra cosa. ${ }^{80}$

Sin embargo, esta costumbre se va a ver alterada muy pronto. El gobernador francés presentaba a su colega español continuas quejas, sobre la penuria de carnes en que se encontraban los habitantes de su territorio. Don José Solano contestaba que él había concedido las licencias suficientes, pero que como los franceses pretendían pagar a los ganaderos en frutos, o en monedas de viejo cuño, los españoles se negaban a llevarles sus reses.

79 Representación del gobernador de Santo Domingo don José Solano y Bote de 24 de agosto de $\mathbf{1 7 7 2}$ dando cuenta a la Corte de la pretensión de los franceses de pagar el ganado comprado a los españoles en frutos de su colonia o en esclavos. A.G.I., Santo Domingo, 1.059 .

80 Orden dirigida al gobernador de Santo Domingo con fecha de 24 de marzo de 1773, para que informase sobre el modo en que los franceses pagaban el ganado comprado a la colonia española. A.G.I., Santo Domingo, 1.059. 
Probablemente la afirmación de Solano fuera un tanto gratuita, ya que el contrabando continuaba. Pero en ella se basó, en vista de la dificultad que aparentemente tenían los franceses de pagar en dinero, para permitir a los "extractores de ganado" cobrar su producto en esclavos, contra todas las normas establecidas. Esta provisión sin embargo duró poco tiempo, pues al año siguiente, como represalia a las pretensiones de los franceses de sobrepaśar los límites de su colonia, Solano suspendió la exportación de ganado. ${ }^{81}$

Pese a todo, don José Solano será un acérrimo defensor de la extracción, y haciendo hincapié en algunas de las medidas que había propuesto su antecesor don Manuel de Azlor, conseguirá muchas de las que le fueron negadas a aquél. A ello contribuye el cambio que se estaba produciendo en las ideas económicas en aras de una mayor libertad.

Una de las providencias que defendió don Manuel de Azlor en sus acuerdos con la colonia francesa, que le fue desaprobada siempre por el gobierno central, fue la de que se permitiese a los comerciantes franceses ir a comprar la mercancía directamente a los hatos españoles. Su sucesor siguió preconizando esta medida, basándose en que, al no haber pastos en la zona francesa, cuando los españoles llevaban allí sus reses tenían que venderlas con la mayor urgencia, ante el temor de que perdieran peso o incluso murieran, aprovechándose de ello sus vecinos para comprar la mercancía a precios inferiores a los convenidos. $Y$ en esta ocasión la Corte aprobó la propuesta. ${ }^{82}$

Poco después el mandatario hispano participaba a la Metrópoli que, desde su punto de vista, no hallaba inconveniente en tolerar a los españoles negociar con sus mulas y caballos en la vecina colonia, dado que no sólo contaban

81 Carta del gobernador de Santo Domingo don José Solano de 24 de octubre de 1774, comunicando a la Corte que había permitido el cambio del ganado español por esclavos, y otra de 24 de junio de 1775 dando cuenta de haber suspendidus la concesión de licencias para la exportación de ganado. A.G.I., Santo Domingo, 1.059.

82 Carta del gobernador don José Solano a la Corte fechada el 20 de septiembre de 1776 y respuesta de aquella de ocho de enero de 1777. A.G.I., Santo Domingo, 1.059. 
con suficientes cabezas, sino que los beneficios obtenidos por la exportación fomentarían la crianza.

Del mismo modo afirmaba, que el exigir a los franceses el pago en dinero representaba una rémora para el comercio de carnes, mostrándose partidario de que los ganaderos pudiesen cobrar en esclavos, que pagarian la mitad de los derechos abonados por los que se traían de otras colonias.

La respuesta de la Metrópoli fue que se ajustase a las instrucciones que se dieron a los gobernadores de Caracas, Cumaná, la Guaira y la Luisiana sobre este asunto. Estas instrucciones permitieron a las colonias señaladas, la exportación de ganados y granos que fuesen necesarios para el sustento de las islas francesas de Barlovento. Pero mientras que a éstas se les mandó que el cobro se hiciera exclusivamente en dinero o "buenas letras", a los dominicanos se les autorizaba a hacerlo también en negros. ${ }^{83}$

Las normas de que se hablan, señalaban que los gobernadores debían admitir la residencia en sus puertos de dos comisarios franceses, encargados de la compra tanto del ganado como del resto de los víveres.

Pero cinco meses después de que estas órdenes fuesen recibidas en Santo Domingo, no había llegado a la colonia española ninguno de estos comisarios. Amparándose en ello, don José Solano va a conseguir nuevas libertades para el comercio ganadero, al solicitar a la Corona que se permitiese a los dominicanos llevar los ganados, y cualquier otro género comestible difícil de transportar por tierra por la distancia, en barcos españoles desde las ciudades costeras más cercanas. Reclamó también Solano, que se rebajasen los derechos cobrados por los esclavos introducidos a cambio del ganado, y de nuevo en esta ocasión la Corte aprobó su propuesta.

83 Representación del gobernador de Santo Domingo don José Solano de 20 de septiembre de 1776 y respuesta de ésta de nueve de enero de 1777. A.G.I., Sunto Domingo, 1.059 .

84 Representación del gobernador don José Solano de 23 de mayo de 1777 dirigida a la Corte, y contestación de aquella de 28 de septiembre del mismo año. A.G.I., Santo Dominggo, 1.059 . 
En esta situación se encontraba el asunto, cuando se firmó el tratado de Aranjuez en I 777 entre España y Francia, para establecer una frontera duradera entre sus posesiones respectivas de Santo Domingo. Y anejo a él, fue concertado uno de policía, en el que se acordaba la mutua ayuda en la captura de los delicuentes, restitución de los esclavos fugitivos, etc.; y en su artículo ocho se concedían aún mayores libertades al tráfico de reses, al establecer que la extracción de ganado se efectuaría del modo más conveniente al gobierno español, y que fuese menos gravoso a los franceses, de manera que el gobernador de Santo Domingo facilitaría los pasaportes tanto a los nacionales que lo pidiesen, como a los "asentistas" de las carnicerías francesas. ${ }^{85}$

El sucesor de Solano, don Isidro de Peralta y Rojas, no va a ser sin embargo tan partidario del paso de ganado como su antecesor. Nada más tomar posesión de sus cargos, recibió una comunicación del general de la colonia francesa conde Dargout, solicitando se concediesen licencias para la saca de 9.000 reses anuales con destino al abastecimiento de sus tropas y colonos, que serían compradas por un comisario nombrado con este fin. Este comisario se encargaría directamente de pagar los derechos correspondientes a la Real Hacienda.

Peralta respondió concediendo cinco licencias, cada una por 400 cabezas, no condescendiendo con las nueve mil que se le pedían, según afirmaba, por no tener pleno conocimiento del estado de los hatos de la isla. ${ }^{86}$

La realidad fue que durante todo su gobierno continuó esta política de recesión de las licencias, quejándose continuamente a la Corte de los abusos que los franceses pretendían en este campo.

85 Tratado de. Policía firmado por los plenipotenciarios español y francés en Aranjuez en 1777 , basado en el ajuste provisional de límites estipulado por los gobernadores respectivos de la jsla de Santo Domingo el 29 de febrero del año anterior. A.H.N., Estado 3.394.

86 Carta del gobernador de Santo Domingo don Isidro de Peralta de 23 de octubre de 1778, dando cuenta a la Corte de las solicitudes de los franceses para que se les abasteciese de carne. A.G.I., Santo Domingo, 1.059. 
Afirmaba el gobernador, que los franceses no querían simplemente que se les suministrase la carne necesaria para su consumo, sino "introducir un total desorden en la compra y extracción de ganados", sin aprecio ni atención a los acuerdos existentes entre las dos colonias. Retiraban a los comisarios encargados de 1levarlas al otro lado de la frontera, obligando a los españoles a hacerlo por sí mismos, para forzarlos a vender allí a precios más bajos y a cambio de algunos productos, en lugar de dinero, letras, o esclavos. ${ }^{87}$

La política seguida por Peralta ocasionó disgustos entre los grandes hateros de la frontera, algunos de los cuales como don José Guzmán, barón de San Miguel de la Atalaya, se consideraban seriamente perjudicados por no encontrar salida legal a sus reses. En vista de ello, el barón envió directamente al Consejo una súplica, solicitando se le permitiera vender a los franceses las tres cuartas partes de su ganado siempre que pudiese, sin "más circunstancias ni requisito, que el de presentar la gracia que se le conceda al presidente de Santo Domingo, para que la ponga el cúmplase", aunque desde luego su petición no fue aceptada.

Con todo ello, continuaba cada vez con más fuerza la extracción clandestina a pesar de que don Manuel González, sucesor de Peralta en el gobierno de la isla, reformó el resguardo de la frontera, estableciendo para su vigilancia dos rondas volantes, una en el sur y otra en el norte. ${ }^{89}$

Intentando paliarlo en lo posible, la real cédula de i2 de abril de $\mathbf{7} 786$, que trataba de las medidas que debían tomarse para el fomento del Santo Domingo español, se ocupaba también de este asunto. Hasta entonces la compra del ganado debían hacerla dos comisarios franceses, quedando

87 Carta del gobernador de Santo Domingo don Isidro de Peralta de cinco de junio de 1782, dando cuenta a la Corte de los abusos cometidos por los carniceros franceses al comprar la carne a los españoles. A.G.I., Santo Domingo, 1.011.

88 Solicitud đe don Juan Gabriel Pérez en nombre de don José Guzmán, barón de San Miguel de la Atalaya, fechada el siete de abril de 1783, para vender su: ganado directamente a la colonia francesa, y resolucion del Consejo de Indias de 16 de octubre del mismo año. A.G.I. Santo Domingo, 1.005.

89 Plan del resguardo de la frontera establecido por el gobernador de Santo Domingo don Manuel González. A.G.I., Santo Domingo, 953 y 1.045. 
el precio al arbitrio de éstos. A partir de ahora quedará anulado el convenio firmado por ambas colonias. El sistema empleado ahora debía ser la celebración de ferias públicas, fijando el gobierno el número de reses que podía presentar a ellas cada ganadero. A estas ferias acudiría todo el que quisiera, pagando los franceses en dinero, esclavos, o utensilios que los españoles necesitasen, presenciando las ventas los comandantes o jueces de la frontera para evitar la saca clandestina. ${ }^{90}$

Pero esta real cédula no consiguió los fines que se proponía. Dos años más tarde, el oidor decano de la Audiencia de Santo Domingo, y gobernador interino a causa de la muerte de don Manuel González, informaba a la Metrópoli que continuaba el contrabando de ganado con el fin de evadir los imprestos establecidos. A pesar de que la mercancía clandestina se vendía siempre a menos precio que la legal, compensaba sin embargo con creces a los hateros al no pagar los reales derechos, y todos los esfuerzos que pudieran hacer las autoridades para evitar este tráfico eran inútiles. ${ }^{91}$

Poco tiempo más tarde, el último gobernador español antes de la cesión de la isla a los franceses, don Joaquín García, en vista de que el contrabando aumentaba en detrimento de la Real Hacienda, propuso varios puntos encaminados a la realización de la extracción.

Consistían éstos en que el otorgamiento de las licencias debía ser privilegio exclusivo del gobernador, el cual además, relacionaría el estado en que se encontraban todos los hatos, y confiscaría el ganado encontrado fuera de sus haciendas sin las correspondientes licencias.

Pero todas estas medidas habían estado vigentes durante mucho tiempo y nunca habían dado ningún resultado. ${ }^{92}$

Es imposible desde luego conocer el número de reses

\footnotetext{
90 Ibídem, nota 18.

91 Ibídem, nota 1.

92 Puntos propuestos por el gobernador de Santo Domingo don Joaquín García con fecha de 25 de marzo de 1790 para la realización de la exportación de ganado a la colonia francesa. A.G.I., Santo Domingo, 953.
} 
que cruzaban anualmente la frontera, pues la mayor parte de ellas lo hacían subrepticiamente como ya hemos señalado.

En los dos últimos años del gobierno de don José Solano se extrajeron, pagando los reales derechos, 4.906 reses. Pero el tráfico en la etapa estudiada fue al parecer mucho mayor, amparado en ocasiones por los propios gobernadores, y otras en abierta desobediencia a aquéllos.

El mismo don Manuel de Azlor, en un informe enviado a la Corte sobre la situación ganadera de la isla, decía que cada año pasaban a la colonia francesa "hasta veinte mil cabezas de ganado". ${ }^{93}$

Al margen de la documentación nos tropezamos con testimonios contradictorios. Un testigo presencial o contemporáneo, afirma que hacia 1789 ingresaban en la zona francesa unas 12.000 reses anuales, ${ }^{94}$ en tanto que en un texto de nuestros días, leemos que en I760 los ganaderos de Santiago, La Vega, Cotui, Hincha, San Rafael, Banica y San Juan de la Maguana, proporcionaban a los francese 15.000 reses anuales, número que se incrementó en un $30 \%$ en $1780{ }^{95}$

No tenemos ninguna prueba sobre estas afirmaciones, pero si tenemos en cuenta el número total de reses vacunas de Santo Domingo y las pocas que llegaban a la capital, es de suponer que el resto lo vendían los hateros en la colonia francesa, con lo que las cifras señaladas no parecen en absoluto exageradas, siendo superado con creces el comercio legal por el clandestino, a pesar de todas las medidas que pudieran tomarse para su regulación.

93 Ibídem, nota 5.

94 Moreau de Saint-Mery, M. L.: Op. cit., pág. 390.

95 Moya Pons, Frank: Op. cit., pág. 303. 



\section{Capítulo V}

\section{O M E R C I O}

\section{La Compañía de Comercio de Barcelona}

Desde el siglo XVI, el régimen comercial imperante en los países europeos va a ser el conocido con el nombre de mercantilismo, en el que la intervención estatal es una base esencial. Los presupuestos mercantilistas eran claros: que las exportaciones superasen a las importaciones. En este aspecto, las colonias se convirtieron en centros productores de materias primas a bajos precios, y, al mismo tiempo, en consumidores de las manufacturas europeas.

Y este sistema económico que había triunfado en Europa desde el siglo XVI, según algunos autores se impone también en España, aunque algo más tarde, adquiriendo su mayor auge cuando ya en gran parte del Continente el esquema estaba evolucionando hacia un sistema de mayor libre-cambio.

Sin embargo, a juicio de otros, no se dio en las relaciones comerciales hispano-americanas ese mercantilismo, tratándose más bien de un régimen de economías complementarias en el que cada colonia, y la Metrópoli como una más, tenía señalada una función determinada, de modo que pudieran evitarse los excedentes de algunos productos y la escasez de otros. En este sentido, el imperio colonial espaiíol "constituía un engranaje político, militar y económico, dentro del cual la Metrópoli no era sino una pieza más". ${ }^{1}$

1 Arcila Farias, Eduardo: Prólogo a El Comercio Canario-Americano, de Francisco Morales Padrón, pág. XVI. 
Los monarcas españoles del siglo XVIII, van a aferrarse al comercio como medio de conseguir el robustecimiento económico del país, de modo que la intervención estatal propia del mercantilismo, estará desde luego presente en todo momento en el tráfico español con sus colonias americanas.

Pero, al mismo tiempo, las nuevas ideas que comienzan a difundirse en este siglo van a tener también eco en la Península, en aras de una mayor libertad económica que favorecerá la iniciativa privada, aunque siempre dentro de los límites marcados por la Corona.

La legislación reguladora del comercio español con América, permaneció invariable desde principios del siglo XVI hasta el XVIII, concretamente hasta la promulgación del Reglamento de $1720,{ }^{2}$ con los consiguientes perjuicios para la economía.

Las limitaciones legales al comercio hispano-americano y la complejidad fiscal, trajeron consigo el insuficiente abastecimiento a las colonias españolas. La Península no les suministraba los artículos necesarios, y sus precios, dado el gran número de impuestos que tenían que abonar, eran elevados. Por todo ello, a lo largo del siglo XVII el comercio americano, ante la desidia de la Metrópoli, se realizaba sobre todo con los extranjeros a través del contrabando.

El cambio de dinastía que tuvo lugar en España a principios del XVIII, tuvo rápidamente repercusiones en el sistema económico español. Las reformas borbónicas van a dejarse sentir por lo que se refiere a la legislación comercial ya desde la primera mitad del siglo, con el Reglamento de I720, que modificaba el sistema fiscal, y con el decreto de I735, que hará desaparecer el sistema de flotas. ${ }^{3}$ De este modo, en los primeros 50 años del siglo XVIII "finalizaba el comercio

2 Rodríguez Casado, Vicente: Comentarios al Decreto y Real Instrucción de I765, regulando las relaciones comerciales de España en Indias. "Anuario de Historia del Derecho Español”. Tomo XIII. Madrid, 1936-1941, pág. 105.

3 Muñoz Pérez, José: La publicación del reglamento de comercio libre a Indias en 1778. "Anuario de Estudios Americanos", Vol. IV. Sevilla, 1947, págs. 635-637. 
monopolizado y restringido de los siglos anteriores". ${ }^{4} \mathrm{La}$ primera mitad del siglo no representa aún el principio del comercio libre, pero sí la transición a las libertades que vendrán años después. Se inician las reformas que darán pie a la promulgación del Reglamento del Comercio Libre de 1778.

Los desastrosos resultados de la política comercial llevada a cabo hasta entonces, hicieron surgir protestas de los economistas españoles que fueron escuchadas por los monarcas, de manera que en la primera mitad del XVIII empieza, no una innovación radical, pero sí una evolución paulatina, ${ }^{5}$ que comienza con el ya citado Proyecto de Galeones de 1720, y alcanzará su apogeo en la época de Carlos III. Así, la situación económica y comercial española, y con ella la de sus colonias, experimenta un cambio substancial e irreversible a lo largo del siglo XVIII.

Por lo que se refiere a Santo Domingo y al periodo que estamos estudiando, la segunda mitad del siglo XVIII, podemos señalar dos etapas en su comercio dentro de la evolución de que ya hemos hablado: la de las grandes compañías en primer lugar, y una segunda en la que aquéllas perderán sus privilegios y que se denominará del libre comercio.

Respecto a la primera, Francia tenía ya una larga experiencia en este tipo de grandes emporios comerciales que, "al reunir en un solo capital considerable numerosos pequeños capitales, permitían emprender operaciones que no estaban al alcance de ninguna fortuna privada de aquella época". ${ }^{6}$ La monarquía francesa que se instala ahora en España, que como ya hemos señalado consideraba el comercio como el principal resorte para levantar la economía del país, va a intentar recuperarlo de los extranjeros por todos los medios, a través de un "sistema que, sin romper con el monopolio

\footnotetext{
4 Morales Padrón, Francisco: Loc. cit., pág. 79.

5 Levene, Ricardo: Comercio de Indias. Antecedentes legales (1713-1778). Documentos para la Historia argentina. Compañía Sud-Americana de Billetes de Banco. Bue nos Aires, 1915. págs. XXIV-XXV.

6 Arcila Farias, Eduardo: Reformas económicas del siglo XVIII en Nueva España. Publicado por la Secretaría de Educación en Sep/Setentas. México, 1974. Tomo I, pág. 29.
} 
restrictivo del periodo anterior, permitiera abrir nuevos cauces a la iniciativa privada". "

Surgen así las compañías privilegiadas de comercio y navegación, que durante algunos años tendrán prácticamente el monopolio del comercio con determinadas regiones americanas. La primera de éstas, la de Honduras, se creó en I7 I 4 y apenas duró tres años. Pero la primera que prospera fue la Compañía de Caracas o Guipuzcoana, cuyos privilegios fueron publicados por el Rey el 25 de septiembre de I $728.8^{8}$

Aparecen después la de Galicia en I734, la de los Cinco Gremios Mayores de Madrid, la de San Fernando de Sevilla, la de Granada, la de La Habana y la de Filipinas. ${ }^{9}$

En Santo Domingo, esta etapa está representada por la Compañía de Comercio de Barcelona, conocida por otros como Compañía Catalana de Comercio. Varios comerciantes de Barcelona presentaron al Consejo un proyecto para su formación, que fue aceptado y aprobado posteriormente por el Monarca con la promulgación de la real cédula de 4 de mayo de 1755 .

En ella se establecían las siguientes bases:

- Que la mencionada Compañía comerciase con las islas de Santo Domingo, Puerto Rico y la Margarita, donde llevaría géneros del país y aquellos extranjeros que no hubiera en él. Las mercancías deberían cargarse en Barcelona, abriéndose allí el correspondiente registro para revisarlo más tarde en Cádiz. Del mismo modo, a su regreso a Cádiz se reconocería la carga traída de aquellos lugares.

- Las embarcaciones de la Compañía que viajaran a aquellas islas quedaban libres del derecho de toneladas, y sus mercancías del de extracción, y a su llegada a In-

7 García-Baquero González, Antonio: Cádiz y el Atlantico (1717-1778). E.E.H.A. Sevilla, 1976. Tomo I, pág. 83.

8 Hussey, Ronald D.: La Compafía de Caracas. 1728-1784. Banco Central de Venezuela. Colección Histórico-Economica Venezolana. Caracas, 1962. Vol. VIII, pág. 65. 9 Arcila Farias, Eduardo: Op. cit., págs. 34-38. 
dias pagarían íntegramente los impuestos de los géneros que iban por palmeo, y la mitad de los incluidos en el Real Proyecto, a excepción de la harina y la loza, que se declaraban totalmente libres. A la vuelta, el oro y la plata pagaban todos los derechos, pero quedaban exentos el azúcar, el palo de tinta, las maderas y el algodón, y reducidos a la mitad los de los demás frutos.

- Con las mismas embarcaciones destinadas a las tres islas mencionadas, se le autorizaba a traficar entre Santo Domingo y Puerto Rico y viceversa sin pagar nuevos derechos, pero nunca entre éstas y la Margarita.

- Los navíos de la Compañía quedaban sujetos a "los mismos honores y privilegios que los de la Compañía de Caracas", interviniendo la Corona en el caso de que fuera apresado alguno por otras naciones, y recibiendo cuantos auxilios necesitasen por parte de todas las autoridades.

- El fondo de la Compañía se estableció en un millón de pesos, pudiendo comenzar sus actividades al reunir los primeros 400.000 , distribuyéndose acciones de 250 pesos que pudieran comprar todos los españoles que lo desearan.

- Los comerciantes barceloneses elegirían 12 representantes para que a su vez éstos nombrasen tres directores, un contador y un tesorero, encargándose con ellos de la redacción de las ordenanzas de la Compañía. Se ordenaba además que estos cargos se eligieran cada tres años, sin aceptarse la reelección a no ser en casos excepcionales. ${ }^{10}$

Al año siguiente de la promulgación de esta real cédula, fueron presentadas al Rey las ordenanzas creadas en su cumplimiento por los comerciantes de Barcelona, con 93 capítulos, la mayoría de los cuales fueron aprobados.

10 R. C. de cuatro de mayo de 1755 , por la que se crea la Ccmpañía de
Comercio de Barcelona. A.G.I., Santo Domingo, 1.100 . 
A este respecto hemos de señalar, que si bien en un principio se prohibió el tráfico de la isla de la Margarita con Santo Domingo y Puerto Rico, las ordenanzas proponían lo contrario, y en este sentido se adoptó un término medio. Los barcos de la Compañía quedaban autorizados a llevar géneros desde la Margarita a Puerto Rico y Santo Domingo, pero no al revés.

De este modo, el seis de mayo de 1756 se aprobaba definitivamente la creación de la Compañía de Comercio de Barcelona y sus ordenanzas. ${ }^{11}$

Pero la Compañía de Barcelona surge en una época en que el auge de estas grandes entidades había pasado. A partir de I753 "la Corona comenzó a limitar cada vez más estos amplísimos poderes", ${ }^{12}$ y a los pocos días de la aprobación de sus ordenanzas, concretamente el i 8 de mayo de aquel mismo año, se publica un decreto por el que se pone fin a los privilegios concedidos a lás compañías, por considerarse perjudiciales a los intereses comunes, ${ }^{13}$ reflejando claramente la nueva línea a seguir por la Corona: una mayor libertad comercial.

Sin embargo, el establecimiento efectivo de la Compañía en la Española no se realizó hasta mayo de 1757 , un año después de la promulgación de este real decreto. ${ }^{14}$ Pero si su creación hizo pensar a algunos en un importante tráfico comercial entre España y Santo Domingo, pronto se vieron defraudados. "la parte española no tiene casi ninguna relación con su Metrópoli, que la tiene sometida al privilegio exclusivo de la Compañía de Cataluña. Esta Compañía, como todas las otras, no provee sino de manera insuficiente las cosas necesarias". ${ }^{15}$

En este mismo sentido se manifestaba en r759 el go-

\footnotetext{
11 R. C. de seis de mayo de 1756 aprobando las ordenanzas de la Compa- 
bernador don Manuel de Azlor, quejándose a la Corte de los pocos frutos que había dado el establecimiento de la mencionada Compañía. Según la primera autoridad de la isla, eran escasos los víveres y ropas que llegaban en sus embarcaciones: "en esta capital se necesitan anualmente tres mil barriles de harina, y en dos años y tres meses sólo han venido setecientos". ${ }^{16}$

Los navíos catalanes habían desembarcado en la capital dominicana vino, aceite, cera y jabón, pero a precios tres veces superiores a los corrientes antes de la creación de la Compañía, siendo al mismo tiempo casi nulos los envíos de toda clase de ropa.

La escasez de productos que la Compañía proporcionaba, y los elevados precios a que se veían obligados a comprar los dominicanos, no tardaron en producir los correspondientes descontentos y, por supuesto, la continuación del comercio ilícito, que suministraba a los vecinos de la isla los mismos géneros que las embarcaciones nacionales, pero a precios sensiblemente inferiores.

Don Manuel de Azlor, consciente de ello, se mostraba partidario de conceder licencias a otros barcos españoles para poder traer los víveres necesarios de las colonias americanas, al tiempo que consideraba que "será indispensable para el logro de los fines del establecimiento de esta compañía, el que sus directores concedan facultad a estos factores para el suplemento de caudales, a fin de proveer de negros, y que las cargazones de víberes y ropas bengan surtidas enteramente de todo lo necesario. Que moderen y bajen sus precios, y proporcionen todas las ventajas favorables al pays, para que no necesiten de socorros ni auxilios forasteros, que me será forzoso aunque sensible dispensar, ínterin se verifique lo propuesto". ${ }^{17}$

Pero aunque en la práctica la Compañía de Barcelona tuviera casi el monopolio del comercio dominicano, legalmente, y sobre todo tras la promulgación del famoso decreto

16 Ibídem, nota 14.

17 Ibídem. 
de 1756 ya señalado, no tenía la exclusiva de este tráfico. $\mathrm{Y}$ así lo hizo constar la Corte al gobernador de Santo Domingo, aprobando, al mismo tiempo, su determinación de enviar embarcaciones a otras colonias en busca de los víveres necesarios. Pero para evitar en lo posible que los comestibles les llegasen de las colonias extranjeras, se dieron las órdenes pertinentes al presidente de la Casa de la Contratación de Cádiz, para que permitiera a cualquier navío que zarpara con destino a La Habana, embarcar víveres tanto para Santo Domingo como para Puerto Rico y la Margarita. dejando así al margen los privilegios que en su tiempo se concedieron a la Compañía Catalana. ${ }^{18}$

De este modo, y aunque durante toda la época tratada los buques de la Real Compañía de Barcelona serán en su mayor parte los que se encarguen del tráfico entre España y Santo Domingo, siguiendo el mismo camino que las otras grandes compañías comerciales, irá perdiendo poco a poco privilegios y la protección estatạl, que había sido fundamental para la creación de este tipo de sociedades.

Así, el artículo 9i de sus ordenanzas, que fueron aprobadas por la Corona, establecía que "en todos los pleytos y dudas que se excitaren, y no estén prevenidas para el conocimiento del presidente de la Casa de Contratación de las Indias en Cádiz, conforme a lo establecido en el capítulo antecedente, el Intendente que es o fuere dei Exército y Principado de Cataluña, en calidad de Juez Conservador, será juez ordinario de la Real Compañía, con la jurisdicción privativa, y con inhibición de la Real Audiencia de Barcelona y otros Tribunales, assí en Cataluña como fuera de ella. Conocerá, decidirá y terminará todas las questiones y pleytos causados por el Comercio Marítimo y Terrestre de la Real Compañía, y por razón y. causa de contratos firmados por los Directores, Factores y demás empleados en la Ciudad de Bar-

18 Carta de la Corte al gobernador de Santo Domingo de 24 de enero de 1760 , en respuesta a la suya de seis de noviembre de 1759, y $R$. O. dirigida al presidente de la Casa de la Contratación con fecha de siete de marzo del mismo año. A.G.I., Inidiferente General, 2.410. 
celona, Principado de Cataluña, en lo restante de España, en América y otros Reynos, assí entre sí, como que hayan mediado con otras personas de qualquiera estado, clase o condición". ${ }^{19}$

Las consecuencias de este artículo fueron claras, y desde luego muy beneficiosas para la Compañía. Cualquier pleito suscitado en las tres islas a que se dedicaba su comercio le era favorable antes de iniciarse. El demandante debía recurrir al intendente de Cataluña para la exposición de sus quejas; la mayoría de los dominicanos carecian de medios económicos para ello, y si alguno los poseía renunciaba a sus derechos, por ser mayores los gastos que el beneficio que pudiera obtener.

Con ese motivo, en i 766 el gobernador de Santo Domingo don Manuel de Azlor, que como ya hemos visto nunca vió con buenos ojos los privilegios de la Compañía, manifestó a la Corte su repulsa por esta situación, representando probablemente el sentir de todos los comerciantes dominicanos.

La respuesta no se hizo esperar, y significó quizás la definitiva quiebra de las prerrogativas de aquélla, ya que, según el fiscal del Consejo de Indias, el citado artículo 9I no podía tener esa interpretación, pues era imposible privar a los naturales de Santo Domingo de la acción de sus leyes, declarándose que los vecinos de las islas "puedan demandar y reconvenir a los factores de la expresada compañía ante los jueces de sus respectivos distritos". ${ }^{20}$

De este modo, y aunque como ya hemos señalado con anterioridad, los navíos de la Compañía siguieron estando en franca mayoría por lo que se refiere al comercio dominicano con la Metrópoli, sus distinciones fueron disminuyendo poco a poco, al mismo tiempo que se intensificaba la acción

19 Barcelona, nueve de enero de 1756. Ordenanzas formadas para el funcionamiento de la Compañía de Comercio de Barcelona. A.G.I., Santo Domingo, 1.100

20 Carta de don Manuel de Azlor de dos de agosto de 1766 sobre los perjuicios ocasionados en Santo Domingo por la Compañía de Comercio de Barcelona, y resolución del fiscal del Consejo de Indias de nueve de febrero de 1767. A.G.l. Santo Domingo, 977. 
de las nuevas teorías económicas que darán paso al llamado libre comercio, en que todos los traficantes, fuesen de la Compañía o no, gozarían de los mismos derechos y obligaciones, terminando así con un monopolio que, aunque legalmente no existía, se había creado en la realidad por los especiales favores concedidos a aquélla.

\section{El Libre Comercio. Cédulas de i765 y i 778}

Tal y como hemos indicado, finalizaba ya la etapa de las grandes compañías comerciales para dejar paso a un régimen comercial más libre.

Las ideas mercantilistas habían ido evolucionando paulatinamente al amparo de las nuevas teorías fisiocráticas y liberalistas, y el deseo reformista de los Borbones, que se manifestó claramente sobre todo en la segunda mitad del siglo XVIII, va a recoger esas nuevas corrientes, aunque desde luego continúan con el proteccionismo.

Fruto de este cambio paulatino de actitud, por lo que se refiere a la variación de la política económica llevada a cabo por los monarcas españoles, será la real cédula e instrucción de i765, declaratoria del libre comercio entre los vasallos de España y las islas de Barlovento.

No se trataba desde luego del establecimiento del librecambio, pero significó la abolición del puerto único para el comercio con las Antillas españolas y la supresión de algunos derechos. Las instrucciones para efectuar este libre comercio se dieron con fecha de 16 de octubre de 1765 , y fueron promulgadas por una real cédula e instrucción posterior de ocho de noviembre del mismo año. ${ }^{21}$

En ella se manifestaba que, dado el escaso número de embarcaciones españolas que se dirigían a los puertos del Caribe, y los gravámenes que tenían que pagar a su salida de

21 Rodríguez Casado, Vicente: Op. cit., pág. 113. 
la Península, quedaba abolido por lo que se refería al comercio de las islas de Cuba, Santo Domingo, Puerto Rico, Margarita y Trinidad, el derecho de palmeo establecido por el Proyecto de Galeones de I720, el de toneladas, el impuesto del seminario de San Telmo, derecho de extranjería y de los de visitas y reconocimiento de carenas, habilitaciones, licencias y otros gastos, "dejando libertad a mis vasallos, tanto de estos reynos como de las citadas islas, para que puedan hacer este comercio en ellas, baxo de las reglas, precauciones, paga de derechos, y por los puertos de estos mis dominios que contiene la instrucción del tenor siguiente". ${ }^{\mathbf{2 2}}$

La citada instrucción constaba de I 5 capítulos, en los que se establecía la abolición de los derechos mencionados para las mercancías transportadas desde España a las islas, entre ellos el del palmeo, que fue sustituido por un $6 \%$ sobre los géneros nacionales y un $7 \%$ sobre los extranjeros, quedando igual que antes los que no estaban sujetos a palmeo y los que llegaban a la Península desde las Antillas; la obligación de dar parte a los administradores de las aduanas de la carga de las embarcaciones y del puerto al que se dirigían, para cobrar los reales derechos correspondientes; quedaban abiertos al tráfico con las Antillas los puertos de Cádiz, Sevilla, Alicante, Cartagena, Málaga, Gijón, Barcelona, Santander y La Coruña; la carga de los navíos que zarpasen con rumbo a las islas del Caribe, debían tener como destino los lugares que se especificaban en los registros, sin poder comerciar entre una y otra isla; cualquier vecino de las colonias españolas de Barlovento era autorizado a extraer frutos a la Península, pagando a su salida un $6 \%$ de alcabala, y llevarse de ella los que le paraciera pagando los mismos derechos que los españoles dedicados a este comercio; del mismo modo, los isleños podían transportar de una isla a otra sus propios frutos, aunque nunca los procedentes

22 R. C. de ocho de novienıbre de 1765, declaratoria del libre comercio con las Antillas. A.G.I. Indiferente General 539. Vid .al respecto Rodríguez Casado Vicente: op. cit. 
de España, pagando también el $6 \%$ de alcabala, en esta ocasión en el puerto de destino. ${ }^{23}$

Este proyecto de libre comercio significó, como ya hemos dicho, dos innovaciones fundamentales: la considerable rebaja de los aranceles pagados por las mercancías que salían de la Metrópoli, y la abolición del monopolio gaditano.

Al mismo tiempo, sirvió de ensayo para lo que luego sería el Reglamento del Libre Comercio de I778, extendido ya a gran parte de las colonias americanas.

Estas primitivas libertades fueron ampliándose paulatinamente en los años posteriores. Así, en I772, las Canarias, ante las continuas peticiones de sus comerciantes, se vieron incluidas en el primitivo reglamento, ${ }^{24}$ y en I774, una real resolución prevenía que, sin embargo de lo ordenado en el capítulo $\mathrm{V}$ de la Real Instrucción del Libre Comercio con las islas de Barlovento de 1765 , no se obligase a los navíos que salieran de la Península con destino a aquellos puertos y para los de Yucatán y Campeche, a desembarcar los géneros en el mismo puerto hacia el que salieron, sino en el que más les conviniera, aunque desde luego siempre dentro de los mencionados lugares.

Además, se declaraba la libertad de derechos a su entrada en la Península, para las maderas, pimienta deTabasco, pescado salado, carey, bija y café, estableciéndose para los cueros al pelo un gravamen de seis maravedíes por libra, y continuando la libertad de impuestos que primitivamente se concedió al azúcar cubano, y que más tarde se amplió a la de otras colonias. ${ }^{25}$

Las facilidades que de este modo se dieron al comercio se dejaron sentir pronto, como se puede observar en la nota que mostramos a continuación, de los derechos de entrada pagados a las Reales Cajas de Santo Domingo por los navíos llegados a su puerto desde 1765 a 1775 :

\footnotetext{
23. Instrucciones que han de seguirse para la realización del libre comercio con las Antillas, dadas el 16 de octubre de 1765. A.G.I., Arribadas, 103.

24 Morales Padrón, Francisco: Op. cit., pág. 97.

25 Real Cédula- de 20 de julio de, 1774, ampliándose el libre comercio. A.G.I. Indiferente General, 2.411.
} 
PRIMER QUINQUENIO

Años Reales Maravedies

I $766 \quad$ I I $8.423 \quad 26$

I767 99.028

I $768 \quad 66.924$

I $769 \quad$ I00.778

I $770 \quad \mathrm{I} 28.43^{2}$

Total. $\overline{5 \mathrm{I} 3.588}$

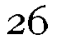

32

27

$2 \mathrm{I}$

I9
SEGUNDO QUINQUENIO

Años Reales Maravedies

$\begin{array}{lll}177 \mathrm{I} & 100.865 & 2\end{array}$

$1772 \quad 71.824$

4

I773 I $36.456 \quad$ I I

I774 I6I.196 I7

I 775 I $45.399 \quad 20$

Por él vemos que los aranceles devengados desde I77 I a I 775 , en que el comercio libre se hallaba ya en plena vigencia en las islas de Barlovento, superan en IO2.I 5 I reales 3 I maravedíes a los de los primeros cinco años, en que la instrucción comenzó a imponerse. Este incremento es muy significativo, sobre todo si tenemos en cuenta que en el primero de los dos quinquenios citados, el impuesto cobrado "fue, la mayor parte, al respecto del 2 I al $26 \%$ deducido de las embarcaciones que conducían víveres de las colonias extranjeras para el abasto de la plaza, y que en el segundo, solamente han pagado el de $6 \%$ las que venían de España bajo el reglamento de franco comercio". ${ }^{27}$

Así pues, queda patente que a consecuencia de ello el tráfico español con Santo Domingo se intensificó considerablemente en estos años, al amparo de las nuevas libertades vigentes.

Sin embargo, como ya hemos dicho anteriormente, el decreto de 1765 "no es otra cosa respecto del reglamento de I778, que una simple y prudente iniciación a manera de ensayo...", ${ }^{28}$ que a juicio de las autoridades tuvo resultados positivos, lo que trajo consigo la promulgación de! denominado Reglamento del Libre Comercio el i2 de octubre de

\footnotetext{
26 Santo Domingo, 20 de junio de 1776. Estado de los derechos de puerto que han ingresado en las Cajas Reales desde 1766 a 1775. A.G.I., Santo Domingo, 1.047. 27 Ibíđem.

28 Muñoz Pérez, José: Op. cit., pág. 4.
} 
I778, comunicado al gobernador dominicano un mes más tarde, y a "cuya práctica debe darse principio en España desde el primer día del año próximo futuro, y en Yndias desde que llegue allá, y bayan arrivando a los puertos habilitados los registros que se despachen según sus reglas". ${ }^{29}$ Por este nuevo reglamento, se extendió el libre comercio a todas las colonias españolas de América con excepción de Venezuela y Nueva España, que no fueron incorporadas a este sistema hasta I789. Se habilitaron para este tráfico 24 puertos en Indias, que fueron clasificados en mayores y menores. En Santo Domingo, el reflejo de esta disposición fue la apertura de un nuevo puerto al comercio peninsular, el de Montecristi, que junto con el de Santo Domingo quedó englobado entre los llamados puertos menores.

Se rebajaron considerablemente los aranceles sobre las exportaciones españolas, tanto para los productos del país como para los extranjeros. Estos derechos variaban según las mercancías fueran transportadas a los puertos mayores o menores. En los primeros, se cobraba un tres y un siete por ciento sobre los géneros españoles y extranjeros respectivamente. En los segundos, entre los que como ya hemos dicho se encontraban catalogados los de Santo Domingo y Montecristi, un I'5 y un $4 \%$ según se tratase de productos nacionales o extranjeros. Además, se declararon libres de toda contribución a su salida de España y de almojarifazgo a su entrada en los puertos americanos, por el tiempo de diez años, las manufacturas de lino, cáñamo y algodón procedentes de las fábricas españolas, y otros 45 productos del mismo origen.

También fueron reformados los impuestos sobre los productos coloniales, anulándose los que hasta entonces pagaban a su salida de los puertos de América, y reduciendo los de entrada a la Península a un dos por ciento sobre el oro, un cinco por ciento sobre la plata, y un tres por ciento

\footnotetext{
29 Comunicación de la Corte al gobernador de Santo Domingo con fecha de 18 de noviembre de 1778 , dándole cuenta de la promulgación del reglamento del Comercio Libre đe 1778. A.G.I., Indiferente General, 2.409.
} 
sobre los demás géneros que no habían sido declarados totalmente libres como las maderas, el café, etc. ${ }^{30}$

A consecuencia del establecimiento del mencionado reglamento, el entonces gobernador de Santo Domingo, don Isidro de Peralta y Rojas, inició las labores necesarias para la habilitación del puerto de Montecristi, encargándolas a don José Alvarez, y dotanto los puestos de un oficial, un "marchamarchista", un guarda mayor y un cabo con cuatro guardas, siendo del parecer de que la nueva oficina fuese independiente de la capital, enviando directamente sus cuentas al tribunal de La Habana, dada su lejanía de Santo Domingo, providencia que fue aprobada aunque de forma interina por la Corte. ${ }^{31}$

Sin embargo, la apertura de este nuevo puerto dominicano al tráfico con la Península no representó un incremento del comercio, a juzgar por la escasez de embarcaciones españolas que llegaron a él en los años posteriores.

El Reglamento significó el inicio de una nueva etapa en las relaciones comerciales entre la Metrópoli y sus colonias, en un afán de eliminar todas las trabas posibles en aras de su intensificación. Pero las libertades concedidas al comercio hispanoamericano no terminaron aquí. Independientemente de él se hacen ampliaciones a algunos particulares, como hemos señalado en el apartado dedicado a la agricultura, de modo que algunos pudieron sacar de la Península una serie de utensilios, tanto españoles como extranjeros, para su conducción a Santo Domingo totalmente libres de derechos. Este fue el caso ya mencionado de don Juan Bautista de Oyarzábal, que solicitó del Rey la concesión de esta gracia para fomentar un ingenio azucarero. ${ }^{32}$

Pocos meses después, en agosto del mismo año, una real

\footnotetext{
30 Muñoz Pérez José: Op. cit., págs. 645-649.

31 Carta de don Isidro de Peralta de 26 de junio de 1779 , dando cuenta a la Corte de la habilitación al libre comercio del puerto de Montecristi. A.G.I., Santo Domingo, 1.059 .

32 Carta de don Isidro de Peralta de 21 de abril de 1784, acusando el recibo de la $R$. O. de 23 de diciembre de 1783 en la que se le comunicaba haber doncedido e1 Rey una serie de gracias a don Juan Bautista de Oyarzábal. A.G.I., Santo Domingo, 946.
} 
orden vino a favorecer de nuevo el tráfico con los puertos menores de América. En ella se hacía constar que, al no haberse mostrado suficiente la rebaja concedida de la mitad de los gravámenes de los géneros destinados a aquéllos. "he venido en franquear enteramente de todos los derechos y arbitrios, los caldos, frutos y géneros españoles, y rebajar la contribución del quatro a sólo el dos por ciento en los efectos extranjeros que se llevaren de los puertos habilitados de España y sus islas de Mallorca, Menorca y Canarias, a los de San Juan de Puerto Rico, Santo Domingo. Montecristi...", y demás puertos menores. ${ }^{33}$

Dos años más tarde, en I786, y como consecuencia de la Junta de Hacienda que se formó en Santo Domingo para estudiar los medios necesarios para su fomento, el comercio dominicano se vio favorecido de nuevo por la política de los monarcas españoles.

Tras examinar el Consejo de Indias y el Rey, las medidas que la Junta había propuesto para salvar la economía del país, se envió al gobernador de Santo Domingo la correspondiente real cédula sobre este asunto. En ella se estableció por lo que se refiere al comercio de aquella isla, que debía facilitarse, en todo lo posible, la entrada en ella de utensilios y herramientas destinados a la agricultura e industria, "de cualquiera parte que se conduzcan, sin exclusión de colonias extranjeras, libres de todos los derechos". Al mismo tiempo, se permitía la exportación del aguardiente de caña a cualquier colonia americana, tanto española como extranjera, totalmente exenta de contribución. ${ }^{34}$

Y posteriormente, en 1789, un nuevo decreto ampliará las gracias concedidas a los puertos menores, entre ellos a Santo Domingo y Montecristi, declarando libre de todos los aranceles, incluso del de alcabala, su comercio con los puertos mayores de América y con los de la Península, aun-

33 R. C. de cinco de agosto de 1784 ampliando la libertad, de comercio. A.G.I., Indiferente General, 660 y 2.423 .

34 R. C. de 12 de abril de 1786 concediend'o varias gracias a los vecino! de la isla para e! fomento de su economía. A.G.I., Santo Domingo, 969 y 1.012. 
que el tráfico con las colonias extranjeras seguiría sujeto a los mismos que hasta entonces. ${ }^{35}$

Todas estas medidas tenían un fin muy concreto: el fomento de los productos coloniales, y con ello la intensificación del intercambio comercial hispano-americano, que los monarcas consideraban como el mejor medio de enriquecer al país y robustecer su propia autoridad.

No se estableció desde luego un libre cambio total tal y como hoy lo entendemos. El proteccionismo continuó claramente. Pero las nuevas tendencias económicas, hicieron que se evolucionase de un sistema en que la cantidad y variedad de aranceles impuestos al comercio representaban sólo dificultades para éste, a otro que, aunque desde luego supervisado por el poder central, trataba de darle todas las facilidades factibles con objeto de intensificarlo en lo posible.

Las ideas reformistas del siglo XVIII encarnadas en España por los Borbones, sobre todo por los de la segunda mitad de este siglo, y en especial por Carlos III, se dejan sentir en todos los aspectos y, como es natural, en el tráfico comercial, al que irán dirigidos gran parte de sus esfuerzos.

Sin embargo, los resultados por lo que se refiere a Santo Domingo no son muy claros. A pesar de todos los intentos que se hicieron para el incremento de sus productos naturales, éstos eran muy escasos, y poca cuenta tenía a los comerciantes llevar sus mercancías a un lugar del que poco podían conseguir a cambio, y en el que la escasez de moneda fue siempre un problema fundamental.

\section{El COMERCio CON LA Metrópoli}

El tráfico mercantil entre Santo Domingo y la Península en la segunda mitad del siglo XVIII, está marcado por dos hitos básicos: la creación de la Real Compañía de Comercio de Barcelona en $\mathbf{1 7 5 5}$, y los comienzos del libre comercio en 1765 .

35 R. O. de 28 de febrero de 1789 , ampliando el libre comercio. A.G.I, Indiferente General, 665 y 2.436 . 
Con anterioridad a la creación de la Compañía el comercio entre ambas era muy escaso, intensificándose a partir de su establecimiento, aunque desde luego no en el grado en que la isla lo necesitaba y que se esperaba.

A este respecto, y como ya hemos señalado, Moreau de Saint Mery nos dice que " la colonia española no tiene casi ninguna relación con su Metrópoli, que la tiene sometida al privilegio exclusivo de la Compañía de Cataluña. Esta compañía, como todas las otras, no provee sino de una manera insuficiente las cosas necesarias..." 36

Ya hemos dicho que la mencionada compañía no tuvo el monopolio de este tráfico, aunque los privilegios que se le concedieron limitaban el intercambio dominicano con España a sus embarcaciones. Así, en el mismo sentido que Moreau de Saint Mery se manifestaba en I759 el entonces gobernador, don Manuel de Azlor, declarando que los resultados obtenidos por el establecimiento de la Compañía no correspondian al objeto con que se hizo. Eran escasos los víveres que había conducido a la isla desde el momento de su creación, al tiempo que, los que llevaba, alcanzaban unos precios que sobrepasaban en "más de una tercia parte en cada especie, de los que aquí se expendían quando en' las graves urgencias de necesidad se importaban de las colonias, dejando su introducción a fabor de S. M. el 2I por ziento de derechos". ${ }^{37}$

A consecuencia de ello, la Corte ordenó a la Compañía aumentar sus envíos al tiempo que previno al presidente de la Casa de la Contratación, que concediese permiso a cualquiera de los navíos que saliera de allí con destino a Cuba para recoger azúcar, y que quisiera conducir harina y otros comestibles a Santo Domingo, así como a Puerto Rico y Margarita, que al parecer se encontraban en igual situación, aunque los comerciantes se mostraron reacios en este asunto. ${ }^{38}$

\footnotetext{
36 Moreau de Saint-Mery, M. L.: Op. cit., pág. 96.

37 Ibídem, nota 14.

38 Carta de la Corte de siete de marzo de 1760 dirigida al presidente de la Casa de la Contratación. A.G.I., Indiferente General, 2.410 .
} 
A pesar de todas las quejas existentes respecto a la actuación de la Compañia, hay que señalar que su fundación significó claramente un incremento en el tráfico comercial entre Santo Domingo y la Península. Así, desde i750 a I756 ambos inclusive, sólo tenemos noticias de dos embarcaciones que sacaran mercancías de Santo Domingo con destino a España, ${ }^{39}$ es decir, que no se alcanzó siquiera la cifra de una al año.

Por el contrario, desde 1757 , en que se estableció en Santo Domingo la Compañía, hasta I765, en que se promulgó el Decreto de Libre Comercio para las Antillas, to hicieron I9; de ellas i I eran de la Compañía de Barcelona, con una media de más de dos navíos anuales. ${ }^{40}$

Por lo que se refiere a las embarcaciones que transportaron géneros a la isla procedentes de España, desde I750 a I 756 fueron siete, es decir una al año, ${ }^{41}$ mientras que desde 1757 a 1765 lo hicieron 21 , más de dos anuales. ${ }^{42}$

Pero mayor importancia para el comercio de la isla con la Metrópoli, tendrá el Decreto de Libre Comercio de I765. Las libertades dadas a todo aquel que llevara mercancías desde España a las Antillas, van a hacer que se desarrolle un tráfico superior al que había tenido lugar hasta entonces, y en el que las embarcaciones llamadas del Libre Comercio o de particulares, desbancarán en cuanto a su número a las de la Compañía de Barcelona, al quedar ésta en condiciones de igualdad respecto a los demás comerciantes en su tráfico con las islas del Caribe.

\footnotetext{
39 Registro de las embarcaciones llegadas a Cádiz desde Santo Domingo desde 1750 a 1778. A.G.I., Contratación, 2.459 y 2.902-A.

40 Cuentas de las Cajas Reales de Santo Domingo desde 1754 a 1765 en A.G.I. Contaduría, 1.069-A y B; Santo Domingo, 1.048 y 1.049 , y registro de las embarcaciones llegadas a España desde Santo Domingo desde 1750 a 1778, en A.G.I., Contratación, 2.459 y 2.902-A.

41 Cuentas de las Cajas Reales de Santo Domingo desde 1754 a 1766 . A.G.I., Contaduría, 1.069-A. Registro de las embarcaciones que salieron de España a Santo Domingo desde 1750 a 1778. A.G.1., Contratación, 1.452 y 2.902-A.

42 Cuentas de las Cajas Reales de Santo Domingo desde 1757 a 1765. A.G.I., Contaduría, 1.069-A y B y Santo Domingo, 1.048 y 1.049. Registro de las embarcaciones Ilegadas a Santo Domingo desde España entre 1750 y 1778. A.G.I., Contratación, 1.452 y 2.902-A.
} 
Al amparo de la nueva reglamentación, desde i766 a I778, en que se extiende la libertad del comercio a la mayor parte de las colonias americanas, son 26 los navíos que transportan mercancías desde Santo Domingo a la Península, con una media de dos al año. ${ }^{43}$ En esta ocasión, y por primera vez desde la creación de la Compañía de Barcelona, los buques particulares superan en número a los de aquélla, que se reducen a nueve en los I 3 años citados. Por lo que respecta a las embarcaciones que descargaron mercancías en Santo Domingo procedentes de la Metrópoli, alcanzaron un total de 6I, de las que sólo i 2 eran propiedad de la Compañía, con uria media anual de más de 4 '5 barcos. ${ }^{44}$

Como se puede apreciar claramente, el reglamento de I765 significó un aire renovador que incrementará el comercio dominicano con España, de modo que llegará a alcanzar grados desconocidos durante el resto del siglo XVIII. El nuevo reglamento de $\mathrm{I} 778$, a pesar de conceder aún mayores libertades al comercio dominicano-español abriendo otro puerto a este tráfico, el de Montecristi, y reduciendo considerablemente los derechos, no hizo por ello que aumentara el número de embarcaciones que transportaban mercancías entre ambos lugares.

Hasta entonces las libertades se habían limitado al área del Caribe, y los comerciantes le concedieron una atención muy superior a la que le habían prestado hasta entonces. Pero al extenderse el libre comercio a casi todas las posesiones americanas, las Antillas dejarán de interesarles, con excepción de la isla de Cuba, donde obtenían azúcar y tabaco suficientes para lograr importantes beneficios.

La escasez de frutos propios del país que los dominicanos pudieran dedicar a la exportación, y la falta de moneda, mal crónico en la Española, fueron dos factores determinan-

43 Cuentas de las Cajas Reales de Santo Domingo desde 1766 a 1775. A.G.I., Santo Domingo, $1.049,1.050$ y 1.051. Registro de las embarcaciones llegadas desde Santo Domingo a España desde 1750 a 1788. A.G.I., Cantratación, 2.459 y 2.902-A e Indiferente General, 2.410, 2.411, 2.413, 2.414, 2.416.

44 Cuentas de las Cajas Reales de Santo Domingo y registro de los navíos salidos de España para Santo Domingo. Ibídem y A.G.I., Contratación, 1.452. 
tes de que los comerciantes peninsulares prefirieran los nuevos puertos americanos abiertos al libre tráfico.

De este modo, desde I779 a I795, en que se produjo la cesión oficial de toda la isla a los franceses, sólo tenemos noticia de I7 navíos que descargaran productos de la isla de Santo Domingo en los puertos españoles, es decir uno al año. ${ }^{45}$

Por lo que se refiere a los que transportaron géneros desde España a la Española, suman un total de 39, con una media de algo más de dos al año. ${ }^{46}$

Así pues, a partir de la promulgación del Reglamento del Libre Comercio de 1778 , el número de navíos que llevaron a cabo el tráfico mercantil entre la Península y su colonia de Santo Domingo disminuyó considerablemente, debido a la ampliación de las libertades a otros puertos americanos que atraían con más fuerza a los comerciantes. Pero no ocurrió lo mismo con el valor de los géneros que esos buques transportaban. Son menos los barcos que se dedican a ello, pero el volumen del comercio no sólo se mantiene, sino que incluso experimenta un ligero crecimiento.

Pero al parecer este incremento del tráfico mercantil no bastaba para cubrir las necesidades de la isla, siendo constantes las quejas presentadas por los gobernadores a este respecto. ${ }^{47}$

La colonia española dependía de su Metrópoli para el abastecimiento de determinados productos, en especial víveres y ropas, que el comercio nacional no suministraba en cantidades suficientes. Las autoridades isleñas achacaban este problema a tres causas fundamentales: la escasez de plata

45 Registro de las embarcaciones Ilegadas a España procedentes de Santo Domingo desưe 1779 a 1795. A.G.I., Indiferente General, 2.180, 2.210, 2.212, 2.215, 2.436, $2.442,2.444,2.446,2.449,2.451,2.453,2.456$ y A. G. S., Sección 17, Dirección General de Rentas. 2. ${ }^{\text {a }}$ Remesa. Leg. 578.

46 Registro de las embarcaciones que salieron de España con destino a Santo Domingo desde $1779^{\circ}$ a 1795. A.G.I., Indiferente General, 2.162, 2.163, 2.177, 2.178, $2.179,2.182,2.186,2.187,2.188,2.192,2.194,2.209-A, 2.210,2.415,2.416,2.417-$ A y 2.436 .

47 Carta de don Isidro de Peralta de 14 de julio de 1783, sobre la falta de abastecimiento a la isla de Santo Domingo por parte del comercio español. A.G.I., Santo Domingo, 947. 
que siempre sufrió la isla, "el considerable premio que ha tenido y aún conserva aquella moneda para reducirla a efectiva, el qual jamás ha bajado del $50 \%$ ", y la "absoluta escasez de cacao, azúcar, añil, algodón y otros frutos comerciales, de que carece esta ysla, con que poder darlos en permuta o pago". ${ }^{48}$

En este sentido, el gobernador don Isidro de Peralta y Rojas manifestaba a la Corte, que los daños causados por las tormentas y lluvias en las labranzas, y la inexistencia de dinero en efectivo, suplida por los "billetes de papel" que no eran aceptados por los mercaderes, "hacen que el comercio nacional no se acerque a la isla". "49

Resultado de las quejas de los dominicanos respecto a las pocas naves españolas que llegaban a sus costas, fueron una serie de reales órdenes de 1784 , dirigidas al comandante del resguardo de Cádiz, juez de arribadas de La Coruña y juez de arribadas de Barcelona, previniéndoles que estimulasen a los comerciantes de sus respectivas jurisdicciones, a enviar a aquella isla algunos registros para proveerlos. La respuesta del comandante de Cádiz fue que haría lo que se le mandaba. El juez de arribadas de la Coruña, por su parte, contestó que lo había comunicado a los mercaderes, que le manifestaron no tener barcos para ello. Sólo el juez de arribadas de Barcelona ofreció resultarlos positivos, respondiendo que, en aquellos momentos, se encontraban cargando en el puerto algunos buques destinados a aquella región, y que incitaría a sus dueños a que se acercaran a la citada isla antes de arribar a su destino. ${ }^{50}$

Sin embargo, ese mismo año llegaron a Santo Domingo tres embarcaciones peninsulares, una de Barcelona y Málaga y dos de Cádiz, tras cuatro años ( I780-I783), en los que sólo

\footnotetext{
48 Informe de don Joaquín García de 25 de agosto de 1789 sobre el estado del comercio dominicano. A.G.I. Indiferente General, 2.436.

49 Carta de don Isidro de Peralta de 23 de junio de 1784 sobre la escasez de víveres sufrida en la Española. A.G.I., Santo Domingo, 947.

50 Cartas del comandante del resguardo de Cádiz de 20 de enero de 1784, del juez de arribadas de la Coruña đe 24 del mismo mes y año y del juea de arribad'as de Barcelona, acusando el recibo de la R. O. de 12 de enero de 1784. A.G.I., Santo Domingo, 947.
} 
un navío nacional había desembarcado mercancías en su puerto. ${ }^{51}$

No quedó por ello resuelto el problema, y cuatro años más tarde, el gobernador interino don Pedro Catani daba cuenta a la Corte, de que "esta ysla sufre un comercio pasivo, y que sus caudales y los que vienen para el cituado pasan a los extranjeros, porque no viniendo de España víveres ni efectos necesarios al sustento de estos havitantes, es preciso que los soliciten de aquéllos". ${ }^{\mathbf{2}}$

Poco después se ordenaba al nuevo gobernador, don Joaquín García, que informara sobre el estado del comercio de la Española. García respondió que su estado era "miserable y de total decadencia". Los barcos catalanes eran, a su juicio, los únicos que de vez en cuando suministraban pequeños cargamentos de zapatos, pañuelos y algo de aceite, vino, pasas, almendras, etc., y "rara o ninguna vez arinas ni velas de sebo, grasas ni otros tan precisos como indispensables a la subsistencia", careciendo la isla incluso de tejidos para la confección de ropa. $\mathrm{Y}$ de nuevo hace hincapié el gobernador, en las mismas causas que sus antecesores ya habían señalado como motivo de esta escasez de naves nacionales, la falta de frutos comerciales para dar a cambio y la inexistencia de plata, todo lo cual hacía que los pocos efectos llevados por los navíos españoles, se vendieran con un 80 ó Ioo\% de beneficio sobre su primitivo valor en la Península. ${ }^{53}$

El Consejo, a la vista de este informe, ordenó al intendente de Barcelona que se reuniese la Junta Particular de Comercio, con el fin de tratar los medios de mejorar el tráfico catalán con Santo Domingo. Y la mencionada Junta, confirmando lo que ya habían señalado las autoridades isleñas, consideró como el remedio más eficaz la recogida del

51 Registro de las embarcaciones llegadas a España desde Santo Domingo entre 1780 y 1784. A.G.I., Indiferente General, 2.179 y 2.209-A y Arribadas, 302.

52 Informe de don Pedro Catani, oidor decano de la Audiencia de Santo Domingo sobre el estado en que se encontraba la isla, con fecha de 15 l de noviembre de 1788. A.G.I., Santo Domingo, 1.012 .

53 Ibídem, nota 48. 
papel moneda que circulaba en la Española, para poder cobrar así sus mercancías en dinero en efectivo. ${ }^{54}$

Respecto a los productos que eran objeto de este comercio, España enviaba a Santo Domingo principalmente víveres (aceitunas, vino, aceite, aguardiente, vinagre, almendras, avellanas, manteca, uvas pasas, legumbres, etc.), sombreros, zapatos, tejidos, armas, hierro, jabón, papel, velas, hilo y algunos otros, por lo que se refiere a los productos españoles, y loza, cristal, algunos tejidos, medias, harina, queso y otros, extranjeros.

Como ejemplo de esto, hacemos constancia del registro de dos navíos que salieron de la Península con destino a la Española, y que pueden darnos una visión general de las mercancías peninsulares que llegaban a aquella isla.

A. Registro del bergantín "La Purísima Concepción", de 220 toneladas, que sale de Barcelona con destino a Montecristi el 12 de abril de I779: ${ }^{55}$

\section{MERCANCÍAS}

VALOR EN REALES

\section{Géneros del reino libres de contribución}

1.000 quintales de harina a 58 reales. 288 sombreros entrefinos a 30 reales.

58.000

8.640

240 resmas de papel blanco a 16 reales.

53 quintales de fideos.

3.840

4.000

10.200

4.827 varas de lienzo de cáñamo blanco.

3.300 go arrobas de velas de sebo.

Total : $\quad \frac{3 \cdot 300}{87.980}$

54 Resolución del Consejo de Indias de 13 de febrero de 1791, ordenando la recolección del papel moneda que circulaba en Santo Domingo, A.G.I., Indiferente General, 2.437 .

55 Registro del bergantín la Purísima Concepción que salió de Barcelona con destino a Montecristi el 12 de abril de 1779. A.G.I., Indiferente General, 2.417-A. 
Géneros del reino con contribución

3.648 arrobas de vino tinto.

7 I quintales de almendras en grano.

33 quintales de avellanas.

I.064 arrobas de aguardiente.

584 arrobas de aceite común.

25 quintales de anís.

960 varas de indianas.

I I. IOO varas de platillas pintadas.
29. 184

I0.650

I. 320

63.840

I 5.184

2.000

4.800

$55 \cdot 500$

Total: $\quad \mathbf{1} 82.478$

Géneros extranjeros

25 quintales de queso de Holanda.

5.000

i 78 quintales de jabón de loza.

21.360

22 quintales de polvos para pelucas

I. 760

994 piezas de bretañas surtidas.

45.284

I. 656 varas de crea ancha.

8.280

260 piezas de cambrayón ordinario.

I 4.560

I 82 varas de platillas blancas y crudas. $\quad 27.400$

270 libras de canela.

I 4.850

I I.083 varas de lienzos de Bramante crudos. $44.33^{2}$

5.087 varas de crehuelas.

I0. 174

I.783 varas de teliz de Flandes para colchones. $7.13^{2}$

$$
\text { Total: } \quad 200.132
$$

Total de los géneros españoles

Total de los géneros extranjeros.

$270.45^{8}$ reales

200.132 reales

Valor total de: $\quad 470.590$ reales 
B. Registro de la fragata "San Diego", que sale de Barcelona en junio de 1785 con destino al puerto de Santo Domingo: ${ }^{56}$

\section{MERCANCÍAS}

VALOR EN REALES

Frutos y géneros españoles

I.536 arrobas de vino tinto.

I2.288

226 '5 arrobas de aguardiente y resolís.

I 3.590

356 quintales de harina.

21.560

269'5 quintales de jabón de loza.

21.560

46 cajas de pisa ordinaria.

2.024

320 arrobas de aceite común.

8.320

4 piezas de paño y 832 cordones de lana.

I 2.930

24 sillas de montar.

I. 600

3 cajas de especiería.

2.400

2 cajas de peltre obrado.

820

I cajón de armas de fuego.

I. IOO

IO2 piezas de papel pintado.

I. 428

840 sobreros surtidos.

6.324

I I'5 quintales de velas de sebo.

2.700

4 quintales de hierro colado.

400

269 pares de zapatos.

I.720

3 IO resmas de papel blanco.

6.200

840 quintales de fideos y otras pastas.

$7 \cdot 345$

Ioo gruesas de cuerdas de guitarra.

200 cuchillos de monte.

I. 200

3.I25 varas de lienzos pintados.

I9. I44

432 navajas de barbero y 800 anzuelos.

I.I 64

I4 libras de coral obrado.

I. 260

I 37 ' 5 libras de seda obrada.

7 libras de azafrán en seco.

29.310

560

I 50 docenas de flores artificiales.

3.600

6 cajas de perfumería.

$3 \cdot 300$

Total : I84.347

56 Registro de la fragata San Diego que salió de Barcelona para Santo Domingo en junio de 1785, A.G.I., Indiferente General, 2.177. 
Géneros extranjeros

600 hojas de talco.

I. 200

37 '5 docenas de hojas de lata. $45^{\circ}$

260 varas de lienzos blancos.

I. 300

I4 libras de pomada.

I 40

2 baúles de quincallería.

4.150

6 cajas de especiería.

8.000

600 vidrios para faroles.

660

Total: $\quad$ I 5.900

Total de los géneros españoles.

I 84.347 reales

Total de los géneros extranjeros.

I 5.900 reales

Valor total de las mercancías.

200.247 reales

Por lo que se refiere a las exportaciones insulares a España, consistieron fundamentalmente en cueros, cacao, azúcar, tabaco, café, corambre y maderas, como se puede apreciar por los registros de dos embarcaciones que tomamos cono ejemplo de este comercio:

A. Razón de la carga que conduce a Cádiz, Málaga y Barcelona la saetía "Nuestra Señora del Rosario", que salió de Santo Domingo el 4 de junio de 1787 , y entró en Cádiz el 3 I de julio del mismo año: ${ }^{57}$

57 Registro de la saetía Nuestra Señora del Rosario, que salio de Santo Domingo para Cádiz en junio de 1787. A.G.I., Inđiferente General, 2.442. 
De cuenta de S. M.

25.050 libras de tabaco en rama y andullo.

1.002 .000

De cuenta de Particulares

4.000 pesos en plata de caja de soldadas.

80.000

I6.724 pesos en plata de registro.

334.480

5.066 pesos en oro de registro.

80 pesos en alhajas de plata.

IOI. 320

I6o pesos en alhajas de oro.

I. 600

Varias alhajas cuyo valor se ignora.

323'5 arrobas de azúcar quebrada.

3 arrobas de azúcar blanca.

3.200

4 fanegas de cacao de Caracas.

ıoo libras de café.

I $5 \cdot 528$

180

I. 928

500

597 codos cúbicos de caoba.

I 12.236

I 5 libras de tabaco en polvo y cigarros. 600

52 tinajitas de barro. $\quad$ I.560

26 libras de dulces.

I 30

I cajoncito con flores artificiales cuyo valor se ignora.

I baúl con géneros devueltos por invendibles.

Valor total de las mercancias:

I. 655.262

B. Razón de la carga que conduce la saetía "Nuestra Señora del Carmen", que salió de Santo Domingo el 7 de julio de I788, y entró en Cádiz el I de septiembre del mismo año. ${ }^{58}$

58 Registro de la saetía Nuestra Señora del Carmen, que salio de Santo Domingo con destino a Cádiz en julio de 1788. A.G.I., Indiferente General, 2.444. 
De cuenta de S. M.

I.500 tercios de tabaco con 6.000 arrobas. $\quad 6.000 .000$ Io cañones de bronce.

De cuenta de particulares

3.000 pesos en plata de caja de soldadas.

60.000

22.767 pesos, 5 reales en plata de registro.

$455 \cdot 35^{2}$

4.397 pesos en oro de registro.

87.940

9 marcos de plata labrada

Varias alhajas sin expresión de su valor.

I.440

65 codos cúbicos de caoba.

12.220

3 arrobas de azúcar blanca.

180

75 libras de café.

375

I fanega de cacao.

510

37 libras de dulces.

I 85

IO8 libras de tabaco.

I cajón con géneros devueltos por invendibles.

$$
\text { Valor total de las mercancías: } \quad 6.622 .522
$$

Aunque los cuatro registros que hemos tomado como ejemplo, puedan hacernos pensar que las exportaciones dominicanas a la Península eran muy superiores a sus importaciones, es totalmente falso.

Desde I750 a I785, las mercancías españolas llegadas a Santo Domingo superaban con creces a las que salieron de allí con destino a España. Y lo que ocurre a partir de este año en que los papeles cambian, es el envío de grandes remesas de tabaco solicitadas por las Reales Fábricas de Sevilla, y que como se puede observar tanto en el registro de la saetía "Nuestra Señora del Rosario", como en el de la de "Nuestra Señora del Carmen", superan con creces el valor del resto de las exportaciones. 
Aunque no poseemos datos completos que nos permitan elaborar un cuadro con el volumen general de las importaciones y exportaciones de Santo Domingo respecto a España, vamos a exponer a continuación los años en que sí conocemos este tráfico casi por completo, como ejemplo de lo expuesto:

Valor de las exportaciones Valor de las importaciones

$\begin{array}{lrcrc}\text { Años } & \text { Reales } & \text { Maravedies } & \text { Reales } & \text { Maravedies } \\ & & & & \\ \text { I773 } & 34.980 & & \text { I.251.I30 } & \text { I7 } \\ \text { I774 } & 86.078 & & 903.036 & \text { I7 } \\ \text { I775 } & \text { I.037.482 } & \text { I7 } & 749.559 & 3 \\ \text { I779 } & \text { I41.48I } & 31 & \text { I.300.63I } & \text { I I } \\ \text { I780 } & & & 391.4 \text { I } 8 & \text { I7 } \\ \text { I785 } & 797.189 & 28 & \text { I.402.072 } & \text { I7 } \\ \text { I786 } & 3.605 .135 & & \text { I.907.088 } & \\ \text { I787 } & \text { I.655.262 } & & 490.005 & \text { I7 } \\ \text { I789 } & \text { I0.149.6I2 } & 22 & \text { I70.195 } & 25 \\ \text { I79I } & \text { I0.627.892 } & & 920.167 & \\ \text { I793 } & 839.475 & & 254.948 & 3 \text { I }\end{array}$

Así pues, excepto en los casos señalados en que se remitieron grandes remesas de tabaco a la Península, la balanza comercial entre los dos países era, tal como se proponía el llamado Pacto Colonial imperante en esta época, desfavorable a los dominicanos, ya que con la salvedad de ese tabaco que no se exportó de forma continua en la etapa estudiada, las cantidades de sus frutos que podían vender en el exterior y concretamente en España, como el azúcar, el café y el cacao, eran mínimas.

59 Cuentas de las Cajas Reales de Santo Domingo entre 1773 y 1775 . A.G.I., Santo Domingo, 1.051. Registro de las embarcaciones que salieron de Santo Domingo con destino a la Península y viceversa desde 1773 a 1793. A.G.I., Indiferente General, $2.162,2.163,2.177,2178,2.179,2.180,2.183,2.187,2.188,2.192,2.210,2.212,2.411$, $2.415,2.416,2.417-A, 2.436,2.442,2.446,2.449$ y 2.453, y A.G.S., Sección 17. Dirección General de Rentas. 2. a Remesa. Leg. 572. 


\section{El Comercio con las colonias Españolas de América}

Aunque con un volumen inferior al tráfico españoldominicano, sobre todo por lo que se refiere a las exportaciones, por la causa ya señalada de los envíos de tabaco, el comercio de Santo Domingo con las demás colonias españolas de América se realiza de forma mucho más continua y uniforme, sin experimentar los fuertes altibajos de aquél.

Este tráfico se hace en general en pequeñas embarcaciones que limitan su campo de acción al mar Caribe, transportando mercancías de aquellos territorios a una y otra parte.

El gobernador don Joaquín García, en un informe que hizo a la Corte en 1789 sobre el estado en que se encontraba el comercio de la isla, señala que "las provincias de Caracas, Cumaná y Puerto Rico suministran a esta isla algún cacao, cordobanes, pescado salado, carne en tasajo, menestras, maíz, queso, manteca y otros frutos de sus terrenos. Desde que empezó en esta capital a correr la moneda de papel, se experimentó mucha escasez, de forma que eran con maior abundancia sus entradas quando corría la plata efectiva". Según García, las únicas relaciones de Santo Domingo con las otras posesiones de España en América, se reducen a las mantenidas con los tres lugares señalados. ${ }^{60}$

Sin embargo, esto no parece ser del todo cierto, ya que, desde I754 a I775, tenemos noticias de que el tráfico intercolonial fue constante, sobre todo si tenemos en cuenta que se trata de un intercambio entre varias provincias que, por encontrarse en un ámbito geográfico similar, no ofrecen mucha variación en cuanto a sus producciones.

Como en el caso del comercio con la Península, también en esta ocasión la Compañía de Barcelona se vio favorecida por las disposiciones reales, ya que según uno de los artículos de la cédula promulgada para su creación, "con las mismas embarcaciones destinadas a las islas u otras menores, podrá traficar los géneros que lleve desde la de Santo Domingo a

60 Ibídem, nota 48. 
Puerto Rico y desde ésta a aquélla sin pagar nuevos derechos". ${ }^{61}$ Pero este privilegio no tuvo efecto alguno en la Española, pues a pesar de él, los navíos de la Compañía actuaron siempre en ella transportando las mercancías entre la isla y la Metrópoli, pero no en el intercambio interprovincial.

Por el contrario, los barcos particulares se ven sometidos a fuertes impuestos: alcabala, armada, almojarifazgo, etc., hasta que, en 1765 , la instrucción otorgada para el libre comercio de los puertos españoles con las islas de Barlovento se ocupó de este asunto en su artículo i i, estableciendo "que los mismos isleños puedan llevar de sus islas a las otras los frutos que respectivamente produzca cada una, pagando el seis por ciento de alcavala a su salida, y otro seis por ciento a la entrada en la isla a donde se lleven". ${ }^{62}$

Este artículo hacía referencia exclusivamente a los productos propios de cada colonia, pero nunca podrían transportarse de una a otra los que se hubieran conducido a ellas desde la Península.

Sin embargo, las corrientes liberalizadoras de que ya hemos hablado se van a dejar sentir en este punto, y así, en 1776 , los dominicanos solicitaron que al llegar los comerciantes a aquel puerto para vender sus géneros, pudiesen reembarcar hacia otros lugares los que no lograran vender allí, "con la única precaución de que se marchamasen a la entrada con las reales armas, para evitar la confusión con los de ilícito comercio", y la Corte accedió a su petición, con lo que los productos, tanto españoles como extranjeros, que se transportaran a Santo Domingo desde España y no encontrasen allí mercado, podrían llevarse después a otras islas del Caribe. ${ }^{63}$

Posteriormente, por decreto de 28 de febrero de 1789 , se declaró libre de derechos el comercio de los puertos menores, entre los que como ya hemos dicho se encontraban los

\footnotetext{
61 Ibídem, nota 11.

62 Instrucciones que se han de observat para la realización del libre comercio, dadas el ocho de agosto de 1765. A.G.I., Arribadas, 103.

63 Informe del fiscal del Consejo de Indias sobre el asunto de nueve de marzo de 1776 y resolución de uno de abril del mismo año. A.G.I., Indiferente General, 2.411.
} 
de Santo Domingo y Montecristi, con todos los demás de la América española. ${ }^{64}$

Este decreto pudo suponer desde luego un considerable incremento del tráfico mercantil entre Santo Domingo y las colonias americanas, pero todo lo que afirmemos en este sentido no dejarán de ser meras suposiciones, ya que mientras que desde I754 a I775 poseemos una exacta relación de los navíos que entraron y salieron de Santo Domingo procedentes y con destino a las colonias españolas, a través de las cuentas de las Cajas Reales, a partir de ese año ya no aparecen las citadas cuentas entre la documentación examinada.

Por lo que respecta a las embarcaciones empleadas en este comercio, pertenecen en su mayor parte a particulares. Son pequeños buques de armadores americanos, que durante toda la segunda mitad del siglo XVIII lo acapararon, quizás por la falta de interés de los peninsulares dada su limitación.

El intercambio se realizaba fundamentalmente con Puerto Rico, Cuba, La Margarita, y con las costas de lo que luego sería Venezuela: Coro, Cumaná, La Guaira, Caracas, Maracaibo, etc., y en ocasiones con otros lugares como Campeche, Santa Marta, Cartagena de Indias o Veracruz.

Por lo que se refiere a los productos que fueron objeto de este tráfico, Santo Domingo importaba principalmente harina, mulas, manteca, sebo, madera, curtidos, queso, velas, sal y otros víveres de Puerto Rico, cueros y azúcar de Cuba, pescado, loza, sal, cacao y cazuelas de la Margarita, y cacao, cordobanes, queso, mulas, cueros, lana, carne, sebo, manteca, sal, malaqueta, pescado y otros comestibles de las costas venezolanas.

Por su parte, Santo Domingo enviaba tabaco, cacao (la mayor parte del cual lo importaba con anterioridad), cordobanes, azúcar, curtidos, ladrillos y madera a Puerto Rico; vino, aguardiente, carne y cacao a Cuba; cueros y tabaco a la Margarita; y brea, alquitrán, vino, aguardiente, maíz, arroz, biz-

64 Real Decreto de 28 de febrero de 1789 sobre libertad de derechos en los puertos menores. A.G.I., Indiferente General, 665 y 2.436 . 
cocho, azúcar, maderas, tabaco y cuero a la capitanía general de Caracas.

Como se puede apreciar, en la mayor parte de los casos los productos de importación y exportación son prácticamente los mismos. El cacao, el azúcar, los cueros, etc., van de un sitio a otro constantemente. Son importados por los dominicanos de otros lugares, a pesar de que ellos normalmente producían los suficientes para sus propias necesidades, y son exportados de nuevo.

El número de barcos dedicados a este comercio es bastante crecido, aunque en la mayoría de las ocasiones el valor de las mercancías que transportaban era escaso. Desde I 754 a I775 ambos inclusive, cargaron géneros en Santo Domingo con destino a las colonias españolas un total de $185 \mathrm{em}-$ barcaciones, con una media de más de ocho al año, y descargaron productos en él procedentes de aquellos lugares 493, más de 22 navíos anualmente, distribuidos en la siguiente forma :

Años Navios que salen de S. Domingo Idem que entran

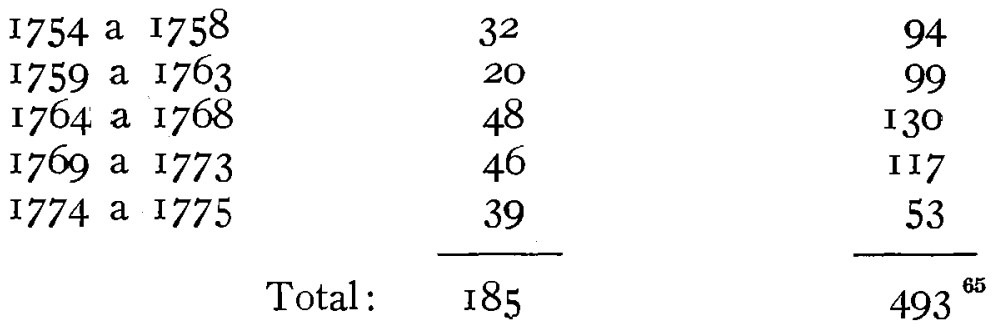

Por lo que se refiere a las importaciones, la mayor parte de este comercio se mantenía con las costas venezolanas y a continuación con Puerto Rico, seguidas de lejos por el resto de las colonias españolas del mar de las Antillas, tal y como podemos observar en el siguiente esquema:

65 Cuentas de las Cajas Reales de Santo Domingo desde 1754 a 1775. A.G.I., Contaduría, 1.069-A y B, y Santo Domingo, 1.048, 1.049, 1.050 y 1.051 . 


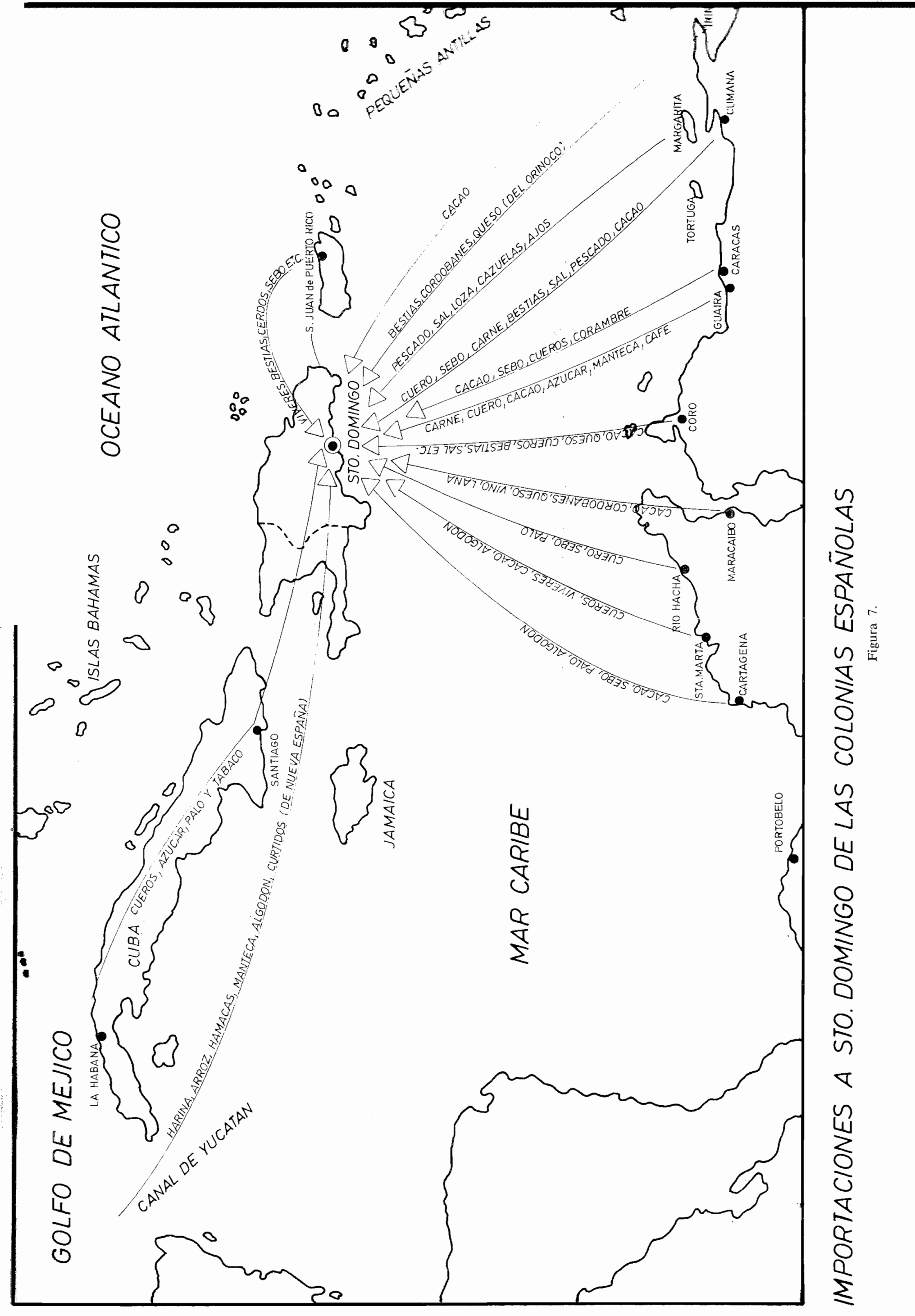



Valor de las mercancías importadas desde I754 a 1775

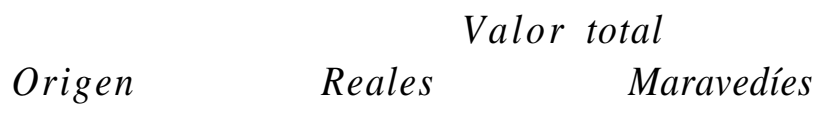

Costa venezolana.

$$
\begin{array}{r}
5.082 .642 \\
550.766 \\
200.870 \\
200.137 \\
96.168 \\
89.507 \\
87.231
\end{array}
$$

I6

Puerto Rico.

La Margarita.

México.

Cuba

Colombia.

I I

Otros lugares.

$23^{\prime} 8$

Total : $\overline{6.307 .323}$

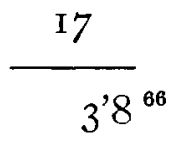

Por lo que respecta a las exportaciones, ocupan el primer lugar las dirigidas a Venezuela y Puerto Rico, seguidas de las de México, Cuba, Colombia y por último la Margarita, con las siguientes cantidades:

Valor de los géneros exportados desde I754 a I775

\section{Destino}

Costa Venezolana

Puerto Rico

México

Cuba

Colombia

La Margarita

Otros lugares

Total
Valor total

Reales

Maravedies

\begin{tabular}{rr} 
I68.439 & I 2 \\
I6I.294 & I I \\
I09.636 & 8 \\
I07.033 & 3 \\
70.995 & I 4 \\
4.500 & \\
44.630 & I 8 \\
\cline { 1 - 1 } 666.528 & $32^{67}$
\end{tabular}

66 Ibídem.

67 Ibídem. 
Como fácilmente se puede apreciar, tanto por la desproporción existente entre las embarcaciones que cargaban y descargaban mercancías en Santo Domingo, como por el valor de éstas, las importaciones superaban con creces a las exportaciones, siendo en todo momento desfavorable para la isla su balanza comercial, tal y como se expresa en el siguiente cuadro:

Valor de las importaciones y' exportaciones dominicanas respecto a las colonias españolas de América desde I754 a I775:

IMPORTACIONES

\begin{tabular}{|c|c|c|c|c|}
\hline$A \tilde{n} o s$ & Reales & Maravedies & Reales & Maravedies \\
\hline I754 & 282.7 I I & 28 & 25.030 & \\
\hline I755 & 482.218 & I 5 & $19.2 \mathrm{I} 6$ & \\
\hline 1756 & 316.969 & I7 & 65.054 & \\
\hline I757 & I 50.029 & I I & 2.704 & \\
\hline I 758 & 179.183 & & 1.276 & \\
\hline I759 & 296.822 & & $2.95^{\circ}$ & \\
\hline 1760 & 266.226 & 9 & $\mathrm{I} .288$ & I7 \\
\hline 1761 & 267.767 & & 6.050 & \\
\hline 1762 & 171.603 & & & \\
\hline 1763 & $3^{6 \mathrm{r} .235}$ & & I 26.726 & \\
\hline 1765 & $2 \mathrm{I} 5.444$ & 5 & 53.626 & 24 \\
\hline 1766 & 348.378 & 7 & I8.8I 5 & 3 \\
\hline 1767 & 282.643 & 23 & I8.912 & \\
\hline 1768 & I64.669 & I I & 6.109 & \\
\hline 1769 & I 1 8.703 & 23 & 23.091 & \\
\hline 1770 & 302.317 & I7 & 28.376 & \\
\hline I77I & $343.40 \mathrm{I}$ & 8 & 54.258 & \\
\hline 1772 & 319.359 & $23^{\prime} 8$ & 72.468 & \\
\hline 1773 & 575.5 I 5 & 8 & 41.726 & \\
\hline 1774 & 617.063 & & $7 \mathrm{x} .15 \mathrm{I}$ & I I \\
\hline 1775 & 245.062 & 2 & 27.701 & I I \\
\hline Total & 6.307 .323 & $3^{\prime} 8$ & 666.528 & $32^{68}$ \\
\hline
\end{tabular}


Así pues, desde I754 a I775 ambos inclusive, y exceptuando I 764 por no aparecer en este año los valores relativos a las exportaciones, éstas representaron sólo un ${ }_{10}{ }_{5} 6 \%$ del total del valor de las importaciones, por lo que respecta a su tráfico con las colonias españolas de América.

Solamente por lo que refiere al comercio con la isla de Cuba, las ventas dominicanas son superiores a sus compras en un I I' $29 \%$, pero por lo relativo al resto de las colonias americanas, la diferencia a favor de las segundas es considerable, dándose algunos casos, como en el del tráfico con la Margarita, en que las exportaciones representan el 2'24\% del valor de las importaciones.

\section{EL COMERCIO CON LAS COLONIAS EXTRANJERAS}

Y EL CONTRABANDO

El sistema económico imperante en la época que estudiamos, prohibía a las posesiones ultramarinas el comercio con los extranjeros. Pero la desidia de la Península respecto a sus colonias en el siglo anterior, hizo que fuesen precisamente el resto de las naciones europeas, Holanda, Inglaterra y Francia especialmente, las que fueran acaparando este tráfico.

El deseo de los monarcas del siglo XVIII por recuperar para los españoles este comercio, dictará severas medidas con el fin de acabar con esta situación, aunque en el caso de la Española, las mismas corrientes liberalizadoras que en la segunda mitad del siglo hacen más fluido el intercambio con la Metrópoli, lo facilitarán también por lo que se refiere a los extranjeros.

En principio desde luego, las órdenes dirigidas a las autoridades dominicanas son claras: "que con ningún pretexto se permita en los puntos de la jurisdicción de ese gobierno la entrada de embarcaciones extranjeras, ni que se concedan licencias para pasar a sus plantaciones, con pretexto de con- 
ducir comestibles para el abasto y surtimiento del público, si no fuese en el caso de muy grave y urgente necesidad". ${ }^{69}$

Con la creación de la Compañía de Comercio de Barcelona se pensó que esas situaciones de "urgente necesidad" desaparecerían, pero al parecer no fue así. Como ya hemos señalado anteriormente, los gobernadores de Santo Domingo se quejarán siempre de los escasos víveres que aquélla les proporcionaba, viéndose obligados por ello a recurrir a las colonias extranjeras cercanas, y en especial a la francesa que se encontraba en la misma isla, con el fin de conseguir aquellas mercancías que su Metrópoli no les suministraba.

Ya hemos dicho también que una de las aspiraciones constantes de los vecinos del Santo Domingo español, como consecuencia de la escasez de productos que les llegaban de la Península y, desde luego, de lo elevado de sus precios, va a ser el conseguir el libre comercio, "a lo menos con los franceses de las colonias que tienen en esta isla", ${ }^{70}$ medida que será apoyada por algunas autoridades incluso extraoficialmente.

Así, don Manuel de Azlor, amparándose en la autorización que tenía para comprar víveres en las colonias vecinas en caso de necesidad, llegó a favorecer este comercio de tal modo. que decretó la abolición de la mitad de los derechos que se cobraban a las embarcaciones que transportaban comestibles desde aquellos lugares a la plaza de Santo Domingo, mientras durase la intervención de los españoles en la guerra de los siete años contra los ingleses. ${ }^{71}$

Al parecer, fue el gobernador don Manuel de Azlor y Urríes el que más se empeñó en intensificar este tráfico, por lo que se transformó en blanco de graves acusaciones que lo mostraban como beneficiario de estos negocios, acusaciones

69 Carta de don Francisco Rubio de nueve de julio de 1759, acusando el recibo de la R. O. de 10 de octubre de 1758. A.G.I. Santo Domingo, 1.011

70 Carta de don Manuel de Azlor de 18 de enero de 1767, apoyando una representación del Cabildo de la ciudad de Santo Domingo en que se proponían los medios necesarios para el fomento de la isla. A.G.I., Santo Domingo, 978.

71 Informe del contador de Barlovento don José Antonio Gelabert de 16 de agosto de 1769. A.G.I., Santo Domingo, 980. 
que desde luego se reflejaron en su juicio de residencia. A este respecto, en I 769. el contador del Tribunal de Cuentas de Barlovento notificaba a la Corte, la extraordinaria suma de dinero que salía "de aquella ysla de Santo Domingo para las extrangeras, con destino a la compra de víveres y otros géneros que no son necesarios más que para el regalo". ${ }^{72} \mathrm{Al}$ mismo tiempo, los oficiales reales de aquellas Cajas informaban también, de la intromisión del gobernador en la recepción de los impuestos cobrados a los navíos procedentes de las colonias extranjeras, rebajándolos en la mayor parte de las ocasiones. ${ }^{73}$

Es difícil saber si el mencionado gobernador toinaba parte o tenía algún beneficio en este comercio, aunque dado que durante los casi i i años en que estuvo al frente de aquel mando concedió $9 \mathrm{I}$ licencias a distintas embarcaciones, sin más requisito que la solicitud del interesado, es fácil suponer que algo debió obtener a cambio. ${ }^{74}$

Para evitar en lo sucesivo hechos semejantes, el Consejo envió un despacho a su sucesor don José Solano y Bote, ordenándole que, cuando considerase necesario recurrir a los extranjeros para el abastecimiento de la capital, lo hiciera sólo con informe previo de los comisarios de abastos y dictamen favorable del fiscal de aquella Audiencia, a no ser en caso de guerra $\mathbf{u}$ otro parecido, en que la necesidad fuese tan urgente que no fuera posible esperar. ${ }^{75}$

Sin embargo, las nuevas corrientes de que ya hemos hablado, los tratados de amistad firmados con la Corona Francesa en la segunda mitad del siglo XVIII, y las ideas liberalizadoras de don José Solano, harán que en I 777 se permita el comercio entre las colonias francesa y española de Santo

72 Carta del contaáor de Barlovento de 16 de agosto de 1769 dirigida a la Corte. A.G.I., Santo Domingo, 968.

73 Carta de los oficiales reales de Santo Domingo de 16 de agosto de 1769. A.G.I., Santo Domingo, 980.

74 Informe de Tomás Ortiz de Landauri de 29 de marzo de 1773. A.G.I., Indiferente General, 2.411.

75 Carta de don Jose Solano de 25 de enero de 1775, acusando recibo del Real Despacho de 23 de noviembre de 1774. A.G.I., Santo Domingo, 984. 
Domingo, por los puertos secos de Dajabón, Hincha, Banica, Las Caobas y otros. ${ }^{76}$

A pesar de ello, continuó el intercambio con otras regiones del Caribe, amparándose siempre las autoridades, al conceder las licencias correspondientes, en la falta de comestibles que sufría el vecindario y en la escasez de moneda. Su sustitución por billetes, rechazados por los comerciantes nacionales, hacían que éstos, ante la imposibilidad de cobrar sus mercancías en dinero efectivo, y no interesándoles los productos dominicanos, escaparan de sus costas a otros lingares. ${ }^{77}$ Las colonias extranjeras ofrecían sus géneros a los españoles a mejores precios, y al mismo tiempo les compraban los suyos, maderas, aguardientes, etc., con lo que los dominicanos recurrirán cada vez más a ellos para el suministro de comestibles.

A este respecto don Pedro Catani, oidor decano de la Audiencia y gobernador interino en aquellos momentos, es.. cribía a la Corte en $\mathbf{1 7 8 8 , ~ " q u e ~ e s t a ~ y s l a ~ s u f r e ~ u n ~ c o m e r c i o ~}$ pasivo y que sus caudales y los que vienen para el cituado, pasan a los extranjeros, y porque no viniendo de España víveres ni efectos necesarios al sustento de estos habitantes, es preciso que lo soliciten de aquéllos". ${ }^{78}$

Así pues, durante toda la etapa que estamos estudiando este comercio fue constante, tanto con los establecimientos franceses de Barlovento, como con las colonias inglesas (Bermuda, Jamaica, Nueva York), y holandesas (San Eustasio, Curaçao).

Santo Domingo compraba en las posesiones extranjeras géneros comestibles principalmente, (harina, vinos, manteca, bacalao, queso, sal), sebo, loza, etc. A cambio de ellos les vendía madera, sobre todo caoba, cueros, corambre y tabaco.

A pesar de todas las prohibiciones existentes sobre el

\footnotetext{
76 R. O. de nueve de enero de 1777 , permitiendo a los dominicanos el comercio con la colonia francesa de la isla. A.G.I., Santo Domingo, 1.059.

77 Carta de don Isidro de Peralta de 17 de enero de 1784, sobre la escasez de viveres y dinero en la isla. A.G.I., Santo Domingo, 947.

78 Ibídem, nota 52.
} 
asunto, desde I754 a I775 ambos inclusive, que son los únicos años sobre los que poseemos datos de este tráfico, a base de las cuentas de las Cajas Reales de aquella isla, descargaron mercancías en Santo Domingo procedentes de las colonias foráneas 198 embarcaciones, y cargaron allí con destino a aquéllas un total de 60 , distribuidas en la siguiente forma : ${ }^{79}$

Años Navíos que descargaron Idem que cargaron

\begin{tabular}{|c|c|c|}
\hline I754 a I758 & 4I & I9 \\
\hline I759 a I763 & 42 & 19 \\
\hline I764 a I768 & 74 & I 5 \\
\hline I 769 a 1773 & 37 & 6 \\
\hline I774 a I775 & 4 & I. \\
\hline
\end{tabular}

Con todo ello, en los 22 años indicados fueron unas nueve embarcaciones anuales las que transportaron géneros a la isla desde aquellos lugares, y dos al año las que exportaron diversas mercancías, alcanzando unas cifras incluso superiores a las que se dedicaban al comercio con la Metrópoli, aunque desde luego el valor global de los productos sea bastante inferior en este caso.

Como fácilmente se puede apreciar por la desproporción existente entre los navíos que extraían e introducían géneros en Santo Domingo, en este caso, y como ocurre en el tráfico con las colonias españolas, también la balanza comercial resultaba francamente desfavorable para los dominicanos, tal y como se observa aún más claramente en el siguiente cuadro, en el que presentamos el movimiento mercantil entre Santo Domingo y las colonias extranjeras desde I754 a I775, excluyéndose I764, por no poseer para esa fecha el valor de las exportaciones a aquellos lugares:

79 Cuentas de las Cajas Reales de Santo Domingo desde 1754 a 1775. A.G.I., Contaduría, 1.069-A y B, y Santo Domingo, 1.048, 1.049, 1.050 y 1.051 . 
Valor de las importaciones y exportaciones dominicanas respecto a las colonias extranjeras de América desde 1754 a $1775 .^{80}$

\begin{tabular}{|c|c|c|c|c|}
\hline \multirow{2}{*}{$A \tilde{n} o s$} & \multicolumn{2}{|c|}{ IMPORTACIONES } & \multicolumn{2}{|c|}{ EXPORTACIONES } \\
\hline & Reales & Maravedies & Reales & Maravedies \\
\hline I754 & 230.074 & 28 & I6.528 & \\
\hline I 755 & 253.708 & & I 8.654 & \\
\hline I 756 & $244 \cdot 350$ & & $20.23 I$ & \\
\hline I 757 & I 39. I 77 & & $5.8 \mathrm{I} 4$ & \\
\hline I 758 & 323.873 & & $5 \cdot 500$ & \\
\hline I 759 & I I9.229 & & I8.026 & \\
\hline 1760 & 200.825 & $3 I$ & I 4.428 & \\
\hline 1761 & $103.20 \mathrm{I}$ & & 4.878 & \\
\hline 1762 & $227 \cdot 330$ & & 23.916 & \\
\hline 1763 & $206.94 \mathrm{I}$ & 9 & 42.866 & I7 \\
\hline 1765 & 297.842 & 4 & I8.966 & 33 \\
\hline 1766 & 345.852 & & I 3.866 & \\
\hline 1767 & 291.478 & Io & 6.960 & \\
\hline 1768 & $178.6 \mathrm{IO}$ & 33 & 4.248 & \\
\hline 1769 & 244.208 & 17 & 1.972 & \\
\hline I 770 & $349 \cdot 454$ & 27 & & \\
\hline I77I & 204.079 & 22 & I 2.500 & \\
\hline $\mathrm{I} 772$ & 6.888 & & 3.200 & \\
\hline I773 & & & 20.694 & \\
\hline I774 & $2 \mathrm{I} 4.4 \mathrm{II}$ & & 2.620 & \\
\hline I 775 & & & & \\
\hline Tota & 1.5 & I I & 255.868 & 16 \\
\hline
\end{tabular}

En cada uno de los años que aparecen en el anterior cuadro, las importaciones dominicanas de las colonias extranjeras superan con creces a sus exportaciones, y teniendo en cuenta el total de unas y otras, vemos que la ventas de Santo 
Domingo a los mencionados lugares representan sólo un 6' $32 \%$ del valor de sus compras en ellas.

De esto se deduce algo claro, a pesar de lo establecido por las leyes, el comercio de La Española con las colonias extranjeras fue constante, sobre todo por lo que se refiere a las importaciones de comestibles y licores ("caldos"), recurriendo a ellas en numerosas ocasiones, en busca de aquelos productos que no podían conseguir en cantidades suficientes de la Península o de sus establecimientos en América.

Hay que señalar además que, al margen de las licencias concedidas por los distintos gobernadores, se desarrollaba un importante tráfico clandestino, a veces con la tolerancia de aquéllos, ${ }^{81}$ y en otras ocasiones con el apoyo de los alcaldes ordinarios, "que por rasón de la administración de justicia deven impedirlo", 82 favorecido por la falta de determinadas mercancías en las embarcaciones españolas que llegaban a aquellas costas, sus elevados precios, y los beneficios que los isleños conseguían con la venta a los extranjeros de algunos de sus productos como la madera y el tabaco.

Este contrabando se realizaba por medio de los navíos que se acercaban ilegalmente a sus costas, y, sobre todo, a través de la frontera con los franceses, pues dada su extensićn y las dificultades del terreno era imposible su total vigilancia.

El resguardo para su supervisión se encontraba constituido desde los año 6o, en tiempos del gobernador don Manuel de Azlor, por 5I guardas divididos en pequeños grupos que se repartían entre distintas poblaciones, de forma que sólo podían detener a un par de contrabandistas sin importancia, pero nunca a los verdaderos traficantes, que a gran escala pasaban sobre todo ganado y madera a la colonia francesa. Estos hombres estaban distribuidos en la siguiente forma:

\footnotetext{
81 Carta del fiscal de la Audiencia de Santo Domingo de 13 de diciembre de 1768, sobre la colaboración del gobierno de la isła en el contrabando. A.G.I., Santo Domingo, 979.

82 Carta de don Isidro de Peralta de dos de febrero de 1781 sobre la participación de los alcaldes ordinarios en el comercio ilícito. A.G.I., Santo Domingo, 1.011.
} 
Establecimiento del resguardo planificado por don Manuel de Azlor: ${ }^{83}$

Numero de plazas

Salario al mes

Un cabo en la capital. en pesos

9 guardias en la capital a I 5 pesos. I 8

Un cabo en la capital para la falúa.

9 guardias en el mismo destino. I 8

4 cabos en las cuatro administraciones de la frontera: Dajabón, San Rafael, Las Caobas y Neiba, a 18 pesos cada uno.

I 6 guardias en los mismos destinos a i 5 pesos.

Un cabo en Montecristi para la falúa.

4 guardias en el mismo destino a i 5 pesos.

Un cabo en Santiago.

2 guardias en Santiago a I 5 pesos.

Un cabo de volantes.

2 guardias volantes a $\mathrm{I} 5$ pesos.

Total: 5 I hombres que cobran al mes.

En I786, el entonces gobernador don Manuel González informaba a la Corte, que el resguardo establecido para evitar el comercio ilícito no producía los resultados que se esperaban, ya que "la división de las partidas en que está subdividido y la residencia fija en los lugares de su destino, constituyéndolos con el trato y conexiones con los demás vecinos, susceptibles del disimulo, tolerancia y corrupción, son otros tantos apoyos para que sin temor se entreguen a este comercio". En vista de ello, González decidió reformar el antiguo sistema creando dos rondas volantes, una destinada a la fron-

83 Establecimiento del resguardo que planeó para la frontera con los franceses el gobernador don Manuel de Azlor. A.G.I., Santo Domingo, 953. 
tera del norte y otra a la del sur. ${ }^{84}$ Cada una de estas rondas se formó con I 6 hombres de a caballo y un cabo, y la del norte quedó además al mando de un juez de comisos subdelegado de la superintendencia. El resguardo quedó estructurado así en la forma siguiente:

Nuevo establecimiento hecho por don Manuel González: ${ }^{85}$

Número de plazas

Un juez de comisos para la ronda del norte.

Un cabo para la misma.

I6 guardias en el mismo destino a 16 pesos.

Un cabo para la ronda del sur.

I6 guardias para la misma ronda volante.

Un cabo en la capital para la falúa.

6 guardias en el mismo destino a I 5 pesos.

Un cabo para la falúa de Montecristi.

4 guardias en la misma falúa a i 5 pesos.

Total: 47 hombres que cobran de salario.
Salario al mes en pesos

Don Manuel González redujo pues el número de guardias encargados de celar por el contrabando, y les ordenó una nueva táctica. Debían actuar moviéndose continuamente a lo largo de la frontera de la jurisdicción de cada una, sin permanecer nunca en el mismo sitio.

Pero a pesar de todas estas reformas el tráfico ilícito continuaba, y en I790, el entonces gobernador de la isla, don Joaquín García, intentaba otro cambio:

\footnotetext{
84 Carta de don Manuel González de uno đe agosto de 1786 sobre el exceso del contrabando en la isla y la necesidad de modificar el resguardo de la frontera. A.G.I., Santo Domingo, 1.045.

85 Nuevo establecimiento del resguaräo hecho por don Manuel González. A.G.I., Santo Domingo, 953.
} 
Nuevas disposiciones para el resguardo hechas por don Joaquin Garcia: ${ }^{86}$

Número de plazas

Salario al mes en pesos

Un cabo en la capital. 30

8 guardias para las puertas de la capital a 16 ps. $\quad$ I 28

Un cabo en la capital para la falúa.

6 guardias para la misma a 16 pesos.

Un cabo en Montecristi para la falúa.

5 guardias para la misma a 16 pesos.

80

4 guardias en Santiago a 16 pesos.

Un cabo de volantes en la frontera sur.

3 guardias con igual destino a 16 pesos.

I8 guardias en las cuatro administraciones de la frontera a 16 pesos.

Total: 48 hombres que cobran de salario.

Tampoco fueron suficientes estas innovaciones, de forma que el comercio ilícito fue algo constante durante toda la etapa estudiada.

Al mismo tiempo que tenía lugar un intenso tráfico con la colonia francesa vecina a través de la frontera, se desarrollaba otro también muy importante en las extensas costas de la isla, basado principalmente en las maderas, especialmente caoba, cuya "extracción se hace no sólo por los medios lícitos del comercio por los barcos españoles, sino también por los del contravando, así por éstos como por los extranjeros, que concurren a la costa ha cargar de maderas prontas y listas para transportarlas inmediatamente a sus colonias". ${ }^{87}$

\footnotetext{
86 Nuevo resguardo establecido por el gobernador don Joaquín García. A.G.I., Santo Domingo, 953.

87 Ibídem, nota 52 .
} 
La costa era grande y su vigilancia escasa, basada en las dos falúas que hemos mencionado y en algunas embarcaciones particulares que se dedicaban al corso. A juicio del oidor decano de aquella Audiencia, don Pedro Catani, un solo guardacostas bien equipado bastaría para asegurarla, pero debía ser por cuenta del gobierno, no navíos corsarios particulares como los empleados entonces, pues pronto se nezclaban ellos mismos en el contrabando. ${ }^{88}$

No todo el mundo se mostraba tan optimista sin embargo a este respecto, y en 1789 , el gobernador don Joaquín García daba cuenta a la Corte, de que por mucha efectividad que mostrasen los guardias todo era inútil, "mientras no haya más arbitrios" y se creara un cuerpo de vigilancia de acuerdo con la extensión tanto de la frontera como de las costas, con un número de hombres muy superior al que la situación de las Reales Cajas permitían. ${ }^{89}$

Así pues, y como ocurrió en el resto de las colonias españolas de América, el contrabando fue un factor esencial en el comercio dominicano, favorecido en este caso por la presencia cercana de los franceses, aunque es evidente la imposibilidad de conocer, y ni siquiera de imaginar, el volumen que representó respecto al legal, por la falta de fuentes que puedan ayudar a esclarecer este punto. Por ello, pretendemos solamente dejar constancia de este fenómeno, que constituyó la principal preocupación de muchas de las autoridades de la isla, pero ante el cual todas se mostraron impotentes.

88 Ibídem.

89 Carta de don Joaquín García de 25 de octubre de 1789 sobre la imposibilidad del gobierno para acabar con el comercio ilícito. A.G.I., Santo Domingo, 948. 



\section{Capítulo VI}

\section{REAL HACIENDA}

Estado de las cajas reales de Santo Domingo

El estado de las Cajas Reales de Santo Domingo en la segunda mitad del siglo XVIII, fue en realidad caótico, tanto por lo que se refiere a su organización como a la existencia de fondos. Al parecer, habría en la isla en esta época sólo dos Reales Cajas, la de la capital, y una sufragánea en Montecristi, de la que apenas tenemos más conocimientos que el de que se encontraba a cargo de un teniente de oficiales reales, cuyo sueldo en 1769 era de 2.200 reales al año. ${ }^{1}$

Por lo que se refiere a las de la capital, no tenemos tampoco noticias, antes de la fecha señalada, de los empleados que trabajan en ella. En i 769 estaban a su frente un contador mayor, don Francisco de Gascúe, y un tesorero, don Raimundo de Esparza, con un salario de 8.823 reales y I 8 maravedíes al año cada uno. Por debajo de ellos se hallaban un oficial mayor de la Contaduría, que tenía asignados 2.400 reales al año, y un alguacil ejecutor con $2.696 .{ }^{2}$

En 1778 , nos encontramos con un alza en el salario del oficial mayor y la aparición de otros dos empleados, tal y como se observa en el siguiente estado:

1 Extracto de la revista pasada por don José de Gelabert en abril de 1769, a los empleados de la Real Hacienda y de la Rala Audiencia de Santo Domingo. A.G.I., Santo Domingo, 1.044 .

2 Ibídem. 
N. ${ }^{\circ}$ de empleados de las cajas reales de Santo Domingo Y SUS SALARIOS

Cargos

Un contador.

Un tesorero.

Un oficial mayor.

Un oficial segundo.

Un oficial supernumerario.

Un alguacil ejecutor.
SUELdos AL AÑ Reales Maravedies

$8.823 \quad 2$

$8.823 \quad 2$

3.840

2.880

I. 440

2.648

$$
\text { Total: } 28.454 \quad-
$$

No sabemos si la aparición de estos dos nuevos cargos es o no anterior a esta fecha. Lo que sí parece cierto, es que ya en esta época debieron existir una serie de trabajadores subalternos en la Real Contaduría, aunque no tenemos dato alguno sobre ellos hasta I787, por una carta dirigida a la Corte por el gobernador don Manuel González proponiendo una serie de reformas en la organización de las Reales Cajas.

En este año, el nuevo tesorero don Fernando de Mauleón, comenzó una investigación sobre la mala situación en que se hallaba la Real Hacienda dada su desastrosa administración. No es desde luego la primera noticia que tenemos a este respecto, pues ya en $175^{8}$ una real orden dirigida a los oficiales reales de Santo Domingo manifestaba, que "aviéndose notado en mi Consejo de las Indias, la ninguna formalidad con que se procedió últimamente en la toma de cuentas de esas mis reales caxas, por averse dispuesto con error, y sin el regular método y claridad que para su comprehensión necesitaban, y así mismo los daños que hasta ahora se han experimentado con motivo de no averos tomado las cuentas los contadores del Tribunal de las islas de Barlovento, en el término en que está prefinido, he parecido ordenaros y mandaros, como lo executo, que en lo subcesivo deis y presenteis

3 Estado de las atenciones de las Cajas Reales de Santo Domingo, fechado el 27 de julio de 1778. A.G.I., Santo Domingo, 1.044. 
las cuentas de mi Real Hacienda anualmente en el mencionado tribunal". ${ }^{4}$

$\mathrm{Y}$ como ya hemos señalado, en I 787 el tesorero informó de nuevo sobre el lamentable estado en que se encontraban los libros de cuentas, y la confusión reinante en las operaciones. ${ }^{5}$

Con este motivo, se reunió en la capital dominicana una Junta de Real Hacienda, que decidió aprobar el plan de reforma presentado por don Fernando Mauleón y remitirlo a la Corte para su ratificación.

El proyecto se basaba en el aumento del número de oficiales reales, que pasarían de tres a cinco, y la disminución a cambio de los escribientes. Al mismo tiempo, se solicitaba un aumento de sueldo para todos los empleados, con excepción del tesorero y el contador que permanecerían como estaban, en la siguiente forma: ${ }^{6}$

Estado actual de la Refal Hacienda Reforma que se solicita Cargos Realesal año Cargos Reales al año

Un oficial mayor. 3.840

Un of icial segundo 2.880

Un oficial supernumerario.

I. 440

Un escribiente.

I.920

Un escribiente.

I. 920

Un escribiente.

Un agregado.
Un oficial mayor. 5.760

Un oficial segundo 4.800

Un oficial tercero 4.320

Un oficial cuarto 3.840

Un oficial quinto 3.360

Un escribiente $\quad 2.880$

Un escribiente $\quad 2.400$

Pero el nuevo plan significaba un aumento en los gastos de la Real Hacienda que la Corte no estaba dispuesta a

\footnotetext{
4 R. O. fechada en el Buen Retiro el 25 de febrero de 1758 y dirigida a Ios Oficiales Reales, de Santo Domingo. A.G.I., Santo Domingo, 1.046,

5 Carta del gobernador de Santo Domingo don Manuel González, de 25 de diciembre de 1787, remitiendo a la Corte un informe del tesorero de aquellas Reales Cajas sobre el estado en que se encontraba la administración de la Real Hacienda. A.G.I., Santo , Domingo, 947.

6 Santo Domingo, 31 de octubre de 1787. Plan propuesto por la Junta' de Real Hacienda de Santo Domingo, para reformar la Real Contaduría. A.G.I., Santo Domingo 947 y 992 .
} 
tolerar, por lo que no sólo no fue aceptado, sino que por real orden de $2 \mathrm{I}$ de octubre de $\mathrm{I} 789$, se ordenó la reducción de los empleados de la Real Contaduría de Santo Domingo a cinco, sin contar desde luego al contador y al tesorero. ${ }^{7}$

A consecuencia de ello, aumentaron las quejas del tesorero sobre la imposibilidad de llevar bien las cuentas con tan corto número de subalternos, ya que tenían que repartirse el trabajo como podían, quedando todos ellos sobrecargados. El primero de estos cinco se encargó de la administración de los diezmos, comisos, alcabalas, papel sellado, naipes y bulas.

El segundo tenía a su cargo el cuidado de los libros reales de cargo y data, y la formación ordenada de las cuentas.

El tercero estaba encargado del despacho de guías, toma de razón de títulos y reales órdenes, licencias de ganado de la parte francesa, libros de intervención de almacenes de artillería, y las liquidaciones de las deudas atrasadas de la Corona.

El cuarto debía contar, recibir, y pagar, todo lo que se recaudaba y satisfacía en la Tesorería, formar las liquidaciones del situado, y los derechos de mar.

El quinto, por último, tuvo como misión la puesta en limpio de todas las cuentas que los demás trabajaban en borrador. ${ }^{8}$

Pero independientemente de que el personal empleado en la Real Contaduría de Santo Domingo no fuera suficiente, la mala administración de las Cajas debió obedecer también a otros factores, como la desidia e incluso los fraudes, como el que al parecer tuvo lugar por parte del contador don Francisco de Gascúe y el tesorero don Raimundo de Esparza, con la expedición de billetes de papel. ${ }^{9}$

7 Carta, del gobernador dé la Española don Joaquín García, fechada el 18 de octubre de 1791, apoyando ante la Corte una solicitud del tesorero de las Reales Cajas de aquella isla, para que se restableciesen en la Contaduría los siete empleados con que contaba antes de la reducción decretada por R. O. de 21 de octubre de 1789. A.G.I., Santo, Domingo, 996.

8 Ibídem.

9 Carta del gobernador don Manuel González de dos de mayo de 1788, informando a la Corte de las investigaciones realizadas sobre los fraudes cometidos contra la Real Hacienda por los oficiales reales Gascué y Esparza. A.G.I., Santo Domingo, 992. 
Por una causa u otra, lo cierto es que sólo contamos para el estudio de la Real Hacienda en Santo Domingo en la segunda mitad del siglo XVIII, con las cuentas presentadas por los oficiales reales de la isla desde el I de enero de I754 al 3I de junio de I775, ya que "las últimas cuentas que se rindieron por estas Reales Cajas fueron el año de 75, y éstas incompletamente... Después de este larguísimo tiempo, todas las cuentas están pendientes, son continuas las quejas de la Contaduría mayor de la Havana exigiéndolas, y de este atraso, abandono o abuso, necesariamente han de seguirse muchos males...".10

Parejo a este desorden administrativo, un mal al parecer endémico en la Tesorería de Santo Domingo, desde luego no desligado de aquél, va a ser la falta de caudales suficientes para atender a sus necesidades.

El $60 \%$ aproximadamente del dinero que entraba en las Cajas provenía del llamado situado, que anualmente les debía ser remitido desde México. Y este situado pocas veces llegaba a la isla puntualmente, ocasionando con ello graves trastornos en la economía pública de la Española.

Así, en los comienzos de la etapa estudiada, se ordenó a los gobernadores dominicanos, como ya hemos dicho al hablar del crecimiento demográfico de esta etapa, la fundación de nuevas poblaciones. Pero la escasez de fondos propios de aquella Tesorería, y el retraso de los subsidios que la de México debía aportar, hacen decir al entonces gobernador de la isla don José Sunyer, que "ni se puede proseguir en la fundación de las nuebas poblaciones, ni podrán subsistir las familias transportadas de Canarias". ${ }^{11}$

Esta falta de dinero se dejaba sentir en todos los ámbitos de la vida del Santo Domingo español, y en r757, debido a ella, se produjo un levantamiento en la guarnición de la ca-

10 Carta del regente de la Audiencia don José Antonio de Urízar de 24 de febrero de 1795, dando cuenta a la Corte de la falta de cuentas bien llevadas en las Redes Cajas de Santo Domingo. A.G.I., Santo Domingo, 999.

11 Carta del gobernador interino de Santo Domingo don José Sunyer y Basteros. con fecha de 28 de junio de 1751, dando cuenta a la Corte de la falta de fondos sufrida en aquellas Redes Cajas. A.G.I., Santo Domingo, 1.092. 
pital, que se amotinó reclamando los salarios que se le adeudaban, que en algunos casos alcanzaban a 28 meses, por la irregularidad con que ese situado llegaba de Nueva España. ${ }^{12} \mathrm{Y}$ esta situación se vio agravada considerablemente en las ocasiones en que los gastos extraordinarios aumentaban, como por ejemplo en caso de guerra, teniendo que recurrir con frecuencia la Real Hacienda a la petición de préstamos a los particulares, sobre todo en algunos casos en que el situado no llegó durante más de dos años. ${ }^{13}$

La no remisión del situado no afectaba sin embargo sólo al erario público. De él dependían muchos salarios, de tal modo que cuando éstos no se pagaban, las consecuencias las sufría toda la isla. El dinero que se iba a otras colonias a cambio de determinados productos no era remplazado por el que había de llegar, y la escasez de moneda para el comercio interior se hizo tan angustiosa, que la Contaduría tuvo que habilitar billetes de papel por valor de I00.000 pesos para sustituirla. ${ }^{14}$

Para acabar con la circulación de estos billetes, el Consejo de Indias expidió severas medidas al virrey de México con el fin de que remitiese a Santo Domingo los caudales correspondientes a las situaciones que se le estaban debiendo, pero no es hasta dos años más tarde, en 1784, cuando llegaron los primeros auxilios a la capital dominicana. ${ }^{15} \mathrm{Y}$ esta cantidad no pudo por sí sola arreglar la situación, ya que si bien bastaba para suplir dos años de situación ordinaria, en el momento en que arribó a la isla se debían ya a ésta más de cuatro, por lo que los billetes de papel no pudieron

\footnotetext{
12 Madrid, cinco de noviembre de 1758. Junta formada para estudiar el motín de los soldados de la guarnición de Santo Domingo, que tuvo lugar en julio del año anterior. A.G.I., Santo Domingo, $\mathbf{1 . 0 8 8 .}$

13 Carta del gobernador de Santo Domingo don Isidro de Peralta y Rojas de 25 de mayo de 1782, informando a la Corte de la falta del envío de los situados, y la necesidad a causa de ello de recurrir a los préstamos. A.G..I., Santo Domingo, 2.677.

14 Carta del gobernador de la Española don Isidro de Penalta, fechada el 16 de diciembre de 1782, dando cuenta a la Corte de la necesidad de habilitar billetes de papel en la isla. A.G.I. Santo Domingo. 946.

15 Carta de don Isidro de Peralta de 25 de noviembre de 1784, informando a la Corte de la llegada a Santo Domingo de $\mathbf{3 0 0 . 0 0 0}$ pesos correspondientes al situado. A.G.I., Santo Domingo, 947.
} 
ser retirados de la circulación. ${ }^{16} \mathrm{Y}$ en 1789 , el procurador general de la ciudad de Santo Domingo escribía a la Corte, sobre los graves perjuicios ocasionados en todo el territorio por el uso de los billetes en lugar de dinero, que "es un gran número señor de papeletas, las que corren baxo la buena fe de que salieron de la Real Contaduría, porque están tan hechas pedazos (como fabricadas sobre materia tan dévil), tan sucias y remendadas, que no es posible distinguírseles el sello: otra gran porción se hallan estancadas y sin giro en las manos de los últimos a que llegaron, por resistirse los demás a recibirlas... Con esto ocurre (y es lo más notable), que desde que las papeletas se pusieron en curso, comensaron a introducirse premios en la plata fuerte, a veces tan exessivos (según la escasez o abundancia de la plata), que han llegado a darse a un ciento por ciento, y de ordinario aun sin quenta... A esto se agrega que como la fábrica de las papeletas no es de difícil imitación, son tantas las que se han introducido falsas, a la cantidad de (igual a la que acompaño con esa nota), que casi se duda si habrán llegado las falsas a cien mil pesos". ${ }^{17}$

Con todo ello, las deudas de las Cajas Reales de Santo Domingo se hicieron exorbitantes, al tiempo que la dificultad ocasionada por la mala administración de que ya hemos hablado, la falta de comprobantes, y el desorden en los libros, hacían muy difícil conocer esas deudas, "por las muchas partidas que se encuentran datadas y no pagadas". ${ }^{18}$

Esta situación se vio agravada con motivo de la guerra declarada a la república francesa, y que Santo Domingo, por su vecindad con el futuro Haití, sufrirá con mucha más intensidad que cualquier otra colonia española en

16 Carta del gobernador don Isidro de Peralta con fecha de 27 de febrero de 1785, dando cuenta a la Corte de la distribución que se había hecho de los 300.000 pesos remitidos de México. A.G.I. Santo Domingo ,947.

17 Carta del procurador general del Cabildo, Justicia y Regimiento de la ciudad de Santo Domingo, de 25 de enero de 1789, informando a la Corte de los males que producía la circulación en la isla del papel moneda. A.G.I., Santo Domingo, 1.007.

18 Carta del gobernador de Santo Domingo don Joaquín García cle 25 de agosto de 1789, dando cuenta a la Corte del desorden imperante en la administración de la Real Hacienda. A.G.I., Santo Domingo, 949. 
América. Los gastos extraordinarios con motivo de esta guerra fueron numerosos, y aunque la Corte expidió taxativas reales órdenes al virrey de México para que enviara a la Española los recursos suficientes con que hacer frente a sus necesidades, las mismas dificultades originadas por la lucha armada, hicieron muchas veces imposible la llegada del subsidio de Nueva España, al tiempo que lo que entraba no era suficiente. ${ }^{19}$

De este modo, y dadas las numerosas deudas que la Contaduría tuvo que contraer en múltiples ocasiones, nada más llegar el dinero se iba en gran parte a manos de los acreedores, y a veces antes de llegar, sin quedar apenas nada para hacer frente a los nuevos gastos, tal y como se observa en la siguiente nota:

\section{Caudales Que debían ingresar en efectivo en las Cajas Reales de Santo Domingo, en el primer SEMESTRE DE $1795^{20}$}

Pesos Reales Maravedies

- Caudal destinado de México $453.934 \quad 4$

- Ídem de la Habana para su regulación y abono a estas Cajas según reales órdenes

$32.672 \quad 5$

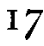

- Idem para sus tropas y las de México

- Para los gastos de marina

Total

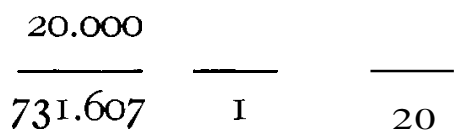

19 Orden dirigida al virrey de Nueva España, con fecha de 10 de noviembre de 1794, para que envíe dinero a Santo Domingo. A.G.I., Santo Domingo, 1.031.

20 Carta del gobernador don Joaquín Garcla de 11 de agosto de 1795, informando a la Corte de la llegada de la última remesa de dinero desde Mexico, y de su distribución. A.G.I. Santo Domingo, 958 
Distribución de esos caudales Pesos Reales Maravedies

- Retenido en la Habana segun su liquidación por los gastos de cuenta de esta isla

$77.496 \quad 7$

17

- Idem por error de cuenta retenido en la Habana de lo que remite México $50.423 \quad 5$

- Dejados en Puerto Rico por el alcance que hacen aquellas Cajas a éstas

- Abonadas al contador de navíos dos libranzas que pagó en Puerto Rico giradas por estas Cajas

- Entregadas en dinero efectivo en las Cajas de Santo Domingo

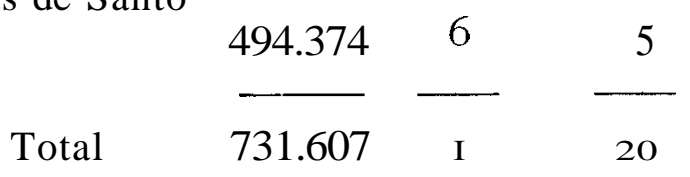

Las Cajas de Santo Domingo tenían cada vez más obligaciones, pues a los gastos ocasionados por la guerra y el pago de los ejércitos que con este motivo llegaron a la isla desde otras colonias, vinieron a sumarse los muy considerables de la evacuación del Santo Domingo español a causa de su cesión a Francia, acordada por el ya mencionado tratado de Basilea firmado por las dos naciones en 1795 .

A pesar de las repetidas órdenes enviadas al virrey de México para que remitiera todos los auxilios posibles a las autoridades dominicanas, "no se ha logrado otra cosa que acrecentar el alcance de los soldados, y vernos empeñados por todas partes cada vez más en unas circunstancias tan progresivas como las del día. en que con motivo de la evacuación no sólo han crecido los gastos, sino que no hay de donde sacar un 
préstamo, en un pays que sólo se ocupa con su perplexidad..." 21

Así pues, las Cajas Reales de Santo Domingo tuvieron que enfrentarse en esta época a dos problemas fundamentales: por una parte la mala administración, que en ocasiones se prestó al fraude, y por otra su dependencia del exterior. Sus recursos eran muy limitados; los mayores beneficios que obtenían eran los procedentes de los gravámenes impuestos al comercio, y hay que tener en cuenta, tal y como hemos dicho en el capítulo anterior, que éste no fue nunca muy intenso. E1 grueso del dinero tenían que recibirlo de la capital del virreinato de Nueva España, y estos fondos que venían de fuera se convirtieron en el primer recurso no sólo de la Real Contaduría, sino de toda la isla. Como ya hemos señalado, de ellos dependía el salario de toda la tropa y la mayor parte de los funcionarios. Cuando se remitía normalmente, el dinero se gastaba y el comercio interior se defendía. Pero cuando no llegaba a tiempo, el poder adquisitivo de los que dependían de él disminuía, y con ello la vida económica de todo el territorio.

En realidad, la poca solvencia de las Reales Cajas no hizo más que reflejar el estado económico de un país pobre, dependiente del exterior para su mantenimiento, no por falta de recursos, sino por una indebida explotación.

Movimiento de las Cajas Reales

\section{A) Entradas}

Para tratar del movimiento de las Cajas Reales de Santo Domingo, hemos de señalar que sólo contamos con las cuentas relativas a $2 \mathrm{I}$ años y medio, desde comienzos de I754, al 3I de junio de I775. Puede ser que el resto de las cuentas se

21 Carta de don Joaquín García fechada el 12 đe abril de 1796, dando cuenta a la Corte de la falta de dinero de aquellas Cajas Reales, para poder costear los gastos de la evacuación y los sueldos de los soldađos. A.G.I., Santo Domingo, 1.033. 
hayan perdido, dada la confusión reinante en la isla en los últimos años del siglo XVIII, el traslado de los archivos a Cuba, etc.

Pero lo más probable es que, tal y como ya hemos señalado, ${ }^{22}$ las cuentas que faltan nunca fueran presentadas, debido a la desastrosa organización de la Real Hacienda. A partir de 1788 , nos hemos encontrado con algunos estados generales de la entrada y salida de caudales en aquella Contaduría. Pero dado que en tales estados es imposible averiguar el movimiento real, por hallarse mezclados en ellos los verdaderos ingresos y los préstamos, son totalmente inútiles para nuestro estudio.

Por esta causa, hemos de limitarnos al examen de las Cajas Reales en los años citados, que aunque no puedan ofrecer una visión exacta de lo que estaba pasando, si pueden darnos una idea de lo que en circunstancias normales ingresaba y se gastaba en la Real Hacienda de Santo Domingo.

Hecha esta aclaración, hemos de indicar que no todos los ingresos que figuran como tales en las cuentas de las Cajas Reales de Santo Domingo en la etapa tratada, lo fueron en realidad. Gran parte de ellos son préstamos que se hacen de unos ramos a otros, y que figuran como entrada en dos ocasiones, en el ramo donante y en el receptor.

Otros a su vez son devoluciones de los préstamos señalados, y que tampoco suponen un nuevo ingreso, pues ya quedaron anotados como tales la primera vez que entraron en la Real Contaduría.

Otros son simplemente, cantidades que sólo están en cierta forma de paso en las Cajas Reales, por llegarles con un fin determinado y totalmente ajeno a ellas, como puede ser el dinero destinado a la Casa Cuna o a limosnas para algunos conventos.

Por último, y aunque al comenzar el ejercicio de cada año individualmente podría considerarse como ingreso el caudal sobrante del año anterior, al tratar una etapa en gene-

22 lbídem, nota 10. 
ral no podemos hacer eso, pues la misma entrada estaría repetida una y otra vez.

Teniendo en cuenta todo esto, encontramos una gran diferencia entre lo que podríamos llamar ingresos totales -los que aparecen en las mencionadas cuentas - , reales, y no efectivos, tal y como se observa en el siguiente cuadro:

\section{Entradas producidas en las Reales cajas De Santo Domingo desde i754 A $1775^{23}$}

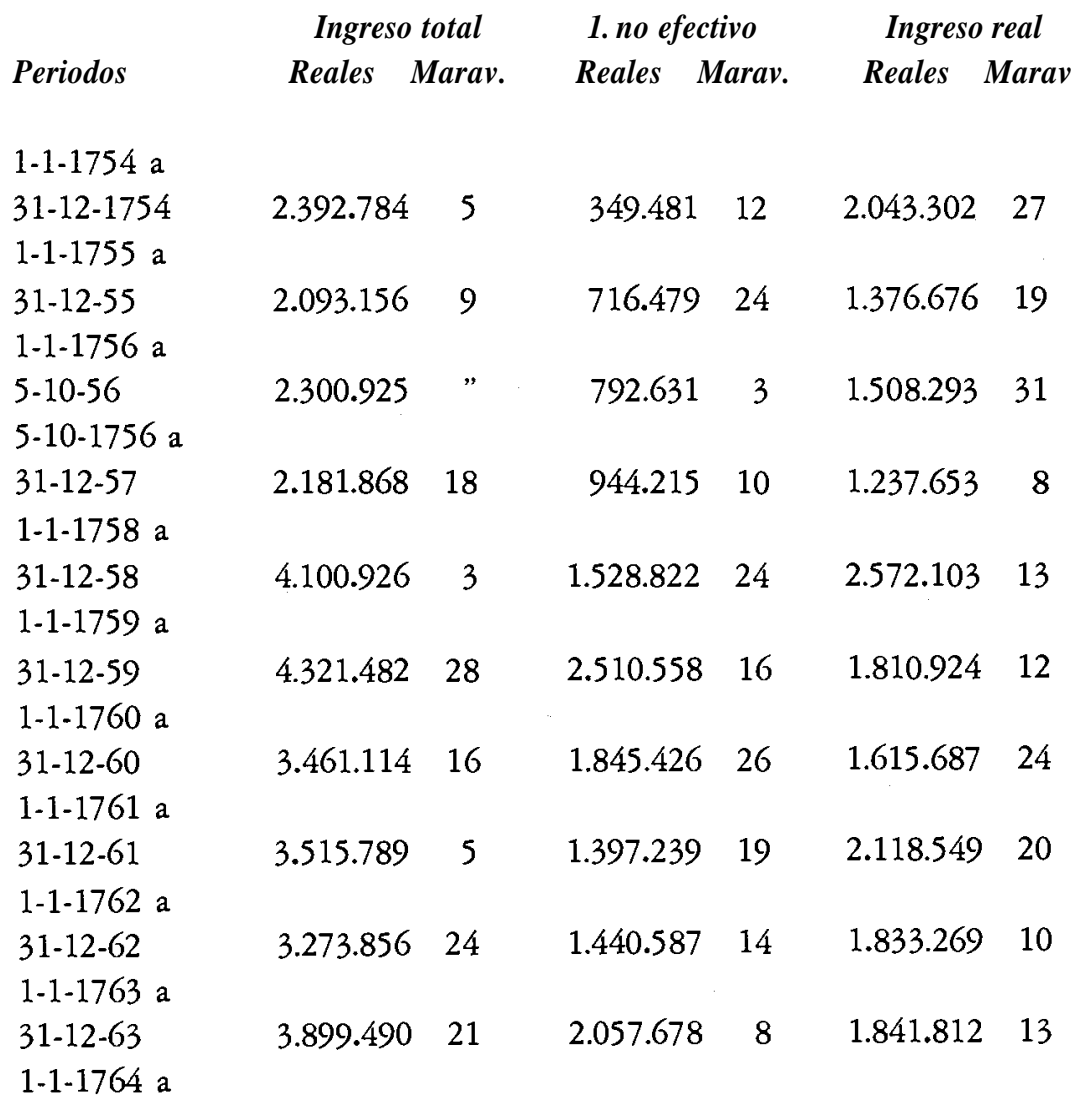

23 Cuentas de las Cajas Reales de Santo Domingo desde el primero de enero de 1754, al 31 de junio de 1775. A.G.I., Contaduría, 1.069-A y B, y Santo Domingo, 1.048, 1.049, 1.050 y 1.051 . 


\begin{tabular}{|c|c|c|c|c|c|c|}
\hline \multirow[b]{2}{*}{ Períodos } & \multicolumn{2}{|c|}{ Ingreso total } & \multicolumn{2}{|c|}{ 1. no efectivo } & \multicolumn{2}{|c|}{ Ingreso real } \\
\hline & Reales & Marav. & Reales $N$ & Marav. & Reales I & Marav. \\
\hline $31-12-64$ & 3.261 .308 & 29 & 1.359 .479 & 33 & 1.901 .828 & 30 \\
\hline $1-1-1765$ a & & & & & & \\
\hline $\begin{array}{l}31-12-65 \\
1-1-1766 \text { a }\end{array}$ & 2.993 .728 & 18 & 1.075 .701 & 29 & 1.918 .026 & 23 \\
\hline $\begin{array}{l}6-2-67 \\
6-2-1767 \text { a }\end{array}$ & 4.624 .510 & 21 & 1.605 .638 & 16 & 3.018 .872 & 5 \\
\hline $\begin{array}{l}31-12-67 \\
1-1-1768 \text { a }\end{array}$ & 2.258 .116 & 22 & 1.874 .380 & 7 & 383.736 & 15 \\
\hline $\begin{array}{l}31-12-68 \\
1-1-1769 \text { a }\end{array}$ & 5.668 .977 & 25 & 2.046 .514 & 6 & 3.622 .463 & 19 \\
\hline $\begin{array}{l}31-12-69 \\
1-1-1770 \text { a }\end{array}$ & 7.897 .706 & 23 & 3.500 .029 & 23 & 4.397 .677 & $"$ \\
\hline $\begin{array}{l}31-12-70 \\
1-1-1771 \text { a }\end{array}$ & 3.396 .467 & 33 & 2.840 .535 & 8 & 555.932 & 25 \\
\hline $\begin{array}{l}31-10-71 \\
31-10-1771 \text { a }\end{array}$ & 7.547 .054 & 9 & 3.438 .080 & 12 & 4.108 .973 & 31 \\
\hline $\begin{array}{l}31-12-72 \\
1-1-1773 \text { a }\end{array}$ & 7.779 .706 & 19 & 5.037 .225 & 6 & 2.742 .481 & 13 \\
\hline $31-12-73$ & 8.587 .624 & 25 & 5.890 .822 & 4 & 2.696 .802 & 21 \\
\hline $\begin{array}{l}1-1-1774 \text { a } \\
31-12-74 \\
1-1-1775 \text { a }\end{array}$ & 6.417 .101 & 12 & 3.096 .777 & 27 & 3.320 .323 & 19 \\
\hline $31-6-75$ & 3.402 .575 & 1 & 3.219 .112 & 16 & 183.462 & 19 \\
\hline Totales & 95.376 .272 & 26 & 48.567 .418 & 3 & 46.808 .854 & 23 \\
\hline
\end{tabular}

Como fácilmente se puede observar, la cantidad no efectiva supone en estos años un 50,92\% del total, mientras que las entradas reales representan un 49,08\%, aunque estas cantidades varían mucho de un año a otro, pues si por ejemplo en el primer quinquenio de los indicados las entradas reales son muy superiores a las otras, es a partir de entonces cuando primero son prácticamentee igualadas y más tarde superadas muchas veces por aquéllas, como podemos apreciar en el próximo cuadro: 
Proporción entre las entradas no efectivas y reales I $754-1775^{24}$

\section{Períodos}

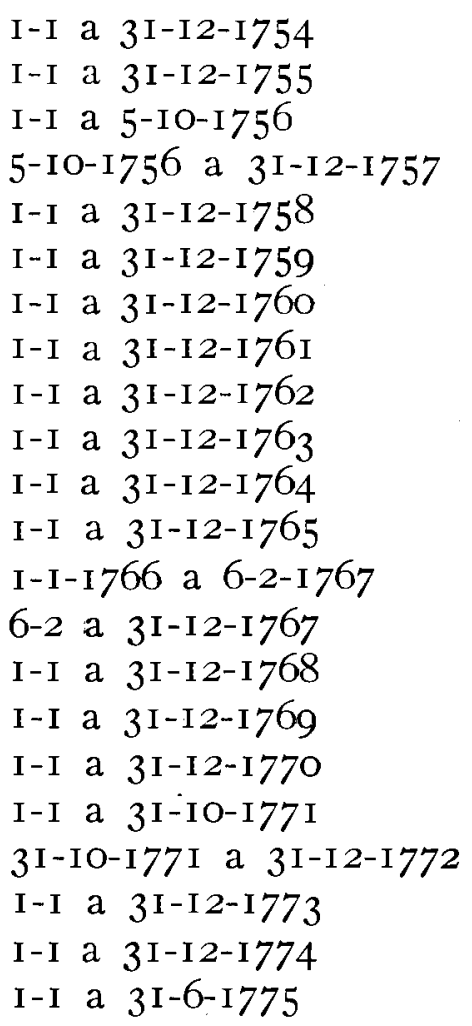

Porcentaje no efectivo

Idem real

I $4,60 \%$
$34,23 \%$
$34,45 \%$
$43,285 \%$
$37,28 \%$
$58,10 \%$
$53,32 \%$
$39,74 \%$

$44 \%$

$52,77 \%$

$41,69 \%$

$35,93 \%$

$34,72 \%$

$83,01 \%$

$36,10 \%$

$44,32 \%$

$83,63 \%$

$45,56 \%$

$64,75 \%$

$68,597 \%$

$48,25 \%$

$94,608 \%$

Total : $50,92 \%$
$85,40 \%$

$65,77 \%$

$65,55 \%$

$56,725 \%$

$62,72 \%$

41,90\%

$46,68 \%$

$60,26 \%$

$56 \%$

$47,23 \%$

$58,31 \%$

$64,07 \%$

$65,28 \%$

I $6,99 \%$

$63,90 \%$

$55,68 \%$

I $6,37 \%$

$54,44 \%$

$35,25 \%$

$31,403 \%$

$5 \mathrm{I}, 75 \%$

$5,392 \%$

$49,08 \%$

Resumiendo en períodos de cinco años, a excepción claro está del último año y medio, los promedios anuales de entradas reales en las Cajas de Santo Domingo serían los siguientes: 
Ingresos reales Promedio anual

Periodos Reales Marav. Reales \% del;total

I-I-I 754 a

$31-12-1758$

I-I-I 759 a

31-12-1763

$1-1-1764$ a

$8.738 .029 \quad 30 \quad$ I.747.605 $66,86 \%$

$31-12-1768$

1-1-1769 a

9.220 .243 I I $\quad$ I. $844.048 \quad 49,9$ I $\%$

3 I-I $2-\mathrm{I} 773$

I-I-I 774 a

3 I-6-I 775

I0.844.927 $24 \quad 2.168 .985 \quad 57,665 \%$

Totales: $\overline{46.808 .854 \quad 23} \quad \overline{2.177 .156} \quad \overline{49,08 \%}{ }^{25}$

Así pues, la media anual de entradas reales en las Cajas de Santo Domingo es ligeramente inferior a la de las entradas no efectivas, y es con ellas con las que podía contar la Real Contaduría para cubrir sus necesidades, por lo que vamos a estudiarlas en primer lugar.

\section{I.-Entradas Reales}

Dentro de las entradas que se produjeron realmente en las Cajas de Santo Domingo, nos encontramos con tres tipos de ingresos. Por una parte está el dinero que no pertenece a las Reales Cajas, no procede de los recursos propios de la Hacienda. Se trata de una serie de cargos que tienen su origen en otras Contadurías, en este caso en la de México, como son el situado, el ingreso de tabacos, el caudal de familias y poblaciones, el de fábrica de cuarteles, y el de atrasados, que examinaremos después.

A continuación aparecen una serie de ramos denominados "fijos". Son aquéllos cuya cobranza se basaba en la costumbre, y que prácticamente se recibieron en toda la etapa estudiada, aunque hay desde luego entre ellos algunos que 
se crearon en esta época. Se encuentran en este grupo los impuestos establecidos sobre el comercio (almojarifazgo, armada, alcabala de viento, arqueo de einbarcaciones, aguada, muelle y seis por ciento de embarcaciones), los derechos de esclavos, comisos, anata de mercedes, venta, renuncia, y arrendamiento de oficios, papel sellado, penas de cámara, extraordinario, bulas, diezmos, novenos, impuesto sobre el ganado, montepíos, depósitos, sal, carcelaje de negros, y el producto del arrendamiento de los solares del Rey.

Por último, existen en las Reales Cajas de Santo Domingo una serie de ramos denominados "casuales", que no ingresaban como norma en la Real Contaduría, pero que lo hacen en ocasiones por causas excepcionales, y entre los cuales nos encontramos con el de alcabala de tierra por las causas que explicaremos más adelante, la cuarta arzobispal, el expolio, el producto de las vacantes mayores y menores, realengos, caudal de pesetas, etc.

\section{El SITUADO}

Como ya hemos señalado, las Reales Cajas de Santo Domingo no contaban con recursos suficientes para atender a sus obligaciones, por lo que, lo mismo que ocurrió con las de otros lugares de América, tuvo que recibir ayuda del exterior. Sus necesidades eran financiadas por otras colonias más favorecidas por la fortuna.

En un principio, la situación asignada a Santo Domingo, junto con la de Puerto Rico, estaba consignada en las Reales Cajas de Panamá. Pero a partir de 1683, y debido a la poca puntualidad con que el dinero del Itsmo llegaba a la Española por falta de embarcaciones que navegasen entre ambas colonias, "he resuelto, a consulta de mi Consejo de las Indias, mudar la consignación de estos dos situados de las caxas de Panamá a las de esa ciudad de Méjico". ${ }^{26}$

\footnotetext{
26 R. C. fechada en Madrid el 27 de julio de 1683 y dirigida al virrey de Nueva España, comunicándole quedar al cargo de las Reales Cajas de México, los situados correspondientes a Santo Domingo y Puerto Rico. A.G.I., Santo Domingo, 1.055 .
} 
El dinero de la situación estaba destinado a pagar los salarios del gobernador, funcionarios de la Audiencia, plana mayor de la plaza, y las tropas. A causa de ello, su cuantía debió variar a lo largo de la segunda mitad del siglo XVIII, por ser cada vez más numerosa la guarnición de la isla.

No sabemos a cuanto ascendió esta asignación desde I754 a I 770, pero en esta última fecha se reguló en 2.I99.I42 reales y dos maravedíes, ${ }^{27}$ aunque en esta cifra estaban incluidos los caudales que llegaban a la isla con el situado, pero que no correspondían exactamente a él, para la compra de tabacos por cuenta del Rey, el pago de deudas atrasadas, etc., ya que solamente en contadas ocasiones, y siempre cuando el año anterior había faltado, el situado de Santo Domingo superó los dos millones de reales.

Es muy difícil por ello saber la cantidad fijada para la situación dominicana, pero dado que contamos con los libros de las Cajas Reales relativos a los 2i años y medio señalados, podemos intentar averiguar la que de hecho ingresó, que es lo que realmente interesa a efectos de la economía isleña.

\section{Cargo de Situación de las Reales Cajas de Santo Domingo, I-I-I754 A 3I-6-I775 ${ }^{28}$}

\section{Períodos}

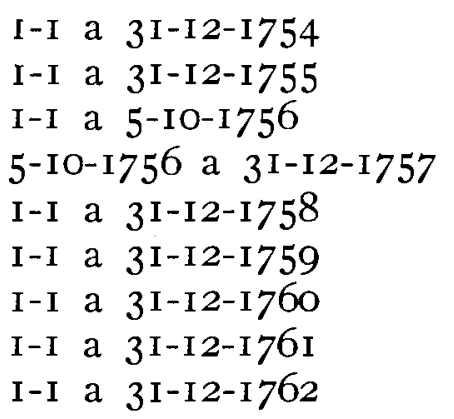

\section{Reales}

$$
\text { I.422.035 }
$$$$
\text { I. } 156.289
$$$$
\text { I.4I9. I09 }
$$$$
977.761
$$$$
\text { I.323.705 }
$$$$
\text { I. } 204.148
$$$$
\text { I.231.902 }
$$$$
1.424 .278
$$$$
\text { I. } 45 \mathrm{I} .242
$$

Maravedies

I I

4

I 4

I 7

I 2

4

25

26

27 Carta del virrey de Nueva España de 27 de mayo de 1796, informando a la Corte de los aumentos experimentados por el situado que se remitía a Santo Domingo. A.G.I., Santo Domingo, 1.033.

28 Ibídem, nota 23. 
Periodos

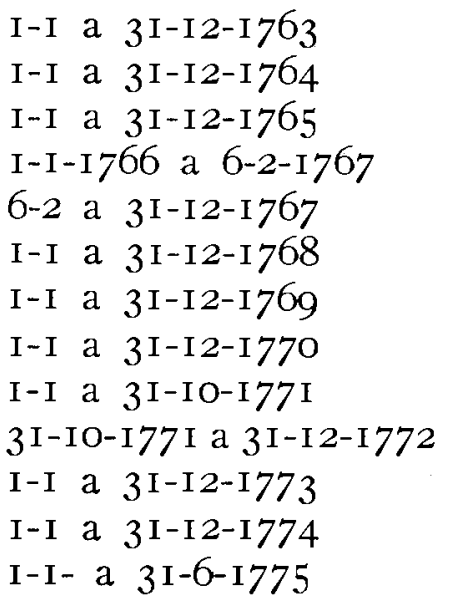

I-I a 3I-I2-I763

I-I a 3I-I2-I 764

I-I a 3I-I 2-I765

I-I-I 766 a 6-2-I767

6-2 a 3I-I 2-I 767

I-I a 3I-I 2-I 768

Total :
Reales

I.473.7 IO

I.3 17.297

I. 600.000

I.753.OI 2

32.000

$2.53^{2.400}$

I. 37 I. 286

2.517 .777

I. $528.49 \mathrm{I}$

I. 57 I. 578

I. $482 . \mathrm{I} 8 \mathrm{I}$

I 2

23

26

23

$3^{2}$

20

28

Resumiendo en quinquenios, el promedio anual sería el siguiente:

Periodos

$$
\begin{aligned}
& 1-1-1754 \text { a } 31-12-1758 \\
& \text { I-I I 759 a } 31-12-1763 \\
& 1-1-1764 \text { a } 3 \text { I-I } 2-I 768 \\
& 1-1-1769 \text { a } 3 \text { I-I } 2-I 773
\end{aligned}
$$

\begin{tabular}{|c|c|c|}
\hline 6.298 .900 & 24 & I. 259.780 \\
\hline 6.785 .282 & 4 & I.357.056 \\
\hline $7.234 .7 \mathrm{IO}$ & I & I.446.942 \\
\hline $6.989 . \mathrm{I} 34$ & I 3 & I.397.826 \\
\hline .308 .0 & 8 & I. 365. \\
\hline
\end{tabular}

Total :
Valor total Promedio anual Reales Marav. Reales

Así pues, el situado en estos 20 años no sufrió gran variación, oscilandaentre I.250.000 reales, y el millón y medio aproximadamente, cantidad que posteriormente al parecer aumentó, pues en un estado de 1.778 sobre la distribución que debía de hacerse de la situación que cada año se enviaba desde México, aparece la cifra de 201.597 pesos, tres reales y 18

29 Ibídem. 
maravedíes, es decir, I.61 2.782 reales y 18 maravedíes, distribuidos según se observa en el esquema adjunto:

Situación. - Importe total de lo que viene: 201.597 pesos, 3 reales, 18 maravedíes, cuya distribución ha de ser la siguiente:

- Al presidente, gobernador y capitán general.

Pesos Reales Marav.

- Al cabo subalterno y teniente del Rey.

$6.893 \quad 3 \quad 2$

3.000

- A cinco ministros togados de la Audiencia.

- Al alcalde mayor de Santiago.

- A un ingeniero segundo.

- Al batallón fijo y su plana mayor.

- Al estado mayor de la plaza con agregación del cuerpo de inválidos.

- A la compañía de artilleros.

- Al estado mayor, oficiales y demás que tienen sus sueldos en las 6 compañías de caballería de milicias regladas.

$\begin{array}{rrr}11.029 & 3 & \text { IO } \\ 687 & 4 & \\ \mathrm{I} .500 & & \end{array}$

$122.524 \quad$ I $\quad 6$

14.400

9.886

9.744

- Al estado mayor, oficiales y demás que tienen sus sueldos en las compañías de milicias de infantería.

- A los volantes del resguardo de la frontera.

- A las i I raciones de caballos de los oficiales de la frontera.

$$
\text { Total: } \overline{201.597} \quad 3 \quad 18^{30}
$$

30 Santo Domingo, 27 de julio de 1778. Ramos consignados en las Reales Cajas de México, que se remiten a Santo Domingo para cubrir las atenciones de cada año. A.G.I. Santo Domingo, 1.044 . 
Como ya hemos señalado, y a pesar de que en los 20 años indicados los situados parecen llegar a Santo Domingo con cierta regularidad, no siempre ocurrió, así.

Por ejemplo, el 20 de abril de $\mathbf{I} 756$ llegaron a la Española 154.585 pesos, un tomín y cinco gramos remitidos por el virrey de Nueva España, cantidad que debería servir "para pagar un año de sueldo a esta guarnición, desde fin de marzo de mil setecientos cinquenta y tres, hasta abril de cinquenta y quatro", ${ }^{31}$ con lo que el atraso era bastante considerable, sobre todo por lo que se refiere al pago de la tropa.

Como ya ha quedado indicado, el situado representaba más del $60 \%$ del total de los ingresos de las Reales Cajas de Santo Domingo, y la impuntualidad en su remisión desde México hizo constantes las protestas de los gobernadores dominicanos, y en consecuencia, las reales órdenes dirigidas al virrey de Nueva Espafia para que los enviara con urgencia a la Espafiola. ${ }^{32}$

\section{INGRESO DE TABACOS}

Como ya hemos señalado en el capítulo referente a la agricultura, en 1763 el entonces gobernador de Santo Domingo, don Manuel de Azlor, aprovechando la toma de la Habana por los ingleses, remitió a Espafia un cargamento de tabaco dominicano, para intentar que la Corona comprase todo el que la isla pudiera producir. ${ }^{33}$

El tabaco fue reconocido por los prácticos de las Rea-

31 Carta del gobernador de Santo Domingo don Francisco Rubio y Peñaaranda. dando cuenta a la Corte de la llegada a la bahía de Ocoa de la fragata La Flecha, con los caudales remitidos desde México. A.G.I., Santo Domingo, 1.092.

32 R. O. de tres de diciembre de 1787 dirigida al virrey de Nueva España, manifestándole que a pesar de las Redes Órdenes de doce de enero y 16 de junio de 1784 para que enviase a Santo Domingo los situados atrasados, éstos no habían llegado. A.G.I., Santo Domingo, 947.

33 Carta del gobernador don Manuel de Azlor de 6 de febrero de 1763, informana la Metrópoli sobre el cultivo tabaquero en Santo Domingo. A.G.I., Indiferente General, 1.745 . 
les Fábricas de Sevilla, y tras su dictamen, a la Corte le pareció bien que todos los años se transportaran remesas de este producto desde aquella tierra a España. Con este fin, se ordenó al virrey de México que mandase a Santo Domingo con el situado de cada año 25.000 pesos más, que estarían dedicados a la compra de tabaco. Al mismo tiempo, se previno también la creación de una factoría que se encargara de su recolección. ${ }^{34}$

Los primeros 25.000 pesos (200.000 reales) llegaron de México con la situación correspondiente a 1.765, aunque en las cuentas de las Cajas Reales no constan hasta el siguiente año de $1766 .{ }^{35}$

A partir de entonces este caudal llegará con regularidad a Santo Domingo, en algunos casos en cuantía mayor a la indicada, tal y como observamos en el siguiente cuadro:

\section{Periodos}

$$
\begin{aligned}
& \text { I-I a 3I-I 2-I 765 } \\
& \text { I-I-I766 a 6-2-I767 } \\
& \text { 6-2 a 3I-I 2-I } 767 \\
& \text { I-I a 3I-I 2-I } 768 \\
& I-I \text { a 3I-I 2-I } 669 \\
& \text { I-I a 3I-I 2-I } 770 \\
& \text { I-I a 3I-IO-I 77I } \\
& \text { 3I-IO-I77I a 3I-I2-I772 } \\
& \text { I-I- a 3I-I 2-I 773 } \\
& \text { I-I a 3I-I2-I } 774
\end{aligned}
$$

\section{Valor en reales}

$$
\begin{array}{r}
400.000 \\
400.000 \\
1.164 .606 \\
400.000 \\
200.000 \\
200.000 \\
600.000
\end{array}
$$$$
\text { Total : } \quad 3.364 .606^{36}
$$

Resumiendo en períodos de cinco años, el promedio anual sería superior a los 25.000 pesos que se ordenaron:

34 Instrucciones formadas el 11 de octubre de 1763, para la creación de una Factoría de Tabacos en Santo Domingo. A.G.I., Santo Domingo, 1.055.

35 Carta del gobernador don Manuel de Azlor de 15 de noviembre de 1765, dando cuenta a la Corte de la llegada a la isla de los primeros 25.000 pesos remitidos desde México para la compra de tabaco. A.G.I., Santo Domingo, 1.055.

36 Ibídem, nota 23. 


\begin{tabular}{|c|c|c|}
\hline Periodos & Reales & Reales \\
\hline I-I-I 765 a 3 I-I $2-I, 769$ & I.964.606 & 392.921 \\
\hline I-I-I 770 a 3 I-I2-I 774 & I. 400.000 & 280.000 \\
\hline Total: & 3.364 .606 & $336.460^{37}$ \\
\hline
\end{tabular}

Sin embargo, en I775, una real orden instaba al gobernador de Santo Domingo a la reducción de las siembras de tabaco en aquella isla al no necesitarse tanto en las Reales Fábricas de Sevilla, ${ }^{38}$ por lo que es de suponer que, a partir de aquel año, las remesas de caudales para este fin se limitarían a los 25.000 pesos indicados, y así, los estados generales de las entradas y salidas de dinero de las Cajas Reales de la Española en I789, nos dan una cantidad de 266.000 reales, ${ }^{39}$ que al año siguiente se ve reducida a $133.333,{ }^{40}$ es decir, 200.000 reales al año -25.000 pesos-, e igual cifra se recibe en $1792^{41}$ y en 1794 .

Hemos de decir por último, que aunque el ingreso destinado a la compra de tabaco podría ser considerado por algunos como una entrada no efectiva, hemos creído mejor englobarlo en las entradas reales, ya que como veremos al hablar de las datas, las relativas a los gastos del tabaco fueron en todo momento considerablemente inferiores a sus correspondientes ingresos, dejando siempre un remanente, que fue utilizado en la Real Contaduría para satisfacer sus necesidades más inmediatas.

\footnotetext{
37 Ibídem.

38 R. O. fechada en Aranjuez el 21 de abril de 1775, previniendo al gobernader de Santo Domingo se redujesen las siembras de tabaco en aquella isla, a 12.000 arrobas al año. A.G.I., Santo Domingo, 1.055 .

39 Entrada y salida de caud'ales en las Cajas Reales de Santo Domingo en 1789. A.G.I., Santo Domingo, 953.

40 Idem en 1790. A.G.I., Santo Domingo, 954.

41 Idem en 1792. A.G.I. Santo Domingo, 956.

42 Idem en 1794. A.G.I., Santo Domingo, 958.
} 


\section{Caudal de familias y poblaciones}

En el siglo XVII, la despoblación del Santo Domingo español fue uno de los mayores problemas con que tuvieron que enfrentarse las autoridades de la isla. Y a este mal intentó ponerse remedio durante el siglo XVIII, sobre todo en su segunda mitad, fundando nuevas poblaciones y fomentando la inmigración de colonos procedentes de las Canarias. Con este motivo se envió una real cédula al juez del comercio de las islas Canarias, en la que se le ordenaba que cuidara de que en los navíos que se despachaban desde allí a las Antillas, fuesen enviadas a Santo Domingo, cada año, 50 familias de a cinco personas. ${ }^{43}$

Las Cajas Reales de Santo Domingo no contaban con recursos suficientes para hacer frente al plan de repoblación, y en consecuencia, se remitió otra real cédula al virrey de Nueva España, ordenándole destinara a Santo Domingo con la situación correspondiente a cada año I6.000 pesos más, para el establecimiento y manutención de 50 familias pobladoras. ${ }^{44}$

El dinero procedente de México debería servir para el mantenimiento de los colonos durante el primer año, y para las costos derivados de las nuevas fundaciones, repartos de tierras, compra de semillas y animales, etc.

En los 20 años que hemos podido examinar, ingresaron en las Cajas Reales con este fin I.777.845 reales y 20 maravedíes. Estas entradas se produjeron todas antes de 1769, fecha en que aproximadamente finalizaron los nuevos establecimientos, aunque desconocemos si este dinero dejó de llegar por este motivo, por orden de la Corte, o por cualquier otra causa.

43 R. C. fechada en el Buen Retiro el uno de diciembre de 1741, y dirigida a don Domingo de la Guerra, Juez de comercio de las islas Canarias, ordenándole la remisión a Santo Domingo de 50 familias pobladoras cada año. A.G.I., Santo Domingo, 1.020 .

44 R. C. fechada en Madrid el 6 de diciembre de 1741 dirigida al virrey de Nueva España, ordenándole remitiese dinero a Santo Domingo para el sostenimiento de las familias pobladoras. A.G.I., Indiferente General, 3.093. 


\section{Caudal ingresado en las R. C. De Santo Domingo PARA FAMILIAS ${ }^{45}$}

Periodos

$I-I$ a 3 I-I 2-I 754

I-I a 3 I-I $2-I 755$

I-I a 5-IO-I 756

5-10-I756 a $3^{\text {I-12-I757 }}$

I-I a $3 \mathrm{I}-\mathrm{I} 2-\mathrm{I} 758$

I-I a 3I-I2-I759

$I-I$ a $3 I-I 2-I 760$

I-I a 3I-I2-I $76 \mathrm{I}$

$I-I$ a $3 I-I 2-I 762$

$I-I$ a $3 I-I 2-I 763$

I-I a 3I-I 2-I 764

I-I a 3I-I 2-I 765

I-I-I 766 a 6-2-I767

6-2 a 3I-I2-I767

I-I a 3I-I 2-I 768
Reales

2I 4 . I 90

-

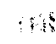

332.278

$265 \cdot 39$ I

92.407

538.560

68.608

80

I 51.9 I 8

2.618

I I0.023

I 7 I

$\mathrm{I} .600$

\section{Total: $\quad$ I.777.845}

Maravedies

6

6

$3 \mathrm{I}$

6

5

Resumiendo en quinquenios, el promedio anual sería:

Periodos

I-I-I754 a 3 I-I $2-I 758$
I-I-I 759 a $31-12-1763$
$1-1-1764$ a $31-12-1768$

Valor total Promedio anual Reales Marav. Reales

$$
\text { Total : } \quad \overline{\mathrm{I} .777 .845} \quad \overline{20} \quad \overline{\mathrm{II}^{2} 8.523^{46}}
$$

Con ello, no se alcanzó ningún año la cifra de I6.000 pesos (I28.000 reales) ordenados al virrey de México, pero, gracias a este dinero. pudo llevarse a cabo la fundación de varias poblaciones como Montecristi, las Caobas, San Mi-

45 ibídem, nota 23.

46 ibídem. 
guel de la Atalaya, etc., y de las que ya hemos hablado con anterioridad.

Cargo de fábrica de CUarteles

Este ingreso debía venir también de México con el situado, para la realización de las obras de fortificación de la isla. Pero desde I754 a I775, sólo llegaron a Santo Domingo con este fin 191.848 reales, 188.280 en 1758 , y 3.568 en I $764,{ }^{47}$ con lo que las necesidades de este ramo se cubrieron a base de préstamos, o del apartado correspondiente a la Real Hacienda en general.

Cargo de atrasados

También el dinero correspondiente a este ramo venía de México con el situado.

Estaba destinado al pago del $6 \%$ de las deudas contraídas en las décadas anteriores ${ }^{48}$ en los veinte años estudiados. Su llegada se produjo a partir de 1766 en la siguiente forma:

\section{Periodos}

$1-1-1766$ a $6-2-1767$

$6-2$ a $31-12-1767$

I-I a $31-12-1768$

I-I a 31-12-1769

I-I a $3 \mathrm{I}-\mathrm{I} 2-\mathrm{I} 77 \mathrm{O}$

I-I a 3 I-IO-I 77 I

3I-IO-I77I a 3I-I2-I 772

I-I a $3 I-I 2-I 773$

I-I a 3I-I 2-I774

I-I a 31-6-1775
Reales

507.563

440.278

692.686

440.278

344.733

220. I 39

220. I 39

Total :

2.865 .818

Maravedies

I7

I7

I7

27

9

$19^{49}$

El promedio anual de estos ingresos sería el siguiente:

47 Ibidem.

48 Ibídem, nota 30.

49 Ibídem, nota 23. 


\begin{tabular}{|c|c|c|c|}
\hline Períodos & Reales & Larav. & Reales \\
\hline I-I-I 766 a $3 \mathrm{I}-\mathrm{I} 2-\mathrm{I} 770$ & I. 640.528 & & 328. 105 \\
\hline I-I-I77I a 3I-6-I775 & I. 225.290 & I9 & 245.058 \\
\hline Total: & $2.865 .8 \mathrm{I} 8$ & I9 & $286.5^{8} \mathrm{I}^{50}$ \\
\hline
\end{tabular}

Esta entrada, igual que la del caudal de familias y la de tabacos, no constituye un ramo fijo de la Real Hacienda, y su dinero tendría como fin el pago de unas deudas determinadas, por lo que su función en las Reales Cajas sería simplemente de paso.

Pero al igual que ocurre con la de tabacos, las datas son inferiores a los ingresos, y sus recursos fueron utilizados a veces, con otros fines que aquéllos para los que se creó.

\section{Cargo de Almojarifazgo}

Es, después del situado, el ramo fijo que más ingresos proporcionó a la Real Hacienda de Santo Domingo.

El almojarifazgo gravaba todas las mercancías que entraban y salían de Santo Domingo, aunque su cuantía varió a lo largo de la segunda mitad del siglo, siendo también diferente según se tratara de géneros españoles o extranjeros.

Así, por lo que se refiere al impuesto sobre las importaciones, a principios de la etapa estudiada era de un cinco por ciento sobre los productos traídos de las colonias españolas, un diez sobre los de Europa y las colonias extranjeras, un $20 \%$ sobre la harina, y un gravamen especial de 22,5 reales por cada pipa de vino.

A partir de la promulgación del decreto de Libre Comercio de España con las Antillas, esta situación cambiará. Desde I769, fecha en que comienza a ser efectivo el Decreto en Santo Domingo, el impuesto quedará fijado en un ${ }_{5}$ ó $20 \%$ sobre los productos extranjeros, y un $5 \%$ sobre los productos españoles no procedentes de España o de las islas comprendidas en el Decreto, que quedaron sujetos a un gra-

50 Ibídem. 
vamen especial independiente de los existentes hasta entonces.

Por lo que respecta al impuesto sobre las exportaciones, desde I750 a I769 fue de un 2,5\% sobre todas las mercancías que salieran de la isla cualquiera que fuera su destino, y a partir de ese año, por la entrada en vigor del Decreto de Libre Comercio con las Antillas ya señalado, esa cantidad se cobró sólo a las que partían hacia las colonias extranjeras. ${ }^{51}$

Cargo del Real Derecho de Almojarifazgo de las Cajas de Santo Domingo ${ }^{52}$

\section{Períodos}

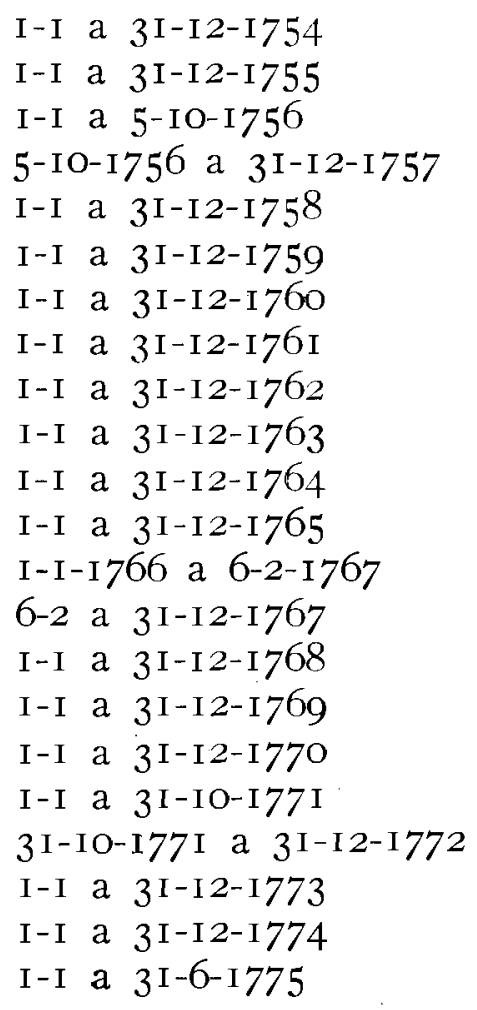

Importaciones Reales-Marav.$$
46.2427
$$$$
50.948 \quad 32
$$$$
23.025 \quad 5
$$$$
46.563 \text { I } 4
$$$$
42.498 \quad 27
$$$$
38.769 \quad 31
$$$$
62.676 \text { I } 3
$$$$
29.75 \text { I I } 2
$$$$
32.006 \quad \text { I4 }
$$$$
63.743 \quad 6
$$$$
79.1072 \mathrm{I}
$$$$
67.038 \quad 14
$$$$
75.524 \quad 25
$$$$
47.978 \quad 28
$$$$
42.37 \text { I } 18
$$$$
43.251 \quad 3
$$$$
67.010 \quad 21
$$$$
52.015 \quad \text { I } 5
$$$$
21.554 \quad 15
$$$$
27.429 \quad \text { I } 7
$$$$
28.717 \quad 8
$$$$
\text { I2.686 I }
$$

Exportaciones Reales-Marav.

$$
\text { Total: } \overline{\text { I.000.9I I }} \frac{7}{7}
$$

51 Ibídem.

52 Ibidem. 
Resumiendo en períodos de cinco años, con excepción como siempre del último año y medio, el promedio anual del ingreso proporcionado por el real derecho de almojarifazgo de entrada sería el siguiente:

Períodos

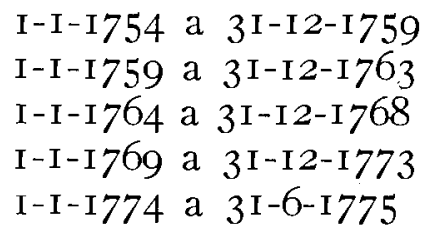

Total:
I. Totales Promedio anual Reales-Marav. Reales

\begin{tabular}{rr}
209.278 & 17 \\
226.947 & 8 \\
312.021 & 4 \\
211.261 & 3 \\
41.403 & 9 \\
\hline 1.000 .911 & -7
\end{tabular}

41.855

$45 \cdot 389$

62.404

42.252

27.602

$46.554 .^{53}$

Como fácilmente podemos apreciar, hay variaciones a lo largo de la segunda mitad del siglo por lo que se refiere al almojarifazgo impuesto sobre las importaciones. En el tercer periodo señalado, hay un incremento considerable por las causas ya explicadas al hablar del comercio, pero en el último, y aunque el tráfico comercial continúa siendo aproximadamente igual al anterior, la reducción de derechos marcada por el Decreto de Libre Comercio con las Antillas de i 765 , rebaja de nuevo la cantidad a los promedios iniciales.

Por lo que respecta al almojarifazgo de salida, los promedios serían como sigue:

\section{Periodos}

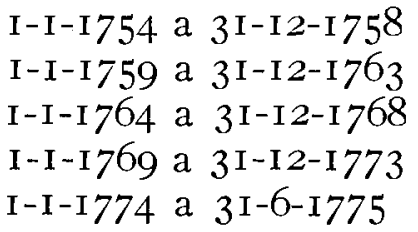

53 Ibídem.

54 Ibîđem.
I. Totales Promedio anual Reales-Marav. Reales

\begin{tabular}{rcc}
5.468 & $3^{2}$ & I.093 \\
7.364 & IO & I.472 \\
I 5.083 & I6 & 3.016 \\
3.373 & I 5 & 674 \\
1.476 & 27 & 984 \\
\hline 32.766 & 32 & I.524.
\end{tabular}


En este caso, las oscilaciones son parecidas a las experimentadas en el derecho de importación, aunque en el periodo que va desde 1773 a I775 la baja se hace notar aún con más fuerza, ya que la mayor parte de las exportaciones dominicanas iban dirigidas a las colonias españolas.

\section{Cargo del Real derecho de Armada}

Al igual que ocurre en el caso del almojarifazgo, también el derecho de armada experimenta variaciones a lo largo de la segunda mitad del siglo XVIII, y en concreto, en los 20 años de que tenemos noticias.

El derecho de armada de entrada gravaba todas las mercancias que llegaban a Santo Domingo, aunque la tarifa era bastante complicada. Se cobraban cuatro reales por cada mula o fanega de cacao, uno por cada botija de manteca o arroba de cerdo, un $2,5 \%$ sobre el vino, y un $0,5 \%$ sobre otros frutos.

A partir de 1769 los géneros extranjeros pagarán un $2 \%$ de su valor, quedando sujetos los españoles a una tarifa variable, aunque en general fue de un $0,5 \%$, mientras que las mercancías procedentes de España, Puerto Rico, Cuba, y la Margarita, quedaban exentas de esta imposición.

El derecho de armada de salida se regía también por normas variables, y también a partir de I769, se fijó en un $2 \%$ para los productos dirigidos a las colonias extranjeras.

Desde I754 al 3I de junio de I775, entraron en las Cajas Reales de Santo Domingo por este concepto las siguientes cantidades:

\begin{tabular}{lrrrr} 
& \multicolumn{2}{c}{$\begin{array}{l}\text { Importaciones } \\
\text { Reales-Marav. }\end{array}$} & \multicolumn{2}{c}{$\begin{array}{c}\text { Exportaciones } \\
\text { Reales-Marav. }\end{array}$} \\
I-I a 3I-I2-I754 & I5.O23 & I3 & 2.824 & IO \\
I-I a 3I-I2-I755 & I6.636 & 8 & I.42I & 5 \\
I-I a 5-IO-I756 & 6.180 & IO & 3.08 I & \\
5-IO-I756 a 3I-I2-I757 & I4.0I6 & 2 & 2.225 & I3 \\
I-I a 3I-I2-I758 & I6.724 & 3I & 349 & 9
\end{tabular}




\section{Períodos}

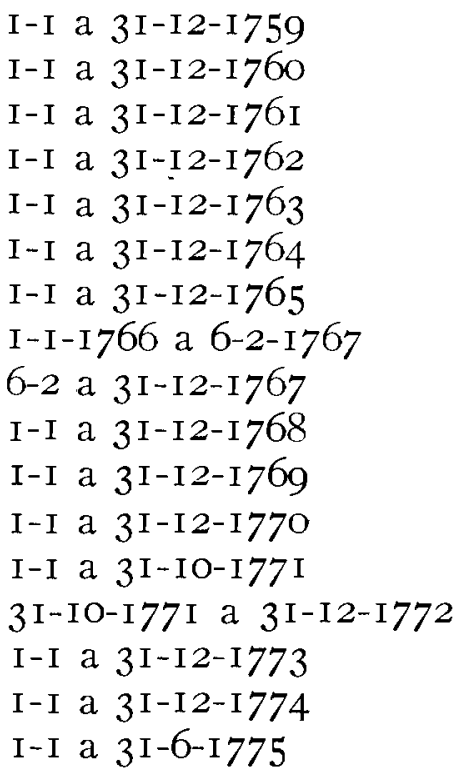

Importaciones Exportaciones Reales-Marav. Reales-Marav.

\begin{tabular}{|c|c|c|c|}
\hline $\mathrm{I} 2.82 \mathrm{O}$ & I 5 & I.297 & I 5 \\
\hline I6.576 & 30 & 1.507 & $2 \mathrm{I}$ \\
\hline 8.338 & I & I.079 & I \\
\hline 6.853 & 2 & 2.174 & I \\
\hline I 7.436 & 6 & 6.678 & I 3 \\
\hline I 7.877 & I I & I. 434 & I 8 \\
\hline I 4.127 & I 4 & 2.765 & I7 \\
\hline I $3.45^{\circ}$ & 6 & I. $33^{8}$ & I7 \\
\hline I I. 55 I & $3^{I}$ & I.I92 & 29 \\
\hline $8.34 \mathrm{I}$ & I9 & 965 & I 2 \\
\hline 6.795 & 9 & I 44 & \\
\hline I 4.047 & 7 & 1.709 & 23 \\
\hline I 3.274 & 23 & 872 & 8 \\
\hline $5 \cdot 392$ & I7 & I. 372 & I I \\
\hline I 2.403 & 3 & I.390 & 7 \\
\hline I I. 727 & IO & $\mathrm{I} .23 \mathrm{I}$ & 16 \\
\hline 6.329 & IO & $3^{I}$ & 5 \\
\hline 55.923 & 6 & 37.085 & I 3. \\
\hline
\end{tabular}

Resumiendo en periodos de cinco años, los promedios anuales del real derecho de armada de entrada en los 2 I,5 años examinados sería como sigue:

\begin{tabular}{|c|c|c|c|}
\hline Periodos & \multicolumn{2}{|c|}{$\begin{array}{c}\text { I. Totales } \\
\text { Reales-Marav. }\end{array}$} & $\begin{array}{l}\text { Promedio anual } \\
\text { Reales }\end{array}$ \\
\hline I-I-I 754 a 3 I-I 2-I 758 & 68.580 & 30 & I $3.7 \mathrm{I} 6$ \\
\hline I-I-I 759 a 3 I-I 2-I 763 & 62.024 & 20 & I 2.404 \\
\hline I-I-I 764 a 3I-I 2-I 768 & $65 \cdot 348$ & I 3 & I 3.069 \\
\hline I-I-I 769 a 3I-I $2-I 773$ & 51.912 & 25 & 10.382 \\
\hline I-I-I 774 a 3 I-6-I 775 & 18.056 & 20 & 12.037 \\
\hline Total: & & 6 & I $2.368 . .^{56}$ \\
\hline $\begin{array}{ll}55 & \text { Ibídem. } \\
56 & \text { Ibídem. }\end{array}$ & & & \\
\hline
\end{tabular}


Por lo que se refiere al derecho de armada de salida, exponemos a continuación los promedios, que al igual que los de entrada no ofrecen mucha variedad:

\begin{tabular}{|c|c|c|c|}
\hline Periodos & \multicolumn{2}{|c|}{ I. Totales } & $\begin{array}{c}\text { Promedio anual } \\
\text { Reales }\end{array}$ \\
\hline I-I-I 754 a 3 I-I 2-I758 & 9.901 & 3 & 1.980 \\
\hline I-I-I 759 a 3I-I 2-I763 & 12.736 & I7 & 2.547 \\
\hline I-I-I 764 a $31-12-1768$ & 7.696 & 25 & I.539 \\
\hline I-I-I 769 a 3 I-I 2-I 773 & $5 \cdot 488$ & I 5 & I.097 \\
\hline I-I-I 774 a 3 I-6-I 775 & I. 262 & $2 \mathrm{I}$ & $84 \mathrm{I}$ \\
\hline Total: & 37.085 & I 3 & $1.757 .^{57}$ \\
\hline
\end{tabular}

Cargo de Alcabala de viento

Este impuesto, gravaba todas las mercancías desembarcadas en Santo Domingo con un $2 \%$ de su valor total, y con un $4 \%$ la harina. Esta norma se mantuvo hasta I769, en que, por la causa que ya hemos señalado, se estableció el impuesto de un $4 \%$ sobre las mercancías extranjeras, y un $2 \%$ sobre las españolas, con las excepciones ya indicadas de las procedentes de España, Puerto Rico, Cuba, y la Margarita, que quedaron libres de esta imposición. Desde el primero de enero de I754 al 3I de junio de I775, entraron en las Cajas Reales de Santo Domingo por este concepto 345.447 reales y 14 maravedíes, cuya distribución aparece en el cuadro adjunto:

Periodos

I-I a 3I-I 2-I754

I-I a 3I-I 2-I 755

I-I a 5-IO-I 756

5-IO-I756 a 3I-I 2-I 757

I-I a $3 \mathrm{I}-\mathrm{I} 2-\mathrm{I} 75^{8}$

I-I a 3I-I 2-I759
Reales

I I. 823

I 5.132

6.176

I 2. I 35

I0. 514

I 1.589
Maravedies

13

I7

I 2

4

$3 \mathrm{I}$

57 Ibiđem. 


\begin{tabular}{|c|c|c|}
\hline Periodos & Reales & Maravedies \\
\hline I-I a 3I-I 2-I760 & I6. 156 & I6 \\
\hline I-I a 3I-I2-I76I & I3. I 32 & 8 \\
\hline I-I a $31-I 2-1762$ & 36.179 & \\
\hline I-I a 3 I-I2-I763 & 19.476 & 8 \\
\hline I-I a 3 I-I 2-I 764 & 23.497 & I3 \\
\hline I-I a 3 I-I $2-I 765$ & $25.09 \mathrm{I}$ & I7 \\
\hline I-I-I 766 a 6-2-I767 & 27.302 & 23 \\
\hline $6-2$ a 3 I-I $2-1767$ & 20.679 & $\mathrm{I}$ \\
\hline I-I a 3I-I2-I768 & I 4.794 & $3^{I}$ \\
\hline I-I a 3I-I 2-I 769 & I I.61 I & 28 \\
\hline I-I a $3^{I-I 2-I 770}$ & 19.020 & I \\
\hline I-I a 3 I-IO-I $77 \mathrm{I}$ & I 5.715 & $2 \mathrm{I}$ \\
\hline $3^{1-1 O-I 771}$ a 3 I-I 2-I 772 & 8.028 & 3 \\
\hline$I-1$ a $3 I-I 2-1773$ & 10.869 & 29 \\
\hline I-I a 3I-I 2-I 774 & I I.032 & 24 \\
\hline I-I a 3 I-6-I 775 & $5 \cdot 488$ & I 2 \\
\hline Total: & $345 \cdot 447$ & I $4 .{ }^{58}$ \\
\hline
\end{tabular}

Resumiendo en periodos de cinco años, y uno último de año y medio, los promedios anuales serían los siguientes: ${ }^{59}$

Períodos

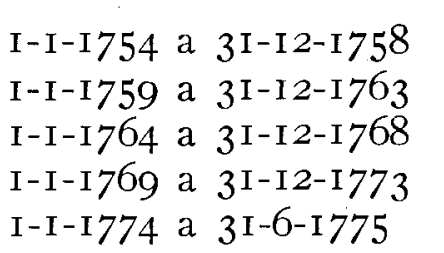

I-I-I 754 a 3 I-I $2-I 75^{8}$

I-I-I759 a $3 \mathrm{I}-12-\mathrm{I} 76_{3}$

I-I-I764 a 3 I-I $2-I 768$

I-I-I774 a 3I-6-I 775
I. Totales Reales-Marav.
Promedio anual Reales I I.I 56 19.306 22.273 I 3.049 I I.OI 4

$$
\begin{array}{llll}
\text { Total : } & \overline{345.447} & \mathbf{1 4} & \overline{\mathrm{I} 6.067}
\end{array}
$$

En esta ocasión los promedios varían considerablemente, siendo desde luego muy superiores en la época en que el tráfico comercial aumentó, para disminuir más tarde no $\begin{array}{ll}58 & \text { Ibídem. } \\ 59 & \text { Ibídem. }\end{array}$ 
por la reducción de aquél, sino por la rebaja en el derecho que se había de cobrar.

Cargo de Seis y Siete por ciento de embarcaciones

Con la aplicación en Santo Domingo del Decreto del Libre Comercio con las Antillas de I765, a partir de I769 dejaron de cobrarse los derechos de alcabala, almojarifazgo, y armada, a las embarcaciones que llegaban a la isla procedentes de España, Puerto Rico, Cuba, y la Margarita, y a las que salían de aquélla con destino a los mencionados lugares.

Todos estos aranceles fueron sustituidos por uno global, consistente en el cobro de un seis por ciento sobre los géneros españoles y un siete por ciento sobre los extranjeros.

Y desde I769 al 31 de junio de I775, los beneficios producidos por este impuesto fueron de 270.326 reales cinco maravedíes, como se observa en el estado adjunto:

\section{Periodos}

I-I a 3 I-I2-I769
I-I a 3 I-I2-I770
I-I a 3 I-IO-I77I
3I-IO-I77I a 3I-I 2-I 772
I-I a 3 I-I2-I773
I-I a 3I-I2-I774
I-I a 3I-6-I775

I-I a 3I-I 2-I 769

I-I a 3 I-I 2-I 770

1 31 a $3-10-177$

$3^{1-10-1771}$ a $3^{1-12-1772}$

I-I a $3 \mathrm{I}-\mathrm{I} 2-\mathrm{I} 773$

I-I a 3I-6-I 775
Importaciones Exportaciones Reales-Marav. Reales-Marav.

Total:

$\begin{array}{rrrr}3.688 & 33 & 1.384 & 30 \\ 9.286 & \mathrm{I} & 7 \mathrm{O} 5 & 29 \\ \mathrm{I} 4.097 & 9 & 4.740 & 23 \\ 24.215 & 2 \mathrm{I} & 9.782 & 28 \\ 79.599 & 2 \mathrm{O} & 3.94 \mathrm{I} & 25 \\ 5 \mathrm{I} .002 & \mathrm{I} 2 & 6.8 \mathrm{I} 5 & \mathrm{I} 7 \\ 38.999 & 23 & 22.085 & 6 \\ & - & & -\end{array}$

El promedio anual de estos ingresos sería así de 4 I.588 reales, aunque en realidad varió bastante en los seis años señalados, pasando de los 5.052 reales de 1769 a los 83.540 de 1773 por ejemplo, pues a medida que el nuevo sistema se iba implantando, aumentaba el comercio con los lugares comprendidos en el Decreto.

60 Cuentas de las Cajas Reales de Santo Domingo desde 1769 a 1775 . A.G.I. Santo Domingo, 1.050 y 1.051 . 
Cargo de Arqueo o Media Anata de embarcaciones

Era éste un impuesto pagado por todos los navíos que llegaban al puerto de Santo Domingo, a razón de un ducado por cada cinco toneladas de peso más un $18 \%$ de fletes y conducción de licencias.

Desde el primero de enero de I754 al 3I de junio de I775, proporcionó a las Reales Cajas de Santo Domingo unos ingresos de 42.067 reales como veremos a continuación:

\section{Periodos}

I-I a 3I-I 2-I 754

I-I a 3I-I 2-I 755

I-I a $5^{-10-1756}$

5-IO-I 756 a 3 I-I 2-I 757

I-I a 3 I-I $2-1758$

I-I a 3 I-I $2-I 759$

I-I a $3 I-I 2-I 760$

I-I a 3I-I2-I 76 I

I-I a 3 I-I $2-I 762$

I-I a $31-12-I 763$

I-I a 3I-I 2-I 764

I-I a 3 I-I 2-I 765

I-I-I 766 a 6-2-I 767

6-2 a 3I-I2-I 767

I-I a 3I-I 2-I 768

I-I a $3 I-I 2-I 769$

I-I a 3I-I 2-I 770

I-I a 3I-IO-I 77 I

3I-IO-I77I a 3I-I 2-I 772

I-I a 3I-I 2-I 773

I-I a 3I-I 2-I 774

I-I a 3I-6-I775
Reales

2.177

2.050

I. 585

I.8I9

$8 \mathrm{I} 4$

I. 227

I.805

I.5 I 5

605

3.1 42

3.992

3. I 39

4.645

2.1 77

I.834

I.958

I. 784

I. 447

I.I32

I. 387

I. 590

234

Maravedies

I 2

I4

I6

3 I

I4

23

30

I2

33

33

I 5

20

I9

I3

8

4

2

7

Total: $\overline{42.067}$

61 Ibídem, nota 23. 
Así, el promedio anual de este ingreso sería de $\mathbf{1 . 9 5 6}$ reales, como se observa en el esquema siguiente:

Periodos

I-I-I 754 a $3^{\mathrm{I}-\mathrm{I} 2-\mathrm{I} 75^{8}}$

I-I-I759 a $3^{1-12-1763}$

I-I-I 764 a 3 I-I $2-I 768$

I-I-I 769 a 3 I-I $2-\mathrm{I} 773$

I-I-I 774 a $3 I-6-I 775$

\section{Totales}

Reales-Marav.

$8.447 \quad 5$

8.296 I I

I $5.789 \quad 33$

$7.709 \quad$ I0

I.824 9

$\overline{42.067}$ -
Promedio anual

Reales

$$
\text { I.689 }
$$

3. I 57

I. $54 \mathrm{I}$

I.216

\section{Total :}

$1.956^{62}$

\section{Cargo del muelle}

Este impuesto fue establecido en i 763 por el entonces gobernador de la isla, don Manuel de Azlor, con el fin de construir un nuevo muelle en el puerto de Santo Domingo, pagado por todos los navíos que llegaban a aquél.

Para esta obra, Azlor decidió cobrar a los que más beneficiados se verían por ella, los dueños o capitanes de las embarcaciones, estableciéndose una tarifa variable según el calibre de cada barco.

Las balandras y goletas pagaban tres pesos, cuatro los bergantines, paquebotes, gabarras y saetías, y seis las fragatas. $^{63}$

Desde 1763 , año en que este derecho comenzó a cobrarse, hasta el 31 de junio de I775, entraron en las Reales Cajas de Santo Domingo procedentes de él I 7.0I 3 reales en la forma siguiente:

62 Ibídem.

63 Madrid, 2 de abril de 1770. Dictamen del fiscal del Consejo de Indias, sobre el nuevo impuesto del Muelle establecido en Santo Domingo por su gobernador don Manue! de Azlor. A.G.I. Santo Domingo, 980. 


\begin{tabular}{|c|c|c|}
\hline Períodos & $\begin{array}{l}\text { Ingresos en } \\
\quad \text { Reales }\end{array}$ & $\begin{array}{l}\text { Promedio anual } \\
\text { Reales }\end{array}$ \\
\hline I-I-I763 a 3I-I2-I 765 & 8.549 & 2.849 \\
\hline I-I-I766 a 3I-I2-I768 & 2.672 & 890 \\
\hline I-I-I769 a 3I-IO-I77I & I. 664 & 554 \\
\hline 3I-IO-I77I a 3I-6-I775 & 4. 128 & I.I 79 \\
\hline Tota & I7.0I 3 & I.36I. ${ }^{64}$ \\
\hline
\end{tabular}

Cargo de Aguada

Procedía este ingreso, del derecho de ocho reales cobrado a cada uno de los navíos que hacían aguada en Santo Domingo. En teoría su producto estaba dedicado a los gastos ocasionados por el cuidado de la fuente pública, pero en realidad éstos fueron considerablemente inferiores a los ingresos.

Desde el primero de enero de I754 al 3 I de junio de I775, entraron en las Cajas Reales de Santo Domingo por este motivo $4.75^{2}$ reales, en la forma siguiente:

\section{Períodos}

$$
\begin{aligned}
& \text { I-I-I } 754 \text { a } 3 \text { I-I 2-I 758 } \\
& \text { I-I-I } 759 \text { a } 3 \text { I-I 2-I } 763 \\
& \text { I-I-I } 764 \text { a } 3^{I-I 2-I ~} 768 \\
& \text { I-I-I } 769 \text { a } 3 \text { I-I 2-I } 773 \\
& \text { I-I-I } 774 \text { a } 3 \text { I-6-I } 775
\end{aligned}
$$

\section{Totales} Reales

$$
\begin{array}{r}
\text { I. I } 52 \\
\text { I.036 } \\
\text { I. } 364 \\
792 \\
408
\end{array}
$$

Promedio anual Reales

\section{Total: $\quad 4.752$}

$$
230
$$$$
207
$$$$
272
$$$$
158
$$$$
272
$$

$$
22 \text { I. }^{65}
$$

64 Cuentas de las Cajas Reales de Santo Domingo desde 1763 a 1775. A.G.I. Santo Domingo, $1.048,1.049,1.050$ y 1.051 .

65 Ibídem, nota 23 
Cargo de derecho de esclayos

Procede esta entrada, de los derechos pagados por todos aquellos que introducían o sacaban esclavos de la isla. Por cada negro esclavo que su dueño sacaba desde Santo Domingo a cualquier otra colonia española, abonaba a la Real Hacienda cinco reales y medio.

Por otra parte, por cada esclavo sellado en la Real Contaduría, requisito indispensable durante mucho tiempo para que ese esclavo fuera considerado de entrada legal, los dueños tenían que pagar un derecho a las Cajas Reales, a razón de 266 reales 23 maravedíes "la pieza", aunque como es sabido un negro no equivalía necesariamente a una pie$z a$, dependiendo de la edad y precio en que se valoraba.

Los ingresos procedentes de este arancel, se deben tanto a los esclavos importados legalmente, como a aquéllos cuya entrada había sido ilegal, pero que tiempo después, al concederse un indulto, los dueños los presentaban en la Real Contaduría para su sello. ${ }^{66}$

Desde I754 a I775 entraron en la Real Hacienda por la entrada y salida de negros, 464.097 reales 24 maravedíes, en su mayor parte pertenecientes a la importación de esclavos, como se observa en el cuadro adjunto:

\section{Períodos}

$$
\begin{aligned}
& \text { I-I a } 3 \text { I-I 2-I754 } \\
& \text { I-I a 3I-I2-I755 } \\
& \text { I-I a 5-IO-I } 756 \\
& \text { 5-IO-I } 756 \text { a } 3^{\mathrm{I}-\mathrm{I} 2-\mathrm{I} 757} \\
& \text { I-I a 3I-I2-I758 } \\
& \text { I-I a 3I-I2-I759 } \\
& \text { I-I a 3I-I2-I } 760
\end{aligned}
$$

Entrada de negros Salida de negros Reales-Marav. Reales-Marav.

$\begin{array}{rrrr}3.000 & & 33 & \\ 10.020 & 4 & \text { IO4 } & \text { I7 } \\ 8.866 & 22 & 27 & \text { I7 } \\ 8.933 & \text { I I } & 94 & \\ & & 66 & \\ & & 38 & \text { I7 } \\ 2.710 & 27 & 16 & 17\end{array}$


Periodos

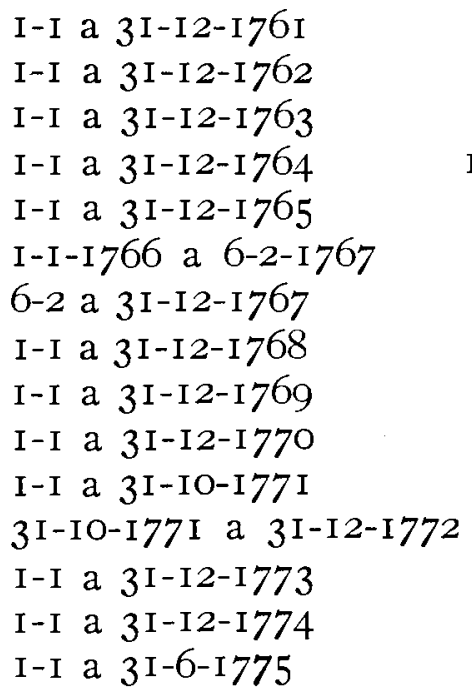

Entrada de negros Salida de negros Reales-Marav. Reales-Marav. 


\section{Cargo de Comisos}

Proviene este ingreso, del remate de los efectos apresados como procedentes del tráfico ilegal, y desde I754 al $3 \mathrm{I}$ de junio de 1775 , produjo a la Real Hacienda más de medio millón de reales distribuidos en los siguientes períodos:

Periodos

$$
\begin{aligned}
& \text { I-I-I754 a } 3 \text { I-I 2-I } 758 \\
& \text { I-I-I759 a } 3 \text { I-I 2-I } 763 \\
& \text { I-I-I764 a } 3 \text { I-I2-I } 768 \\
& \text { I-I-I769 a } 3 \text { I-I 2-I } 773 \\
& \text { I-I-I } 774 \text { a } 3 \text { I-6-I } 775
\end{aligned}
$$

I. Totales Promedio anual Reales-Marav. Reales

$$
\text { Total : } \overline{505.835} \quad \overline{I 7}^{2} / 3 \quad \overline{23.527}^{69}
$$

Procede del cobro a los beneficiarios de una merced de la Corona o un cargo público, de un I05 \% de la mitad del producto del principal y un tercio de esa merced, más un I $8 \%$ de flete y conducción.

Desde el primero de enero de I754 al 3I de junio de I775, se recaudaron en las Reales Cajas con este motivo más de 250.000 reales, distribuidos en los siguientes períodos:

Períodos

I-I-I 754 a 3 I-I $2-I 758$

I-I-I759 a 3I-I 2-I 663

I-I-I 764 a $3 I-I 2-I 768$.

I-I-I 769 a 3 I-I 2-I 773

I-I-I 774 a 3I-6-I775

I. Totales Promedio anual Reales-Marav. Reales $58.257 \quad \mathrm{I} 8$

I I.65I

6 I.I II I 14

I 2.230 $48.1 \mathrm{I} 5 \mathrm{I} 2$

9.623

I $77.585 \quad 26$

23.5 I 7

$2.737 \quad 2 \mathrm{I}$

1.824

$$
\text { Total: } \overline{287.847} \quad \overline{23}
$$

I $3.388^{70}$

69 Ibídem.

70 Ibídem. 


\section{Cargo de Oficios}

Procede este cargo, de los remates en subasta pública de determinados oficios, de la renta producida por el arrendamiento de otros, o del pago a la Real Hacienda de un tercio del valor de cualquiera de esos cargos en caso de renuncia.

Desde I754 al 3 I de junio de I775, entraron en las Cajas Reales de Santo Domingo por este ramo i82.779 reales, tal y como se observa en el cuadro siguiente:

Periodos

I-I-I 754 a $3 \mathrm{I}-\mathrm{I} 2-\mathrm{I} 758$

I-I-I 759 a $3 I-I 2-I 763$

I-I-I 764 a $3 I-I 2-I 768$

I-I-I 669 a 3 I-I 2-I 773

I-I-I774 a 3I-6-I 775

I. Totales Promedio anual Reales-Marav. Reales

Total: I $5.595 \quad 28$

23.6249
38.067 I9 $85.473 \quad 25$ $20.017 \quad 33$

33

$\mathrm{I} 82.779 \quad \mathrm{I} 2$
3.1 19

4.724 7.6 I 3 I 7.094 I 3.344

$8.5 \mathrm{II}^{71}$

Cargo del Papel Sellado

Procede del beneficio producido por el papel oficial expedido en la isla. Desde I754 a I 775, aportó a la Rieal Hacienda de Santo Domingo un ingreso de casi un cuarto de millón de reales, distribuidos en los siguientes períodos:

Períodos

I-I-I754 a 3 I-I 2-I 758

I-I-I 759 a $3 I-I 2-I 763$

I-I-I 764 a $3 I-I 2-I 768$

I-I-I 769 a 3 I-I 2-I 773

I-I-I 774 a 3 I-6-I 775

Total :
I. Totales Promedio anual Reales-Marav. Reales

$\begin{array}{rrr}54.235 & 32 & 10.847 \\ 50.388 & 18 & 10.077 \\ 30.477 & 8 & 6.095 \\ 76.853 & 4 & 15.370 \\ 37.234 & 12 & 24.822 \\ & 6 & \frac{11.590}{{ }^{72}}\end{array}$

71 Ibídem.

72 Ibidem. 


\section{Penas de Cámara y Justicia}

Se trata en realidad de dos ramos separados, pero el origen de sus escasos recursos es el mismo: las multas impuestas en la isla por el Cabildo a los funcionarios residenciados, de los que se comprobaba su participación en juegos de azar, o su mala conducta en general.

Los ingresos así producidos eran muy parcos, y desde el primero de enero de I754 al 3 I de junio de I775, se reducen a 66.090 reales para los dos apartados, que entraron en las Cajas Reales en los períodos que se expresan a continuación:

Periodos

I-I-I754 a 3 I-I 2-I $75^{8}$

I-I-I759 a 3 I-I $2-I 763$

I-I-I 764 a 3 I-I $2-I 768$

I-I-I769 a 3I-I 2-I 773

I-I-I 774 a 3 I-6-I 775
I. Totales Promedio anual Reales-Marav. Reales

Total: $\overline{66.090} \overline{6} \quad \overline{3.073}{ }^{73}$

\section{Cargo de Extraordinario}

Son los beneficios producidos a la Real Hacienda por la venta de pólvora, municiones, $\mathfrak{u}$ otros objetos de los reales almacenes. En los años mencionados ingresaron en las Reales Cajas por este concepto 216. 579 reales y 6 maravedíes, en la forma siguiente: 
Períodos

$$
\begin{aligned}
& \text { I-I-I 754 a } 3 \text { I-I 2-I } 758 \\
& \text { I-I-I } 759 \text { a } 3 \text { I-I 2-I } 763 \\
& \text { I-I-I } 764 \text { a } 3 \text { I-I 2-I } 768 \\
& \text { I-I-I } 769 \text { a } 3 \text { I-I 2-I } 773 \\
& \text { I-I-I } 774 \text { a } 3 \text { I-6-I } 775
\end{aligned}
$$$$
\text { Total : } 2 \text { I6.579 }
$$

\section{Reales-Marav. Reales \\ I. Totales Promedio anual$$
\text { Reales-Marao. Reales }
$$ 
arrendamiento de los diezmos desde el primero de enero de I 769 al 31 de junio de $1775 .{ }^{76}$

\section{Cargo de Ganado}

Es el dinero obtenido, por el impuesto establecido sobre el ganado del Santo Domingo español que pasaba a la colonia francesa.

En I754 ingresaron en las Reales Cajas de Santo Domingo por este concepto, 156.396 reales. Pero ya no aparece en las cuentas ninguna nueva entrada hasta $I 769$, y desde esta fecha al $3 \mathrm{I}$ de junio de I775, entraron en la Real Contaduría procedentes de este derecho 341.603 reales. ${ }^{77}$

\section{Cargo de Montepíos}

En I768 se creó en Santo Domingo el Montepío Militar. $\mathrm{Su}$ función era la asistencia a viudas y huérfanos de militares. Para ello, a partir de ese año todos los militares sufrieron un descuento en sus haberes con el fin de mantener este ramo, cuya administración quedó a cargo de la Real Hacienda.

Desde el primero de enero de 1769 al 31 de junio de 1775 , produjo un ingreso de IOg.I 39 reales y 25 maravedíes. ${ }^{78}$

Tres años más tarde se organizó el Montepío Político con el mismo fin que aquél, el de socorrer a las viudas y huérfanos de los funcionarios civiles. Desde I77 I a I775, entraron en las Cajas por este concepto 22.027 reales, 5 maravedíes. ${ }^{79}$

En esta misma línea debe considerarse el descuento que 
se fijó en I775 de ocho maravedíes por cada peso de sueldo a todos los militares de la isla, para las atenciones de los inválidos, y que en los seis primeros meses de ese año produjeron $5.5 \mathrm{I} 2$ reales, 30 maravedies. ${ }^{80}$

\section{Cargo de Depósitos}

En teoría, este apartado no correspondería a un ramo fijo de la Real Hacienda, ya que según indica su nombre, serían meros depósitos ingresados en ella con motivo de las aprensiones de comisos, de las testamentarías, etc., hasta que los jueces dictaminaran el fin que había de darse a estos bienes.

Pero en realidad funcionó como un verdadero ramo, ya que dados los ingresos considerables de que se trataron, que luego no salieron en su mayor parte de la Contaduría, sirvieron a ésta en múltiples ocasiones para paliar en parte sus graves necesidades.

Desde el primero de enero de I754 al 3 I de junio de I775, entraron por este concepto I.I 36.013 reales y 3 maravedíes, de los que como veremos más tarde al examinar las datas, sólọ salieron pequeñas cantidades. ${ }^{81}$

\section{CaRgo de LA SAL}

Se trata de un impuesto que comienzan a cobrar las Cajas Reales de Santo Domingo a partir de 1765 , consistente en el pago de dos reales por cada fanega de sal que entraba en la capital. Tenía como fin crear una cerca en una sabana cercana a ella, para que el ganado que llegaba para el consumo público no se perdiera, por carecer de un lugar donde guardarlo hasta su muerte. 
$\mathrm{Y}$ desde 1765 al $3 \mathrm{I}$ de junio de 1775 , ingresaron con este motivo en la Real Contaduría 47.247 reales, un maravedí, ${ }^{82}$ con una media de 4.500 reales al año aproximadamente.

\section{Cargo de CARCELAJe de negros}

Es el dinero obtenido por el cobro a los dueños de esclavos, de cuatro reales por cada uno de aquéllos que tenían que sacar de la cárcel. Si un negro cometía una fechoría, era encarcelado como cualquier blanco. Pero para salir de allí, su dueño, responsable de él, tenía que pagar esa especie de multa.

Desde I754 a I775 los beneficios producidos por este concepto fueron mínimos, reduciéndose a un total de I.720 reales, ${ }^{83}$ con una media anual de 80 reales, por lo que cada año eran sacados de la cárcel por sus dueños unos 20 negros aproximadamente.

\section{Cargos de arrendamiento de fincas,}

Gallera y VEnTa DE LADRillos

Son los tres últimos ramos de Real Hacienda considerados como fijos. El primero procede del arrendamiento de un solar cercano a la Atarazana perteneciente al Rey, en 80 reales al año.

El segundo, del producto del arrendamiento de una gallera también propiedad real, y el tercero de la venta de ladrillos fabricados en el tejar real.

$\mathrm{Su}$ rendimiento es escaso, pues desde I754 a I775 ingresaron entre los tres sólo 5.558 reales. ${ }^{84}$

82 Ibídem.

83 Ibídem.

84 Ibídem. 
Cargo de Alcabala de tierra

Tradicionalmente se considera como uno de los ramos fijos de Real Hacienda, procedente del gravamen impuesto sobre todas las compras y ventas realizadas en un determinado lugar.

Pero en el caso de Santo Domingo en la segunda mitad del siglo XVIII, el asunto es complicado, ya que durante gran parte de esta etapa sus vecinos se vieron libres de ese arancel.

Así, en una real cédula de I743 dirigida a la ciudad de Santo Domingo, se manifestaba que, habiéndose prorrogado en 1738 por el tiempo de diez años la exención del derecho de alcabala, y habiendo representado la ciudad en I740, que ya que con motivo de la guerra contra los ingleses se habían hecho numerosos gastos, se prorrogara por otros diez años esta libertad, "he venido a consulta del expresado mi Consejo de veinte y nuebe de octubre de mil setezientos y quarenta, en conceder a la enunziada ciudad de Santo Domingo, la gracia de relebarla y eximirla del derecho de alcabala por otros diez años más". ${ }^{85}$

Esta gracia fue prorrogada de nuevo más tarde por real orden de 23 de febrero de 1755 por seis años más, ${ }^{86}$ de tal forma que no comenzó a cobrarse este impuesto en Santo Domingo durante la segunda mitad del siglo XVIII, hasta 1762 , en que se declaró "no ser deferible por ahora la prorrogación que se solicita". ${ }^{87}$

Sin embargo, en el mismo año volvió a prorrogarse

85 R. C. fechada en el Pardo, el 14 de marzo de 1743 y dirigida a la ciudad de Santo Domingo, sobre la prorrogación de la libertad del derecho de alcabala por 10 años. A.G.I., Santo Domingo, 1.065 .

86 Carta del Cabildo de la ciudad de Santo Domingo de 10 de diciembre de 1759, solicitando a la Corte, se le informe sobre a partir de cuando deberían contarse los seis años, por los que se les eximía de pagar alcabala según $R$. O. de 23 de febrero de 1755. A.G.I., Santo Domingo, 928.

87 Madrid, 8 de enero de 1762. Informe del fiscal del Consejo de Indias, sobre la solicitud del Cabildo de la ciudad de Santo Domingo de que se les eximiese de pagar el derecho de alcabala y resolución del Consejo de 16 de junio de 1762. A.G.I., Santo Domingo, 1.003. 
esta gracia por diez años más, "que han de empezar a correr y contarse, desde el próximo de mil setecientos sesenta y tres en adelante", ${ }^{88}$ aunque en estos años se cobraron por este concepto algunas cantidades.

En 1772 volvió a ampliarse por cinco años más. ${ }^{89}$ Así, a causa de las exenciones, un arancel que en teoría debía gravar todas las compras y ventas realizadas en la isla, produjo en $2 \mathrm{I}$ años y medio sólo 5.208 reales, es decir, unos 242 reales al año. ${ }^{90}$

\section{RAMOS ECLESIÁSTICOS}

Englobamos en este apartado los relativos a la Cuarta arzobispal, Expolio, Mésıdas eclesiásticas, y vacantes mayores y menores, considerados como "ramos casuales de Real Hacienda".

El cargo de cuarta arzobispal, procede de la cuarta parte de los diezmos correspondientes al arzobispado, llamándose de Expolio en el caso de morir el arzobispo, en cuyo caso la Hacienda se hacía cargo de sus bienes para el pago de deudas, etc.

Las mesadas ecliesiásticas consistían, en el producto obtenido por el cobro del primer mes de un nuevo cargo eclesiástico, más el I $8 \%$ de flete y conducción, mientras que los de vacantes mayores y menores, eran los beneficios de aquellos puestos eclesiásticos que no estaban cubiertos.

Por todos estos ramos entraron en las Cajas Reales de Santo Domingo desde el primero de enero de I754 al 3I de junio de $\mathrm{I} 775,852.82 \mathrm{I}$ reales $\mathrm{I} 8$ maravedies. ${ }^{92}$

88 R. C. de 16 de diciembre de 1762, dirigida a la ciudad de Santo Domingo, eximiendo a sus habitantes por diez años del pago del derecho de alcabala. A.G.I., Santo Domingo, 1.065 .

89 Consejo de 10 de junio de 1772, sobre el problema del derecho de alcabala en Santo Domingo, y resolución real de 9 de julio de 1772. A.G.I. Indiferente General, 562.

90 Ibídem, nota 23.

91 Santo Domingo, 27 de julio de 1778. Liquidacion y demostración de los ramos casuales de Real Hacienda, formada por $R$.O. de 10 de noviembre de 1776. A.G.I., Santo Domingo, 1.044 .

92 Ibídem, nota 23. 


\section{Cargo de Realengos}

También se considera como un ramo casual de la Real Hacienda, ${ }^{93}$ y procede de la venta y composición de tierras pertenecientes al Rey.

Así, el r4 de febrero de $\mathrm{r} 768$, se cobraron 554 reales a Doña Luisa Pimentel, por el precio de 55.428 varas de tierras realengas que resultó tener de más en su ingenio; en el mes de noviembre del mismo año, don Silvestre Mexia pagaba a la Real Hacienda 9.I60 reales en que se remataron unas tierras realengas, y el I de diciembre, Martín de León pagó I i.or 2 reales, "en que se compuso" unas tierras en la jurisdicción de Azúa.

En los veintiún años y medio de que tenemos noticias, ingresaron en las Cajas Reales por este concepto r66.999 reales y medio, con un media de 7.767 reales al año. ${ }^{95}$

Al lado de todas estas entradas de que hemos hablado, nos encontramos con otros ramos casuales, como los de quintos reales, caudal de pesetas, remisiones de Cajas subalternas, resulta de cuentas, venta de harinas, imposición de pulperías, etc., que sólo se cobran en raras ocasiones, y que en los $2 \mathrm{I}$ años y medio que hemos examinado proporcionaron entre todos unos ingresos de 842.392 reales I4 I/3 de maravedí. ${ }^{96}$

\section{2.-Entradas no EFECTIVAS}

Como ya hemos señalado, en las cuentas de las Cajas Reales de Santo Domingo aparecen una serie de ingresos que no se produjeron en realidad.

Desde el primero de enero de 1754 al $3^{x}$ de junio de

93 Ibídem, nota 91.

94 Rèlación jurada del tesorero y el contador de las Reales Cajas de Santo Domingo, fechada el 3 de junio de 1769 , de los caudales procedentes del beneficio de realengos d'esde el 4 de febrero de 1768 al 3 de junio de 1769, mandados cobrar por el oidor juez de realengos. A.G.I., Santo Domingo, 1.050.

95 Ibídem, nota 23.

96 Ibídem. 
I775, nos encontramos en aquéllas con unos cargos que suman 48.567 .418 reales tres maravedíes, ${ }^{97}$ y cuya entrada en la Contaduría nunca tuvo lugar. La mayor parte de esta cantidad pertenece al ramo llamado de alcance de cuentas, es decir, lo sobrante de cada ejercicio que pasa al siguiente.

Le siguen en importancia los préstamos, dinero que pasa de un ramo a otro cuyas necesidades son mayores.

A continuación nos encontramos los reintegros que se hacen a determinados ramos por haberlos prestado antes.

$\mathrm{Y}$ todas estas cantidades no pueden ser consideradas como verdaderas entradas, pues ya quedaron anotadas como tales cuando se realizó su ingreso en las Reales Cajas por primera vez.

Por último, entre las entradas no efectivas se encuentran las dedicadas a las limosnas de la Casa Cuna de la capital y algunos conventos, que sólo se encuentran de paso en la Real Hacienda. Los 48.567 .418 reales tres maravedíes señalados, se distribuyen en la forma siguiente:

Ramos

Alcance de cuentas

Préstamos a situación

Préstamos a extraordinario

Préstamos a familias

Préstamos a otros ramos

Reintegros

Limosnas

\section{I.Totales}

Reales-Marav.

\begin{tabular}{|c|c|c|}
\hline 23.147 .991 & 5 & $47,663 \%$ \\
\hline 12.133 .481 & 13 & $24,983 \%$ \\
\hline 1.286 .911 & 2 & $2,649 \%$ \\
\hline 1.114 .784 & 22 & $2,295 \%$ \\
\hline 1.288 .128 & 4 & $2,652 \%$ \\
\hline 9.404 .131 & 18 & $19,363 \%$ \\
\hline 191.990 & 7 & $0,395 \%$ \\
\hline 48.567 .418 & 3.98 & \\
\hline
\end{tabular}

\section{B. Salidas (Datas).}

Al igual que ocurre con los cargos, también por lo que se refiere a las datas. hemos de señalar que no todas las que aparecen como tales lo son realmente. 
En las cuentas de las Cajas Reales de Santo Domingo, aparecen una serie de salidas que no pueden ser consideradas así, pues como sucede en el caso de las entradas no se llegan a verificar. Se trata en esta ocasión de las llamadas datas de préstamos, reintegros, y limosnas, y de las que hablaremos más adelante.

Teniendo en cuenta esto, hemos de distinguir entre las salidas reales y las no efectivas, tal y como hicimos con los cargos.

Salidas producidas en las R. C. De Santo Domingo DESDE I754 A ${\text { I } 775 .{ }^{99}}^{99}$

Salida total S. no efectiva Salida real

Periodos Reales-Marav. Reales Marav. Reales-Marav.

1-1-1754 a

$31-12-54$

$1.485 .768 \quad 21$

30.648

$1.455 .120 \quad 21$

1-1-1755 a

31-12-55

$1.316 .931 \quad 11$

27.536

$1.289 .395 \quad 11$

$1-1-1756$ a

5-10-56

$1.268 .590 \quad 26$

$1.268 .590 \quad 26$

5-10-1756 a

31-12-57

$2.446 .436 \quad 23$

$\begin{array}{llll}439.038 & 16 & 2.007 .398 & 7\end{array}$

$1-1-1758$ a

31-12-58

$3.006 .927 \quad 32$

$1.109 .952 \quad 28$

$1.896 .975 \quad 4$

$1.1-1759$ a

31-12-59

$3.416 .512 \quad 25$

1.442 .567

$1.973 .945 \quad 22$

1-1-1760 a

31-12-60

$\begin{array}{llllll}3.053 .060 & 27 & 1.164 .949 & 4 & 1.888 .111 & 23\end{array}$

$1-1-1761$ a

31-12-61

$2.894 .482 \quad 18$

$\begin{array}{llll}894.535 & 25 & 1.999 .946 & 27\end{array}$

1-1-1762 a

31-12-62

$\begin{array}{lllll}2.764 .149 & 4 & 645.939 & 4 & 2.118 .210\end{array}$

99 Ibídcm. 
Salida total S. no efectiva Salida real

Periodos Reales-Marav. Reales Marav. Reales-Marav.

\begin{tabular}{|c|c|c|c|c|c|c|}
\hline $31-12-63$ & 3.706 .263 & 17 & 1.176 .913 & 24 & 2.529 .349 & 27 \\
\hline $1-1-1764$ a & & & & & & \\
\hline $31-12-64$ & 3.225 .016 & 15 & 1.082 .883 & 9 & 2.142 .133 & 6 \\
\hline $1-1-1765$ a & & & & & & \\
\hline $\begin{array}{l}31-12-65 \\
1-1-1766 \text { a }\end{array}$ & 2.579 .167 & 11 & 1.005 .964 & 18 & 1.573 .202 & 27 \\
\hline $\begin{array}{l}6-2-67 \\
6-2-1767 \text { a }\end{array}$ & 2.640 .807 & 9 & 763.192 & 6 & 1.877 .615 & 3 \\
\hline $\begin{array}{l}31-12-67 \\
1-1-1768 \text { a }\end{array}$ & 1.262 .018 & 2 & 299.247 & 4 & 962.770 & 32 \\
\hline $31-12-68$ & 3.679 .589 & 21 & 929.426 & 5 & 2.750 .163 & 16 \\
\hline $\begin{array}{l}1-1-1769 \text { a } \\
31-12-69\end{array}$ & 4.314 .871 & 4,5 & 1.980 .028 & 9 & 2.334 .842 & 29,5 \\
\hline $1-1-1770$ a & & & & & & \\
\hline $\begin{array}{l}31-12-70 \\
1-1-1771 \mathrm{a}\end{array}$ & 2.696 .757 & 30 & 772.432 & 15 & 1.924 .325 & 15 \\
\hline $\begin{array}{l}31-10-71 \\
31-10-1771 \text { a }\end{array}$ & 5.456 .759 & 19 & 2.414 .032 & 11 & 3.042 .727 & 8 \\
\hline $31-12-72$ & 5.357 .759 & 32 & 2.948 .368 & 19 & 2.409 .391 & 13 \\
\hline $1-1-1773$ a & & & & & & \\
\hline $31-12-73$ & 5.795 .750 & 21 & 3.252 .813 & 25 & 2.542 .936 & 30 \\
\hline $1-1-1774$ a & & & & & & \\
\hline $31-12-74$ & 4.243 .905 & 17 & 569.298 & & 3.674 .607 & 17 \\
\hline $1-1-1775$ a & & & & & & \\
\hline $31-6.75$ & 2.338 .535 & 17 & $1.225 .90 ?$ & 9 & 1.112 .626 & 8 \\
\hline Total & 68.950 .062 & 28,5 & 24.175 .675 & 30 & 44.774 .386 & 32,5 \\
\hline
\end{tabular}

En esta ocasión, y a diferencia de lo que ocurre con los cargos, las datas reales son superiores a las no efectivas, pues representan un 64,937\% respecto a los gastos totales, mientras que aquéllas sólo alcanzan un $35,063 \%$. 
Pero como pasaba con las entradas, también en esta ocasión los porcentajes varían según los años. En el primer lustro son considerablemente inferiores las datas no efectivas, que poco a poco irán subiendo, tal y como se observa en el cuadro siguiente:

\section{Períodos}

I-I a 3I-I 2-I 754

I-I a 3 I-I $2-I 755$

I-I a $5^{-I O-I} 756$

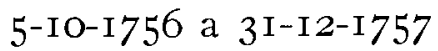

I-I a 3I-I 2-I 758

I-I a $3 I-I 2-I 759$

I-I a 3 I-I $2-I 760$

I-I a 3I-I 2-I 76 I

I-I a 3 I-I $2-I 762$

I-I a 3I-I 2-I 763

I-I a 3 I-I2-I 764

I-I a $3 \mathrm{I}-\mathrm{I} 2-\mathrm{I} 765$

I-I-I 766 a 6-2-I 767

6-2 a 31-12-1767

I-I a 3I-I 2-I 768

I-I a 3I-I2-I 769

I-I a 3I-I 2-I 770

I-I a 3I-IO-I77I

3I-IO-I77 a 3I-I2-I772

I-I a 3I-I 2-I 773

I-I a 3I-I 2-I774

I-I a 3I-6-I775
Porcentaje no efectivo

$$
2,063 \%
$$$$
2,10 \%
$$

$0 \%$

I $7,946 \%$

$36,91 \%$

$42,22 \%$

$38,15 \%$

$30,90 \%$

$23,37 \%$

$31,754 \%$

$33,58 \%$

$39 \%$

$28,90 \%$

$23,76 \%$

$25,26 \%$

$45,90 \%$

$28,64 \%$

$44,24 \%$

$55,03 \%$

$56,12 \%$

I $3,4 \mathrm{I} \%$

$52,42 \%$

Totales:
$35,063 \%$
Idem real
$97,937 \%$
$97,90 \%$
$100 \%$

$82,054 \%$

$63,09 \%$

$57,78 \%$

$6 \mathrm{I}, 85 \%$

$69,10 \%$

$76,63 \%$

$68,246 \%$

$66,42 \%$

$61 \%$

$7 \mathrm{I}, \mathrm{I0} \%$

$76,24 \%$

$74,74 \%$

$54,10 \%$

$7 \mathrm{I}, 36 \%$

$55,76 \%$

$44,97 \%$

$43,88 \%$

$86,59 \%$

$47,58 \%$

$64,937 \%{ }^{100}$

100 Ibídem. 
Resumiendo en períodos de cinco años, con excepción de I774 a I775, nos encontraríamos con los siguientes promedios anuales por lo que respecta a las datas reales:

Períodos

\begin{tabular}{|c|c|c|c|}
\hline I-I-I754 a 3I-I 2-I758 & 7.917 .480 & I & I. $5^{8} 3.496$ \\
\hline I-I-I759 a 3I-I 2-I763 & 10.509 .563 & $3 \mathrm{I}$ & 2.101 .912 \\
\hline I-I-I764 a 3I-I2-I768 & $9 \cdot 305.885$ & I6 & І.86I. I77 \\
\hline I-I-I 769 a 3 I-I 2-I773 & I 2.254 .223 & 27,5 & $2.45^{0.844}$ \\
\hline I-I-I774 a 3I-6-I775 & 4.787 .233 & 25 & 3.191 .488 \\
\hline & 44.774 & $3^{2,5}$ & $2.082 .5^{2}$ \\
\hline
\end{tabular}
Reales-Marav. Reales

I.-DATAS REALES

Salida real Promedio anual

\section{DATAS DE SITUACIÓN Y SALARIOS}

Como ya hemos señalado al hablar de los cargos, el situado tenía como fin satisfacer los gastos de la tropa, sus salarios, los de los funcionarios de la Audiencia, y algunos otros, como podemos observar en el resumen que exponemos a continuación, de las datas de situación relativas a I 76 I :

Reales Maravedies

- Para el prest mensual del batallón fijo de infantería, compañía de artillería y cuerpo de inválidos en todo el año I76I.

- A los mismos cuerpos por el 498.928 aumento del prest en los meses de mayo, junio y julio de I 76 I. 
Reales Maravedies

- A los mismos cuerpos por la gratificación que les corresponde desde enero a octubre de I76I.

8.312

- Para el prest mensual en I76I de las tropas destacadas en Montecristi.

- Para el sueldo del batallón fijo desde el $\mathrm{I}$ de mayo de I760 al $3^{\mathrm{I}}$ de abril de I76 .

- Idem para la compañía de artillería.

- Idem para el cuerpo de inválidos.

- Para el sueldo del batallón de infantería, compañía de artillería y cuerpo de inválidos en los meses de julio, agosto, septiembre y octubre de I757.

- Para el sueldo de las compañías de caballería del norte y y sur, desde el I de mayo de I760 al 3I de abril de I76I.

- A las mismas compañías de caballería por la gratificación de ese mismo año.

- A las mismas compañías por sus sueldos de marzo, abril mayo, y junio de I757

- Para abonar a los capitanes del batallón, por cuenta de los alcances correspondientes a los desertores por las deudas que tenían con aquéllos. 
Reales Maravedies

- Para la gratificación de los oficiales de artillería desde el I de mayo de 1760 al 3I de abril de I76I.

- Para el sueldo de un artillero que se olvidó en junio de I 760.

- Para la congrua del Dean y y Cabildo de Santo Domingo correspondiente a $\mathbf{I} 758$.

- A cuatro oidores, por su sueldo desde el primero de mayo de 1760 al 31 de abril de I761, a 17.647 reales 2 maravedíes.

- Al gobernador por su salario en la misma fecha.

- Al teniente del rey por su sueldo en la misma fecha.

- Al fiscal de la Audiencia por su salario en el mismo año, menos 2.800 reales que se le descuentan.

- A un ingeniero ordinario por su sueldo en el mismo año.

- Al ingeniero Lorenzo de Córdoba por el mismo concepto.

- Al alcalde mayor de Santiago por su sueldo en el mismo período.

Las datas de situación y salarios, representan desde luego el apartado más importante dentro de los gastos de la Real Hacienda de Santo Domingo, y desde I754 a I775

102 Cuentas de las Cajas Reales de Santo Domingo en el año de 1761. A.G.I, Santo Domingo, 1.048. 
alcanzó un total de 29.874 .766 reales 19 maravedíes, distribuidos en la siguiente forma:

Periodos

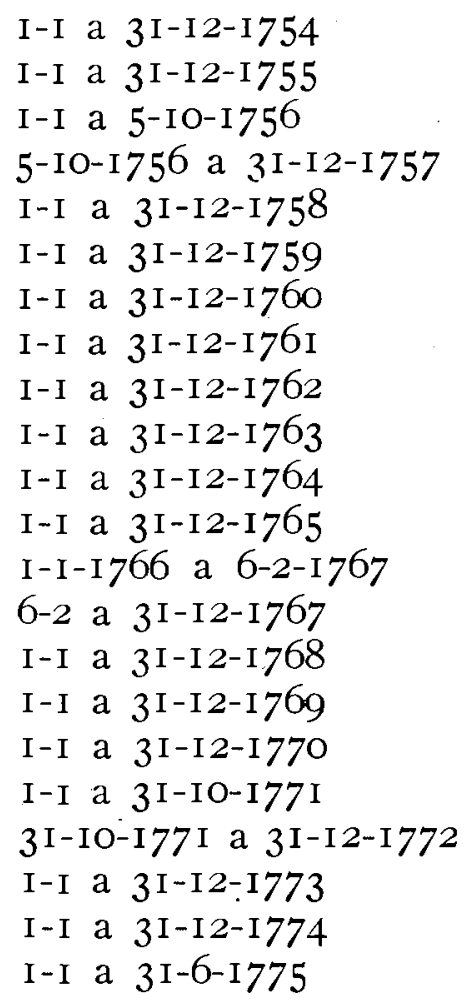

Reales Maravedies

$$
1.246 .054
$$

I.I 19.100

I.075.965

I. 478.355

I.44I.086

I. $215.85^{8}$

I. 3 I I. 353

I. 457.343

I. $264.45^{2}$

I. 327.953

I. 47 I. 428

I. 203.069

I. 597.826 700.707

2.037 .494

I.3 I9.96I

732.138

I.836.787

I. 8 I0.780

I. 453.024

2. 168.360 605.666
9

27

I

33

I

8

23

I6

I 4

3

9

7

28

8

5

I9

IO

2

7

I4

I 3

Total: $\quad 29.874 .766$

I9. ${ }^{103}$

Resumiendo en períodos de cinco años, a excepción como en casos anteriores del último año y medio, el promedio anual de los gastos de salarios y situación sería el siguiente:

103 Ibídem, nota 23. 


\begin{tabular}{|c|c|c|c|}
\hline Períodos & \multicolumn{2}{|c|}{$\begin{array}{c}\text { Salida total } \\
\text { Reales - Marav. }\end{array}$} & $\begin{array}{l}\text { Promedio anual } \\
\text { Reales }\end{array}$ \\
\hline I-I-I 754 a 3 I-I $2-I 758$ & 6.360 .562 & 3 & 1.272 .112 \\
\hline I-I-I 759 a 3 I-I $2-1763$ & 6.576 .960 & 30 & I.3 5.392 \\
\hline I-I-I 764 a 3 I-I 2-I 768 & 7.010 .525 & 18 & 1.402 .105 \\
\hline I-I-I769 a 3I-I2-I773 & $7.152 .69 \mathrm{I}$ & 9 & I. 430.538 \\
\hline I-I-I 774 a 3 I-6-I 775 & 2.774 .026 & 27 & I.849.350 \\
\hline Total: & 874.766 & 19 & I.389.524 \\
\hline
\end{tabular}

Así pues, en los 2 I años y medio examinados, el promedio anual de estos gastos es de $\mathbf{1} .389 .524$ reales. Pero si en los comienzos no llega al millón y medio de reales, al final alcanza casi los dos millones, tras experimentar un alza progresiva en los años intermedios.

Data de Tabacos, Atrasados y

Cuarteles y Fortificaciones

Como ya dijimos al hablar de los cargos, este dinero se gastaba en la compra de tabaco por cuenta del Rey, el pago de deudas antiguas de la Hacienda, y los reparos de las fortificaciones de la isla, alcanzando desde el I de enero de I754 al 3 I de junio de 1775 , la cifra de 2.356 .360 reales y 4 maravedíes por lo que se refiere a la primera, 1.263.094 reales, 28 maravedíes por lo que respecta a la segunda, y I.260.9I 3 por lo que se refiere a la tercera. ${ }^{105}$

DATA DE FAMILIAS Y POBLACIONES

Los gastos ocasionados en la fundación de nuevas poblaciones, y el mantenimiento de los colonos llegados a la isla durante el primer año de su estancia en ella, fueron desde

104 Ibídem.

105 Ibídem. 
I754 a 1768, fecha en que dejan de aparecer estas datas en las cuentas de las Cajas Reales de Santo Domingo, de 2.207.097 reales y 16 maravedíes, distribuidos en los siguientes períodos:

Periodos

I-I- a 31-I2-I754

$I-I$ a $3 I-I 2-1755$

I-I a 5-10-1756

5-10-I 756 a $3^{\text {I-I } 2-I 757}$

I-I a 3 I-I $2-I 75^{8}$

I-I a 3I-I 2-I 759

I-I a $31-12-1760$

$I-I$ a $3 I-I 2-I 76 I$

$\mathrm{I}-\mathrm{I}$ a $3 \mathrm{I}-\mathrm{I} 2-\mathrm{I} 762$

I-I a $31-12-1763$

I-I a 3 I-I $2-I 764$

I-I a 3I-I 2-I 765

I-I-I 766 a 6-2-I 767

6-2 a 3I-1 2-I 767

I-I a 3I-I 2-I 768
Reales Maravedies

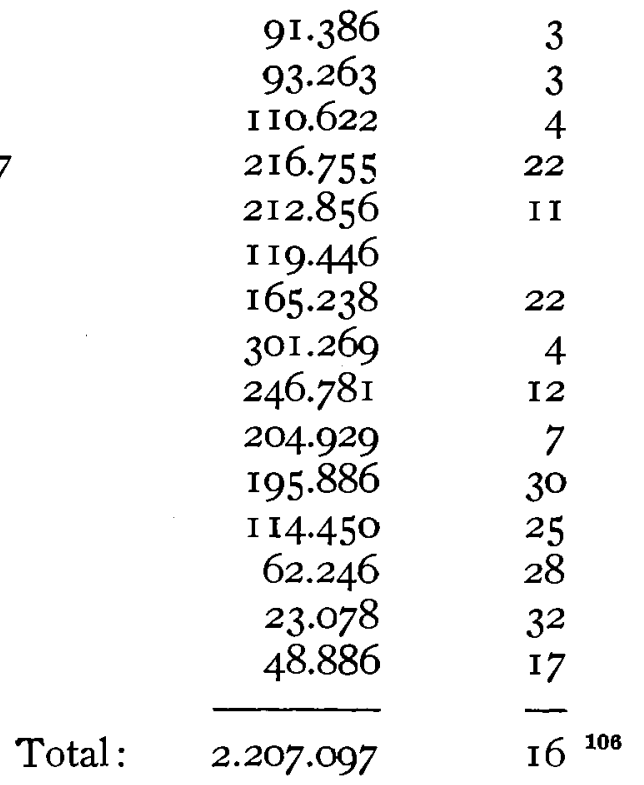

Resumiendo en períodos de cinco años, el promedio anual sería el siguiente:

\begin{tabular}{|c|c|c|c|}
\hline Períodos & \multicolumn{2}{|c|}{$\begin{array}{c}\text { Salida total } \\
\text { Reales - Marav. }\end{array}$} & $\begin{array}{c}\text { Promedio anual } \\
\text { Reales }\end{array}$ \\
\hline I-I-I 754 a $3^{\text {I-I } 2-I 75^{8}}$ & 724.883 & 9 & r 44.976 \\
\hline I-I-I 759 a 3 I-I $2-\mathrm{I} 763$ & 1.037 .664 & I I & 207.532 \\
\hline I-I-I 764 a 3 I-I 2-I 768 & $444 \cdot 549$ & 30 & 88.909 \\
\hline Total & 07 & I6 & $147.139^{11}$ \\
\hline
\end{tabular}

106 Ibídem.

107 Ibídem. 


\section{Data de Real Hacienda}

Dependen de este ramo los salarios del sobrestante de las reales fábricas, el armero, el contador y el tesorero de las Cajas Reales, además de los gastos de las Reales Fábricas, el cuidado de la capilla y el reloj de la Audiencia, y multitud de gastos que no tenían asignación en ningún otro ramo.

Desde el primero de enero de I754 al 3 I de junio de I 775 , estas datas alcanzaron la cifra de 1.739 .769 reales y 24 maravedíes, distribuidos en la siguiente forma:

Períodos

\begin{tabular}{|c|c|c|c|}
\hline I-I-I 754 a 3 I-I $2-I 75^{8}$ & 559.130 & 8 & I I I 826 \\
\hline I-I-I 759 a 3 I-I 2-I 763 & 364.983 & 8 & 72.996 \\
\hline I-I-I 764 a 3I-I 2-I 768 & 341.022 & 23 & 68.204 \\
\hline I-I-I 769 a 3 I-I 2-I 773 & $4 \mathrm{OI} \cdot 3 \mathrm{II}$ & 29 & 80.262 \\
\hline I-I-I 774 a 3I-6-I 775 & $73.32 \mathrm{I}$ & 24 & 50.880 \\
\hline Total: & I.739.769 & 24 & 80.919 \\
\hline
\end{tabular}

Salida total Promedio anual Reales-Marav. Reales

$\mathrm{Y}$ al lado de estos gastos normales de la Real Hacienda, nos encontramos con los llamados gastos extraordinarios, dinero empleado en obras públicas como la de la cárcel, la madera comprada por cuenta del gobierno, gastos de cuarteles, o aquéllos ocasionados con motivo de las guerras. Todas estas salidas representaron en $\operatorname{los} 2 \mathrm{I}$ años y medio que hemos podido examinar, un total de 2.687.129 reales y 2 maravedíes. ${ }^{109}$ con un promedio anual de 124.982 reales.

108 Ibídem.

109 Ibídem. 


\section{Datas de Comisos Y DEPósitos}

Son las datas ocasionadas, con motivo de la venta en pública subasta de los efectos de contrabando apresados, la parte correspondiente a los jueces, a los aprehensores, etc., y la devolución de aquéllos hechos indebidamente.

Desde el primero de enero de I754 al $3 \mathrm{I}$ de junio de I775, estas datas alcanzaron la cifra de 87 I.57 I reales, un maravedí y medio. ${ }^{\mathbf{1 1 0}}$

\section{Datas eClesiásticas}

Comprenden los gastos ocasionados en la distribución de los diezmos, el pago de los dos novenos correspondientes al Rey, la cuarta parte perteneciente al arzobispado, el expolio por muerte de éste, la distribución de bulas, y el pago a las dignidades eclesiásticas que ocupaban un cargo interinamente por encontrarse en aquellos momentos vacante.

Se trata en realidad de las datas correspondientes a los cargos de diezmos, novenos, cuarta arzobispal, expolio, bulas y vacantes mayores y menores.

Desde I754 a I775, estos gastos supusieron un total de I.7 I I.897 reales tres maravedies, distribuidos en la siguiente forma:

Data de Diezmos

Reales Maravedies

Data de novenos

Data de Cuarta Arzobispal

Data de Expolio

Data de Bulas

Data de Vacantes

\begin{tabular}{crc} 
& I. IO2.555 & I3 \\
& I 54.594 & I9 \\
287.129 & I6 \\
79.1 I6 & 9 \\
& 46.638 & 6 \\
& 41.863 & 8 \\
\multirow{4}{*}{ Total } & I.7 I I.897 & $-3^{111}$
\end{tabular}

110 Ibídem.

111 Ibidem. 


\section{Data De Montepíos}

Se trata de las cantidades abonadas a las viudas y huérfanos de los militares y funcionarios civiles, a base del descuento que mensualmente se hacía de sus salarios.

Por lo que se refiere al Montepío Militar, desde I769 en que empezó a funcionar, hasta el $3 \mathrm{I}$ de junio de $\mathrm{I} 775$, estas salidas fueron de 89 . I42 reales, mientras que las relativas al Montepío de Ministros, que se inició en I77 I, fueron de I 5.866 reales nueve maravedies. ${ }^{112}$

\section{Datas VARIAS}

Por último, nos encontramos con una serie de salidas de poca cuantía relativamente en las Cajas de Santo Domingo, como las de los gastos de Penas de Cámara y Justicia, Reparos de la Real Fuerza, Fábrica del Muelle, Resulta de Cuentas, Arbitrio de la sal, Caudal de Pesetas, Compra de Harinas y algunas otras, cuyo valor desde el primero de enero de $I 754$ al 3 I de junio de I775, fue de 696.778 reales y 25 maravedíes entre todas. ${ }^{113}$

\section{2.-DATAS No EFECTIVAS}

Como hicimos con los cargos, hemos de señalar también aquí la presencia en las cuentas de las Cajas Reales de Santo Domingo, de una serie de salidas que no se produjeron nunca en realidad.

Son las llamadas datas de préstamos, reintegro de préstamos y limosnas.

En el primer caso, se trata del dinero prestado por un 
ramo de la Real Hacienda a otro, y cuya salida se anota dos veces, en el ramo donante al hacerse el préstamo, y en el receptor al hacerse el verdadero gasto.

En las cuentas de las Cajas Reales de Santo Domingo figuran por este concepto, desde el primero de enero de I754 al 31 de junio de $I 775$, la cantidad de 10.485 .586 reales, distribuidos en la siguiente forma:

\section{Reales Maravedíes}

Préstamos a Situación.

Préstamos a Familias. 8.972.355 I7

Préstamos a Cuarteles y Fortifi-

$824.726 \quad 28$

caciones.

Idem para compra de harinas.

399.700

32

Idem a Penas de Cámara y Justicia.

89.056

Idem a Extraordinario.

54.985

28

Idem a Diezmos.

47.200

30

Idem a Casa Cuna.

Idem a Novenos.

$27.2 \mathrm{I} 4$

20

19.989

I7

Idem a Montepío.

17.720

Idem al ramo de Sal.

I 5.473

I 5

I I . O23

29

Idem a Muelle.

4.803

25

Idem a Media Anata.

En el segundo caso se trata de la devolución de esos préstamos, que también figuran dos veces, una al pasar del ramo receptor al donante, y otra, cuando se gasta en este último. Esta data representa en los años señalados, un total de $\mathbf{I} 3.498 .099$ reales y 20 maravedíes. ${ }^{\mathbf{1 1 5}}$

Por último, en el caso de las limosnas, y como ya hemos dicho al hablar de los cargos, es un dinero que sólo se encuentra de paso en las Cajas Reales, por lo que no puede consi-

114 Ibídem.

115 Ibídem, 
derarse ni como verdadera entrada ni como verdadera salida, y que en los 21 años y medio que hemos podido examinar, alcanzan un total de 167.990 reales 7 maravedíes por lo que se refiere a las destinadas a la Casa Cuna, y 24.000 reales a las dedicadas al Hospital de San Lázaro y el convento de San Pedro Mártir. ${ }^{116}$

\section{Conclusiones}

Tres son las principales conclusiones que pueden sacarse de todo lo expuesto: la falta de dinero propio en las Cajas Reales de Santo Domingo, su dependencia del exterior derivada de aquélla, y la existencia de una economía pública ficticia, totalmente artificial, al basarse en esa aportación externa.

El principal problema a que tuvo que enfrentarse la Real Contaduría de Santo Domingo en la segunda mitad del siglo XVIII, y en general durante toda la etapa colonial, fue la falta de recursos propios de la isla, que sè reflejaba en los escasos ingresos que aquélla percibía por los medios fiscales vigentes.

Sólo el 20,976 \% de las entradas reales producidas en la Real Tesorería de la Española proceden de la misma isla, el $4,307 \%$ de los gravámenes impuestos sobre el comercio, y el resto, de los demás cargos existentes en ella. Esta escasez de medios era un reflejo claro de la situación económica del Santo Domingo español en general. Ya hemos hablado anteriormente del pobre estado en que se encontraban la agricultura y el comercio, y de los intentos realizados para acabar con esta situación. La escasa actividad económica del territorio se dejaba sentir en los beneficios hacendísticos, y debido a ello, los recursos propios de las Reales Cajas de Santo Domingo fueron siempre muy parcos, no pudiendo por sí solas cumplir todas las obligaciones que le estaban encomendadas.

116 Ibídem. 
Para solucionar este problema hubo que recurrir a medios externos: el situado. La atención de las necesidades de las Cajas Reales de una colonia americana a cargo de las de otra, que por factores diversos se encontraban en mejor situación, fue algo corriente en el imperio español. En este caso, fue la Real Contaduría de México la encargada de remitir caudales a la de la Española, con el fin de que con ellos pudiera pagarse a la tropa, funcionarios reales, etc.

Posteriormente, esta obligación de las Cajas de Nueva España se amplió, teniendo además que aportar el dinero suficiente para la compra del tabaco dominicano por cuenta de la Corona española, para atender al mantenimiento de las familias de colonos que llegaron de las islas Canarias con el fin de formar nuevas poblaciones en Santo Domingo, así como los costos de éstas, los de cuarteles, y el pago de las deudas atrasadas de la Corona en aquel territorio, con lo que la dependencia de la Tesorería de Santo Domingo respecto a la mexicana se hizo cada vez mayor.

Así, la mayor parte del dinero que entraba en las Cajas Reales en la segunda mitad del siglo XVIII llegaba de fuera, - concretamente un 79,024\% de los ingresos reales - en razón del situado $(6 \mathrm{I}, 5.02 \%)$, dinero para la compra de tabacos $(7,188 \%)$, caudal de familias y poblaciones $(3,799 \%)$, cargo de cuarteles $(0,4 \mathrm{I} 0 \%)$, y atrasados $(6,125 \%)$.

La dependencia fue pues total en esta época, de modo que como ya hemos señalado, cuando el dinero de Nueva España no llegaba a tiempo a la isla, la falta de moneda hacía decaer la actividad económica, teniendo que recurrir en algunas ocasiones a la emisión de billetes de papel que sustituyeron a aquélla. Esta dependencia de las remesas exteriores de dinero, hace de la economía pública de Santo Domingo en esta época una economía artificial, en la que se gastaba más de lo que se producía, aunque en los 21 años examinados los gastos sean ligeramente inferiores a los ingresos, pues en éstos están desde luego englobados los ya mencionados recursos exteriores.

Las autoridades dominicanas intentaron por todos los 
medios mejorar esta situación, y así, en la segunda mitad del siglo XVIII, comienzan a cobrarse nuevos impuestos como el del muelle — desde I763-, el de la sal — desde I765-, o el nuevo impuesto de ganados, pero cuyas aportaciones siguieron siendo mínimas en relación a las necesidades de las Cajas Reales, y a la que procedía de México.

Ocurre pues, con las Cajas Reales del Santo Domingo español en este período, lo mismo que sucede con la economía dominicana en general de la misma etapa, que depende para su mantenimiento del exterior, pues, por sí misma, la isla fue incapaz de producir lo necesario para desarrollar una actividad económica normal. 



\section{Capítulo VII}

\section{E L G O B I E R N O}

La isla de Santo Domingo fue, desde los principios de la colonización americana, una de las llamadas provincias mayores indianas, es decir, aquéllas en las que el gobernador era al mismo tiempo presidente de la Audiencia.

La Audiencia de Santo Domingo, la primera de las creadas en el Nuevo Continente, fue fundada en 15 II ${ }^{1}$ y abarcaba en sus comienzos todos los territorios descubiertos en el Nuevo Mundo. Pero poco a poco, y debido a la importancia y extensión de las nuevas colonias, se fueron constituyendo otras y separándose de la primitiva, que vio así paulatinamente reducir su demarcación territorial, hasta quedar limitada a las Antillas mayores.

Al iniciarse el siglo XVIII, la Audiencia de Santo Domingo comprendía las Antillas, la Florida (como dependencia de Cuba), y todos los territorios venezolanos. Pero en I7I7, la provincia de Venezuela pasó a formar parte del recién creado virreinato de Nueva Granada. ${ }^{2}$

Este virreinato desaparece al poco tiempo, y vuelve a aparecer en I739, quedando integradas en él las regiones ya señaladas. Pero a petición del gobernador de Venezuela, el Rey, en I742, concedió al gobierno y capitanía general de Caracas la separación del virreinato, pasando a depender de nuevo en lo jurídico de la Audiencia dominicana. ${ }^{3}$

1 Malagón Barceló, Javier: El distrito de la Audiencla de Santo Domingo en los siglos XVI a XIX. Publicaciones de la Universidad de Santo Domingo. Vol. XXIII. Editora Montalvo. Ciudad Trujillo, 1942, pág. 2.

2 Ibídem, págs. 2-3.

3 Ibídem, pág. 24. 
Así, en la segunda mitad del siglo XVIII, la Audiencia de Santo Domingo comprendía las colonias de la Española, Puerto Rico, Cuba, La Florida y Venezuela. Todos estos territorios tenían sus propias autoridades, algunas de las cuales, como las de Cuba, Puerto Rico y Caracas, eran también capitanes generales, dependiendo sólo de la Audiencia en los asuntos jurídicos, como tribunal supremo de apelación.

Posteriormente, en septiembre de $I 777$, la jurisdicción de la Audiencia de la Española se vió incrementada por la incorporación de nuevas regiones: Cumaná, Maracaibo, la Guayana, Trinidad y la Margarita, que fueron separadas de la de Santa $\mathrm{Fe}^{4}$

Pero la gran extensión territorial de esta Audiencia, trajo consigo graves inconvenientes para los habitantes de las zonas que comprendía, sobre todo de las situadas en el Continente, por lo que, en 1786 , vio de nuevo mermado su territorio al crearse una nueva Audiencia en la capitanía general de Caracas, cuyo distrito abarcaba además de aquella provincia, las de Cumaná, Maracaibo, la Guayana y las islas de Trinidad y la Margarita, quedando limitada la jurisdicción de la Española a Santo Domingo, Cuba, la Florida y Puerto Rico. ${ }^{5}$

A la vez que una demarcación territorial, la Audiencia era también una corte o tribunal superior de justicia, que pronunciaba sentencia en última instancia.

A1 iniciarse la segunda mitad del siglo XVIII, la Audiencia de Santo Domingo estaba integrada por cinco oidores, un fiscal de lo civil y otro de lo criminal, que cobraban cada uno 17.647 reales y 2 maravedíes anuales, ${ }^{6}$ un agente

\footnotetext{
4 Ibídem.

5 R. C. fechada en San Ildefonso el 31 de julio de 1786, ordenándose la reducción de la jurisdicción de la Audiencia ce Santo Domingo. A.G.I., Santo Domingo, 897 .

6 Data de salarios sacada de las cuentas de las Cajas Reales de Santo Domingo en 1754 y 1755. A.G.I., Contaduría, 1.069-A.
} 
fiscal, y otro relator. A partir de 1768 hubo dos puestos más, un nuevo relator y otro agente fiscal. ${ }^{\mathbf{}}$

Posteriormente, en 1776, se creó un nuevo cargo en la Audiencia de Santo Domingo, el de regente, una especie de oidor supremo ${ }^{8}$ con las funciones de presidir el tribunal en ausencia del presidente, coordinar la actuación de los demás ministros, repartir los procesos entre aquéllos, etc., "teniendo la dirección de lo contencioso y económico, si no están el virrey o el presidente", así como la gobernación interina en caso de faltar la suprema autoridad del territorio. ${ }^{\mathbf{9}}$

El salario asignado a este ministro fue de 6.600 pesos anuales, al tiempo que el de los oidores ascendió en estos momentos a 3.300 pesos, quedando establecido en 500 pesos al año el de los dos relatores y los dos agentes fiscales.

En 1786, con motivo de la limitación territorial a que se vio sometida la Audiencia de la Española, se ordenó también la disminución del número de sus ministros, que quedaron reducidos "al regente, tres oydores y el fiscal de lo civil, que lo ha de ser también de lo criminal ", ${ }^{11}$ aunque años más tarde, en I79I, tuvo que nombrarse un agente que ayudara al único fiscal que había quedado en aquélla, ante la imposibilidad de resolver por sí solo todos los asuntos que le estaban encomendados.

Y como presidente de este tribunal, se encontraba el go-

7 Carta de la Audiencia a la Corte con fecha de diez de noviembre de 1768, acusando el recibo de la R. C. de 16 de diciembre de 1767, por la que se ordenaba la creación de dos nuevos puestos en aquel tribunal. A.G.I., Santo Domingo, 979.

8 Título de nueva creación de regente de la Audiencia de Santo Domingo, con fecha 21 de octubre de 1776, a favor de don Andrés de Pueyo y Urríes. A.G.I., Santo Domingo, 913.

9 Instrucciones dadas en Aranjuez el 20 de junio de 1776, sobre la actuación que deberán tener los regentes de las audiencias americanas. A.G.I., Indiferente General, 843.

10 Reglamento de los sueldos anuales que han de gozar los ministros principales y subalternos de todas las audiencias de América y Filipinas desde el uno de julio de 1776. Dado en el Pardo el 11 de marzo de 1776. A.G.I., Indiferente General, 657.

$11 R$. C. fechada en San Ildefonso el 31 de julio de 1786, ordenando la reducción de la jurisdicción territorial de la Audiencia de Santo Domingo, y la disminución del número de sus ministros. A.G.I., Santo Domingo, 897.

12 R. C. fechada en Madrid el siete de febrero de 1791, ordenando la creación del cargo de un agente fiscal para la Audiencia de Santo Domingo, A.G.I., Santo Domingo. 898. 
bernador de la isla. La suprema autoridad de Santo Domingo era el gobernador, al mismo tiempo presidente de la Audiencia como ya hemos dicho, capitán general, superintendente de Real Hacienda y vicepatrono eclesiástico, en representación del poder real. El gobernador era el delegado del Rey en su territorio, y tenía facultades para legislar en él, nombrar corregidores y alcaldes mayores, confirmar la elección de los alcaldes ordinarios efectuada por los regidores de cada población, etc.

Poseía además el mando supremo de la tropa, y dado el carácter militar que adquirió la isla de Santo Domingo, por su situación en el disputado mar de las Antillas y la presencia de los franceses en la parte occidental de la colonia, ésta fue su principal característica. Todos los gobernadores dominicanos de la segunda mitad del siglo XVIII fueron militares, y aunque legalmente se hallaba establecido que, en caso de que este cargo quedara vacante, fuese ocupado por la Audiencia en la persona de su oidor decano, desde 1736 se ordenó que, en el caso de la Española, lo hiciera el teniente del Rey de la plaza de Santo Domingo, con el fin de que el resto de las autoridades isleñas estuviesen en todo momento supeditadas a la militar. ${ }^{13}$

En la época que estamos estudiando, los gobernadores fueron nombrados siempre por un período de ocho años, aunque en algunas ocasiones sobrepasaron desde luego esta etapa, como ocurrió por ejemplo con don Manuel de Azlor por prorrogársele su mandato, y en otras fueron relevados antes de cumplirla, por ser destinados a otros cargos en los que el Rey juzgaba podían servirle mejor, como en el caso de don José Solano y Bote.

Hemos de señalar, que la mayoría de los gobernadores que fueron nombrados en esta etapa proceden de otras gobernaciones, como Tarifa, Puerto Rico, y dos de ellos de la de Caracas. Es difícil explicar las razones de ésto, pues si por una parte se podía considerar como un ascenso, algu-

13 Expediente sobre la sucesión en el mando de la isla por ausencia o muerte del gobernador. Real resolución sobre el asunto con fecha ocho de septiembre de 1736. A.G.I., Santo Domingo, 988. 
nos de los territorios de que llegaron estas autoridades, como el de Caracas, tenían en esta época mayor importancia económica que Santo Domingo. Quizás se deba simplemente a una cuestión de prestigio, por tratarse de la presidencia de la Audiencia más antigua de América, aunque en este caso la antigüedad no fuera pareja con la importancia real de la provincia.

El sueldo del gobernador dominicano era de 55.147 reales dos maravedies al año, 6.893 pesos aproximadamente, ${ }^{14}$ hasta que en I 776 se elaboró el nuevo Reglamento de los sueldos que deberían disfrutar los ministros de las colonias americanas, y se elevó a 8.000 pesos anuales. ${ }^{15}$

En la segunda mitad del siglo XVIII hubo en la isla I I gobernadores, cuatro de ellos interinos, y uno, el último, que aunque en un principio fue nombrado interinamente a la muerte de don Manuel González, fue designado más tarde para ocupar el cargo.

Al finalizar los ocho años para los que el gobernador había sido nombrado, tenía que verse sometido según las leyes a un juicio de residencia, en el que debía dar cuenta de su actuación en la etapa de su mandato, y ser juzgado por ella. Pero de los siete que fueron elegidos por el Monarca en este período, se excluyen desde luego de este número los interinos, sólo tenemos noticias de tres de ellos que fueran sometidos a él, don Francisco Rubio y Peñaranda, don Manuel de Azlor, y don José Solano y Bote, ya que los demás, o murieron antes de finalizar su mandato a fueron excluidos de él, como en el caso de don Isidro de Peralta y Rojas.

Los gobernadores de FERnando VI

Nuestro período se inicia con la gobernación de don José Colomo, que coincide casi con los comienzos del reinado del nuevo Monarca español Fernando VI.

14 Data de salarios en 1768, sacada de las cuentas de las Cajas Reales de Santo Domingo. A.G.I., Santo Domingo, 1.048.

15 Ibíđem, nota 10. 
En I748, el Rey nombró como gobernador, capitán general y presidente de la Audiencia de la Española, a don José Colomo, ${ }^{16}$ quien recibió el cargo de manos de su antecesor, don Pedro Zorrilla de San Martín, en septiembre de I750. ${ }^{17}$

Don José Colomo había ejercido antes el puesto de gobernador de Puerto Rico, desde I743 hasta I750, fecha en que marchó a Santo Domingo para hacerse cargo de su nuevo destino, siendo ascendido en el primero al grado de brigadier.

Pero no tuvo tiempo de demostrar en Santo Domingo sus buenas o malas dotes de gobernante, pues al poco tiempo de tomar posesión del mando supremo de la isla, fue aquejado de una grave enfermedad, que le ocasionó la muerte el 8 de octubre del mismo año, siendo sepultado en el convento de San Francisco de aquella capital. ${ }^{18}$

Inmediatamente se hizo cargo del gobierno interinamente, siguiendo la norma imperante en aquellos momentos por lo que se refiere a la sucesión de los gobernadores, el teniente del Rey de la plaza, don José Sunyer y Basteros. ${ }^{19}$

El nuevo dirigente "se tomó a empeño no dejar decaer la colonia, que se hallaba ya muy repuesta de sus antiguos quebrantos, y encarrilada por la amplia vía del progreso". Prestó sobre todo atención al problema de la frontera con los franceses, que ocupaban la parte occidental de la Española, y emprendió algunas mejoras por lo que respecta a las obras públicas, entre ellas la reparación del palacio del gobierno. ${ }^{20}$

16 Nombramiento de gobernador, capitán general y presidente de la Audiencia de la Española a favor de don José Colomo. Dado en San Lorenzo el nueve de noviembre de 1748. A.G.I., Santo Domingo, 967.

17 Carta del teniente del rey de la plaza de Santo Domingo de 10 de octubre de 1750, dando cuenta a la Corte de que don José Colomo había tomado posesión de sus empleos el cinco de septiembre de aquel mismo año, y de su muerte ocurrida poco después. A.G.I., Santo Domingo, 942.

18 García José Gabriel: Loc. cit., tomo I, pág. 207.

19 Ibídem, nota 17.

20 Ibídem, nota 18. 
Según afirma José Gabriel García, "lo encontraron hasta el 18 de julio de $175 \mathrm{r}$ en su morada", ${ }^{21}$ pero no es hasta el 6 de agosto siguiente, cuando la Audiencia informó al Consejo de Indias del fallecimiento del gobernador interino, y de la toma de posesión de sus cargos por parte del sargento mayor de la plaza don Pedro López Ossorio, conforme a lo prevenido en el artículo 85 del reglamento, y cédula de ocho de septiembre de 1736 .

Al mismo tiempo que daba cuenta de estos sucesos, la Audiencia elevaba al Rey "la más reverente súplica, a fin de que consiga este oficial, alguna distinción correspondiente al honor de havernos presidido, o sea empleándolo en la thenencia del Rey que oy se halla vaca, o en otra ocupación proporcionada a su mérito militar", ${ }^{22}$ aunque no tenemos noticias de que esta demanda fuera atendida, sobre todo porque la llegada del nuevo gobernador se produjo casi en seguida.

Esta nueva autoridad había sido ya nombrada a principios de aquel año de I75I para el gobierno de la isla.

En 175I, el Rey dictaba un real decreto por el que, "en atención al dilatado mérito y buenos servicios de don Francisco Rubio to de mis guardias españolas de infantería, le he conferido los empleos de governador, y capitán general de la ysla Española, y presidente de la Audiencia de Santo Domingo, que están vacantes por muerte de don José Colomo". ${ }^{23}$

La expedición del título tuvo lugar el siguiente mes de febrero en el Buen Retiro, designándole como primera autoridad de la isla por el tiempo de ocho años, que comenzarían a contarse desde el día en que tomara posesíńn de sus cargos. ${ }^{24}$

\footnotetext{
21 Ibídem.

22 Carta de la Audiencia de Santo Domingo de seis de agosto de 1751, dando cuenta a la Corte del fallecimiento del gobernador interino, y la toma de posesión de sus cargos por parte del sargento mayor de la plaza. A.G.I., Santo Domingo, 966.

23 R. D. de 23 de enero de 1751 nombrando gobernador, capitán general y presidente de la Audiencia de Santo Domingo a don Francisco Rubio y Peñaranda A.G.I., Santo Domingo, 300 y 942 .

24 Título de gobernador de Santo Domingo a favor de don Francisco Rubio y Peñaranda, expedido en el Buen Retiro el 23 de febrero de 1751. A.G.I., Santo Domingo, 909 y 967 .
} 
Don Francisco Rubio y Peñaranda, llegó a la Española poco tiempo después de la muerte del teniente del rey don José Sunyer y Basteros, y el 20 de agosto de aquel mismo año de 1751, recibió de los "Señores justicias y reximiento" de la ciudad de Santo Domingo, los empleos de gobernador, capitán general y presidente de la Audiencia. ${ }^{25}$

Don Francisco Rubio, como todos los gobernadores que tuvo la isla en esta época, procedía de la carrera militar. Sirvió en I 7 I9 en la campana de Navarra, pasando posteriormente a Génova a las órdenes del Príncipe Pío, para obligar a los franceses a levantar el sitio de Rosas. Estuvo después en varias batallas importantes, en la toma de Omán, y en la expedición a Italia que mandaba el duque de Montemar, en los sitios de Alejandría, Valencia del Po y Casal, y otros hechos de armas, hasta que herido de importancia se retiró a España para su restablecimiento, permaneciendo allí hasta su nombramiento como primera autoridad de la Española. ${ }^{26}$

La principal preocupación de don Francisco Rubio y Peñarand a a su llegada a la isla, será el fomento de la inmigración. Rápidamente se dio cuenta de que el mejor remedio para levantarla de la decadencia en que se encontraba, era poblar la llamada banda del norte, que había sido abandonada en el siglo anterior. Se hizo intérprete desde los primeros momentos de su gobierno, de la política repobladora de la monarquía española, aumentando durante su mandato la llegada de familias colonizadoras procedentes de las islas Canarias. ${ }^{27}$

De este modo, impulsó considerablemente la nueva fundación de San Fernando de Montecristi, comenzada años antes, incrementando el número de sus habitantes, y consi-

25 Certificación del escribano de la presidencia de 28 de septiembre de 1759, sobre la toma de posesión de sus empleos en Santo Domingo por parte de don Francisco Rubio. A.G.I., Escribanía de Cámara, 16-A.

26 Santo Domingo, 10 de junio de 1757. Relación de méritos y servicios del brigadier don Francisco Rubio y Peñaranda. A.G.I., Santo Domingo, 942.

27 García, José Gabriel: Op. cit., tomo I, pág. 209. 
guiendo un real indulto de libre comercio de esta ciudad con todas las naciones, por un tiempo de diez años. ${ }^{28}$

Fomentó asimismo la de San Felipe de Puerto de Plata, cuyo establecimiento se había iniciado durante el gobierno de don Alfonso de Castro y Mazo, comenzando la creación de otra nueva población en la bahía de Samaná, con el nombre de Santa Bárbara de Samaná, a base de familias de las islas Canarias, y la villa de San Juan de la Maguana, cerca de donde se encontraba la antigua ciudad del mismo nombre que fue abandonada en el siglo XVII. ${ }^{29}$ Se ocupó también desde luego, de la protección de las fronteras y de las obras públicas, debiéndose a él la colocación de un reloj de sol situado frente al palacio del gobierno ${ }^{30}$ y la reparación de las murallas de la ciudad, que se encontraban en bastante mal estado. ${ }^{31}$

Tuvo que enfrentarse a algunos problemas que surgieron con la Audiencia, con motivo de un bando que publicó, recién ingresado en sus cargos, prohibiendo la exportación de ganados a la colonia francesa vecina. En este bando, don Francisco Rubio y Peñaranda daba facultad al gobernador de las armas de la villa de Hincha, "para conocer a prebención y substanciar las causas de comisos". La Audiencia le pidió rápidamente explicaciones sobre este hecho $\mathrm{y}$, al mismo tiempo, envió a la Corte un memorial de Tomás de la Cruz, alcalde ordinario de Hincha, en el que manifestaba "que este governador y sus tropas tienen avandonada la frontera, dexando adelantar a los franceses con muchos nuevos establecimientos, sin que para su reparo se haia movido a dar el menor paso". ${ }^{32}$

A juzgar por la sentencia que se dio en su juicio de re-

28 Moya Pons, Frank: Loc. cit., pág. 305.

29 Peguero, Luís Josep: Loc. cit., tomo II, pág. 14.

30 Garcia, José Gabriel: Op. cit., tomo I, pág. 210.

31 Certificación del escribano de la Real Hacienda de Santo Domingo de 11 de septiembre de 1759, sobre las obras de fortificación realizadas en la época de don Francisco Rubio. Sacada del juicio de residencia a que se sometió a don Francisco Rubio. A.G.I., Escribanía de Cámara, 16-A.

32 Informe de Tomás de la Cruz, alcaide ordinario de la villa de Hincha, fechado el 11 de junio de 1755. A.G.I., Santo Domingo, 283. 
sidencia a don Francisco Rubio, todo esto era falso y, con toda probabilidad, se debía simplemente a un enfrentamiento entre el gobernador de las armas y el alcalde ordinario (encargado hasta entonces de las causas de comisos) por una parte, y de la Audiencia y el gobernador por otra, como representantes de dos jurisdicciones distintas, la judicial y la militar respectivamente, que se interferían constantemente, por ser el capitán general gobernador y presidente de la Audiencia al mismo tiempo.

Sin embargo, el Consejo de Indias, intentando resolver esta disputa, no tuvo en cuenta las razones que adujo don Francisco Rubio para la realización de esta innovación, desaprobándole lo que había ejecutado en este asunto, y por tanto, desautorizando al gobernador de las armas de la villa de Hincha para conocer en las causas de comisos, ordenándosele taxativamente, que no embarazara en manera alguna a los alcaldes ordinarios en esa tarea. ${ }^{33}$

Otro problema surgido durante su gobierno fue la sublevación del batallón fijo de Santo Domingo, que tuvo lugar el 13 de julio de I757. El motivo que produjo este levantamiento, fue la tardanza en la remisión del situado que debía enviarse desde México todos los años, y con ello, la falta de dinero con que pagar a las tropas. Por esta causa, se reunieron unos 180 soldados con todas sus armas frente a la Catedral, y enviaron un piquete al fuerte de Santa Bárbara apoderándose de él, apuntando toda su artillería hacia la ciudad, y conminando a las autoridades a que se les pagasen sus sueldos atrasados. La Compañía de Jesús se ofreció a actuar como intermediario en el conflicto sin ningún resultado, ya que los amotinados exigían el pago de los 28 meses que se les debia y no había dinero para ello. Ante este fracaso, don Francisco Rubio designó para tratar con ellos a un oidor de la Audiencia, don José Gómez Buelta, y tras largas negociaciones, sus peticiones se redujeron al abono

33 Resolución del Consejo de Indias de nueve de octubre de 1756. A.G.I., Santo Domingo, 283. 
de tres meses de los salarios atrasados, y que "por vía de prest se les asistiese todos los meses con seis pesos, mandándose a sus capitanes les subministrasen todo lo demás necesario..." El gobernador, comprendiendo los problemas en que los soldados se encontraban al carecer de sus emolumentos actuó con prudencia, aceptando estas proposiciones, y prometiendo a todos el perdón si entregaban sus armas, volviendo con ello la normalidad a la ciudad. ${ }^{34}$

En enero de 1758 , don Francisco Rubio y Peñaranda solicitó a la Corte que, puesto que sólo quedaban I I meses para el término de su mandato, se le permitiera regresar a España en cuanto llegara su sucesor, concediéndosele la residencia por apoderado, con el fin de no tener que permanecer en la isla por más tiempo. ${ }^{35} \mathrm{E} 1$ Rey no sólo accedió a esta petición, sino que además lo nombró comandante militar de Madrid, ${ }^{36}$ aunque en realidad no fue relevado por su sucesor en aquel gobierno hasta el 4 de agosto de I759. ${ }^{37}$

El resultado del juicio de residencia al que se le sometió no pudo ser mejor, quedando absuelto por completo, "en atención a no haverle resultado cargo alguno", señalándose en la sentencia, que en todo momento había actuado cumplidamente con los empleos que detentaba, sin que nadie pudiera hacerle alguna acusación, fomentando las nuevas poblaciones, cuidando las obras públicas, etc. ${ }^{38}$

34 Madrid, 11 de noviembre de 1758. Expediente surgido con motivo del levantamiento del batallón fijo de la plaza de Santo Domingo. A.G.I. Santo Domingo, 1.088.

35 Carta de don Francisco Rubio y Peñaranda de 11 de enero de 1758 dirigida a la Corte, solicitando se le concediese la residencia por apoderado. A.G.I., Santo Domingo, 942 .

36 R. C. de 15 de abril de 1758, accediendo a conceder a don Francisco Rubio la residencia por apoderado. A.G.I., Escribanía de Cámara, 16-A.

37 Carta del gobernador de Santo Domingo don Manuel de Azlor y Urríes de 10 de octubre de 1759 , dando cuenta a la Corte de haber llegado a la isla y de haber tomado posesion de sus empleos el cuatro de agosto de aquel año. A.G.I., Santo Domingo, 283 y 944.

38 Sentencia del juicio de residencia a que se sometio a don Francisco Rubio y Peñaranda, dada el 24 de octubre de 1759. A.G.I., Escribanía de Cámara, 16-A. 


\section{Los Gobernadores de CarLos III}

A consecuencia de la promoción de don Francisco Rubio y Peñaranda a la comandancia militar de Madrid, en I758 un real decreto nombraba para sustituirle como gobernador, capitán general de la isla Española, y presidente de su Real Audiencia, a don Manuel de Azlor y Urríes, coronel del regimiento de dragones de Frisia, ${ }^{39}$ que comenzó su mandato en I759, casi coincidiendo con la llegada de un nuevo Monarca al trono español, Carlos III.

Procedente como su antecesor de la carrera militar, don Manuel de Azlor era aragonés, ${ }^{40}$ y había servido desde I727 los empleos de alférez, teniente, y capitán de dragones, "exento graduado, theniente coronel en la compañía de granaderos de a cavallo", y coronel de dragones del regimiento de Frisia. ${ }^{41}$

Tras su designación como gobernador de la Española partió para la isla, donde desembarcó el 3 de agosto de I759, recibiendo sus cargos al día siguiente de manos de su predecesor don Francisco Rubio. ${ }^{42}$

La principal preocupación de don Manuel de Azlor y Urríes durante la etapa de su mandato, será el incremento demográfico del Santo Domingo español, como medio de conseguir un florecimiento económico y de contener a los franceses en los territorios que entonces ocupaban.

En este sentido, fomentó las fundaciones de sus predecesores, como las de San Fernando de Montecristi, Santa Bárbara de Samaná, en la bahía de Samaná, ${ }^{43}$ San Ra-

39 R. D. fechado en el Buen Retiro el uno đe mayo de 1758 , nombrando gobernador de la Española a don Manuel de Azlor. A.G.I., Santo Domingo, 300 y 943.

40 Alcedo, Antonio de: Loc. cit., pág. 32.

41 Carta del gobernador de Santo Domingo don Manuel de Azlor fechada el 18 de octubre de 1769 , dando cuenta a la Corte de su deseo de que se le relevase de su cargo. A.G.I., Santo Domingo, 944.

42 Carta del gobernador de Santo Domingo don Manuel de Azlor de 10 de octubre de 1759, dando cuenta a la Corte de su llegada a la isla, y de haber tomado posesión de sus empleos. A.G.I., Santo Domingo, 283 y 944.

43 Carta del gobernador de Sinto Domingo don Manuel de Azlor de 15 de enero de 1760 , dando cuenta a la Corte de la fundación de una nueva población en la bahía de Samaná. A.G.I., Santo Domingo, 1.011. 
fael de la Angostura en la zona fronteriza, ${ }^{44}$ San Gabriel de las Caobas, ${ }^{45}$ Santa Cruz de Neiba, ${ }^{46}$ San Miguel de la Atalaya, ${ }^{47}$ y Dajabón, ${ }^{48}$ e intentó también la creación de otra en la boca del río Haina, como medio de proteger la capital de cualquier ataque. ${ }^{49}$

Respecto a las obras públicas, preconizó la construcción de una nueva cárcel, ya que según el informe del ingeniero de la plaza, la que existía en aquellos momentos "no sólo amenaza ruina, sino que parece contra toda regla el que se mantenga en pie", ${ }^{50}$ siendo necesario derribarla y levantarla de nuevo.

Se ocupó también de la reparación del muelle del puerto de Santo Domingo, por ser "frecuentes los clamores con que llamaron repetidamente la atención de todo el público, y particularmente del gobierno, los dueños de barcos que frecuentan este puerto, sobre la dilación en las cargas y descargas". Esta obra hizo que quedaran resguardadas la casa de la Aduana y la de los guardas, que amenazaban con quedar destruidas con las crecientes, y la misma muralla, que quedaría al descubierto tras la ruina de aquélla. ${ }^{5}$

En las relaciones con la colonia francesa vecina, rea-

\footnotetext{
44 Carta del gobernador de la Española don Manuel de Azlor fechada el 10 de noviembre de 1763, danđo cuenta a la Corte de la situación de las nuevas fundaciones. A.G.I., Santo Domingo, 1.020.

45 Carta de don Manuel de Azlor de 31 de mayo de 1768, informando a la Corte de la solicitud que le hizo don Fernando de Espinosa para la fundación dei un pueblo en el paraje de las Caobas. A.G.I., Santo Domingo, 979.

46 Moya Pons, Frank: Op. cit., pág. 287.

47 Expediente surgido con motivo de la solicitud de don José Guzmán para crear un pueblo a su costa en la zona de la Atalaya, 1768 a 1770. A.G.I., Santo Domingo, 1.005 .

48 Expediente surgido con motivo de la solicitud de don Gaspar de Leoz y Echalas para la fundación de un pueblo en Dajabón. 1768 a 1771. A.G.I., Santo Domingo, 979.

49 Carta del gobernador de Santo Domingo don Manueh de Azlor, de 21 de febrero de 1761, informando a la Corte de la conveniencia de fundar una población en la boca del río Haina. A.G.I., Santo Domingo, 1.011.

50 Carta del gobernador de la Española don Manuel de Azlor de 19 de enero de 1770, informando a la Corte de la necesidad de construir una nueva cárcell en la capital de la isla. A.G.I., Santo Domingo, 981.

51 Carta de la Audiencia de Santo Domingo de 26 de enero de 1771 y otra de los oficiales reales de aquella plaza de 25 de abril del mismo año, contestando a la R. C. de cinco de agosto de 1770 , en 1a que se les ordenaba que informasen sobre las obras que el gobernador pretendía hacer en el muelle. A.G.I., Santo Domingo, 983.
} 
lizó la política de convivencia y buena armonía preconizada por el Monarca español, como reflejo del entendimiento entre las dos Metrópolis. Causa de ello fue el convenio que firmó el I I de diciembre de 1766 con el señor Valtiere, representante del gobernador francés, sobre la mutua entrega de los negros fugitivos y de los soldados desertores. ${ }^{52}$

Un hombre que desarrolló tan gran actividad durante la etapa de su gobierno, no podía dejar de tener seguidores fervientes. Pero al mismo tiempo, no podían faltarle tampoco enemigos, y éstos los encontró principalmente en los ministros de la Real Audiencia. En 1762, don Manuel de Azlor y Urríes daba cuenta a la Corte, de haber tenido serias diferencias con el oidor don José Gómez Buelta y otros ministros, que "estos días pasados llegó a términos que estuve ya para hacerle sumaria y prenderlo, acompañándome con los alcaldes ordinarios". No llegó a hacerlo por haberse retractado el mencionado oidor, ofreciéndose a darle entera satisfacción y a presentar la dimisión de su cargo. En vista de ello, don Manuel de Azlor manifestaba al Consejo de Indias, que la dimisión debía serle aceptada como único medio de que la normalidad volviera a la Audiencia. Se mostraba también partidario el gobernador, de que se "amonestasse con este motivo a toda la Audiencia y a cada uno de sus oydores, que no se mezclen en asumptos de govierno, pues aquí todos quieren ser governadores y capitanes generales, y continuamente van sembrando especies". 53

La chispa que había hecho estallar esta disputa fue un pasquín que circulaba por la ciudad, y que el gobernador atribuyó a don José Gómez Buelta, atacando a los oficiales reales y, particularmente, al comandante de artillería don Benito Lisle, que al parecer se vio favorecido siempre tan-

52 Santo Domingo, 11 de diciembre de 1766. Acuerdo firmado por el gobernador del Santo Domingo español don Manuel de Azlor y el representante de la colonia francesa señor Valtiere, sobre la mutua entrega de los negros fugitivos de una y otra colonia. A.G.I., Santo Domingo, 1.011.

53 Cartas del gobernador don Manuel de Azlor de 25 de julio y seis de diciembre de 1762, informando a la Corte de la actuación de varios ministros de la Audiencia de la Española. A.G.I., Santo Domingo, 1.011. 
to por don Manuel de Azlor, como por su predecesor en el cargo.

El asunto finalizó con la aceptación por parte de la Corte de la dimisión del oidor don José Gómez Buelta, concediéndosele licencia para regresar a España en breve plazo dejando afianzada su residencia, y las imposiciones de algunas multas a otros ministros. ${ }^{\mathbf{5 4}}$

Pero los problemas entre don Manuel de Azlor y la Audiencia Real de Santo Domingo no terminaron aquí. En 1766, el gobernador inició una visita general a la isla. Con este motivo, consultó a la Audiencia sobre quién debía encargarse en su ausencia del gobierno interino, para evitar en lo posible las discrepancias. Don Manuel de Azlor consideraba que, según la legislación existente sobre este asunto, el gobierno, capitanía general, y presidencia de la Audiencia, quedaban al cargo del teniente del Rey de la plaza de Santo Domingo, en aquellos momentos don Luís de Cassasola. Pero los miembros de aquel tribunal manifestaron, que debían subdelegarse en él "los ramos de mayor consecuencia". ${ }^{55}$ En vista de ello, don Manuel de Azlor, en contra de su parecer, dejó comisionado al teniente del Rey sólo en el mando militar, y "para el despacho de los expedientes que no sufran dilación y necesitasen de pronta providencia". ${ }^{56}$

A pesar de esta medida, las tensiones se agudizaron con la ausencia del gobernador, pues toda la Audiencia se oponía a cualquier determinación del teniente del Rey, negándose a considerarlo como la primera autoridad de la isla en aquellos momentos, tal y como se les comunicó por

54 Carta del gobernador de Santo Domingo de 19 de abril de 1762, remitiendo a la Corte un folleto que circulaba por la ciudad, y resolución del Rey al respecto de uno de julio de 1763. A.G.I., Santo Domingo, 1.011.

55 Carta de don Manuel de Azlor de 15 de enero de 1766, y otra de la Audiencia de 21 de enero del mismo año, solicitando a la Corte se les informase claramente sobre quien debía ocupar el gobierno interino de la isla por ausencia de su primera autoridad. A.G.I., Santo Domingo, 977.

56 Carta del teniente del rey de la plaza de Santo Domingo de 16 de febrero de 1766, sobre los problemas presentados en la isla a cauea de su gobernación interina. A.G.I., Santo Domingo, 1.094. 
real cédula de $5_{5}$ de diciembre de aquel mismo año. En ella se declaraba "que el teniente del rey don Luís de Cassasola, succeda interinamente en el govierno, capitanía general y presidencia de la Audiencia, en el caso de que el que exerza en propiedad estos empleos falte o salga fuera del distrito de la ysla". ${ }^{57}$

Sin embargo no todo fueron ataques contra don Manuel de Azlor y Urríes. Al igual que fieros detractores tuvo también fieles seguidores, entre ellos los miembros del Cabildo de la ciudad de Santo Domingo, que, en enero de 1767, con motivo de finalizar el período de ocho años señalado para su gobierno, solicitaba al Rey que, en vista de su buena actuación y el celo que desarrolló en todos los asuntos que le fueron confiados, se le prorrogara por ocho años más en aquel destino. ${ }^{58}$ El Monarca accedió a ello, aunque va a ser el mismo don Manuel de Azlor el que pedirá su cese en 1769, aduciendo lo avanzado de su edad, 61 años, y su deseo de regresar a España. Pero el Rey ordenó su permanencia en el gobierno de Santo Domingo, hasta el momento en que quedasen arregladas las diferencias existentes con los franceses, por la delimitación de la frontera común en aquella isla. ${ }^{59}$

Sin embargo no llegó a finalizar este asunto, ya que en septiembre de I770, un real decreto accedía por fin a sus peticiones relevándole de aquellos cargos, que podía abandonar en el momento en que llegara el sucesor que se había designado, don José Solano y Bote, y al que entregó el mando en $\mathrm{I} 7 \mathrm{I}_{\mathrm{I}}{ }^{60}$

57 R.C. de 15 de diciembre de 1766, declaratoria de quién debía ocupar la gobernación interina de la Española, por ausencia, enfermedad o muerte del gobernador. A G.I., Santo Domingo, 890.

58 Carta del Cabildo de la ciudad de Santo Domingo de nueve de enero de 1767, solicitando a la Corte se prorrogase por ocho años más el gobierno de don Manuel de Azlor. A.G.I., Santo Domingo, 944.

59 Carta del gobernador de Santo Domingo don Manuel de Azlor de $\mathbf{1 8}$ de octubre de 1769 pidiendo a la Corte se le relevase de su cargo, y respuesta de $\mathbf{b}$ Corte de 16 de febrero de 1770. A.G.I., Santo Domingo, 944.

60 R.D. de seis de septiembre de 1770, nombrando como gobernador de Santo Domingo a don José Solano y Bote, y carta de éste de 20 de abril de 1771, dando cuenta de haberse hecho cargo del gobierno de la isla. A.G.I., Indiiferente General, 585 y Santo Domingo, 940 y 944. 
Don Manuel de Azlor tuvo que afrontar graves acusaciones en el juicio de residencia al que se le sometió. La más importante de ellas, fue la de haber dado excesivas licencias a los comerciantes para traer víveres de las colonias extranjeras, sin existir verdadera necesidad, sin dictamen del Real Acuerdo y fiscal de la Audiencia, e instancia del síndico procurador general tal y como prevenían las leyes. ${ }^{61}$

A pesar de ello la sentencia le fue favorable, absolviéndole de la acusación por lo que respecta al tiempo de guerra, desde el I de agosto de 1765 al mismo día y mes de 1766 , y desde junio de I770 a octubre del mismo año, por justificarlo la necesidad, dejándose la resolución de lo que se refería al resto del tiempo de su gobierno en manos del Rey. Por lo demás, se le declaró "por buen ministro, digno y acrehedor a que S. M. le continúe las honrras y gracias con que hasta aquí se ha servido premiar sus méritos". ${ }^{62}$

Es indudable desde luego, que aunque legalmente se pudieron poner algunos reparos a su actuación, la etapa de su mandato fue de una gran actividad para la isla en todos los campos: fundación de nuevas poblaciones, incremento del tráfico mercantil, etc. Precisamente por eso su labor fue recompensada por el Monarca, que le concedió el título de brigadier en i 760 , el de mariscal de campo en I 763 , y por último el de teniente general en $1770 .{ }^{63}$

En I770, y a causa de las reiteradas peticiones hechas por don Manuel de Azlor para que se le relevase de sus cargos, el Rey promulgaba un decreto por el que "he condescendido a que lo practique, luego que llegue el sucesor que lo releve", nombrando para sus empleos al capitán de navío de lar Real Armada don José Solano y Bote, entonces gober-

61 Certificación del escribano de cámara y gobierno de la ciudad de Santo Domingo sobre las licencias concedidas a distintas embarcaciones, para traer víveres de las colonias extranjeras durante el gobierno de don Manuel de Azlor. Sacada del expediente sobre el juicio de residencia a que se sometio a este gobernador. A.H.N. Consejos, 21.465 .

62 Santo Domingo, 19 de julio de 1771. Sentencia del juicio de residencia al que se sometió al gobernador don Manuel de Azlor. A.H.N., Consejos, 21.465.

63 Título de brigadier concedido a don Manuel de Azlor con fecha de nueve de octubre de 1760. Idem de mariscal de campo con fecha de 24 de abril de 1763 y de teniente general en 1770. A.G.I., Santo Domingo, 944. 
nador de Venezuela y capitán general de Caracas, ${ }^{64}$ expidiéndosele el correspondiente título el 20 del mismo mes y año, tomando posesión de la gobernación y capitanía general que se le acababa de asignar, el $\mathrm{I} 7$ de abril del siguiente año de $1771{ }^{65}$

Don José Solano y Bote inició su carrera militar como guardiamarina en Cádiz, sirviendo "en las guerras de los años cuarenta a cuarenta y ocho en el navío El león", de la escuadra mandada por el marqués de la Victoria, y posteriormente en la de don Francisco Liaño. A continuación, desde I 749 a I 753, marchó dos veces a Francia y una a Inglaterra para realizar estudios de marina de guerra, siendo nombrado después comisario para el establecimiento de los límites entre las posesiones españolas y portuguesas en América, y siendo ascendido para esta misión a capitán de fragata. Con este fin se embarcó en I754, realizando una gran expedición por el Orinoco, el Casiquiare, y el Negro, regresando a España en I761, donde se le encomendó al año siguiente el mando del navío "el Rayo". En i 763 fue nombrado gobernador y capitán general de la provincia de Caracas, donde permaneció hasta su nombramiento como gobernador, capitán general, y presidente de la Audiencia de Santo Domingo, cargos de los que tomó posesión en la fecha ya señalada. ${ }^{66}$

Durante su mandato en la Española, don José Solano intentó por todos los medios el fomento de la agricultura, especialmente del tabaco, para cuyo transporte desde Santiago y la Vega al puerto de la capital, dispuso que se hiciera navegable el río Yuma. ${ }^{67}$

64 R. D. de seis de septiembre de 1770 , nonkarando gobernador de la Española a don José Solano. A.G.I., Indiferente General, 585.

65 Título de gobernađor, capitán general y presidente de la Audiencia de la Española a favor de don José Solano y Bote, expedido con fecha 20 de septiembre de 1770, y carta de aquél de 20 de abril de 1771, dando cuenta a la Corte de haber tomado posesión de sus empleos. A.G.I., Santo Domingo, 912, 940 y 944.

66 Santo Domingo, uno de agosto de 1766. Relación de los méritos y servicios del gobernador de Santo Domingo don José Solano y Bote. A.G.I., Santo Domingo, 945. 67 Santo Domingo, nueve de febrero de 1779, Sentencia del juicio de residencia a que se sometio al gobernador de Santo Domingo don José Solano. A.H.N., Consejos, 20.766 . 
Se ocupó de la reparación de la cárcel de aquella ciudad, y de la construcción de almacenes y aduanas para su puerto, ${ }^{68}$ del arreglo de las murallas, fábrica de cuarteles y fortificaciones como las de San Fernando de Montecristi, Santa Bárbara de Samaná, San Felipe de Puerto de Plata, y la boca del río Haina, ${ }^{69}$ sin abandonar por ello el aspecto cultural que se empeñó en mejorar, dando realce a la Universidad y creando una escuela de matemáticas en Santo Domingo, ${ }^{70}$ y una sociedad o Cámara de agricultura. ${ }^{7}$

Gran parte de sus esfuerzos estuvieron dirigidos a terminar con el contrabando y la excesiva exportación de ganado. Con este fin estableció un fuerte resguardo en la frontera, "con la guarnición de tres compañías de sesenta y tres hombres de infantería y del batallón de esta plaza, que anualmente se mudan, y de veinte guardas de a cava1lo", dotándose además nueve guardas de mar con destino a la falúa y al puerto, tres de a caballo para las puertas de la ciudad, y otros tres en Hincha, con lo que al parecer se pusieron algunas trabas serias al comercio ilícito. ${ }^{72}$

En esta misma línea, se negó a conceder licencias para traer víveres de las colonias extranjeras, para que no hubiera el menor motivo de negociación prohibida. Y con el fin de que aquéllos no faltasen en el abastecimiento de la capital, fomentó el libre comercio, acabando así con cualquier pretexto para acudir a los foráneos. ${ }^{73}$

Inmediatamente se dio cuenta, de los beneficios que reportaría a la colonia el que se permitiera a sus vecinos la traída de utensilios, y sobre todo de esclavos, de la parte

\footnotetext{
68 Carta del gobernador đe Santo Domingo don José Solano fechada el 24 de enero de 1773, informando a la Corte da las reparaciones que eran necesarias en la ciudad. A.G.I., Santo Domingo, 983.

69 Memorial sobre el gobierno de la Española de don José Solano y Bote de 18 de agosto de 1781, certificado por don Francisco Xavier de Elipe, notario del Rey. A.G.I., Santo Domingo, 1.006 .

70 Ibídem, nota 67.

71 Moreau de Saint-Mery, M. L.: Loc. cit., pág. 159.

72 Certificación de los oficiales reales de Santo Domingo de 28 de enero de 1779 , sobre los gastos ocasionados en la lucha contra el contrabando durante el gobierno de don José Solano. A.H.N., Consejos, 20.766.

73 Ibídem, nota 69.
} 
francesa a cambio de sus reses, y luchó por conseguir del Rey este beneficio, aumentando por esta causa considerablemente el tráfico mercantil entre ambas colonias. ${ }^{74}$

Mejoró la recaudación de impuestos, incrementando en gran manera el caudal de la Real Hacienda, "de forma que casi llegó a duplicar su valor en aquellas Reales Cajas", atendiendo con gran interés a la buena distribución de los situados. ${ }^{75}$

Dada su actuación como comisario de límites entre las posesiones españolas y portuguesas en el subcontinente sur, se le encargó la firma de un tratado que estableciera una frontera definitiva entre los franceses y los españoles residentes en aquella isla. Con este fin pasó dos veces a los territorios en conflicto para su reconocimiento, firmando un acuerdo provisional en $1772,{ }^{76}$ y otro en Puerto Príncipe al año siguiente, que no fueron ratificados sin embargo por las respectivas Metrópolis, ya que, si bien fue aprobado por el Monarca español, fue desautorizado por la Corona francesa como perjudicial a sus intereses. Con este motivo se dieron nuevas órdenes a don José Solano, para que tratara de llegar a un acuerdo que significara el término de las discordias, ${ }^{77}$ y por fin, en febrero de 1776 , los representantes francés y español concertaron otro convenio en el que se hacía una descripción detallada de los límites, y en la que se basó el posterior tratado de Aranjuez de $1777 .{ }^{78}$

Una vez finalizada esta comisión, don José Solano so-

74 Ibídem, nota 71.

75 Ibídem, nota 69.

76 Acuerdo provisional firmado por los comisionados español y francés el 25 de febrero de 1772, para arreglar los problemas fronterizos entre las dos colonias de la isia. A.G.I., Santo Domingo, 1.018.

77 Carta del gobernađor de Santo Domingo don José Solano de 24 de septiembre de 1773, dando cuenta a la Corte de la firma de un nuevo acuerdo entre las dos colonias el 25 de agosto anterior, y carta de la Corte al gobernador fechada en Aranjuez el 18 de mayo de 1774. A.G.I., Santo Domingo, 1.019.

78 Instrumento firmado por los comisarios español y francés el 28 de agosto de 1776, como base del tratado definitivo de límites entre las dos colonias de Samto Domingo. A.G.I., Santo Domingo, 1.019 . 
licitó que se le relevase de sus empleos, dejando afianzada su residencia por apoderado para poder regresar cuanto antes a España. El Rey accedió a su petición, pero se le ordenó que permaneciera en la isla hasta la llegada de su sucesor don Isidro de Peralta y Rojas, nombrado en enero de I778, y al que se previno que dada la premura de don José Solano por volver a la Península, se dirigiera con la mayor celeridad posible a Santo Domingo. ${ }^{79} \mathrm{Y}$ así, el 3 de agosto de aquel mismo año, Solano pudo al fin hacer entrega de sus empleos a su sucesor ${ }^{80}$ sin que se cumplieran los ocho años para los que había sido designado.

Los siete años que duró su gobierno, constituyeron al parecer uno de los períodos más fructíferos para la isla. El único cargo que se le hizo en su juicio de residencia fue el de dar empleos a sus familiares, acusación de la que resultó absuelto. Y dada su "acreditada conducta, desinterés y fuerza con que particular y generalmente desempeñó las importantes atenciones de sus empleos, haviéndose notado la puntualidad con que daba cumplimiento a las reales órdenes", fue declarado por "buen ministro, limpio, recto, y zeloso del servicio del Rey, y muy acrehedor a que su magestad se digne dispensar las mayores honrras y gracias", ${ }^{81}$ siendo nombrado a continuación, en premio a sus méritos, jefe de la escuadra que operaba en las Antillas en la guerra contra los ingleses, y ascendido posteriormente a capitán general. ${ }^{82}$

En enero de $\mathbf{7 7 7 8}$, un real decreto designaba al coronel don Isidro de Peralta y Rojas, como gobernador, capitán general, y presidente de la Audiencia de Santo Domingo, en

79 Carta del gobernador de Santo Domingo don José Solano y Bote de 27 de abril de 1777, solicitando a la Corte se le relevase de su cargo y se le concediese le residencia por apoderado. Respuesta de la Corte de 30 de diciembre del mismo año, y carta de ésta al inuevo gobernador con fecha de 16 de mayo de 1778. A.G.I., Santo Domingo, 945.

80 Carta del gobernador de Santo Domingo don Isidro de Peralta y Rojas de nueve de agosto de 1778, dando cuenta a la Corte de haber tomado posesión de sus empleos. A.G.I., Santo Domingo, 940 y 945.

81 Ibídem, nota 67.

82 García, José Gabriel: Op. cit., tomo I, pág. 228. 
sustitución de don José Solano y Bote, ${ }^{83}$ expidiéndosele el correspondiente título en mayo de aquel mismo año. ${ }^{84}$

Natural de Granada, ${ }^{85}$ comenzó su carrera como capitán del regimiento de infantería de Cataluña el 12 de octubre de I742, pasando dos años más tarde al regimiento de Navarra, y en I 745 al de Galicia con destino en Niza. Estuvo entonces en la campaña de Italia, regresando a Cataluña en I752, Dos años después fue nombrado segundo teniente de reales guardias españolas, actuando en la campaña de Portugal y regresando de nuevo a Cataluña al finalizar la guerra. Permaneció allí hasta 1768 , año en que se le concedió el gobierno político y militar de la plaza de Tarifa, cargo que detentó hasta su nombramiento como gobernador, capitán general, y presidente de la Audiencia de Santo Domingo, ${ }^{86}$ tomando posesión de sus nuevos empleos el 3 de agosto de i778, como ya hemos indicado. ${ }^{87}$

Don Isidro de Peralta y Rojas comenzó su mandato al parecer dando muestras de gran actividad, y al poco tiempo de su llegada a la Española, daba cuenta a la Corte de su deseo de realizar una visita general a toda la isla, "para reducir a nuevas poblaciones a las muchas gentes dispersas en bojíos por los montes, reconocer los puestos interiores, pueblos, puertos y caletas, y la raya que nos divide de las posesiones francesas". La visita sin embargo se fue demorando por falta de dinero para realizarla, y en esta situación, en I779 de nuevo estalló la guerra entre España y Francia por un lado, que apoyaban a los nacientes Estados Unidos en su

\footnotetext{
83 Carta de la Corte dirigida a don Isidro de Peralta y Rojas con fecha de 25 de marzo de 1778, comunicándole haber sido nombrado gobernador de la Española por R. D. de 23 de enero del-mismo año. A.G.I., Santo Domingo, 945.

84 Título de gobernador, capitán general y presidente de la Audiencia de la Española a favor de don Isidro de Peralta y Rojas con fecha de ocho de mayo ide 1778. A.G.I., Santo Domingo, 945.

85 Alcedo, Antonio de: Op. cit, pág. 33.

86 Carta 'del gobernador de Santo Domingo don Isidro de Peralta y Rojas de 20 de noviembre de 1779 , haciendo relación a la Corte de sus mériłos y servicios. A.G.I., Santo Domingo, 946.

87 Carta del gobermađor don Isidro de Peralta y Rojas de nueve de agosto de 1778, dando cuenta a la Corte de haber tomado posesión de sus empleos en Santo Domingo. A.G.I., Santo Domingo, 940 y 945.
} 
independencia, e Inglaterra por el otro. Con este motivo, se dio aviso rápidamente al gobernador de Santo Domingo, para que en el caso de que no hubiera comenzado su proyectada visita general a la isla. la suspendiera mientras durasen las hostilidades. ${ }^{88}$

Durante su gobierno, don Isidro de Peralta se vio envuelto en las disputas internas propias de una ciudad pequeña, en la que todos trataban de establecer su superioridad. Así, en 1782, junto con los tres oidores más antiguos de aquella Audiencia, don Luís de Chaves, don Agustín de Emparán y don Ramón Jover, daba cuenta a la Corte de los afanes de poder y "preminencias" de la Curia Metropolitana, que al hallar siempre una barrera para sus propósitos en los ministros de aquel tribunal, y siéndole necesario "el apoyo de la magistratura para el logro de sus avaros proyectos", se aprovechaba de la inexperiencia del oidor más moderno, don Manuel Bravo, para formar una oposición al presidente, creando cada vez más obstáculos a la administración de justicia. El Consejo sin embargo no sólo no dio la razón al gobernador, sino que, manifestando que las acusaciones hechas no estaban justificadas, declaró que "sería muy conveniente se le removiese de aquel destino, para que así se vuelva a establecer el espíritu de paz y buena armonía, que ha dejado de reinar desde que principió su govierno". Pero el Rey no accedió a ello, y lo único que se hizo al respecto fue remitir una carta a don Francisco Gamboa, regente de la Audiencia, ordenándosele que advirtiera a sus ministros, con el fin, de que se restableciera el buen orden en el tribunal. ${ }^{89}$

También tuvo dificultades don Isidro de Peralta con el teniente del rey de la plaza de Santo Domingo, don Joa-

\footnotetext{
88 Carta del gobernador de Santo Domingo don Isidro de Peralta y Rojas de 15 de mayo de 1779 dirigida a la Corte, y respuesta de aquélla de 26 de octubre del mismo año. A.G.I., Santo Domingo, 945.

89 Carta del presidente de la Audiencia de Santo Domingo y tres oidores de aquel tribunal dirigida a la Corte con fecha de 12 de octubre de 1782, resolución del Consejo de Indias de 22 de noviembre de 1783, y respuesta del regente de la Audiencia de 25 de mayo d'e 1784 a la carta acordada de 19 de febrero de 1784. A.G.I., Santo Domingo, 986.
} 
quín García, a pesar de que tradicionalmente estas dos autoridades estuvieron siempre unidas para hacer frente al poder de la Audiencia. En la Semana Santa de I782, por indisposición del gobernador, fue sustituido en las ceremonias del jueves y el viernes santo por don Joaquín García. El jueves estuvieron con él todos los capitulares del Ayuntamiento, tal y como prevenían las normas vigentes. Pero el viernes no acudió ninguno, habiéndose puesto previamente de acuerdo para ello, "pretextando querer evitar competencias con el que representa". El teniente del rey se quejó entonces de este agravio a don Isidro de Peralta, pero éste, "no sólo dexó ajado el honor del suplicante, sino también el suyo propio", ya que García acudió a los oficios exclusivamente como representante de aquél. Es extraño desde luego, ver como por primera vez en toda la época estudiada se enfrentan estas dos autoridades. Normalmente el gobernador apoyaba en todo momento al teniente del Rey, como vimos claramente en el caso de don Manuel de Azlor, como segundo representante de la autoridad militar, que siempre intentó imponerse sobre la civil. Pero en esta ocasión, don Isidro de Peralta no sólo no exigió una reparación al Cabildo en favor de don Joaquín García, sino que además "le añadió nuevos ultrajes y agravios, y le cercena y niega los honores, facultades y prerrogativas, que le concede el real título con que sirve sus empleos". ${ }^{\circ 0}$ Por esta causa, el Consejo de Indias impuso una serie de multas a los capitulares deI Ayuntamiento, por desacato contria la representación del Patronato Real, y se advirtió al gobernador por su comportamiento, ordenándole que en lo sucesivo apoyara, conforme a las leyes, los derechos del teniente del Rey. ${ }^{91}$

Pero a pesar de que el Consejo de Indias, desde que surgieron las primeras disputas, no se conformaba sólo con

90 Petición de don Santiago Sáenz a la Corte fechada en Madrid el 25 de enero de 1783 , en virtud del poder que le concedió don Joaquín García, teniente del rey de la plaza de Santo Domingo. A.G.I., Santo Domingo, 1.023.

91 Resoluciớn đel Consejo de Indias de 17 de marzo de 1783 y carta del gobernador don Isidro de Peralta y Rojas de 20 de diciembre del mismo año, acusando el recibo de la R.C. de 26 de jullo de 1783. A.G.I., Santo Domingo, 1p.023. 
desaprobar la conducta de don Isidro de Peralta y Rojas, sino que incluso se mostraba partidario de que se le relevase de sus cargos, el gobernador era al parecer protegido por el Monarca, que se negó en todo momento a hacer caso de las opiniones del Consejo a este respecto, premiándole incluso por sus méritos con el ascenso a brigadier de infantería. ${ }^{92}$

En otros aspectos, durante su gobierno se incrementaron considerablemente las licencias concedidas a distintas embarcaciones para traer comestibles de las colonias extranjeras. Estos permisos habían descendido netamente en tiempos de don José Solano y Bote. Por ello, el Consejo de Indias de nuevo desaprobó su actuación, remitiéndole una comunicación en la que le manifestaba, que tenía noticias ciertas de que en los puertos dominicanos se admitían sin dificultad los navíos extranjeros, a pesar de estar prohibido por las leyes y las reales órdenes promulgtadas sobre el asunto. ${ }^{93}$

Don Isidro de Peralta y Rojas fue relevado de sus empleos en julio de 1785, ordenándosele su regreso a España cuando entregara el mando a su sucesor, dejando afianzada la residencia por apoderado, por necesitarlo allí el Rey. Se nombró para sustituirle a don Manuel González, entonces gobernador y capitán general de Caracas. ${ }^{94}$

Sin embargo, Peralta no pudo regresar a la Península, pues antes de la llegada a la isla de don Manuel González, se vio aquejado de una grave enfermedad, y murió el 26 de septiembre de aquel mismo año, ocupando la gobernación interina el teniente del Rey don Joaquín García Moreno. ${ }^{95}$

92 Carta del gobernador de Santo Domingo don Isidro de Peralta y Rojas con fecha de 18 de junio de 1784, acusando el recibo del real despacho de brigader de infantería que se le concedió por decreto de 23 de marzo de 1784. A.G.I., Santo Domingo, 946.

93 Carta del gobernador don Isidro de Peralta y Rojas dando cuenta a la Corte de haber recibido una comunicación del Consejo sobre los navíos extranjeros que llegaban a Santo Domingo. A.G.I. Santo Domingo, 946.

94 R. C. fechada en San Ildefonso el uno de agosto de 1785, relevar:do de sus cargos a don Isidro de Peralta y Rojas. A.G.I., Santo Domingo, 947.

95 Carta del teniente del rey de la plaza de Santo Domingo de 29 de septiembre de 1785, dando cuenta a la Corte del fallecimiento del gobernador de la isla. A. G.I., Santo Domingo, 940 . 
A pesar de que el gobierno de don Isidro de Peralta y Rojas, no ofreció al parecer resultado positivo pära la isla, resaltando sólo en este período los problemas surgidos entre las distintas entidades isleñas por imponer su supremacía, el 15 de febrero de 1786 , una real orden fechada en el Pardo lo relevaba de su juicio de residencia, "en consideración a los méritos y servicios". ${ }^{86}$

En julio de 1785 , se expidió el título de gobernador, capitán general y presidente de la Audiencia de Santo Domingo, a favor del brigadier don Manuel González, al igual que sus antecesores por el tiempo de ocho años, contados desde el día en que tomara posesión de sus empleos. ${ }^{97}$

Don Manuel González no llegó sin embargo a la isla hasta el I7 de abril del siguiente año de I786, tomando posesión de sus cargos aquel mismo día de manos del coronel don Joaquín García, teniente del Rey de aquella plaza, y en aquellos momentos gobernador interino. ${ }^{98}$

Don Manuel González permaneció sólo dos años en este nuevo destino, a lo largo de los cuales prestó una atención especial al problema del contrabando. Considerando de poca utilidad el resguardo establecido para su vigilancia, creó otro, del que ya hemos hablado en el capítulo referente al comercio, de dos rondas volantes de 16 hombres cada una y un cabo, una de ellas destinada a la frontera del norte y otra a la del sur. ${ }^{99}$

Más militar que político, limitó casi su actuación a este campo: reorganización de milicias, mejora de las fortificaciones, lucha contra el comercio ilícito, etc., dejando los

\footnotetext{
96 R. O. de 15 de febrero de 1786, relevando al que fue gobernador de Santo Domingo don Isidro de Peralta y Rojas de su juicio de residencia. A.G.I., Santo Domingo, 968.

97 Título de gobernador, capitán general y presidente de la Audiencia de la Española a favor de don Manuel González, expedido en Aranjuez el tres de julid de 1785. A.G.I., Santo Domingo, 915 y 967.

98 Carta del gobernađor de Santo Domingo don Mamuel González de 25 de abril de 1786, dando cuenta a la Corte de su llegada a la isla. A.G.I., Santo Domingo, 940 y 947 .

99 Carta del gobernador de la Española don Manuel González de cuatro de agosto de 1786, dando cuenta a la Corte de la modificación que había llevado a cabo en el resguardo de la isla. A.G.I., Santo Domingo, 953.
} 
asuntos administrativos en manos de la Audiencia, con lo que no tuvo desde luego ningún problema. Actuó además de intermediario, buscando en todo momento la concordia en las disputas surgidas entre este tribunal y el teniente del rey de la plaza, y de las que hablaremos a continuación.

Falleció el 2 de junio de $\mathrm{I} 788,{ }^{100}$ y en "atención al mérito, desinterés y zelo del brigadier don Manuel González, acreditado singularmente en el corto tiempo que sirvió en el govierno y capitanía general y presidencia de esa Audiencia", el Rey, por real cédula de 20 de diciembre de I790, lo dispensaba del juicio de residencia a que según la ley debía ser sometido. ${ }^{101}$ Sin embargo, cuando esta real cédula llegó a la Española, el juicio ya se había llevado a cabo, testimoniando a favor del residenciado todas las entidades de la isla, entre ellas el Cabildo de la capital, ${ }^{102}$ resultando "absuelto del único cargo que en el sindicato se le hiso, lo que manifiesta su desinterés, su zelo y justificada conducta en el juicioso exercicio de su empleo". ${ }^{103}$

\section{LOS GOBIERNOS INTERINOS. LOS PROBLEMAS SOBRE LA} SUCESIÓN DEL MANDO POR MUERTE DEL GOBERNADOR

A la muerte de don Manuel González, sobreviene en la isla una etapa que podríamos calificar de vacío de poder, en la que se producen distintas interinidades, en continuas disputas entre la Audiencia de Santo Domingo y el teniente del rey de la plaza, sobre quién debería ocupar el primer cargo del territorio.

\footnotetext{
100 Carta del oidor decano de la Audiencia de Santo Domingo de junio de 1788, dando cuenta a la Corte del fallecimiento del gobernador de la isla don Manuel González. A.G.I., Santo Domingo, 948.

101 R. C. de 20 de diciembre de 1790 , relevando al que fuera gobernador de Santo Domingo don Manuel González de su juicio de residencia. A.H.N. Consejos, 20.766.

102 Informe del Cabildo de la capital dominicana fechado en 1790 , a favor del que fue gobernador de la isla don Manuel González en su juicio de residencia. A.G.I. Santo Domingo, 953.

103 Sentencia del juicio de residencia que se hizo a don Manuel González, fechada en Santo Domingo el 12 de abril de 1791. A.H.N. Consejos, 20.766.
} 
Ya en tiempos del gobernador don Manuel de Azlor se planteó esta cuestión, con motivo de ausentarse el capitán general de la capital para realizar una visita general a la isla. En el título del entonces teniente del rey y cabo subalterno de la ciudad de Santo Domingo, don Luís de Cassasola, se señalaba que el nombramiento se le hacía con las mismas prerrogativas que a su antecesor, y que en caso de ausencia o falta del gobernador, "ha de recaer en vos en ínterin, el mando político y militar de ella con la presidencia de su Audiencia", tal y como estaba dispuesto desde $1736 .{ }^{104} \mathrm{En}$ esta ocasión el gobernador, aunque partidario de que lo sustituyese don Luís de Cassasola, para evitar las disputas accedió a las pretensiones de la Audiencia de dejar en sus manos los asuntos administrativos, concretamente en su oidor decano, pero dando cuenta de ello a la Corte para que decidiera sobre el asunto. ${ }^{105}$ En virtud de ello, se expidió una real cédula en diciembre de 1766, en la que el Rey, con dictamen del Consejo de Indias, declaraba que el teniente del rey debía sustituir o suceder interinamente en el gobierno, capitanía general, y presidencia de la Audiencia, "en el caso de que el que exerza en propiedad estos empleos, falte o salga fuera del distrito de esa ysla, y que assí se debe observar en los acontecimientos que ocurran en lo sucesivo". ${ }^{106}$

En junio de 1780, con motivo de la muerte de don Luís de Cassasola, se expidió el título de cabo subalterno y teniente del rey de la plaza de Santo Domingo a favor del coronel don Joaquín García Moreno, con las mismas facultades que su antecesor, incluida la de sustituir al gobernador "en cualquier caso de enfermedad, ausencia, u otro accidente, según lo tengo resuelto a consulta de mi Consejo de In-

104 Titulo de cabo subalterno y teniente del rey de la plaza de Santo Domingo a favor de don Luís de Cassasola, fechado en Madrid el 19 de febrero de 1765. A.G.1. Santo Domingo, 988.

105 Resolución del Consejo de Indias de 25 de septiembre de 1766, ante la representación enviada por el gobernador de Santo Domingo don Manuel de Azlor, sobre el gobierno interino de la isla. A.G.I. Santo Domingo, 921.

106 R. C. fechada en Madrid el 15 de diciembre de 1766, ordenando a las autoridades dominicanas, que el teniente del rey de la plaza de Santo Domingo ocupara las vacantes de gobernadores. A.G.I., Santo Domingo, 890. 
dias de nueve de agosto de 1732, por real cédula de ocho de septiembre de $1736 "$. ${ }^{107}$

Con este motivo, cuando en 1785 muere don Isidro de Peralta y Rojas antes de la llegada de su sucesor, ocupa la gobernación interina don Joaquín García. ${ }^{108}$ Pero la Audiencia no se mostró acorde con ello. En 1776 se había creado un nuevo cargo dentro de las audiencias americanas, el de regente. $\mathrm{Y}$ en las instrucciones dadas para su actuación, en su capítulo 66, se declaraba que en las vacantes de virreyes o presidentes, "y en consecuencia de reunírseles a los regentes las facultades y prerrogativas de los decanos, como ya se halla dispuesto por mi real persona, sustituirán éstos el cargo de virrey o presidente, según y en la forma en que se halla prevenido respecto a los decanos". ${ }^{109}$

Pero hay que tener en cuenta que en el caso de Santo Domingo, y dado su carácter eminentemente militar de que ya hemos hablado, el gobierno interino no recaía en los decanos de la Audiencia desde 1736, sino en el teniente del Rey.

Sin embargo, amparándose en esta instrucción, la Audiencia, en tiempos de don Manuel González, reclamará para ella la sucesión interina, y en esta ocasión, el dictamen del Consejo de Indias y la decisión real le fueron favorables, declarándose que en lo sucesivo debía observarse en Santo Domingo lo dispuesto en la mencionada instrucción, a pesar de lo establecido en el título del teniente del Rey. ${ }^{\mathbf{1 1 0}}$

Con este motivo, cuando el 2 de agosto de I788 muere don Manuel González, es don Pedro Catani, oidor decano de la Audiencia, quien por estar vacante el puesto de regen-

107 Título de cabo subalterno y teniente del rey de la plaza de Santo Domingo a favor de don Joaquín García, expedido en Aranjuez el 16 de junio de 1780 . A.G.I., Santo Domingo, 988.

108 Carta del teniente del rey de la plaza de Santo Domingo don Joaquín García de 29 de septiembre de 1785, dando cuenta a la Corte de haberse hecho cargo de la gobernación interina de Santo Domingo. A.G.I., Santo Domingo, 947.

109 Ibídem, nota 9.

110 Carta de la Audiencia de Santo Domingo de 12 de febrero de 1786, dirigida a la Corte, y otra del gobernador de la isla don Manuel González de 12 de mayo del año siguiente, contestando a la R.C. de 22 de enero de 1787. A.G.I., Santo Domingo, 988 y 991 . 
te se hace cargo del gobierno interino, ${ }^{111}$ entregándolo el I 5 de septiembre del mismo año al nuevo regente, don José Antonio de Urízar, que había llegado a la capital tres días antes. ${ }^{112}$

El problema sin embargo no quedó resuelto, ya que el 2 de abril de 1788 se había expedido una nueva real cédula, declaratoria de la sucesión del mando militar en las plazas y provincias de América, a favor del teniente del Rey o primeros oficiales de los lugares respectivos. El documento sólo hacía referencia al mando militar, pero en ella se amparó don Joaquín García para reclamar de la Audiencia el gobierno interino, negándose desde luego a ello aquel tribunal. ${ }^{113}$

Tanto la Audiencia como el teniente del Rey dieron cuenta de la disputa al Consejo de Indias, la primera quejándose de las pretensiones del segundo a pesar de la existencia de la real cédula de I787. ${ }^{114}$ Aquél, reclamando de la Corte una nueva orden que aclarara de una vez y para siempre este asunto. ${ }^{115}$

En virtud de ello, fue expedida una nueva real cédula el 17 de septiembre de I788, en la que se prevenía que, para evitar en lo sucesivo todo motivo de disputas, en conformidad con lo mandado en la de abril de aquel mismo año, en caso de ausencia, enfermedad o muerte del gobernador, debía recibir interinamente "el mando ab-

111 Carta del oidor decano de la Audiencia de Santo Domingo de cuatro de junio de 1788, dando cuenta a la Corte de haber tomado posesión de la gobernación interina de la isla. A.G.I., Santo Domingo, 948.

112 Cartas del oidor decano de la Audiencia de Santo Domingo de 16 y 25 de septiembre de 1788, dando cuenta a la Corte, de la llegada del regente de la misma. A.G.I., Santo Domingo, 940 y 948.

113 Carta de don Joaquín García de 24 de julio de 1788 , solicitando a la Corte se aclarase definitivamente el asunto de la gobernación interina. A.G.I., Santo Domingo, 1.088 .

114 Representación del oidor decano de la Audiencia de Santo Domingo de 25 de julio de 1787, informando a la Corte de las pretensiones del teniente del rey de la plaza de Santo Domingo, de ocupar la gobernación interina de la isla. A.G.I., Santo Domingo, 948.

115 Ibídem, nota 113 
soluto militar y político", con todas las funciones anejas a dichos empleos, el teniente del Rey de aquella plaza, "derogando lo dispuesto en la real cédula de 22 de enero de 1787 , en la instrucción de regentes y leyes que en ella se citan". ${ }^{116}$

Obedeciendo estas nuevas órdenes, la Audiencia hizo entrega de los empleos en litigio al teniente del Rey el I de diciembre de $\mathbf{I} 788,{ }^{117}$ terminando así con una disputa que había durado años, aunque posteriormente, en I789, una circular expedida en Madrid va a traer nuevas reformas en este asunto, al declarar que, en los lugares en que no hubiese Audiencia, el teniente del Rey debía sustituir al gobernador en todos sus cargos, si no hubiera oficial de mayor graduación, pero en las regiones en que existiera aquel tribunal, en caso de vacante del virreinato o presidencia, recaería en él el mando tanto político como militar. ${ }^{118}$

Sin embargo, esta variación en las normas vigentes no representó un nuevo problema en Santo Domingo, ya que para entonces don Joaquín García había sido nombrado gobernador oficialmente, y posteriormente la isla es abandonada por los españoles.

El Último gobernador DEL SIgLO

Como ya hemos señalado, don Joaquín García tomó posesión del gobierno interino de la isla Española el I de diciembre de 1788 , y continuará en él, aunque ya no de forma interina, hasta la cesión de la parte española de la isla a los franceses en I795 y posterior evacuación.

116 Carta de la Audiencia de Santo Domingo de 24 de diciembre de 1788, acusando el recibo đe la R. C. de 17 de septiembre de 1788. A.G.I., Santo Domingo, 993.

117 Carta del teniente del rey de ia plaza de Santo Domingo don Joaquín García -de 25 de dicicmbre de 1788, dando cuenta a la Corte de haberse hecho cargo de la gobernación interina de la isla. A.G.I., Santo Domingo, 948.

118 Circular expedida en Madrid el dos de agosto de 1789, sobre las personas que deben ocupar las vacantes de virreyes o gobernadores. A.G.I., Indiferente General, 662 . 
Don Joaquín García nació en I73 I ó I732, comenzando su carrera en I 757 como cadete, y siendo posteriormente subteniente del Real Cuerpo de Artillería. En r762 fue ascendido a ayudante mayor, actuando en la campaña de Portugal, y partiendo después a La Habana y Puerto Rico para la formación de sus milicias.

Sirvió a continuación en el Regimiento de Toledo, marchando ya como sargento mayor a Santo Domingo para la organización de sus milicias, que comenzó en tiempos de don Manuel de Azlor y finalizó con don José Solano, alcanzando por este servicio el grado de comandante en I77 I y el

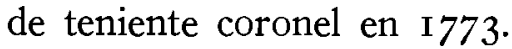

En I 776 actuó como comisario de límites para el convenio que se firmó en febrero de aquel año, y en premio a su actuación, fue ascendido a coronel en 1778 y nombrado teniente del Rey y sargento mayor de la plaza dos años después. ${ }^{119}$

En $\mathrm{I} 785$, con motivo de la muerte de don Isidro de Peralta y Rojas, ocupó la gobernación interina hasta la llegada de don Manuel González, cargo que adquirió de nuevo en I788, con motivo de la muerte de éste y lo ordenado en la real cédula de 17 de septiembre de ese mismo año.

El 20 de marzo de 1789 se confirmó a don Joaquín García en aquellos cargos, con la expedición a su favor del título de gobernador, capitán general, y presidente de la Audiencia, por el tiempo de ocho años desde el día en que tomara posesión de sus empleos, ${ }^{120}$ cosa que hizo el 20 de mayo siguiente. ${ }^{121}$.

Desde el momento en qué comenzó su mandato, la prin-

119 Memorial de don Joaquín de Inza en representación đe don Joaquín García, fechado en Madrid el 20 de diciembre de 1777 solicitando el grado de coronel, y hoja

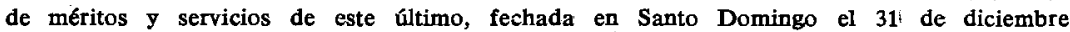
de 1782. A.G.I., Indiferente General, 1.501 y 1.948 .

120 Título de gobernador, capitán general y presidente de la Audiencia de la Española a favor đe don Joaquín García, expedido en Madrid el 20 de marzo de 1789. A.G.I., Santo Dumingo, 915.

121 Carta del gobernador de Santo Domingo don Joaquín García de 25 de mayo de 1789, informando a la Corte de haber tomado posesión de sus empleos. A.G.I., Santo Domingo, 1.013. 
cipal preocupación de don Joaquín García será la lucha contra el contrabando. A su juicio, la isla necesitaba más hombres dedicados a eliminar el comercio ilícito, así como un guardacostas, ya que dada su inexistencia, constantemente "ingleses y franceses burlan la vigilancia española". ${ }^{122}$

Su antecesor, don Manuel González, introdujo una serie de cambios en el método del resguardo, para evitar las exportaciones clandestinas de ganado y la introducción a cambio de diversos géneros, pero no lo había conseguido. En vista de ello, el nuevo gobernador se mostraba partidario de que se habilitara a los administradores comandantes de frontera y de poblaciones interiores, para que como subdelegados del gobierno vigilasen el contrabando. Propuso además, la creación de un nuevo resguardo más amplio que el existente hasta entonces, y del que ya hemos dado cuenta al hablar del comercio ilegal, y una serie de normas por las que debía regirse el tráfico ganadero. ${ }^{123}$

En otros aspectos, los tiempos en que tocó gobernar a don Joaquín García no fueron nada fáciles para la isla, ya que muy pronto estalló la guerra contra la república francesa, y, a consecuencia de su vecindad con su colonia en la Española, va a ser Santo Domingo la colonia americana que más directamente sufra las consecuencias de ella.

Al margen de la lucha armada, un problema fundamental durante toda esta época, será la falta de comestibles para el abastecimiento de la capital. Los comerciantes desde luego, se negaban a correr el riesgo de que sus navíos fueran apresados por los enemigos en su viaje desde España, y la escasez de víveres se dejaba sentir agudamente. Los artículos de primera necesidad, como la harina o el arroz, alcanzaban precios cada vez más altos, y pocos podían adqui-

\footnotetext{
122 Carta del gobernađor de Santo Domingo don Joaquin García de 25 de octubre de 1789, dando cuenta a la Corte de las dificultades existentes para acabar con el contrabando. A.G.I., Santo Domingo, 948.

123 Carta del gobernador de Santo Domingo don Joaquín García de 25 de marzo de 1790, informando a la Corte de los medios que consideraba precisos para acabar con el contrabando. A.G.I., Santo Domingo, 953.
} 
rirlos, "sucediendo muchas veces que un pan de media livra era un regalo y una gracia que dispensaba el que conseguía un barril de arina (pagando antes 34 ó 36 pesos)". ${ }^{124}$ Esta situación trajo consigo, el que el gobernador tuviera que recurrir en demanda de víveres a las colonias inglesas y a los Estados Unidos. Las escasas embarcaciones dominicanas y las anglo-americanas comenzaron a traerlos de aquellos lugares, ${ }^{125}$ viéndose socorridos también por el intendente de Puerto Rico, que logró enviarles I.000 barriles de harina, cesando con ello la penuria existente hasta entonces. ${ }^{126}$

Con motivo de la lucha contra los franceses, don Joaquín García partió hacia la zona fronteriza como capitán general de la parte española, para participar en los combates contra los republicanos de la colonia vecina. El gobernador estableció su cuartel general en Bayajá, dejando en el gobierno interino, de acuerdo con las últimas órdenes recibidas a este respecto, al regente de la Audiencia don José Antonio de Urízar. ${ }^{127}$ Desde Bayajá, García dirigió las operaciones de la campaña, e incluso se puso él mismo al frente del ejército en alguna ocasión. ${ }^{128}$

El último gran problema con que tuvo que enfrentarse don Joaquín García en la etapa de su mandato, fue la evacuación de los españoles que quisieron abandonar la isla con motivo de la cesión de toda ella a los franceses, por

124 Carta del gobernador đon Joaquín García de 25 de julio de 1793, dando cuenta a la Corte de la escasez de productos de primera necesidad en la isla. A.G.I., Santo Domingo, 1.031 .

125 Carta del regente de la Auđiencia don José Antonio de Urízar de 20 de julio de 1794, dando cuenta a la Corte de la necesidad de recurrir a las colonias extranjeras para conseguir víveres. A.G.I., Santo Domingo, 1.032.

126 Carta del regente de la Audiencia don José Antonio de Urízar de 25 de agosto de 1794, informando a la Corte de la ayuda prestada a aquella colonia por el intendente de Puerto Rico. A.G.I. Santo Domingo, 957.

127 Carta del gobernador de Santo Domingo don Joaquín García de 22 de enero de 1794, informando al duque de Alcudia de que se encontraba preparado para salir hacia la frontera, dejanđo al regente la gobernación interina. A.G.I., Estado, 14-74.

128 Relación de las operaciones del ejército de don Joaquín García desde su salida de Bayajá el ocho de mayo de 1794, hasta el 13 del mismo mes y año. A.G.I., Santo Domingo, 969. 
el tratado de Basilea de I795, y su entrega a las autoridades de la colonia vecina. En el mencionado tratado se acordó, que todos los españoles que lo desearan podrían salir de Santo Domingo y dirigirse a la isla de Cuba, donde se les concederían nuevas tierras. Pero los primeros que llegaron a La Habana no tardaron en darse cuenta de la imposibilidad de esto. A su arribo a aquel puerto, cada familia fue asistida con un real y medio por día, cantidad al parecer totalmente insuficiente, ${ }^{129}$ mientras que por otro lado, las tierras productivas que podrían conseguir eran muy escasas.

Por su parte, el gobernador de Santo Domingo encontraba serias dificultades para llevar a cabo el plan de evacuación, dada la falta de navíos para ello, y de dinero para el socorro de las familias. ${ }^{130}$ Mientras, la nueva guerra contra Inglaterra, que hizo que otra vez franceses y españoles se aliaran, demoró la entrega de la colonia española, que cada vez se encontraba más pobre y abandonada por la Metrópoli, hasta principios de I80I, en que por fin, Toussaint de Louverture se hizo cargo de la capital, pudiendo salir de ella el gobernador, que se dirigió a Maracaibo en el barco danés "La Elisa", ${ }^{131}$ y desde allí a La Habana. ${ }^{132}$

Es difícil saber lo que hubiera sucedido, si don Joaquín García hubiera llegado al gobierno de la isla en circunstancias más favorables. Dada la gravedad de los problemas a que tuvo que hacer frente y la situación crítica en que se

129 Carta del visitador general intendente de La Habana de cinco de enero de 1796, dando cuenta a la Corte de lo resuelto en una junta celebrada el 10 de noviembre anterior, para estudiar los medios de socorrer a las familias procedentes de Santo Domingo, A.G.I., Santo Domingo, 1.033 .

130 Carta de la Corte de 22 de enero de 1796 dirigida al gobernador de Santo Domingo, contestando a la suya de 11 de agosto del año antericr, sobre la falta de caudales en aquellas Reales Cajas. A.G.I., Santo Domingo, 1.033.

131 Maracaibo, 21 de marzo de 1801, Relación de las personas que llegaron de Santo Domingo en el paquebote danés la Elisa, tras la entrega de la isla a Toussaint. A.G.I., Santo Domingo, 1.037.

132 Carta del gobernador de Santo Domingo don Joaquín García de 29 de julio de 1801, dando cuenta a la Corte de su llegada a la Habana desde Maracaibo. A.G.I., Santo Domingo, 960. 
encontraba el Santo Domingo español en este período, vio totalmente limitado su campo de acción. Tuvo que contentarse con defender del empuje y los ataques de los revolucionarios de la colonia francesa los territorios de su jurisdicción, y facilitar en lo posible la emigración española.

A pesar de ello, su actuación fue al parecer bastante buena, y a consecuencia de ella, se le propuso para el ascenso a brigadier. ${ }^{133}$

133 R. O. de 17 de abril de 1791 dirigida al gobernador de Santo Domingo, informándole haber sido comprendido en la promoción a brigadier. A.G.I., Santo Domingo, 954. 


\section{Capítulo VIII}

\section{E L E J E R C I T O}

La situación de la isla de Santo Domingo, en un punto tan estratégico como el Mar Caribe, y la presencia de los franceses en su tercio occidental, le dieron un carácter eminentemente militar, que hará que se incremente considerablemente a lo largo de la segunda mitad del siglo XVIII la guarnición de aquel país.

En los comienzos de la etapa citada, la defensa de la isla dependía exclusivamente del batallón fijo de infantería de la capital, con una dotación de 637 hombres, ${ }^{1}$ una compañía de artillería con 6r plazas, y dos compañías de caballería con $5^{\circ}$ hombres cada una, que estaban dedicadas sobre todo a la vigilancia de la zona fronteriza para evitar el contrabando. ${ }^{2}$ Con todo ello, la población militar del Santo Domingo español en esta época era de 798 plazas, en las que no se encontraban incluidas las de los oficiales.

A este incremento de soldados no fue desde luego ajeno, el movimiento reformista que se produce en este siglo y en el que se tiende a construir un nuevo estado, desarrollán-

1 Extracto de la revista pasada en el mes de abril de 1769 por don José de Gelabert, al batallón fijo de la plaza de Santo Domingo. A.G.I., Santo Domingo, 1.044.

2 Extracto de la revista pasada en enero de 1767 por el gobernador de Santo Domingo don Manuel de Azlor, a la compañía de artillería de Santo Domingo, y a las dos de caballería de la frontera. A.G.I., Santo Domingo, 932. 
dose una importante labor a la hora de reformar el ejército y la marina, sobre todo por lo que se refiere al reinado de Carlos III, y que se manifiesta claramente con la promulgación de las ordenanzas que llevan su nombre, cuyas normas incluso hoy siguen vigentes en la vida militar. ${ }^{3}$

Ya durante la época de Fernando VI, el ejército fue organizado en regimientos a la manera francesa, convirtiéndose en un arma moderna y eficaz. En las Ordenanzas de Carlos III, se aumentó el número de regimientos y se alterj́ su forma interna, primero en el cuerpo de infantería, y después en el resto de las armas. ${ }^{4}$

Se estructuraron además las armas de artillería e ingenieros, que durante el período de Fernando VI habían estado al mando de un mismo director general. ${ }^{5}$

Todas estas reformas van a sentirse desde luego en el ejército americano. Estaba formado éste en el caso de Santo Domingo, por una tropa permanente formada por profesionales, integrados en el batallón fijo de infantería y en la compañía de artillería.

Pero donde más van a notarse las reformas borbónicas será en las llamadas "milicias", que a finales de este siglo llegan a formar "un cuerpo orgánico de carácter militar, con una reglamentación tan estricta como la del ejército", alcanzando ahora su mayor grado de perfeccionamiento. ${ }^{6}$

Ya durante el reinado de Felipe II, se inició en Castilla el reclutamiento de milicias de voluntarios al lado de los ejércitos profesionales, ${ }^{7}$ pero no es en realidad hasta el si-

3 Rodríguez Casado, Vicente: El ejército y la marina en el reinado de Carlos III. Separata del "Boletín del Instituto Riva Agüero", núm. 3, págs. 130-131.

4 Ibídem, pág. 131.

5 Ibídem, pág. 138.

6 Oñat, Roberto y Carlos Roa: Regimen legal del ejército en el reino de Chile. Notas para su estudio. "Estudios de Historia del Derecho Chileno", núm. 1. Universidad Católica de Chile. Santiago de Chile, 1953, pág. 185.

7 Rodríguez Casado, Vicente: Op. cit., pág. 133. 
glo XVII cuando se estructuran en la Española. "Los monarcas españoles creyeron resolver el problema de la defensa imperial e interior de las colonias, llamando a filas a sus vasallos coloniales". ${ }^{8}$ Las fortalezas americanas ya no eran suficientes para su defensa, y la tropa regular no bastaba tampoco a este fin, y el único medio a que se pudo recurrir, era la creación de un ejército criollo que se integrara en las milicias. La Corona pretendió así que se creasen en las colonias americanas cuerpos militares nacionales, en los que "debían servir todos los españoles y todos los vasallos americanos aptos para las fatigas militares.

La integración en los cuerpos milicianos debía hacerse por sorteo, a base de padrones y listas de los habitantes de los pueblos y ciudades". ${ }^{9}$

Siguiendo esta política, por real orden de 21 de diciembre de 1770 , se resolvió la creación de I 5 compañías de infantería de milicias regladas, y seis de caballería de la misma clase. ${ }^{10}$

Cada compañía de infantería se formó con una dotación de Ioo hombres, y las de caballería con 50 cada una, ${ }^{11}$ con lo que la dotación de la isla aumentó hasta 2.498 plazas sin contar con los oficiales.

Vino posteriormente a incrementar este número, la ampliación del batallón fijo de infantería de la plaza de Santo Domingo, que en un principio constaba de siete compañías, número que aumentó a 12 , que aunque menores que las an-

8 Velázquez, M.a del Carmen: El estado de guerra en Nueva España, 1760-1808. El Colegio de México. México, 1950, pág. 89.

9 Ibídem, pág. 93.

10 Circular de 26 de septiembre de 1772 dirigida por don Julián de Arriaga al conde de O'Reilly, manifestándole hallarse el Rey enterado del establecimiento de las milicias regladas prevenidas por la R.O. de 21 de diciembre de 1770. A.G I., Indiferente General, 665 .

11 Estado de 24 de mayo de 1771, que muestra el número de armas necesarias para las compañías de infantería y caballería regladas de Santo Domingo. A.G.I., Santo Domingo, 944. 
teriores, debían sumar en total 847 hombres, ${ }^{12}$ con lo que de nuevo se acrecentó el número de soldados hasta 2.708. En I782 se alcanzó la cifra de 2.830 , con la creación de una compañia de Fieles Prácticos destinada a la vigilancia de la frontera con $\mathrm{I} 20$ hombres, y la ampliación a 63 plazas de la compañía de artillería de la capital, ${ }^{13}$ aunque la dotación de la isla nunca estuvo completa.

\section{El Batallón Fijo de Infantería}

Creado en I738, fue desde luego en todo momento el cuerpo militar de mayor entidad en Santo Domingo. Su uniforme estaba formado por "casaca, chupa y calzón blanco de lienzo, buelta y collarín azul, botón blanco". ${ }^{14}$

$\mathrm{Al}$ frente de él, y de toda la guarnición de la isla, se encontraba el gobernador de la Española, como capitán general de aquélla. Segundo jefe y comandante de este cuerpo era el teniente del rey, constituyendo el resto de lo que se denominaba "plana mayor" de la plaza junto con el sargento mayor, ayudante mayor, dos subtenientes abanderados, un capellán, un cirujano, un maestro armero, un tambor mayor, y dos pífanos. ${ }^{15}$

En los comienzos de la segunda mitad del siglo XVIII, el batallón estaba formado por una compañía de granaderos y otras seis compañías llamadas "sencillas". Cada una de

12 Estado del batallón fijo de infantería de la plaza de Santo Domingo, según la visita realizađa al mismo por el capitán general de la isla don José Solano; en el mes de enero de 1777. A.G.I., Santo Domingo, 1.095.

13 Relación del estado de la tropa de la isla de Santo Domingo de seis de abril de 1783, remitida a la Corte por el gobernador don Isidro de Peralta. A.G.I., Indiferente General, 2.677.

14 Ibídem.

15 Aranjuez, 18 de junio de 1771. Reglamento de los sueldos que deberán cobrar los miembros de todos los batallones o regimientos de infantería de Santo Domingo. A.G.I., Santo Domingo, 1.089 . 
ellas estaba dirigida por un capitán, en su mayor parte con grado de comandantes o tenientes coroneles, un teniente y un subteniente, con lo que el número de oficiales sin contar los encuadrados en la plana mayor era de $2 \mathrm{I}$. Integraban la tropa en cada una de ellas tres sargentos, dos tambores, siete cabos y 79 soldados, es decir, las 637 plazas ya señaladas, ${ }^{16}$ que unidas a las de los $2 \mathrm{I}$ oficiales suman 658 .

En I77I se experimentó un cambio en este batallón, al aumentar a nueve el número de sus compañías, ascendiendo con ello el número de oficiales a 27 , aunque el de la tropa quedó limitado a 607 por reducirse el tamaño de las compañías. ${ }^{17}$

En los años siguientes el batallón sufrió una nueva reforma, adquiriendo ya la estructura que tendrá definitivamente hasta su salida de Santo Domingo. El número de compañías quedó fijado en $\mathrm{I} 2$, una de ellas de granaderos y I I normales, con una dotación total de 847 hombres al mando de 36 oficiales. Nueve de estas compañías permanecían en la capital, y las otras tres quedaban destacadas en la frontera, siendo relevadas de aquel destino cada año. ${ }^{18}$

Sin embargo, el batallón no alcanzó nunca el número efectivo de plazas que lo formaban, y así, en i 763 , el gobernador don Manuel de Azlor y Urríes informaba a la Corte, que en la visita que le hizo aquel año había 68 bajas, con lo que la fuerza real se reducía a 569 hombres. ${ }^{19}$

Cuando ya el batallón contaba con 847 plazas tampoco estuvo nunca al completo, tal y como se deduce de las visitas realizadas por los gobernadores como capitanes generales, de las que dejamos constancia a continuación:

\footnotetext{
16 Ibídem, nota 1.

17 Ibídem, nota 15.

18 Estado de la fuerza del batallón fijo de la ciuđad de Santo Domingo en febrero de 1781. A.G.I., Indiferente General, 1.948.

19 Carta del gobernador de la Española don Manuel de Azlor de 13 de noviembre de 1763, dando cuenta a la Corte del estado en que se encontraba el batallón fijo de aquella plaza. A.G.I., Santo Domingo, 1.094.
} 
Fuerza del Batallón Fijo de la plaza, según algunas DE LAS VISITAS REALIZADAS A ÉL POR LOS GOBERNADORES

\begin{tabular}{|c|c|c|c|c|}
\hline Años & \multicolumn{2}{|c|}{ Oficialidad } & $\begin{array}{r}T r \\
\text { Dotación }\end{array}$ & $\begin{array}{l}\text { pa } \\
\text { Fuerza re }\end{array}$ \\
\hline I 777 & 36 & 32 & 847 & $839^{20}$ \\
\hline $178 \mathrm{I}$ & $3^{6}$ & 33 & 847 & $717^{21}$ \\
\hline I782 & & & 847 & $689^{22}$ \\
\hline I 784 & 36 & 32 & 847 & $5^{18^{23}}$ \\
\hline I 785 & & & 847 & $483^{24}$ \\
\hline I 789 & & & 847 & $65^{25}$ \\
\hline I794 & & & 847 & $671^{26}$ \\
\hline I796 & 36 & 33 & 847 & $48 I^{27}$ \\
\hline
\end{tabular}

Así pues, a pesar de que se incrementa el número de plazas del batallón fijo de infantería de Santo Domingo, solamente en los primeros años después de la ampliación se

\footnotetext{
20 Ibídem, nota 12.

21 Ibídem, nota 18.

22 Estado de la fuerza total de la isla de Santo Domingo de 17 de marzo de
} 1782. A.G.I., Indiferente General, 1.579.

23 Relación de la fuerza con que se halla el batallón fijo de la ciudad de Santo Domingo, el uno de septiembre de 1784. A.G.I., Santo Domingo, 1.088.

24 Carta del gobernador de Santo Domingo don Isidro de Peralta y Rojas de 23 de marzo de 1785, dando cuenta a la Corte de la falta de tropas en la isla. A,G.I, Santo Domingo, 947.

25 Carta de don Joaquín García Moreno de 25 de noviembre de 1789, remitiendo a la Corte una relación de todas las tropas de la isla, obedeciendo la $F_{r} O$, de 17 de agosto de aquel mismo año. A.G.I., Santo Domingo, 949.

26 Revista pasada por el gobernador de Santo Domingo don Joaquín García Moreno, al batallón fijo de la plaza de Santo Domingo, en el mes de julio de 1784. A.G.I., Santo Domingo, 1.089 .

27 Revista pasada por el gobernador de la Española don Joaquín García Moreno al batallon fijo de infantería de la capital, el nueve de mayo de 1796. A.G.I., Santo Domingo, 1.091 . 
acerca a la fuerza que debería tener, llegando en algunas ocasiones a faltar para su completo hasta el $40 \%$ de la tropa.

La Compañía de Artillería

Constituye en esta época el cuerpo más antiguo de la isla, pues fue creada en I7 Io. ${ }^{28}$

Esta compañía sufrió pocas variaciones en la etapa estudiada, ya que en los años 50 la integraban 6i hombres, y a finales del siglo 63. En un principio estaba formada por un capitán, un teniente, un subteniente, dos sargentos, un cabo bombardero, cuatro bombarderos, dos minadores, un armero, cuatro cabos artilleros, 44 artilleros, un tambor, un herrero y un carpintero, es decir, tres oficiales y $6 \mathrm{I}$ hombres de tropa. ${ }^{29}$

No sabemos a ciencia cierta en que momento se crearon los dos nuevos puestos de que hemos hablado, pero en la revista pasada a la tropa por el gobernador don Isidro de Peralta y Rojas el I7 de marzo de I782, ya nos encontramos a esta compañía con 63 plazas, sin contar con las de los oficiales. Una de estas nuevas plazas era de sargento. ${ }^{30}$

La compañía de artillería la componía gente especializada, quizás la más preparada de la población militar de la isla, y tal y como podemos observar en el siguiente cuadro, en los años en que poseemos noticias de las revistas que le pasaron los gobernadores, estuvo casi siempre completa:

\footnotetext{
28 Ibídem, nota 13. .

29 Ibidem, nota 2.

30 Ibídem, nota 22.
} 
Fuerza de la Compañía de Artillería según LAS REVISTAS PASADAS POR LOS GOBERNADORES

Oficialidad

Años

I 767

1769

1777

1782

\section{Dotación Fuerza Real}

$\begin{array}{ll}3 & 3 \\ 3 & 2 \\ 3 & 3 \\ 3 & 3\end{array}$

Tropa

Dotación Fuerza real
$6 \mathbf{I}$

$6 \mathrm{I}$

$6 \mathrm{I}$

63
$6 I^{31}$

$6 I^{32}$

$6 I^{33}$

$63^{34}$

\section{Compañías de Caballería}

Como ya hemos dicho anteriormente, en los comienzos de la segunda mitad del siglo XVIII había en la isla dos compañías de caballería, una destinada en la frontera norte y otra en la del sur. Cada una de ellas se encontraba al mando de un capitán, un teniente, y un subteniente, integrando la tropa dos sargentos, un trompeta, cuatro cabos y 43 soldados montados. Cada compañia tenía pues 50 hombres y tres oficiales, ${ }^{35}$ sumando un total de cien hombres y seis oficiales.

Pero siguiendo la política de creación de un ejército colonial de la que ya hemos hablado, por real orden de 2I de diciembre de 1770 , se mandaba la organización en Santo Domingo de seis compañías de caballería de milicias disciplinadas, que sustituirían a las dos anteriores. ${ }^{36}$

Su uniforme fue el siguiente: casaca, chupa y calzón blanco de lienzo, con "buelta, collarín y solapa azul". Formaban cada una de las seis compañías 50 hombres bajo el mando de tres oficiales, ${ }^{37}$ alcanzando un total de 18 oficiales y 300 hombres de tropa.

31 Ibídem, nota 2.

32 Revista pasada por don José de Gelabert a la compañia de artilleria de la ciudad de Santo Domingo, el 31 de mayo de 1769. A.G.I., Santo Domingo, 1.044.

33 Ibídem, nota 12.

34 Ibíđem, nota 22.

35 Ibídem, nota 2.

36 Ibídem, nota 10.

37 Ibídem, nota 13. 
El fin de este cuerpo era la vigilancia de la frontera. Una de ellas estaba destinada en Dajabón, otra en Bani, una en San Juan de la Maguana, una en San Miguel de la Atalaya y dos en Santiago de los Caballeros. Esta última ciudad no se encontraba muy cerca de la zona limítrofe, pero no ocurría lo mismo con gran parte de su dilatada jurisdicción, una de las que proporcionaba más ganado para el comercio ilícito con los franceses. Tenía también este cuerpo su plana mayor, constituida por un comandante, un ayudante mayor y dos trompetas. ${ }^{38}$

Las dos revistas pasadas a las compañías de caballería antes de su ampliación a seis, muestran este cuerpo al completo. ${ }^{39}$ Posteriormente, aunque la cosa cambie en algunas ocasiones por lo que se refiere a los oficiales, no ocurrió lo mismo al parecer con la tropa, pues al estar formada por naturales de la isla, era más fácil que sus fuerzas estuvieran al completo:

\section{Fuerzas de las Compañías de Caballería SEGÚN LAS VISITAS DE I 782 Y I 784}

\begin{tabular}{ccccc} 
& \multicolumn{2}{c}{ Oficialidad } & \multicolumn{2}{c}{ Tropa } \\
Años & Dotación Fuerza real & Dotación Fuerza real \\
$\mathrm{I782}$ & & & 300 & $3^{300^{40}}$ \\
$\mathrm{I} 784$ & $\mathrm{I} 8$ & $\mathrm{I} 4$ & 300 & $3^{40}$
\end{tabular}

Estas entidades militares formadas a costa de los isleños, no estaban integradas en los llamados cuerpos veteranos, que eran en realidad los soldados profesionales. Por ello en algunas ocasiones, como en casos de necesidad para las labores de la tierra, o por no hacer falta para la defensa

38 Estado que manifiesta la fuerza de las compañías de milicias de caballería de Santo Domingo el 24 de enero de 1784. A.G.I., Indiferente General, 1.948.

39 Revista pasada por don Manuel de Azlor en 1767 a las compañías de milicias de caballería de Santo Domingo, y revista pasada por đơn José de Gelabert al mismo cuerpo, en mayo de 1769. A.G.I., Santo Domingo, 932 y 1.044.

40 Ibídem, nota 22.

41 Estado que manifiesta la fuerza con que se encuentran las milicias de infantería de la isla de Santo Domingo, de 24 de enero de 1784. A.G.I., Indiferente General, 1.948. 
de la isla, quedaban sólo dos en servicio, enviándose las otras cuatro a sus respectivos domicilios. ${ }^{42}$

\section{Compañías de Milicias de Infantería}

Al igual que las milicias de caballería fueron creadas, por real orden de $1770,{ }^{43}$ con el fin de contar con una tropa isleña que pudiera acudir a la defensa de su territorio, que la Metrópoli se veía incapaz de proteger.

$\mathrm{Su}$ uniforme era semejante al de aquéllas, pero con "buelta, collarín y alamares encarnados". ${ }^{44}$

Se establecieron 5 compañías de este tipo con Ioo plazas cada una, doce de ellas de blancos y las otras tres de morenos libres, ${ }^{45}$ sumando un total de 1.500 hombres distribuidos en la siguiente forma:

Lugares de residencia

Santo Domingo

San Carlos

Santa Cruz del Seibo

Concepción de la Vega

Santiago de los Caballeros

San Fernando de Montecristi

San Felipe de Puerto Plata

Hincha

Azúa

\section{$N .^{\circ}$ de compañias}

De blancos De morenos

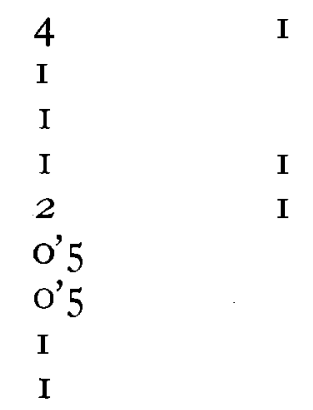

\section{Total}

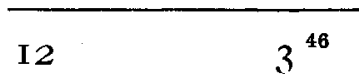

Cada una de estas compañías estaba dirigida por su correspondiente capitán, y la formaban además un teniente y

42 Ibídem, nota 22.

43 Ibídem, nota 10.

44 Ibídem, nota 13.

45 Ibídem, nota 11.

46 Informe del capitán general de la isla de Santo Domingo de 25 de abril de 1790, sobre las milicias regladas existentes en ella. A.G.I., Santo Domingo, 954. 
un subteniente, tres sargentos, un tambor, I2 cabos y 84 soldados. ${ }^{47}$

En algunos momentos llegaron a estar completas, por el mismo motivo que ya hemos señalado en las de caballería de estar formadas por naturales de la isla. Pero en algunas ocasiones las bajas se dejan sentir, aunque no muy sensiblemente, como observamos en las revistas pasadas a este cuerpo por los capitanes generales de Santo Domingo, y de las que dejamos constancia a continuación:

Fuerza de las i5 Compañías de Milicias de Infantería SEGÚN LAS REVISTAS DE I $77 \mathrm{I}$, I 782 Y I 784

Oficialidad

Tropa

$A \tilde{n} o s$ Dotación Fuerza real Dotación Fuerza real

I $77 \mathrm{I}$

I.500

I. $500^{48}$

1782

I 784

I 5

I.500

I 3

1.500

I. $434^{49}$

I. $418^{50}$

Como ya hemos indicado, al igual que las milicias de caballería también éstas las constituian hombres del país, y no sólo blancos, ya que según hemos señalado, tres de ellas estaban formadas por "morenos libres", aunque no sabemos por qué estuvieron separadas de las de blancos.

\section{La Compañía de Fieles Prácticos Y LAS Milicias URBanas}

El último cuerpo militar creado en Santo Domingo en el siglo XVIII, fue una compañía de Fieles Prácticos, fundada en 1782 para las rondas de la frontera. Pero no tene-

47 Estado de las fuerzas de las compañías de milicias de Santo Domingo de 25 de enero de 1784. A.G.I., Indiferente General, 1.948.

48 Ibídem, nota 11.

49 Ibídem, nota 22.

50 Ibídem, nota 47. 
mos de ella más noticia que la relativa a su establecimiento. ${ }^{51}$

Por último hemos de señalar la existencia de las denominadas milicias urbanas. Las integraban los vecinos de las distintas ciudades de la isla que normalmente vivían en sus casas, pero a cuya movilización podía recurrirse en caso de necesidad. En I 789 alcanzaban una fuerza efectiva de 5.7I7 hombres, aunque tampoco tenemos noticias de sus actividades en estos años. ${ }^{\mathbf{5}}$

Los Soldados

Es poco lo que podemos decir sobre la vida de los soldados, sobre todo por lo que se refiere a los integrantes de las milicias. Por lo que respecta a la tropa veterana, y exceptuando las dos compañías de caballería que existieron hasta su sustitución por las milicias regladas, tenemos algunas aunque escasas noticias.

$\mathrm{E}$ l origen de los soldados que integraban los cuerpos profesionales era muy variado, aunque en su mayor parte fueron vecinos de la propia isla. Santo Domingo no era un destino muy codiciado por los militares veteranos, por lo que a pesar de los deseos de la Corona de que las tropas regulares fueran españolas, no tuvieron más remedio que recurrir a los naturales para incrementar el número de hombres encargados de la defensa del territorio. Les seguían en número los españoles, los procedentes de otras colonias españolas en América, y en último lugar un corto número de extranjeros.

En I769, el batallón de infantería y la compañia de artillería sumaban un total de 698 plazas, que estaban ocupadas por hombres de las siguientes procedencias:

51 Ibidem, nota 13.

52 Ibídem, nota 25. 
Lugares de origen

Santo Domingo

Españoles

Americanos

Franceses, alemanes, portugueses e italianos

Total $\frac{31}{698^{54}}$

En 1777 , cuando el número de plazas había aumentado a 908 , de las que 903 se encontraban ocupadas, aunque sólo 900 de forma efectiva por pertenecer las otras tres al cuerpo de inválidos, la procedencia de la tropa era la siguiente:

Lugares de origen Número de plazas

Santo Domingo

Españoles

Americanos

Extranjeros
Numero de plazas

$$
337^{53}
$$

277

53

31
$98^{54}$ 
en su mayor parte de los territorios de la Corona de Castilla. De los 283 españoles integrados en estos cuerpos en I777, 234 venían de allí, y sólo 49 de los reinos de Aragón, Valencia y Navarra, tal y como se observa en el siguiente cuadro:

Lugares de origen

Plazas

Andalucía.

Castilla la Vieja.

$7 \mathrm{I}$

Galicia.

53

Castilla la Nueva.

35

Canarias.

Extremadura.

Aragón.

Valencia.

Vizcaya.

Cataluña.

12

Montañas.

IO

Mallorca.

Navarra.

Murcia.

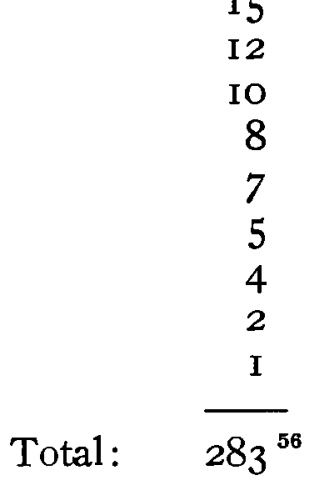

Con ello, los castellanos alcanzan un total en esta fecha del $82^{\prime} 68 \%$ de los soldados metropolitanos en Santo Domingo, mientras que los otros sólo representan un I 7'3 I \%.

Respecto a los sueldos de estos hombres de tropa, variaban según el cuerpo y compañía en que estuviesen, experimentándose además un cambio en I77I, con el nuevo reglamento que se formó fijando los salırios que debían cobrar. 
Sueldos AL Mes ANTES DE I77I EXPREsAdos EN PESOS ${ }^{57}$ Grados Granaderos Infantería Artillería Caballería

Sargentos.

Cabos.

Cabos bombarderos.

Tambores.

Trompetas.

Soldados.

Soldados bombarderos.

Soldados minadores.
I5

I4

12

I 5

14

13

I2

I I

I3

I3

I4

I 2

12

I2

I I

12

13

I3

En I77I, el nuevo reglamento fijó otros salarios para la compañía de granaderos y las de infantería sencillas del batallón fijo, así como para la de artillería, notándose en general una rebaja en aquéllas, tal y como se expresa a continuación:

Grados

Sargentos primeros.

Sargentos segundos.

Cabos.

Cabos bombarderos.

Tambores.

Soldados.

Soldados minadores.

Soldados bombarderos.
Granaderos Infantes Artilleros

$\begin{array}{lrl}\text { I8 } & \text { I6 } & \text { I8 } \\ \text { I6 } & \text { I4 } & \text { I } \\ \text { I2 } & \text { I I } & \text { I2 } \\ & & \text { I4 } \\ \text { I I } & \text { IO } & \text { I I } \\ \text { IO } & 9 & \text { IO } \\ & & \text { I2 } \\ & & \text { I2 }{ }^{58}\end{array}$

No podemos apreciar si estos salarios eran altos o bajos, ya que no poseemos datos sobre los precios que nos permitan establecer una proporción real, pero lo que sí sabemos es que rara vez los cobraban a tiempo.

57 Ibídem, nota 1.

58 Ibídem, nota 15. 
En I757 don Francisco Rubio y Peñaranda, entonces gobernador de Santo Domingo, daba cuenta a la Corte de que con el situado que acababa de llegar de México en la fragata "la Flora", se pagaría a la tropa el sueldo de un año, desde primeros de abril de I754 a finales de marzo de I755, por lo que de seguir así, "siempre este batallón padezerá el atraso de tres años o más". ${ }^{59}$

Además, cuando los soldados cobraban este dinero tenían que desprenderse inmediatamente de la mayor parte de él, ya que, "necesitando ínterin llega el situado de que sus capitanes les subministren la media, el zapato, y lo demás preciso para subsistir, lo hazen a unos precios tan excesibos, que cuando llega el tiempo de cobrar no alcanzan lo que se les satisfaze para pagar estos alcances". ${ }^{60}$

Esta situación produjo en 1756 un grave motín entre los soldados del batallón fijo de la plaza. Este cuerpo se creó como ya hemos señalado en I738. Y ya desde entonces los situados comenzaron a llegar a la isla con retraso, y "como entonces y después a havido algunos meses de intermedio o en cada año, ha resultado los tres años de atraso en que se halla la guarnición al tiempo que se llega cada situado". ${ }^{61}$

Como ya hemos indicado, en 1757 la tropa cobró su salario hasta finales de 1755 , y a los pocos días de ello, el 13 de julio de aquel año, entre las dos y las tres de la mañana, parte del batallón fijo decidió sublevarse. I80 hombres se presentaron con sus armas ante la catedral. Desde allí enviaron un piquete de 60 que se apoderó del fuerte de Santa Bárbara, que dominaba la mayor parte de la ciudad, exigiendo se les pagara todo el dinero que se les debía. ${ }^{62}$

Al parecer este levantamiento iba dirigido más que

59 Carta del gobernador de Santo Domingo don Francisco Rubio y Peñaranda de 17 de junio de 1757, en contestación a la R. O. de 21 de noviembre de 1755- A.G.I., Santo Domingo, 1.088.

60 Madrid, 5 de noviembre de 1758. Expediente del Consejo de Indias sobre la sublevación del batallón de Santo Domingo, A.G.I., Santo Domingo, 1.088.

61 Ibídem. nota 59.

62 Carta ,del Cabildo de la ciudad de Santo Domingo de 18 de julio de 1757, informando a la Corte de la sublevación del batallón fijo. A.G.I., Santo Domingo, 942. 
contra el gobierno contra sus capitanes, "que combertidos de oficiales militares en mercaderes y comerciantes, haxen en aquel país grangería de la necesidad del soldado". ${ }^{63}$

El motín se solucionó cuando el gobernador de la isla, ante la imposibilidad de abonarles todo lo que se les debía por falta de medios, les prometió que se les pagarían tres meses de sueldo sin descuento alguno, como préstamo a cuenta de sus alcances, y el perdón para todos los que intervinieron en la acción.

Pero aunque fue resuelto este problema acuciante, no ocurrió lo mismo con la situación del soldado. Los situados no llegaron nunca de México con la regularidad que debían, y a la tropa se le seguía suministrando ropa a cuenta de sus salarios, que algunos ni siquiera veían cuando llegaban, de forma que su vida fue siempre bastante miserable.

63 Ibídem, nota 60.

64 Carta del director del Colegio de la Compañía de Jesús de 28 de noviembre de 1757, informando a la Corte sobre la sublevación del batallón fijo de Santo Domingo. A.G.I., Santo Domingo, 1.088. 


\title{
Capítulo IX
}

\section{RELACIONES CON LA COLONIA FRANCESA}

\section{DE LA LLEGADA DE LOS FRANCESES A LA}

\author{
SEGUNDA MITAD DEL SIGLO XVIII
}

Como ya hemos señalado en el capítulo relativo a la población, las ciudades del norte y el oeste de la Española avanzaron considerablemente a lo largo del siglo XVI, a base del lucrativo comercio que llevaban a cabo con los extranjeros, sobre todo con los holandeses y portugueses. Y este tráfico ilegal trajo consigo, a principios del siglo XVII, la despoblación por real orden de aquellos lugares: La Yaguana, Bayajá, Montecristi, Puerto Plata y otros. ${ }^{1}$

$\mathrm{Y}$, "abandonadas de esta suerte las costas del norte de la isla de Santo Domingo, los bucaneros, compañeros y afines de los filibusteros, se establecieron y construyeron sus viviendas en aquella costa arrasada". ${ }^{2}$

Los franceses por su parte, arrojados por los españoles de la isla de San Cristóbal, se unieron a aquéllos refugiándose en la Española, aunque allí "vivieron perseguidos de sus legítimos dueños y conquistadores en continua guerra durante muchos años, hasta que, reconociéndolos el Rey de Francia como vasallos, nombró gobernador". ${ }^{3}$

De este modo, desde principios del siglo XVII los franceses se encontraban ya en la isla de Santo Domingo, aun-

\footnotetext{
1 Vid. al respecto Lugo, Américo; Hernández Tapia, Concepción; Mac Lean, J. : Loc. cit.

2 Mac Lean, J. y T. Pina Chevalier: Loc. cit, pág. 6.

3 Alcedo, Antonio de: Loc. cit., tomo II, pág. 26.
} 
que no lograron su reconocimiento por parte de la Corona francesa hasta 1665.

Pronto comenzaron desde luego las pugnas entre los dos grupos de colonos, ante las pretensiones de los franceses de ampliar cada vez más su territorio. Pero no tardaron mucho en darse cuenta de que sus intereses podían complementarse. El Santo Domingo español carecía de una serie de manufacturas que su Metrópoli no podía proporcionarle. Por otro lado, a los franceses les faltaba el ganado preciso para su alimentación y para los trabajos agrícolas, de modo que, "a partir de I68I, empezó a desarrollarse un activo comercio de caballos, carne salada, y cueros de vaca, a cambio de mercancías europeas llegadas en barcos franceses". ${ }^{5}$

Ya desde la celebración de la Paz de Nimega, en I678, entre Francia, España y Holanda, comenzaron una serie de negociaciones entre las autoridades españolas y francesas de la isla, iniciándose con ello un cierto reconocimiento de la presencia francesa en Santo Domingo. Pero con la ruptura de esta paz en 1683 , la situación cambiará radicalmente. Francia ordenó a su gobernador la toma de toda la isla Española, en I689, con motivo de estallar la lucha general en la cuarta guerra entre España y Francia, con lo que se produjo también la pugna entre sus dos colonias de Santo Domingo. ${ }^{\dot{6}}$

Esta lucha se mantiene hasta 1697 , año en que se firma la $\mathrm{Paz}$ de Ryswick, por la que, según algunos autores, la $\mathrm{Co}-$ rona francesa consiguió que el Rey de España, Carlos III, "le hiciese cesión de aquella parte de la isla en que se habían establecido". " Pero tal cesión no existió. Por este tratado Francia devolvió a España todos los territorios conquistados durante la guerra, volviendo las cosas al estado en que se encontraban antes de iniciarse la contienda.

Los franceses se basaron en este punto para intentar le-

\footnotetext{
4 Mac Lean, J. y T. Pina Chevalier: Op. cit., pág. 7.

5 Moya Pons, Frank: Loc. cit,, pág. 189.

6 Mac Lean, J. y T. Pina Chevalier: Op. cit., pág. 10.

7 Ibídem, nota 3.
} 
gitimar su presencia en la Española, pues antes de la guerra ellos se encontraban ya en la parte occidental de Santo Domingo. Pero la realidad es que, en el Tratado de Reyswick, no se habla para nada de la cesión de la parte occidental de la isla a los franceses. Esta ocupación se mantuvo sólo por la tolerancia de las autoridades españolas, pero no apoyada en un título legal. ${ }^{8}$

Los colonos franceses, amparándose en la paz y en el abandono en que los gobernadores españoles mantuvieron la frontera durante mucho tiempo, se dedicaron a extender sus posesiones, fundando nuevos establecimientos cada vez más al este. ${ }^{9}$

De este modo, al tiempo que se producen casi ininterrumpidamente una serie de enfrentamientos en la frontera, se llevan también a cabo una serie de "negociaciones, acuerdos, acercamiento y colaboración, entre las autoridades y los pueblos de ambas colonias". ${ }^{10}$

Así, y aunque como ya hemos señalado no existía título legal alguno que justificara la presencia francesa en Santo Domingo, se inicia una línea de armonía y buena vecindad, que imperará también a lo largo del siglo XVIII entre las dos Coronas.

El siglo XVIII va a representar en toda Europa, una revalorización de los territorios americanos. Inglaterra, ya desde la segunda mitad del siglo XVII, intenta imponer un imperialismo cómercial. Portugal, aviva al mismo tiempo sus intereses americanos, pretendiendo asegurarse la posesión de la colonia de Sacramento. En Francia, América "es muy tenida en cuenta a la hora de las grandes determinaciones políticas", mientras en España, el Nuevo Continente figura siempre en el primer plano de la política exterior. ${ }^{11}$

8 Rodríguez Demorizi, Emilio: Acerca del Tratado de Ryswick "Revista CLIO. Revista Cuatrimestre de la Academia Dominicana de la Historia”. Vol. 22, Santo Domingo, 1.954, págs. 127-132.

9 Mac Lean, J. y T. Pina Chevalier: Op. cit., pág. 14.

10 Moya Pons, Frank: Op. cit., pág. 259.

11 Palacio Atard, Vicente: El equilibrio de América en la diplomacia del siglo XVIII. "Estuđios Americanos", vol. 1, núm. 3. Sevilla, mayo de 1949, págs. 464-465. 
Las Indias españolas eran ambicionadas desde mucho antes por el resto de las potencias europeas, aunque la forma en que se propusieron su dominio varió mucho de una a otra.

Luís XVI consideraba, "que la supremacía comercial de Francia en los dominios americanos de España, debía resultar de una estrecha asociación política y económica entre ambos países". Los ingleses por su parte, pensaban que tenían que acabar con el monopolio español, aprovechándose de las ventajas obtenidas hasta entonces a través del contrabando y abriendo nuevas vías de penetración con fines desde luego comerciales. ${ }^{12}$

En la Paz de Utrecht, que puso fin a la guerra de $\mathrm{Su}-$ cesión Española, Inglaterra trata por todos los medios de conseguir el equilibrio de poderes en Europa, "para poder dedicarse sin trabas a la expansión ultramarina y al desarrollo comercial". Hasta entonces, el predominio francés en Norte América era claro. Pero, a partir de ahora, los ingleses irán imponiendo su presencia cada vez con más fuerza. Mientras, en el subcontinente sur, los portugueses, con la alianza inglesa, afianzan su poder en la zona sur del Brasil, consiguiendo la recuperación de la colonia de Sacramento, y la rectificación en el norte de los límites con la Guayana francesa. ${ }^{13}$

La posición española seguía siendo desde luego muy fuerte en América. Pero a partir de la Paz de Utrecht, la Corte comprende la amenaza representada por las ambiciones de Francia e Inglaterra, e inicia una política de defensa de sus posesiones ultramarinas.

Ya desde comienzos del siglo se da cuenta del peligro británico, y se produce un acercamiento a Francia que, por lo que se refiere a Santo Domingo, se manifiesta en una real cédula que en 1702 se remitió al gobernador de la isla. En

12 Gil Munilla, Octavio: El Río de la Plata en la política internacional. Génesis del virreinato. E.E.H.A. Sevilla, 1949, págs. 20-26

13 Palacio Atard, Vicente: Op. cit., págs. 467-469. 
ella, se le comunicaba haber tenido noticias de que el capitán general, en lugar de contribuir a que se estableciesen buenas relaciones entre las dos colonias para su defensa común, había permitido que los españoles adelantasen sus haciendas a costa de los territorios ocupados por los franceses, y se le ordenaba que modificara su actitud inmediatamente.

Poco a poco se iniciaron de nuevo las conversaciones entre los gobernadores de las dos colonias, dirigidas al establecimiento de unos límites definitivos. Pero la realidad era, que a los colonos les importaban poco los acuerdos a que pudieran llegar sus autoridades. Las usurpaciones clandestinās de terrenos por parte de los franceses continuaron, de modo que, en I727, los españoles tuvieron que colocar un cuerpo de guardia en Dajabón para guardar en lo posible sus límites, y otra guardia frente a Mirebalais en I736. En I74I, los españoles desalojaron a los franceses del Dondón, fijando una nueva guardia en Bacín Caimán, y otra en el sur, en Río Mulito, a donde habían llegado las fundaciones francesas. ${ }^{15}$

Diez años más tarde, ya en la segunda mitad del siglo, el gobernador interino, don José Sunyer y Basteros, hacía partícipe a la Corte de los recelos que experimentaba, por haberle llegado rumores del establecimiento de un nuevo grupo de franceses que acababan de arribar de Europa, en los parajes conocidos con el nombre de "Dariel". Los nuevos colonos desembarcados en la isla, sólo venían a agravar la gran necesidad de terreno que tenían los franceses, y con ello, a facilitar su mayor extensión en la isla de Santo Domingo. ${ }^{16}$

En este estado de mutuo recelo se encontraban los asun-

14 R. C. fechada en Madrid el 23 de junio de 1702 dirigida al gobernador de Santo Domingo, ordenándole el establecimiento de la buena armonía con los franceses. A.G.I., Santo Domingo, 303.

15 Mac Lean, J, y T. Pina Chevalier: Op. cit., pág. 17.

16 Carta del gobernador interino de Santo Domingo don José Sunyer y Basteros, fechada el 25 de enero de 1751, informando a la Corte del desembarco de nuevos colonos en la parte francesa, y del temor de que realizasen nuevas fundaciones. A.G! I., Santo Domingo, 942. 
tos fronterizos, cuando, en I759, el gobernador de Santo Domingo recibió una real cédula de su Corte, en la que se le manifestaba que "aunque en el año de mill zetecientos y treze, se pasaron avisos a la Corte de Franzia, para que los franzeses se contubiesen en el terreno que ocupaban en esa ysla en el tiempo de guerra, no a agradecido efecto alguno esta diligenzia, ni los demás medios suaues aplicados hasta aora, y antes uien, se reconoce intentan no sólo mantenerse en el país que en esa ysla han ocupado indeuidamente, sino extenderse en perjuicio de mi Rieal Corona, he resuelto que les obligue con las fuerzas y que les desamparen, y en su consecuencia, os ordeno deis las providenzias nezesarias, para que se pase a desalojar los franzeses, assí de lo que nuevamente han ocupado en esa ysla, como de todo el terreno que tienen en ella, pues lo que poseen es con usurpación violenta, y sin derecho alguno". ${ }^{17}$

Siguiendo estas órdenes, se intensificó la vigilancia de la frontera, descubriéndose por la zona norte diez establecimientos franceses fundados en el río Garaguey, en su parte este, arrasándose seis de ellos por orden del gobernador español, e impidiéndose además que continuaran otros, que hasta más de 50 se pretendían crear en aquella zona.

Pera una cosa eran las órdenes recibidas de la Corte, y otra lo que en realidad tenía lugar en Santo Domingo. Así, de los diez establecimientos mencionados sólo se destruyeron seis, pues en los otros cuatro, los colonos franceses hicieron frente con las armas a los españoles, mientras que el gobernador general de la parte francesa les enviaba un destacamento para reforzarlos, hasta que incluso las seis estancias demolidas se restablecieron. ${ }^{18}$

En la frontera del sur, se descubrieron también dos fincas dedicadas a la siembra de café y otros frutos, pertene-

17 R. C. fechada en el Buen Retiro el 12 de septiembre de 1759, y dirigida al gobernador de Santo Domingo, ordenándole la expulsion de los franceses de toda la isla. A.G.I., Santo Domingo, 303.

18 Nómina de diez establecimientos franceses fundados en el río Garagüey. Santo Domingo, 11 de julio de 1761. A.G.I., Santo Domingo, 1.018. 
cientes a los señores Villard y Rabí, en la zona conocida como Arroyo Seco, "aguas vertientes hacia Hincha". El gobernador, don Manuel de Azlor, ordenó su demolición al comandante de la frontera del norte don Andrés de Heredia, que no llegó a realizar la acción por haberle hecho frente los colonos franceses. ${ }^{19}$

La realidad es que la política oficial era muy diferente al espíritu de convivencia que, lógicamente, tenía que imponerse entre los colonos de ambas naciones. Ya hemos dicho, que no tardaron mucho en darse cuenta de que la coexistencia pacífica sólo traería beneficios para todos. Las relaciones comerciales, aunque oficialmente prohibidas, eran cada vez más intensas, sobre todo por lo que se refiere al tráfico ganadero. ${ }^{\mathbf{2 0}}$ Este comercio, en muchas ocasiones, se vio apoyado por los propios gobernadores, como observamos ya desde 1740, con el proyecto del entonces capitán general de la isla Zorrilla de San Martín de legalizar el paso de ganado entre ambas colonias, y su decisión de mantenerlo a pesar de las órdenes contrarias que recibió al respecto de la Corte. ${ }^{\mathbf{2 1}}$

La tranquilidad en la frontera era fundamental para el buen desarrollo de este comercio, en el que los colonos españoles, e incluso las mismas autoridades, estaban interesadas, y que casi siempre favorecieron, ${ }^{22}$ por lo que difícilmente podía convenir el alejamiento de los franceses, aunque desde luego los españoles estuvieron en contra de un avance progresivo de aquéllos hacia la parte oriental de la isla.

19 Carta del gobernador de Santo Domingo don Manuel de Azlor de 11 de julio de 1761, informando a la Corte de lo ocurrido tras el descubrimiento de dos establecimientos franceses en Arroyo Seco. A.G.I., Santo Domingo, 1.018.

20 Moreau de Saint-Mery, M. L.: Loc. cit., pág. 359.

21 Madrid, 1740-43. Expediente sobre el paso de ganado a la colonia francesa. A.G.I., Santo Domingo, 314.

22 Informe de Tomás de la Cruz, alcalde ordinario de la villa de Hircha, fechado el 11 de mayo de 1755, dando cuenta a la Corte, de la dejadez en que el gobierno tenía la frontera. A.G.I., Santo Domingo, 283. 


\section{El Pacto de Familia de i76i y la intervención en la Guerra de los Siete AÑos.}

Al mismo tiempo que las relaciones comerciales servían para suavizar las tensiones existentes entre las dos colonias de la Española, tuvo mucho que ver también en el asentamiento definitivo de esa dualidad en la isla, el entendimiento que se va produciendo entre las dos Metrópolis, especialmente desde la subida al trono de Carlos III, que culminó con el llamado Tercer Pacto de Familia estipulado por ambas Coronas en I76г, y que condujo a la entrada de España en la Guerra de los Siete Años. ${ }^{23}$

De I7I3 a I750, Inglaterra avanza sus conquistas en el subcontinente norte. Sus colonias se extienden territorialmente y además se enriquecen, al tiempo que su población se incrementa considerablemente. Mientras, la idea del equilibrio que había pretendido en Europa para tener las manos libres en América, será buscada ahora por España para defender sus dominios. ${ }^{24}$ Así, con la subida al trono de Fernando VI, la Corona española buscará la unión con Francia, que ya había sido patrocinada por aquélla con anterioridad, para detener el empuje inglés. Sin embargo, "la paz de Aquisgrán, la tendencia anglófila de una parte de la Corte, y la actitud del gobierno británico, hicieron fracasar el proyecto". ${ }^{25}$

Pero la Coronación de Carlos III, significará un cambio sustancial en la política exterior, que acabará con el neutralismo que por todos los medios intentó imponer su antecesor.

La persistencia de la rivalidad anglo-francesa, era fundamental para la tranquilidad del imperio español. Mientras ambas potencias tuvieran en América una fuerza semejante, los territorios españoles no tendrían nada que temer.

Por eso, cuando en el transcurso de la Guerra de los

\footnotetext{
23 Pérez y Pérez, Carlos Federico: Loc. cit., pág. 65.

24 Palacio Atard, Vicente: Op. cit., págs. 471-473.

25 Gil Munilla, Octavio: Op. cit., págs, 36-37.
} 
Siete Años, en la que ambas se encontraban enfrentadas, se vio que la balanza se inclinaba descaradamente en favor de Inglaterra, a Carlos III no le quedó más remedio que intervenir. ${ }^{26}$

En un principio, trató de ser mediador entre las dos naciones para acabar con el conflicto. Pero las negociaciones resultaron inútiles, y España no tuvo ya más solución que recurrir a la alianza con los franceses, para que el equilibrio americano fuera un hecho.

Los británicos explotaban Honduras sin que las protestas españolas sirvieran para nada, y su presencia en el Caribe era cada vez más fuerte. La actitud inflexible de Inglaterra, y la conciencia del peligro que su triunfo representaría, en resumen, "la idea del equilibrio americano", es la base de la alianza hispano-francesa de $1761 .{ }^{27}$ Se llegó así a la firma del Tercer Pacto de Familia entre España y Francia, el I 5 de agosto de 1761, que condujo a la declaración de guerra a la primera por parte de la Gran Bretaña, a comienzos del año siguiente.

A consecuencia de ello, se expidieron una serie de órdenes al gobernador de Santo Domingo, en las que se le manifestaba el interés que tenía el Rey en la conservación de las posesiones francesas, "aun en tiempo de la neutralidad con los ingleses". Por ello, debía facilitar los víveres que sus gobernadores necesitaran, y hacer causa común con su defensa, de modo que, "en todo lo que no sea perjudicial a la propia defensa de los dominios de S.M., ha de extender V.S. sus auxilios a los franceses". ${ }^{29}$

Esta nueva actitud llevó en 1762, a la firma de un tratado entre don León de Fontenelle y don Ignacio Caro de Oviedo, como representantes de los gobernadores francés y español respectivamente.

26 Ibídem, pág. 45.

27 Palacio Atard, Vicente: Op. cit., pág. 477.

28 Gil Munilla, Octavio: Op. cit., págs. 63-64.

29 Madrid, 23 de abril de 1762. Carta dirigida al gobernador de Santo Domingo, ordenándole ayude en lo posible a sus vecinos franceses en la guerra contra los ingleses. A.G.I., Santo Domingo, 1.018 
El tratado constaba de trece artículos en los que se establecían los siguientes puntos: ${ }^{\mathbf{3 0}}$

- Que en caso de que una de las dos colonias de la isla sea atacada, debe ser socorrida por la otra, y si las dos lo fuesen, la menos necesitada deberá ayudar a la otra.

- Para facilitar la comunicación y el más rápido auxilio en caso de necesidad, se abrirá un camino por la zona denominada de la Angostura.

- En el caso de que una de las dos colonias se vea precisada a retirarse a los terrenos de la otra a causa de la guerra, encontrará buen asilo, y recibirá los auxilios que necesite como si fueran una sola nación.

- Debiendo procurarse las dos naciones la subsistencia necesaria para la defensa común, los españoles deberán "por ahora, y durante la guerra, sin que pueda esto hacer obligación, ejemplo ni costumbre en adelante, ni para el tiempo de la paz", proporcionar a los franceses hasta 800 cabezas de ganado vacuno macho al mes. Seiscientas de ellas pasarán por la frontera del norte, y doscientas por la del sur.

A cambio, los franceses facilitarán a los españoles productos agrícolas y municiones.

- Las embarcaciones de una de las colonias serán recibidas en los puertos de la otra, cuando los suyos estén bloqueados por los enemigos, pudiendo hacer allí la libre venta de sus géneros como si fueran navíos del país.

- Se establecerá un sistema de correos, para que los generales de las dos colonias puedan comunicarse con la mayor brevedad.

- Como antes de atacar la colonia francesa, los navíos enemigos tendrán que pasar por delante de las costas españolas, se pasará noticia a aquélla rápidamente por

30 Santo Domingo, 21 de julio de 1762. Tratado firmado por don León de Fontenelle y don Ignacio Caro y Oviedo, con motivo del pacto de familia firmado entre ambas naciones. A.G.I. Santo Domingo, 1.059. 
la parte de Dajabón, para que esté alerta sobre el nứmero de tropas que se acercan.

- Las dos colonias se entregarán mutuamente los desertores del ejército, para evitar la indisciplina de las tropas.

- Los esclavos fugitivos deberán también ser detenidos por los justicias, entregándose a sus naciones respectivas, con la única condición de que las personas encargadas de recibirlos, juren no castigarlos con la pena de muerte, mutilación, u otro castigo excesivo. $\mathrm{Y}$ si el esclavo contrae matrimonio en una colonia que no sea la suya, quedará en ella, pagándose su valor a su antiguo dueño.

- También deberá restituirse cualquier delincuente que se refugie en la otra nación, con tal de que sea reclamado por el gobernador de la colonia de que sea súbdito, y la caución de no imponerle un castigo excesivamente grave.

- Para evitar el contrabando de ganado y otros géneros, los vendedores autorizados deberán mostrar el permiso de las autoridades, y el pase firmado de las guardias de su tránsito.

- Que el que ejercitare ese contrabando, quedará sujeto a la confiscación tal y como ordenan las leyes.

- Este tratado se considerará interino, hasta la aprobación definitiva de los respectivos monarcas.

Sin embargo, este tratado tuvo poca vigencia por lo que se refiere a los acuerdos que se hicieron a causa de la guerra, pues España entró en ella cuando ya estaba concluyendo, de manera que a finales de i 762 , se acordaron ya los artículos preliminares para la paz, finalizando en seguida las hostilidades. ${ }^{31}$ En noviembre de 1763 , se recibió en San-

31 Carta del gobernador don Manuel de Azlor de seis de febrero de 1763, acusando el recibo de la $R, O$. de ocho de điciembre de 1762 , șobre haberse frimado los preliminares para la paz. A.G.I., Santo Domingo, 944. 
to Domingo el real despacho en que se ordenaba a las autoridades dominicanas, la publicación en su distrito del ajuste definitivo de la paz entre España y Francia por una parte, e Inglaterra y Portugal por la otra. ${ }^{32}$

La guerra había ya terminado, pero los franceses no estaban dispuestos a renunciar a las ventajas obtenidas por el tratado de I762, y así, a comienzos del año siguiente, el comisario general de la parte francesa, Juan Bautista Bertrand, escribía al capitán general de Santo Domingo solicitándole que, en lugar de las ochocientas cabezas de ganado al mes que se habían fijado en aquél, pudieran pasar mensualmente a la parte francesa I.OOO reses; pedía también un préstamo para el socorro de las tropas y los reparos necesarios en las fortificaciones, y que se autorizara así mismo la venta de "mill cavallos que se necesitan para montar actualmente seiscientos hombres de tropa ligera, que el sor. conde de Belzún, comandante general de toda la que hay en dicha colonia, a creado con el beneplácito del Rey mi señor, y los quatrocientos restantes, para remontar los reductos de coraza que deben llegar". ${ }^{33}$

La respuesta del gobernador don Manuel de Azlor fue clara: que el convenio en el que se estableció que los españoles debian suministrar a los franceses 800 reses al mes no tenía ya valor, puesto que en el tratado se decía literalmente "por ahora y durante la guerra", y habiendo terminado aquélla, quedaba sin vigencia este artículo.

A pesar de ello, don Manuel de Azlor se manifestaba dispuesto a permitir el paso a la colonia francesa, de 800 cabezas de ganado vacuno macho al mes, con tal de que no se considerase una obligación española. Que los comisarios franceses fueran a la parte española, donde acordarían libre-

32 Real despacho fechado en el Buen Retiro el 30 de marzo de 1763 dirigido al gobernador de Santo Domingo, comunicándole haberse ajustado la paz. A.G.I., Indiferente General, 539, y carta de don Manuel de Azlor de dos de noviembre del mismo año, acusando el recibo de aquél. A.G.I., Santo Domingo, 974.

33 Santo Domingo, 24 de marzo de 1763. Traducción de una carta del Sr. Bertrand a don Manuel de Azlor solicitando el paso de ganado. A.G.I., Santo Domingo, 1.059. 
mente el precio con los hateros, y que la salida se hiciera por Dajabón, San Rafael de la Angostura, San Gabriel de las Caobas o Neiba, donde se llevaría una perfecta contabilidad sobre el asunto.

Proponía además don Manuel de Azlor en su carta, que las autoridades francesas obligaran a volver a la parte española, a todo el que hiciese el comercio de ganado sin pasar por las mencionadas guardias, y que su carga fuera apresada.

Al mismo tiempo, y como este ganado que se autorizaba a exportar estaba dedicado, en teoría, al mantenimiento de las tropas que permanecían en la isla a pesar de haber finalizado la guerra, el gobernador francés debía prohibir las pequeñas carnicerías, que en su mayor parte vivían del contrabando.

Respecto a la venta de los caballos que Bertrand solicitaba, Azlor declaró no poder acceder en este punto, por no haber en la parte española ni siquiera el número suficiente de ellos para abastecer las necesidades internas, y del mismo modo, manifestó que le era imposible también conceder el préstamo a la vecina colonia, por encontrarse exiguo el caudal de las Cajas Reales. ${ }^{34}$

Con motivo de la negativa de Azlor, se creó una fuerté tirantez entre el gobernador español y el comisario francés, sobre todo porque el primero se negó además a prohibir la marca de los negros, práctica obligatoria entonces en las colonias españolas, como aquél le solicitaba, pretextando que la mayoría de los esclavos presentados por los españoles para su sello, eran fugitivos de la parte francesa. ${ }^{35}$

Pero las súplicas de Bertrand llegaron a su Corte, de modo que el embajador de Francia en España solicitó del gobierno de Madrid, se continuara con la venta de ganados de la colonia española de Santo Domingo a su vecina fran-

\footnotetext{
34 Carta del gobernador de Santo Domingo don Manuel de Azlor dirigida al señor Bertrand con fecha de siete de mayo de 1763 , respondiendo a la solicitud' sobre el paso de ganađos que aquél le había hecho. A.G.I., Santo Domingo, 1.059.

35 Guarico, cinco de junio de 1763. Carta del señor Bertrand a dón Manuel de Azlor sobre la negativa de éste a acceder a sus deseos. A.G.I., Santo Domingo, 1.018.
} 
cesa. Esta petición tuvo como consecuencia una real orden dirigida al gobernador de Santo Domingo, encargándole, de parte del Rey, que siguiera permitiendo el paso del ganado vacuno necesario para la subsistencia de los franceses, sobre todo teniendo en cuenta el mayor consumo que representaba el aumento de tropa que los guarnecía. El único límite que el capitán general debía poner, era el abastecimiento de la parte española y el mantenimiento de la crianza en los hatos. Para lograr este fin, debía reunirse con el general del Guarico, y acordar con él el número de reses necesario, y la forma y momento de su exportación. ${ }^{36}$

A esta real orden respondió el gobernador de la Española, que había hecho ya un repartimiento de la zona sur con este fin, sin que por ello cesase el comercio clandestino, "pues no habiéndose admitido con cierto fríbolo pretexto el que se apromptó por la villa de Hincha, no se ha hecho más instancia por el general del Guarico, y es constante que todas las colonias están provehidas de carne con sobrada abundancia". A pesar de ello, manifestó que se pondría de acuerdo con el general francés para tratar de nuevo el asunto. ${ }^{37}$

En esta situación, fue nombrado como gobernador general de la parte francesa el conde D'Estaing, con indicaciones de su Corte de reconocer, junto con su colega español, los lugares más apropiados para establecer fortalezas que sirvieran a la defensa conjunta. ${ }^{38}$

Pero los acuerdos de mutua ayuda en caso de guerra o de comercio entre las dos colonias, no solucionaban un problema fundamental en la isla: la cuestión de los límites. Así,

36 R.C. de cinco de octubre de 1763 dirigida al gobernađor de Santo Domingo, comunicándole que permitiese la franca extracción de ganado a la colonia francesa de la isla. A.G.I., Santo Domingo, 1.059.

37 Carta del gobernador de Santo Domingo don Manuel de Azlor de 17 de marzo de 1764, informando a la Corte del paso clandestino de ganado a la colonia francesa vecina. A.G.I., Santo Domingo, 1.059.

38 Carta del gobernador de la Española don Manuel de Azlor de 11 de mayo de 1764, acusardo el recibo de la R. C. de 21 de febrero de aquel mismo año, comunicándole el nombramiento del conde D'Estaing como gobernador general de la parte francesa. A.G.I., Santo Domingo, 1.018 . 
en I764 don Manuel de Azlor escribía a la Corte, que el comandante de la frontera del sur, don Fernando de Espinosa, había descubierto que el señor Villard, al que ya se había advertido por haber establecido una hacienda en territorio español, había hecho una tercera fundación con siembra de café en la zona de Arroyo Seco. Con este motivo, el gobernador español informaba que la única solución para terminar con estas invasiones progresivas, era señalar unos límites fijos y definitivos entre las dos colonias, asunto que consideraba sería fácil de arreglar, dado el buen entendimiento existente entonces entre ambas Metrópolis. ${ }^{39}$

La respuesta de la Corona fue clara: que se procediera de acuerdo con el gobernador de la parte francesa al establecimiento de "unos límites claros, que no puedan producir en lo sucesivo ninguna disputa".40

D'Estaing arribó a la colonia francesa de Santo Domingo el I9 de abril de I $764,{ }^{41}$ pero no es hasta dos años más tarde, en I766, cuando Azlor comienza una visita general a la isla, y en especial a las fronteras, con el fin de llegar a un acuerdo definitivo. El io de mayo de aquel mismo año, finalizó la visita a los "puertos, costas y puestos principales de esta ysla, y los de las colonias francesas". ${ }^{42}$

El 23 de septiembre, también de 1766 , debió haber iniciado la visita de "la parte del norte y frontera del sur". ${ }^{43}$ Pero los temporales que tuvieron lugar en el mes de octubre hicieron los caminos intransitables, con los ríos desbordados y sin poder vadearlos, por la que, a principios del mes

39 Carta' del gobernador de Santo Domingo don Manuel de Azlor de 6 de abril de 1764, dando cuenta a la Corte de la necesidad de establecer unos límites fijos y definitivos con la colonia francesa vecina, A.G.I., Santo Domingo ,1.018.

40 R. O. de 21 de diciembre de 1764 autorizando al gobernador de Santo Domingo don Manuel de Azlor, a establecer los límites entre las dos colonias de la isla de acuerdo con las autoridades de la parte francesa: A.G.I., Santo Domingo, 1.018.

41 Ibídem, nota 38.

42 Carta del gobernador de Santo Domingo don Manuel de Azlor de 16 de mayo de 1766, dando cuenta a la Corte de haber visitado la frontera y costa norte de la isla. A.G.I, Santo Domingo, 1.018.

43 Carta del gobernador de la Española don Manuel de Azlor de 22 de septiembre de 1766, informando a la Corte de su próxima salida de la capital para finalizar la visita que tenía que realizar a la isla. A.G.I., Santo Domingo ,1.018. 
de noviembre, tuvo que regresar a la capital sin haberla finalizado. ${ }^{44}$

En esta situación se encontraba el asunto, cuando el gobernador general de la parte francesa fue sustituido por el príncipe de Rohan. Coincidiendo con su llegada al Guarico, el capitán general de la parte española recibió una comunicación de la Corte, en la que se le manifestaba que el Rey había tenido conocimiento de que no se respetaba en aquella isla la recíproca restitución de negros esclavos, desertores del ejército, y demás delincuentes, tal y como se acordó entre las autoridades de ambas colonias. En vista de ello, se le ordenaba que tomara activas medidas con el fin de evitar estos problemas. ${ }^{45}$

Pero con este mismo motivo, el señor Valtiere, que había sido comisionado por el príncipe de Rohan para pasar a la parte española y entrevistarse con su gobernador, llegó a un acuerdo con este último, antes de que la mencionada real orden fuera recibida en Santo Domingo. El i I de diciembre de aquel año se firmó un tratado entre ambos, basado en la mutua entrega de los negros fugitivos de una y otra nación, en el que se estipularon los siguientes puntos: ${ }^{46}$

- Que los negros fugitivos de una y otra nación, serán restituidos de buena fe, así como los negros hurtados, pagando siempre por ellos sus dueños el precio de 25 pesos que fue fijado en el tratado de 1762 .

- Todos los soldados desertores serán así mismo devueltos.

- Sobre los grupos de negros cimarrones fortificados en

44 Carta del gobernador de Santo Domingo don Manuel de Azlor de 10 de noviembre de 1766, comunicando a la Corte haber tenido que suspender la proyectada visita a la isla a causa de los temporales, A.G.I., Santo Domingo, 1.018.

45 R. $O$. fechada en Madrid el 23 de diciembre de 1766, dirigida al gobernador don Manuel de Azlor, conminándole a restituir a la colonia francesa los desertores y esclavos. A.G.I., Santo Domingo, 1.018.

46 Acuerdo firmado el 11 de diciembre de 1766 entre don Manuel de Azlor y el señor Valtiére como representantes de las colonias española y francesa de la isla respectivamente, sobre la mutua restitución de los negros fugitivos. A.G.I., Santo Domingo, 1.101 . 
los montes cercanos a las fronteras, de una y otra parte, se tomarán las medidas más oportunas para apresarlos y destruir totalmente sus establecimientos.

- Se prohibe a todos los pobladores de la frontera, hacer trabajo alguno sobre sus terrenos "más allá de los límites que están concedidos", ni sobre terreno que se considere dudoso, hasta que se establezcan unos límites definitivos.

- Aunque el convenio de 1762 finalizó, por lo que se refiere a la venta del ganado español a los franceses, el gobernador de Santo Domingo accede "ahora, y en el ínterim que el Rey mi amo disponga otra cosa ${ }^{71}$, a que los carniceros franceses vengan a los hatos españoles a comprar el ganado que aquélla colonia necesitare, pagando un impuesto de 24 reales por cada mancuerna.

Este acuerdo no fue muy bien acogido en la Corte española. El fiscal del Consejo de Indias manifestó al respecto, que el gobernador de Santo Domingo había procedido a celebrar este nuevo convenio sin que hubiera recibido autorización para su otorgamiento, y que se había excedido claramente, al permitir que los carniceros franceses pasaran a la colonia española a comprar el ganado, cuando esto estaba totalmente en contra de las leyes. ${ }^{47}$

Ajeno a estos reproches, don Manuel de Azlor insistía de nuevo en la necesidad de que se arreglaran, de una vez para siempre, los límites con la colonia francesa, para evitar de ese modo las diarias usurpaciones de terrenos por parte de aquélla. ${ }^{48}$

Los problemas en la frontera eran continuos, y los co-

47 Madrid, 1767. Expediente del Consejo de Indias sobre el tratado firmado en diciembre de 1766 entre los señores Valtiére y Azlor en la Española. A.G.I., Santo Domingo, 1.101.

48 Carta del gobernador de Santo Domingo don Manuel de Azlor de 22 de septiembre de 1767 y otra de 31 de mayo del año siguiente, insistiendo a la Corte sobre la necesidad de establecer unos límites definitivos entre las dos colonias de la isla. A.G.I., Santo Domingo, 1.018. 
mandantes de ella llegaron a apresar a varios franceses, que fueron encontrados cultivando en territorio español. Casi todos los días había "quejas y denuncias, de que los franceses adelantaban sus trabajos en las fronteras y se introducen en nuestros terrenos". ${ }^{49}$

Por lo que se refiere al tráfico ganadero, las irregularidades eran también notorias. El gobernador francés solicitaba de su colega español, la autorización para comprar caballos para el ejército. Y antes de que éste tuviera tiempo de conceder o negar la licencia correspondiente, los caballos habían pasado ya a la parte francesa. ${ }^{50}$

Al mismo tiempo, con motivo de la visita que don Manuel de Azlor realizó a la isla, tuvo conocimiento del número de reses existentes en los hatos y, en consecuencia, del incremento que anualmente debían experimentar las crianzas, dándose cuenta por ello, de que "se hace una extracción clandestina de la maior consideración a las colonias francesas, por caminos y veredas extraviadas". ${ }^{51}$

En I 770, llegó a la colonia francesa de Santo Domingo un nuevo gobernador, el conde de Nolivos, quien comunicó su arribada a su colega español, con los correspondientes ofrecimientos para estrechar relaciones y conseguir una armonía perfecta. Al mismo tiempo, le informaba de los deseos de la Corona francesa de establecer unos límites fijos en la isla. Como Azlor se encontraba sin instrucciones de su Corte a este respecto, respondió que, mientras sus Metrópolis discutían sobre el asunto, él debía vigilar para que sus súbditos se contuvieran dentro de sus territorios. Pero el gobernador de la Española sabía que esto no era posible,

49 Carta del gobernador de la Española don Manuel de Azlor de $\mathbf{3 0}$ de mayo de 1769, informando a la Corte de las continuas violaciones de la frontera entre las colonias española y francesa de Santo Domingo. A.G.I., Santo Domingo, 1.101.

50 Carta de don Manuel de Azlor de 21 de febrero de 1769, dando cuenta a la Corte de las irregularidades cometidas por don Francisco Lorencis, teniente del batallón fijo de Santo Domingo y destinado en la frontera del sur, permitiendo a los franceses la compra de caballos sin esperar la determinación del gobernador al respecto. A.G.I., Santo Domingo, 1.059.

51 Carta del gobernador de Santo Domingo don Manuel de Azlor de $\mathbf{3 0}$ de junio de 1769. sobre el paso clandestino de ganado a la colonia francesa. A.G.I., Santo Domingo, 1.059 . 
a no ser que de verdad se fijaran unos límites definitivos entre ambas colonias, de manera que no pudieran dejar lugar a ninguna duda, sobre a quién pertenecía cada terreno. $\mathrm{Y}$ de esta creencia hizo de nuevo partícipe a la Corte, solicitando del Rey que se le concediesen "las facultades que son necesarias para evacuar esta importante comisión, respecto al conocimiento práctico que tengo de toda la frontera". ${ }^{52}$

El 24 de mayo de aquel mismo año, el señor de Vicent, coronel de infantería de los ejércitos franceses, y teniente del Rey de la plaza del Guarico, llegó a Santo Domingo a presentar al gobernador español un tratado de ocho capítulos, para el que solicitaba su aprobación. ${ }^{53}$

Los ocho capítulos propuestos por el gobernador francés eran los siguientes: ${ }^{54}$

- Las personas que crucen la frontera sin pasaporte del comandante de su nación, serán remitidas a los cuerpos de guardia de sus respectivas colonias.

- La persona que pase la frontera para vender ganado o mercancías en la otra colonia, llevará la licencia correspondiente del comandante de su nación, y por ella, se le autorizará a la venta los domingos en la plaza pública, y ante testigos.

- Se permitirá al conde de Nolivos enviar uno o más hombres a la colonia española, con el fin de comprar allí trescientos caballos para la tropa.

- Del mismo modo, podrá hacer seguir y arrestar aun en territorio español, a los esclavos fugitivos.

52 Carta de don Manuel de Azlor de 17 de marzo de 1770, informando a la Corte de la llegada al Guarico del conde de Nolivos, nuevo gobernador de la colonia francesa, y de la necesidad de firmar con aquélla un tratado de límites. A.G.I., Santo Domingo, 1.018 .

53 Carta del gobernador de Santo Domingo don Manuel de Azlor de 23 de junio de 1770, dando cuenta a la Corte de la llegada a Santo Domingo del señor Vicent, enviado por el gobernador francés, para proponerle la firma de un tratado entre ambas colonias. A.G.I., Santo Domingo, 1.059.

54 Tratado propuesto por el gobernador general de la parte francesa conde de Nolivos a su colega español, fechado en Puerto Príncipe en 1770. A.G.I., Santo Domingo, 1.059 . 
- En caso de surgir algún problema relativo a los límites entre los vasallos de ambas naciones, los comandantes de los cuerpos de guardia se avisarán mutuamente e irán juntos al punto en discordia, y buscarán un remedio provisional hasta que sus gobernadores tomen una decisión definitiva sobre el asunto.

- Se observará puntualmente el artículo quinto del tratado firmado en I 766 entre el gobernador don Manuel de Azlor y el señor Valtiere, en el que se estableció el derecho que los carniceros franceses debian pagar en la colonia española por la compra de las reses.

- También se respetará el artículo segundo del mencionado tratado, sobre la mutua devolución de los soldados desertores.

- El tratado de i766 será observado, siempre que no vaya en contra de lo establecido en éste.

Don Manuel de Azlor, a la vista de esta propuesta, aceptó los artículos primero y segundo con algunas salvedades, como la de que a los españoles sólo se les permitiría vender caballos en la colonia francesa llevando una licencia del gobernador, y a cambio sólo podrían traerse dinero o víveres.

Respecto a los artículos tercero y cuarto, debían quedar en stispenso, según don Manuel de Azlor, hasta conocer la opinión de su Corte. Los restantes puntos del acuerdo sí fueron aprobados por el gobernador español, que rápidamente informó a su Metrópoli sobre este asunto. ${ }^{55}$

Pero los problemas no cesaron con ello, las acusaciones mutuas por no respetar los acuerdos eran constantes. El gobernador francés culpaba al español de no entregar a los fugitivos de su colonia, haciendo justicia así a los súbditos franceses los comandantes españoles. ${ }^{56}$

55 Carta del gobernador de Santo Domingo don Manuel de Azlor de 20 de junio de 1770, informando a la Corte del tratado que le había propuesto el conde do Nolivos. A.G.I., Santo Domingo, 1.059.

56 Carta del conde de Nolivos fechada en el Guarico el 5 de septiembre de 1771 y dirigida al gobernador de Santo Domingo don José Solano, sobre no respetar los acuerdos sobre la entrega de los negros fugitivos. A.G.I., Santo Domingo, 1.018. 
El nuevo gobernador español, don José Solano, inculpaba a su colega francés, por su colaboración con los colonos que sobrepasaban la "conocida raya de tolerancia", y por su afán de extender el territorio francés en la isla. ${ }^{57} \mathrm{Y}$ sólo el peligro común que ambas colonias sentirán, con motivo de los rumores cada vez más insistentes de que estallaría la guerra contra Inglaterra, los hará olvidarse momentáneamente de esas disputas.

\section{LOS TRATADOS DE I773 A I775}

La alianza con Francia no resultó todo lo sólida que pensaba Carlos III, como se mostró claramente en algunas ocasiones. En 1765, los ingleses habian desembarcado en las islas Malvinas, que ellos llamaron Falkland, fundando allí el establecimiento de Port Egmont, ${ }^{58}$ hasta que, en I770, fueron expulsados por una expedición española enviada con este fin. ${ }^{59}$

La Corona británica se mostró ofendida, por lo que consideraba había sido una injuria inferida contra ella, y Carlos III, que hubiera querido hacerle frente y no acceder a las reclamaciones que se le presentaron, tuvo que claudicar ante la poca predisposición de los franceses a intervenir en su favor. ${ }^{60}$

La primera ocasión en que el Pacto de Familia fue puesto a prueba, el Monarca español sufrió pues una grave desilusión, y a partir de ahora, tomará sus decisiones internacionales sin contar para nada con Francia. Sin embargo, el pacto sigue vigente, y las relaciones con Francia continúan siendo fundamentales para frenar a los ingleses.

57 Carta del gobernador de Santo Domingo de 24 de septiembre de 1771 , informando al Consejo de Indias de los avances que los franceses realizaban en la frontera. A.G.I., Santo Domingo, 1.018. .

58 Hidaigo Nieto, Manuel: La cuestión de las Malvinas. Contribución al estudio de las relaciones hispanoringlesas en el siglo XVIII. C.S.I.C. Instituto Gonzalo Fernández de Oviedo. Madrid, 1947, pág. 5.

59 Ibíđem, pág. 175.

60 Gil Munilla, Octavio: Op. cit., pág. 161. 
Así, por lo que se refiere a la isla de Santo Domingo, estas relaciones se estrechan más, y en I772 se inician una serie de negociaciones, llevadas a cabo quizás con más seriedad que las anteriores, y que probablemente por ello darán más frutos.

A comienzos de aquel año, se firmó un acuerdo provisional entre el vizconde de Ferronnays por parte francesa, y don Fernando de Espinosa por parte española, en el que se establecía que las dos colonias esperarían las decisiones de sus Cortes respectivas, sobre los franceses que se habian establecido en territorio español. Pero si a los diez meses no se habían recibido órdenes claras al respecto, se les obligaría a abandonar los terrenos ocupados. Estos diez meses, que don José Solano permitió sólo como espera, no podían ser considerados como título alguno por parte de los ocupantes. Se hablaba, además en él, de que, hasta la decisión de las dos Coronas, las autoridades francesas no darían autorización alguna a sus súbditos, para su asentamiento en lugares cercanos a la frontera. ${ }^{61}$

Por la misma fecha en que este acuerdo se realizaba, la Corte española tomaba al fin una decisión sobre el asunto de los límites, comunicando al gobernador del Santo Domingo español, que "tiene resuelto S. M. el establecimiento de límites, que deseado igualmente por el Rey Christianísimo, deben V.S. y el general francés formalizarle, para lo que es previo antecedente la visita de toda la ysla". Para esta misión no se daban a don José Solano órdenes concretas, ya que para su realización era fundamental el conocimiento real del país. ${ }^{62}$

A esta real orden respondió don José Solano, que había iniciado las conversaciones con el gobernador general de la colonia francesa, conde de Nolivos, quien convino en

61 Carta del gobernador de Santo Domingo don José Solano de 10 de marzo de 1772, remitiendo a la Corte el acuerdo provisional firmado con los franceses el 25 de febrero de aquel mismo año. A.G.I., Santo Domingo, 1.018.

62 R. O. fechada en Madrid el 19 de abril de 1772 dirigida al gobernador de Santo Domingo don José Solano, previniéndole que llegara a un acuerdo definitivo de límites entre las dos colonias con las autoridades de la parte francesa. A.G.I., Santo Domingo, 1.018 . 
la retirada de los colonos establecidos "de la antigua raya de tolerancia acá", y en la realización de una visita completa a toda la zona fronteriza. Pero Nolivos fue sustituido de repente por un gobernador interino, Ferronnays, quien afirmó no contar con órdenes de su Corte para efectuar un tratado de límites, por lo que el capitán general español tuvo que pactar con aquél la espera de diez meses de que ya hemos hablado. ${ }^{63}$

Fue nombrado entonces gobernador de la parte francesa el señor de la Valliére, a quien Solano insistió sobre el asunto. Pero, el nuevo general, respondió también que no tenía instrucciones de las autoridades de su Metrópoli sobre el tema, y "le manda su Corte mantenga las cosas, en el estado en que se hallaban en 25 de febrero de este año", fecha en que el mandatario español concedió un plazo de diez meses a su colega francés, por lo que solicitó un nuevo aplazamiento.

Don José Solano contestó, que las órdenes que él tenía eran de acordar los límites provisionales, que serían más tarde ratificados por las autoridades centrales, negándose la Valliére a ello, ${ }^{64}$ hasta que por fin, en julio de 1773 , recibió un mandato de su Corte, para que llegara a un acuerdo provisional de límites con su colega español. ${ }^{65}$

Al poco tiempo, don José Solano participaba al Consejo de Indias haber firmado el convenio provisional de límites. En él había tenido que hacer algunas concesiones, ya que, "para que los límites pasasen por unos linderos perpetuos, ha sido preciso dejar a la parte francesa algunos terrenos, como son la margen meridional del río Garagey, desde la boca del arroyo Bajón hasta su origen, tomando por raya la cresta de las lomas Atrabesadas y Siguapo, que

63 Carta del gobernador don José Solano de 24 de octubre de 1772, dando cuenta a la Corte de las dificultades existentes para llegar a un acuerdo de límites por la sustitución de su colega francés. A.G.I., Santo Domingo, 1.018.

64 Carta de don José Solano de 25 de noviembre de 1772, sobre las dificultades existentes para la firma de un acuerdo de límites, por la falta de órdenes de su Corte a este respecto, con que se enfrentaba su colega francés. A.G.I., Santo Domingo, 1.019.

65 Carta del gobernador don José Solano de 24 de julio de 1773, informando a la Corte de la carta que le remitió su colega francés, manifestándole tener ya órdenes de su Corona para la firma de un tratado de límites. A.G.I., Santo Domingo, 1.019. 
bierten a dicho río; así mismo, parte de la loma de Jatiel; otra parte en el Palo del Indio, con bertientes a la parte francesa, tomando la loma Sucia por raya, y otra parte en el río Cordón, retirando la raya al bértice de la sierra Prieta". ${ }^{66}$

La firma del acuerdo provisional tuvo lugar en la población de San Gabriel de las Caobas, el 25 de agosto de I773, y las negociaciones no fueron nada fáciles. El mandatario francés pretendía, que la frontera fuera una línea recta desde el río Neiba en el sur, hasta la villa de San Juan de la Maguana, y desde allí al río Dajabón. Con ello, quedaban en la parte francesa los distritos de Azúa, Neiba. Banica, Hincha, San Rafael y San Miguel, "que son los terrenos de la isla más ventajosos para la cría de ganados". $Y$ para que el gobernador francés cediese, fue necesario que don José Solano amenazara con no entregar los negros fugitivos, y con suspender el comercio ganadero.

La frontera quedó así establecida en el río Dajabón por el norte, dirigiéndose luego hacia el oeste, dejando en la parte española las poblaciones de San Rafael, San Miguel, etc., y marchando después hacia el sur hasta llegar al río Pedernales. La línea divisoria pasaría así, por los "ríos, crestas o vértices de serranías, más inmediatos a los que una y otra nación poseía al presente". ${ }^{68}$

La Corte española se mostró conforme con este principio de acuerdo, pero la de Francia lo desaprobó formalmente, por medio de su embajador en España, declarándolo nulo. Por ello, y aunque se vio claramente que lo que los franceses querían era ganar tiempo para profundizar cada vez más su penetración, la Corona comunicó al gobernador, don Jo-

66 Carta de don José Solano fechada en las Caobas el 28 de agosto de 1773, informando de la necesidad de conceder algunos territorios a los franceses para hacer posible el acuerdo provisional de límites. A.H.N., Estado, 3.393.

67 Carta de don José Solano de 24 de septiembre de 1773, informando a la Corte de las dificultades existentes para la firma del tratado de límites con los franceses. A.H.N., Estado, 3.393.

68 Carta del gobernador don José Solano de 24 de septiembre de 1773, informando a la Corte sobre la consecución del acuerdo provisional de límites con la colonia francesa. A.G.I., Santo Domingo, 1.019. 


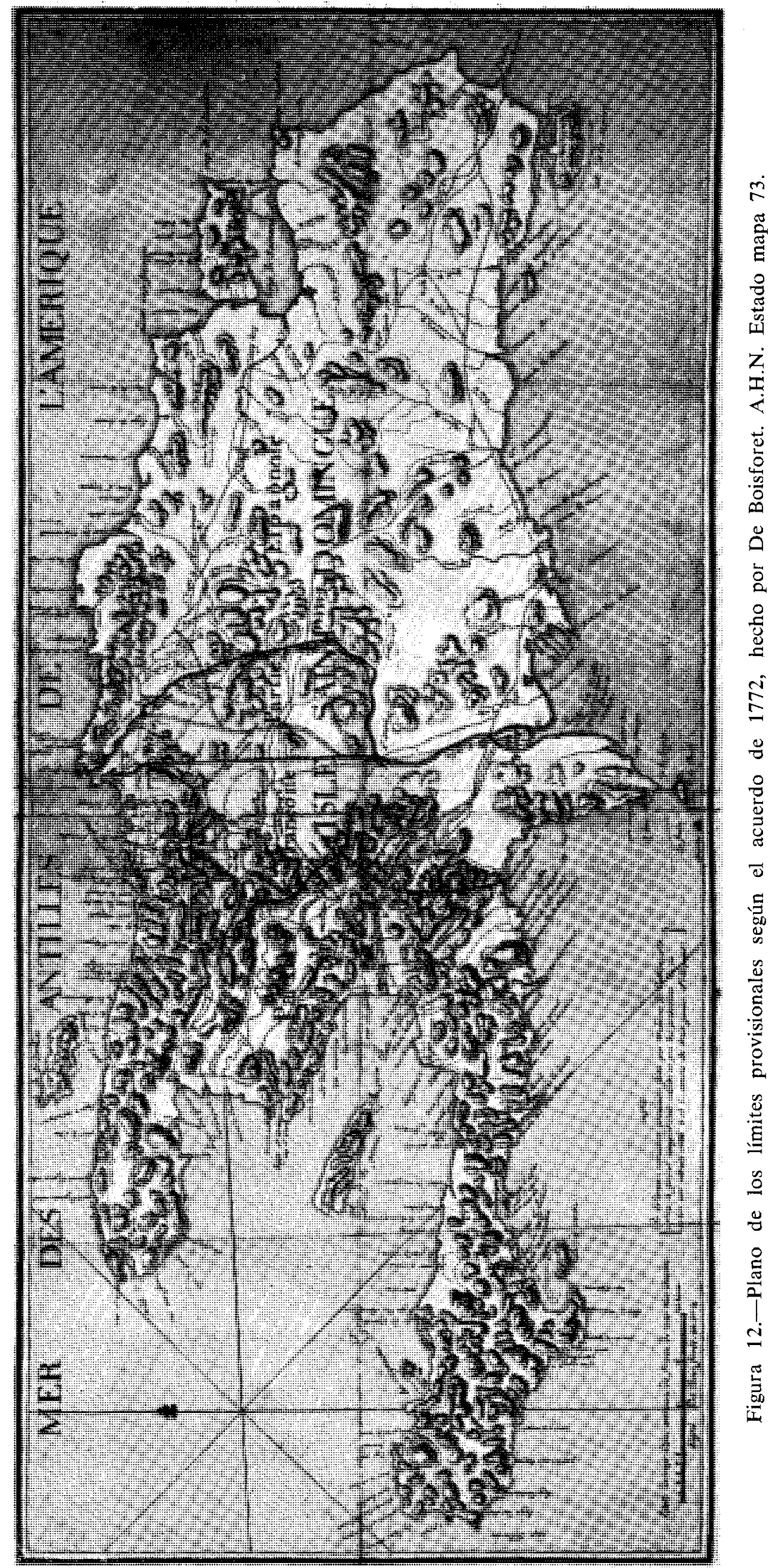




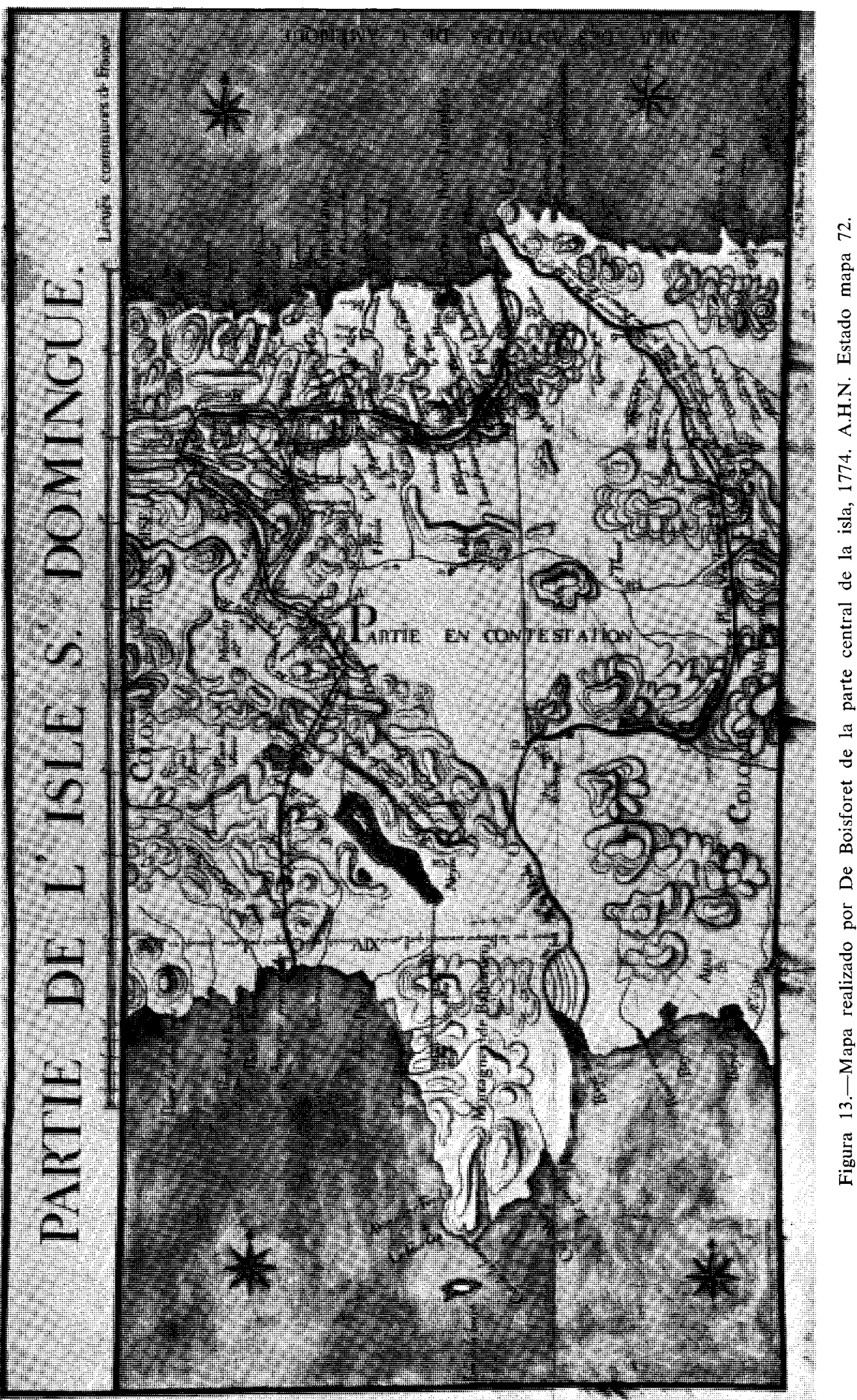


sé Solano y Bote, que para atajar esos males, o al menos hacer una última prueba respecto a la mala o buena fe de las autoridades de la nación vecina, se ventilaría este asunto y se ajustaría el tratado, entre el embajador español en París conde de Aranda por un lado, y el representante francés por el otro. ${ }^{69}$ Con este motivo, se dieron las órdenes correspondientes al conde de Aranda. ${ }^{70}$

Entre tanto, los colonos franceses de Santo Domingo continuaron avanzando en territorio español, en un intento de no sólo asegurarse los terrenos que ya ocupaban en la parte oriental de los límites acordados, sino de extenderse mucho más al interior, mientras, la Corte francesa ordenaba a su gobernador que se mantuvieran las cosas como estaban, consagrando así la usurpación. ${ }^{71}$

La respuesta del gobernador español fue retener los negros fugitivos, en tanto que su colega francés no hiciera evacuar las zonas ocupadas por los franceses desde $1772 .{ }^{72}$

Al año siguiente, el vizconde de Choiseul, brigadier de los ejércitos de Francia, pidió a don José Solano que levantara la retención de los negros huidos de su colonia, ofreciendo a cambio la evacuación de los territorios ocupados desde el acuerdo de I773. Pero aquél respondió que sólo reanudaría la entrega, si el abandono se hacía de todos los terrenos usurpados desde el convenio de 25 de febrero de I772, ya que el tratado provisional de I773 había sido declarado nulo por la Corte francesa. ${ }^{73}$

69 Carta del Consejo de Indias de 18 de mayo de 1774 dirigida a don José Solano, informándole de haber desaprobado la Corte francesa el acuerdo provisional de límites de 1773. A.G.I., Santo Domingo, 1.019.

70 Carta de la Corte fechada en Aranjuez el 12 de abril de 1774, comunicando al conde de Aranda la decision real de que arreglase en París un traslado de límites entre las dos colonias de la isla de Santo Domingo. A.H.N., iEstado, 3.393.

71 Carta del gobernador don José Solano de 24 de septiembre de 1774, informando a la Corte de los avances realizados por los franceses en la zona fronteriza. A.H.N., Estado, 3.391.

72 Carta de don José Solano de 25 de noviembre de 1774, dando cuenta a: 1a Cor. te de las represalias que había tomado por los avances de los franceses en la frontera, A.G. I., Santo Domingo, 1.019.

73 Carta de don José Solano de 25 de agosto de 1775 , informando a la Corte de las propuestas de los franceses para conseguir que se le entregasen los negros fugitivos. A.G.I., Santo Domingo, 1.019. 
Los franceses sin embargo continuaron avanzando, sin que sus autoridadies hicieran nada para evitarlo, en vista de lo cual, don José Solano suspendió "la provisión de carnes que V.S. me previno con fecha de 25 de diciembre de 74 , suspendiera después de algún tiempo de haber suspendido la de desertores". ${ }^{74}$

Estas medidas hicieron ceder, al menos aparentemente, a las autoridades francesas, de manera que el i2 de noviembre de I775, don José Solano firmó un acuerdo provisional con el vizconde de Choiseul, como representante del gobernador de la colonia francesa de la isla. En él se estableció que la situación en la frontera, debía permanecer en el estado en que se encontraba el 25 de febrero de 1772 , siendo destruidas las nuevas instalaciones francesas. Para evitar todo desorden hasta que se fijaran los linderos definitivos, los comisarios de límites visitarían las fronteras acompañados por sus respectivos comandantes, exploración que se realizaría una vez al año.

Se hablaba también en él, de la mutua devolución de los negros fugitivos y de los desertores, así como de la de cualquier delincuente.

Por último, el gobernador de la parte española se comprometía a proporcionar a sus vecinos, todos los auxilios posibles para la subsistencia de su colonia. ${ }^{75}$

\section{El Tratado de Aranjuez de i777 \\ Y LA GUERRA CONTRA INGLATERRA}

Las Cortes española y francesa juzgaron que, el acuerdo de límites de $\mathrm{I} 775$, no era "lo bastante claro i extensivo para concluir todo motivo de rozamiento", e intentando acabar con todas las hostilidades, dieron nuevas órdenes al respecto a sus respectivos gobernadores. ${ }^{76}$

74 Carta de don José Solano de 24 de junio de 1775, informando a la Corte de las nuevas represalias tomadas contra los franceses. A.G.I., Santo Domingo, 1.019.

75 Carta de don José Solano de 25 de noviembre de 1775, remitiendo a la Corte el acuerdo provisional que firmo el 12 de noviembre de aquel mismo año con el vizconde de Choiseul, A.G.I., Santo Domingo, 1.019.

76 Mac Lean, J. y T. Pina Chevalier: Op. cit., pág. 21. 
Se llegó así, el 29 de febrero de I776, a la firma de un nuevo convenio en la población de San Miguel de la Atalaya, a pesar de las graves dificultades existentes para ello. El gobernador español, don José Solano, se negó a autorizar la permanencia de los establecimientos franceses fundados en territorio español después de I773, y su colega francés, intentaba por todos los medios que aquéllos no fueran destruidos. ${ }^{77}$

La puesta en práctica de este nuevo acuerdo, se inició con el nombramiento de dos comisarios y los ingenieros correspondientes, para que recorrieran con detenimiento toda la línea fronteriza y colocaran unas pirámides indicadoras, de forma que no quedara ninguna duda.

La línea divisoria se trazó, tomando como punto de partida por el norte el río Dajabón, y el Pedernales por el sur. Su realización trajo consigo el alzamiento de una serie de mapas topográficos y una descripción detallada de toda la zona, que ambos comisarios firmaron en el Guarico el 28 de agosto de $1776 .^{78}$

El acuerdo de San Miguel de la Atalaya, y la descripción de límites hecha por los dos comisarios, fueron la base del tratado definitivo entre ambos países, firmado en Aranjuez en $\mathbf{I 7 7 7 .}$

En mayo de aquel año, se expidió una real cédula dirigida al conde de Floridablanca, manifestándole que, "por cuanto de la estrecha y natural amistad que mantengo con el rey christianísimo, mi mui caro y mui amado sobrino, nace el deseo de afirmar cada día más tan feliz unión", ambos monarcas habían decidido firmar un tratado definitivo, que fijara de una vez por todas los límites en la isla de Santo Domingo, así como otro "de policía y buena vecindad". Y a

77 Carta del conde de Vergenes al marqués de Ossun, fechada en Versalles el 13 de mayo de 1776, sobre las dificultades que existieron para la firma del acuerdo provisional. A.G.I., Santo Domingo, 1.019.

78 Mac Lean, J. y T. Pina Chevalier: Op. cit., págs. 21-22. 
él se le nombraba ministro plenipotenciario, para llegar con su colega francés a los mencionados acuerdos. ${ }^{79}$

Los plenipotenciarios se dieron prisa en la comisión que se les encargó, y en junio de aquel mismo año signaron en Aranjuez el tratado de límites, a la vista de los convenios anteriores, y de la descripción de límites ya señalada. En él se estipularon los siguientes artículos: ${ }^{80}$

- Artículo I.": "Quedarán por límites perpetuos e invariables entre las dos naciones, la boca del río Daxabón o de Massacre por la parte del norte de la citada ysla, y por la del sur, la boca del río Pedernales".

- Artículo 2. ${ }^{\circ}$ La zona intermedia entre ambos ríos, quedaría tal y como figuraba en el acuerdo de 29 de febrero de 1776 , y en consecuencia, según los comisarios de límites habían colocado las correspondientes marcas.

- Artículo $3 .^{\circ}$ : Para la mayor solemnidad de su ajuste, y quitar toda duda en lo sucesivo, firmarán los dos plenipotenciarios el mismo plano original que vino de la isla de Santo Domingo.

- Artículo $4^{\circ}$ : Con el fin de evitar problemas en el futuro sobre el uso de las aguas del río Dajabón, se impedirá cualquier acción en las respectivas orillas que vaya en per juicio del libre curso del mismo, aunque cada uno pueda edificar en su margen los diques necesarios para protegerse de las crecidas, siempre que no interrumpan el libre curso del mismo.

- Artículo $5^{\circ}$ : Los sujetos establecidos en zonas que por el mencionado instrumento de 1776 pertenezcan a la nación contraria, deben retirarse inmediatamente a sus líneas.

79 R. C. fechada en Aranjuez en mayo de 1777 dirigida a don José Moñino, conde đe Floridablanca, ordenándole la firma de un tratado de límites entre las dos colonias de Santo Domingo con la Corona francesa. A.H.N., Estado 3.394.

80 Tratado de límites entre las dos colonias de la isla de Santo Domingo, firmado en Aranjuez el tres de junio de 1777 entre el representante francés marqués D'Ossun y el español conde de Floridablanca. A.G.I., Santo Domingo, 1.019. 


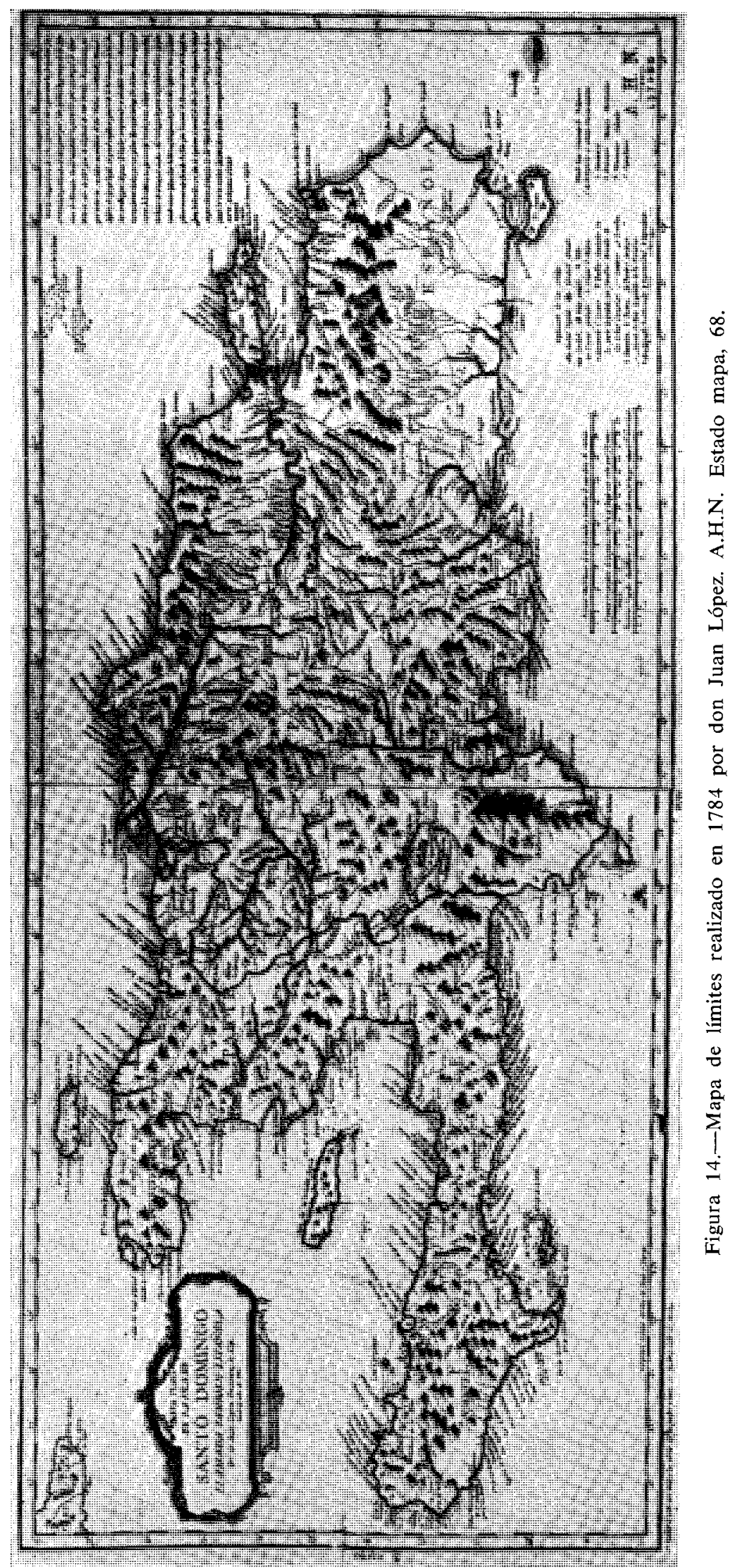


- Artículo 6. ${ }^{\circ}$ : Para que las pirámides que fijan los límites sigan en su lugar, se declarará rebelde a cualquier sujeto que las cambie o destruya, siendo juzgado en consejo de guerra y condenado a muerte.

- Artículo $7^{\circ}$ : Cada una de las colonias nombrará un inspector de fronteras, para la observancia de todos los puntos estipulados.

- Artículo 8.": Tanto los españoles como los franceses podrán atravesar los territorios de sus vecinos, estableciendo para ello cada nación los reglamentos oportunos, y en el caso de tratarse de tropas, deberá anteceder siempre aviso y mutuo convenio.

- Artículo 9. ${ }^{\circ}$ : Este tratado será aprobado y ratificado por los respectivos Monarcas en el término de dos meses.

Adjunto a este tratado de límites se firmó, tal y como se ordenó a Floridablanca, otro de "policía y buena vecindad" formado por doce artículos. En ellos se convenía en la mutua entrega de los desertores, esclavos fugitivos, y cualquier tipo de delincuente que se dirigiera a la otra colonia, aunque siempre bajo la promesa de que no se les castigaría con la pena de muerte o mutilación.

Al mismo tiempo, se acordó la organización de batidas conjuntas por los montes de la frontera, para apresar a los negros que vivían en ellos en estado "cimarrón".

Se hablaba también en este tratado del comercio ganadero, estableciéndose que se haría siempre del modo que fuera más conveniente al gobierno español, y resultara menos gravoso a los franceses, así como la unión de las dos zonas, en caso de guerra o ataque imprevisto a cualquiera de ellas. ${ }^{81}$

El gobernador de Santol Domingo, don José Solano, recibió las copias de este tratado, ya ratificado, el 20 de agosto

81 Aranjuez, 1777. Tratado de policía firmado por los pleripotenciarios español y francés anejo al anterior, para la mejor armonía entre las colonias francesa y española de Santo Domingo. A.H.N., Estado, 3.394. 
de aquel mismo año, aunque su publicación en la isla no se llevó a cabo hasta el 25 de noviembre, por haberse puesto primero de acuerdo con su colega francés para tal fin. ${ }^{82}$

La demarcación establecida en Aranjuez, no fue sin embargo bien acogida en la colonia francesa. La fijación de la frontera se consideró como un éxito de los españoles, que dejaba insatisfechos los deseos de expansión de sus vecinos, pues "en esa ocasión, España recuperó mucha de la tierra que había perdido en la isla". ${ }^{83}$

Pero decididas a que las disputas terminaran por fin, las autoridades respectivas determinaron respetar el tratado. $\mathrm{Y}$ al poco tiempo, se habían puesto de acuerdo para la captura conjunta de los negros cimarrones que habitaban en la zona fronteriza. En diciembre de aquel año, don José Solano envió las tropas necesarias para que realizaran una batida, junto con las destinadas a este objeto por su colega, "a fin de aprehender los que en ella haya, destruir sus establecimientos, y asegurar la tranquilidad de los avitantes vecinos". ${ }^{84}$

A pesar de ello los problemas se produjeron, ya que, por una parte, los franceses pedían cada vez más ganado para su abastecimiento, llegando a solicitar "el que se les diese anualmente nueve mil reses, para el gasto de su tropa y colonias". Y a ello se negó el nuevo gobernador español, don Isidro de Peralta y Rojas, arguyendo no tener pleno conocimiento del estado de las crianzas de la isla, accediendo sólo por el momento, a la concesión de cinco licencias por 400 reses cada una. ${ }^{85}$

82 Carta đel gobernador de Santo Domingo don José Solano de 25 de novienbre de 1777, informando a la Corte de la llegada del tratado de Aranjuez, y certifcación del escribano de cámara de la misma fecha sobre su publicación. A.G.I., Santo Domingo, 1.019 .

83 Peña Batlle, Manuel Arturo: Loc. cit., págs. 96-97.

84 Carta de don José Solano de 17 de noviembre de 1777, remitiendo a la Corte un acuerdo convenido con su colega francés para la aprensión de los negros cimarrones, y otra de 24 de diciembre del mismo afio, dando cuenta de haber designado la tropa necesaria para este fin. A.G.I., Santo Domingo, 1.019.

85 Carta del gobernador de Santo Domingo don Isidro de Peralta de 23 de octubre de 1778, comunicando a la Corte la solicitud del general de la Colontia francesa conde D'Argout para que se le vendiese ganado, y respuesta a esta petición. '.A.G.I., Santo Domingo, 1.059. 
Los franceses además no se resignaron a permanecer en los límites que se les habían fijado, y alguno llegó a quitar las señales que marcaban la línea fronteriza, aunque los testimonios no se ponen de acuerdo a este respecto. El gobernador francés pasó un oficio a don Isidro de Peralta, comunicándole que diez españoles, con uno que parecía oficial, habían cruzado la frontera y destruido haciendas en la parte francesa, "robado negros y cometido excesos de hostilidad, como ymbasores y ladrones de asalto, sin preceder provocación". Por su parte, las autoridades españolas de la frontera comunicaban, que, en la ronda realizada en enero de aquel año, observaron una clara usurpación de terreno español en el valle de las Guaranas, realizada por un tal Gapy que había cambiado de lugar el mojón I74, y en consecuencia, destruyeron sus sembrados.

En este estado de cosas, se produjo la alianza forzosa entre las dos naciones con motivo de su intervención en la guerra de la independencia de los Estados Unidos, en la que España y Francia ayudaron a las colonias de Norteamérica a segregarse de la Gran Bretaña.

Tanto Francia como España esperaban, desde el final de la guerra de los Siete Años, el momento de tomarse la revancha de Inglaterra. Carlos III ya lo había intentado antes can motivo del incidente de las Malvinas, pero el apoyo de Francia falló en aquella ocasión, y tuvo que ceder ante las pretensiones inglesas. Ahora, ambas potencias tendrán su oportunidad, e intentarán no desaprovecharla.

Desde que se inició el conflicto inglés con sus colonias norteamericanas, el mantener la paz con España y Francia será una necesidad imperiosa para el Reino Unido. Y a partir sobre todo de I775, la sublevación de aquellas colonias se convirtió en "un asunto de interés general". ${ }^{87}$ Carlos III se dio cuenta en seguida de que podía aprovecharse de la situación, dedicándose al rearme que le era necesario para

\footnotetext{
86 Carta del gobernador de la Española don Isidro de Peralta de 30 de noviembre de 1780, informando a la Corte de lo ocurrido con motivo de la usurpación de terreno español llevada a cabo por un colono francés. A.G.I., Santo Domingo, 1.019.

87 Gil Munilla, Octavio: Op. cit., pág. 243.
} 
cuando llegara el momento de enfrentarse con Inglaterra, y a solucionar el problema de los portugueses en el sur del Brasil, por considerar que los británicos no se encontraban, entonces, en condiciones de auxiliar a sus aliados. ${ }^{88}$

En 1776 , las colonias norteamericanas declararon unilateralmente su independencia de la Metrópoli, produciéndose así lo que fue "la primera guerra anticolonial de la historia moderna, al tiempo que la primera manifestación política violenta de las nuevas ideas contra el antiguo régimen". ${ }^{89}$

Antes de que España entrara realmente en la lucha, se hicieron en Santo Domingo preparativos para ella. En I777, el gobernador de La Habana comunicó a su colega dominicano, los rumores que corrían por la isla de Cuba sobre los fracasos de las tropas británicas del general Howe frente a los colonos norteamericanos, y que "al mismo tiempo ha corrido en esta plaza la voz vaga, de que el objeto de este general es caer de improviso sobre esa ysla, una vez que mira como imposible la reducción de las colonias al dominio británico". Ante estas noticias, el capitán general de la Española pasó una comunicación a la primera autoridad de la colonia francesa, e inició los preparativos necesarios por si la invasión se intentaba. ${ }^{90}$

En I778, España reconoció oficialmente la independencia de los Estados Unidos, cosa que Francia había hecho ya con anterioridad. Con este motivo, a comienzos de 1779 la entrada en la guerra era ya inminente. La Corte envió una circular a todos los virreyes y gobernadores de América, comunicándoles que, aunque aún no se había roto la paz con Inglaterra, era necesario que permanecieran atentos a los acontecimientos, por si los ingleses cometían "de improviso algún atentado, como suelen, particularmente en los buques

\footnotetext{
88 Ibídem, págs. 289-349.

89 Comellas, José Luís: Historia de España moderna y contemporánea. 1474-1967. Edit. Rialp. Madrid, 1968, págs. 369-370.

90 Carta de don José Solano de 25 de diciembre de 1777, informando a la Corte sobre los rumores que le había comunicado el de la Habana, sobre un peligro de invasión inglesa a Santo Domingo. A.G.I., Santo Domingo, 945.
} 
que navegan de esos a estos dominios". Por esta causa, las autoridades no debían permitir la salida de ningún barco con destino a España. ${ }^{91}$

Lo que en realidad estaba sucediendo en aquellos momentos, era que la Corona española preparaba su intervención directa en el conflicto. Así, varios meses más tarde, una nueva real orden mandaba al gobernador de Santo Domingo, que toda la tropa permaneciera en sus puestos, y que no se concediera licencia alguna hasta nueva orden.

La guerra estalló por fin, y desde el primer momento, las instrucciones dadas por Francia y España a los mandatarios de sus respectivas colonias de Santo Domingo fueron claras: que colaborasen estrechamente en la defensa común. La Corte francesa comunicó al conde D'Estaing, general de la escuadra de las Indias, que, "con las fuerzas de mar y tierra que están a su disposición, concurra eficazmente a la defensa y seguridad de los dominios españoles, y acompañen, protejan y apoyen, cualquiera empresas que sus gobernadores formen contra las posesiones inglesas". Al mismo tiempo, se proponía al gobernador español que recurriera al Guarico y demás territorios franceses, siempre que necesitaran auxilios. ${ }^{93}$

Pero la realidad va a ser muy distinta. En el Santo Domingo español la falta de soldados en caso de un ataque enemigo era evidente, pues no había en él más tropa veterana "que los ochocientos quarenta y tres hombres que componen el batallón fijo, y sesenta y uno de la compañía de artillería". Viendo en peligro la capital, el capitán general don Isidro de Peralta ordenó retirar las compañías que se hallaban destacadas en la frontera colocando en ella a la compañía de

91 Circular fechada en el Pardo el 22 de marzo de 1779, dirigida a tođas las autoridades de América, ordenándoles no permitiesen la salida de barcos para España, ante el peligro de ser atacados por los ingleses. A.G.I., Indiferente' General, 2.417-A.

92 Carta de don Isidro de Peralta de 26 de agosto de 1789, acusando el recibo de la R. C. de 12 de mayo de 1779 , sobre suspender las licencias de las tropas. A.G.I., Santo Domingo, 945.

93 Carta de don Isidro de Peralta de siete de diciembre de 1779, acusando el recibo de la de 26 de junio de 1779, en que se le informaba de las ordenes dadas por la Corte francesa al general de su escuadra. A.G.I., Santo Domingo, 945 y 1.087. 
milicias regladas de infantería de la villa de Hincha. Al mismo tiempo, puso sobre las armas las cuatro compañías de milicias de infantería de la ciudad de Santo Domingo, con las cuales, y parte del batallón, envió pequeños destacamentos a cubrir las baterías de Montecristi, Puerto Plata, Samaná, Sabana de la Mar, Haina, San Jerónimo, y la Caleta, con un total de I20 hombres, permaneciendo en Santo Domingo para su defensa un total de mil. ${ }^{94}$

$\mathrm{Y}$ a pesar de que la Corte francesa había ordenado al general del Guarico, que socorriera con gente de armas a la colonia española de Santo Domingo cuando lo necesitase, "dicho general no puede socorrerme, porque no tiene tropas suficientes para sí, y por la grande y desierta distancia que nos separa". ${ }^{95}$ Además, el mismo conde D'Argout, comandante general de las colonias francesas en la Española, enviaba repetidas instancias a don Isidro de Peralta "para que le de socorros de tropa, persuadido de que será atacada aquella parte con preferencia a ésta". ${ }^{96}$

La Corte francesa decidió entonces la partida de dos mil soldados con destino al Guarico, que debían pasar siempre que fuera necesario a las órdenes del gobernador de Santo Domingo, para ser empleados en la defensa de los territorios. españoles, y concurrir a las empresas formadas contra los establecimientos británicos. ${ }^{97}$

Pero a pesar de esta armonía imperante entre las dos Coronas, y de la pretendida unión de sus colonias contra el peligro común, los recelos de los vecinos dominicanos no se desvanecían. Don Isidro de Peralta acusaba a los franceses

94 Carta de don Isidro đe Peralta de 30 de agosto de 1779, dando cuenta a la Corte de la falta de tropas para đefender la colonia de los ingleses. A.G.I., Santo Domingo, 1.087 .

95 Carta de don Isidro de Peralta de 25 de febrero de 1780, informando a la Corte de la imposibilidad de que los franceses le ayudaran con tropas por falta de ellas A.G.I., Santo Domingo, 1.087

96 Ibídem, nota 94.

97 R. O. fechada en Aranjuez el ocho de mayo de 1780 dirigida al intendente del ejército de la Habana, para que remitiese a Santo Domingo el dinero suficiente para socorrer a los 2.000 hombres de tropa que enviaban los franceses a aquella isla, a modo de préstamo a la Corona francesa. A.G.N., Tomo I de las fotocopias de documentos del A.N. de Cuba, cexidas al A.G.N. 'de la República Dominicana. Legajo 2, núm. 101. 
de hacer excesivas exigencias, no quedando nunca complacidos "según las muchas demandas que hacen, tropiezos que ponen, y defensas que el gobierno francés ejecuta, de todo contravandista que se aprende", contribuyendo a incrementar la desconfianza los rumores que corrían por Santo Domingo, de que "será cedida (por fin de la guerra), esta ysla a Francia".

Sin embargo, se llevaron a cabo algunas operaciones conjuntas. En I78I, llegaron al Guarico para establecerse en la frontera española más cercana a aquella colonia, 6.000 hombres de armas españoles, correspondiendo al Santo Domingo español correr a cargo de su abastecimiento de carnes, así como del de las escuadras española y francesa, "que deben operar unidas". ${ }^{99}$

En I 782, se organizó una expedición hispano-francesa contra Jamaica. Y para su realización, el gobierno dominicano debía enviarles cuantos víveres y refrescos pudiera, una vez que las tropas llegaran a aquella isla. ${ }^{100}$ Mientras, tenía órdenes de abastecer de ganado y otros víveres, a las escuadras francesa y española que se encontraban ancladas en el Guarico. ${ }^{101}$

A pesar de la colaboración entre ambas potencias, lo cierto es que España mostró un mayor empuje en la lucha. Gálvez, al mando de la escuadra, y basándose en gran parte en los auxilios que le proporcionó el gobernador de Santo Domingo, especialmente de víveres y pertrechos de guerra,

98 Carta de don Isidro de Peralta de 15 de octubre de 1780, informando a la Corte de las constantes exigencias de los franceses. A.G.I., Santo Domingo, 945.

99 Carta de don Isidro de Peralta de 9 de noviembre de 1781, acusando la noticia de la llegada al Guarico de 6.000 españoles, y manifestando haber dado las órdenes necesarias para su mantenimiento, dirigida a don Bernardo de Gálvez. Otra carta de Gálvez al gobernador dominicano de 3 de diciembre del mismo año, comunicándole hallarse enterado đe las órdenes que dio para el abastecimiento de carnes a las tropas españolas y francesas. A.G.I., Indiferente General, 1.579.

100 Carta de don Isidro de Peralta de 17 de abril de 1782, informanđo a la Corte de haber recibido carta de don Bernardo de Gálvez de 18 de marzo de aquel mismo año, comunicándole la formación de una expedición contra Jamaica. A.G.I., Santo Do. mingo, 945.

101 Carta de don Isidro de Peralta de 15 de julio de 1782, comunicando a la Corte haber provisto a las escuadras francesa y española ancladas en el Guarico. A.G.I., Santo Domingo, 945 . 
conquistó toda la costa norte del golfo mexicano, expulsando a los ingleses de Pensacola y la Florida. ${ }^{\mathbf{1 0 2}}$

Sin embargo, también los franceses tuvieron que ayudar a los españoles, y así, desde el I I de octubre de 1780 al 20 de febrero de 1782, permanecieron en la colonia española mil soldados de la parte occidental, pertenecientes al regimiento de Enghien. ${ }^{103}$

Al poco tiempo del regreso de estos hombres a su territorio, ante las constantes peticiones de su comandante general para que éste se llevara a cabo, una escuadra inglesa comenzó a rondar las costas del norte de Santo Domingo, sobre todo por la zona de Puerto Plata. Por ello, el gobernador don Isidro de Peralta tuvo que ordenar, que se mantuviera sobre las armas la media compañía de voluntarios de infantería de aquella ciudad, pues la presencia de los enemigos en el litoral, hacía incluso casi imposible la entrada de los navíos españoles en aquel puerto. ${ }^{104}$

Afortunadamente, por aquellas mismas fechas llegó a Santo Domingo una real orden, en la que se comunicaba a su capitán general haberse ratificado los preliminares para la paz, que se firmó en Versalles en 1783. Los ingleses se retiraron a sus bases. y el gobernador de la Española mandó regresar a sus domicilios a las ocho compañías de milicias de infantería del Seibo, la Vega, Santiago, Hincha, y Azúa, que hacían servicio en la capital, y dio las demás disposiciones convenientes a la paz. ${ }^{105}$

102 Correspondencia entre don Bernardo de Gálvez y don Isidro de Peralta (17811782), sobre el apoyo prestado por la isla en las operaciones militares. A.G.I., Indiferente General, 1.579 y Santo Domingo, 945.

103 Carta de don Isidro de Peralta de 18 de enero de 1783, informando a la Corte de los elevados gastos causados por el regimiento de Enghien. A.G.I., Santo Domingo, 946.

104 Carta de don Isidro de Peralta de 7 de enero de 1783, informando a la Corte de la presencia de embarcaciones inglesas en el norte de la isla, y otra de $\mathbf{1 6}$ de marzo del mismo año, sobre las dificultades de los navíos para entrar en Puerto de Plata. A.G.I., Santo Domingo, 946.

105 Carta de don Isidro de Peralta de cuatro de mayo de 1783, dando cuenta a la Corte de haber recibido la R. O. en que se le comunicaba la ratificación en París de los preliminares de la paz, y de haber tomado las medidas oportunas al respecto. A.G.I., Santo Domingo, 946 


\section{Capítulo $\mathrm{X}$}

\section{LA REVOLUCION FRANCESA Y LA CESION DE LA ISLA}

\section{La Revolución Francesa en la isla de Santo Domingo}

Hacia I789, el Estado francés había entrado en una aguda crisis. La confusión reinaba tanto en la administración judicial como en la económica, haciéndose necesarias una serie de reformas, que ni el Rey ni las clases privilegiadas podían llevar a cabo.

En realidad las nuevas ideas fueron ganando adeptos mucho antes de que el hecho revolucionario en sí se produjera. Desde 1770 , triunfaban de manera clara los principios basados en el enciclopedismo, gracias a la ascensión de una clase social hasta entonces en cierto modo despreciada, la burguesía.

Pero no es hasta 1788 , cuando vence el espíritu de la Revolución, propiciado por la inadecuación entre la realidad de la vida francesa y las normas vigentes, y dirigido en esta ocasión por los "privilegiados". Su revuelta logra la victoria en un principio. Pero al poco tiempo se verán desbancados por la burguesía, con la creación de la Asamblea Nacional. Posteriormente, también ella se verá desbordada por los acontecimientos, que llevarán a una auténtica revolución de las masas dirigida por los radicales como Dantón, Marat, etc.

Con la Revolución francesa triunfan una serie de postulados, como los ya famosos de libertad, igualdad, y frater- 
nidad, que necesariamente tenían que ejercer una influencia decisiva en la colonia de Saint Domingue. En la parte occidental de la isla Española, los franceses habían acumulado un gran número de esclavos que, "por su magnitud, y por el modo de vida que se les deparaba, eran por un lado imposibles de asimilar a la cultura del resto de los pobladores, y por el otro, su gravitación resultaba decisiva en el destino de la colonia". ${ }^{1}$

Así, el movimiento revolucionario que conmovió a Francia desde 1789 , encontró una tierra abonada para el desarro1lo de sus ideas en la colonia francesa de Santo Domingo, "que fue el campo de experimentación más propicio, al desenvolvimiento de los principios proclamados por la revolución". ${ }^{2}$

La declaración por parte de la Asamblea Nacional de la igualdad de todos los hombres, tuvo consecuencias claras en lo que más tarde sería la República de Haití. La gran masa de esclavos negros, privada de todos los derechos, hubo de recibirla con la mayor alegría. Pero los colonos blancos, cuyo bienestar dependió en todo momento de su mano de obra esclava, se negaron a admitir cualquier signo de igualdad entre ellos y los hombres de color.

"La negativa provocó el enfrentamiento, cuyo primer estallido fue la rebelión capitaneada por los mulatos Ogé y Chavanne". ${ }^{3}$ Los dos rebeldes, tras ocasionar serios problemas, fueron apresados y ejecutados. Pero después de su muerte, la revolución cundió entre los negros con una violencia y un furor inusitados, siendo su víctima más inmediata, además de los colonos franceses, el Santo Domingo español por su vecindad con aquéllos.

Cuando el gobernador de Santo Domingo, don Joaquín García, tuvo conocimiento de las agitaciones producidas en la colonia francesa de la isla, puso las tropas en estado de alerta. La política seguida en un principio fue de espera de

1 Pérez y Pérez, Carlos Federico: Loc. cit., pág. 80.

2 Peña Batlle, Manuel Arturo: Loc. cit., pág. 100.

3 Pérez y Pérez, Carlos Federico: Op. cit., pág. 81. 
los acontecimientos, si exceptuamos el apresamiento de Vicente Ogé y Chavanne, que pasaron a refugiarse a la zona española, y su entrega a los franceses. ${ }^{4}$

El temor del capitán general español era que las nuevas ideas se propagaran en los territorios de su jurisdicción, aunque todas las primeras personalidades de la isla intentasen tranquilizar a la Corona una y otra vez sobre este asunto. Así, en 1789, el regente de la Audiencia, don José Antonio de Urízar, escribía a la Corte que "semejantes sucesos ni ecos, no producen la menor impresión en estos fidelísimos havitantes y vasallos de S. M., antes bien, los escuchan con la mayor desestimación", a pesar de las tentadoras proposiciones contenidas en varios impresos relativos a los acontecimientos, distribuidos por la colonia. ${ }^{\mathbf{5}}$

Algunos de estos papeles, como el titulado "Una palabrita al oído", fueron remitidos por el gobernador a la Metrópoli por hacer referencia a las posesiones españolas. En él se calificaba como un acierto el proyecto francés de convocar a las colonias a los Estados Generales. Se afirmaba que las colonias no pertenecerían siempre a Europa, y era imposible que ésta las mantuviera por la fuerza, pues "repentinamente las minas se agotarán, los metales pasarán a Asia, y al mismo tiempo, Méjico y Perú traerán sus mercancías de la China y de la India por el mar del Sur. La superstición española retrasa por sí sola estos acontecimientos, pero la ira de los colonos españoles contra la Metrópoli la acelerará". En cambio, si se trataba a las colonias como provincias. se sentirían en igualdad respecto a las demás de la nación, y así, su independencia se retrasaría, e incluso, en el momento de producirse, quedarían unidas a Europa por fuertes lazos. ${ }^{6}$

La revolución producida en Francia tuvo desde luego un amplio eco en sus estableciinientos de Saint Domingue.

4 Moya Pons, Frank: Loc. cit., pág. 340.

5 Carta del regente de la Audiencia de Santo Domingo, don José Antonio de Urizar de 24 de noviembre de 1789, informando a la Corte de los nulos efectos producidos en la colonia española por las agitaciones de sus vecinos. A.G.I., Santo Domingo, 1.027.

6 Carta del gobernador de Santo Domingo don Joaquín García de 25 de febrero de 1790, remitiendo a la Corte varios folletos de la colonia francesa, entre ellos el titulado "un mot a l'oreille". A.G.I., Santo Domingo, 1.027. 
Los principios de libertad, igualdad y fraternidad, que por supuesto no fueron aceptados por los colonos blancos del Guarico, produjeron rápidamente un levantamiento de los mulatos de la región del Artibonito. Varias familias francesas de esta zona cruzaron la frontera, un total de 28 blancos con 64 esclavos y 43 animales, para pedir asilo en la parte española. ${ }^{7}$

El comandante interino del Guarico, Combefort, se mostró desde el principio enemigo de las reformas preconizadas por la Revolución, intentando por todos los medios acabar con las nuevas ideas, que cundieron en primer lugar entre los mulatos. Siguiendo esta política, reclamó a las autoridades españolas la detención de "unos malévolos, que desde la ciudad de París se propusieron desembarcar en tierra española, y particularmente en Montecristi, con el fatal designio de transtornar la colonia, y obtener perfecta igualdad entre las gentes de color y los blancos". Entre ellos se encontraba un cuarterón libre, procedente del Dondón, llamado Vicente Ogé. ${ }^{8}$

A la sublevación de los mulatos de la parte francesa, vino a unirse la discordia existente entre los mismos blancos. Con motivo del triunfo de la Revolución en Francia, se crearon asambleas en Saint Domingue semejantes a las establecidas en la Metrópoli. De este modo surgieron una en el norte y otra en el sur, cada una de las cuales intentó, por todos los medios, hacer prevalecer su opinión. ${ }^{9}$

Ante esta anarquía, la Corte española ordenó a su representante en Santo Domingo, que vigilara constantemente para que no se introdujese en el distrito de su mando, nadie

7 Carta de don Joaquín García de 25 de abril de 1790, informando a la Corte de los sucesos del Guarico, y relación individual de los franceses fugitivos de la parte de Artibonito, que se han presentado en la comandancia de San Miguel de la Atalaya. A.G.I., Santo Domingo, 954.

8 Carta del gobernador de Santo Domingo don Joaquín García de 25 de mayo de 1790, informando a la Corte de la solicitud hecha por el comandante interino del Guarico para el apresamiento del mulato Vicente Ogé y otros rebeldes. A.G.I., Santo Domingo, 1.028 .

9 Carta de don Joaquín García de 25 de junio de 1790, dando cuenta a la Corte de los desórdenes producidos en el Guarico. A.G.I., Santo Domingo, 954. 
que pudiera influir en los vasallos españoles con ideas contrarias a "la debida subordinación". ${ }^{10}$

A ello respondió don Joaquín García, que ya desde i789 había prestado la mayor atención a cada uno de los emigrados que pasaron a su territorio, aunque, a su juicio, los habitantes de la parte española habían dado pruebas de sobra, de la "maior subordinación y amor a SS. MM.", durante los tumultos producidos en la colonia vecina. ${ }^{11}$

A las preocupaciones del gobernador dominicano, en su intento de que las ideas revolucionarias no entrasen en su jurisdicción, pronto vinieron a unirse las diplomáticas. El capitán general español tenía serias dudas, sobre cuáles debían ser sus relaciones con el Guarico tras el cambio político ocurrido en él. La asamblea establecida allí, solicitaba el reconocimiento oficial de las autoridades de Santo Domingo, las cuales no sabían qué posición tomar. $\mathrm{Y}$ al no decidirse el primer mandatario dominicano al reconocimiento que se le pedía, tuvo que hacer frente a los panfletos revolucionarios, que "dicen que nuestra España está confabulada con la Austria, Prusia y Cerdeña, contra la revolución de la Francia". ${ }^{12}$

A pesar de todo ello, en la primera etapa se impuso el espíritu de convivencia que los monarcas habían patrocinado hasta entonces. Obedeciendo a este entendimiento, los dirigentes de la parte española dieron las órdenes correspondientes para que se apresara a los mulatos alzados y refugiados en su jurisdicrión. Así, fue capturado uno de sus líderes en la villa de San Juan de la Maguana. Se trataba del ya citado Chavanne, "que se titula mayor general de la su-

10 Carta de don Joaquín Galcía de 25 de junio de 1790 , acusando recibo de la R. O. de 25 de mayo de aquel año, sobre la vigilancia que debía observar para que no penetrase en la colonia española persona alguna con ideas revolucionarias. A.G.I, Santo Domingo, 954.

11 Carta del gobernador don Joaquín García Moreno de 25 de julio de 1790, dando cuenta a la Corte de haber realizado una activa vigilancia de tod'as las personas que cruzaban la frontera. A.G.I., Santo Domingo, 954.

12 Carta del gobernador de Santo Domingo don Joaquín García de 25 de septiembre de 1790, informando a la Corte de las dudas que se le presentaban en sus relaciones con la colonia francesa, y otra de 25 de octubre del mismo año, fando cuenta de los recelos de los revolucionarios franceses. A.G.I., Santo Domingo, 954. 
blevación de la colonia inmediata". Chavanne fue conducido a la capital, y encarcelado en uno de los calabozos del batallón fijo de aquella plaza. ${ }^{13}$

Sin embargo, el movimiento mulato continuó, en esta ocasión en la zona de la Grande Riviére, acaudillado por Vicente Ogé, representante de la asociación parisina "Sociedad de los amigos de los negros". Ante estas nuevas revueltas, el gobernador español previno a sus subordinados en la frontera, con el fin de evitar cualquier atentado que pudiera producirse en su territorio. Ordenó además que, si los rebeldes querían cruzar la línea de demarcación para pedir asilo, intentaran convencerlos para que regresaran a su país, pero que si alguno no aceptaba, fuera conducido a la ciudad de Santo Domingo totalmente desarmado. ${ }^{14}$

En esta situación, se presentaron ante el comandante de la guardia de San Rafael Vicente Ogé y i 5 compañeros suyos, pidiéndole los pasaportes necesarios para llegar ante el gobernador español. El citado comandante no se atrevió a apresarlos, como se le había mandado, por estar todos armados, y les dio los visados que solicitaban. Pero pasó aviso inmediatamente al comandante de Hincha, que al parecer contaba con más fuerzas que él, para que los prendiese. El comandante de Hincha los capturó efectivamente y los condujo a la capital. Las autoridades francesas reclamaron entonces su extradición, así como la de Chavanne, basándose en el tratado de policía existente entre ambas colonias. ${ }^{15}$

Tras algunas dudas, el capitán general español accedió a entregarlos "por ser conforme a nuestros tratados, y a lo que nos enseña el derecho público para semejantes casos".

13 Carta de don Joaquín García Moreno de 25 de noviembre de 1790, dando cuenta a la Corte del apresamiento del mulato Chavanne en San Juan de la Maguana. A.G.I., Santo Domingo, 954 y $\mathbf{1 . 0 2 8 .}$

14 Carta de don Joaquín García Moreno de 25 de noviembre de 1790, informando a la Corte de las revueltas de mulatos producidas en el Guarico. A.G.I., Santo Domingo, 954.

15 Carta del regente de la Audiencia de Santo Domingo don José Antonio de Urízar de 25 de noviembre de 1790, informando a la Corte del apresamiento en territorio español del mulato Vicente Ogé y su conducción a la capital. A.G.I., Santo Domingo, 1.027. 


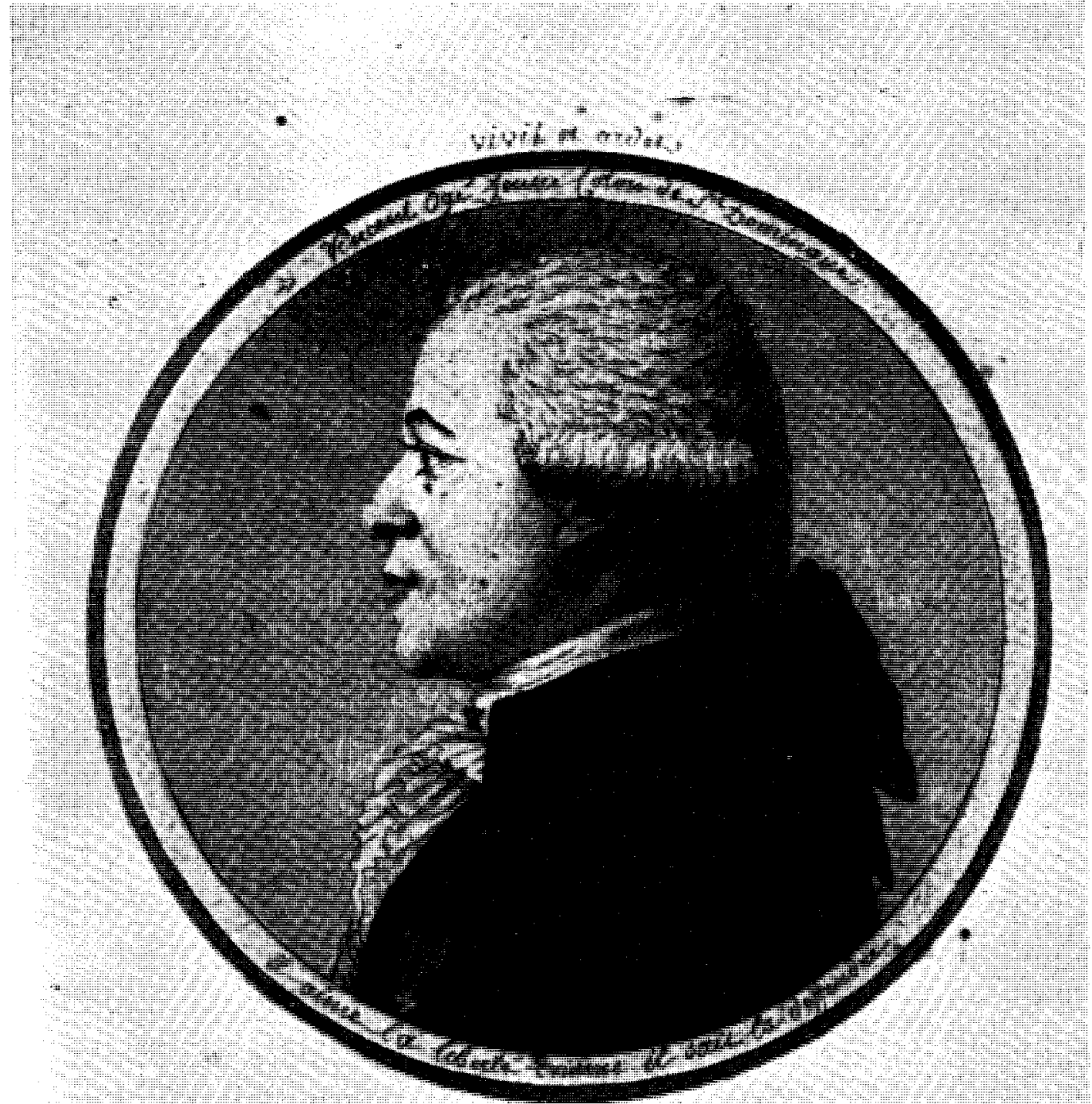

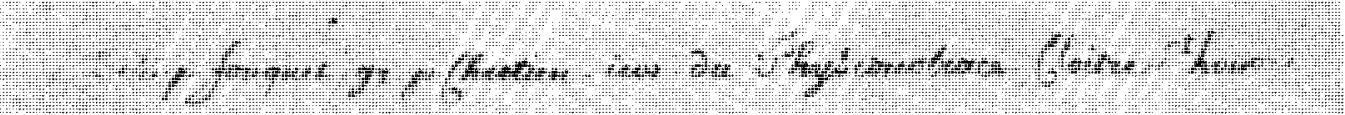

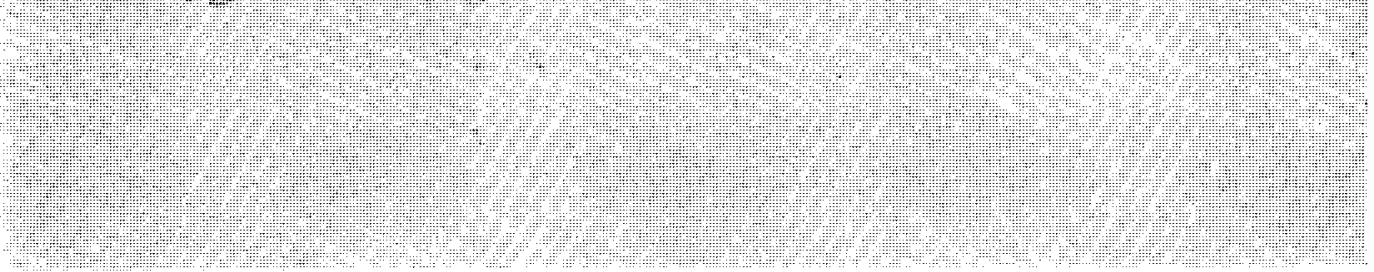

Figura 15.-Retrato de Vicente Ogé grabado por Fouquet. A.G.I. Santo Domingo, 1.029. 
A tal fin, arribó a Santo Domingo una fragata procedente del Guarico. ${ }^{16}$

A pesar del apresamiento de los caudillos mulatos mencionados, la situación no pareció cambiar en la colonia francesa. A comienzos de I79I, llegaron a ella una fragata y dos navíos de guerra con nuevas tropas, un batallón del regimiento de Normandía y otro del de Artois. Su misión era el restablecimiento del orden en aquella parte de la isla. Pero en lugar de ello, incitaron a levantarse a los soldados que se encontraban ya en Saint Domingue. Cortaron la cabeza a su coronel y huyeron de Puerto Príncipe, refugiándose en las cercanías de la población española de San Gabriel de las Caobas. ${ }^{17}$

Ante este nuevo motivo de temor, la Corte ordenó que, para proteger al Santo Domingo español "de los acontecimientos y desórdenes experimentados hasta ahora en las colonias francesas de nuestra frontera, se transporte a esa capital a las órdenes de V. S., el regimiento de ynfantería de Cantabria que se halla en Puerto Rico", ${ }^{18}$ produciéndose la llegada de estos refuerzos entre el 25 de mayo y el 9 de junio de I79. ${ }^{19}$

En este estado de cosas, se recibió en el Guarico la copia de un decreto de la Asamblea Nacional, fechado el I $_{5}$ de mayo de I79I, en el que se declaraba a todos los hombres de color hijos de padres libres, "ciudadanos activos y admisibles en todas las asambleas". Los colonos blancos se opusieron desde luego violentamente a ello, y decidieron que, si cuando llegäran las nuevas tropas y los comisionados de la

16 Carta del regente de la Audiencia don José Antonio de Urízar fechada el 25 de diciembre de 1790, dando cuenta a la Corte de la entrega hecha a las autoridades de la colonia francesa de Vicente Ogé y sus compañeros. A.G.I., Santo Domingo, 1.027. 17 Carta d'el gobernador de Santo Domingo don Joaquín García de 16 de marzo de 1791, informando a la Metrópoli de la sublevación de las tropas de la colonia vecina. A.G.I., Santo Domingo, 954 y 1.029.

18 R. O. fechada en Madrid el 25 de marzo de 1791, comunicando al gobernador de la Española la decisión de que marchase a aquella isla para su defensa el regimiento de Cantabria. A.G.I., Santo Domingo, 1.029.

19 Carta de don Joaquín García Moreno con fecha de 18 de junio de 1791, informando a la Corte haber llegado a aquella capital desđe Puerto Rico, el regimiento de Cantabria completo. A.G.I., Santo Domingo, 1.030 . 
Metrópoli que se estaban esperando, traían consigo aquel decreto para ponerlo en ejecución, no permitirían de ninguna manera su desembarco.

Vino a agravar esta tensión un nuevo decreto que llegó a la colonia francesa, ordenando que, a todo esclavo que entregase a su dueño $25^{\circ}$ pesos, se le concediera la libertad. $\mathrm{Y}$ el que no tuviese esa cantidad quedaría igualmente libre, sirviendo a su amo por un período de cinco años. ${ }^{20}$

De esta revuelta situación intentaron aprovecharse rápidamente los británicos, que ofrecieron poner a disposición de los colonos blancos 18 navíos, y un considerable número de soldados, para defender sus intereses. ${ }^{21}$

Por otra parte, los dos decretos señalados van a producir una alianza inconcebible unos meses antes, la de los colonos blancos y mulatos libres. Los esclavos se levantaban violentamente contra los criollos, que se negaban a reconocer su derecho a la libertad. Los blancos, temerosos de tener que enfrentarse al mismo tiempo a los esclavos y mulatos, cedieron en parte a las aspiraciones de estos últimos con el fin de lograr su apoyo contra aquéllos. ${ }^{22}$

Todo ello va a hacer cambiar la actitud de las autoridades españolas de la isla respecto al conflicto. De la primitiva neutralidad, se pasa a una intervención solapada a favor de los negros. Los blancos de la colonia contaban, como ya hemos dicho, con el apoyo de Inglaterra; los mulatos con el del gobierno francés; y los negros, comienzan a tener también su propio aliado en el Santo Domingo español, que vio en estas pugnas existentes entre los distintos grupos étnicos y

20 Carta del gobernador de Santo Domingo don Joaquín García de 24 de julio de 1791, informando a la Corte de lo ocurrido en el Guarico, con motivo de la llegada de la copia de un decreto de la Asamblea Nacional de 15 de mayo de aquel año, y otra de 25 de agosto del mismo año, con motivo de haber llegado a la colonia francesa un nuevo decreto fechado el 16 de mayo de 1791. A.G.I., Santo Domingo, 954.

21 Carta del gobernador de Santo Domingo don Joaquín García: de $\mathbf{2 4}$ de agosto de 1791, dando cuenta a la Corte de los ofrecimientos de los ingleses a los franceses blancos del Guarico para prestarles apoyo frente a los republicanos. A.G.I., Santo Domingo, 1.029.

22 Carta de don Joaquín García Moreno con fecha de 25 de septiembre de 1791, informando a su Corte del acuerdo establecido entre los blancos y los mulatos del Guarico para acabar con los desmanes de los negros. A.G.I., Santo Domingo, 954 y 1.021. 
sociales del Guarico, un modo de arrojar a los franceses de toda la Española.

E1 comandante general de la colonia francesa hacía constantes peticiones de auxilio a su colega hispano, amparándose en los tratados de mutua ayuda firmados entre ambos países. El capitán general de Santo Domingo respondía a ello, diciendo que, además de no tener tropas suficientes para socorrerle, los sucesos que se estaban desarrollando eran enfrentamientos internos entre los mismos súbditos franceses, y los tratados de que hablaba sólo hacían referencia a los casos de guerra con otras naciones. ${ }^{23}$

Ante esta negativa, los dirigentes franceses acusaban a los españoles "de favorecer y auxiliar a los negros con municiones para la destrucción de la colonia, sin otro fundamento que unas cartas que pudieron haver de ios insurgentes, en las quales, ni consta nombre ni firma de español alguno". ${ }^{24}$ Ciertamente, pese a las protestas del gobernador español, la colaboración existió como ya hemos señalado.

La situación del Guarico se hacía crítica, viviéndose en un constante estado de anarquía. Los soldados del regimiento de Artois, destinados a poner orden en la colonia, fueron los primeros en contribuir a deshacerlo. El 2 I de noviembre de I79I, prendieron fuego a las construcciones de Puerto Príncipe más cercanas al mar. Robaron lo que les pareció y no respetaron siquiera las vidas humanas, de manera que "aseguran pasan de 250 personas las que han perecido, de todas hedades y clases". ${ }^{25}$

Al poco tiempo se produjo otra sangrienta matanza, al tomar los negros sublevados la población de Juana Méndez.

23 Carta de don Joaquín García Moreno fechada el 16 de septiembre de 1791, informando a la Corte de la solicitud que le hicieron las autoridades de la colonia francesa para que las auxiliase con tropas y de lo que les respondió. A.G.I., Santo Domingo, 954.

24 Carta del gobernador dominicano don Joaquín García de 25 de diciembre de 1791, dando cuenta a la Corte de las acusaciones que hacían los franceses a los españoles de colaborar con los negros rebeldes. A.G.I., Santo Domingo, 954.

25 Carta de don Joaquín García Moreno fechada el 25 de diciembre de 1791, in. formando a la Corte del desorden imperante en la colonia vecina. A.G.S., Secretaría de Guerra. Serie 46, Guerra Moderna, 7.149. 
Este establecimiento se encontraba en la colonia francesa, pero cercano al puesto español de Dajabón, donde se refugiaron los atemorizados colonos que lograron escapar. A consecuencia de ello, el capitán general mandó reforzar la frontera, enviando un mayor número de tropas desde la capital. ${ }^{26}$

Las órdenes que el gobernador español tenía de su Corte, eran de no mezclarse en los sucesos de la colonia vecina, guardando la más completa neutralidad. Pero siguiendo su política de intervención a favor de los negros, no se conformaba con una espera pasiva de los acontecimientos. Y así, solicita instrucciones concretas de la Metrópoli, sobre cuál debía ser su actitud si los esclavos rebeldes se acercaban a la frontera pidiendo asilo. Si se les concedía, "los franceses blancos, que no aspiran sino a criticar las acciones y providencia del gobierno español, se persuadirán y dirán por medio de la prensa que los españoles están coligados con los filántropo y brigantes. Y si los negros, llenos de confianza, encuentran en nosotros resistencia en prestar asilo, podrían violar nuestro terreno por las armas". ${ }^{27}$

El general francés era consciente, de que si los insurgentes eran acosados correrían al territorio hispano. Por esta causa. envió un oficio al brigadier don Andrés de Heredia, comandante español de la frontera norte, para que, en el caso de que esto ocurriera, le concediera su permiso con el fin de perseguirlos dentro de la jurisdicción española. Heredia desde luego se negó a semejante peticibn, arguyendo que esto significaría una manifiesta violación del derecho de asilo o derecho de gentes. ${ }^{28}$

26 Carta de don Joaquín García Moreno fechada el 25 de enero de 1792, dando cuenta a la corte de la toma de Juana Méndez por los negros. A.G.I., Santo Domingo, 955 y 1.030 .

27 Carta de don Joaquín García Moreno de 22 de febrero de 1792, acusando el recibo de la R. O. de 24 de noviembre de 1791, en la que se le comunicaba la decisión real de que guardase la neutralidad en los conflictos del Guarico, y otra del 27 del mismo mes y año, solicitando instrucciones para el caso de que los negros cruzasen la frontera para pedir asilo en su territorio. A.G.I., Santo Domingo, 955.

28 Carta del gobernador don Joaquín García con fecha de 4 de septiembre de 1792, informando a la Corte de la solicitud que le hizo el gobernador francés para poder perseguir a los negros rebeldes en los terrenos españoles. A.G.I., Santo Domingo, 955. 
En la colonia francesa se desconfiaba plenamente de la actitud de los españoles. Los folletos que circulaban por ella hacían aparecer a los habitantes de Santo Domingo como "brigantes", y manifestaban que, "en acabando con los negros, se dirigirán a esta nación". ${ }^{29}$

La realidad era que, en la zona española, se había admitido hasta entonces tanto a los blancos escapados en un principio de la revolución, como más tarde a los blancos y mulatos que huyeron del furor de los negros levantados. ${ }^{30}$

Pero como ya hemos hecho notar, las acusaciones que se hicieron no eran del todo falsas. Los esclavos rebeldes intentaron, desde el primer momento, que los dirigentes dominicanos favorecieran su causa y les prestasen su auxilio. El general negro Jacinto envió una carta al capitán general de Santo Domingo, comunicándole que, antes que caer en manos de los blancos franceses, se rendiría a las autoridades hispanas. El otro caudillo de color importante en aquellos momentos, Juan Francisco, se manifestó en el mismo sentido.

Don Joaquín García, aunque tenía órdenes de su gobierno de mantener la más estricta neutralidad, no los rechazaba. Pensaba que, en el caso de que se iniciaran las hostilidades con la República Francesa, como parecía inminente, sería ventajoso contar con estos negros. Su idea era persuadirlos "a la unión y a la subordinación española, bajo los principios de nuestro dignísimo monarca, y no darles lugar a que atiendan ni admitan los que se le hagan por el govierno de su nación, que seran los más acomodados y los más eficaces, para vencer este primero y grabe obstáculo y reunirse a unos hombres que, acostumbrados a las armas, los miran

29 Carta del gobernador de Santo Domingo don Joaquín Garcíz de 30 de octubre de 1792, dando cuenta a la Corte del contenido de varios folletos publicados en el Guarico. A.G.I., Santo Domingo, 955.

30 Cartas del gobernador don Joaquín García de 18 y 25 de noviembre de 1792 y otra de 19 de marzo de 1793, dando cuenta a la Corte de las personas procedentes de la colonia francesa que habían pedido asilo en su jurisdicción. A.G.I., Santo Domingo, 955, 956 y 1.030 . 
con particular atención, para con ellos hacernos la guerra ofensiva con ardor y con empeño". ${ }^{31}$

Por estas fechas se hablaba ya de una guerra inmediata. Por una parte, el gobernador de Santo Domingo recibió de su Corte la orden de permanecer alerta en todo momento, para no ser sorprendido por una declaración repentina de las hostilidades, que podía fácilmente producirse. Por otra, en la colonia francesa los rumores de una rápida ruptura con España eran cada vez más fuertes.

Por último, la noticia de la muerte del monarca francés vino a agravar la tensión existente, e hizo que gran número de colonos franceses pasaran a la zona española, pues viendo como un azote la Revolución, "desean alejarse de la colonia y de todo lo que signifique partido republicano". ${ }^{32}$

\section{La guerra contra la República Francesa}

En 1792 Austria y Prusia formaron una coalición, con el fin de defender la monarquía como forma de gobierno en contra de los postulados de la Convención Nacional francesa, que, al poco tiempo, suprimió, como se esperaba, el sistema monárquico.

Esta determinación agravó los recelos existentes en los demás países europeos contra el fenómeno revolucionario, recelos que, tras la muerte del Monarca galo, se vieron plasmados en la declaración de guerra a la República Francesa por parte de aquéllos, entre los cuales desde luego se encontraba España, aliada con Inglaterra en esta ocasión.

La declaración de las hostilidades fue hecha pública en Santo Domingo el 30 de mayo de, 1793, por un bando de

31 Carta del gobernador dominicano don Joaquín García fechada el 12 de marzo de 1793, informando a la Corte de las manifestaciones de los negros rebeldes sobre su actitud respecto a la colonia española, y haciendo notar las ventajas que acarrearía el tenerlos como aliados. A.G.S., Secretaría de Guerra, serie 46. Guerra Moderna, 7.158.

32 Carta del gobernador don Joaquín García de 6 de marzo de 1793, acusando el recibo de la R.O. de 26 de enero de aquel mismo año, y otra de 25 de abril de 1793, sobre los rumores que corrían por la colonia francesa. A.G.I., Santo Domingo, 956 y 1.030. 
su gobernador y capitán general don Joaquín García Moreno. Las autoridades dominicanas venían preparándose con anterioridad para esta situación, estableciendo relaciones con los negros sublevados de la colonia francesa. Y tan pronto como estalló la lucha, estos hombres de color fueron incorporados como auxiliares a las tropas españolas. ${ }^{33}$

Contando con su ayuda, García se propuso en primer lugar la ocupación del Dondón y Juana Méndez, en territorio francés, cuya conquista dejaría aseguradas las posesiones españolas desde el río Dajabón hasta el Arroyo Seco. A comienzos del mes de julio, el cordón del norte tomó la plaza de Juana Méndez. ${ }^{34}$ Al mes siguiente, el coronel don Joaquín Cabrera salió de San Rafael de la Angostura, con la intención de examinar las zonas del Dondón y de la Marmelade. Después de su reconocimiento se retiró a San Miguel de la Atalaya, y allí fue atacado por sorpresa por los franceses. Los galos, sin embargo, tuvieron que batirse en retirada, dejando en el campo de batalla un cañón, alimentos y municiones. El balance del combate para los españoles fue de dos muertos y diez heridos. ${ }^{35}$

Al poco tiempo, se produjo la conquista de la Marmelade para los españoles. La ocupación la hicieron las tropas auxiliares mandadas por el que más tarde se convertiría en el más importante de los caudillos negros, Toussaint L'Ouverture. Toussaint no tenía órdenes de atacar la población, sino sólo de causar problemas a los franceses hostigando las zonas inmediatas, y haciendo imposible las comunicaciones de la plaza con el exterior. Pero viendo que la situación le era totalmente favorable, resolvió el ataque, obligando a huir a la guarnición francesa, que tuvo que abandonar nueve cañones y la escasa munición que le quedaba. ${ }^{36}$

33 Pérez y Pérez, Carlos Federico: Op. Cit. ,págs. 81-82.

34 Carta de don Joaquín García Moreno con fecha de 7 de julio de 1793, sobre la toma de Juana Méndez. A.G.S., Secretaría de Guerra, serie 46. Guerra Moderna, 7.158.

35 Carta de don Joaquín García Moreno fechada el 16 de agosto de 1793 informando del ataque sufrido en San Miguel de la Atalaya, y estado que manifiesta las perdidas españolas en la batalla. A.G.I., Santo Domingo, 956.

36 Santo Domingo, 22 de agosto de 1793. Relación de la toma de la Marmelade por el general negro Toussaint el 28 de julio de aquel año. A.G.I., Santo Domingo, 956. 
Los ingleses por su parte, enviaron una expedición desde Jamaica que se apoderó de Jeremíe, y cuyo plan era ganar para ellos toda la colonia del Guarico. Posteriormente, tomaron el Môle de San Nicolás y Jacmel. ${ }^{37}$

Cada vez era mayor el número de colonos franceses contrarios a la Revolución, que se refugiaban en territorio español. Solicitaban armas y municiones para ponerse al servicio del Rey de España contra la República. ${ }^{38}$

Entre tanto, los españoles proseguían sus avances. Los negros auxiliares, dirigidos por Toussaint, tomaron posesión de Juana Gives en diciembre de I793. A continuación, las tropas del Santo Domingo español conquistaron Limbé y Port Margot, en la costa norte. Las parroquias de los Veretes y la Petit Riviére, ambas en la región del Artibonito, enviaron una delegación al comandante de San Rafael ofreciéndole "juramento de sumisión y vasallaje, admitiendo $\mathrm{y}$ arbolando el pavellón castellano". Fueron seguidas en esta actitud por las de Gros-Norme, Plaisance, el Borgne y Port a Piment. ${ }^{39}$

En esta situación, el capitán general don Joaquín García marchó hacia la frontera. Dejó en la capital al cargo del gobierno interino al regente de la Audiencia, don José Antonio de Úrízar, según se le había ordenado por real cédula en I789, y salió de Santo Domingo el 24 de enero de I794. ${ }^{40}$

Don Joaquín García había persuadido con anterioridad al jefe de la escuadra española, don Gabriel de Aristizábal,

37 Carta del gobernador de Cuba de 1 de octubre de 1793, dando cuenta al duque de Alcươia de la expedición organizada por los ingleses contra la colonia francesa de Santo Domingo, y otra del gobernador de Santo Domingo don Joaquín García de 25 del mismo mes y año, informando a la Corte de los avances de los ingleses en el Guarico. A.G.I., Estado, 14-42 y Santo Domingo, 956.

38 Carta de don Joaquín Gatcía Moreno de 25 de octubre de 1793, informando a la Corte de las peticiones de armas que le hacían los refugiados de la colonia francesa. A.G.I., Santo Domingo, 956.

39 Carta de don Joaquín García Moreno de 12 de septiembre de 1794, informando a la Corte de los avances realizados por los españoles en la colonia francesa. A.G.I., Santo Domingo, 957.

40 Carta del gobernador de Santo Domingo don Joaquin García de 22 de enero de 1794, informando al duque de Alcudia de su inmediata salida de la capital hacia Dajabón, y otra del regente de la Audiencia don José Antonio de Urízar de 25 de febrero de 1794, dando cuenta de que la salida se produjo el 24 de enero da aquel afio. A.G.I., Estado 14-74 y 13-6. 
de la necesidad de tomar de manos de los franceses la plaza de Bayajá. Aristizábal se dirigió entonces hacia allí por mar, mientras las tropas auxiliares y el ejército de operaciones hostigaban a sus contrincantes por tierra. El jefe de la escuradra entró en la bahía el 28 de enero de I794, y conminó a la rendición incondicional a los defensores de la ciudad, que, ante la imposibilidad de resistir con éxito, tuvieron que aceptarla. ${ }^{41}$ Cayeron así en manos de los españoles I.o3 I hombres de la guarnición, 40 cañones de diversos calibres, y gran cantidad de fusiles y municiones. ${ }^{42}$

Cuando don Joaquín García llegó a Dajabón, se encontró con la noticia de la rendición de Bayajá y se trasladó allí. El 3 de febrero entró en la citada plaza, "habiendo reconocido todo el recinto de ella, para hacerme cargo de su estado, fuertes, artillería, y demás que es correspondiente a mi inteligencia", y estableció en ella su cuartel general. ${ }^{43}$

La causa parecía totalmente perdida para los partidarios de la Revolución; españoles e ingleses realizaban espectaculares avances en sus conquistas.

Pero la situación va a cambiar radicalmente a partir de ahora. Como ya hemos señalado, las autoridades de la colonia española supieron atraerse a los negros rebeldes de la parte francesa, con el fin de arrojar a sus vecinos de toda la isla con su ayuda. Se unieron así para formar las llamadas tropas auxiliares, Juan Francisco, Biassou, Toussaint L'Ouverture, y otros caudillos de color, que proporcionaron importantes triunfos a los españoles.

Pero en agosto de I793, un decreto de la Convención Nacional de París determinó la abolición de la esclavitud, ${ }^{44}$ y las consecuencias de este hecho iban a reflejarse claramente en la lucha.

41 García, José Gabriel: Loc. cit., Tomo I. pág. 255.

42 Estado de la tropa y artillería que se entregaron a las tropas españolas el 29 de enero de 1794 con la rendición de Bayajá. A.G.I., Santo Domingo, 957.

43 Carta de don Joaquín García Moreno fechada el 5 de febrero de 1794, comunicanđo a la Corte haber entrado en Dajabón el 30 de enero de aquel año, y en Bayajá el 3 de febrero siguiente. A.G.I., Santo Domingo, 957.

44 Decretos de la Convención Nacional sobre la abolición de la esclavitud de $16^{\circ}$ pluviose del 2.0 año de la República Francesa Una e Indivisible. A.G.I., Estado, 49. 
Los delegados de la República Francesa en el Guarico llevaron a cabo una gran actividad, encaminada a ganarse a los negros que combatían del lado español, entre los que pronto aparecerán las deserciones. Los negros auxiliares Petit Tomás, Bartelemy y Luís, se volvieron contra la colonia española declarando que les habían engañado. Se dirigieron hacia Port Margot, donde llevaron a cabo varios ataques, aunque sin éxito, marchando después hacia el Borgne. Uno de los hombres que iba con ellos, avisó oportunamente al capitán de los piquetes de Puerto Rico que guarnecían la zona, quien, por este motivo, preparó todo a conciencia para hacerles frente. Juan Francisco, por su parte, acudió voluntario para luchar contra los desertores. Pero cuando marchaba hacia el campamento de Petit Tomás, los rebeldes, conocedores ya de lo que sucedía, escaparon rápidamente. ${ }^{45}$

A pesar de este aparente triunfo, los españoles perderán desde ahora, en cuestión de meses, lo que habían conquistado hasta entonces. Y a ello contribuyó de forma decisiva, el paso al bando republicano francés de Toussaint L'Ouverture con 4.000 hombres. ${ }^{46}$

Desconociéndose aún la decisión de Toussaint de luchar en el partido contrario, don Joaquín García se preparaba desde Bayajá para proseguir el avance. El regente, don José Antonio de Urízar, envió varias embarcaciones desde la capital, con víveres y piezas de artillería, que debían contribuir al bloqueo español del Guarico.

El capitán general de la isla partió con este fin de Bayajá el 8 de mayo, al frente del ejército de operaciones. Las tropas marcharon hacia el fuerte de "Yaguesi" y lo atacaron. Pero sus intentos por conquistarlo resultaron infructuosos, y tuvieron que retirarse sin, tomarlo. Regresaron entonces a Bayajá, terminando así, en un rotundo fracaso, los

45 Carta de don Joaquín García Moreno de 16 de febrero de 1794, dando cuenta a la Corte de la separación de varios negros auxiliares para unirse a los republicanos franceses, y otra de 20 de febrero del mismo año, informando del ataque de que fueron objeto los rebeldes por parte de Juan Francisco. A.G.I., Estado 14-87 y 14-84.

46 Moya Pons, Frank: Op. cit., pág 328. 
planes previstos para acabar de una vez con la resistencia de Saint Domingue. ${ }^{47}$

El empuje de los negros al servicio de los franceses fue entonces considerable. Un grupo de ellos asaltaron las parroquias de la Petit Riviére y los Veretes, obligando a la guarnición española que las protegía "a acampar al otro lado del río". ${ }^{48}$

Al mismo tiempo, surgen algunos enfrentamientos entre los caudillos negros Juan Francisco y Toussaint, que hacen pensar ya claramente, en el cambio experimentado por este último a favor de la colonia francesa. Toussaint atacó por sorpresa a las tropas de Juan Francisco, aunque se cuidó muy bien de justificar su acción ante las autoridades españolas, ignorantes aún de su traición. En este sentido, manifestó haberlo hecho porque Juan Francisco lo había hostigado primero, declarando que su actitud no iba dirigida contra la Corona hispana, a la que según él se mantenía fiel. ${ }^{49}$

Rápidamente los republicanos tomaron Port Margot, de manera que, en cuestión de meses, la única plaza del norte del Guarico que permanecía aún en poder de los españoles era la de Bayajá, y cada vez más en peligro.

Mientras, el capitán general de la isla regresó a la capital abandonando la lucha, "en silla de ruedas y su salud bien quebrantada". ${ }^{50}$

47 Carta del regente de la Audiencia de la Española don José Antonio de Urízar de 22 de abril de 1794, informando a la Corte de los preparativos que había realizado para contribuir desde la capital a la toma del Guarico, y otra del gobernador don Joaquín García fechada el 16 de mayo de 1794, enviando a la Metrópoli una relación de las operaciones del ejército desde su salida de Bayajá el 8 de mayo hasta su regreso el 12 del mismo mes. A.G.I., Santo Domingo, 969 y Estado, 14-91.

48 Carta de don Joaquín García de 6 de julio de 1794, informando a la Corte de los ataques de los negros rebeldes a la Petit Riviére. A.G.I., Santo Domingo, 1.089.

49 Carta de don Joaquín García Moreno de 6 de agosto de 1794, informando a la Corte de los ataques de Toussaint a Juan Francisco. A.G.I., Santo Domingo, 1.089.

50 Carta del gobernador de Bayajá de 6 de octubre de 1794, dando cuenta al duque de Alcudia de los avances de los republicanos; y otra del regente de la Audiencia don José Antonio de Urizar de 25 del mismo mes y año, informando de la llegada del gobernador a la capital, encontrándose enfermo. A.G.I., Estado, 14-61 y Santo Domingo, 1.032 . 
Las derrotas comenzaron a darse en cadena. Toussaint L'Ouverture, luchando ya sin tapujos al lado de los republicanos franceses, atacó San Rafael de la Angostura, que cayó en poder de los negros. El comandante general de las tropas, a pesar de contar para su defensa con 300 soldados, decidió evacuar las fuerzas a Banica, dejando toda la artillería en San Rafael. La villa de San Miguel de la Atalaya siguió entonces la misma suerte. Su comandante estaba dispuesto a hacer frente a sus atacantes, pero el comandante general le ordenó que retrocediera con él a Banica.

Por el abandono de estas dos poblaciones, "toda la ysla, diferentes paizanos que se hallaron en aquel puesto, y algunos oficiales de guerra, claman y la denominan vergonzosa e innominiosa fuga". ${ }^{51}$

Los ingleses por el contrario continuaban sus avances, y su comandante general se estableció en Puerto Príncipe. Mientras, la colonia española perdió las parroquias de $\mathrm{Mi}$ rebalais y el Grand Bois, que anteriormente habían pasado en forma voluntaria a su dominación, y cuyos hombres marcharon después a atacar San Gabriel de las Caobas. Al parecer, no fue ajena a esta actitud la acción de los ingleses, empeñados en apoderarse de toda la colonia francesa. Nada más salir los españoles de los dos lugares mencionados, los ingleses ocuparon el Grand Bois, izándose allí la bandera británica, y lo mismo "iba a suceder en la parroquia de Mirabelé". ${ }^{52}$

En Europa, la guerra era también adversa a los españoles. El ejército francés penetró en la Península. La coalición formada por Inglaterra, España, Austria y Prusia se desintegraba, y Godoy, viéndose acosado, inició las conversaciones de paz con la República Francesa.

51 Carta de don Joaquín García Moreno de 20 de noviembre de 1794, dando cuena la Corte de las pérdidas de San Rafael y San Miguel, y otra del regente de la Audiencia sobre el mismo asunto. A.G.I., Santo Domingo, 1.089 y 1.032 .

52 Carta del regente de la Audiencia don José Antonio de Urízar fechada el 25 de agosto de 1795, dando cuenta a la Corte de las pérdidas de territorios en la colonia francesa. A.G.I., Santo Domingo, 1.033. 
El tratado de Basilea y los problemas SURGIDOS CON LOS INGLESES

Los plenipotenciarios del Rey de España y de la Junta de Salud Pública de Francia, tras varias deliberaciones, llegaron a la redacción de un tratado de paz definitivo en Basilea. La firma tuvo lugar el 22 de julio de 1795 , y fue ratificado por la Convención Nacional y por Carlos IV varios días después.

Por él, a cambio de recuperar los territorios que le habían sido arrebatados en la Península, España tuvo que ceder a Francia la isla de Santo Domingo. Y así, su capítulo IX determinaba que, "en cambio de la restitución de que se habla en el artículo IV, el Rey de España por sí y sus sucesores, cede y abandona en toda propiedad a la república francesa, toda la parte española de la isla de Santo Domingo en las Antillas.

Un mes después de saberse en aquella isla la ratificación del presente tratado, las tropas españolas estarán promptas a evacuar las plazas, puertos y establecimientos que allí ocupan... Los habitantes de la parte española de Santo Domingo que por sus intereses $\mathfrak{u}$ otros motivos, prefieran transferirse con sus bienes a las posesiones de S. M. Católica, podrán hacerlo en el espacio de un año, contado desde la fecha de este tratado". ${ }^{53}$

Para ayudar en lo posible a aquéllos que quisieran salir de la isla, se les consentía hacerlo, como ya queda expuesto, con todas sus pertenencias. La Corona española decidió además concederles terrenos en Cuba, de un valor semejante a los que poseían en la Española, y que su transporte fuera costeado por la Real Hacienda.

La Audiencia y el ejército serían los últimos en abandonar la isla, con el fin de que contribuyeran eficazmente a la

53 Lugo Lovatón, Ramón: El tratado de Basilea. Editora Montalvo. Ciudad Trujillo, 1951, pág. 12. 
evacuación, y a la defensa de los intereses de los españoles que decidieran emigrar. ${ }^{54}$

En Santo Domingo, la notificación oficial de que la colonia se traspasaba a la República Francesa se hizo el I7 de octubre de $1795,{ }^{55}$ produciéndose la lógica consternación entre sus pobladores. El conocimiento de lo acordado en Basilea, produjo desde luego serios descontentos en la Española. "Sus componentes se habían formado al amparo de la tradición del más antiguo asiento español en el nuevo mundo". 56

Sin embargo, para que Francia consiguiera la propiedad real de sus nuevos territorios, hubo que esperar aún algunos años. Los franceses no se encontraban en aquellos momentos en condiciones de hacerse cargo de sus nuevas posesiones, pues tenían serias dificultades incluso para mantener las antiguas.

Los ingleses, asentados en gran parte del Guarico, no estaban dispuestos a arrojar por la borda las conquistas que habían conseguido. Su propósito era expulsar a los galos de toda la isla y hacerse dueños de ella.

Nada más conocerse la noticia de la paz, los británicos se dirigieron con sus buques a la bahía de Manzanillo, de la que se apropiaron. Al mismo tiempo, acopiaron todo el ganado español que pudieron, intentando almacenar los víveres necesarios para proseguir su campaña. ${ }^{57}$

En estos momentos, la Corte española comunićs al gobernador dominicano que no se deshiciera de las tropas, sino que las tuviese listas "en disposición de que no nos coja

54 Copia de una R. C. fechada en San Ildefonso el 8 de septiembre de 1795, remitiendo al gobernador de Santo Domingo el tratado definitivo de paz, y dándole las instrucciones necesarias para su cumplimiento. A.G.I., Estado, 17.4.

55 Carta del gobernador don Joaquín García Moreno de 17 de octubre de 1795 , comunicando a la Corte la publicación del tratado de paz con Francia. A.G.K. Santo Domingo, 1.090 .

56 Pérez y Pérez, Carlos Federico: Op. cit., pág. 85.

57 Carta del arzobispo de Santo Domingo Fray Fernando Portillo de 24 de enero de 1796, dando cuenta al príncipe de la $\mathrm{Paz}$ de la situación en que se encontraba la isla. A.G.I., Estado,11-44 
desprevenidos, qualquiera sorpresa que pueda intentar la nación ynglesa, de quien debemos recelar". ${ }^{58}$

Los ingleses esparcieron por toda la isla una proclama, en apariencia favorable al Rey de España, aconsejando a los colonos dominicanos la partida, con el fin de continuar bajo el dominio de su Corona. Su pretensión era clara, que los españoles dejaran la colonia para así ocuparse sólo de los desorganizados franceses. Pero además, se ofrecieron a defender a aquellos hispanos que quedaran, y los vecinos de muchos pueblos prefirieron vivir bajo su gobierno, antes que soportar los desórdenes de los republicanos franceses y de sus negros.

Los británicos hicieron gala, en todo momento, de la más escrupulosa neutralidad respecto a la Corona española, y de todos los respetos debidos a su territorio. Y así, la mayor parte de las poblaciones dominicanas estaban dispuestas a solicitar su auxilio, o pasar a servir en sus tropas hasta arrojar a los franceses, en el caso de que la proyectada entrega se llevara a cabo.

Contribuyó efectivamente a esta política de atracción de los colonos españoles intentada por el Reino Unido, el comportamiento de sus hombres en las relaciones comerciales. Pagaban generosamente tanto el ganado como los demás géneros comprados a los isleños, que se veían así mucho más satisfechos que cuando realizaban negocios con los que hasta entonces fueron sus vecinos. ${ }^{59}$

En esta situación, se produjo un cambio radical en las alianzas internacionales por lo que se refiere a España, que firmó con los franceses un tratado en San Ildefonso en I796, rememorando los antiguos pactos de familia. ${ }^{60}$

58 Carta del capitán general de Santo Domingo don Joaquín García de 9 de septiembre de 1796 dirigida al príncipe de la $\mathrm{Paz}$, acusando el recibo de la $\mathrm{R}$. O de 27 de enero de 1796 , en la que se le comunicaba se mantuviesel alerta respecto los ingleses. A.G.I., Estado, 5-64.

59 Carta del arzobispo de Santo Domingo de 9 de agosto de 1796 dando cuenta a la Corte de la proclama lanzada por los ingleses, y otra de 17 de septiembre del mismo af́o, informando de los avances corseguidos por aquéllos entre la población. A.G.I., Estado, 11-66 y 11-45.

60 Pérez y Pérez, Carlos Federico: Op. cit., págs. 88-89. 
Sin embargo, como ocurre en la mayor parte de los casos, la noticia se supo tarde en Santo Domingo.

En diciembre de aquel año el capitán general de la isla escribió a la Corte, que habían llegado rumores a sus oidos de haberse realizado una alianza ofensivo-defensiva con Francia, al tiempo que se declaraba la guerra a Inglaterra. Tuvo conocimiento de esta novedad, a través de los impresos extranjeros y los informes de los nacionales que arribaban a aquel puerto. Pero no recibió al respecto ningún aviso oficial, a pesar de que por su crítica situación, en medio de franceses e ingleses, necesitaba quizás más que nadie de este informe. ${ }^{61}$

Al poco tiempo los ingleses comenzaron las hostilidades, "y después de haber fascinado a los crédulos vecinos de la frontera, nos atacan por Neiva, el puesto del fondo, valiéndose de los brigantes de Pineau y Manisel, y demás negros hasta 200".

Posteriormente sitiaron y bloquearon el puerto de Santo Domingo, con una escuadra formada por nueve navíos, seis fragatas, otros buques de guerra, y $5^{\circ}$ velas de transporte. ${ }^{62}$

Pero poco quedaba ya a los británicos en aquella isla. Los republicanos, tras muchos esfuerzos, fueron consolidando lentamente su autoridad, sobre todo gracias al apoyo de las tropas negras declaradas libres por la Convención. Formaron así una gruesa expedición que logró arrojarlos de muchas de sus posesiones. ${ }^{63}$

Cada vez se hizo más difícil para sus enemigos sostenerse en la Española. Enfrentados a las tropas de Toussaint

61 Carta del gobernador de la Española don Joaquín García fechada el 31 de diciembre de 1796, solicitanđo de la Metrópoli se le informase sobre la verdad o falsedad de la alianza con la República francesa y la ruptura con Inglaterra. A.G.I., Estado, 5-201.

62 Carta del gobernador García de 3 de marzo de 1797, informando a la Corte de los ataques de los ingleses y otra de 28 de abril del mismo año dando cuenţa del bloqueo del puerto por los británicos. A.G.I. Santo Domingo, 960, y A.H.N., Estado, 3.394.

63 Carta del regente de la Audiencia de Santo Domingo don José Antonio de Urízar de 29 de abril de 1797, dando cuenta a la Corte del triunfo de las tropas del Guarico contra los ingleses, A.G.I., Santo Domingo ,960. 
L'Ouverture por un lado, y teniendo que luchar contra las enfermedades por otro, se vieron en la necesidad de abandonarla por fin en $1798 .{ }^{64}$

\section{Consecuencias del Tratado de Basilea}

En el tratado de Basilea, como ya hemos indicado, se acordó la libre salida de la isla de todos los españoles que lo desearan. La partida de los colonos con todos sus bienes, se efectuaría en el término de un año. Con este motivo, la Corona dispuso conceder a los emigrantes nuevos terrenos en la de Cuba, equivalentes a los que abandonaban en Santo Domingo.

Sin embargo, esta alternativa no era suficiente. Los primeros que marcharon allí se encontraron con que no había medios para atenderlos. Las tierras que pudieron ofrecerles eran las peores del país, pues lógicamente las buenas se encontraban ya ocupadas. ${ }^{65}$

Cuando supieron estas noticias los que permanecían en la Española, el desánimo cundió entre ellos. Esto hizo que las autoridades dominicanas suplicaran de la Corte, que se prorrogase a tres años el tiempo permitido para la evacuación. Su propósito era que los vecinos pudieran vender sus posesiones sin tantas prisas, y contar así con algunos recursos en la nueva vida que iban a emprender. Al mismo tiempo, pidieron también que las mercedes otorgadas en Cuba fueran extendidas a otros lugares como Puerto Rico y Caracas. ${ }^{66}$

A pesar de todos los inconvenientes, la emigración desde luego continuó, aunque los distintos autores no se ponen de acuerdo respecto a su importancia. Para algunos fue considerable, siendo inútiles los esfuerzos de los franceses por evitarla. "Los pobladores pudientes y los que lograron allegarse los elementos indispensables al viaje de expatria-

64 Pérez y Pérez, Carlos Federico: Op. cit., pág. 89.

65 Moya Pons, Frank: Op. cit., pág. 345.

66 Carta de don José Antonio de Urízar fechada el 3 de noviembre de 1795 , solicitando a la Corte se amplien los términos de la evacuación. A.G.I. Santo Domingo, 1.033 . 
ción se fueron de Santo Domingo, creando así un verdadero problema a las autoridades españolas. Nadie quiso quedarse para ser francés". ${ }^{\mathbf{6 7}}$

Para otros, la mayoría de la población dominicana continuó allí, frenada por las malas condiciones de hospitalidad que encontraron los emigrantes, y tratando de ejercer toda la influencia posible sobre el gobierno español para que la decisión de la cesión fuera reconsiderada. De esta forma, en 1796 se fueron de la Española 1.800 personas; pero la mayor parte de ellas fueron militares que no tenían posesiones en la colonia. ${ }^{68}$

Desde luego, la imposibilidad de que los franceses se hicieran cargo de la parte española, con el consiguiente retraso en la entrega, hizo pensar a muchos que ésta nunca tendría lugar, y prefirieron permanecer en la isla en espera de los acontecimientos. ${ }^{69}$ a Cuba.

A comienzos de I795, los evacuados empezaron a llegar

La primera noticia que tenemos a este respecto es una carta del gobernador de la Habana, don Luís de las Casas, dirigida al príncipe de la Paz, en la cual le comunicaba que habían desembarcado en su territorio 95 emigrados procedentes de Santo Domingo, que fueron transportados en el navío "el Asia".

Poco tiempo después arribaban a aquel puerto 613 personas más, en dos embarcaciones diferentes. ${ }^{70}$

A consecuencia de las órdenes que la Metrópoli remitió al respecto a las autoridades cubanas, tenían que cubrir las necesidades de estos nuevos pobladores. Por ello, se celebró una junta en la ciudad de La Habana, que deliberó sobre las medidas que podían tomarse para que los refugiados

67 Peña Batlle, Manuel Arturo: El tratado de Basilea. Desnacionalización del Santo Domingo español. Impresora Dominicana. Ciudad Trujillo, 1952. pág. 14.

68 Moya Pons, Frank: Op. cit., pág. 351.

69 Pérez y Pérez, Carlos Federico: Op. cit., pág. 87.

70 Carta del gobernador de la Habana don Luís de las Casas al príncipe de la Paz de 1795, comunicándole la llegada de los primeros emigrados de Santo Domingo, y otra de 5 de enero de 1796, informándole de nuevos desembarcos. A.G.I., Estado, 5-175 y 5-21. 
de Santo Domingo estuvieran atendidos en la mejor forma posible.

Se acordaron cinco puntos: acoger y alimentar a los que lo necesitaran con un real y medio diario, y "poniéndoles en la cabaña algún barracón y la casa del Pilar"; ir colocando a los artesanos y labradores a medida que arribaban a la isla; nombrar personas serias y de toda confianza que cuidasen de su desembarco y alojamiento; reclamar al gobernador de Santo Domingo una relación completa de los que seguirían después para estar preparados al respecto, y por último, solicitar del virrey de Nueva España el dinero con qué asistir a los recién llegados. ${ }^{71}$

Pero estas medidas resultaron tatalmente insuficientes. La cantidad que se asignó a los emigrados para su sustento era al parecer ridícula, mientras que el agrupamiento de distintas familias en los lugares destinados a ello no podía satisfacer a nadie.

El Rey, a consecuencia de los informes negativos que recibió sobre este asunto, de una representación del regente de la Audiencia de Santo Domingo,y otra de los principales hacendados de la ciudad de Santiago, prorrogó por un año más el plazo concedido a los que desearan partir de la Española. Además, podrían encaminarse no sólo a Cuba, sino también a las islas de Trinidad y Puerto Rico. ${ }^{72}$

La emigración a Cuba continuó a pesar de todo, y desde el 4 de marzo al 17 de septiembre de 1796, desembarcaron en La Habana procedentes de Santo Domingo 912 personas. ${ }^{73}$

Aunque no podemos fijar la cuantía de este movimiento

71 Carta del visitador general intendente de la Habana de 5 de enero de 1796, comunicando a la Corte la celebración de una Junta el $\mathbf{5}$ de noviembre del año anterior, para estudiar los medios de auxiliar a los emigrantes dominicanos. A.G.I., Santo Domingo, $\mathbf{1 . 0 3 3 .}$

72 Carta del gobernador de Santo Domingo don Joaquín García de 12 de abril de 1796, acusando el recibo de la real resolución de 27 de enero del mismo año, sobre la ampliación de tiempo y lugares para los emigrantes. A.G.I., Estado, 5-72.

73 Cartas del gobernador de La Habana, don Luís de las Casas de 11 de marzo, 7 de abril, 28 de junio, 5 de agosto y 19 de septiembre de 1796, informando a la Corte de la llegada de emigrantes dominicanos a aquel puerto. A.G.I., Estado, 5-99, 5-142, 5-153, y $5-189$. 
migratorio producido tras la paz de Basilea, debió tener bastante importancia. La primera preocupación de los dirigentes de la parte occidental de la isla fue detener estas salidas, y para ello desplegaron todos sus esfuerzos.

En este sentido, hicieron circular por toda la Española una carta del comisario francés, señor Roume, en la que exhortaba a los dominicanos a quedarse, ya que más tarde podrían marcharse siempre que quisieran con sus bienes, "si tuvieran la necesidad de preferir las cadenas del despotismo a los derechos del republicanismo". ${ }^{7}$

Por su parte, don Esteban Laveaux, gobernador general y representante máximo de la República Francesa en el Guarico, lanzó también una proclama dirigida a todos los españoles residentes' en la isla, donde les manifestaba que los franceses eran sus amigos y debían vivir con ellos, "pues hallaréis en la fundación de nuestra constitución, que está establecida sobre los principios de nuestra misma religión, Libertad, Igualdad y Fraternidad. Estas tres virtudes quedan por los republicanos tan indelebles, como las tres virtudes theologales.

Libertad. Os assegura a jamás el libre albeldrío de profesar el culto y religión que más conviene a cada uno... Igualdad. Todos los hombres son iguales delante de la Lei, y todos tienen derecho para conseguir a todos los empleos y onrras çiviles o militares.

Fraternidad. Pues ciudadanos, nos os asseguramos y ratificaremos con juramento, que os consideramos como hermanos nuestros; lo sereis ahora por adopción y luego lo sereis por gusto; y nosotros de inclinación y cariño". ${ }^{75}$

Tales declaraciones ocasionaron las quejas de las autoridades españolas, temerosas, de que los deseos de igualdad hicieran rebelarse a los esclavos. ${ }^{76}$

74 Peña Batlle, Manuel Arturo: El tratado..., págs. 49-50.

75 El Guarico, 2 de noviembre de 1795. Proclamación de Esteban Laveaux, gobernador general de Saint Domingue, a todos los españoles residentes en aquella isla. A.G.I. Estado, 11-22.

76 Cartas del gobernador de Santo Domingo don Joaquín García, y del regente de su Audiencia de 21 y 23 de noviembre de 1795 respectivamente, dando cuenta a la Corte de la actitud tomada por los comisarios franceses. A.G.I., Estado, 5-49 y Santo Domingo, 1.033. 
Don Joaquín García escribió rápidamente a don Esteban Laveaux, protestando por lo irregular de su actuación. Le hizo notar al mismo tiempo, que los esclavos eran gran parte de la riqueza de los colonos. Se había dado a éstos un plazo de dos años para salir de la isla con sus bienes si así lo deseaban, y por lo tanto, era ilegal despojarlos de sus siervos entre tanto. ${ }^{77}$

A pesar de estas reclamaciones, los gobernantes dominicanos pensaban que las citadas proclamas no hicieron mella en el espíritu de los esclavos de la parte española. Sin embargo, meses más tarde, en octubre de 1796, los acontecimientos vinieron a contradecirlos.

La propaganda francesa sobre la igualdad de todos los hombres tuvo sus frutos, aunque desde luego poco importantes, en la sublevación de los esclavos de una hacienda azucarera cercana a la capital, propiedad del marqués de Iranda. Era el ingenio conocido con el nombre de Boca, Nigua, a cuyo frente se encontraba don Juan Bautista de Oyarzábal, y que contaba con unos 200 siervos para su funcionamiento.

Los negros se amotinaron "contra la persona de su amo, meditando seguidamente contra el de todo blanco, contando poseer la misma hacienda, hacer esclavo al que no tomase las armas a su favor o matarlo, engrosar pronto su vanda con las negradas que volarían de las haciendas vecinas al oir el sonido de la libertad... Y sobre estos sucesos alagüeños, contaban con poseer la ciudad y establecer un gobierno como el del Guarico y demás de la parte francesa ...".

Atacaron la casa principal, aunque Oyarzábal logró escapar, y ocuparon todo el ingenio. Incendiaron y destrozaron todo lo que les pareció, hasta que llegó la tropa avisada por uno de los negros opuestos a la revuelta y pudo acabar con ella. ${ }^{78}$

77 Carta de don Joaquín García Moreno a don Esteban Laveaux de 25 de noviembre do 1795 protestando por la actuación de los comisarios franceses. A.G.I., Estado, 5-49.

78 Carta del capitán general de Santo Domingo don Joaquín García de 13 de diciembre de 1796, informando a la Corte de la sublevación de los esclavos de la hacienda Boca Nigua el 30 de octubre de aquel año. A.G.I., Estado, 5-202. 
En la lucha con los soldados murieron siete negros y diez fueron heridos, apresándose después a 69 , entre los que se hallaban los principales cabecillas.

La sentencia de la justicia fue feroz. Los cinco más destacados en el levantamiento fueron condenados a la horca, "y cortadas sus cabezas y desquartizados sus cuerpos, se fixen en los parajes más públicos". A otros dos también los llevaron a la horca, a 58 se les castigó con ioo azotes en la picota, a siete con 50, y a otros seis negros y negras menores de 17 años, con 25 a cada uno. ${ }^{79}$

\section{LA ENTREGA}

Desde que en I795 tuvo lugar la cesión oficial de la Española a los franceses hasta la entrega real, los gobernantes del Santo Domingo español hicieron frente a muchos problemas. Entre ellos estaban desde luego, la falta de dinero con que costear la evacuación y los temores a los asaltos de las bandas de negros.

El deseo del gobernador dominicano era dejar la isla cuanto antes. $\mathrm{Y}$ nada más recibir la noticia de lo acordado, cedió a los franceses la plaza de Bayajá. A continuación dispuso el abandono gradual de las restantes, con el fin de concentrar las tropas en la capital hasta el momento de la partida. ${ }^{80}$

La toma de Bayajá tuvo lugar el I4 de junio de I796 por el señor Santhonax, presidente de la comisión delegada por el gobierno francés en el Guarico. Las tropas españolas que guarnecían aquella plaza, embarcaron en los navíos de la escuadra mandada por don Gabriel de Aristizábal, que partió hacia La Habana. ${ }^{81}$

79 Santo Domingo, 24 đe diciembre de 1796. Testimonio de la sentencia dada contra los negros de la hacienda Boca Nigua. A.G.I., Estado, 13-32 y Santo Domingo, 1.033.

80 Carta del regente de la Audiencia de Santo Domingo de 16 de junio de 1796, dando cuentał a la Corte de los esfuerzos realizados por las autoridades isleñas para llevar a cabo la cesión. A.G.I., Estado, 13-24.

81 Carta del marqués de Casa Calvo, gobernador de la plaza de Bayajá, dando cuenta a la Corte de su entrega a los delegados franceses. A.G.I., Estado, 5-67. 
Pero la operación no pudo hacerse con la rapidez que deseaba don Joaquín García. La colonia francesa no estaba en aquellos momentos en condiciones de ocupar la parte española, al tener que enfrentarse a los ingleses por un lado, y a las partidas de negros rebeldes por el otro.

Por ello, tras la toma de Bayajá se limitaron a enviar un comisario a la ciudad de Santo Domingo con una misión clara: atraer a la causa francesa al mayor número posible de vecinos, de manera que sus tierras no quedaran desiertas.

Con esta demora, la situación de los españoles era cada vez peor. El gobernador se quejaba constantemente de que la entrega no pudiera hacerse, pues vivían "en el mismo conflicto que nos vimos en medio de la guerra o tal vez peor... Entonces teníamos un sólo enemigo, más fuerzas, medios y facultades. Hoy nos hallamos con dos enemigos que combatir, los yngleses, que opuestos a la Francia codician con vehemencia toda la isla ya cedida, y los negros, que siéndolo del color blanco y poco subordinados a ningún poder, aspiran a la independencia por diversos aunque conocidos rodeos". ${ }^{82}$

Pero de repente los franceses pasaron un oficio a su comisario residente en Santo Domingo, manifestándole que se hallaban dispuestos a hacerse cargo de la capital. En aquellos momentos era sin embargo imposible la salida de los españoles, por "no haver podido subsistir en nuestros puertos nuestras embarcaciones".

Esta contingencia hizo que solicitaran de aquéllos que comenzaran a tomar posesión del resto de las poblaciones, dejando la capital para el mes de noviembre en que, pasado el período de los temporales, los navíos regresarían de La Habāna. ${ }^{83}$

Laveaux envió entonces a Toussaint a tomar las villas

82 Carta del gobernador don Joaquín García fechada el 16 de mayo de 1796, dando cuenta a la Corte de la situación en que se encontraban los españoles por no llevarse a cabo de forma efectiva la cesión. A.G.I., Estađo, 5-127.

83 Carta del regente de la Audiencia de Santo Domingo de 22 de julio de 1796, informando a la Corte de las dificultades existentes para la entrega de la isla. A.G.I., Estado, 13-26. 
de Banica y San Gabriel de las Caobas. Su ocupación con unas tropas indisciplinadas, que pronto cometieron excesos, atemorizó a todos los habitantes de la zona, y produjo las naturales protestas por parte de don Joaquín García.

Pero la posesión de aquellos lugares por parte de los franceses duró poco. Los ingleses expulsaron de ellos à los hombres de Toussaint con gran rapidez, realizando al mismo tiempo una importante labor de propaganda entre los asustados colonos españoles. ${ }^{84}$

Esto hizo declarar a las autoridades de Saint Domingue que no podían encargarse de los hasta entonces territorios españoles, por hallarse vendidos a los ingleses antes de que ellos llegaran. ${ }^{\mathbf{8 5}}$

La realidad era que los republicanos no estaban capacitados para marchar sobre sus nuevas propiedades, a pesar de que ya había pasado el plazo estipulado para la cesión, por no contar con la suficiente autoridad ni siquiera en su antigua colonia.

La población española de las zonas fronterizas, huía hacia la capital escapando de los negros. Los soldados de color, exaltados porque los franceses no les pagaban sus sueldos, asaltaban a los vecinos indefensos con el fin de robarles sin que el Directorio Colonial pudiera hacer nada para dominarlos. ${ }^{86}$

Al año siguiente la situación pareció mejorar. Los republicanos tomaron de nuevo San Gabriel de las Caobas y Banica, y después San Juan de la Maguana y Santa Cruz de Neiba, acabando con la política de atracción de la población llevada a cabo por los británicos. ${ }^{87}$

En el mes de julio, los españoles dejaron Dajabón en

84 Pérez y Pérez, Carlos Federico: Opus. cit, ,pág. 88.

85 Carta del señor Raimond a don Joaquín García, fechada en octubre de 1796, quejándose ante él por el supuesto entenđimiento entre los ingleses y los españoles para no llevar a cabo la entrega. A.G.I., Estado, 5-180.

86 Carta del arzobispo de Santo Domingo de 27 de enero de 1797, informando a la Corte de los ataques llevados a cabo por los negros contra los españoles. A.G.I., Estado, 11-60.

87 Carta del regente de la Audiencia de Santo Domingo de 29 de abril de 1797, dando cuenta a la Corte de la toma de varias plazas por parte de los franceses. A.G.I., Estado, 13-42. 
manos del Directorio Colonial, y a los pocos días la ciudad de San Fernando de Montecristi, habiéndose presentado con algunas tropas, y los despachos necesarios, los agentes de la comisión del gobierno. ${ }^{88}$

La cesión total seguía sin embargo alargándose considerablemente, y en la capital dominicana corrieron algunas noticias inquietantes. Se trataba del regreso a París del general del Guarico, expulsado por Toussaint L'Ouverture, que se hizo dueño absoluto de la colonia. ${ }^{89}$

Enfrascados los franceses en una verdadera guerra civil durante los años siguientes, la evacuación se suspendió transitoriamente. Mientras, la emigración española continuaba, culminando con la salida de la Real Audiencia a finales de 1799. La única autoridad que quedó entonces en Santo Domingo fue el gobernador, acompañado por 1.220 soldados y oficiales, de los que sólo podía contar con 65 I por encontrarse el resto de baja. ${ }^{90}$

En esta situación. el Cabildo de la capital dominicana envió una solicitud a la Corte, pidiendo al Rey "que se difiera y suspenda la entrega, hasta tanto que venga la resolución superior del primer cónsul Bonaparte". Esta representación estaba dictada por el temor a que fuesen las tropas negras las encargadas de tomar la ciudad. ${ }^{\mathbf{1}}$

La cesión se realizó sin embargo al año siguiente contra la voluntad de la Corte parisina, pues Toussaint L'Ouverture decidió llevar a cabo por su cuenta lo acordado en Basilea.

Al frente de sus hombres entró en la parte española por la frontera del sur, concretamente por la jurisdicción de

88 Carta de don Joaquín García Moreno de 11 de septiembre de 1797, comunicando a la Corte la entrega de Dajabón y Montecristi a los franceses. A.H.N., Estado, 3.394.

89 Carta de don José Fuentes fechada en la Habana el 1 de diciembre de 1798, dando cuenta a la Corte de que Toussaint se había apoderado de toda la colonia francesa. A.G.I., Estado, 15-54.

90 Carta de don Joaquín García Moreno de 10 de noviembre de 1799, informando a la Corte sobre la salida de la Audiencia de la isla, y estado que manifiesta la fuerza efectiva de la guarnición de la plaza. A.H.N., Estado, 3.394.

91 Rodríguez Guerra, Luís: Documentos del Archivo Eclesiástico. "Boletín del Archivo General de la Nación", vol. 3. Ciudad Trujillo, 1940, pág. 287. 
Azúa, enviando al general Moisés con otra columna por el norte. Toussaint atravesó Azúa y Bani y marchó a rodear la capital, esperando allí a que su ejército se incrementara con la llegada de Moisés.

Se supo entonces en Santo Domingo la caída de Santiago después de alguna resistencia, y también las de la Vega y Cotui. E, intentando evitar todo acto de violencia, el gobernador envió una comisión a negociar con el caudillo negro, consiguiendo que ordenara detenerse a Moisés.

A cambio, estipuló la entrega de la capital, que comenzó así el 25 de enero de I80I con la ocupación por las tropas de Toussaint del puesto de Haina, a la que sucedió al día siguiente la del castillo de San Jerónimo y la de la ciudad. ${ }^{92}$

$\mathrm{Y}$ aunque posteriormente el cónsul Bonaparte declararía sin valor semejante cesión, ${ }^{93}$ lo cierto es que el gobernador, y las últimas tropas españolas, salieron de la isla el 22 de febrero de aquel mismo año. ${ }^{94}$

El tratado de Basilea había creado un estado ficticio en la Española. El dominio francés era ya impensable, tanto en su propia colonia, donde las ideas revolucionarias hicieron de la independencia un hecho real, como en la española, por ser imposible destruir en ella las raíces hispanas. ${ }^{95}$

$Y$ así, los negros del Guarico arrojaron a los blancos de sus antiguos territorios, formando al poco tiempo su propia nación, Haití.

Los colonos españoles lograron por su parte recuperar sus posesiones a comienzos del siglo XIX, para llegar a la independencia más tarde sin ninguna relación con sus vecinos, manifestándose en la isla una dualidad que aún hoy se mantiene.

92 Carta de don Joaquín García Moreno de 4 de febrero de 1801, informando a la Corte de la entrega de la capital a Toussaint. A.H.N., Estado, 3.394.

93 Peña Batlle, Manuel Arturo: Historia de la cuestion..., pág. 104.

94 Carta de don Joaquín García Moreno de 4 de marzo de 1801, informando a la Corte de su salida de Santo Domingo, una vez finalizada la entrega. A.H.N., Estado, 3.394. 95 Peña Batle, Manuel Arturo: Historia de la cuestión..., pág. 101. 
A PENDICES 


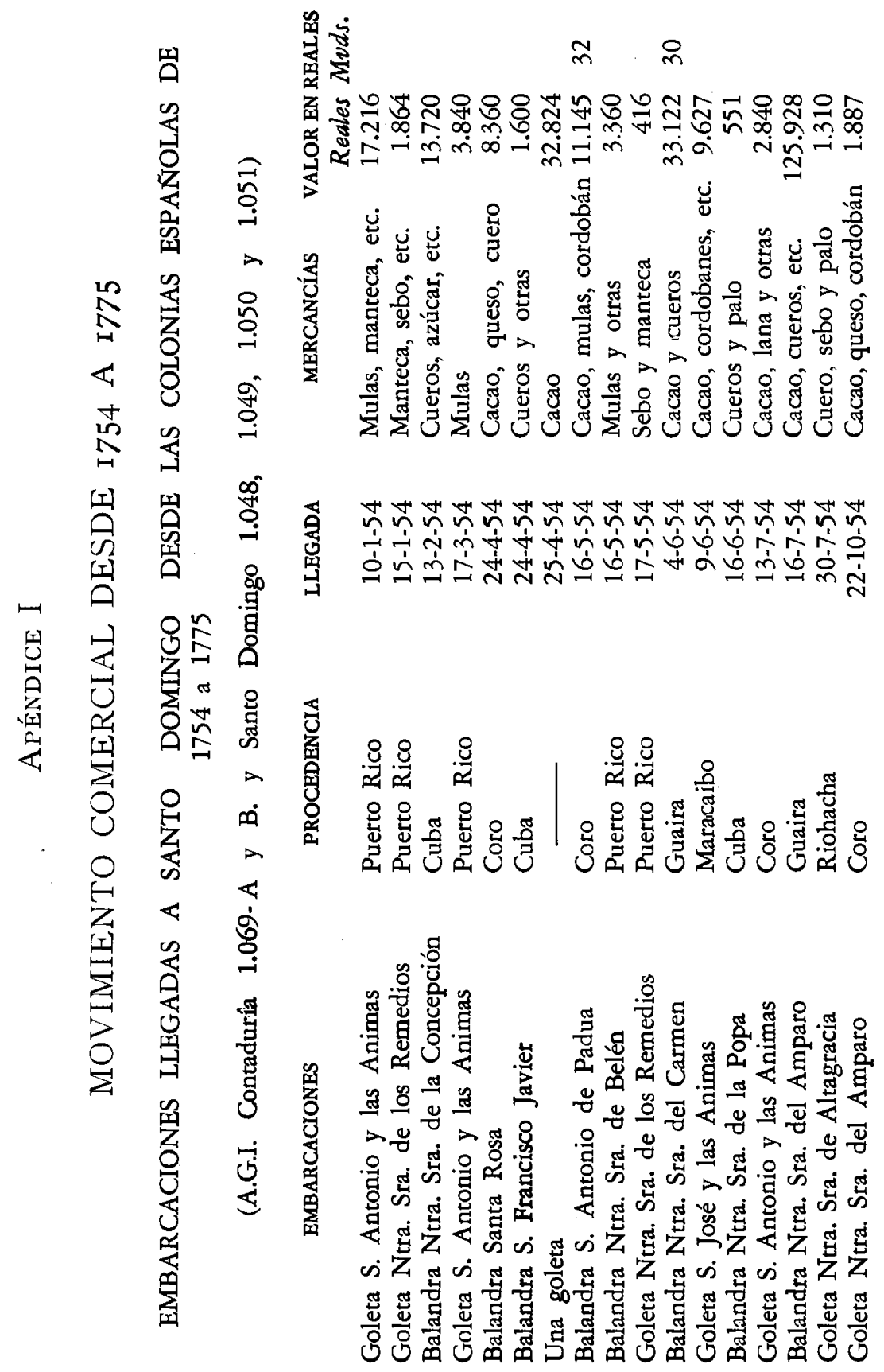


岳富

苗

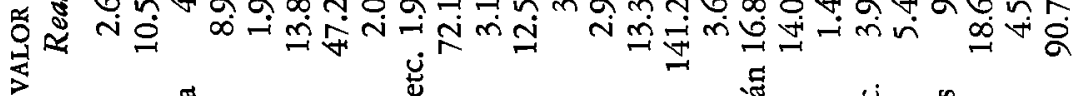

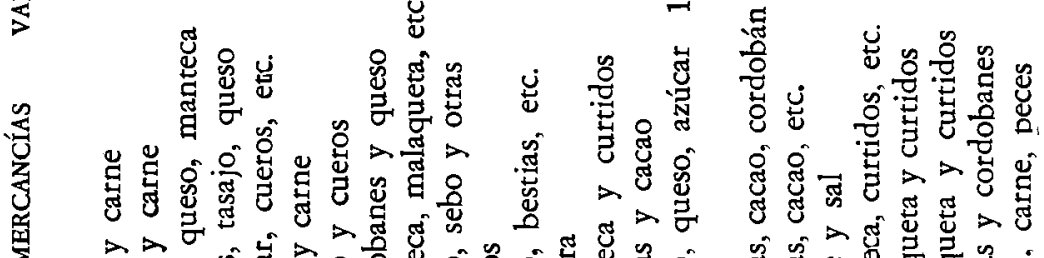

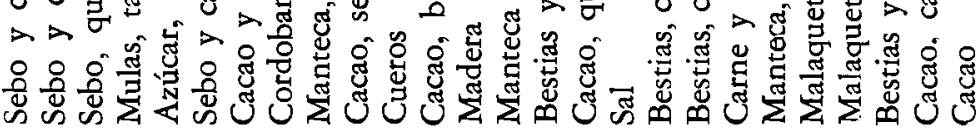

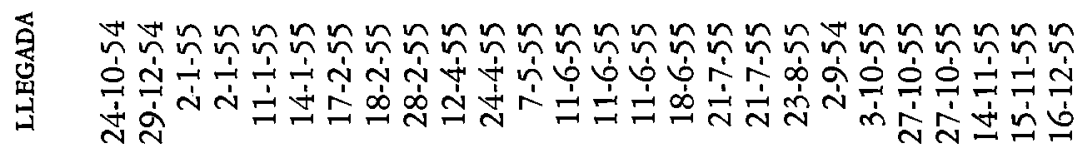

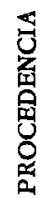

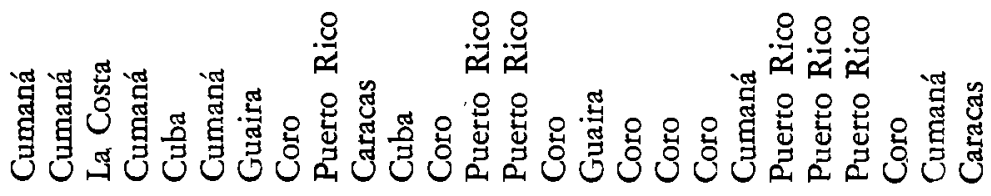

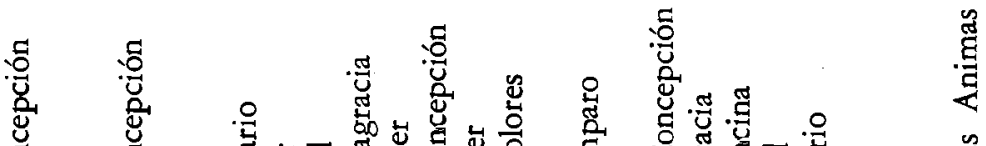

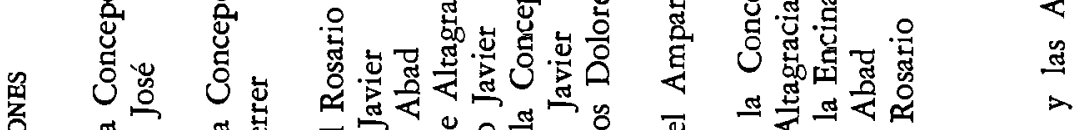

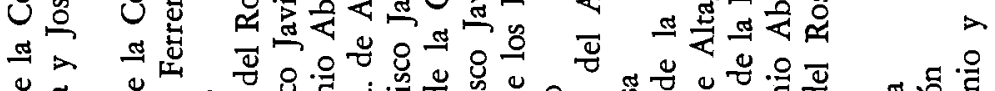

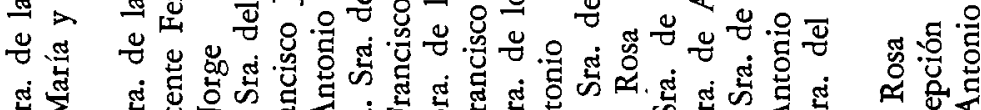

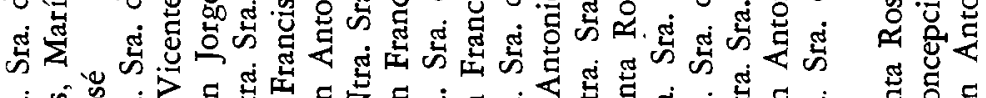

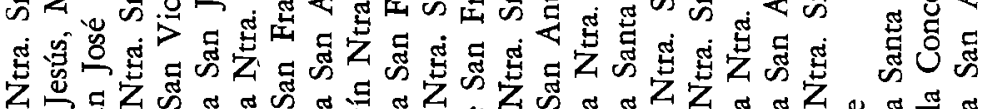

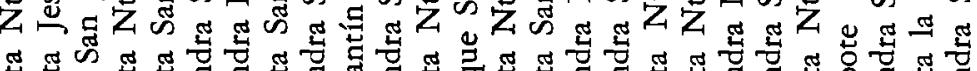

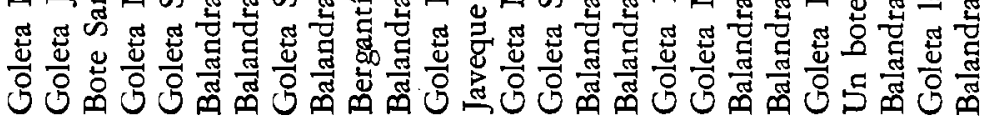


苗

$=6$

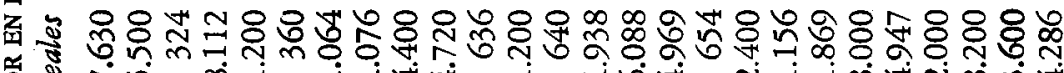

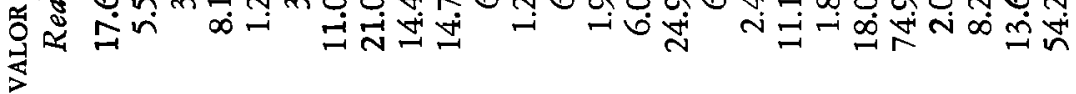

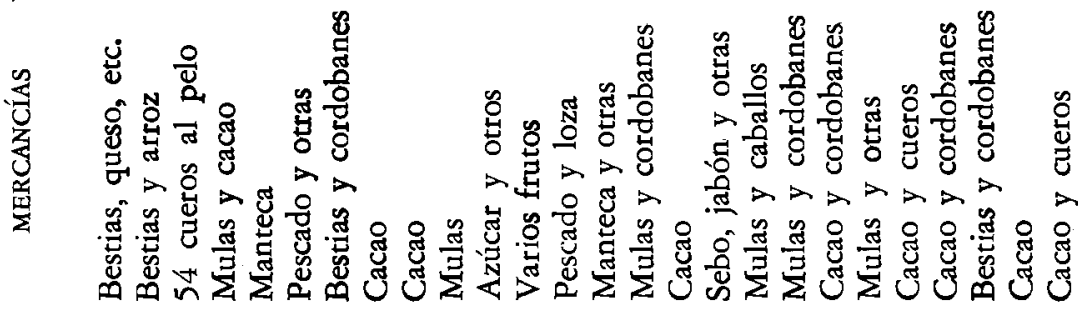

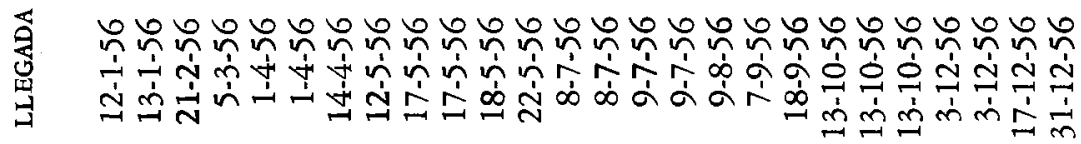

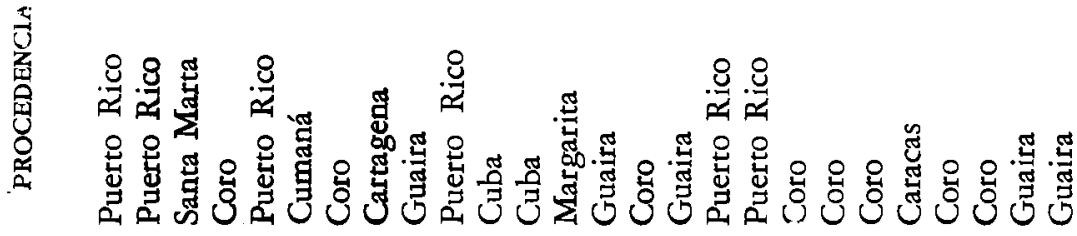

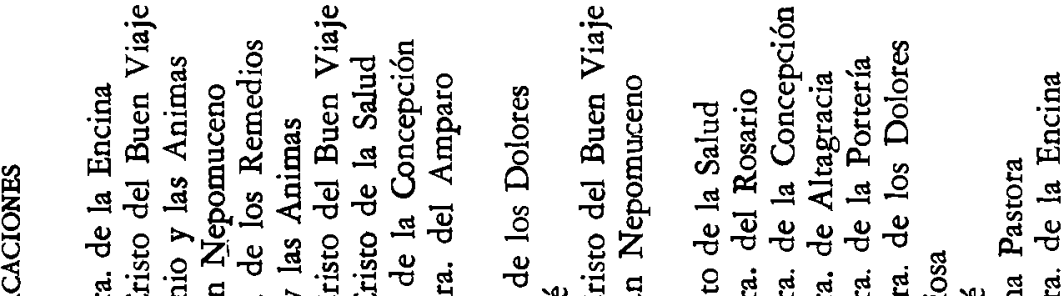

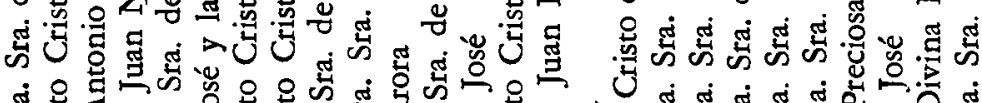

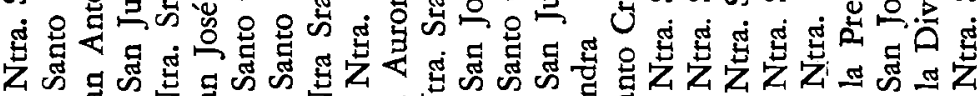

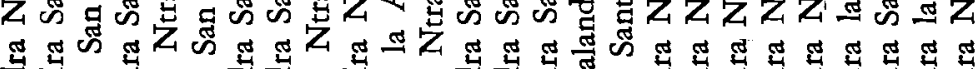

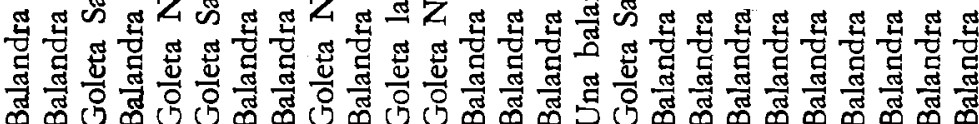


崖富

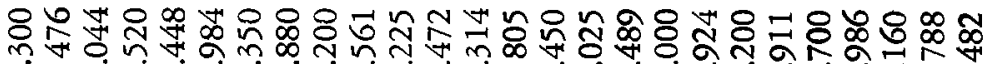
nิ

岁

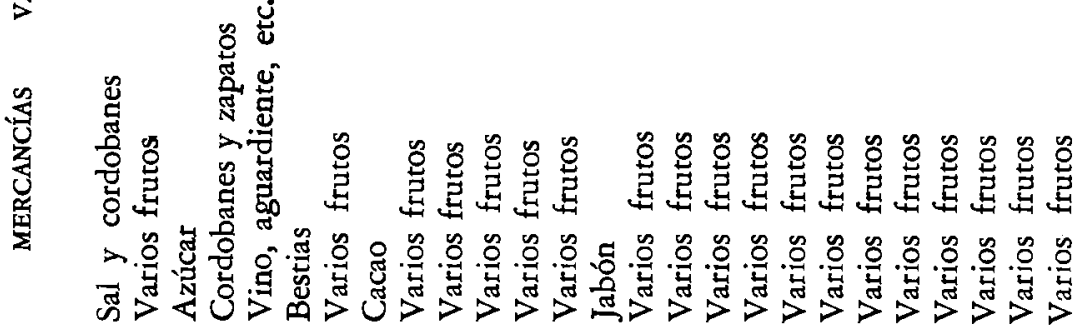

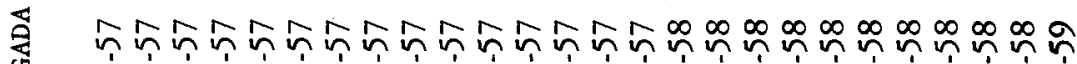

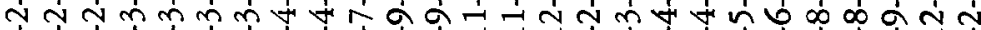
ஸे

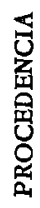

䓂

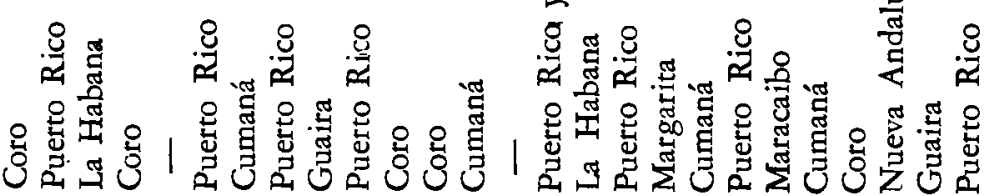

$\underset{⿴}{0}$

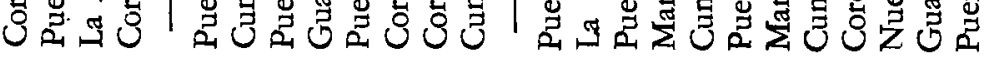

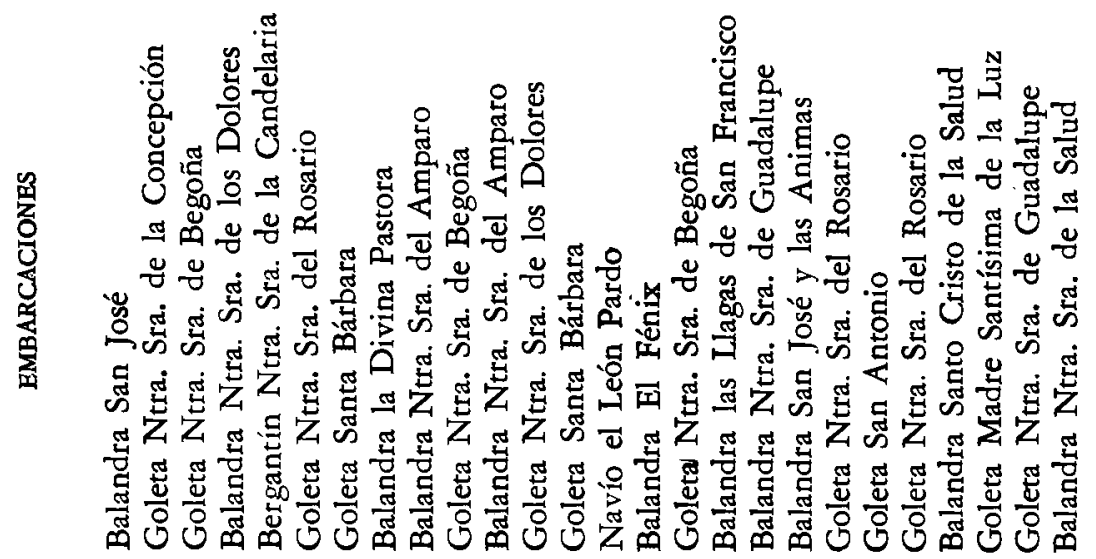


嵒客

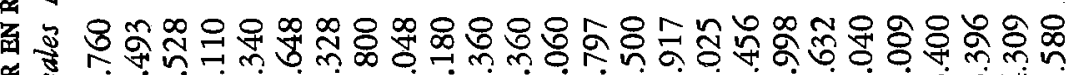
娄

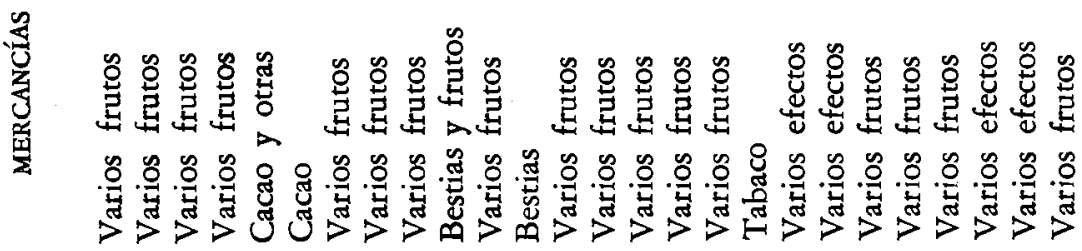

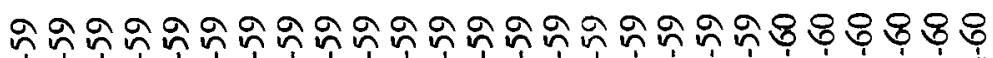

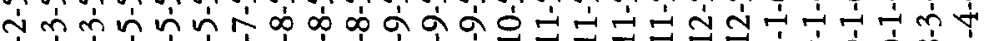
ป்

咅

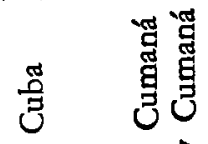

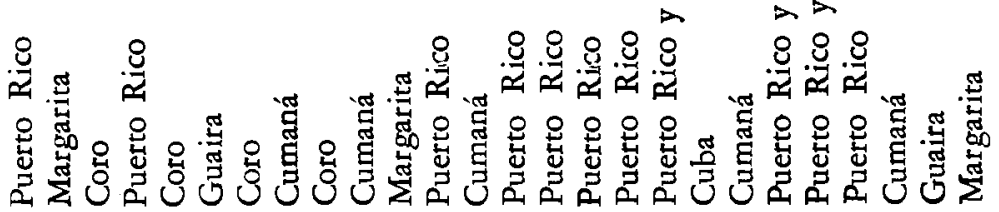

选

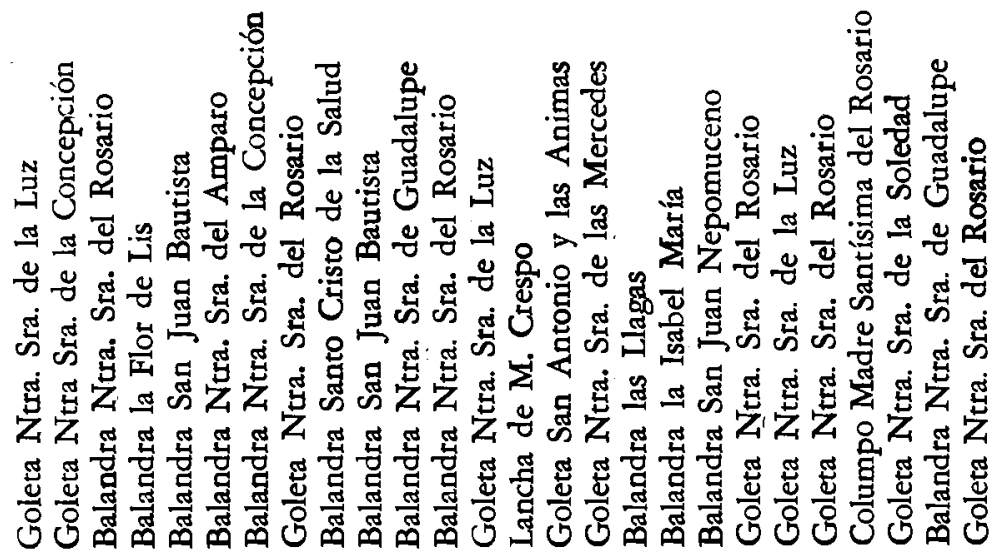


魚密二

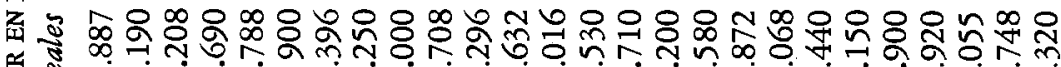

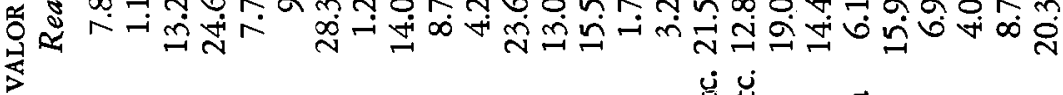

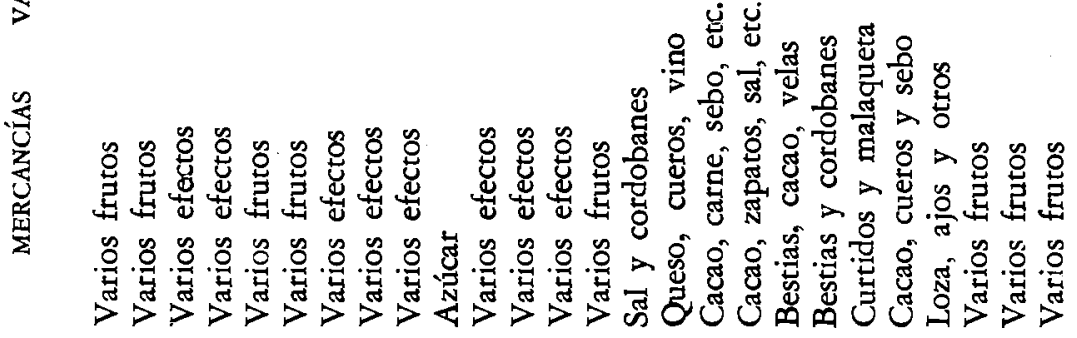

\%

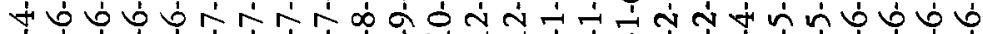

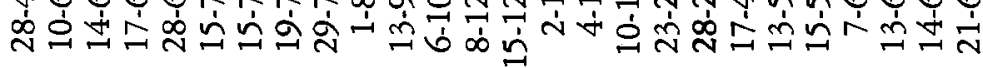

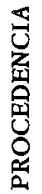
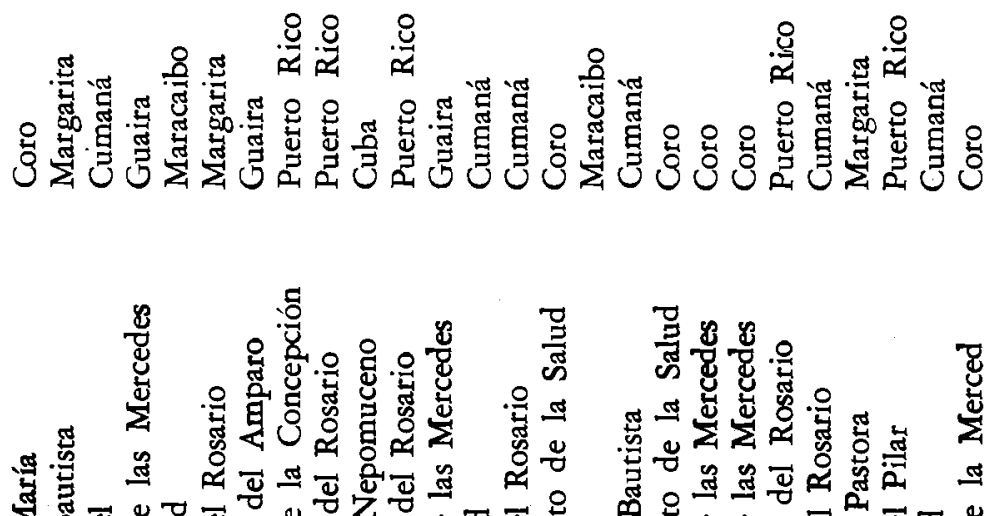

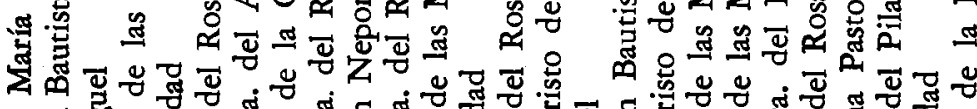
ब

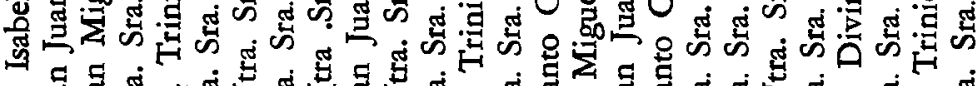

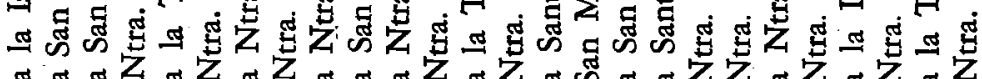

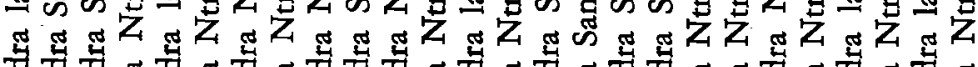

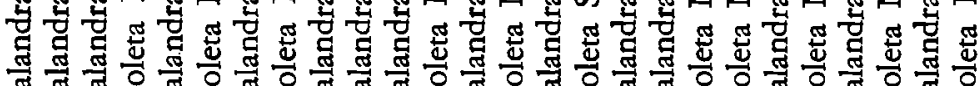

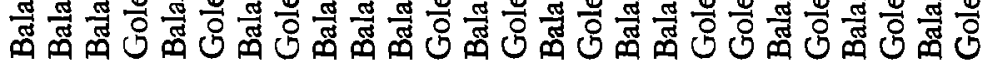


岱选

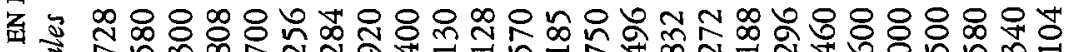

ดั

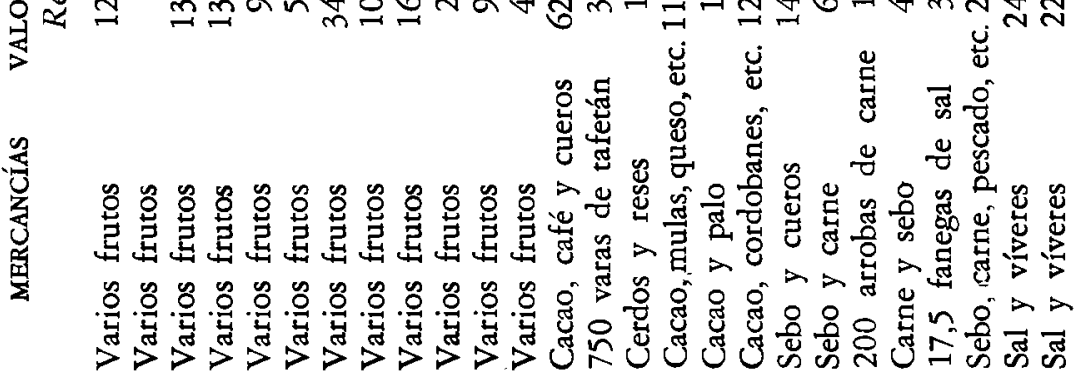

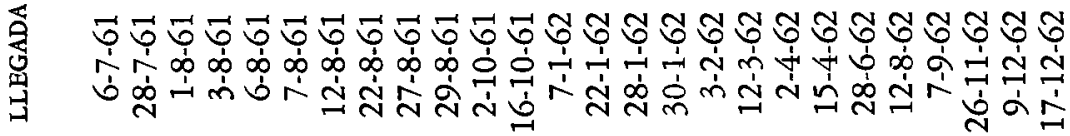

迅

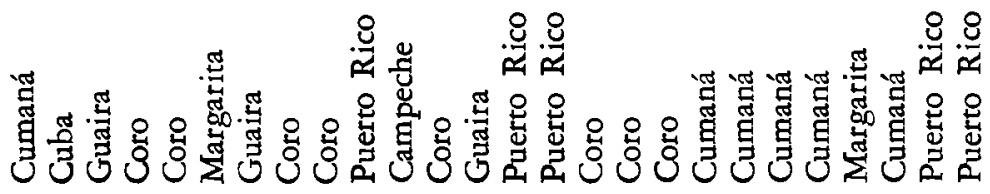

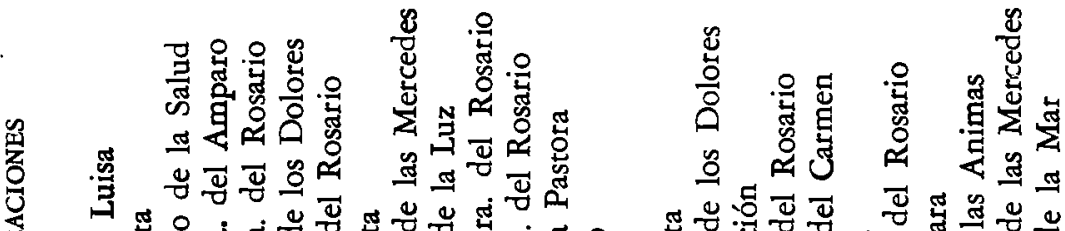

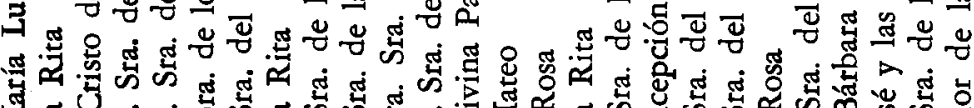

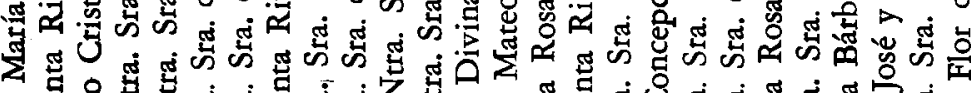

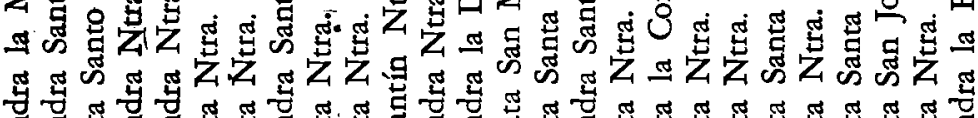

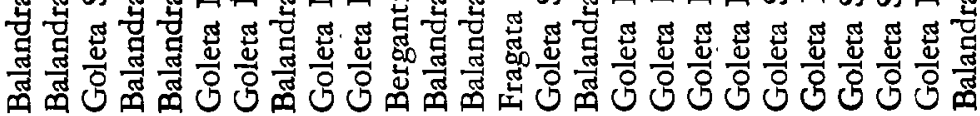


裉蓄

สกำ-

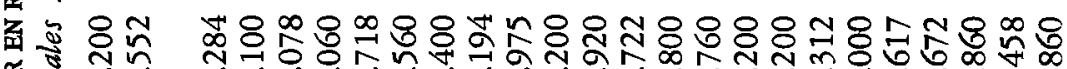

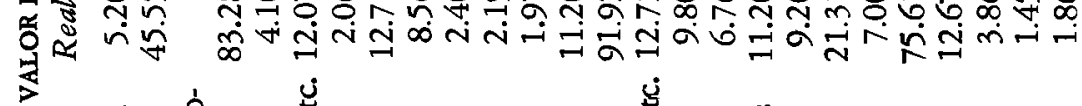

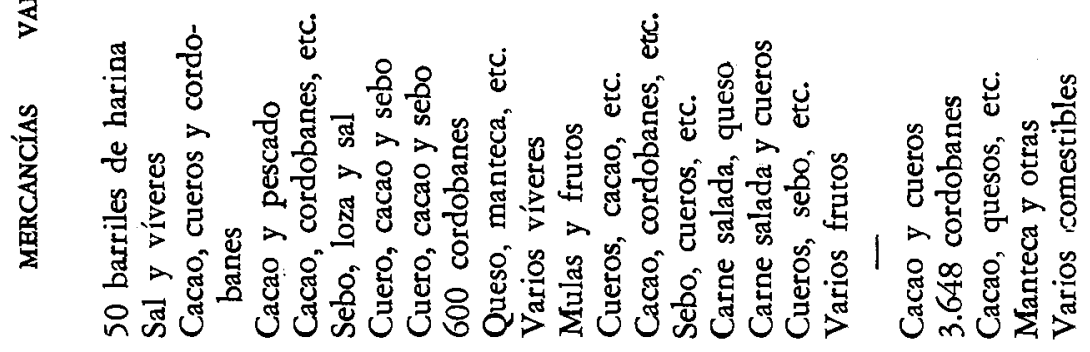

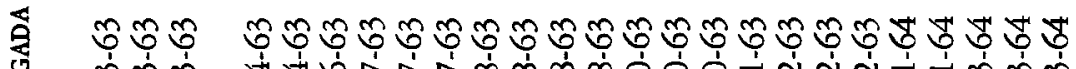

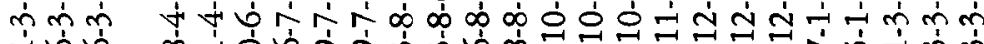

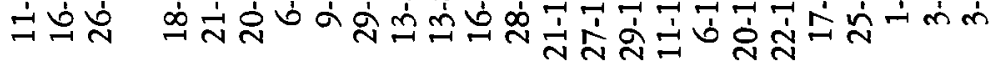

氙

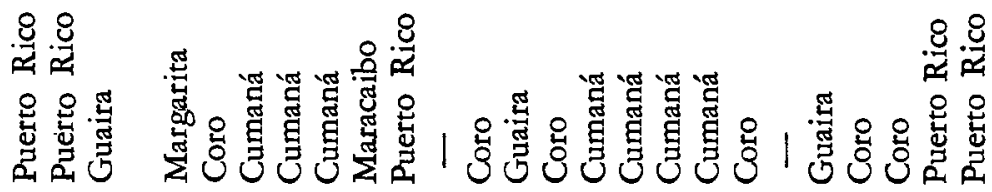

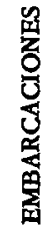

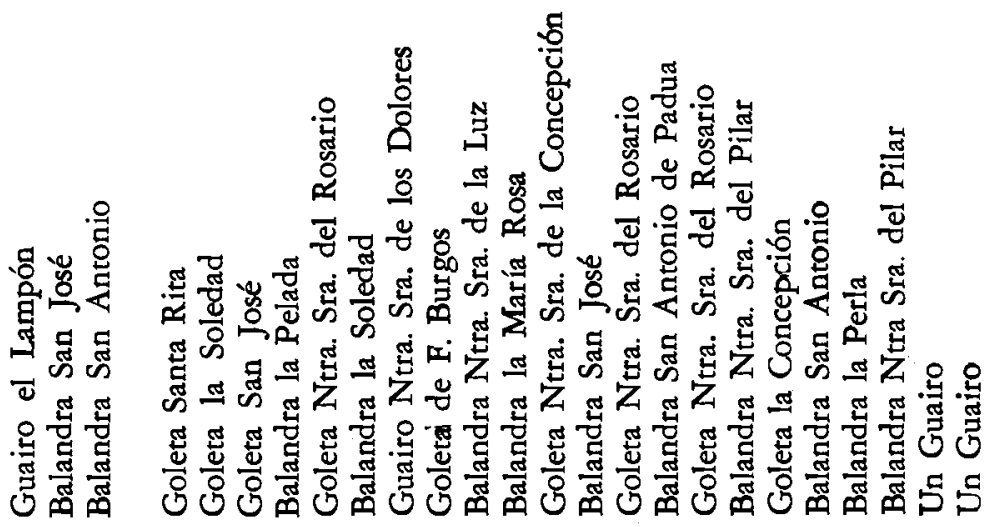




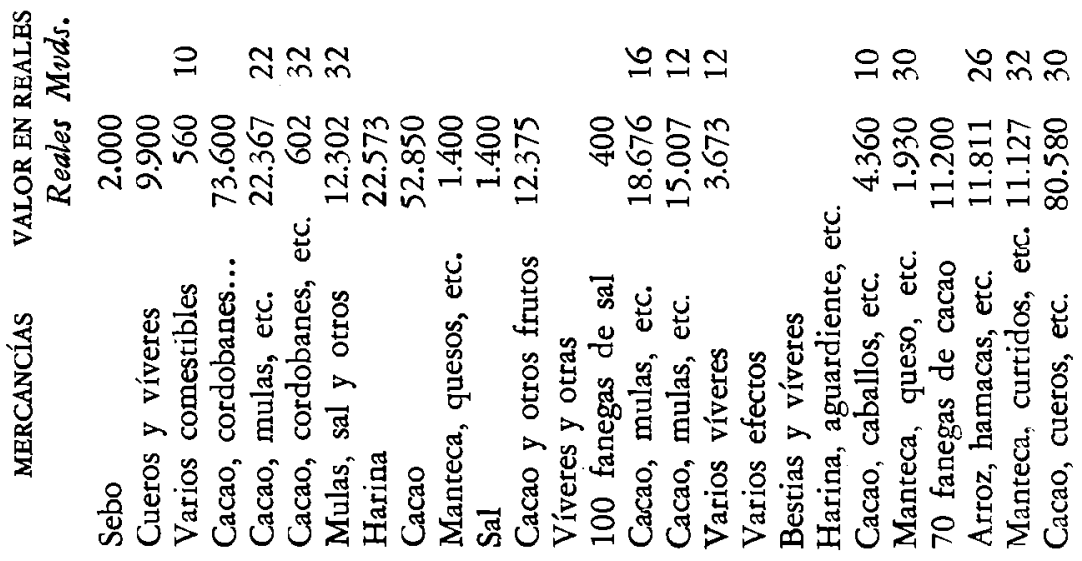

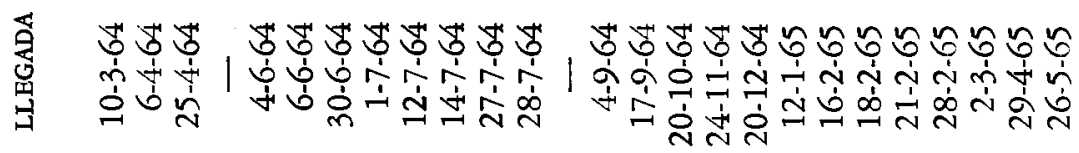

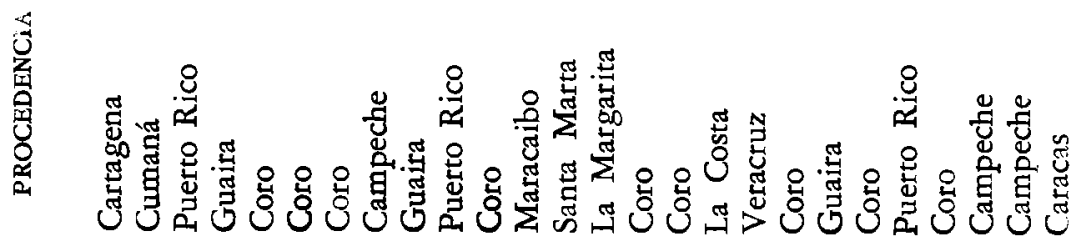

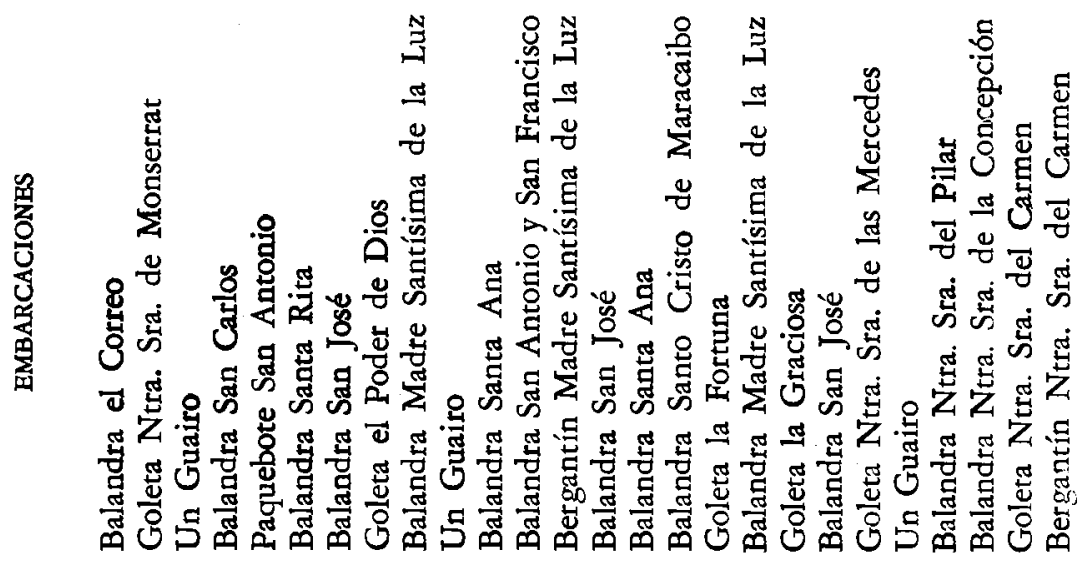




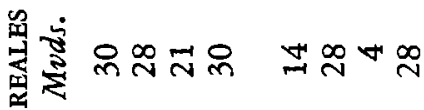

¿

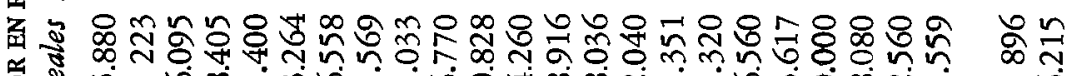

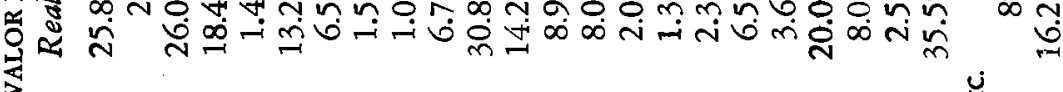

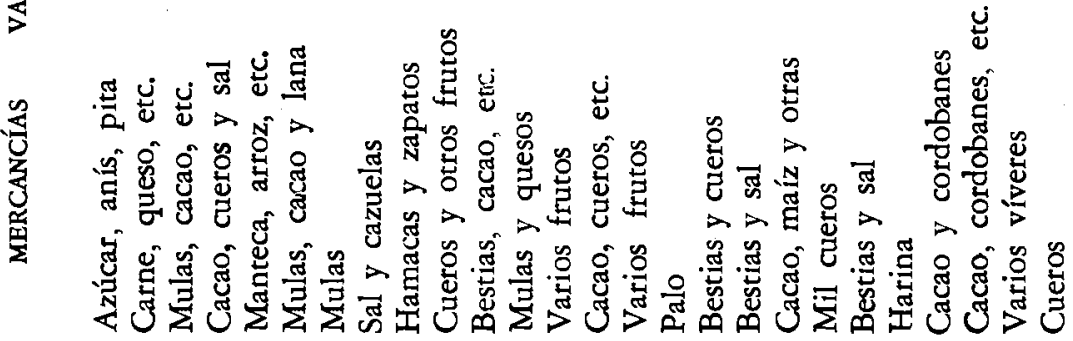

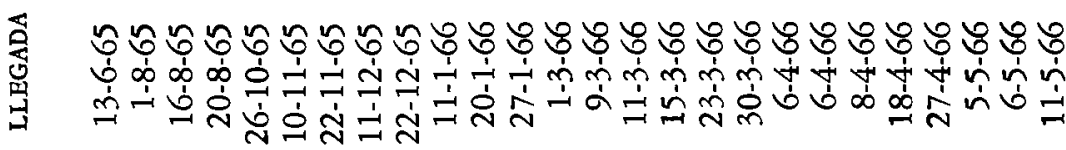

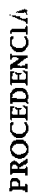

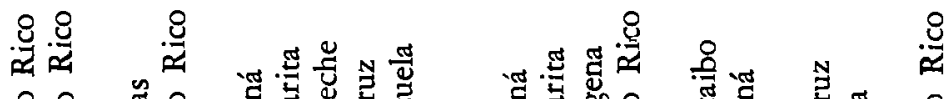

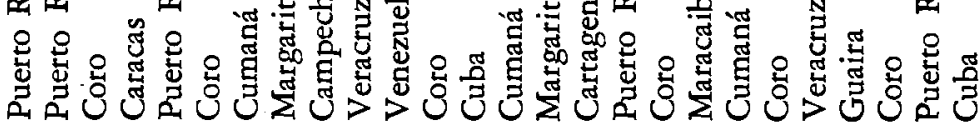

号

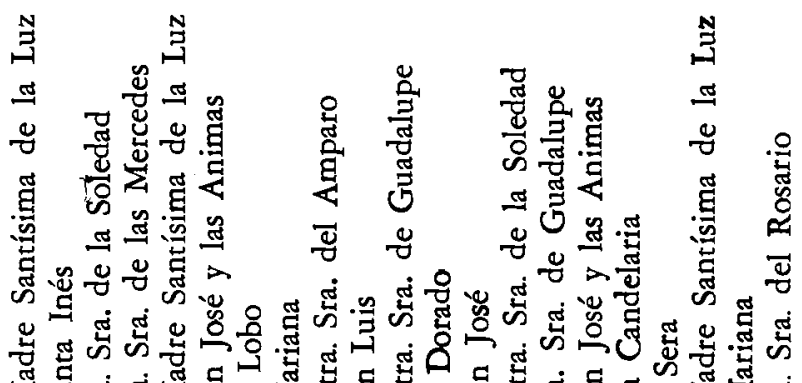

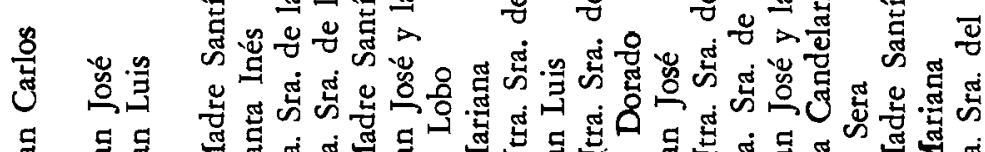

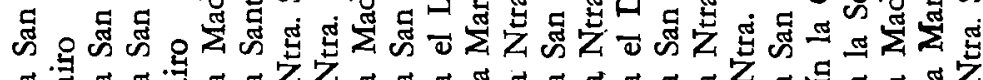
젼

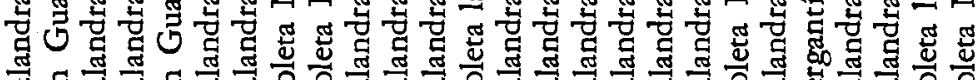

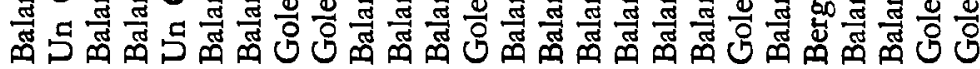


幽宽

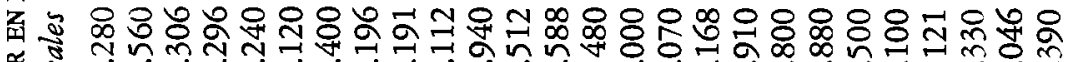

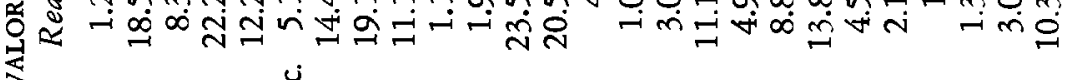

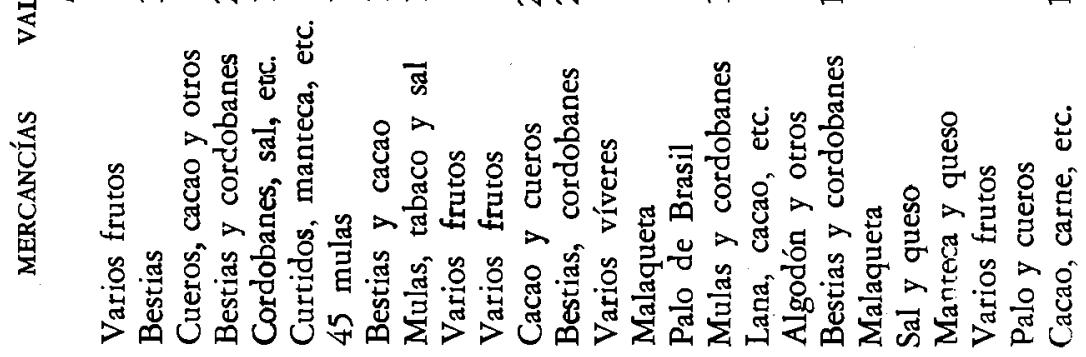

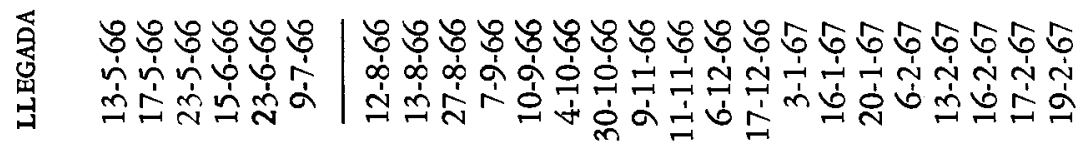

㺃

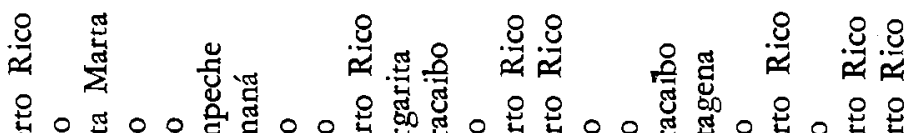
羙융

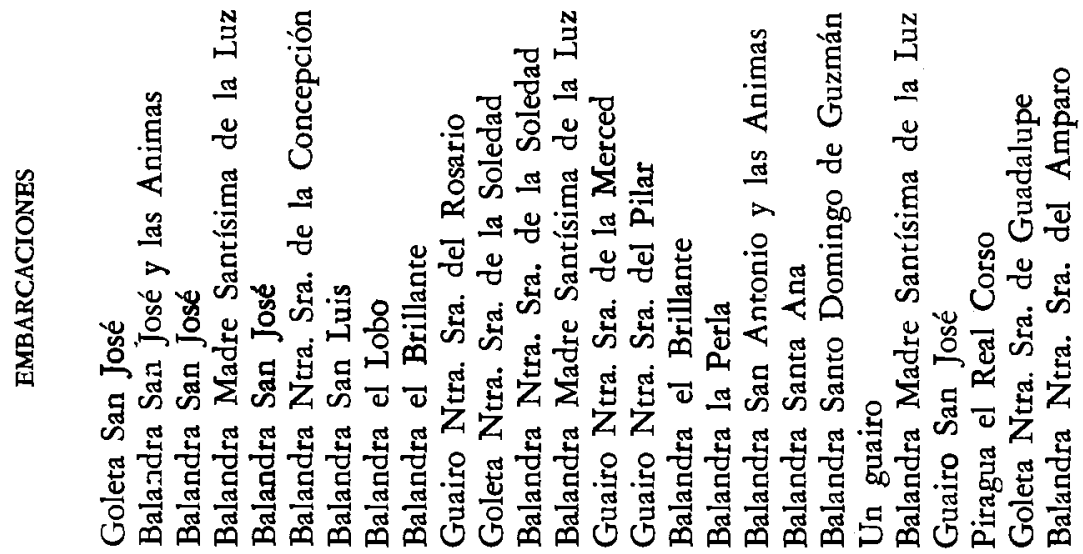


思富 $\stackrel{2}{\rightarrow}$ ก

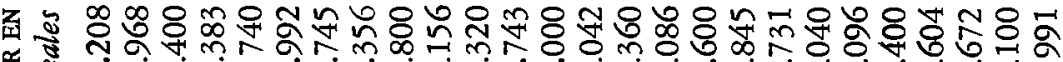
过

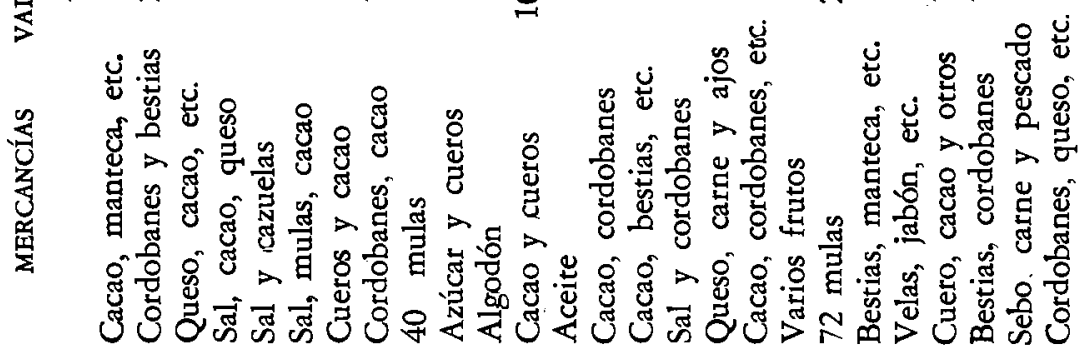

द ヘ่ n่

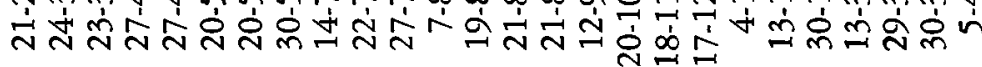

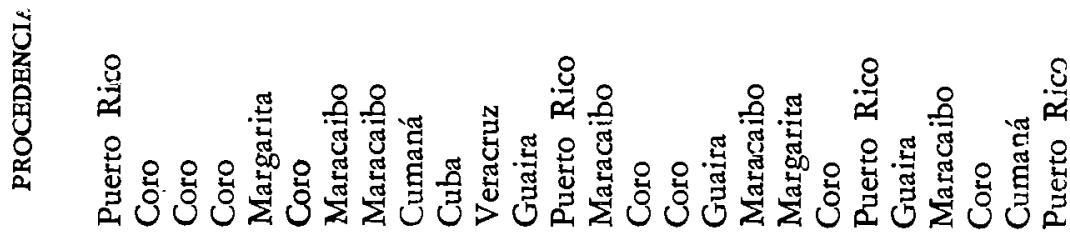

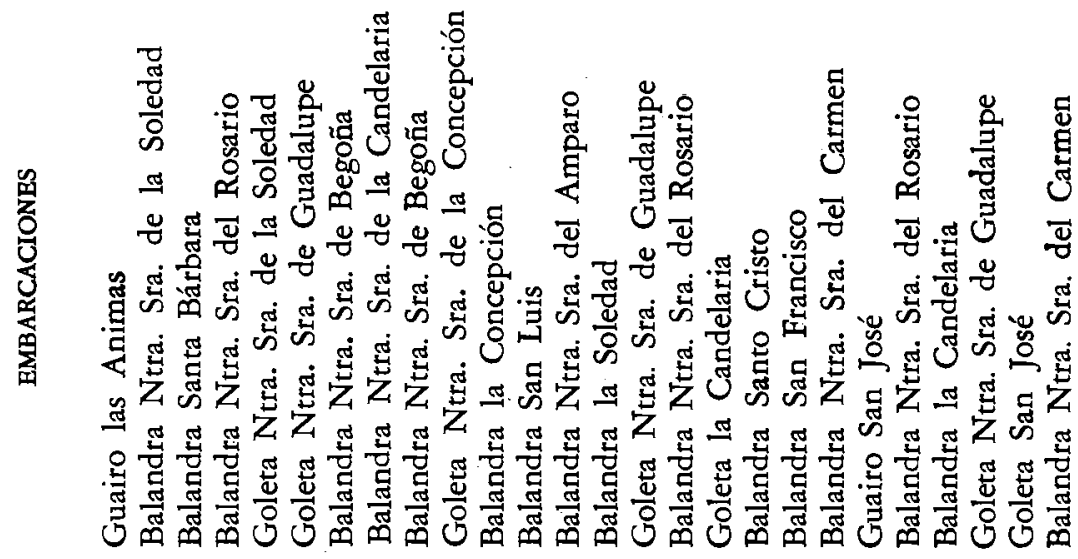




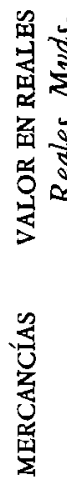

$\stackrel{\dot{s}}{\stackrel{\Sigma}{z}}=$

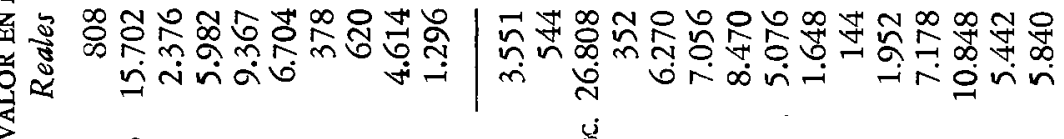

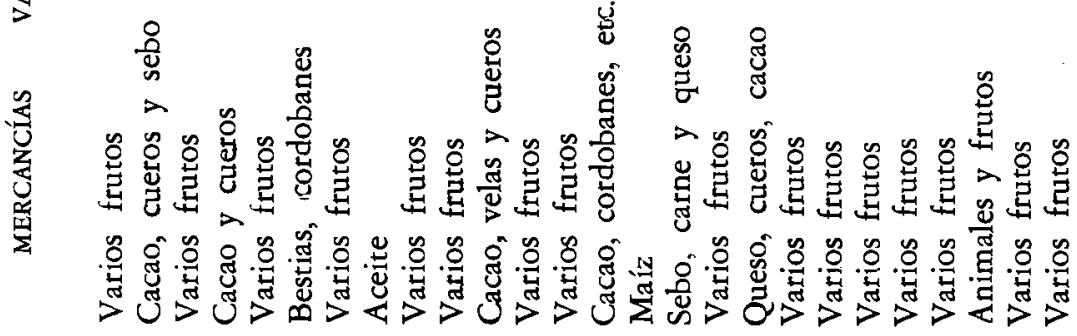

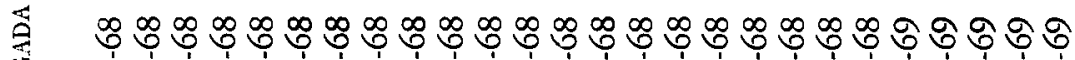

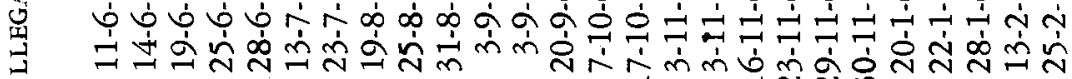

芑
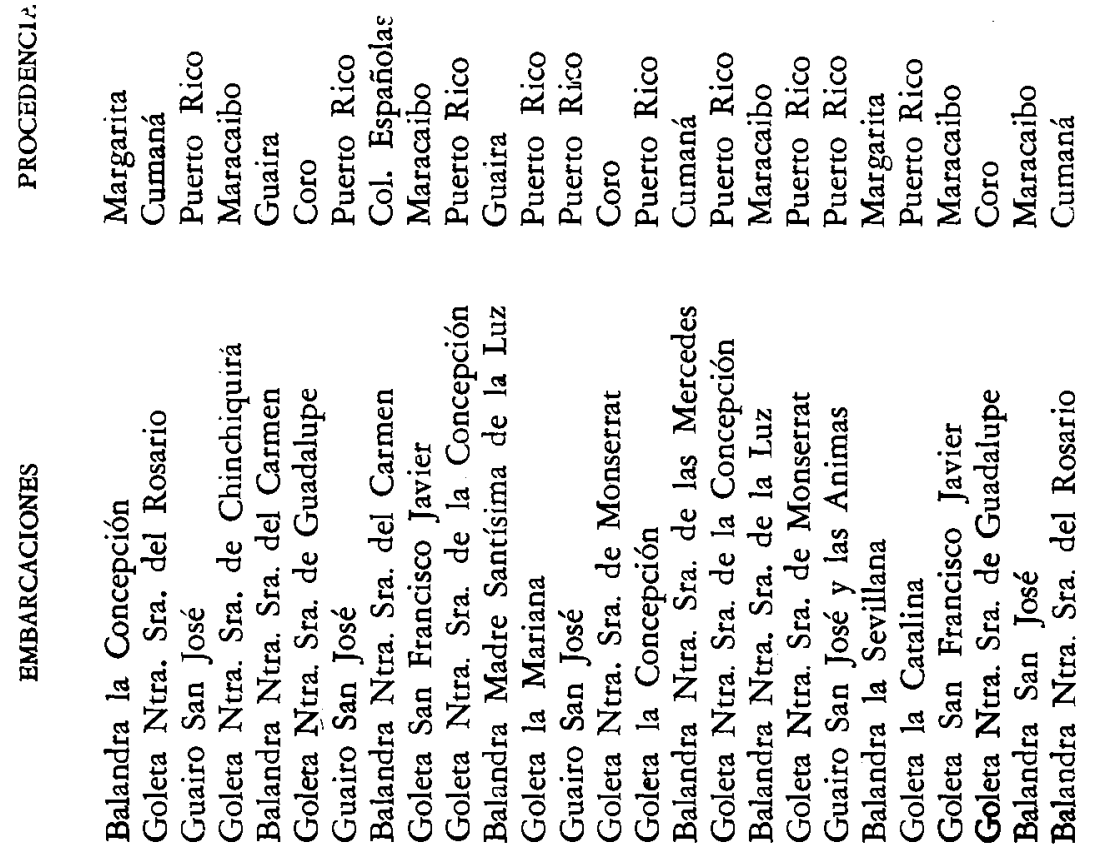
量富 กิ

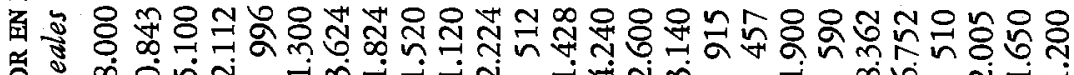

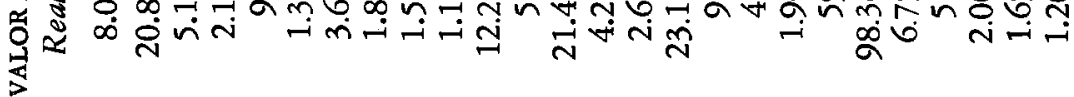

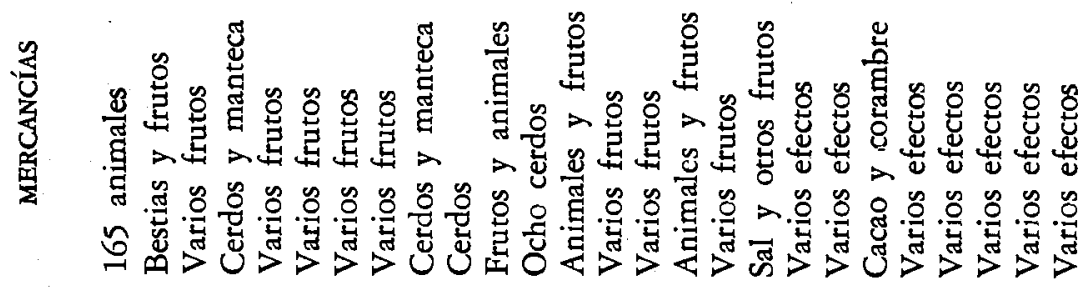

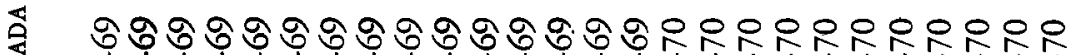

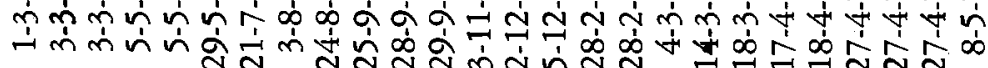

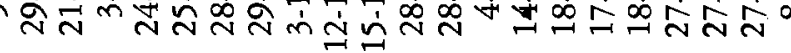

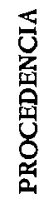

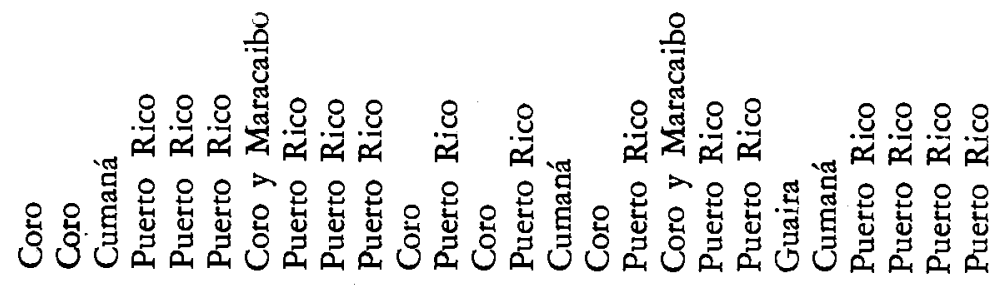

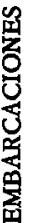

皇量

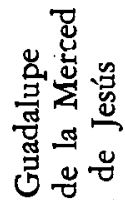

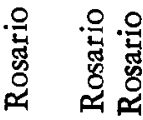

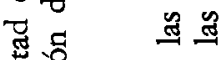

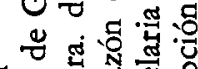

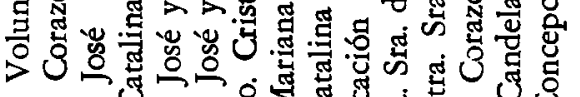

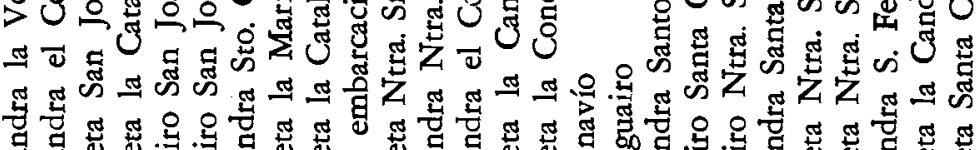

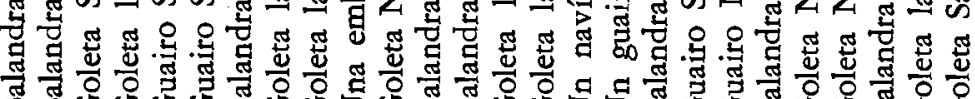

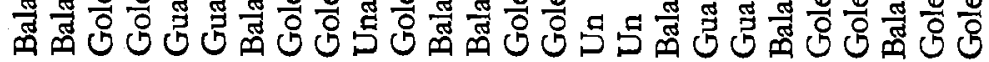




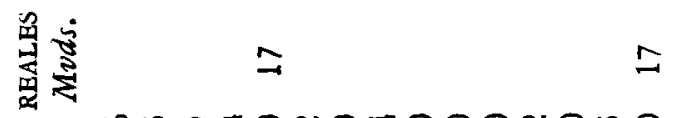

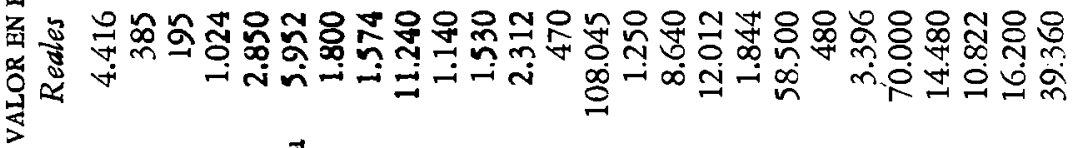

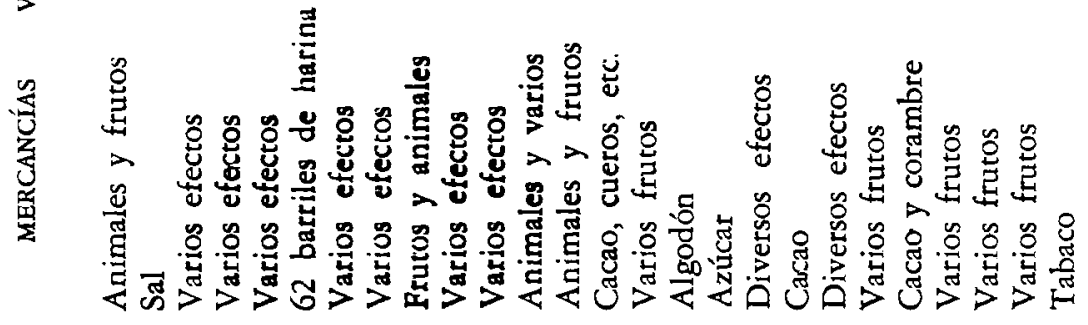

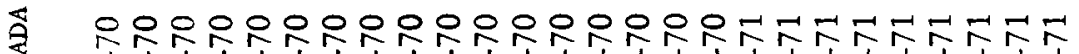
ஸ் n்ப்ட்

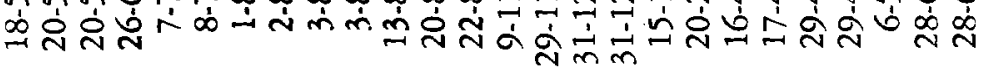
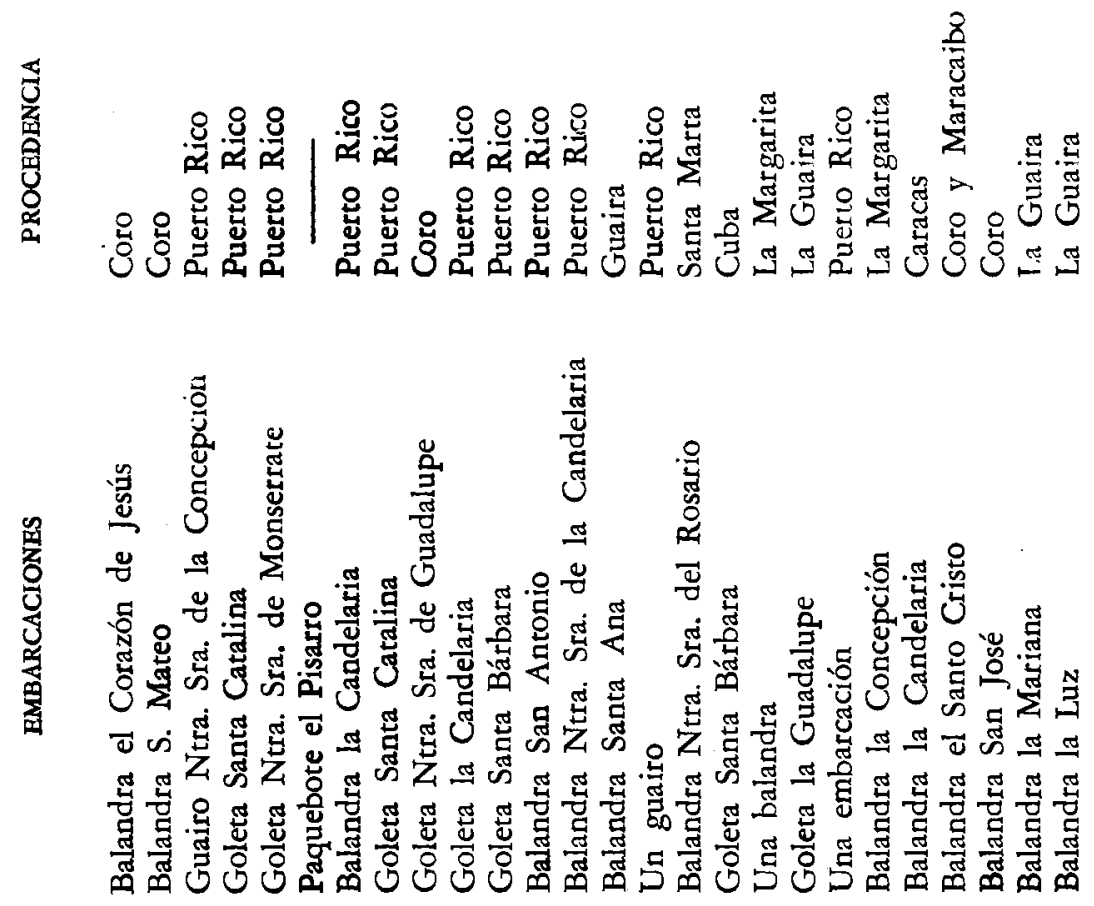
焉富

$\infty$

$\stackrel{\infty}{0}$

곤 过

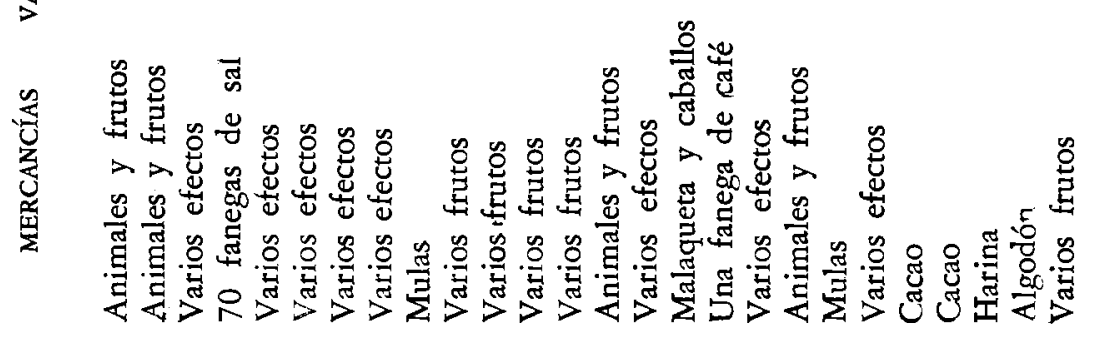

㤂

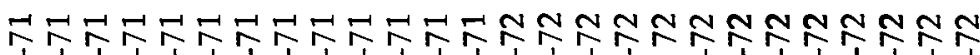

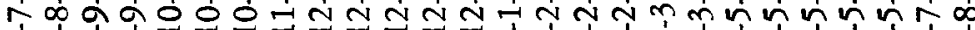
n்

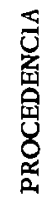

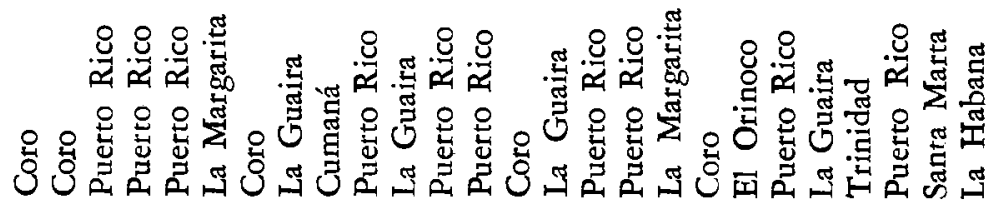

琴

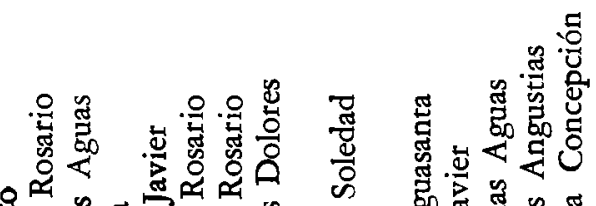

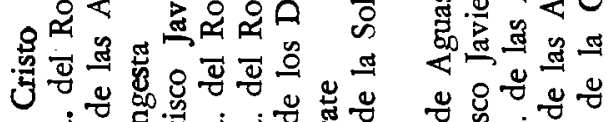

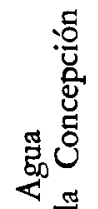

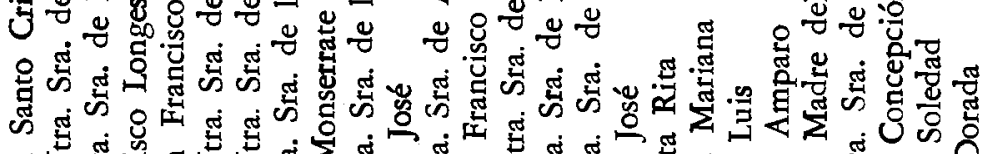

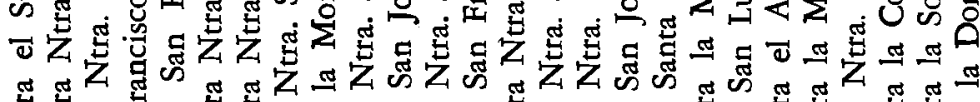

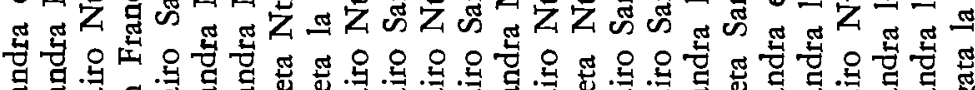

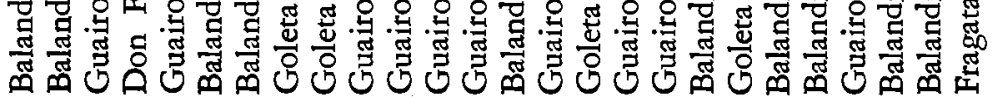




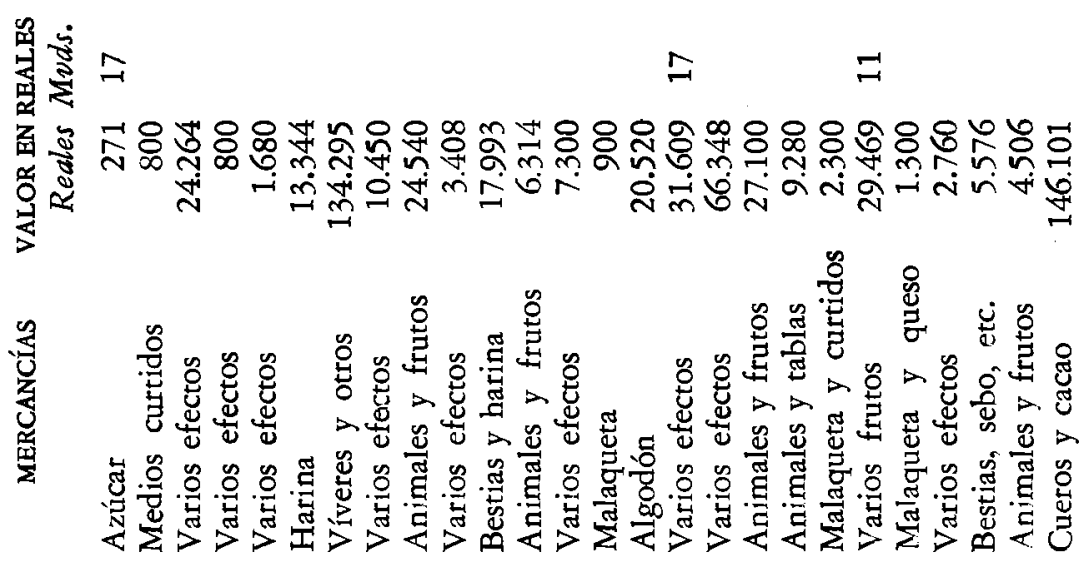

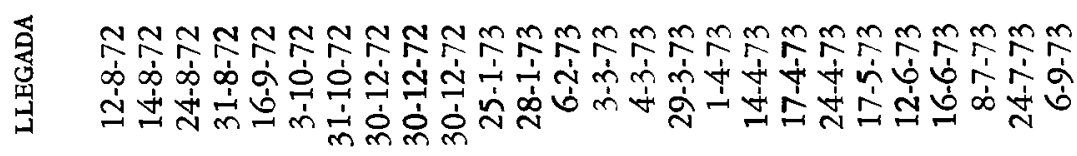

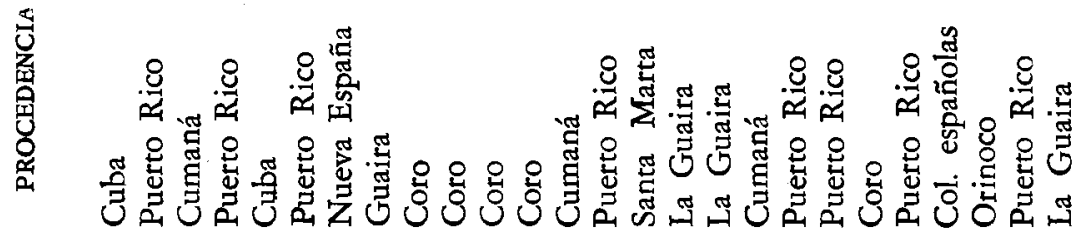

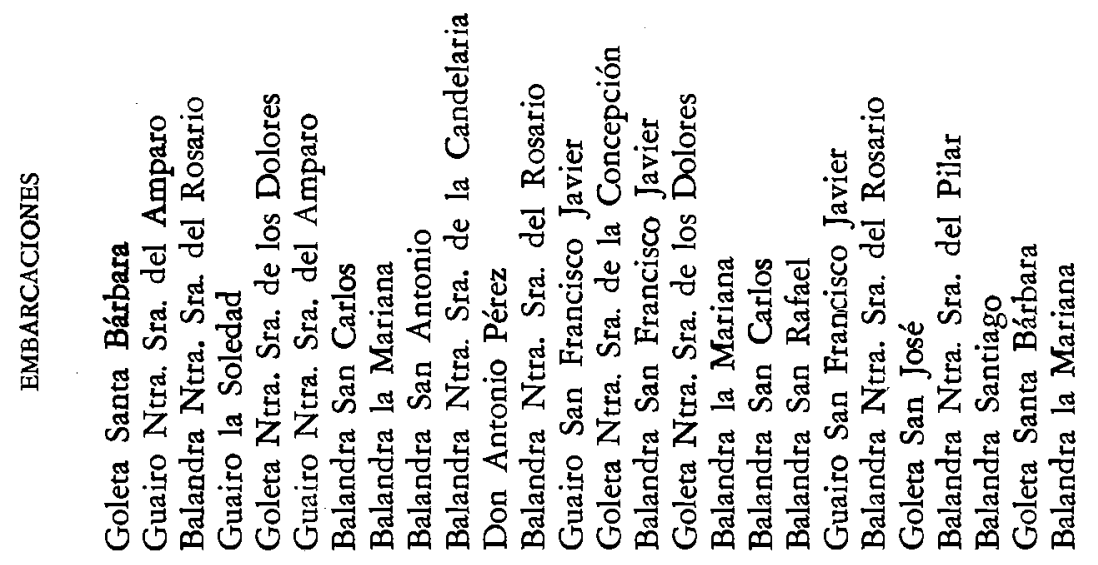


舅蓄

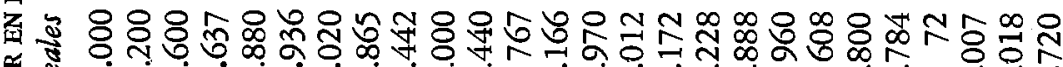

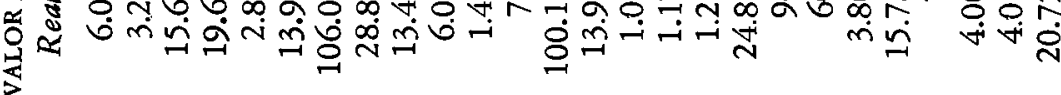

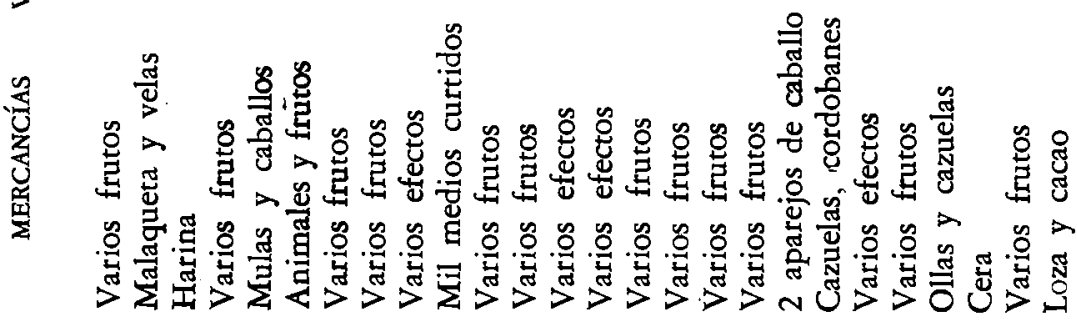

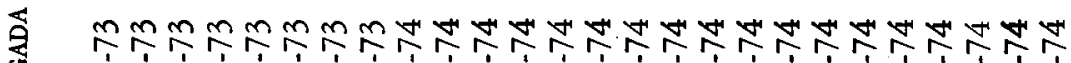

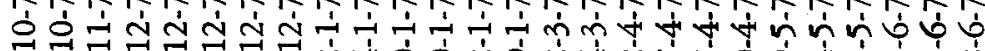

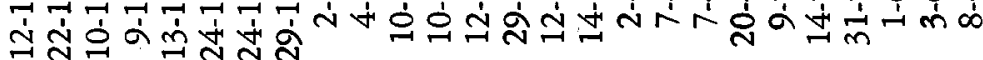
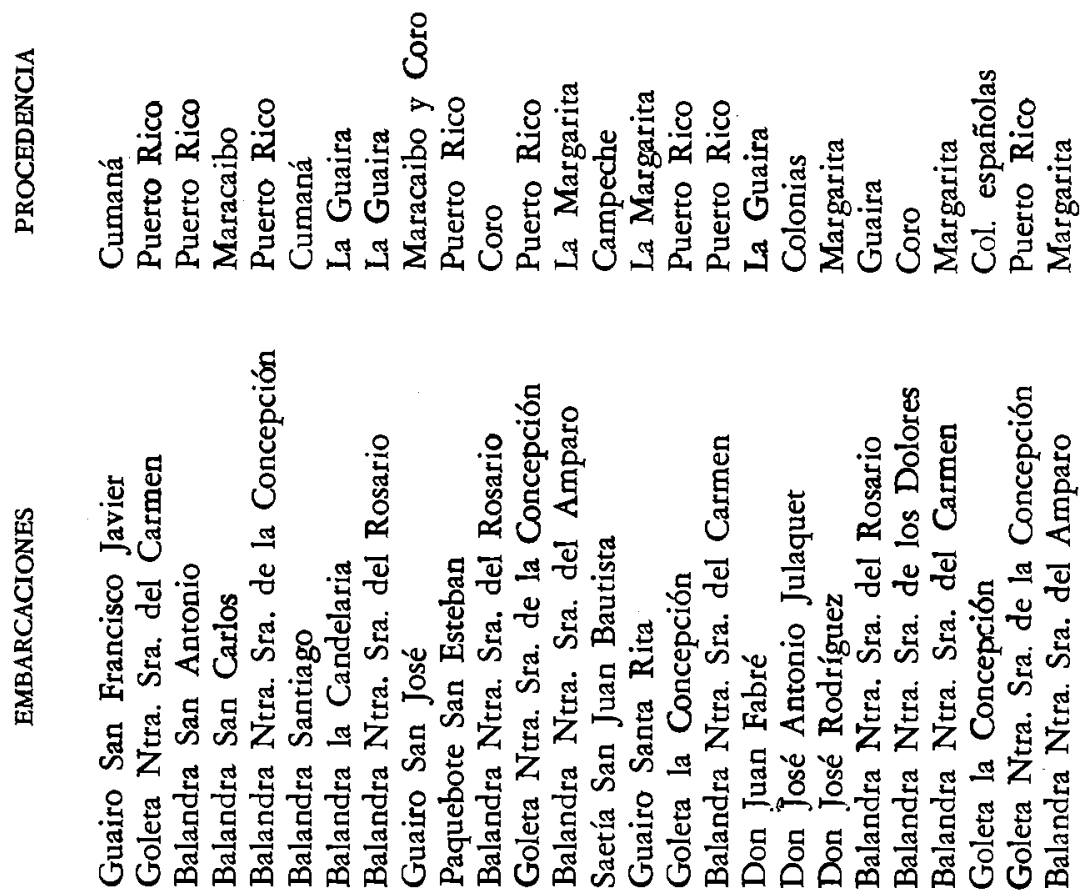
思恋

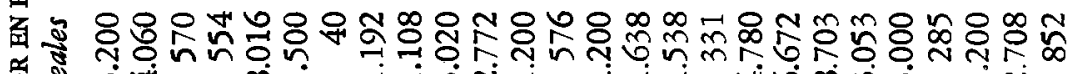

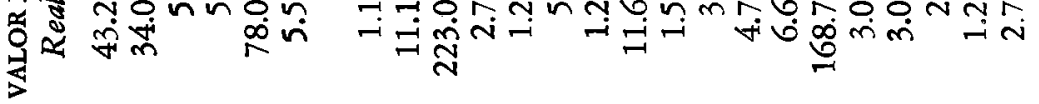

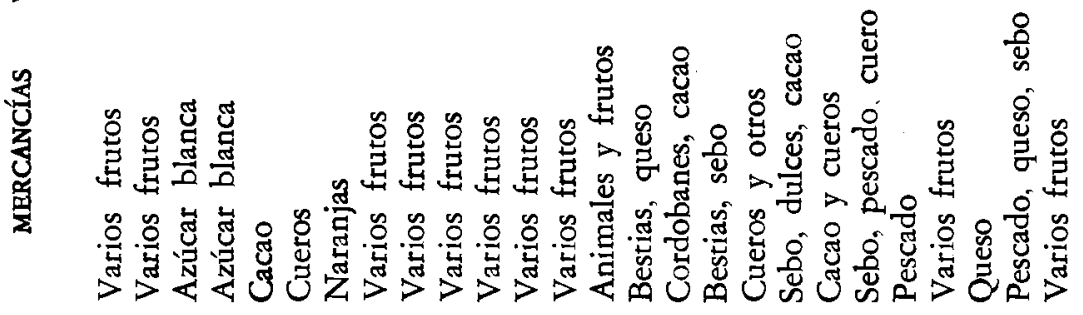

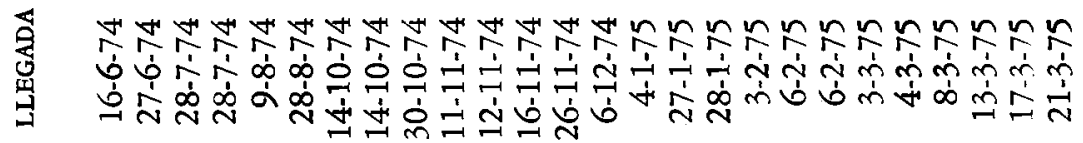

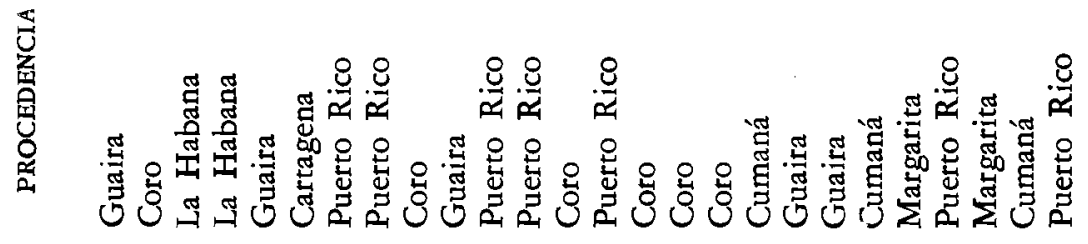

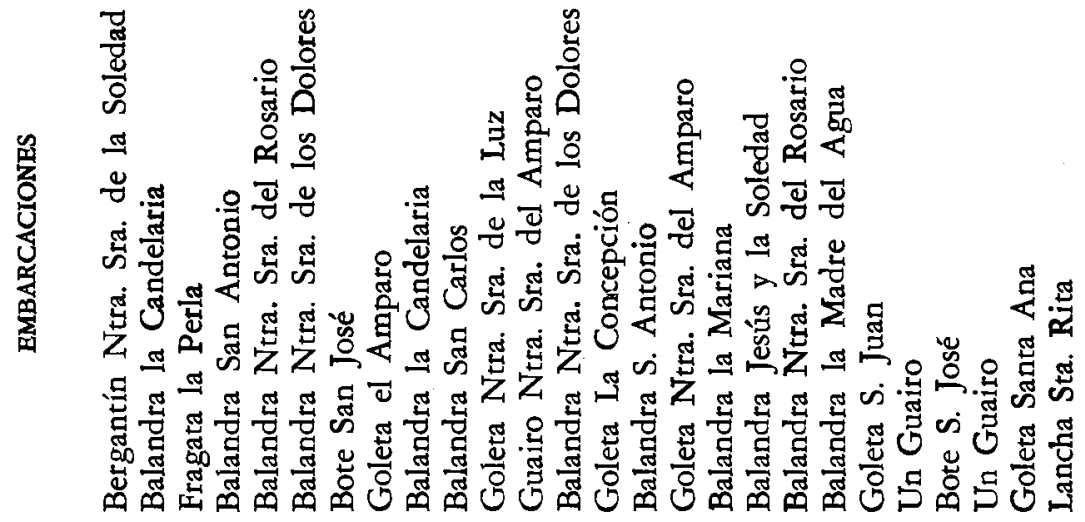




\section{舀蓄}

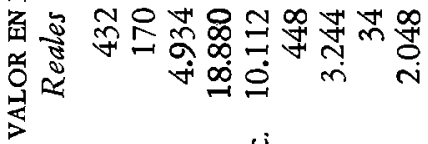

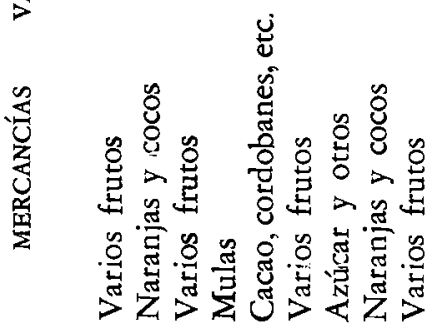

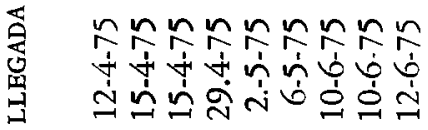

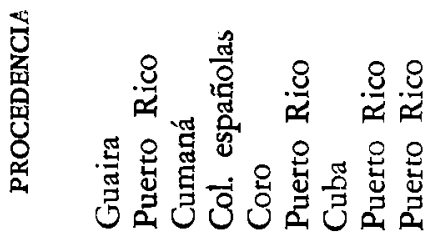

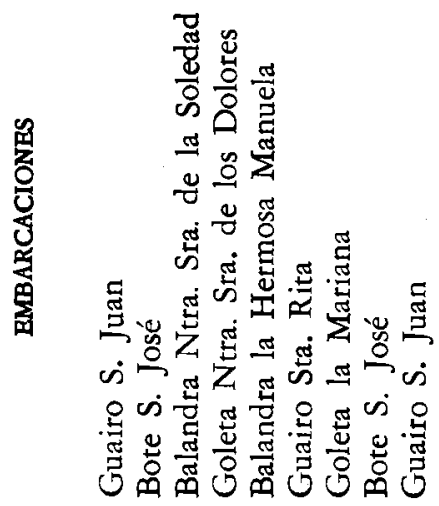




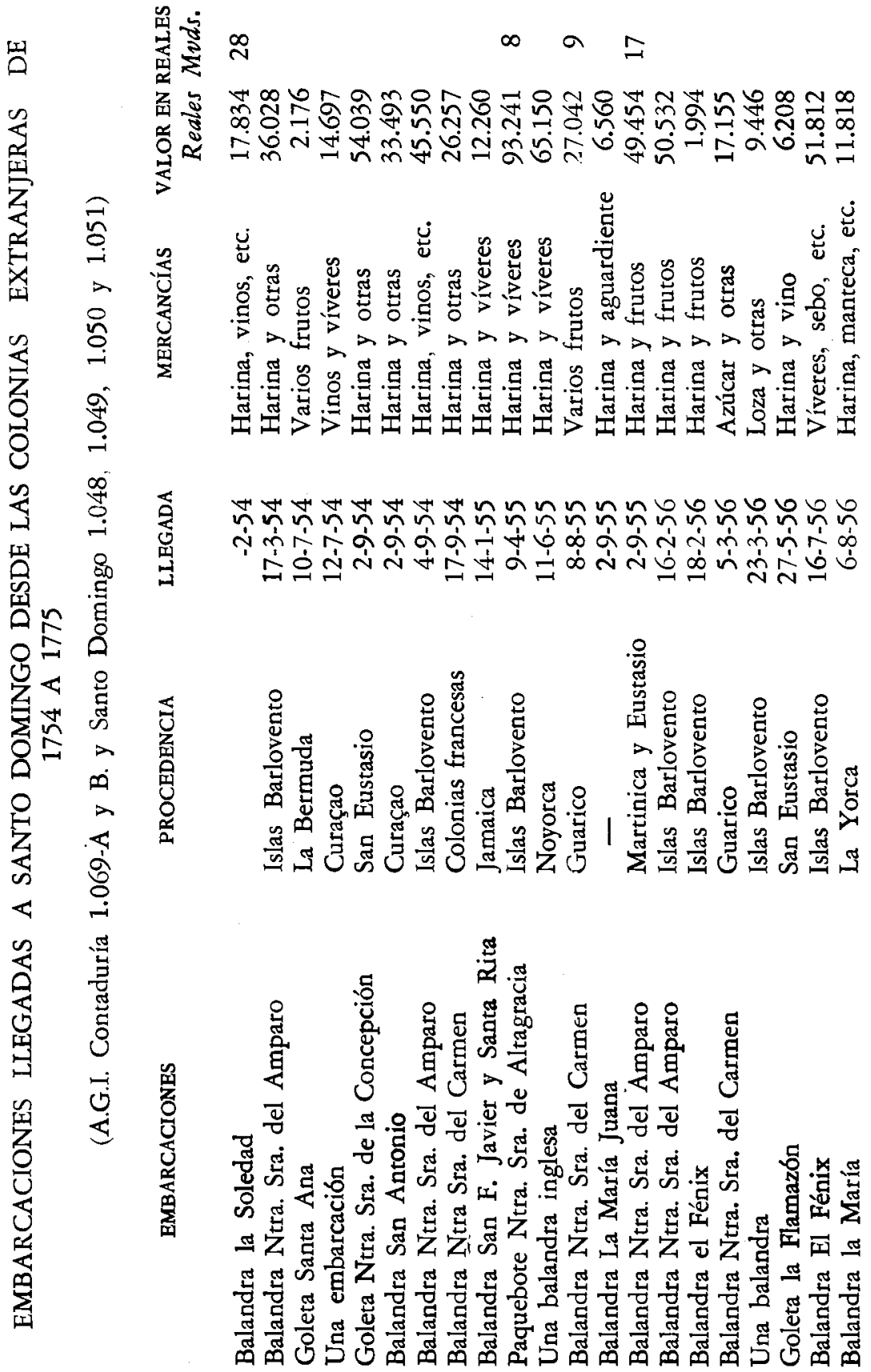


密富

戛

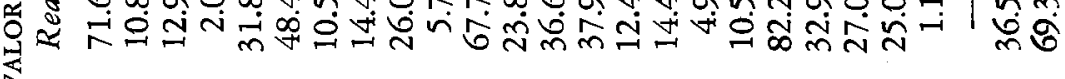

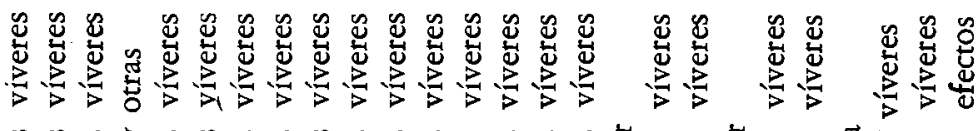

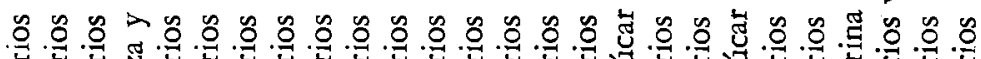

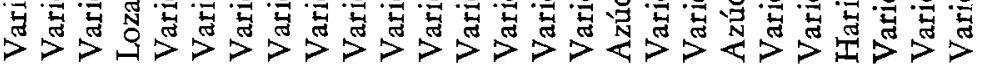

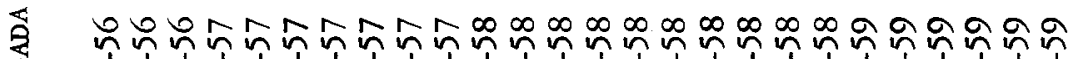

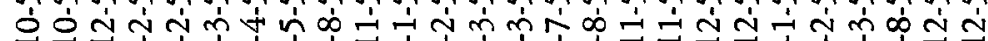
实向

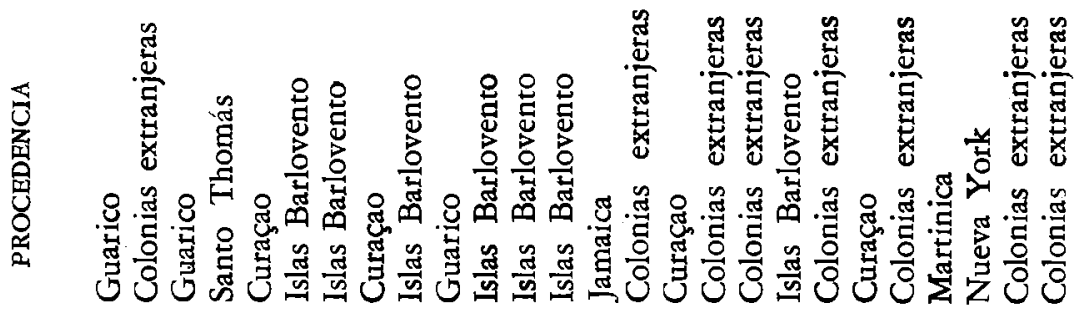

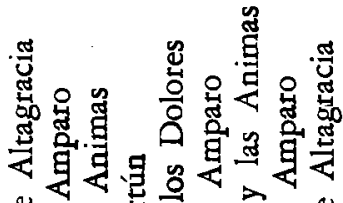

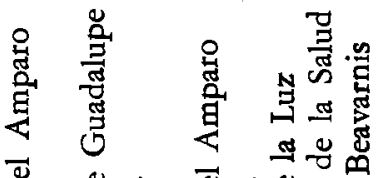

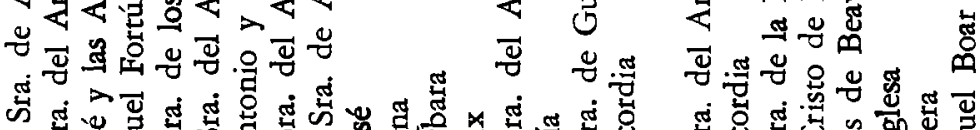

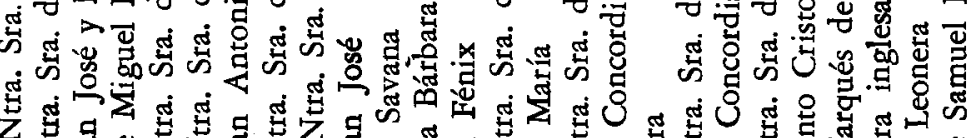

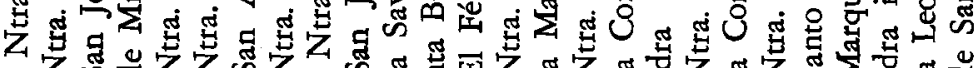

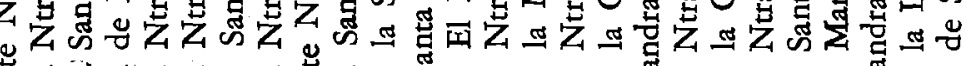

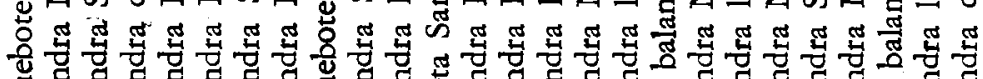

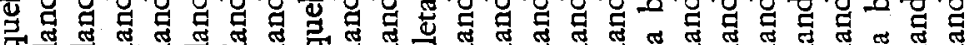

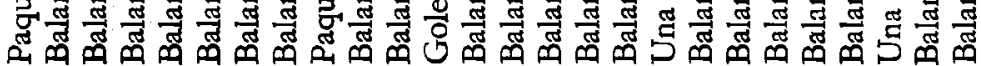


䖢守

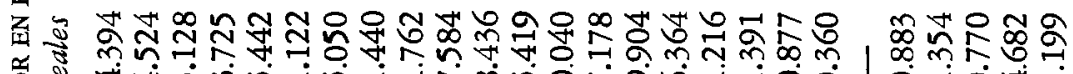

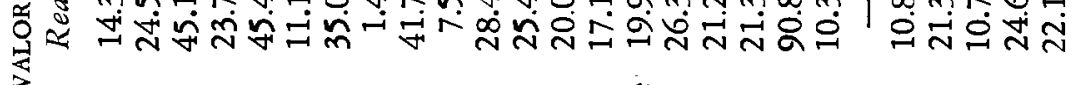

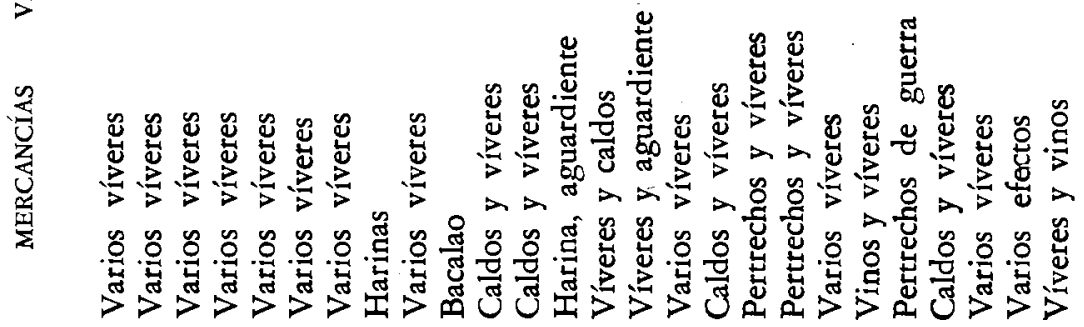

車

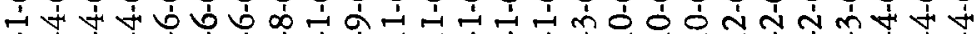
क +
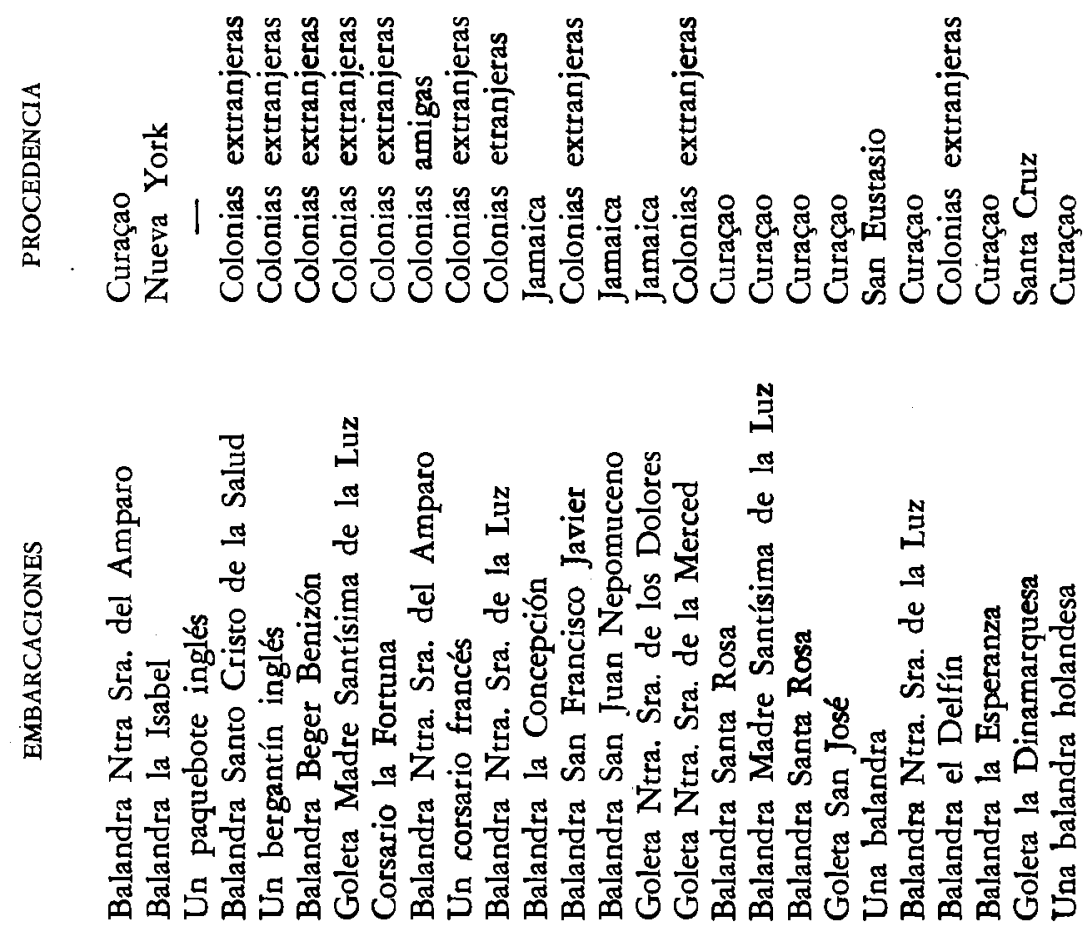


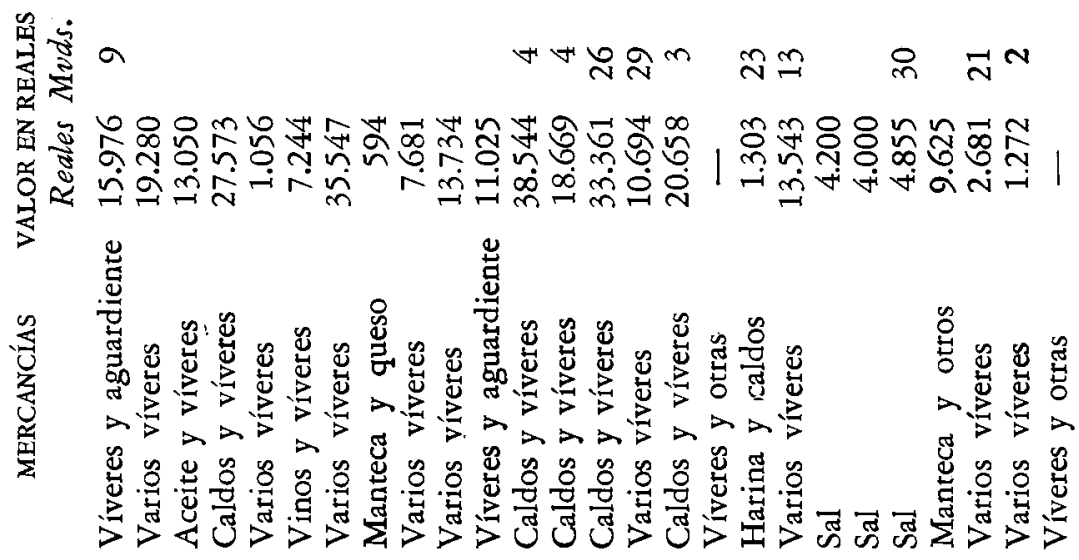

द

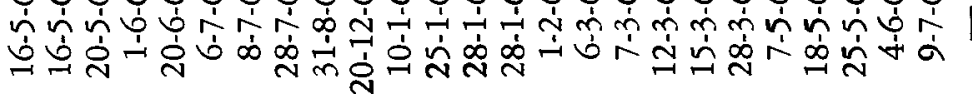
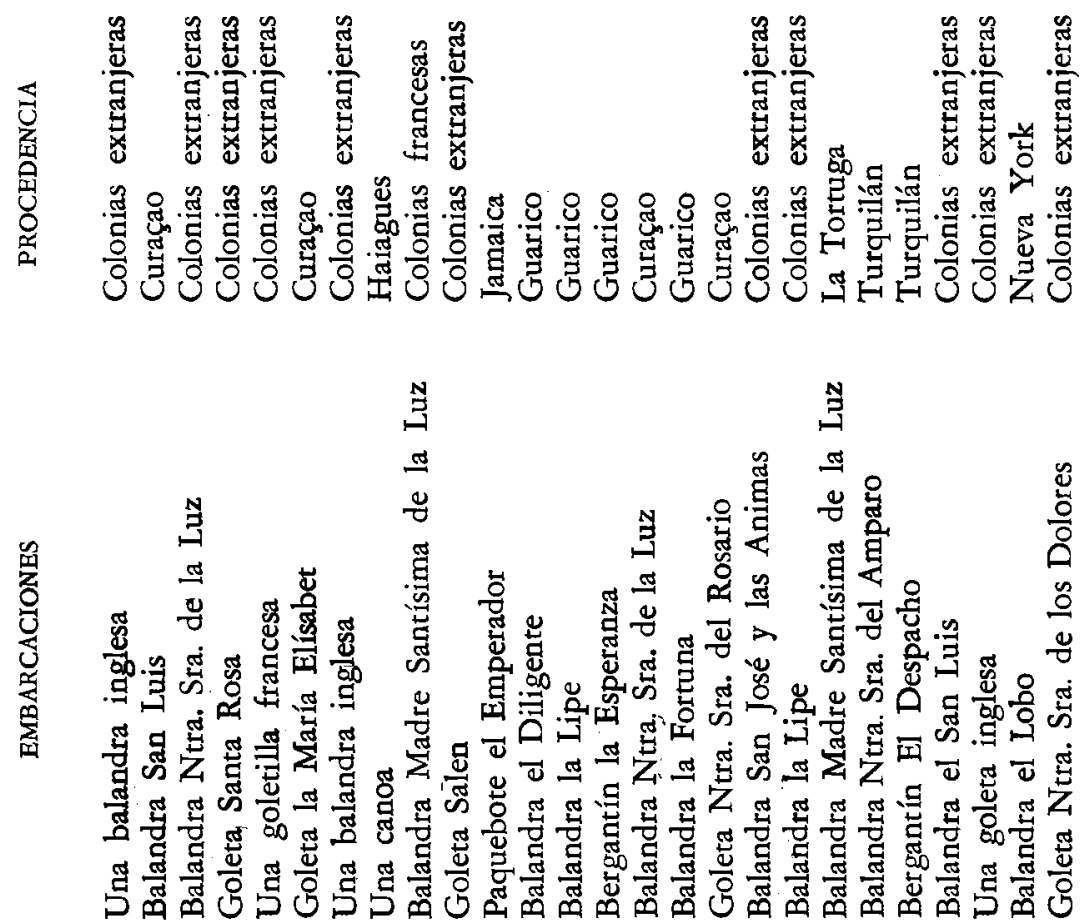


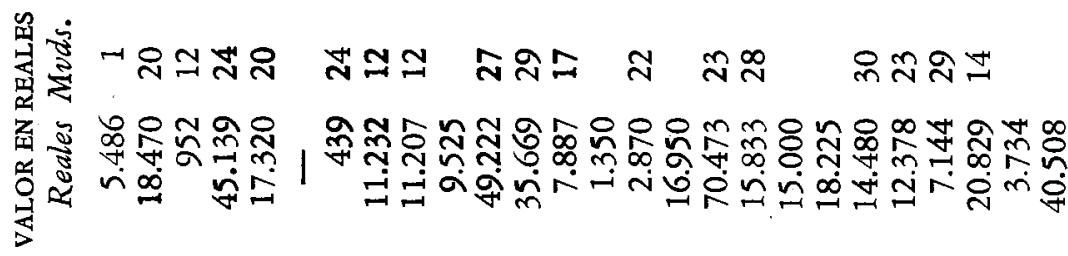

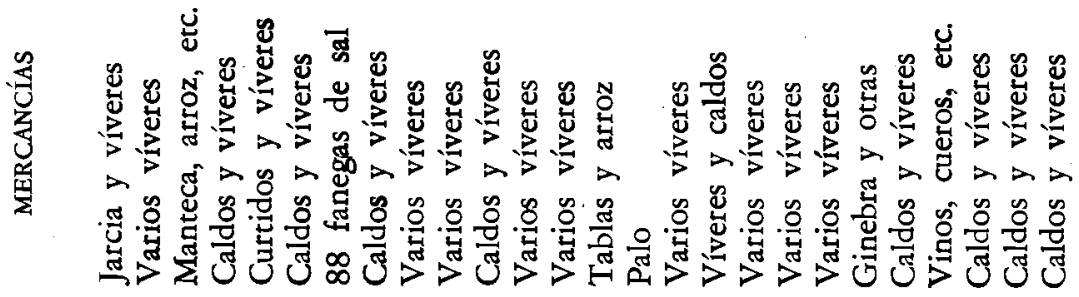

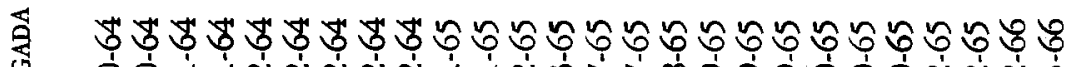

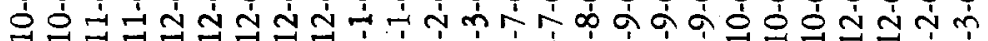

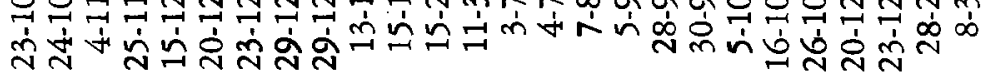

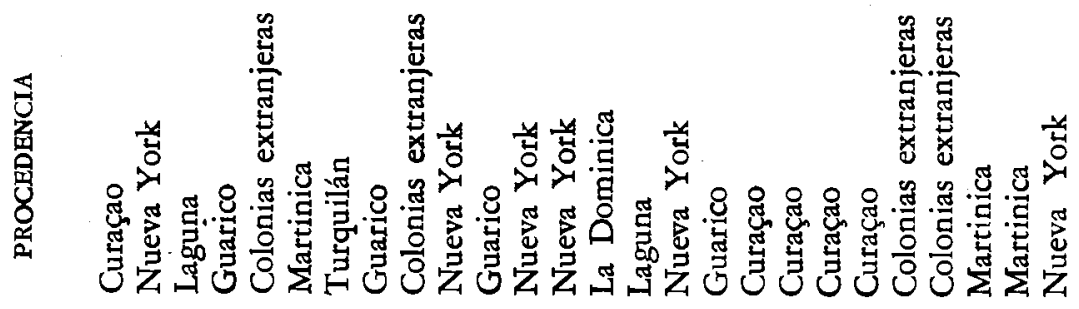

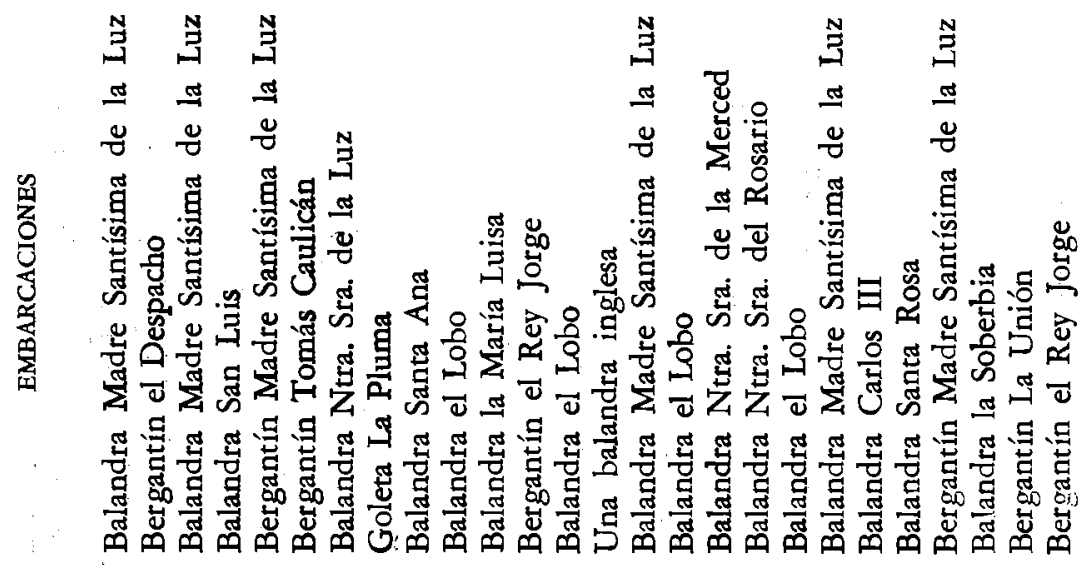


自

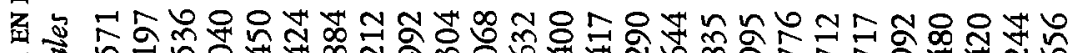
\&

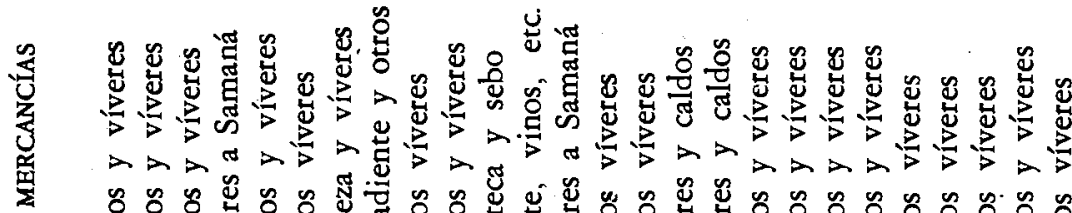

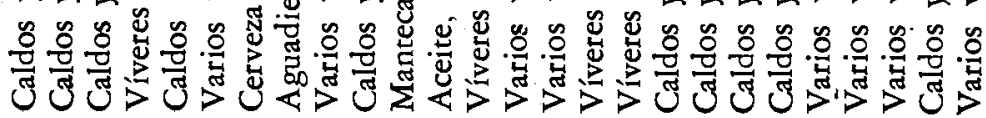

志

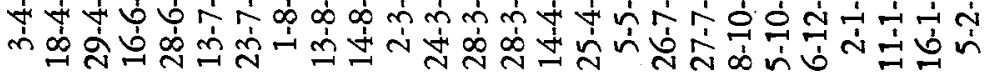

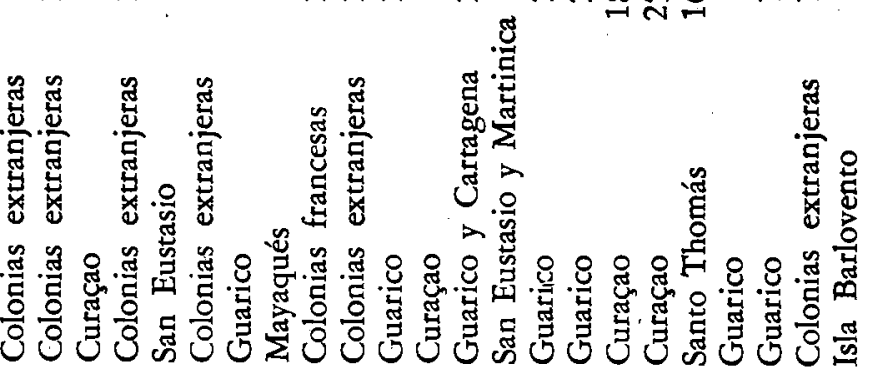

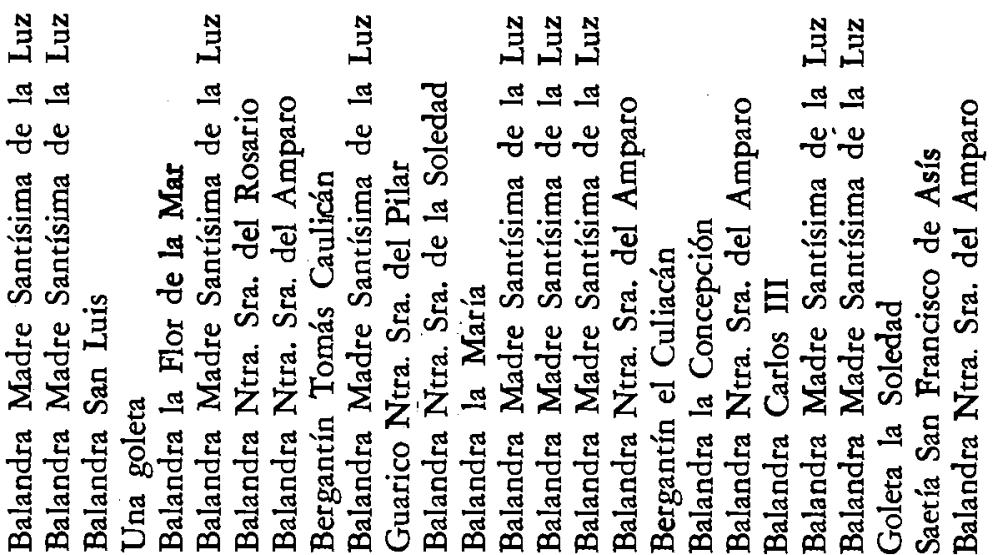




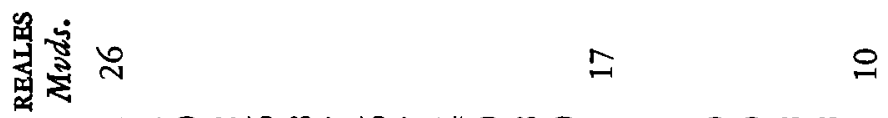

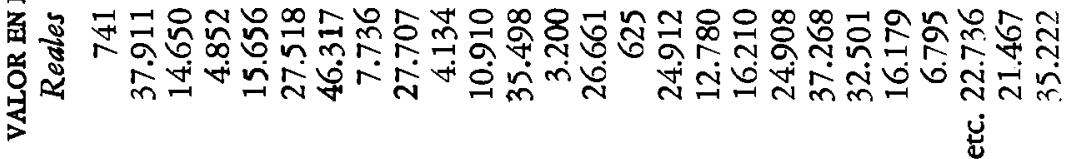

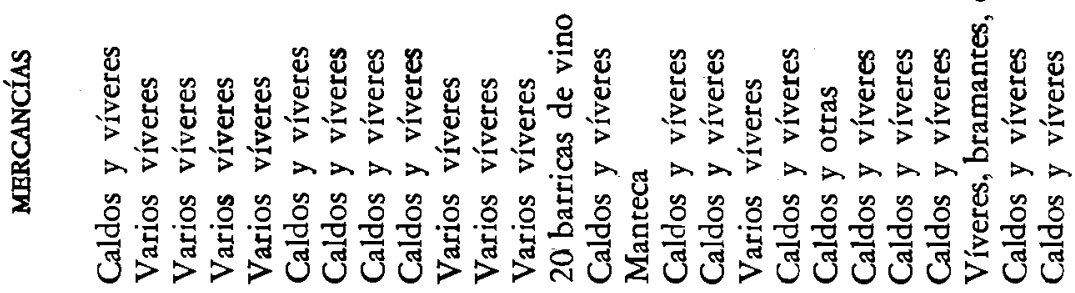

언 $\quad$ \% +่ ó bु
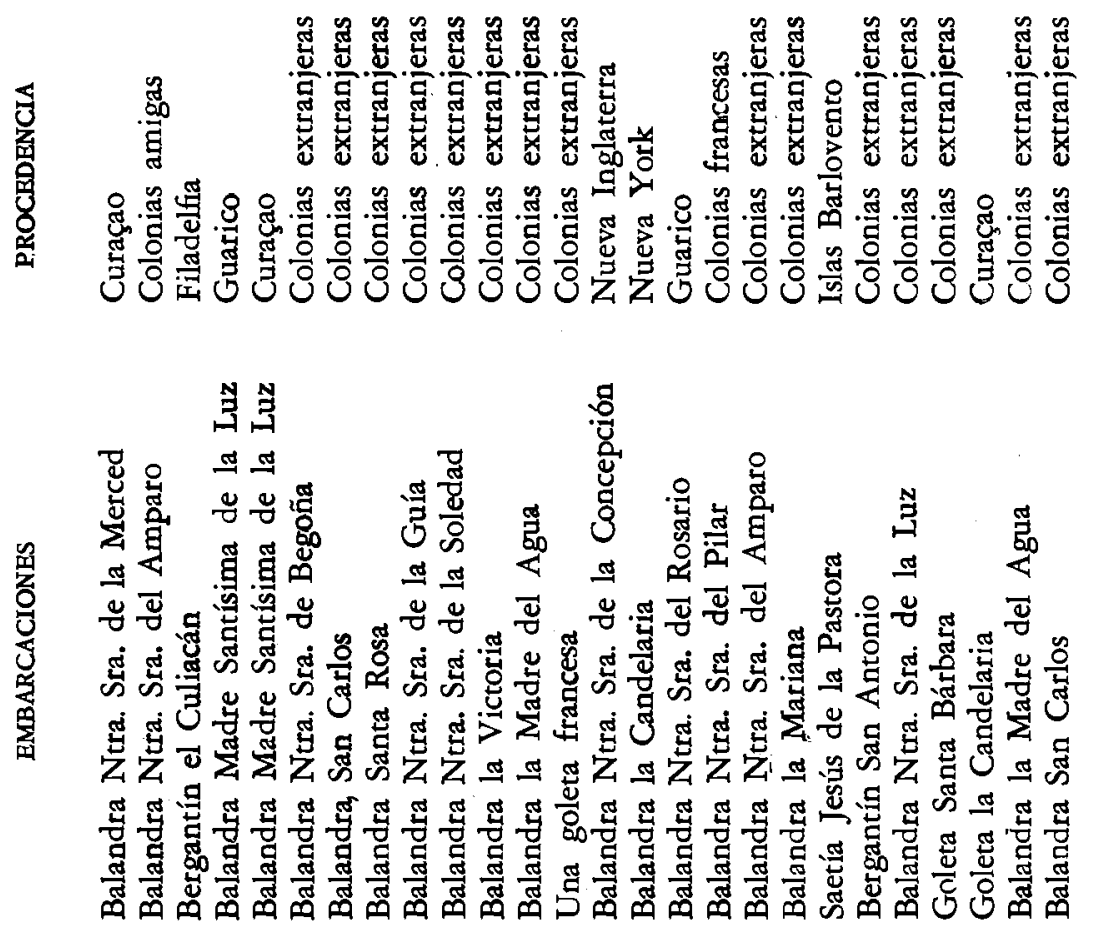


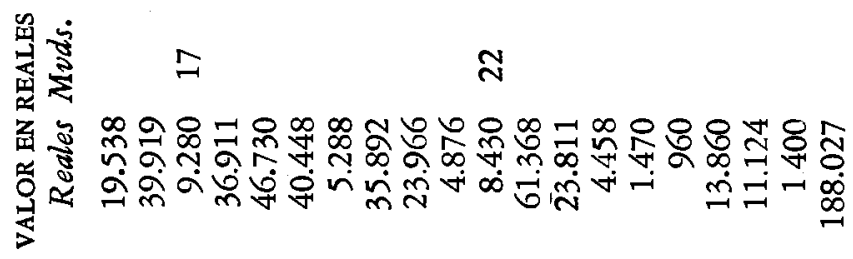

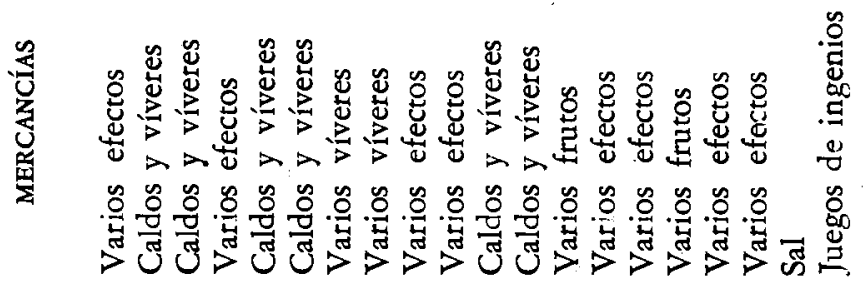

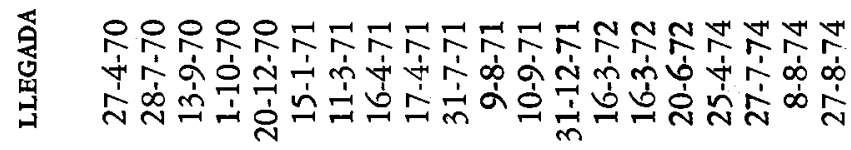
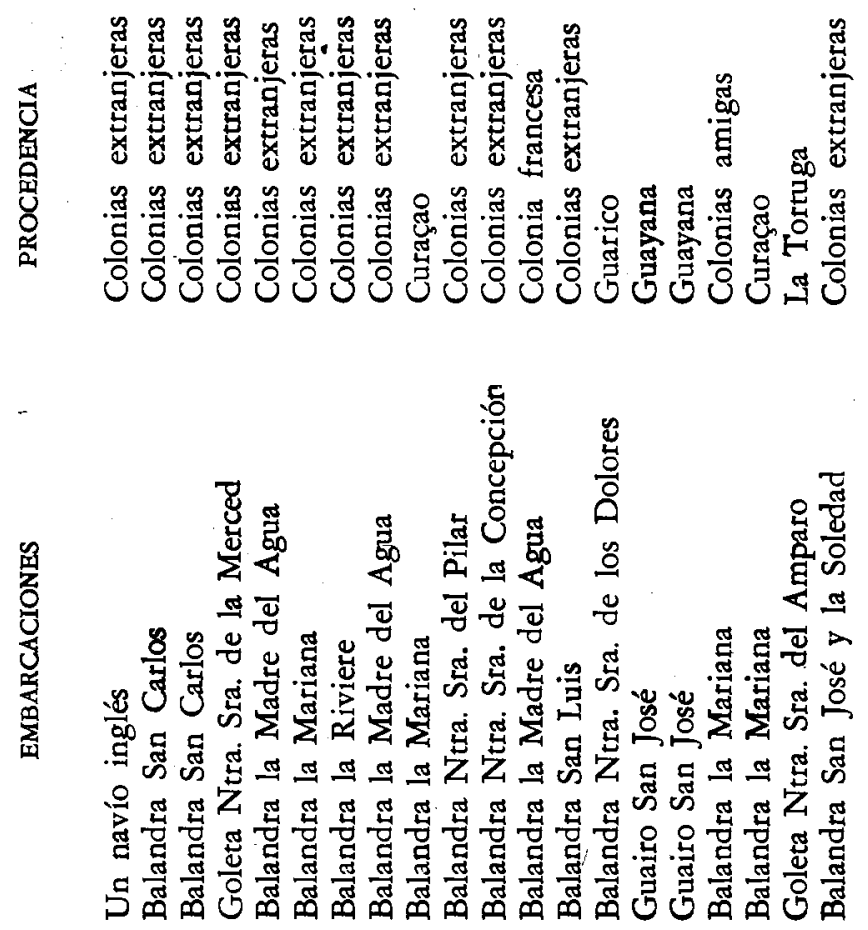


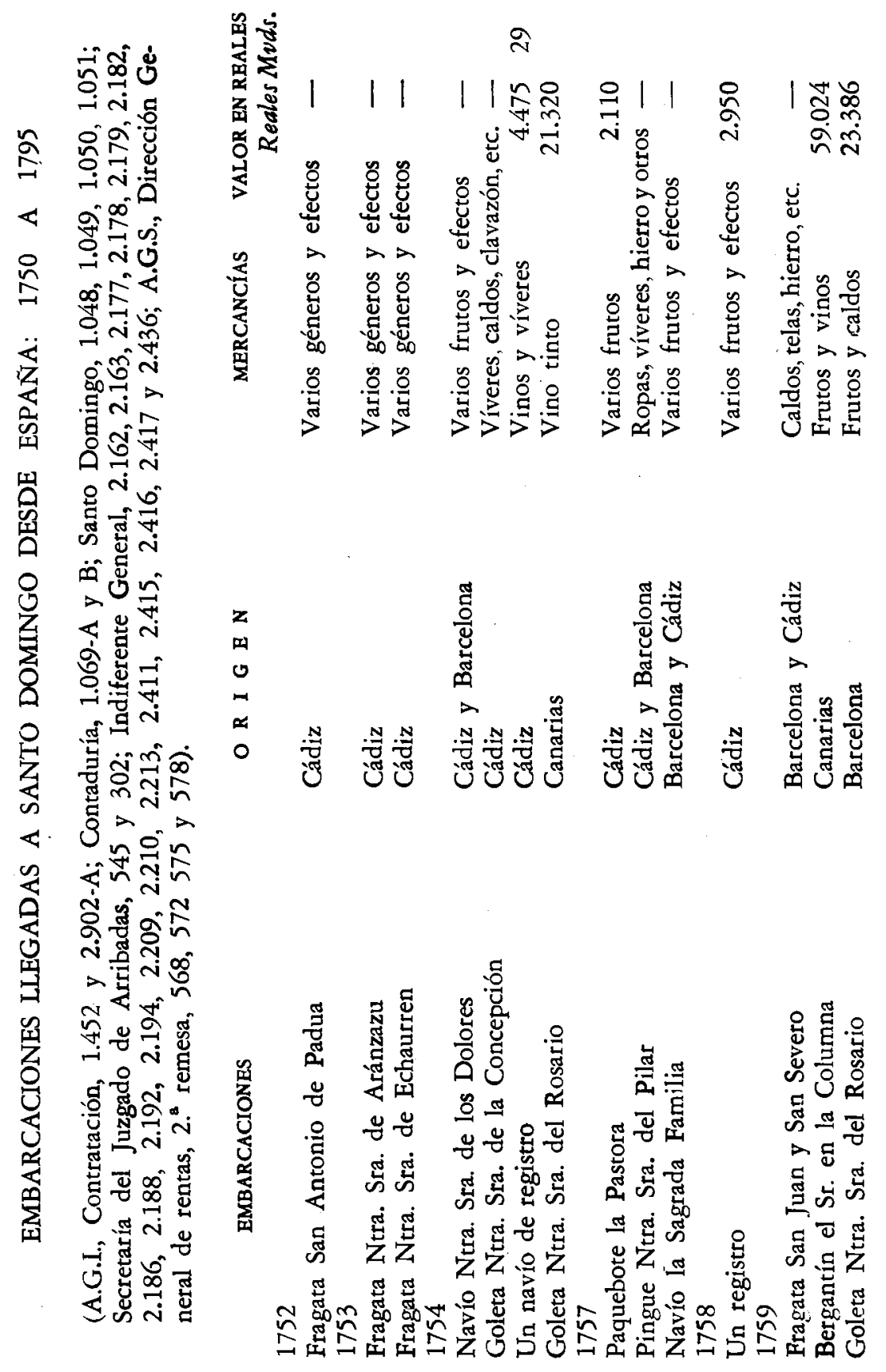



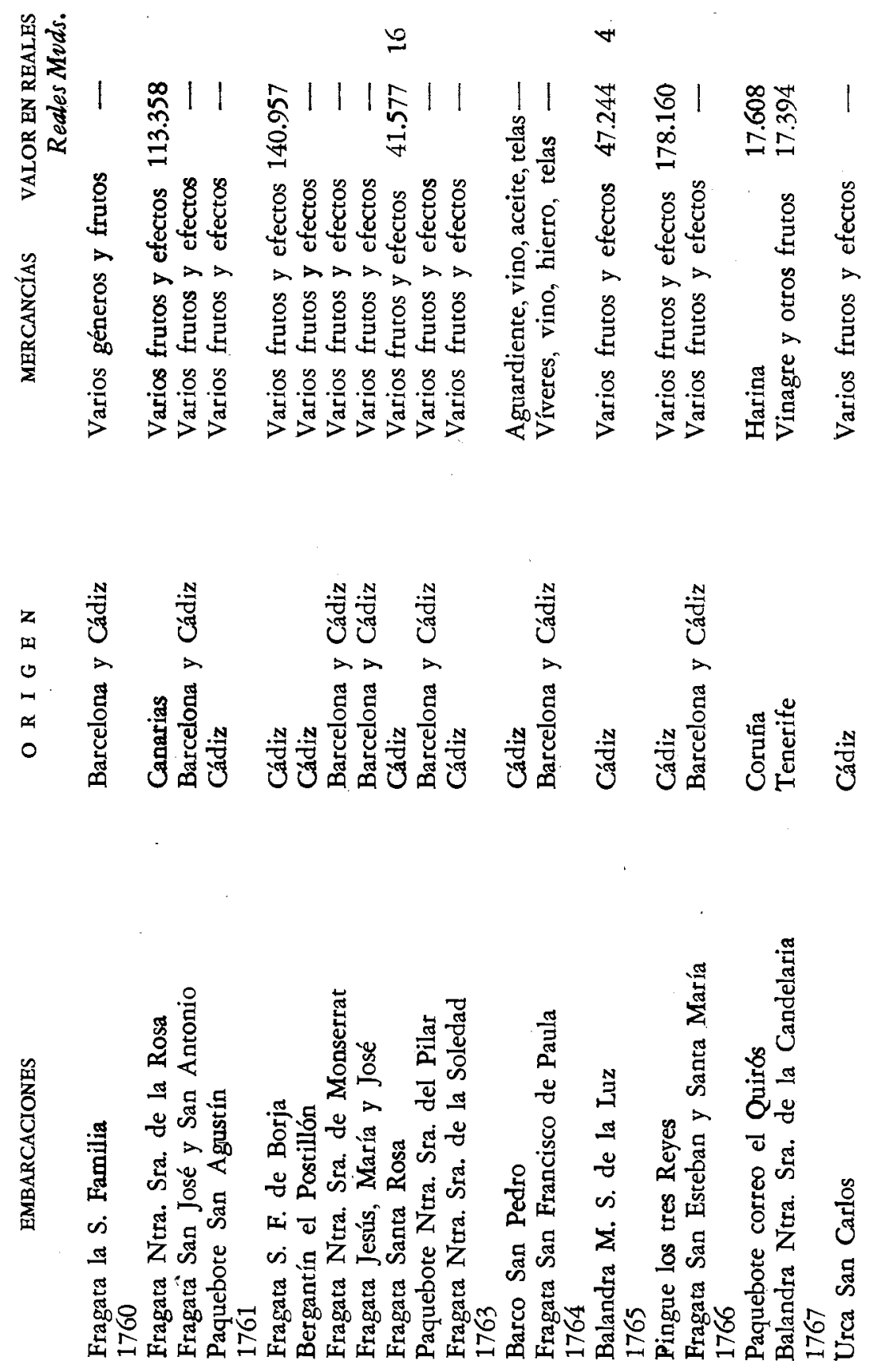

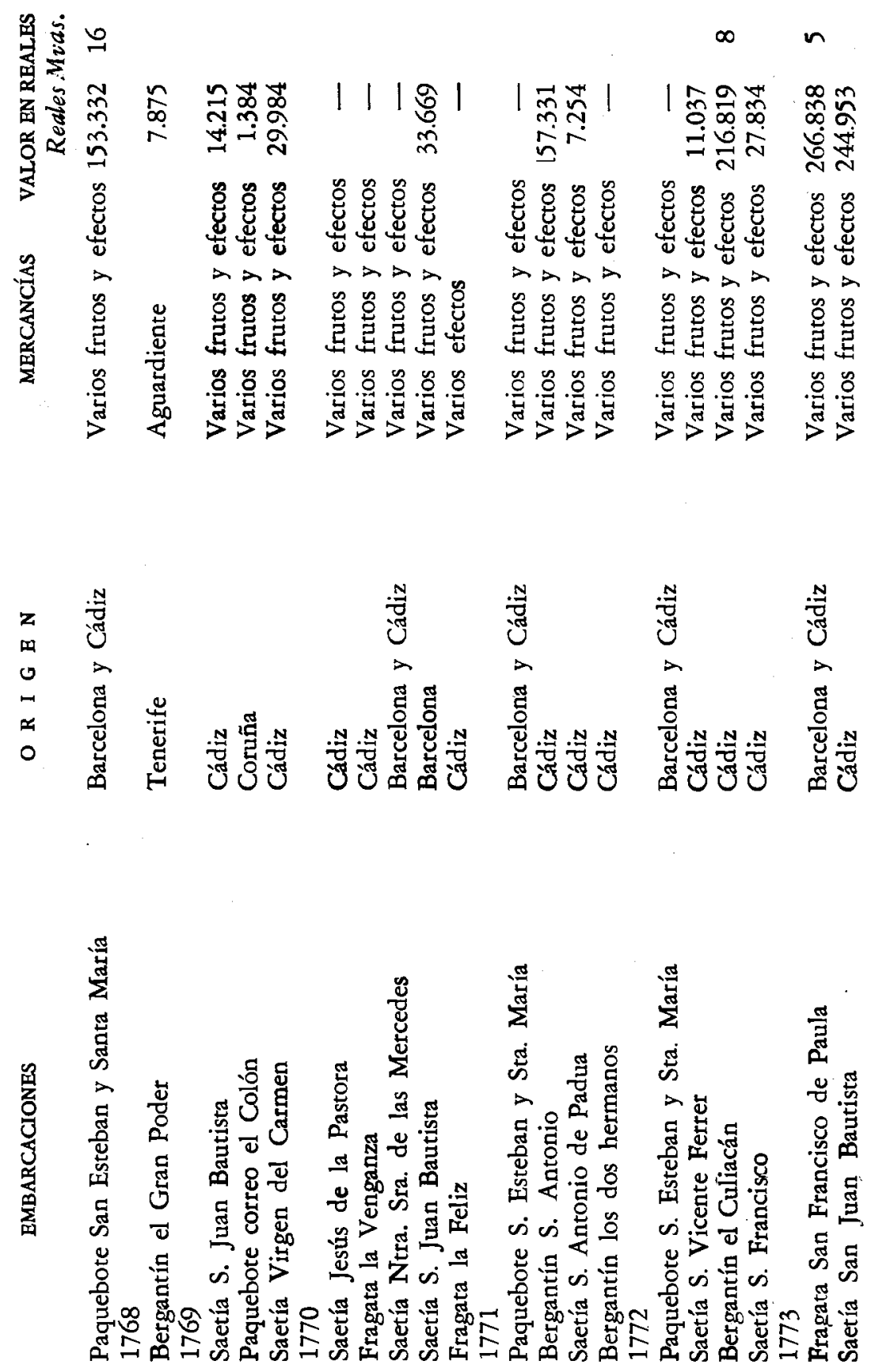

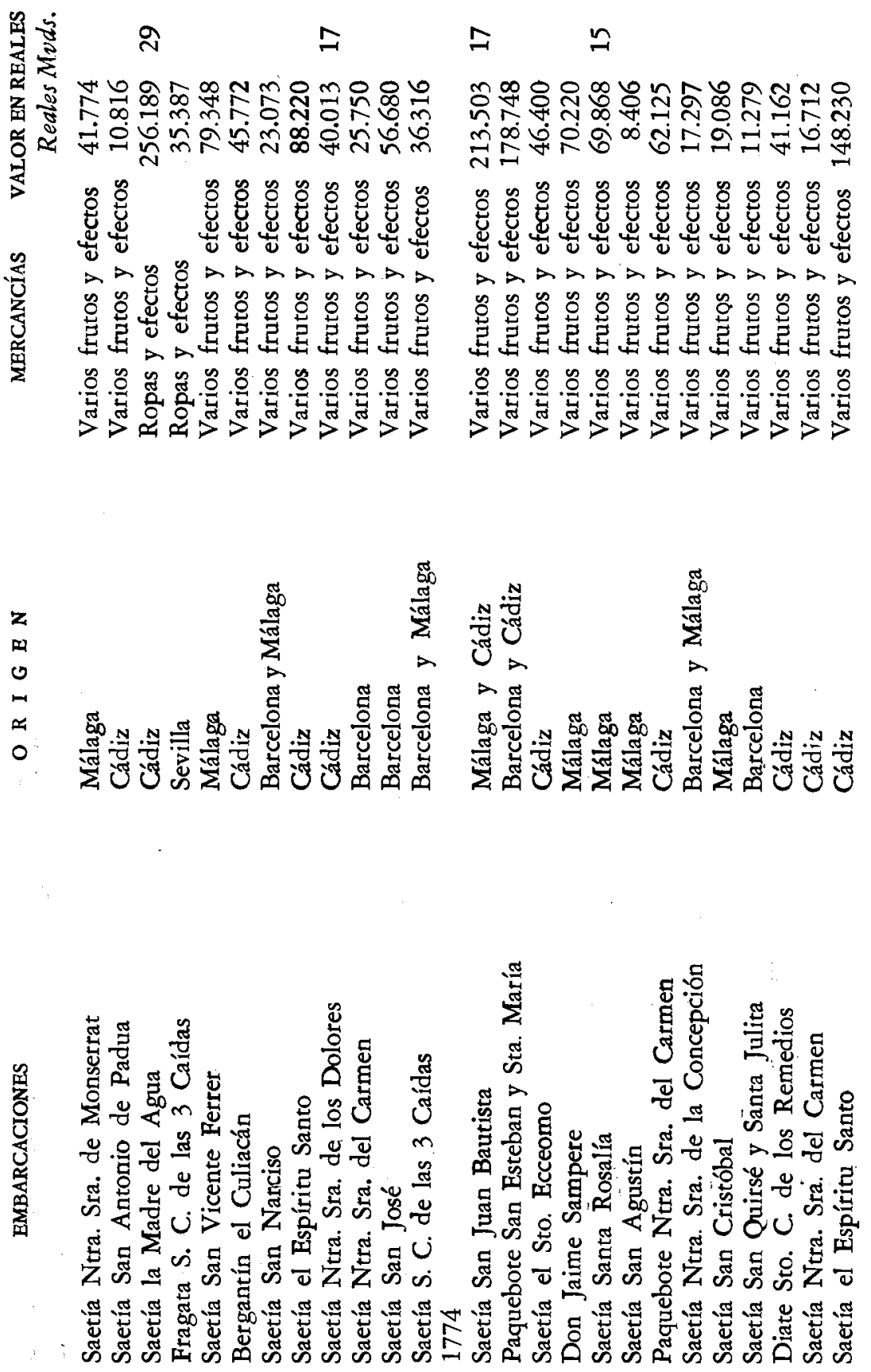

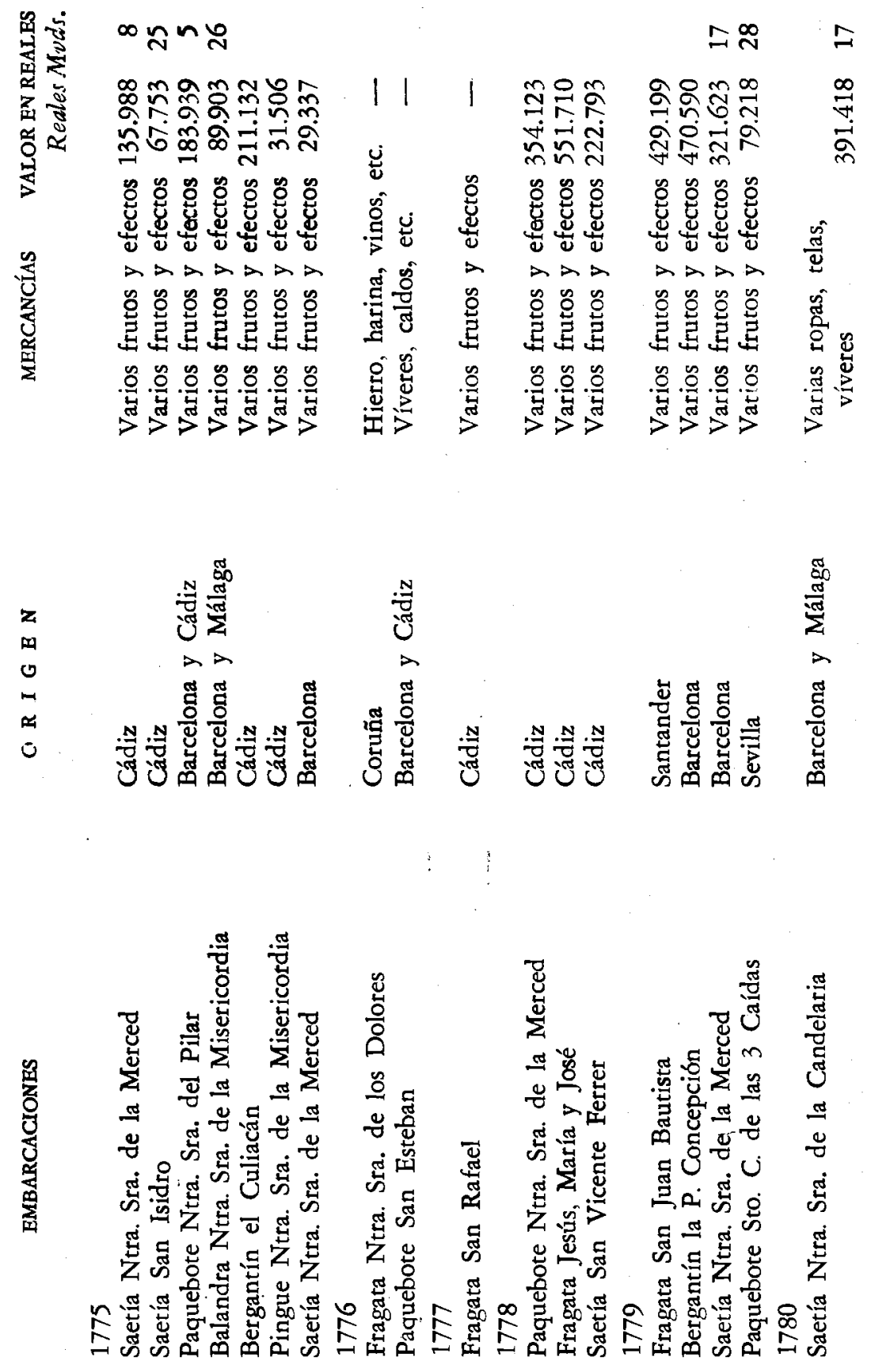

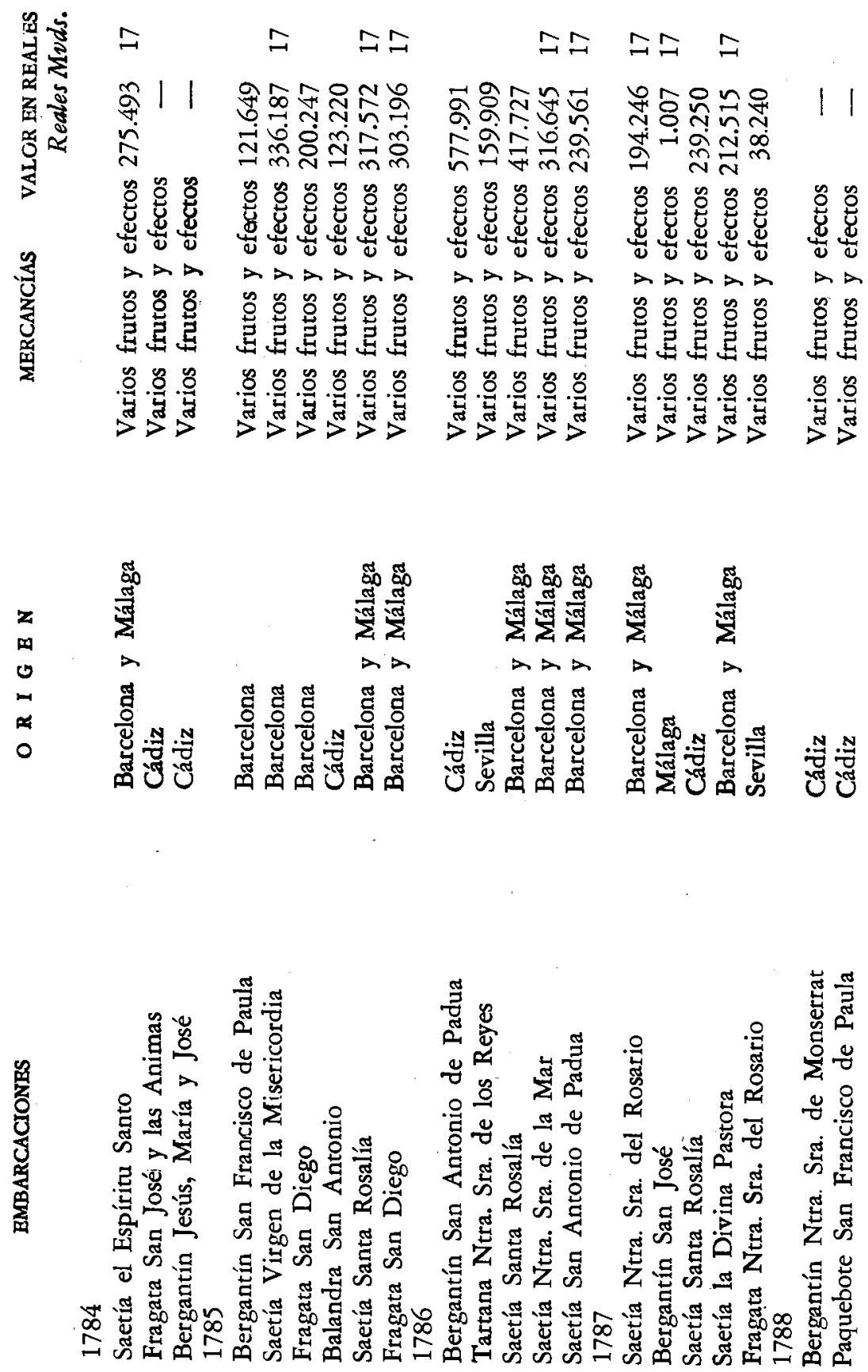
SANTO DOMINGO TIERRA DE FRONTERA (1750 - 1800)

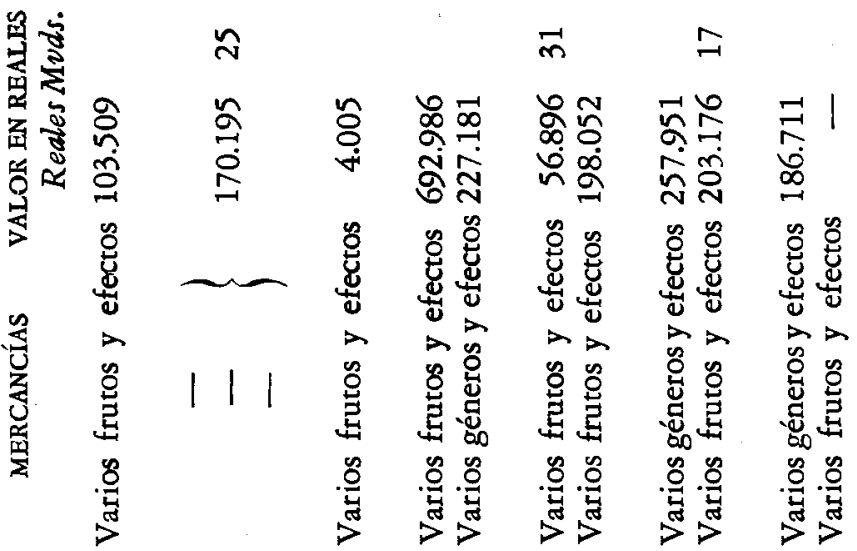

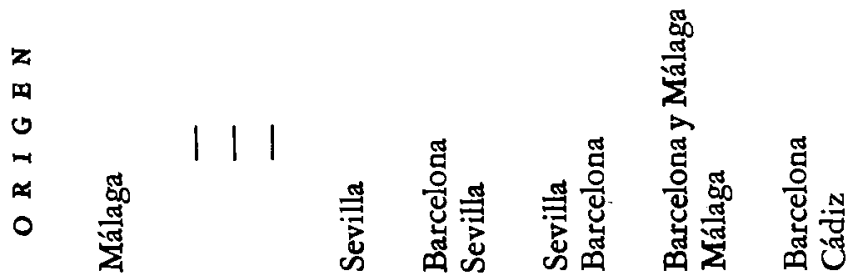

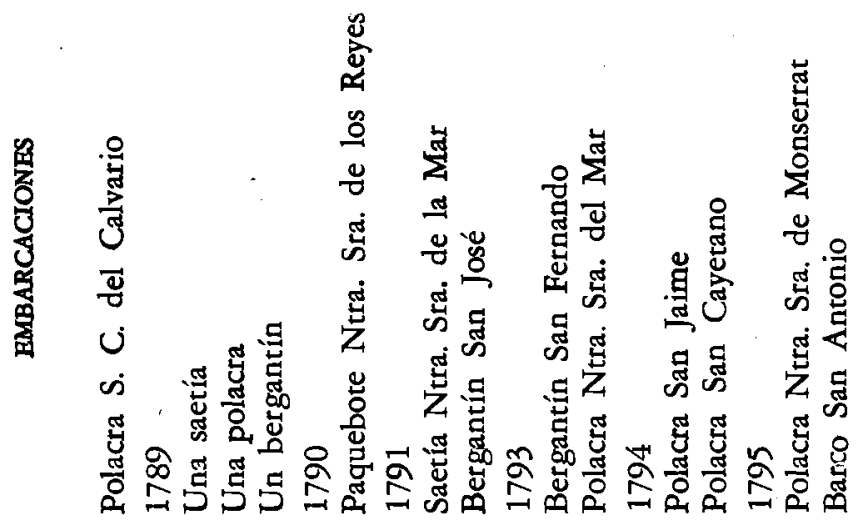




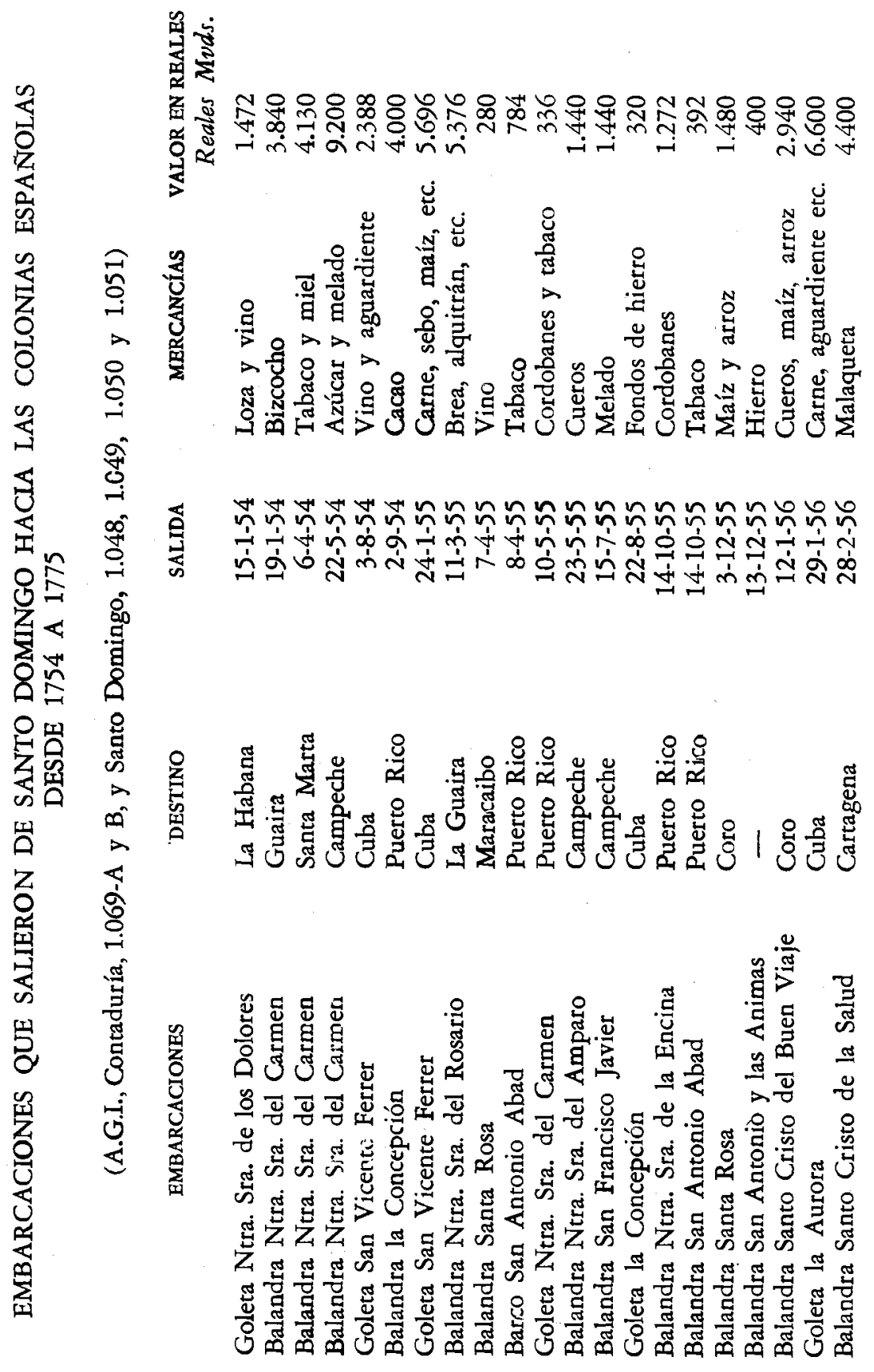




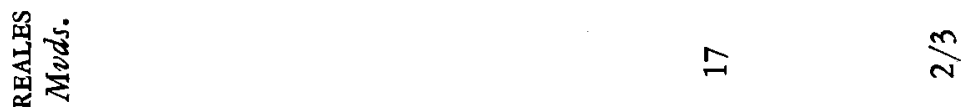

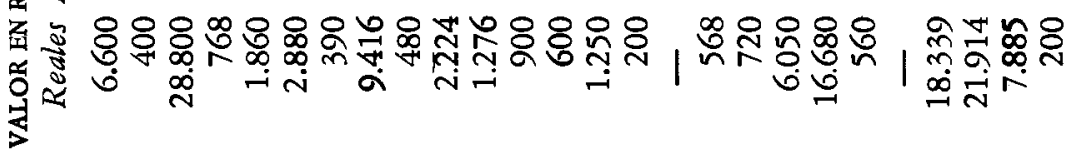

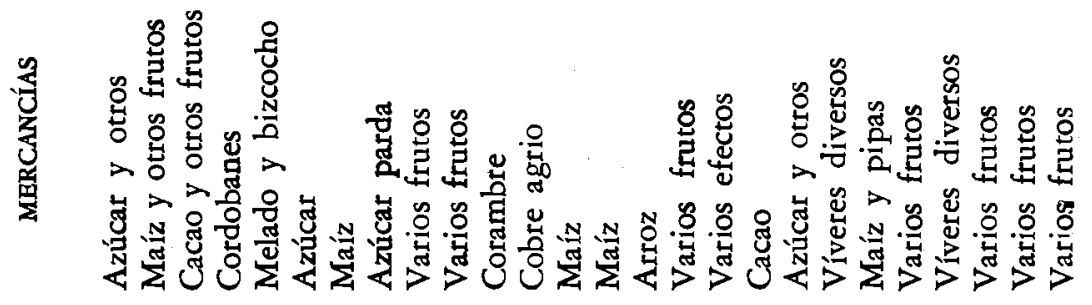

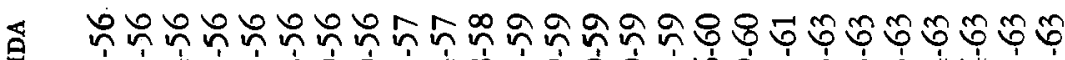

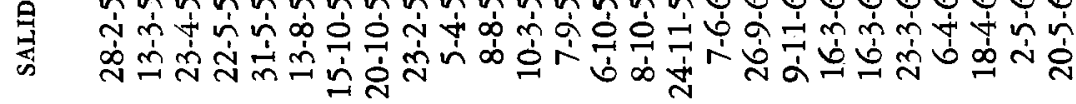

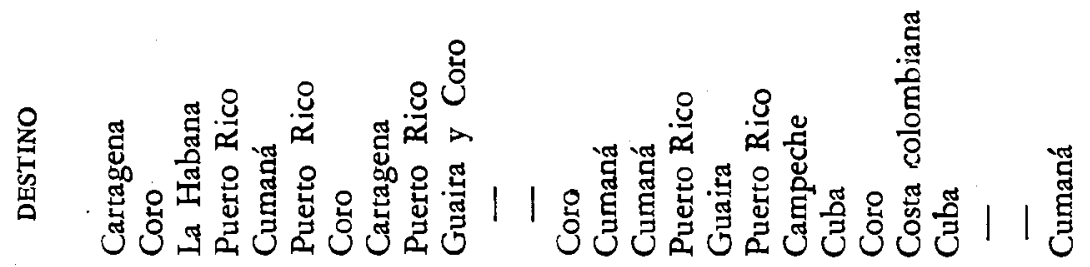

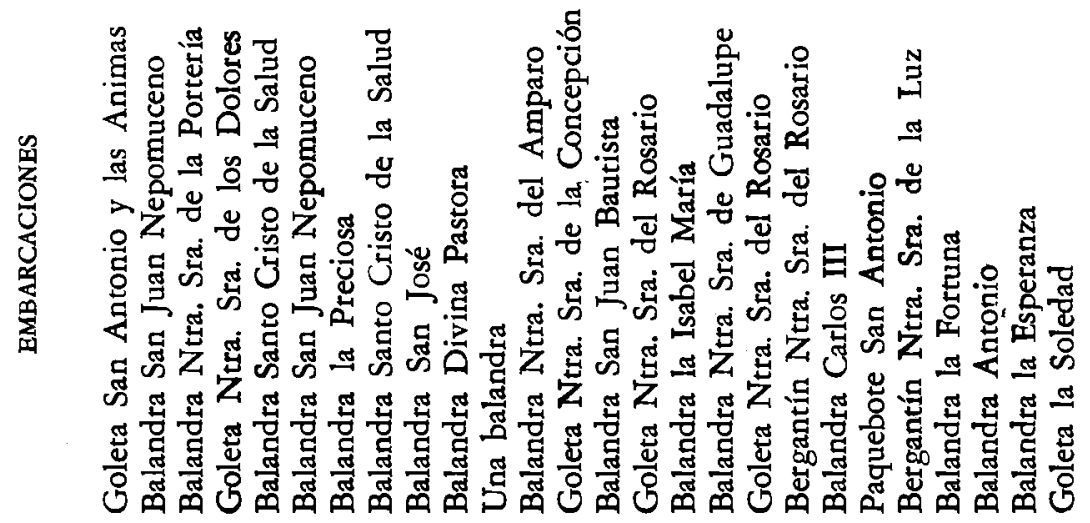




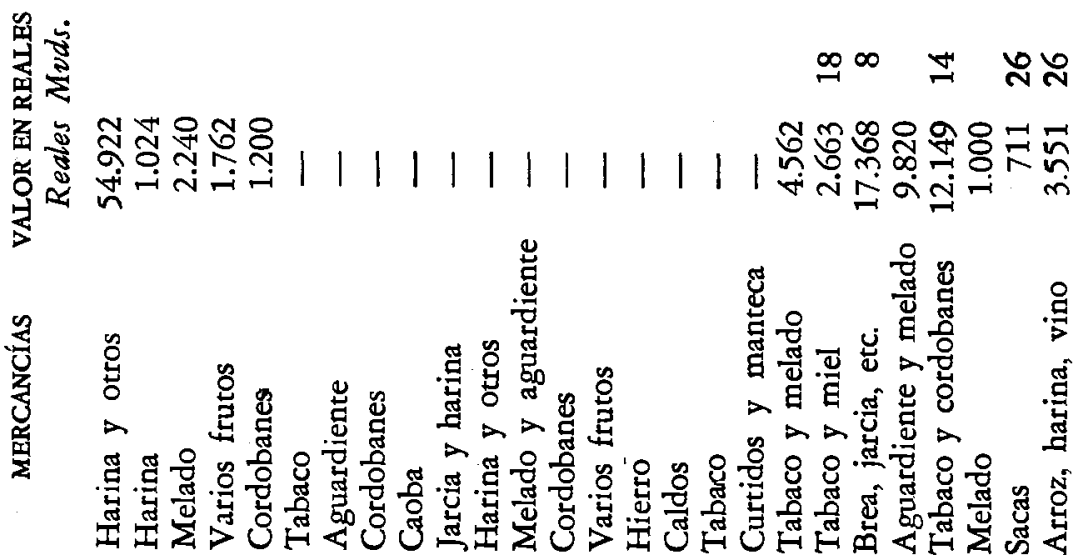

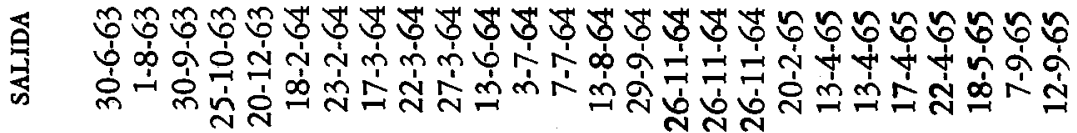

）

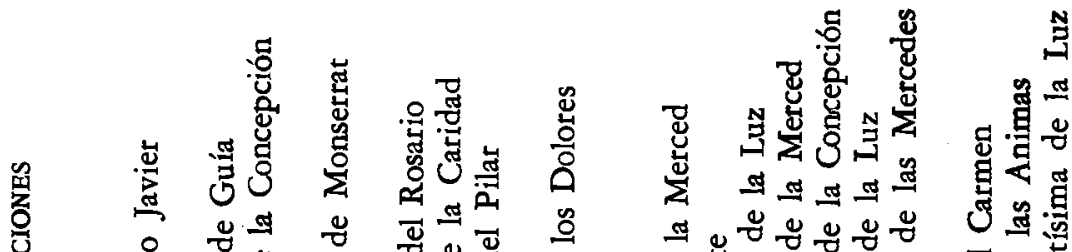

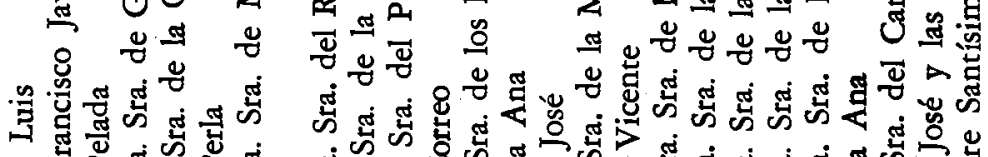

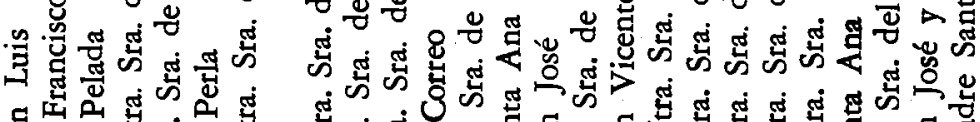
出 月

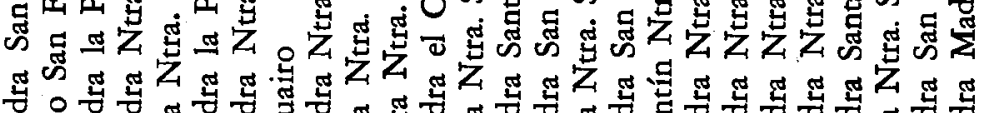

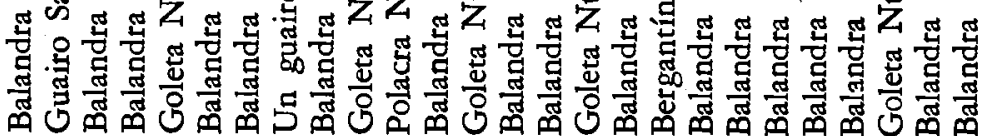




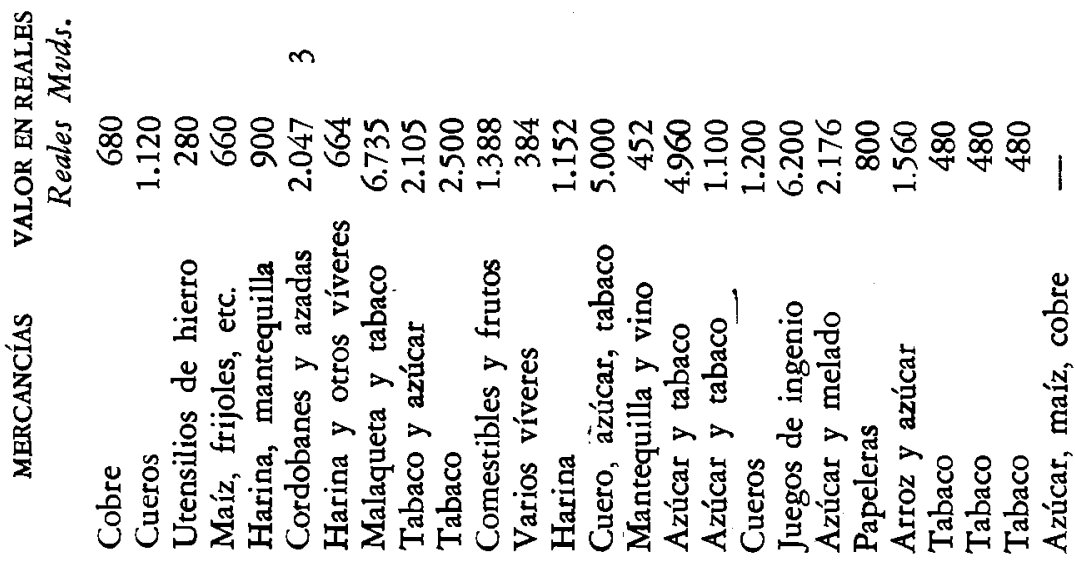

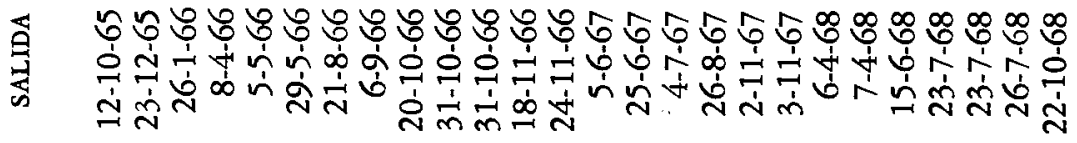

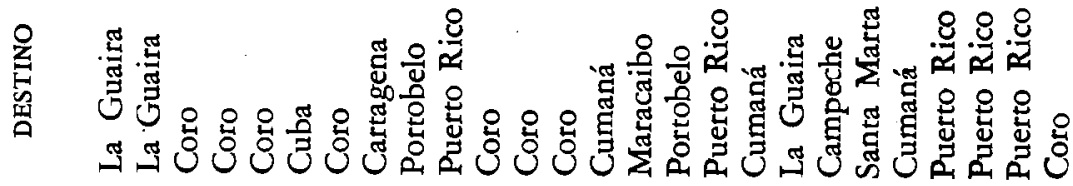

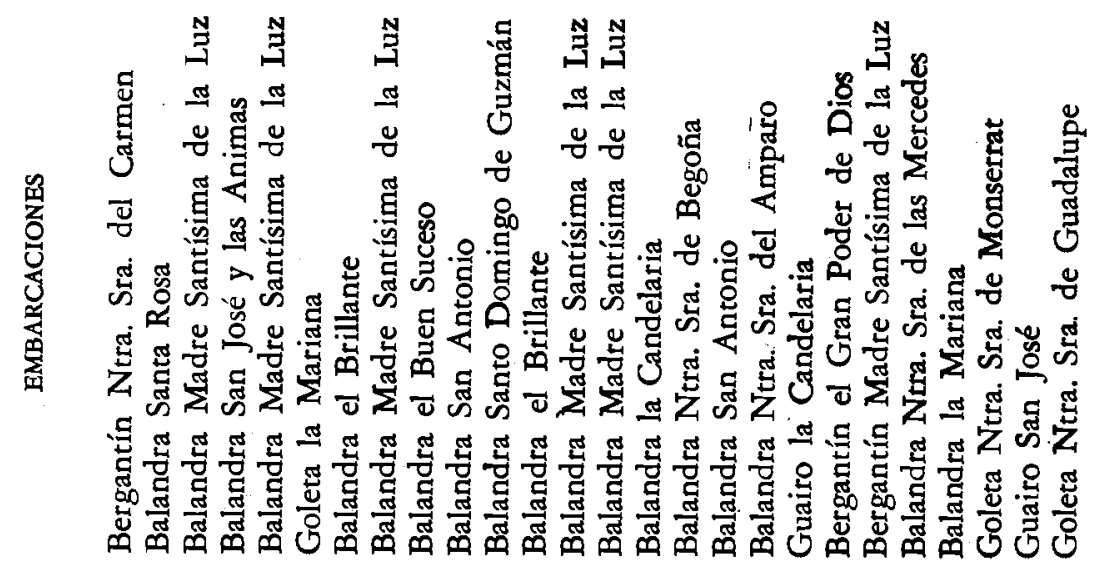




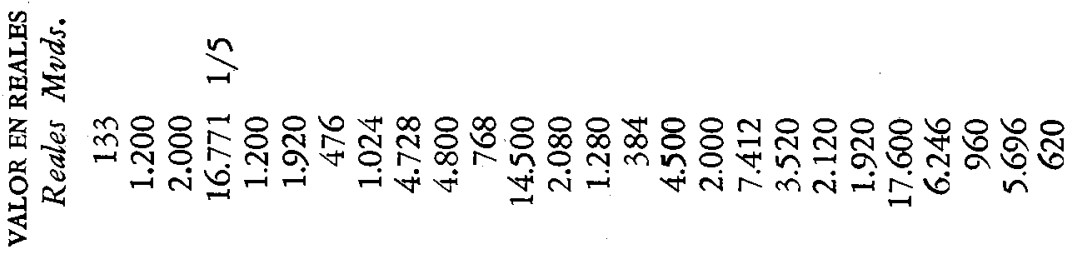

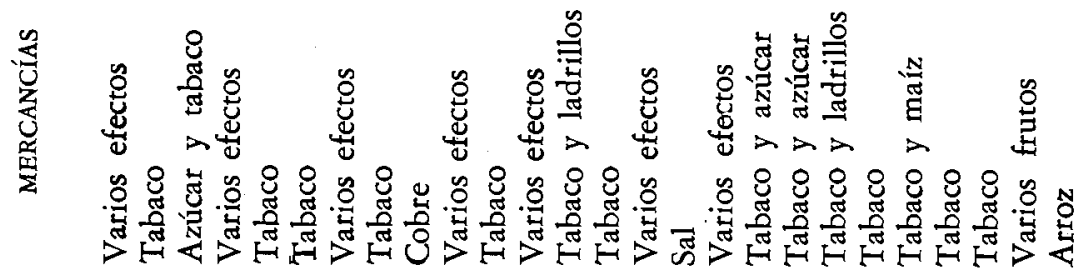

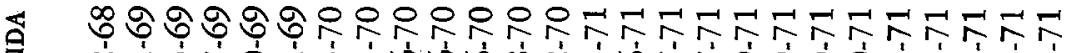

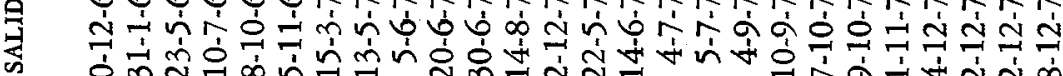

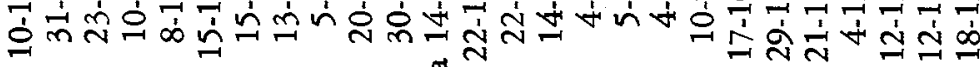

$$
\text { 疍 }
$$

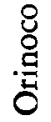

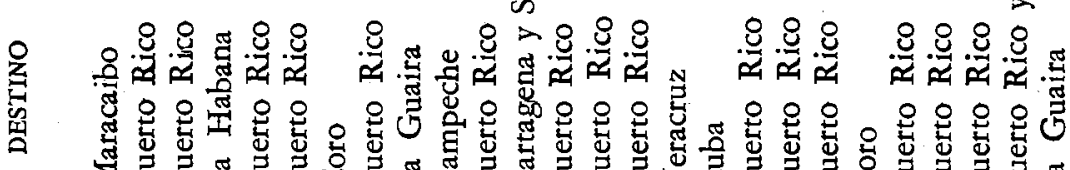

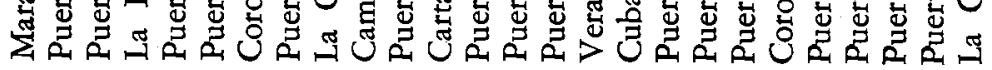

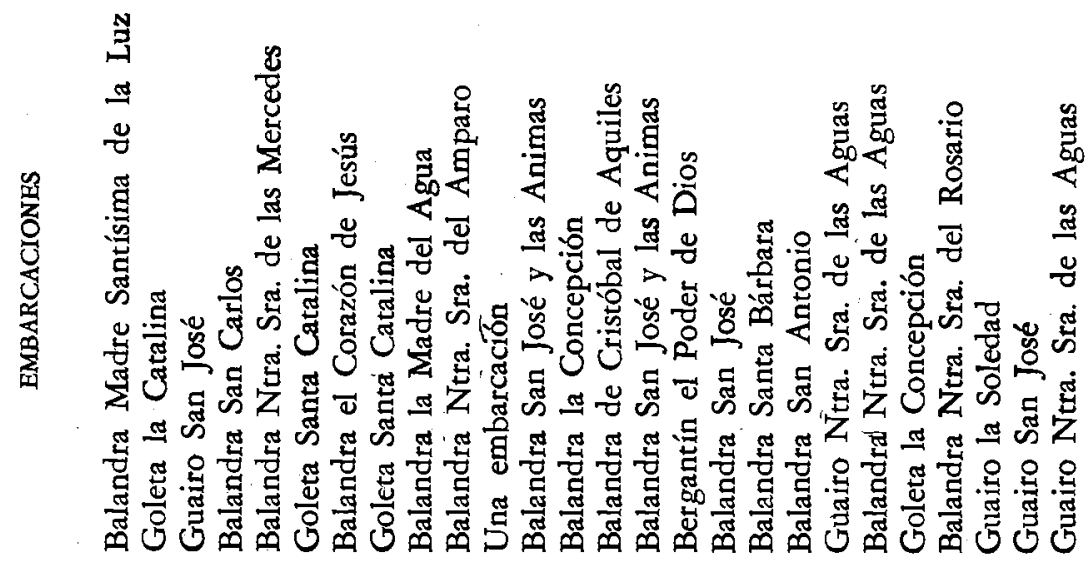


葛通

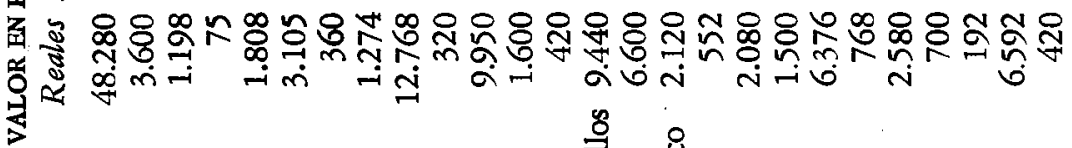

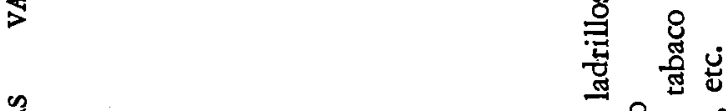

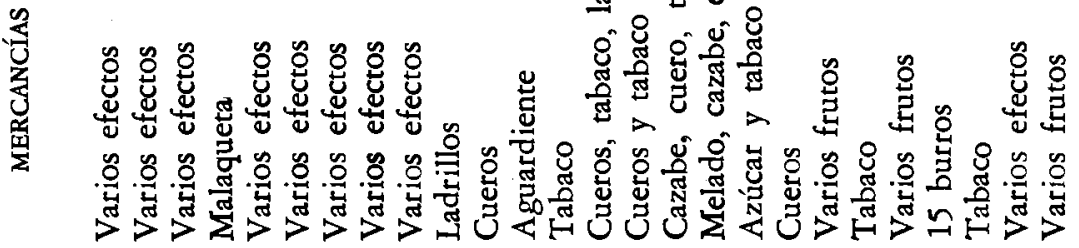

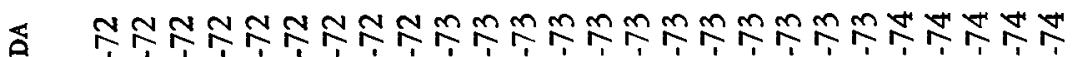
花 Ә่

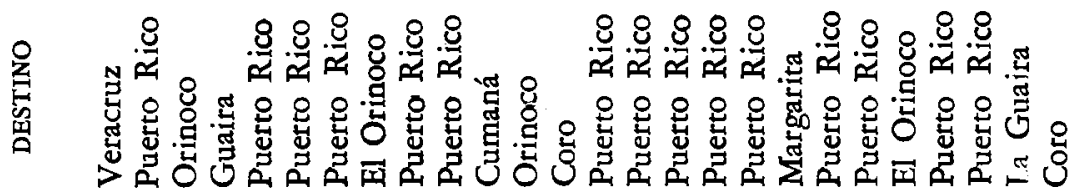

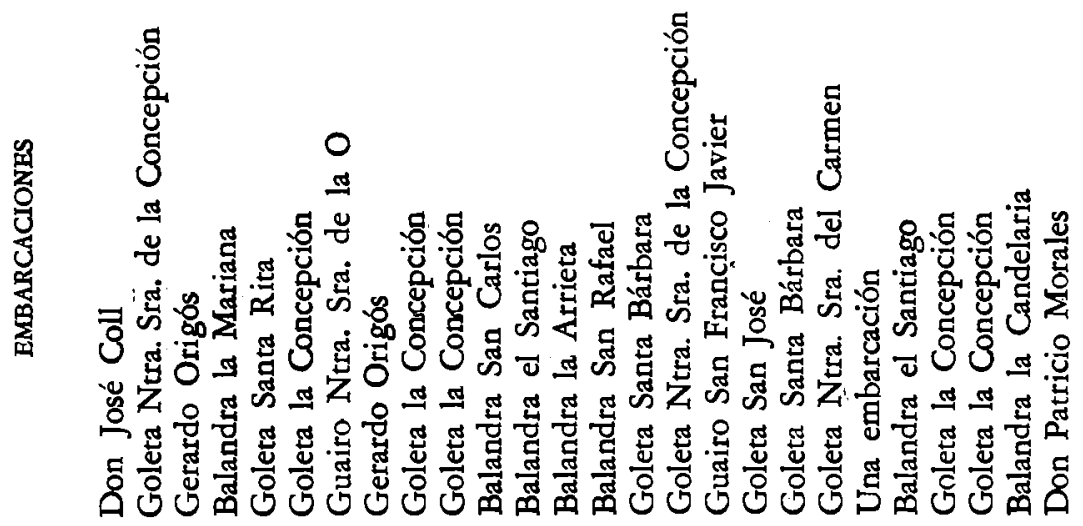




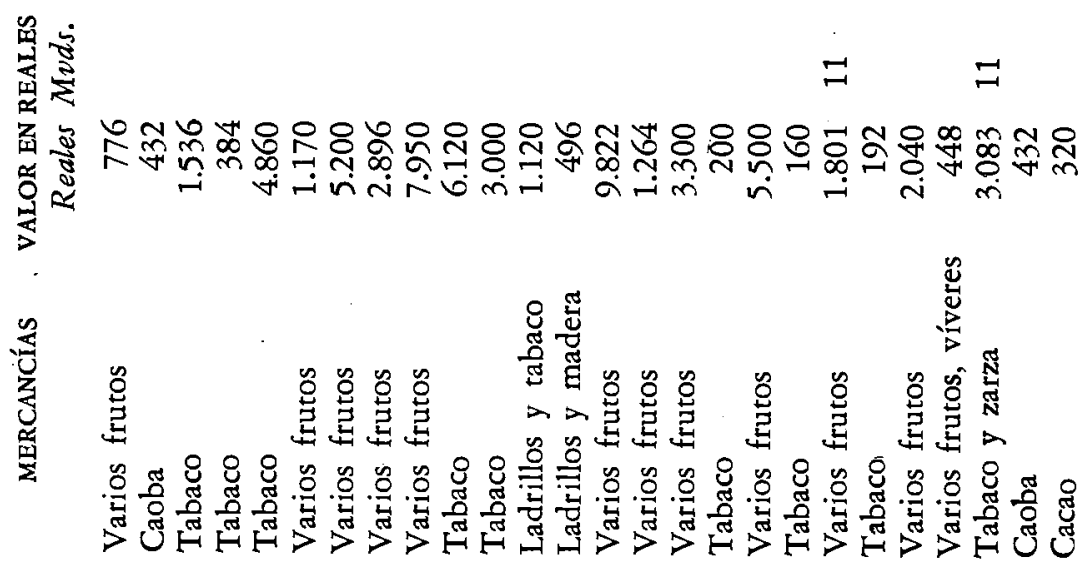

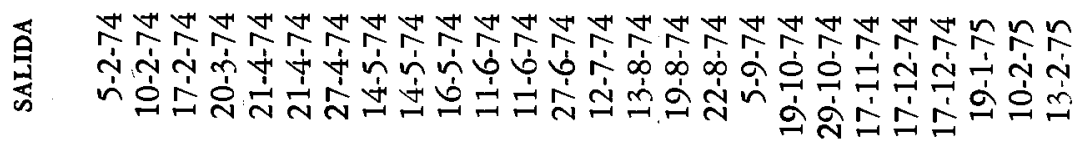
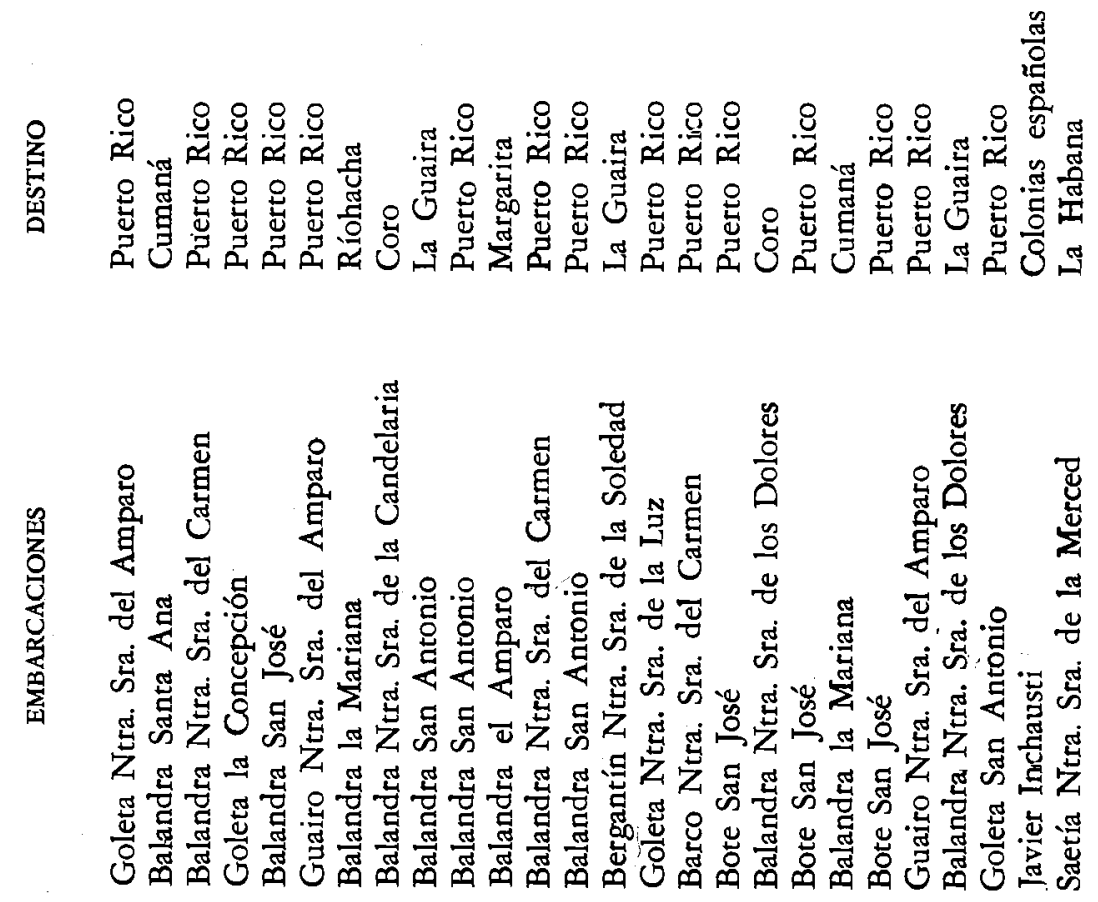


\section{岁离}

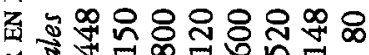

告

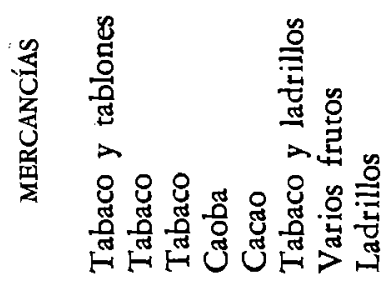

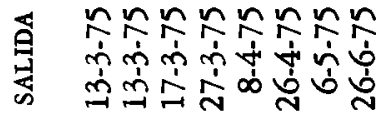
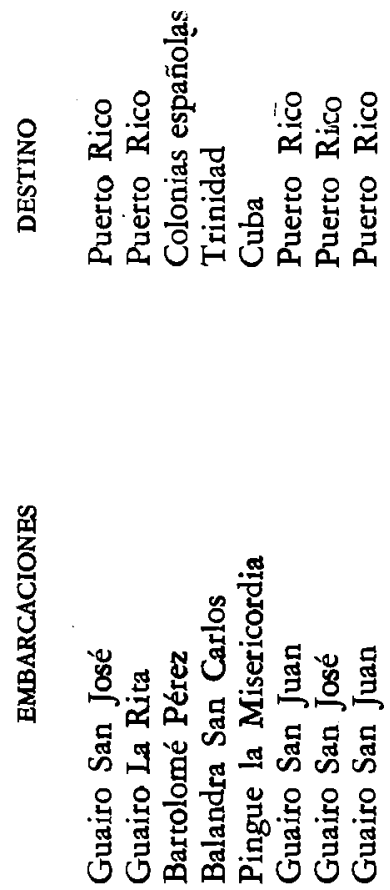


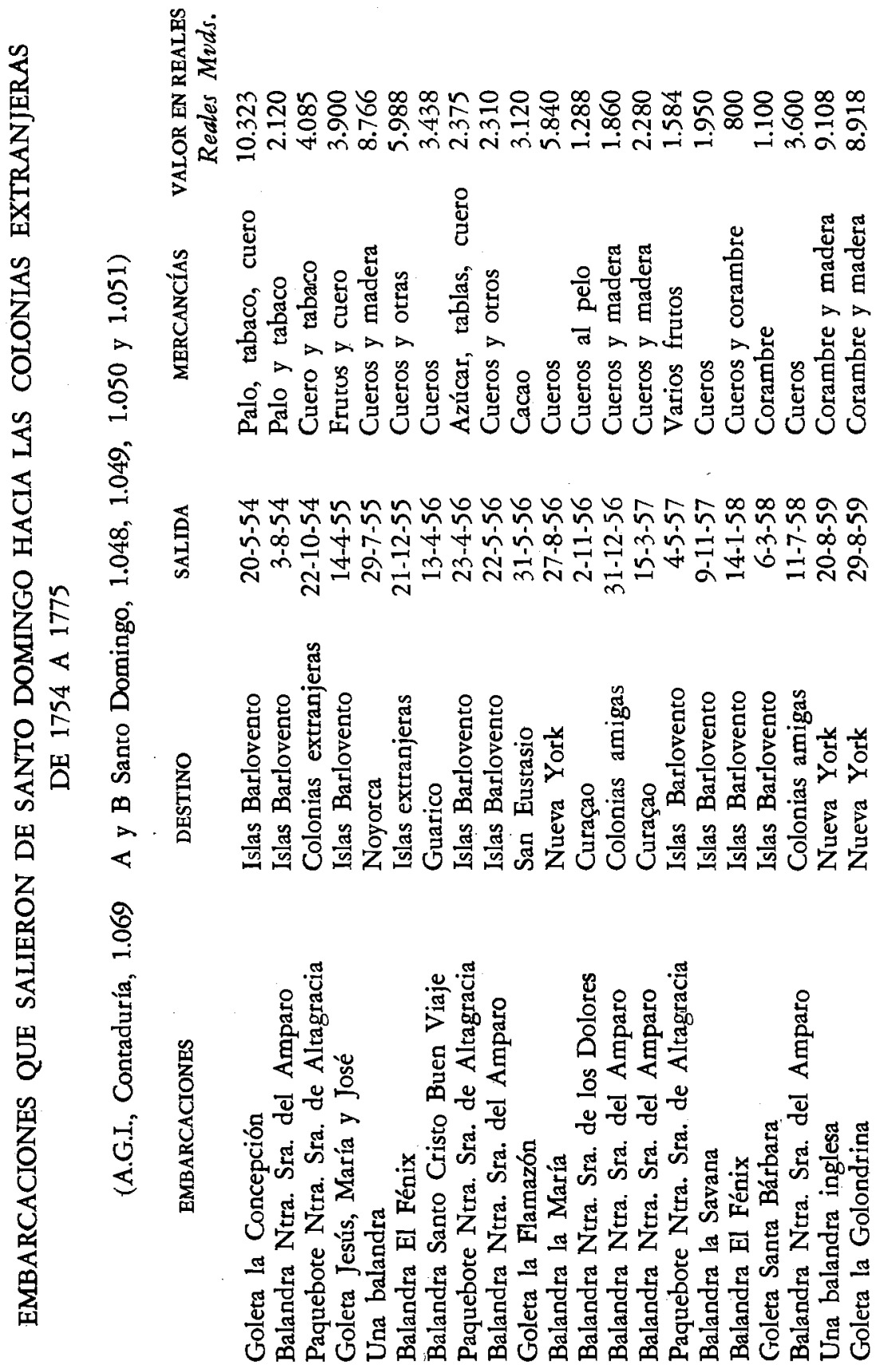




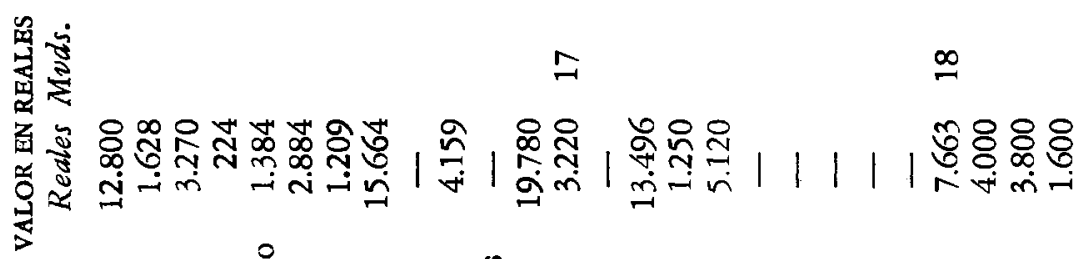

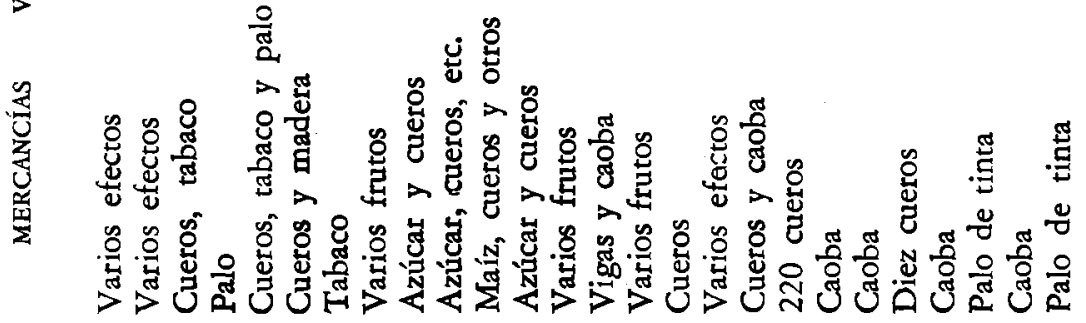

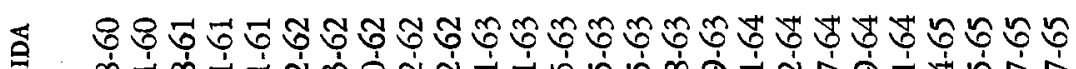
至
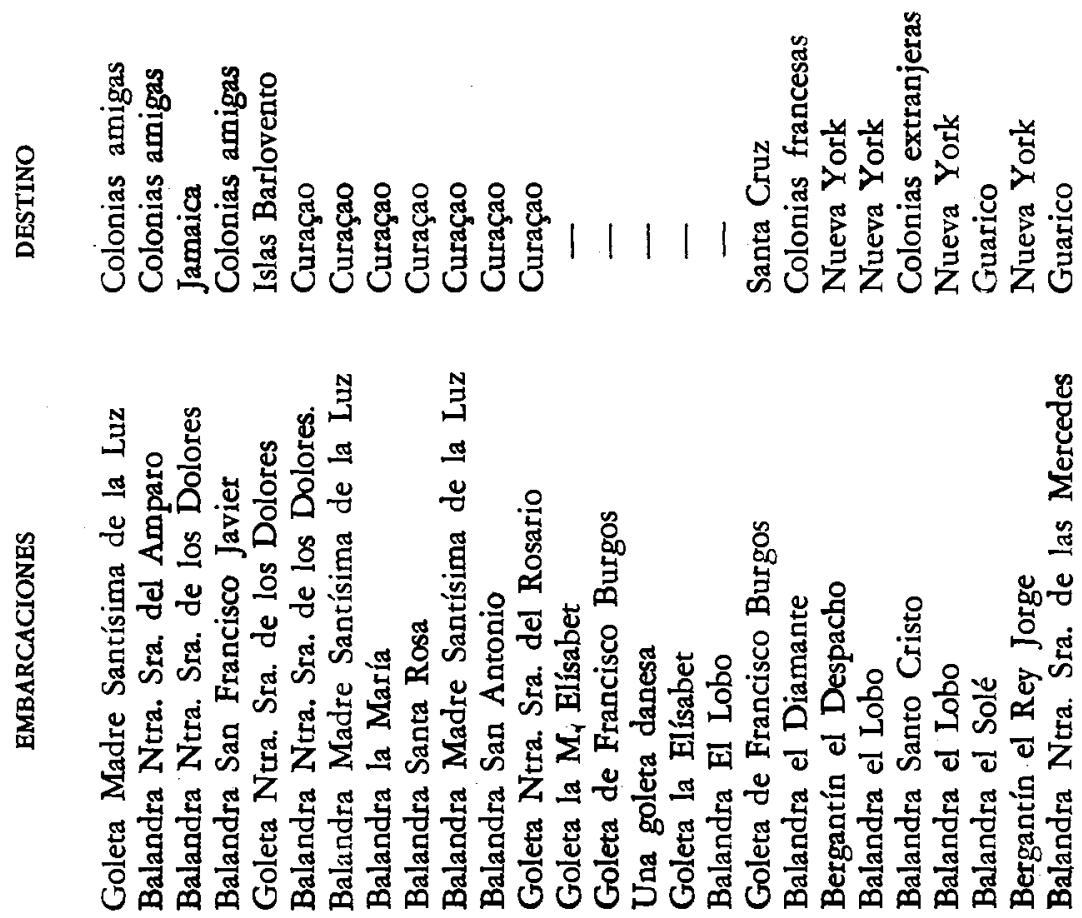
鱼㐫

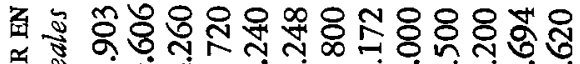

연

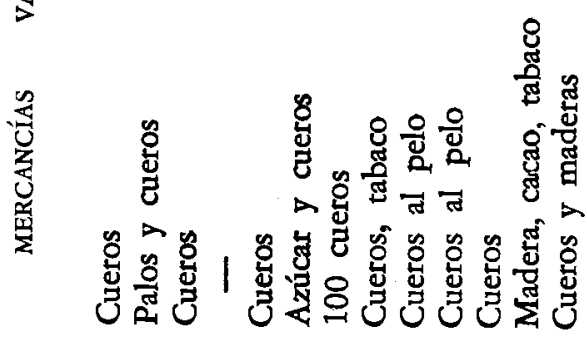

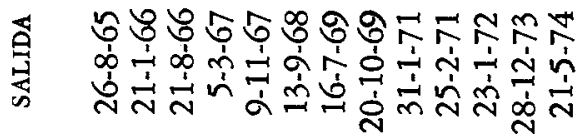

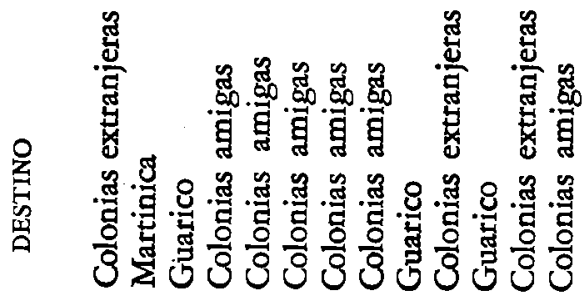

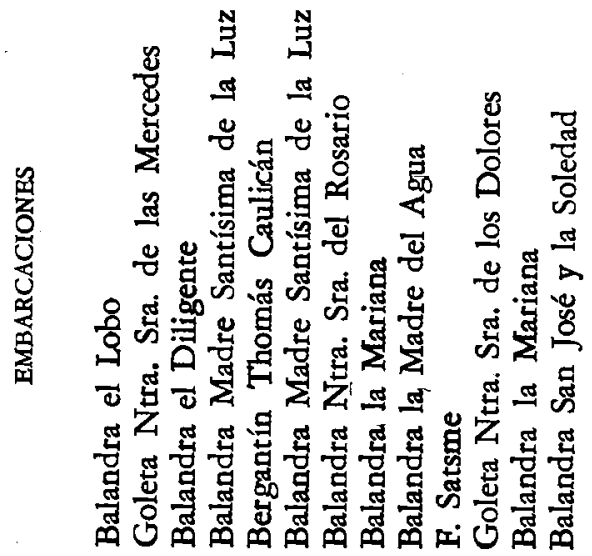




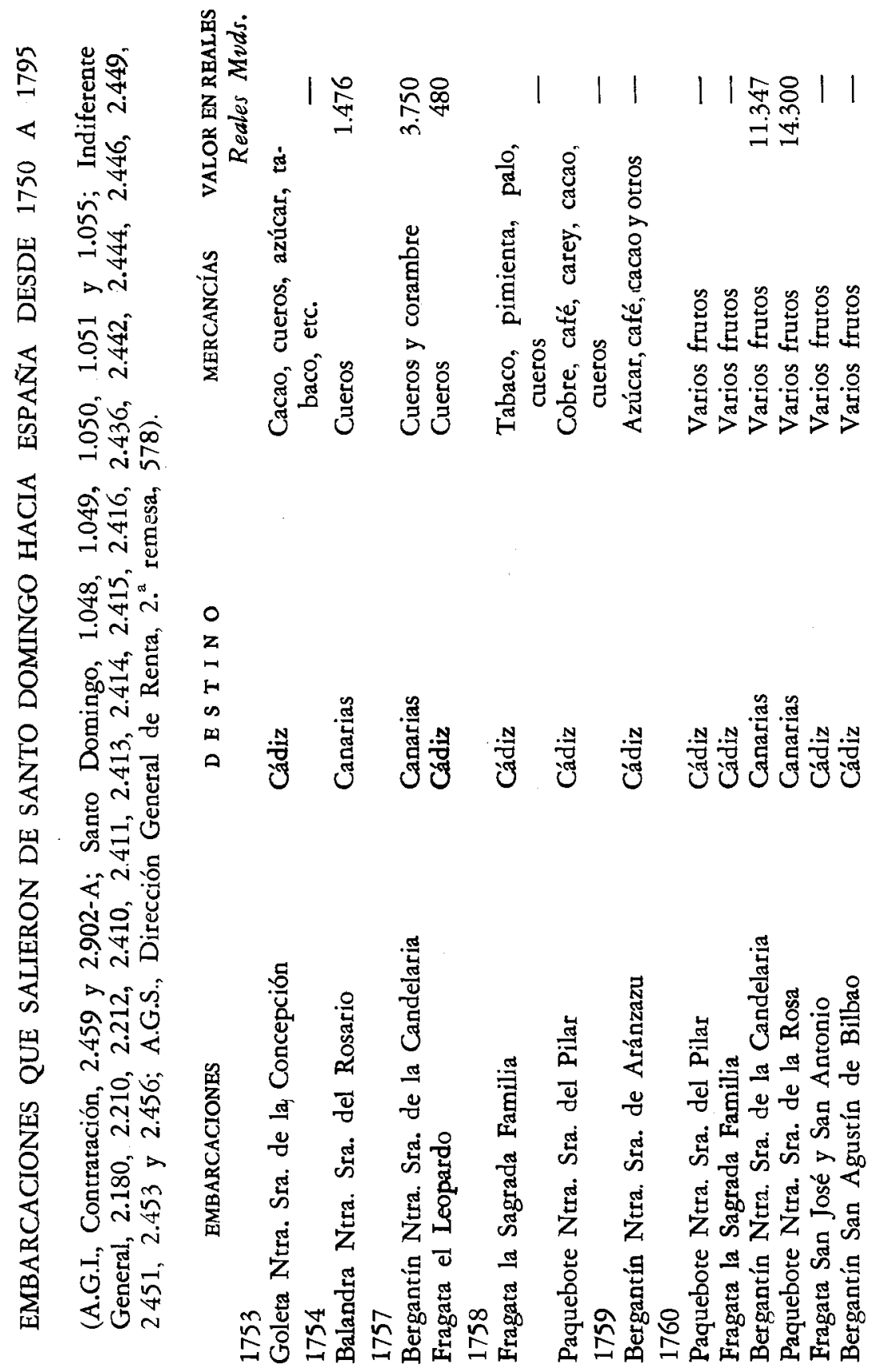




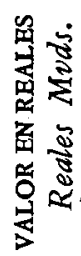

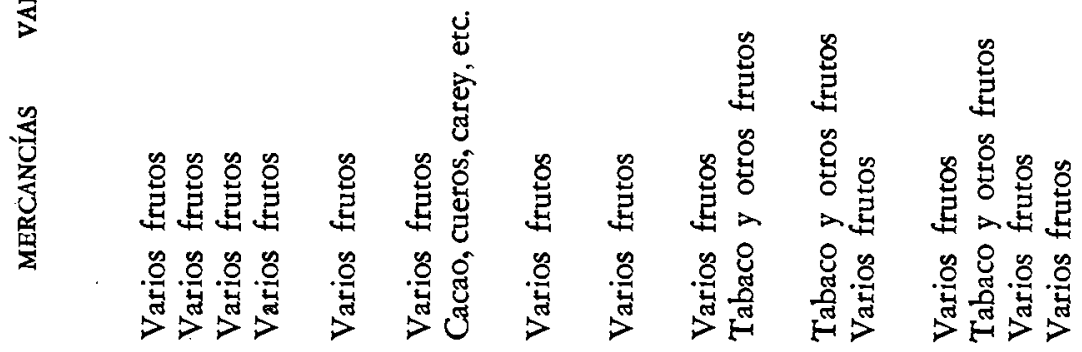

6
$z$
1
1
1
0

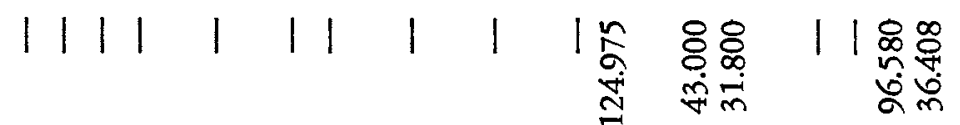

क

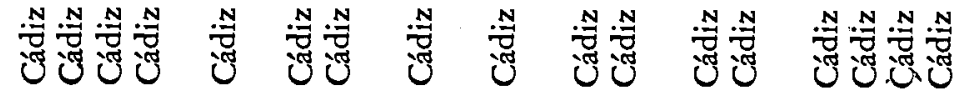

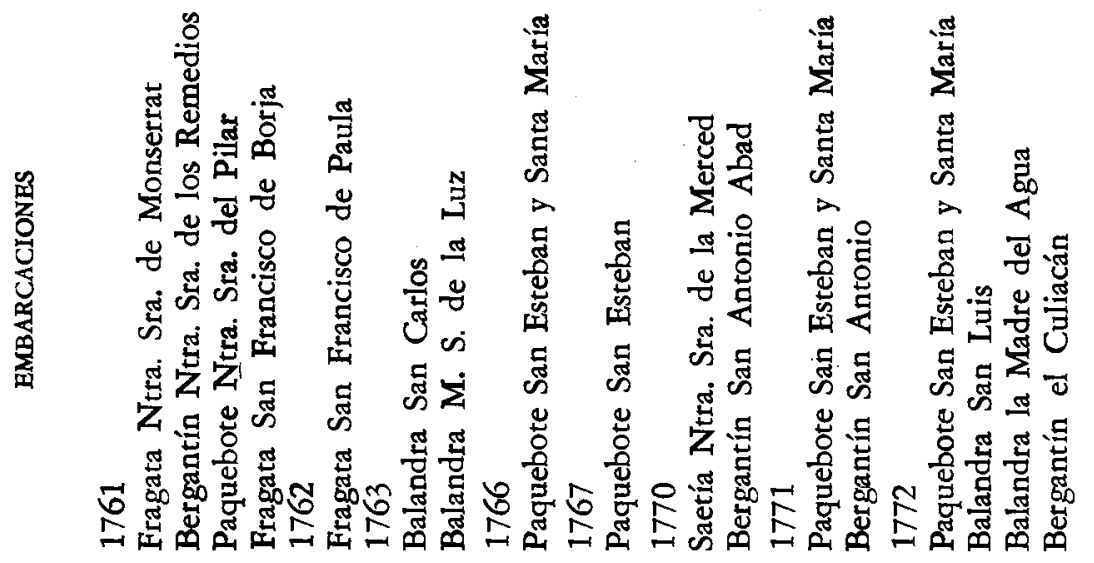


SANTO DOMINGO TIERRA DE FRONTERA $(1750-1800)$

照

迹

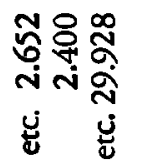

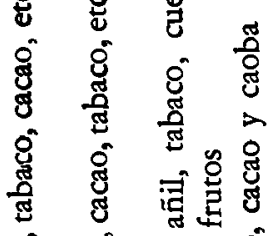

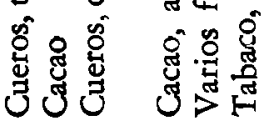

A

$\vec{m}$

茲

I

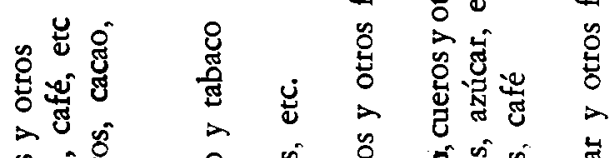

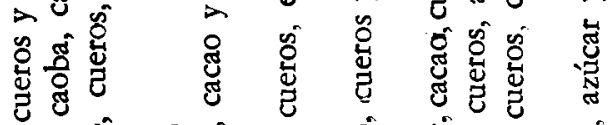

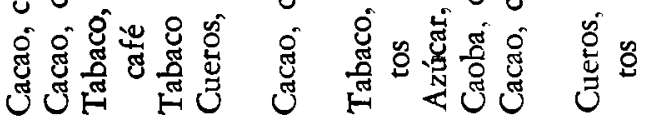

0
2
1
in
m

m

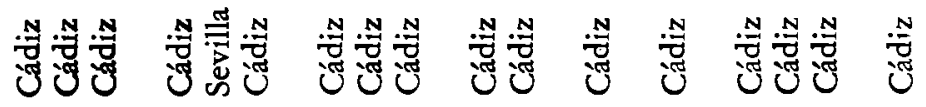

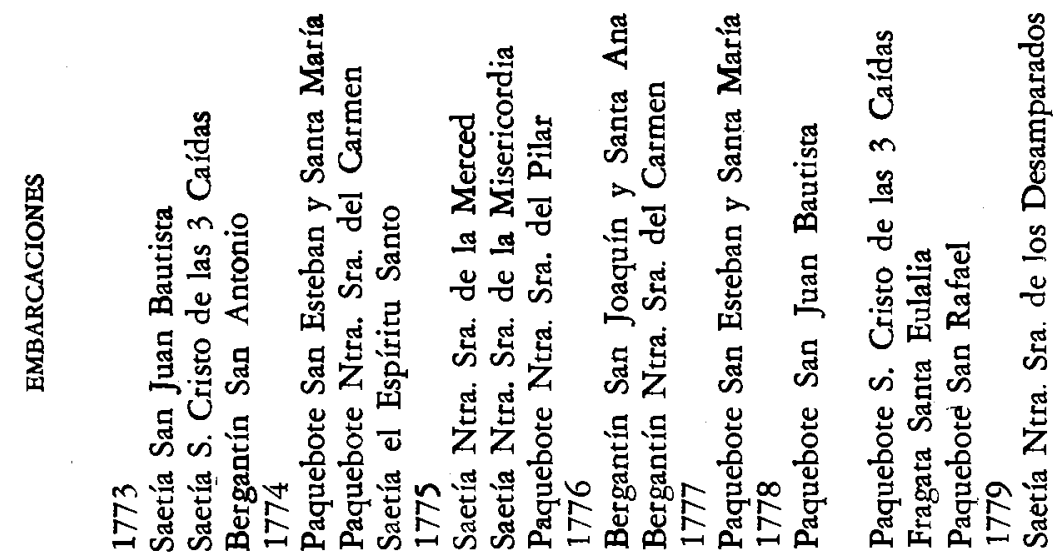


通

$\stackrel{\infty}{\sim}$

สิ

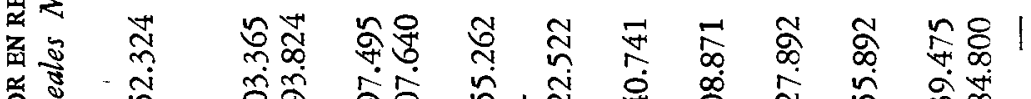

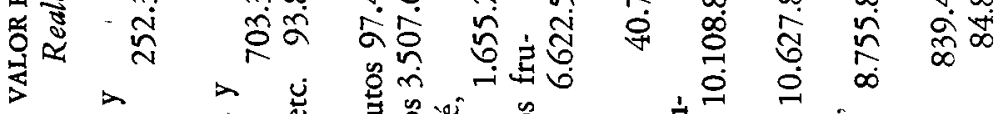

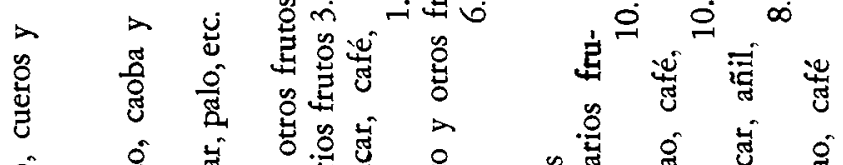

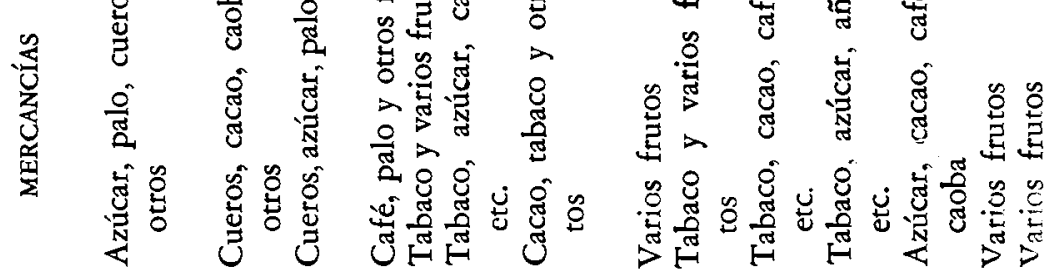
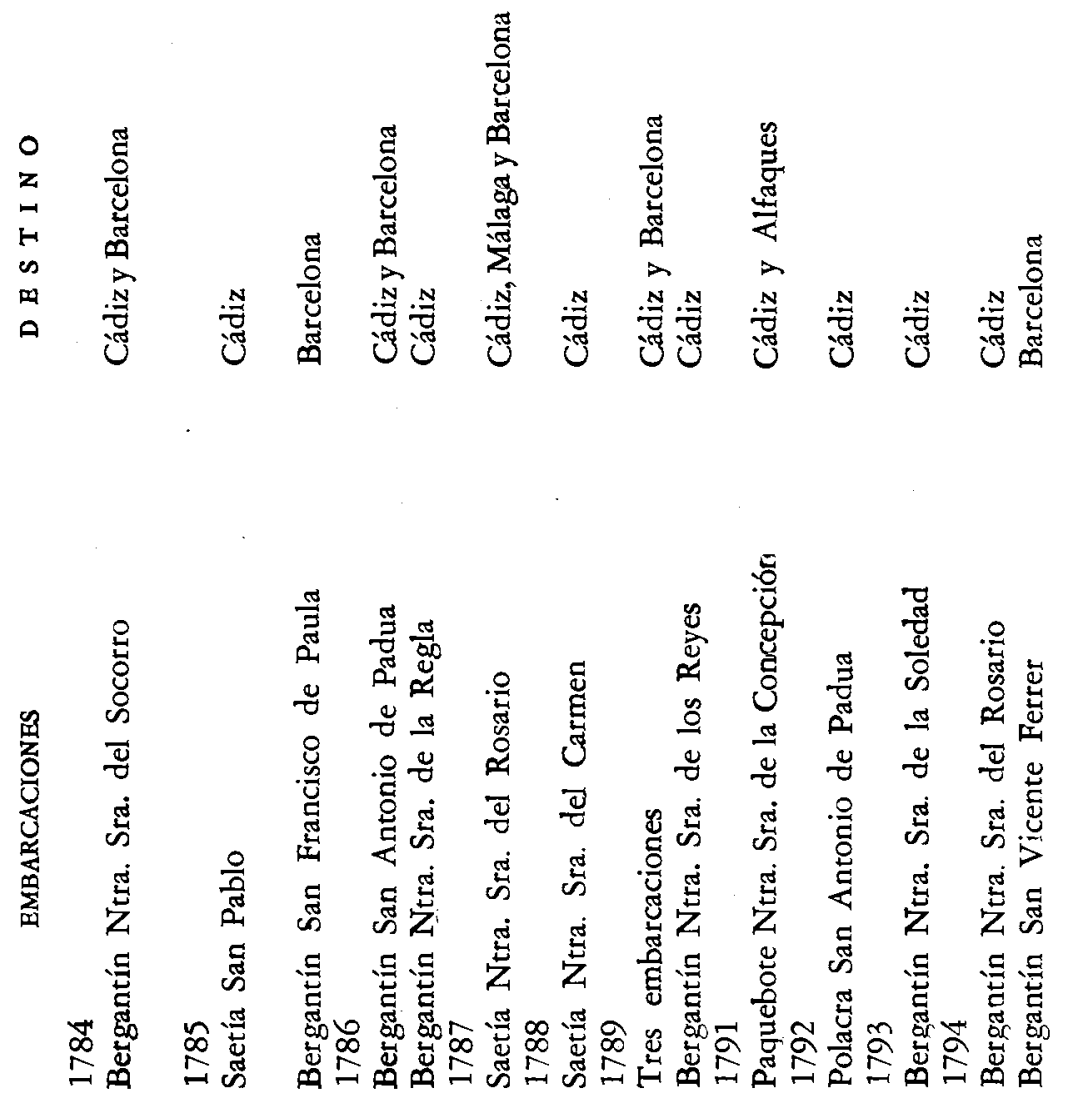
MOVIMIENTO DE LAS CAJAS REALES DE SANTO DOMINGO DESDE I754 A I775

ENTRADAS PRODUCIDAS EN LAS CAJAS REALES DE SANTO DOMINGO DESDE EL 1 DE ENERO DE 1754

AL 31 DE JUNIO DE 1775

(A.G.I. Contaduría 1.069-A y B y Sto. Domingo 1.048, 1.049, 1.050 y 1.051 )

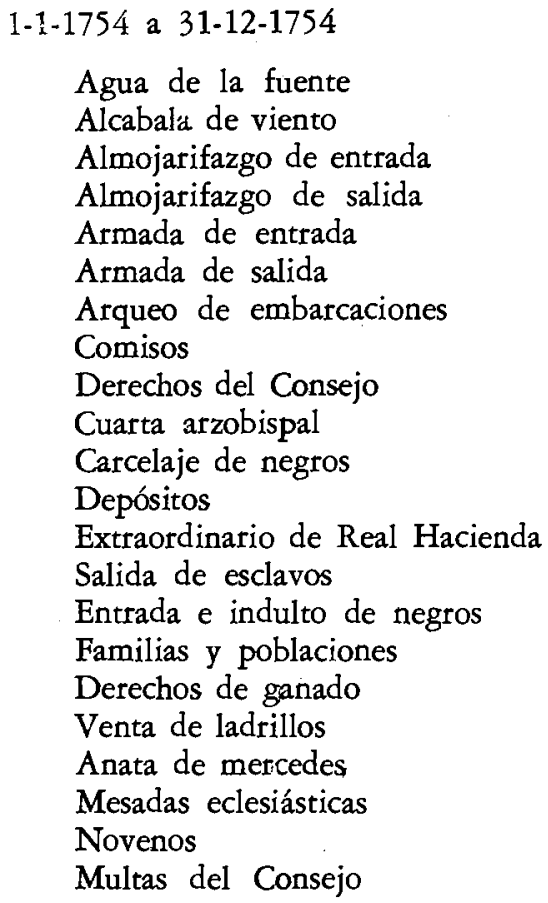

Agua de la fuente

Alcabalá de viento

Almojarifazgo de entrada

Almojarifazgo de salida

Armada de entrada

Armada de salida

Arqueo de embarcaciones

Comisos

Derechos del Consejo

Cuarta arzobispal

Carcelaje de negros

Depósitos

Extraordinario de Real Hacienda

Salida de esclavos

Entrada e indulto de negros

Familias y poblaciones

Derechos de ganado

Venta de ladrillos

Anata de mercedes

Mesadas eclesiásticas

Novenos

Multas del Consejo

REALES

MARAVEDÍES

280

11.823

46.242

1.357

15.023

2.824

2.177

1.642

1.709

25.556

148

88.396

11.492

33

3.000

214.190

156.396

760

3.542

792

11.612

4.000
13

7

24

13

10

12

15

2

33

28

32

6

19

29

12 
REALES MARAVEDÍES

Oficios

6.520

Papel sellado

1.353

Penas de Cámara y gastos de justicia

Quintos reales

Resulta de cuentas

6.499

Salarios y Situación

Renta del solar

Alcance de cuentas

Préstamos a Situación

Reintegro de préstamos

$1-1$ al $31-12-1755$

Agua de la fuente 240

Alcabala de viento

15.132

Almojarifazgo de entrada

50.948

Almojarifazgo de salida

1.029

Armada de entrada

16.636

Armada de salida

1.421

Arqueo de embarcaciones

2.050

Comisos

7.571

Derechos del Consejo

1.002

Cuarta arzobispal

25.603

Cancelaje de negros

Depósitos

44

27.572

Extraordinario

1.892

Salida de esclavos

Entrada e indulto de negros

Venta de ladrillos

10.020

648

Anata de mercedes

15.889

Mesadas eclesiásticas

2.472

12.019

1.682

Oficios

25.847

Papel sellado

480

Penas de Cámara

Situación y salarios

Renta del solar

Alcance de cuentas

688.271

Préstamos a situación

28.208 
1-1 al 5-10-1756

\begin{tabular}{|c|c|}
\hline REALES & MARAVEDÍES \\
\hline \multicolumn{2}{|l|}{216} \\
\hline 6.176 & 12 \\
\hline 23.025 & 5 \\
\hline 2.183 & 17 \\
\hline 6.180 & 10 \\
\hline \multicolumn{2}{|l|}{3.081} \\
\hline 1.585 & 16 \\
\hline 960 & 33 \\
\hline \multicolumn{2}{|l|}{1.304} \\
\hline 11.177 & 22 \\
\hline \multicolumn{2}{|l|}{620} \\
\hline 27 & 17 \\
\hline 8.866 & 22 \\
\hline \multicolumn{2}{|l|}{934} \\
\hline 12.922 & 26 \\
\hline 2.026 & 23 \\
\hline 6291 & 17 \\
\hline 1.605 & 1 \\
\hline 1.419 .109 & 14 \\
\hline 775.671 & 3 \\
\hline 16.960 & \\
\hline 2.300 .925 & 0 \\
\hline
\end{tabular}

5-10-1756 a 31-12-1757

Agua de la fuente

Alcabala de viento

12.135

Almojarifazgo de entrada

46.563

Almojarifazgo de salida

Armada de entrada

14.016

Armada de salida

2.225

Arqueo de embarcaciones

1.819

Producto de Bulas

Comisos

38.296

Cuarta arzobispal

57.272

Carcelaje de negros

Depósitos

9.391

5.848

Salida de esclavos

Entrada e indulto de esclavos

8.933

216

Venta de ladrillos

Anata de mercedes

1.762

Mesadas oclesiásticas 
Novenos

REALES

MARAVEDÍES

Oficios

25.488

14

Papel sellado

2.093

11

Penas de Cámara

12.519

32

Situación

96

Renta del solar

977.761

17

Alcance de cuentas

240

Préstamos a Situación

477.385

Reintegro a préstamos

325.548

141.282

Total: $\quad 2.181 .868$

18

$1-1$ a 31-12-1758

Agua de la fuente

Alcabala de viento

10.514

Almojarifazgo de entrada

42.498

246

Almojarifazgo de salida

Armada de entrada

16.724

349

814

Arqueo de embarcaciones

2.422

Comisos

28.695

Cuarta arzobispal

Cuarteles

Carcelaje de negros

188.280

Descuentos a empleados

104

2.400

Depósitos

60.504

Extraordinario

2.170

66

Salida de esclavos

Familias y poblaciones

Anata de mercedes

332.278

6.246

3.024

Mesadas eclesiásticas

20.771

3.273

8.224

Oticios

Papel sellado

512.000

Recolección de pesetas

Situación

1.323 .705

6.651

8

Vacantes mayores

Alcance de cuentas

Préstamos a Situación

318.022

537.902

27

13

31

Préstamos a familias

67.464

Reintegros a préstamos

605.433

17

Total: $\quad 4.100 .926$ 
1-1 a 31-12-1759

Agua de la fuente

Alcabala de viento

Almojarifazgo de entrada

Almojarifazgo de salida

Armada de entrada

Armada de salida

Arqueo de embarcaciones

Bulas

Cuarta arzobispal

Carcelaje de negros

Descuentos

Depósitos

Extraordinario

Salida de esclavos

Familias

Anata de mercedes

Novenos

Oficios

Papel sellado

Penas de Cámara

Situación

Alcance de cuentas

Préstamos a situación

Préstamos a familias

Cuarteles (préstamos)

Reintegro de préstamos

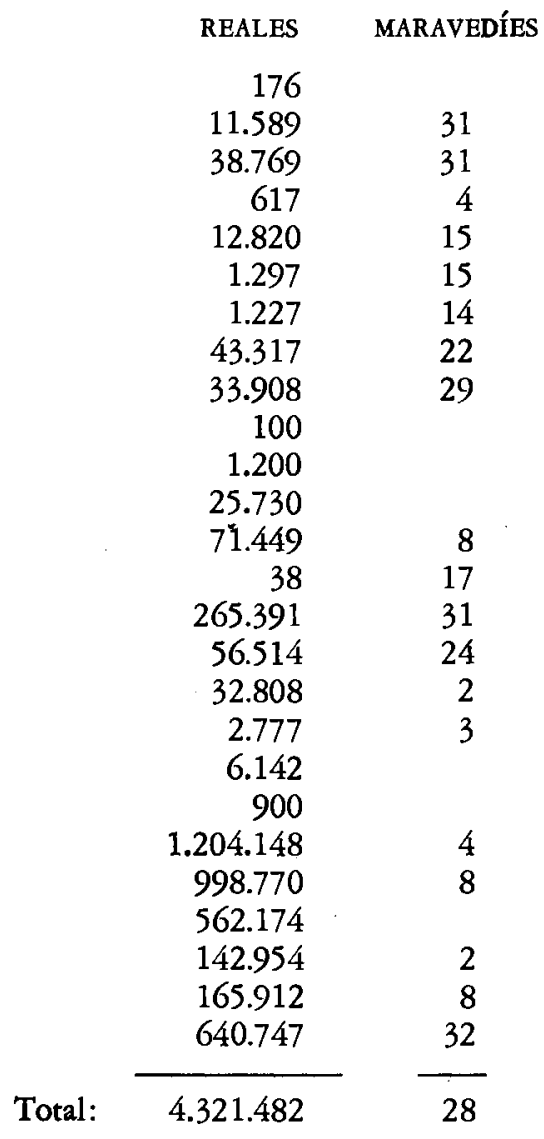

$1-1$ a $31-12-1760$

Agua de la fuente

228

Alcabala de viento

16.156

62.676

1.056

16.576

1.507

1.805

26.151

5.227

32.999

1.200

95.588
16

13

22

30

21

23

23

5

26

33 
Extraordinario

Salida de esclavos

Entrada e indulto de esclavos

Familias

Anata de mercedes

Mesadas eclesiásticas

Oficios

Papel sellado

Penas de cámara

Situación

Alcance de cuentas

Préstamos a situación

Préstamos a compra de harina

Préstamos a familias

Préstamos a cuarteles

Reintegro de préstamos

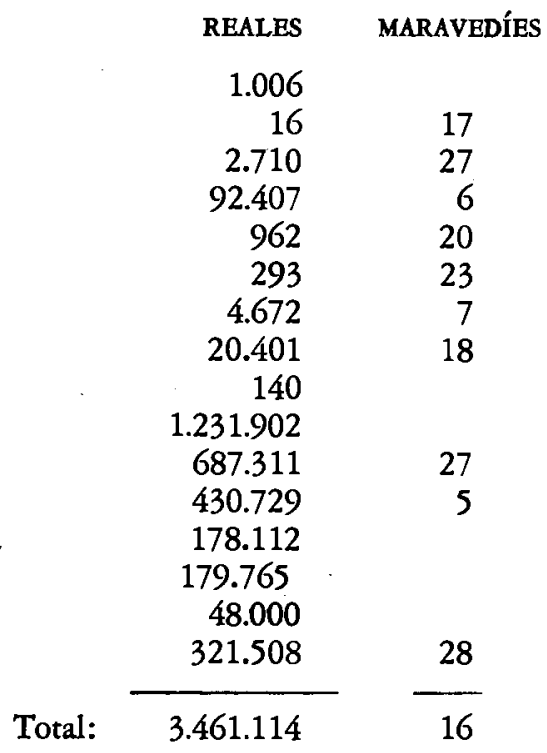


REALES

Papel sellado

Penas de cámara

Situación

Renta del solar

Alcance de cuentas

Préstamos a situación

Préstamos a familias

Reintegro de préstamos

$\begin{array}{rrc} & \text { REALES } & \text { MARAVEdíES } \\ 4.370 & 17 \\ 466 & \\ 1.424 .278 & 25 \\ 800 & \\ 407.829 & 11 \\ 513.369 & 3 \\ 141.600 & 5 \\ & 334.441 & 5\end{array}$

$1-1$ a $31-12-1762$

Agua de la fuente

Alcabala de tierra

Alcabala de viento

Almojarifazgo de entrada

Almojarifazgo de salida

Armada de entrada

Armada de salida

Arqueo de embarcaciones

Bulas

Comisos

Cuarta arzobispal

Carcelaje de negros

Descuentos

Depósitos

Extraordinario

Entrada de esclavos

Familias

Anata de mercedes

Mesadas eclesiásticas

Novenos

Oficios

Papel sellado

Penas de Cámara

Situación

Alcance de cuentas

Préstamos a situación

Préstamos a extraordinario por guerra

Préstamos a familias

Préstamos a cuarteles

Reintegro de préstamos
112

46

36.179

32.006

391

6.853

2.174

605

21.312

56.787

31.676

144

1.200

48.057

20.119

19.197

68.608

445

293

14.093

4.480

13.179

4.064

1.451 .242

646.526

317.334

223.182

62.108

178.701

Total: $\frac{12.734}{3.273 .856}-\frac{20}{24}$ 
1-1 al 31-12-1763

\begin{tabular}{|c|c|}
\hline REALES & MARAVEDÍES \\
\hline \multicolumn{2}{|l|}{328} \\
\hline 19.476 & 8 \\
\hline 63.743 & 6 \\
\hline 4.961 & 17 \\
\hline 17.436 & 6 \\
\hline 6.678 & 13 \\
\hline 3.142 & \\
\hline 6.820 & \\
\hline 46.293 & 29 \\
\hline 38.629 & 14 \\
\hline \multicolumn{2}{|l|}{296} \\
\hline \multicolumn{2}{|l|}{1.200} \\
\hline \multicolumn{2}{|l|}{27.200} \\
\hline 1.468 & 25 \\
\hline \multicolumn{2}{|l|}{55} \\
\hline \multicolumn{2}{|l|}{93.876} \\
\hline \multicolumn{2}{|l|}{80} \\
\hline 1.327 & 14 \\
\hline 205 & 12 \\
\hline 17.177 & 22 \\
\hline \multicolumn{2}{|l|}{6.509} \\
\hline \multicolumn{2}{|l|}{4.543} \\
\hline \multicolumn{2}{|l|}{6.295} \\
\hline \multicolumn{2}{|l|}{280} \\
\hline 1.473 .710 & 17 \\
\hline \multicolumn{2}{|l|}{80} \\
\hline 509.708 & 4 \\
\hline \multicolumn{2}{|l|}{543.108} \\
\hline \multicolumn{2}{|l|}{8.622} \\
\hline 765.479 & 23 \\
\hline \multicolumn{2}{|l|}{150.295} \\
\hline \multicolumn{2}{|l|}{80.464} \\
\hline 3.899 .490 & 21 \\
\hline
\end{tabular}

Agua de la fuente

Alcabala de viento

19.476

Almojarifazgo de entrada

4.743

Almojarifazgo de salida

17.436

Armada de entrada

6.678

Armada de salida

3.142

Arqueo de embarcaciones

6.820

Comisos

46.293

Cuarta arzobispal

Carcelaje de negros

Descuentos

Depósitos

Extraordinario

Salida de esclavos

Entrada e indulto de esclavos

Familias

Anata de mercedes

Mesadas eclesiásticas

Novenos

Muelle

Oficios

Papel sellado

Penas de Cámara

Situación

Renta del solar

Alcance de cuentas

Préstamos a situación

Préstamos a muelle

Préstamos para la guerra

Préstamos a familias

Préstamos a cuarteles

$1-1$ al $31-12-1764$

Agua de la fuente

Alcabala de tierra

Alcabala de viento

Almojarifazgo de entrada

Almojarifazgo de salida

1.511

Armada de entrada

17.877 
REALES

Armada de salida

Arqueo de embarcaciones

Bulas

Comisos

Cuarta arzobispal

Cuarteles

Carcelaje de negros

Descuentos

Depósitos

Extraordinario

Salida de esclavos

Entrada e indulto de esclavos

Familias

Anata de mercedes

Mesadas eclesiásticas

Muelle

Novenos

Oficios

Papel sellado

Penas de Cámara

Situación

Alcance de cuentas

Préstamos a situación

Préstamos a muelle

Préstamos para la guerra

Préstamos a familias

Préstamos a cuarteles

Reintegro de préstamos

\begin{tabular}{|c|c|}
\hline REALES & MARAVEDÍES \\
\hline 1.434 & 18 \\
\hline 3.992 & \\
\hline 19.440 & \\
\hline 3.170 & \\
\hline 35.447 & 29 \\
\hline 3.568 & \\
\hline 144 & \\
\hline 1.200 & \\
\hline 8.440 & \\
\hline 29.583 & \\
\hline 203 & 17 \\
\hline 155.389 & 19 \\
\hline 151.918 & \\
\hline 12.009 & \\
\hline 1.209 & 18 \\
\hline 1.072 & \\
\hline 15.207 & 32 \\
\hline 5.292 & \\
\hline 12.809 & 22 \\
\hline 400 & \\
\hline 1.317 .297 & \\
\hline 116.045 & 23 \\
\hline 533.464 & 8 \\
\hline 2.690 & \\
\hline 264.648 & 30 \\
\hline 195.886 & 30 \\
\hline 94.826 & 10 \\
\hline 151.918 & \\
\hline 3.261 .308 & 29 \\
\hline
\end{tabular}

1-1 al 31-12-1765

Agua de la fuente

Alcabala de tierra

Alcabala de viento

Almojarifazgo de entrada

25.091

67.038

1.863

Almojarifazgo de salida

14.127

2.765

3.139

7.923

268

45.052
17

14

26

14

17

33

21

10 
Carcelaje de negros

REALES

MARAVEDÍES

Descuentos

136

Depósitos

1.200

Extraordinario

47.600

Salida de esclavos

Entrada e indulto de esclavos

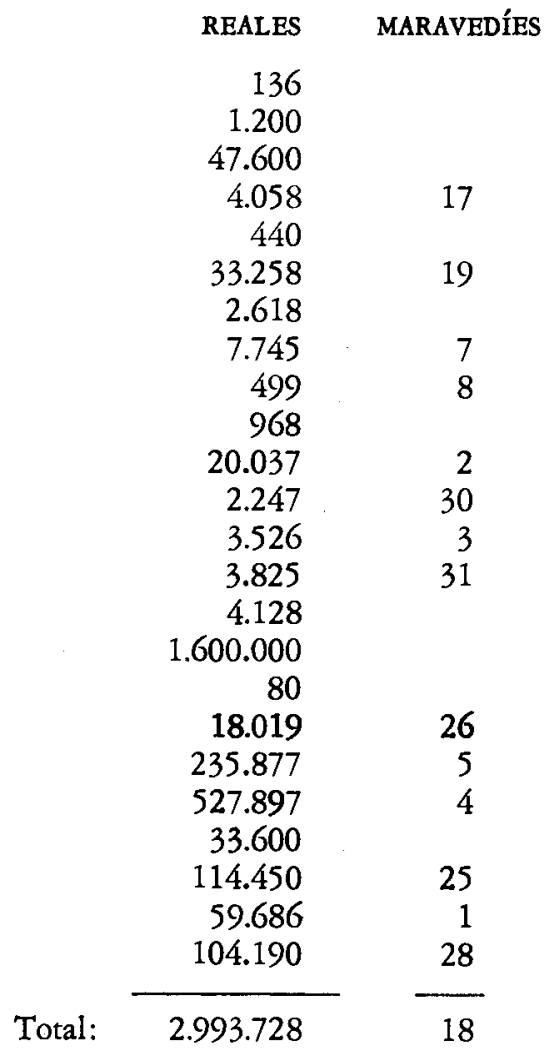

Familias

Anata de mercedes

Mesadas eclesiásticas

Muelle

Novenos

Oficios

Papel sellado

Penas de cámara

Sal

Situación

Renta del solar

Vacantes menores

Alcance de cuentas

Préstamos a situación

Préstamos a guerra

Préstamos a familias

Préstamos a cuarteles

Reintegro de préstamos

Total: $2.993 .728 \quad-18$

1-1-1766 al 6-2-1767

Agua de la fuente

Alcabala de viento

27.302

Almojarifazgo de entrada

Almojarifazgo de salida

807

Armada de entrada

13.450

Armada de salida

1.338

Arqueo de embarcaciones

4.645

Atrasados

507.563

Bulas

16.080

Comisos

621

Derechos del Consejo

260

Cuarta arzobispal

16.000

Carcelaje de negros

124

Descuentos

1.200

Depósitos

9.649 
REALES

Expolio

Extraordinario

Salida de esclavos

Entrada e indulto de esclavos

Familias

Anata de mencedes

Mesadas eclesiásticas

Muelle

Oficios

Papel sellado

Penas de Cámara

Situación

Renta del solar

Tabaco

Alcance de cuentas

Préstamos a situación

Caudal prestado para harina

Préstamos a familias

Préstamos a cuarteles

Reintegro de préstamos

Casa cuna

Limosnas

\begin{tabular}{|c|c|}
\hline REALES & MARAVEDÍ \\
\hline 16.321 & 8 \\
\hline 5.693 & 27 \\
\hline 198 & \\
\hline 14.750 & 7 \\
\hline 110.023 & \\
\hline 20.217 & \\
\hline 2.286 & \\
\hline 1.216 & \\
\hline 9.079 & 23 \\
\hline 9.778 & 17 \\
\hline 1.208 & \\
\hline 1.753 .012 & 12 \\
\hline 160 & \\
\hline 400.000 & \\
\hline 434.560 & 29 \\
\hline 417.419 & 27 \\
\hline 400.000 & \\
\hline 60.259 & 28 \\
\hline 35.792 & \\
\hline 193.606 & \\
\hline 48.000 & \\
\hline 16.000 & \\
\hline 4.624 .510 & 21 \\
\hline
\end{tabular}

\section{$6-2$ a $31-12-1767$}

Agua de la fuente

Alcabala de tierra

Alcabala de viento

Almojarifazgo de entrada

Almojarifazgo de salida

Armada de entrada

Armada de salida

Arqueo de embarcaciones

Bulas

Cuarta arzobispal

Cancelaje de negros

Descuentos

Depósitos

Expolio

Extraordinario

Salida de esclavos

Entrada $e$ indulto de negros
184

8

20.679

47.978

10.619

11.551

1.192

2.177

10.960

55.773

1.000

2.480

55.773

25.361

154

6.754

\section{1}

28

10

31

29

15

17

25 
Familias y poblaciones

REALES MARAVEDÍES

Anata de mercedes 171

Mesadas eclesiásticas

Muelle

Novenos

Oficios

37.795

Papel sellado

814

Penas de cámara

2.058

3.383

Situación

32.000

Vacantes menores

Vacantes mayores

13.188

Alcance de cuentas

Préstamos a situación

Total: $2.258 .116 \quad-\quad-22$

\section{1-1 a 31-12-1768}

Agua de la fuente

Alcabala de tierra

Alcabala de viento

664

Almojarifazgo de entrada

14.794

42.371

Almojarifazgo de salida

Armada de entrada

8.341

Armada de salida

Arqueo de embarcaciones

1.834

Atrasados

440.278

Bulas

9.697

Comisos

Carcelaje de negros

11.636

140

Depósitos

36.741

Extraordinario

5.770

170

Salida de esclavos

1.600

Familias

1.961

Anata de mercedes

584

Muelle

18.920

Novenos

20.634

Oficios

2.304

Papel sellado

4.880

Penas de cámara

5.900

Resulta de cuentas

9.520

Sal

2.532 .400

Situación

Renta del solar 
REALES MARAVEDÍES

Tabaco

Vacantes menores

400.000

Vacantes mayores

7.298

42.528

Alcance de cuentas

Préstamos a situación

1.010 .265

Reintegros

Casa Cuna

$\begin{array}{crr} & \text { REALES } & \text { MARAVEDÍES } \\ & 400.000 & \\ 7.298 & 30 \\ & 42.528 & 16 \\ & 1.010 .265 & 1 \\ & 316.929 & 26 \\ & 623.319 & 13 \\ & 96.000 & \\ \text { Total: } & 5.668 .977 & -25\end{array}$

$1-1$ a $31-12-1769$

Agua de la fuente

180

Alcabala de viento

11.611

Almojarifazgo de entrada

43.251

Almojarifazgo de salida

74

Armada de entrada

6.795

Armada de salida

Arqueo de embarcaciones

1.958

3.668

Seis por ciento de entrada

1.384

Seis por ciento de salida

692.686

Atrasados

Bulas

103.321

Comisos

77.082

Remisiones de cajas subalternas

102.648

Depósitos

89.120

178.924

Diezmos

55.651

Expolio

8.365

Extraordinario

220

Salida de esclavos

29.357

Entrada e indulto de esclavos

67.476
6.596

Impuesto de ganados

Anata de mercedes

6.596
7.749

Mesadas eclesiásticas

15.300

Montepío militar

624

Muelle

19.021

Novenos

46.413

Papel sellado

475

Penas de Cámara

9.333

Realengos

49.631

135.796

Resulta de cuentas

2.316

9

19

33

30

17

$282 / 3$

30

26

26
17

Sal

1.371 .286

Situación

1.164 .606

27

7

18

5

24

11

Tabaco 
Vacante menor

Vacantes mayores

Alcance de cuentas

Préstamos a situación

Reintegro de préstamos

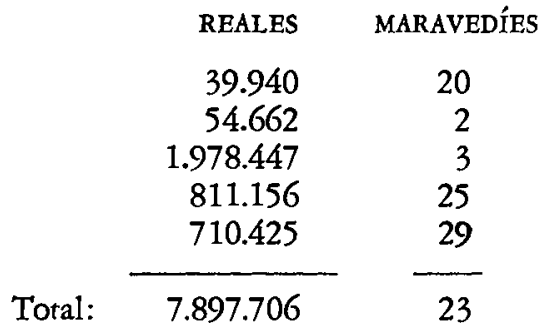

1-1 al $31-12-1770$

Agua de la fuente 136

Alcabala de viento

Almojarifazgo de entrada

Almojarifazgo de salida

Armada de entrada

Armada de salida

Arqueo de embarcaciones

Seis por ciento de entrada

Seis por ciento de salida

Bulas

Comisos

Depósitos

Diezmos

Expolio

Extraordinario

Salida de esclavos

Entrada e indulto de esclavos

Impuesto del ganado

Anata de mercedes

Mesadas eclesiásticas

Montepío militar

Muelle

Novenos

Oficios

Papel sellado

Penas de cámara

Realengos

Resulta de cuentas

Sal

Alcance de cuentas

Préstamos a situación

Reintegro de préstamos

\begin{tabular}{rr}
136 & \\
19.020 & 1 \\
67.010 & 21 \\
612 & 20 \\
14.047 & 7 \\
1.709 & 23 \\
1.784 & 13 \\
9.286 & 1 \\
705 & 29 \\
39.234 & 30 \\
8.497 & 6 \\
53.518 & 20 \\
181.384 & 13 \\
5.600 & \\
2.196 & 27 \\
110 & \\
16.133 & 11 \\
1.200 & \\
7.069 & 13 \\
1.278 & 21 \\
10.572 & \\
536 & \\
19.974 & 22 \\
13.307 & 4 \\
30.134 & 13 \\
17.663 & 27 \\
7.120 & \\
10.779 & 14 \\
15.309 & 29 \\
2.107 .548 & 23 \\
732.138 & 19 \\
848 & \\
\hline 3.396 .467 & 33
\end{tabular}




\begin{tabular}{|c|c|}
\hline REALES & MARAVEDÍES \\
\hline 136 & \\
\hline 15.715 & 21 \\
\hline 52.015 & 15 \\
\hline 521 & 23 \\
\hline 13.274 & 23 \\
\hline 872 & 8 \\
\hline 1.447 & \\
\hline 14.097 & 9 \\
\hline 4.740 & 23 \\
\hline 440.278 & 17 \\
\hline 140.345 & 32 \\
\hline 3.361 & 12 \\
\hline 91.794 & 1 \\
\hline 182.990 & 28 \\
\hline 7.050 & 29 \\
\hline 66 & \\
\hline 68.096 & 18 \\
\hline 275 & 9 \\
\hline 19.202 & 14 \\
\hline 9.826 & 10 \\
\hline 504 & \\
\hline 19.301 & 18 \\
\hline 6.480 & \\
\hline 4.969 & 17 \\
\hline 10.690 & \\
\hline 480 & \\
\hline 53.101 & 21 \\
\hline 26.634 & \\
\hline 2.927 & \\
\hline 2.517 .777 & 23 \\
\hline 400.000 & \\
\hline 699.326 & 2 \\
\hline 828.474 & 30 \\
\hline 1.910 .279 & 14 \\
\hline 7.547 .054 & 9 \\
\hline
\end{tabular}

31-10-1771 a 31-12-1772

Agua de la fuente

Alcabala de viento

Almojarifazgo de entrada 
Armada de salida

REALES

MARAVEDÍES

Arqueo de embarcaciones

1.372

1.132

11

Seis por ciento de entrada

24.215

8

Seis por ciento de salida

9.782

21

Atrasados

344.733

28

Bulas

Comisos

140.544

27

28.360

2

Descuentos

1.440

Depósitos

30.082

12

Diezmos

Extraordinario

Salida de esclavos

182.462

27

2.664

Impuesto de ganados

49

95.809

12.785

4.534

Mesadas eclesiásticas

11.253

4.114

Montepio militar

728

Muelle

Multas del Consejo

4.000

Novenos

19.301

14.339

36.970

Papel sellado

1.160

Penas de cámara

120

Pulperías

862

Realengos

4.370

Sal

1.528 .491

Situación

280

Renta del solar

200.000

Tabaco

2.100 .829

Alcance de cuentas

Préstamos a situación

Préstamos a penas de cámara

1.605 .867

Préstamos a diezmos

3.345

2.877

Reintegro de préstamos

\begin{tabular}{|c|c|}
\hline & $\begin{array}{r}3.345 \\
2.877 \\
1.324 .306\end{array}$ \\
\hline Total: & 7.779 .706 \\
\hline
\end{tabular}

$1-1$ al $31-12-1773$

Agua de la fuente

Alcabala de tierra

189

Alcabala de viento

10.869

Almojarifazgo de entrada

27.429

816.

Almojarifazgo de salida 
REALES MARAVEDÍES

Armada de entrada

Armada de salida

Arqueo de embarcaciones

Seis por ciento de entrada

Seis por ciento de salida

Atrasados

Bulas

Comisos

Descuentos

Depósitos

Diezmos

Extraordinario

Salida de esclavos

Gallera

Impuestos del ganado

Mercedes

Mesadas eclesiásticas

Montepío militar

Montepío político

Muelle

Multas del Consejo

Novenos

Oficios

Papel sellado

Penas de cámara

Realengos

Sal

Situación

Tabaco

Alcance de cuentas

Préstamos a situación

Préstamos a penas de cámara

Préstamos a diezmos

Reintegro de préstamos

Casa Cuna

\begin{tabular}{|c|c|}
\hline REALES & MARAVEDÍE \\
\hline 12.403 & 3 \\
\hline 1.390 & 7 \\
\hline 1.387 & 4 \\
\hline 79.599 & 20 \\
\hline 3.941 & 25 \\
\hline 220.139 & 9 \\
\hline 35.767 & 18 \\
\hline 27.131 & 7 \\
\hline 526 & 25 \\
\hline 137.362 & \\
\hline 150.752 & \\
\hline 809 & 2 \\
\hline 5 & 17 \\
\hline 400 & \\
\hline 71.090 & 33 \\
\hline 23.037 & 31 \\
\hline 372 & 19 \\
\hline 29.197 & 8 \\
\hline 3.933 & 11 \\
\hline 504 & \\
\hline 400 & \\
\hline 15.943 & 12 \\
\hline 4.933 & 11 \\
\hline 4.304 & \\
\hline 456 & \\
\hline 56.283 & 32 \\
\hline 3.704 & \\
\hline 1.571 .578 & \\
\hline 200.000 & \\
\hline 2.195 .531 & 32 \\
\hline 1.453 .024 & 7 \\
\hline 9.734 & \\
\hline 10.306 & 18 \\
\hline 2.214 .225 & 15 \\
\hline 8.000 & \\
\hline 8.587 .624 & 25 \\
\hline
\end{tabular}

1-1 al 31-12-1774

Agua de la fuente

Alcabala de tierra

3.980

Alcabala de viento

Almojarifazgo de entrada

11.032

28.717 
Almojarifazgo de salida

Armada de entrada

REALES

MARAVEDÍES

Armada de salida

1.429

21

11.727

10

Arqueo de embarcaciones

1.231

1.590

16

Seis por ciento de entrada

51.002

12

Seis por ciento de salida

6.815

17

Atrasados

220.139

Bulas

59.620

Comisos

112.578

25

Depósitos

231.611

29

Diezmos

Extraordinario

212.858

8.534

22

Salida de esclavos

Entrada e indulto de esclavos

60

47.957

400

Gallera

Impuesto del ganado

Mercedes

106.026

1.425

19.864

4.152

1.496

Montepío político

Muelle

Novenos

22.520

Oficios

Papel sellado

19.137

36.914

Penas de cámara

Pulperías

353

Sal

4.971

Situación

Renta del solar

Tabaco

Vacantes menores

Alcance de cuentas

Préstamos a situación

Préstamos a penas de cámara

Reintegro de préstamos

Limosnas

Casa Cuna

\section{1-1 a $31-6-1775$}

Agua de la fuente 
REALES

Almojarifazgo de salida

Armada de entrada

Armada de salida

Arqueo de embarcaciones

Seis por ciento de entrada

Seis por ciento de salida

Bulas

Comisos

Descuentos

Depósitos

Extraordinario

Salida de esclavos

Entrada e indulto de esclavos

Inválidos

Mercedes

Montepío militar

Muelle

Oficios

Papel sellado

Alcance de cuentas

Préstamos a situación

Préstamos a penas de cámara

Casa Cuna

\begin{tabular}{|c|c|}
\hline REALES & MARAVEDÍES \\
\hline 47 & 6 \\
\hline 6.329 & 10 \\
\hline 31 & 5 \\
\hline 234 & 7 \\
\hline 38.999 & 23 \\
\hline 22.085 & 6 \\
\hline 5.600 & \\
\hline 60.331 & 4 \\
\hline 738 & 17 \\
\hline 7.008 & \\
\hline 100 & \\
\hline 22 & \\
\hline 10.422 & 17 \\
\hline 5.512 & 30 \\
\hline 1.312 & 8 \\
\hline 3.750 & 9 \\
\hline 1.400 & \\
\hline 880 & \\
\hline 320 & \\
\hline 2.606 .869 & 20 \\
\hline 605.666 & 13 \\
\hline 1.440 & \\
\hline 5.136 & 17 \\
\hline 3.402 .575 & 1 \\
\hline
\end{tabular}


SALIDAS PRODUCIDAS EN LAS CAJAS REALES DE SANTO DOMINGO DESDE EL I DE ENERO DE 1754

AL 31 DE JUNIO DE 1775

(A.G.I. Contaduría 1.069-A y B, y Santo Domingo 1.048, 1.049, 1.050, 1.051)

1-1 al 31-12-1754

$\begin{array}{crc} & \text { REALES } & \text { MARAVEDÍES } \\ & 28.027 & 17 \\ 3.667 & 20 \\ 91.386 & 3 \\ 11.612 & 12 \\ 38 & \\ 462 & 17 \\ & 73.872 & 11 \\ & 1.246 .054 & 9 \\ & 30.648 & \\ \text { Total: } & 1.485 .768 & 21\end{array}$

1-1 al 31-12-1755

Agua de la fuente 273

Depósitos

8.138

Extraordinario de Real Hacienda

1.192

Familias y poblaciones

93.263

Novenos

12.019

Real Hacienda

55.408

Salarios y situación

Reintegro de préstamos

\begin{tabular}{lrr} 
& 273 & \\
& 8.138 & 28 \\
& 1.192 & 5 \\
& 93.263 & 3 \\
& 12.019 & 2 \\
& 55.408 & 14 \\
& 1.119 .100 & 27 \\
& 27.536 & \\
\cline { 2 - 2 } Total: & 1.316 .931 & \\
\cline { 2 - 3 } & & 11
\end{tabular}

1-1 a 5-10-1756

Agua de la fuente

Expolio

Extraordinario de Real Hacienda

Familias y poblaciones

Penas de Cámara y Justicia

Real Hacienda

Salarios y situación

\begin{tabular}{rrr} 
& 14 & \\
& 3.200 & \\
5.370 & \\
110.622 & 4 \\
400 & \\
73.019 & 21 \\
& 1.075 .965 & 1 \\
\hline Total: & 1.268 .590 & $\frac{26}{26}$
\end{tabular}


5-10-1756 a 31-12-1757

\begin{tabular}{crr} 
& REALES & MARAVEDÍES \\
& 240 & \\
& 31.275 & 7 \\
& 23.418 & 26 \\
& 33.537 & 17 \\
& 216.755 & 22 \\
& 4.000 & \\
& 25.488 & 14 \\
& 194.326 & 24 \\
& 1.478 .355 & 33 \\
& 293.020 & 15 \\
& 146.018 & 1 \\
\cline { 2 - 2 } Total: & 2.446 .436 &
\end{tabular}

Agua de la fuente

Depósitos

Expolio

Extraordinario de Real Hacienda

17

Familias y poblaciones

Multas del Consejo

Novenos

Real Hacienda

Salarios y situación

Préstamos a situación

Reintegro de préstamos

Total: $2.446 .436 \quad 23$

$1-1$ al $31-12-1758$

Vacantes mayores

6.651

4.277

Cuarteles y fortificaciones

22.091

Cuarta arzobispal

2.174

Depósitos

24.563

Extraordinario de Real Hacienda

212.856

Familias y poblaciones

20.771

Novenos

162.503

Real Hacienda

Salarios y situación

Préstamos a cuarteles y fortificaciones

1.441 .086

5.600

Préstamos a familias

96.000

Préstamos a situación

273.571

Reintegro de préstamos

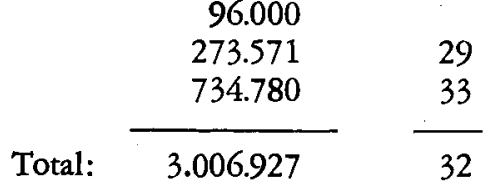

\section{1}

32

8

17

11

20

6

1

29

33

32

$1-1$ al $31-12-1759$

Bulas

36.736

Cuarteles y fortificaciones

188.774

Cuarta arzobispal

33.908

Depósitos

60.029

34.328

119.446

Familias y poblaciones

24.808

Novenos

525

Penas de Cámara y Justicia

Caudal de pesetas

196.444

Real Hacienda

63.087

Salarios y situación

1.215 .858

14

29

1

7

2

29

8 


\begin{tabular}{|c|c|c|}
\hline & REALES & MARAVEDÍES \\
\hline Préstamos a cuarteles y fortificaciones & 133.912 & 8 \\
\hline Préstamos a familias & 130.954 & 2 \\
\hline Préstamos a novenos & 17.720 & \\
\hline Préstamos a situación & 524.078 & 22 \\
\hline Reintegro de préstamos & 635.902 & 5 \\
\hline Total: & 3.416 .512 & 25 \\
\hline
\end{tabular}

$1-1$ a $31-12-1760$

Bulas

Comisos

Cuarteles y fortificaciones

Cuarta arzobispal

Depósitos

Extraordinario de Real Hacienda

Familias y poblaciones

Compra de harina

Real Hacienda

Salarios y situación

Préstamos a cuarteles y fortificaciones

Préstamos a familias

Préstamos para compra de harina

Préstamos a situación

Reintegro de préstamos

\begin{tabular}{crr} 
& 9.902 & 6 \\
& 8.523 & 26 \\
& 130.418 & 33 \\
& 32.999 & 26 \\
& 39.520 & 24 \\
& 10.694 & \\
& 165.238 & 22 \\
& 89.056 & \\
& 90.403 & 33 \\
& 1.311 .353 & 23 \\
Total: & 48.000 & \\
& 99.765 & \\
& 89.056 & \\
& 395.779 & 32 \\
& 532.348 & 6 \\
\cline { 2 - 2 } Taciones & 3.053 .060 & 27
\end{tabular}

1-1 al 31-12-1761

Agua de la fuente

259

Cuarteles y fortificaciones

Cuarta arzobispal

Depósitos

Extraordinario de Real Hacienda

Familias y poblaciones

Novenos

Penas de Cámara y Justicia

Real Hacienda

Reparos de la Real Fuerza

Salarios y situación

Préstamos a familias

Préstamos a situación

Reintegro de préstamos

\begin{tabular}{crr} 
& 259 & \\
& 55.314 & 31 \\
31.322 & 22 \\
25.072 & 25 \\
26.624 & \\
301.269 & 4 \\
28.623 & 29 \\
& 818 & 15 \\
& 41.975 & 33 \\
& 31.322 & 22 \\
& 1.457 .343 & 16 \\
& 61.600 & \\
& 12.734 & 20 \\
& 820.201 & 5 \\
\hline \multirow{3}{*}{ Total: } & 2.894 .482 & 18
\end{tabular}


Cuarteles y fortificaciones

Cuarta arzobispal

Depósitos

Extraordinario de Real Hacienda

Extraordinario por guerra

Familias y poblaciones

Novenos

Real Hacienda

Reparos de la Real Fuerza

Salarios y situación

Préstamos a cuarteles y fortificaciones

Préstamos a familias

Préstamos a situación

Reintegro de préstamos
I-I al $31-12-1762$

\begin{tabular}{crc} 
& REALES & MARAVEDÍES \\
& 165.060 & 10 \\
& 31.676 & 24 \\
& 776 & \\
$\mathrm{da}$ & 55.391 & 10 \\
& 248.150 & 30 \\
& 246.781 & 12 \\
& 14.093 & 26 \\
& 61.312 & 5 \\
& 30.515 & 5 \\
& 1.264 .452 & 14 \\
& 58.701 & 16 \\
& 62.508 & 30 \\
Total: & 26.151 & 23 \\
& 498.577 & 3 \\
\cline { 2 - 2 } & 2.764 .149 & -14
\end{tabular}

$1-1$ al $31-12-1763$

Cuarteles y fortificaciones

Cuarta arzobispal

Depósitos

Extraordinario de Real Hacienda

Extraordinario por la guerra

Familias y poblaciones

Muelle

Penas de Cámara y Justicia

Real Hacienda

Salariós y situación

Préstamos a cuarteles y fortificaciones

Préstamos a familias

Préstamos a muelle

Reintegro de préstamos

\begin{tabular}{crr} 
& 233.650 & 8 \\
& 38.629 & 14 \\
& 19.125 & 9 \\
& 75.206 & 17 \\
& 516.632 & 19 \\
& 204.929 & 7 \\
& 2.113 & 25 \\
& 2.906 & 17 \\
& 108.203 & 10 \\
& 1.327 .953 & 3 \\
& 24.000 & \\
Total: & 68.570 & 6 \\
& 2.113 & 25 \\
& 1.082 .229 & 27 \\
\cline { 2 - 2 } & 3.706 .263 &
\end{tabular}

$1-1$ al $31-12-1764$

Comisos

Cuarteles y fortificaciones

60.175

35.447

4.052

Depósitos

48.059

264.748 


\begin{tabular}{|c|c|c|}
\hline & REALES & MARAVEDÍE \\
\hline Familias y poblaciones & 195.886 & 30 \\
\hline Indulto de negros & 6.552 & \\
\hline Muelle & 2.690 & \\
\hline Novenos & 4.404 & 20 \\
\hline Penas de Cámara y Justicia & 1.142 & \\
\hline Real Hacienda & 47.065 & 3 \\
\hline Salarios y situación & 1.471 .428 & 9 \\
\hline Préstamos a cuarteles y fortificaciones & 76.151 & 8 \\
\hline Préstamos a familias & 130.622 & 30 \\
\hline Préstamos para la guerra & 13.600 & 30 \\
\hline Préstamos a muelle & 2.690 & \\
\hline Préstamos a situación & 25.594 & \\
\hline Reintegro de préstamos & 834.224 & 9 \\
\hline Total: & 3.225 .016 & 15 \\
\hline
\end{tabular}

1-1 al 31-12-1765

Comisos

Cuarteles y fortificaciones.

Cuarta arzobispal 45.052

Derechos del Consejo

Extraordinario de Real Hacienda

43.668

Extraordinario por la guerra

33.600

Familias y poblaciones

114.450

Indulto de negros

Muelle

1.101

Penas de Cámara y Justicia

3.159

Real Hacienda

67.979

Salarios y situación

203.069

Préstamos a cuarteles y fortificaciones

17.543

Préstamos a familias

114.450

Préstamos para la guerra

33.600

Reintegro de préstamos

Total: $\frac{840.371}{2.579 .167} \quad \frac{4}{11}$

1-1-1766 al 6-2-1767

Cuarteles y fortificaciones

Cuarta arzobispal

Derechos del Consejo

Expolio

Extraordinario de Real Hacienda 
REALES MARAVEDÍES

Familias y poblaciones

62.246

28

Indulto de negros

3.360

Muelle

1.476

22

Novenos

Penas de Cámara y Justicia

Real Hacienda

Salarios y situación

Préstamos a cuarteles y fortificaciones

Préstamos a familias

Préstamos al Montepío

Reintegro de préstamos

Limosnas

Casa Cuna
$12.772 \quad 30$

$4.314 \quad 16$

$86.621 \quad 12$

$1.597 .826 \quad 28$

$35.792 \quad 20$

$60.255 \quad 28$

$732 \quad 32$

$602.410 \quad 28$

16.000

48.000

6-2-1767 al 31-12-1767

Atrasados

77.405

4.620

Expolio

95.135

23.078

Familias y poblaciones

3.787

Real Hacienda

58.036

Salarios y situación

Préstamos al Montepío

700.707

Préstamos a situación

8.480

25

13

32

30

\begin{tabular}{|c|c|}
\hline & 8.480 \\
\hline & 290.766 \\
\hline Total: & 1.262 .018 \\
\hline
\end{tabular}

1-1 al $31-12-1768$

Atrasados

370.117

25.946

721

Expolio

181.676

48.886

4.001

Familias y poblaciones

Penas de Cámara y Justicia

81.320

Salarios y situación

Préstamos al Montepío

Préstamos a situación

2.037 .494

4.800

Reintegro de préstamos

\begin{tabular}{|c|c|c|}
\hline & 4.001 & \\
\hline & 81.320 & 12 \\
\hline & 2.037 .494 & 8 \\
\hline & 4.800 & \\
\hline & 316.929 & 26 \\
\hline & 607.696 & 13 \\
\hline Total: & 3.679 .589 & 21 \\
\hline
\end{tabular}




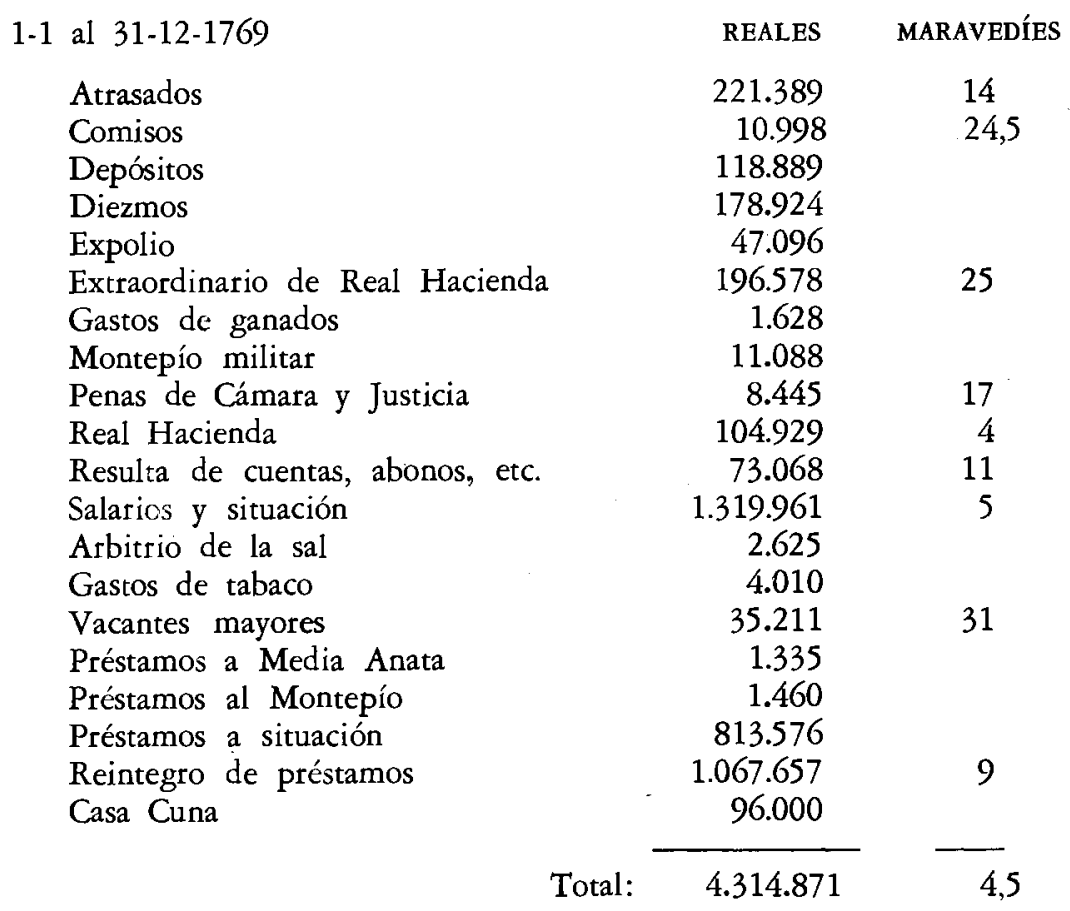

1-1 al $31-12-1770$

Atrasados

10.153

Depósitos

19.594

181.384

61.974

İxtraordinario de Real Hacienda

14.784

Montepío Militar

818 .

Muelle

18.379

58.400

Real Hacienda

13.886

Resulta de Cuentas y Abonos

732.138

Salarios y situación

812.812

Préstamos a Diezmos

Préstamos a gastos de Justicia

13.502

14.919

732.138

Préstamos a situación

11.023

Reintegro de préstamos

\begin{tabular}{rrr} 
& 13.502 & 8 \\
& 14.919 & 27 \\
& 732.138 & 19 \\
& 11.023 & 29 \\
& 848 & \\
\cline { 2 - 3 } Total: & 2.696 .757 &
\end{tabular}


1-1 al $31-10-1771$

Atrasados

Comisos

Depósitos

Diezmos

Extraordirario de Real Hacienda

Montepío Militar

Monrepío político

Muelle

Penas de Cámara y Justicia

Real Hacienda

Salarios y Situación

Arbitrio de la sal

Tabaco

Préstamos a Diezmos

Préstamos a Gastos de Justicia

Préstamos a Situación

Reintegro a préstamos
REALES MARAVEDÍES

239.836

5.200

$4.876 \quad 17$

182.990

493.414

14.784

1.113

504

9.350

53.456

1.836 .787

13.113

187.300

528

4.569

898.128

1.510 .805

Total: $\quad 5.456 .759$
22

28

4

11

26

10

1

25

28

17

24

10

19

31-10-1771 al 31-12-1772

Atrasados

16.000

Comisos

14.160

Cuarteles y fortificaciones

89.448

43.482

Depósitos

185.339

Diezmos

62.033

14.784

Montepío Militar

800

728

Muelle

4.000

Multas del Consejo

Penas de Cámara y Justicia

9.207

Real Hacienda

101.232

10.400

Resulta de Cuentas y Abonos

1.810 .780

7.440

Arbitrio de la Sal

39.556

Tabaco

2.877

8.047

Préstamos a Gastos de Justicia

Préstamos a situación

1.605 .866

Reintegro de préstamos

1.323 .578

Casa Cuna

8.000

28 
$1-1$ al $31-12-1773$

Atrasados
Comisos
Cuarteles y fortificaciones
Depósitos
Diezmos
Extraordinario de Real Hacienda
Montepío Militar
Montepío político
Penas de Cámara y Justicia
Real Hacienda
Reparos de la Real Fuerza
Salarios y situación
Tabacos
Préstamos a Casa Cuna
Préstamos a Diezmos
Prestamos a Gastos de Justicia
Préstamos a situación
Reintegro de préstamos
Casa Cuna

REALES MARAVEDÍES

117.983

39.936

71.501

37.952

161.058

46.569

13.552

8.741

10.190

83.293

56.574

1.453 .024

442.560

14.853

10.306

26.009

1.619 .114

1.571 .677

10.853

5.795 .750
13

15

18

13

6

3

26

7

22

18

12

5

24

21

$1-1$ al $31-12-1774$

Atrasados

130.208

25

Comisos

50.328

Cuarteles y fortificaciones

101.449

125.095

Depósitos

212.858

66.612

Extraordinario de Real Hacienda

16.335

5.211

11.119

65.634

49.333

Montepio político

Penas de Cámara y Justicia

Real Hacienda

Reparos de la Real Fuerza

2.168 .360

Salarios y situación

672.058

539.238

Préstamos a situación

Reintegro de préstamos

24.923

Casa Cuna

5.136

12

22

14

28

26

29

28

14

33

2

15

17

Total: 4.243 .905

17 
$1-1$ al $31-6-1775$

Atrasados

Comisos

Cuarteles y fortificaciones

Depósitos

Extraordinario de Real Hacienda

Montepío Militar

Penas de Cámara y Justicia

Real Hacienda

Reparos de la Real Fuerza

Tabaco

Salarios y situación

Préstamos a Casa Cuna

Préstamos a Gastos dé Justicia

Préstamos a situación

Limosnas

Reintegro de préstamos
REALES MARAVEDÍES

80.000

24.264

65.362

122.725

817

3.814

1.440

7.686

2.788

198.061

605.666

5.136

1.440

605.666

8.000

605.666

32

21

6

30

8

13

17

13

13

Total: $\quad 2.338 .535$ 


\section{B I B L I O G R A F I A}

Alcedo, Antonio de: Diccionario geográfico-histórico de las Indias Occidentales o América. Tomo II. Imprenta Hermanos García. Madrid, 1787.

Arcila Farias, Eduardo: Comercio entre Venezuela y México en los siglos XVII y XVIII. Fondo de Cultura Económica. México, 1950.

- Reformas económicas del siglo XVIII en Nueva España. Ediciones Oasis, S. A. México, 1974.

Burzio, Humberto F.: Diccionario de la moneda hispano-americana. Fondo Histórico y Bibliográfico José Toribio Medina. Santiago de Chile, 1958

Carpentier, Alejo: El siglo de las luces. Ediciones Revolución. La Habana, 1965.

Cartoteca Histórica. Servicio Geográfico del Ejército. Sección de Documentación. Madrid, 1974.

Comellas, J. L.: Historia de España Moderna y Contemporánea. 1474-1967. Ediciones Rialp. Madrid, 1968.

Cordova-Bello, Eleazar: La independencia de Haití y su influencia en Hispano-América. Instituto Panamericano de Geografía e Historia. Caracas, 1967.

Diaz Soler, Luís M.: Historia de la esclavitud negra en Puerto Rico. Universidad de Puerto Rico. Río Piedras, 1965.

Franco, J. L.: Historia de la revolución de Haití. 2. ${ }^{\text {a }}$ edición. Editora Nacional, Santo Domingo, 1971.

García, José Gabriel: Compendio de la Historia de Santo Domingo. Imprenta Hermanos García. Santo Domingo, 1893.

García-Baquero González, Antonio: Cádiz y el Atlántico. (1717-1778). Escuela de Estudios Hispano-Americanos. Sevilla, 1976.

Gil-Bermejo García, Juana: Panorama histórico de la Agricultura en Puerto Rico. Escuela de Estudios Hispano-Americanos. Sevilla, 1970.

Gil Munilla, Octavio: El Rio de la Plata en la política internacional. Génesis del virreinato. Escuela de Estudios Hispano-Americanos. Sevilla, 1949. 
González, Julio: Mapas y planos de Santo Domingo. Dirección General de Archivos y Bibliotecas Madrid, 1973.

Gutiérrez del Arroyo, Isabel: El reformismo ilustrado en Puerto Rico. Fondo de Cultura Económica. México, 1953.

Hernández Tapia. Concepción: Despoblaciones de la isla de Santo Domingo en el siglo XVII. Separata del tomo XVII del "Anuario de Estudios Americanos". Sevilla, 1970.

Herr, Richard: España y la revolución del siglo XVIII. Aguilar, S. A. de Ediciones. Jerez de la Frontera, 1964.

Hidalgo Nieto, Manuel: La cuestión de las Malvinas. C.S.I.C. Instituto Gonzalo Fernández de Oviedo. Madrid, 1947.

Hussey, Ronald D.: La Compañia de Caracas, 1728-1784. Banco Central de Venezuela. Colección histórico-económica venezolana. Vol. VIII. Caracas, 1962.

Incháustegui, J. Marino: Documentos para estadio. Marco de la época y problemas del tratado de Basilea de 1795, en la parte española de Santo Domingo. Academia Dominicana de la Historia. Buenos Aires, 1957.

Izard, Miguel: Comercio libre, guerras coloniales y mercado americano. Nadal Jordi y Gabriel Tortella edits.

Konetzke, Richard: Colección de documentos para la historia de la formación social de Hispano-América. 1493-1810. C.S.I.C. Madrid, 1962.

Larraz López, José: La época del mercantilismo en Castilla. (1500-1700). Real Academia de Ciencias Morales y Políticas. Madrid, 1943.

Levene, Ricardo: Documentos para la Historia Argentina. T. V. Comercio de Indias. Antecedentes legales, 1713-1778. Comp. Sud-Americana de Billetes de Banco. Buenos Aires, 1915.

López Cantos, Angel: Historia de Puerto Rico. 16S0-1700. Escuela de Estudios Hispano-Americanos. Sevilla, 1975.

Lugo, Américo: Baltasar López de Castro y la despoblación del norte de la Española. 2. ${ }^{\text {a }}$ edición. Publicaciones de la Secretaría de Educación. Santo Domingo, 1974.

Lugo Lovatón, Ramón: El Tratado de Basilea. Editora Montalvo. Ciudad Trujillo, 1951.

MacLean, J. y T. Pina Chevalier: Datos históricos sobre la frontera dominico-haitiana. S. I. Santo Domingo, 1921.

Malagón Barceló, Javier: El distrito de la Audiencia de Santo Domingo, en los siglos XVI a XIX. Publicaciones de la Universidad de Santo Domingo. Vol. XXIII. Editora Montalvo. Ciudad Trujillo, 1942.

- Un documento del siglo XVIII para la historia de la esclavitud en las Antillas. Separata de "Imago Mundi", Año III, núm. 9. Buenos Aires, 1955. 
Martínez Shaw, Carlos: La procedencia de los capitales en la industria naviera catalana del siglo XVIII. Los barcos del comercio atlántico (1744-1752). Separata del tomo XXX del "Anuario de Estudios Americanos". Escuela de Estudios Hispano-Americanos. Sevilla, 1973.

Morales Padrón, Francisco: Colonos canarios en Indias. Separata del tomo VIII del "Anuario de Estudios Americanos". Escuela de Estudios Hispano-Americanos. Sevilla, 1951.

- El comercio canario-americano. Escuela de Estudios Hispano-Americanos. Sevilla, 1955.

- Manual de Historia Universal. Tomo VI. Historia de América. 2. edición. Espasa-Calpe. Madrid, 1975.

Moreau de Saint-Mery, M. L.: Descripción de la parte española de Santo Domingo. Editorial Montalvo. Ciudad Trujillo, 1944.

Moreno Fraginals, Manuel: El ingenio. Comisión Nacional Cubana de la Unesco. La Habana, 1964.

Moya Pons, Frank: Historia colonial de Santo Domingo. Universidad Católica Madre y Maestra. Santiago (Rep. Dominicana), 1974.

Muñoz, Pérez, José: La publicación del reglamento de comercio libre a Indias de 1778. Separata del vol. IV del "Anuario de Estudios Americanos", Sevilla, 1947.

Muro Orejón, Antonio: Cedulario americano del siglo XVIII. Escuela de Estudios Hispano-Americanos. Sevilla, 1956.

Nadal, Jordi y Gabriel Tortella (edits.): Agricultura, comercio colonial y crecimiento económico en la España Contemporánea. Actas del Primer Coloquio de Historia Económica de España. Barcelona, 11-12 de mayo de 1972. Editorial Ariel. Barcelona, 1974.

Oñat, Roberto y Carlos Roa: Régimen legal del ejército en el reino de Chile. Notas para su estudio. Estudios de Historia del Derecho Chileno núm. 1. Universidad Católica de Chile. Santiago de Chile, 1953.

Ots Capdequi, J. M.: España en América. El régimen de tierras en la época colonial. Fondo de Cultura Económica. México, 1959.

Palacio Atard, Vicente: El equilibrio de América en la diplomacia del siglo XVIII. Revista "Estudios Americanos", Vol. I, núm. 3, mayo 1949, págs. 461-479.

Peguero, Luís Joseph: Historia de la conquista de la isla española de Santo Domingo, trasumptada el año de 1762. Edición, estudio preliminar y notas de Pedro J. Santiago. Publicaciones del Museo de las Casas Reales. Santo Domingo, 1975.

Peña Batlle, Manuel Arturo: Historia de la cuestión fronteriza dominicohaitiana. L Sánchez Andújar. Ciudad Trujillo, 1946.

- El Tratado de Basilea. Desnacionalización del Santo Domingo Español. Impresora Dominicana. Ciudad Trujillo, 1952. 
Pérez de Barradas, José: Los mestizos de América. Cultura Clásica y Moderna. Madrid, 1948.

Pérez y Pérez, Carlos Federico. Historia diplomática de Santo Domingo (1492-1861). Universidad Nacional Pedro Henríquez Ureña. Santo Domingo, 1973.

Ramos, Demetrio: Mineria y comercio interprovincial en Hispano-América. Seminario de Historia de América. Universidad de Valladolid, 1970.

Rodríguez Casado, Vicente: Comentarios al Decreto y Real Instrucción de 1765, regulando las relaciones comerciales de España en Indias. "Anuario de Historia del Derecho Español" tomo XIII, págs. 100-135. Madrid, 1936-41.

- El ejército y la marina en el reinado de Carlos III. Separata del "BOletín del Instituto Riva-Agüero" núm. 3, págs. 129-156.

Rodriguez Demorizi, Emilio: Relaciones geográficas de Santo Domingo. Sociedad Dominicana de Geografía. Vol. 1.

- Acerca del Tratado de Riswick. Revista "Clío" (Revista cuatrimestre de la Academia Dominicana de la Historia), vol. 22. págs. 127-132. Santo Domingc, 1954.

- Relaciones históricas de Santo Domingo. Vol. 3. Editora Montalvo. Ciudad Trujillo, 1957.

- Cesión de Santo Domingo a Francia. "Archivo General de la Nación", vol. XIV. Ciudad Trujillo, 1958.

- Nueva fundación de Puerto de Plata (1736) Sociedad Dominicana de Geografía. Vol. VII. Santo Domingo, 1975.

- Samaná, pasado y porvenir. Sociedad Dominicana de Geografía. Vol. V. Santo Domingo, 1973.

Rodríguez-Ferrer, Miguel: El tabaco habano. Su historia, sus cultivos, sus vicisitudes, sur mías afamadas vegas. Imprenta del Colegio Nacional de Sordomudos. Madrid, 1851.

Rodríguez Guerra, Luís: Documentos del Archivo Eclesiástico. "Boletín del Archivo General de la Nación", vol. 3. Ciudad Trujillo, 1940.

Rodríguez Vicente, Encarnación: La contabilidad virreinal como fuente histórica. Separata del tomo XII del "Anuario de Estudios Americanos". Sevilla, 1966.

Sánchez Valverde, Antonio: Idea del valor de la isla española. Editora Nacional, Santo Domingo, 1971.

Sarrailh, Jean: La España ilustrada de la segunda mitad del siglo XVIII. Fondo de Cultura Económica. México, 1957.

Sucre, Luís Alberto: Gobernadores y capitanes generales de Venezuela. Litografía y Tipografía del Comercio. Caracas, 1928. 
Tolentíno Rojas, Vicente: Reseña geográfica, histórica y estadística de la República Dominicana. Impresora Dominicana. Ciudad Trujillo, 1954.

Utrera, Fray Cipriano de: Dilucidaciones históricas, Santo Domingo, 1927.

- Historia militar de Santo Domingo (Documentos y Noticias). Ciudad Trujillo, 1953.

Vázquez de Espinosa, Antonio: Compendio y descripción de las Indias Occidentales. Smithsonian Institution. Washington, 1948.

Velázquez, María del Carmen: El estado de guerra en Nueva España. 1760-1808. El Colegio de México. México, 1950.

Vila Vilar, Enriqueta: Condicionamientos y limitaciones en Puerto Rico en el siglo XVII. Escuela de Estudios Hispano-Americanos. Sevilla, 1973.

Zapatero, J. L.: La guerra en el Caribe en el siglo XVIII. Instituto de Cultura Puertorriqueña, San Juan de Puerto Rico, 1964. 



\section{INDICE DE NOMBRES Y LUGARES}

\section{$-\mathrm{A}-$}

Acevedo, Juan: 101.

Alcedo, Antonio de: 3, 12, 15, 16.

Alejandría: 294.

Alicante: 183.

Alvarez, José: 187.

Alvarez de Abreu, arzobispo: 30, 32, 34.

América: 5, 11, 12, 14, 23, 29, 50, $63,64,69,70,95,100,122,128$, $130,174,181,186,188,203,205$, $208,209,214,215,219,228,236$, $291,304,316,334,335,343,344$, $348,372$.

Andalucía: 336.

Angostura, San Rafael de la: 8, 35, $39,41,42,45,60,134,135,160$, $161,171,216,298,299,350,352$, $364,382,389,390,394$.

Antillano, archipiélago: 15.

Antillas, Las: 1, 11, 14, 16, 21, 25, $95,182,183,191,192,243,246$, 247, 248, 253, 287, 307, 395.

Antillas, Mar de las: 104, 206, 290. Aquisgrán, Paz de: 348.

Aragón: 336.

Aranda, conde de: 365 .

Aranjuez: 70, 97, 118, 368, 370.

Aranjuez, Tratado de: 168, 306, 366, 367.

Argout, conde de; Comandante general de la parte francesa: 168 , 374.

Aristizábal, Gabriel de; jefe de la escuadra española en las Antillas: 390, 391, 404.

Arroyo Naranjo, paraje de: 85,86 .
Arroyo Seco, paraje de: 347, 355, 389.

Artibonito, río: 22, 280, 390 .

Artois, Regimiento de: 383, 385.

Asia: 379.

Atalaya, barón de la: vid. Guzmán, José.

Atalaya, San Miguel de la: 8, 35, $39,42,45,62,244,245,299,331$, $364,367,389,394$.

Atlántico: 14.

Atrabesada (sic), Loma: 363.

Aullamas, las: 84 .

Austria: 153, 381, 388, 394.

Austria, M. ${ }^{a}$ Teresa de: 153 .

Azlor y Urríes, Manuel de; gobernador: $27,56,58-62,78,79,89,91$, $98,101,105,106,122-124,141$, $158-162,164,166,171,179,181$, $190,210,215,216,240,255,290$, $291,298,300-303,310,314,318$, $327,347,352,353,355,357-360$.

Azúa, Montes de: 104.

Azúa, villa de: $20,35,39,42,58$, $60,63,108,133,136,141,143$, 152-154, 268, 332, 364, 376, 408.

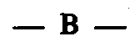

Bacín Caimán: 345.

Bahoruco, Sierra del: 21, 79.

Bajón, Arroyo: 363.

Bani o Vani, villa de: $13,35,39$, $42,133,136,141,331$.

Banica, villa de: $20,35,39,42,60$, $63,133,136,141,144,145,152$, $153,171,212,364,394,406$.

Barcelona: 176, 177, 180, 181, 183, 194, 195, 198. 
Barcelona, Compañía de comercio de: 123, 173, 176, 178, 179, 180, 189, 191, 192, 203, 210.

Barlovento, Islas de: 50, 163, 167, 182-185, 204, 211-213, 222.

Bartelemy, Caudillo negro: 391.

Basilea: 395, 396, 407.

Basilea, Tratado de: 1, 7, 28, 36, 46, 229, 321, 395, 399, 401, 408.

Bayaguaná, San Juan Bautista de: 35, 39, 41, 42, 62, 133, 144-146.

Bayajá: $25,29,47,320,341,391-$ 393, 404, 405.

Bayamo Largo: 111.

Bellecombe, gobernador francés: 81 .

Belzún, conde de. Comandante general de la parte francesa: 352 .

Bermuda, La: 212.

Bertrand, comisario francés: 160, 352, 353.

Biassou, caudillo de color: 391 .

Bobadilla, Juan de. Cura de Neiba: $82,84,85$.

Boca Nigua: 403.

Bonaparte: 407, 408.

Borgne, el: 390, 392.

Boyá, villa de: 35, 39, 42, 63, 134, 146.

Brasil: 95, 344, 372.

Bravo, Manuel; oidor: 309.

Buen Retiro, El: 78, 293.

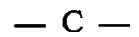

Cabrera, Joaquín; coronel: 389.

Cádiz: 105, 107-109, 114, 116, 120, 176, 180, 183, 194, 198-200, 304.

Caleta, fuerte de la: 374 .

Calvo, Miguel: 114, 115.

Cambita, hacienda: 101.

Campeche: 50, 184, 205.

Camú, río: 112.

Canarias: 28, 50, 52, 54, 56, 58, 60, 98, 188, 243, 284, 294, 295, 336.

Canca: 101, 108.

Cantabria, Regimiento de: 383

Caobas, San Gabriel de las: 8, 31, $33,35,39,42,45,60,161,212$, 216, 244, 299, 352, 364, 383, 394, 406.
Caracas: 50, 51, 123, 128, 167, 200, 203, 205, 206, 287, 288, 290, 291, 304, 311, 399.

Caracas, Compañía de comercio guipuzcoana o de: 176, 177 .

Carenero Grande: 58.

Caribe, islas del: 5, 182, 183, 191, 204, 212.

Caribe, mar del: 67, 203, 323.

Carlos III: 2, 6, 120, 175, 189, 298, $324,342,348,361,371$.

Carlos IV: 395.

Carlos VI de Austria: 53.

Caro de Oviedo, Ignacio: 121, 159, 349.

Cartagena: 183 .

Cartagena de Indias: 205.

Casabuena, Bartolomé de; juez de Indias de Canarias: 54.

Casal: 294.

Casas, Luís de las; gobernador de la Habana: 400.

Casiquiare, río: 304.

Cassasola, Luís de; teniente del Rey: 301, 302, 314.

Castilla: 14, 324, 335.

Castilla la Nueva: 336.

Castilla la Vieja: 336.

Castro y Mazo, Alfonso; gobernador de Santo Domingo: 57, 295.

Cataluña: 180, 181, 308, 336.

Cataluña, compañía de comercio de: 178, 190.

Cataluña, Regimiento de: 308.

Catani, Pedro; oidor decano: 36, 127, 136, 195, 212, 219, 315.

Caucino, hacienda de: 101.

Cerdeña: 381.

Chavanne, caudillo de color: 378, $379,381,382$.

Chávez y Mendoza, Luís; oidor decano: 81, 309.

China: 379.

Choiseul, vizconde de; brigadier francés: $365,366$.

Cibao, cordillera del: 22, 23.

Colombia: 207.

Colomo, José; gobernador de Santo Domingo: 6, 156, 291-293.

Colón, Cristóbal: 14. 
Combefort, comandante interino del Guarico: 380 .

Concepción de la Vega. Vid Vega.

Conquista, duque de la; virrey de México: 52.

Córdoba, Lorenzo de; ingeniero: 58, 275.

Cordón, río: 364 .

Coro: 205.

Coruña, La: 183, 194.

Cotui o Cotuy: 20, 35, 39, 41, 42, 59, 63, 108, 112, 133, 144, 145, 152, 153, 171, 408.

Cotuy. Vid. Cotui.

Cruz, Tomás de la; alcalde ordinario de Hincha: 156, 157, 295.

Cuba, isla de: $11,14,15,25,28,46$, 49, 99, 105, 106, 110, 113, 118, $128,183,190,192,205,207,203$, 231, 249, 251, 253, 287, 288, 321, 372, 395, 399, 400, 401.

Cumaná: 203, 205, 288.

Curaçao: 210.

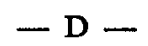

Dajabón, villa de: 35, 39, 41, 42, 45, 60-62, 160, 161, 212, 216, 299, 331, 345, 351, 352, 386, 391, 406.

Dajabón o Daxabón, río: 61, 363, 364, 367, 368, 389. Vid. Massacre.

Daniel, Lorenzo: 101.

Dantón: 377,

Dariel, El: 345.

Dátiles, Punta de los: 18.

Daxabón. Vid. Dajabón y Massacre.

Dondón, el: 100, 345, 380, 389.

Duarte, Pico: 21.

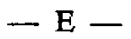

Emparán, Agustín de; oidor: 309.

Enghien, Regimiento de: 370.

España: 1, 2, 4, 7, 11, 12, 14, 25, 28, 93, 99, 102, 105, 106, 110, $115,117,120,122-124,138,140$, $153,159,161,165,168,173-175$, $178,180-186,188-193,195,196$,
198, 199, 201-204, 212, 240, 241, 246, 249, 251, 253, 234, 257, 301, $302,302,307,308,311,319,342$ $344,348,349,351-353,364,370-$ $373,375,381,388,390,394,395$, 397.

Española, La: 1, 2, 5, 7, 8, 11, 13, $14,18,23,27,36,47,48,50,52$, $67,76,78,82,87,95,97,130$, 142, i49, 178, 192, 193, 195, 196, 204, 209, 215, 225, 228, 240, 242, 284, 288-290, 292-294, 298, 304, $317-319,325,326,341-343,348$, $354,358,372,374,376,378,385$, 395, 396, 398-402, 404, 408.

Esparza, Raimundo de; tesorero: 221, 224.

Espinosa, Fernando de; capitán de la frontera: $60,355,362$.

Estados Unidos: 308, 320, 371, 372.

Estaing, conde de; gobernador general del Guarico: 354, 355, 373.

Esterlín, Nicolás: 101.

Europa: 93, 117, 118, 173, 246, 343345, 348, 379, 394.

Exido: 101, 108.

Extremadura: 336.

$$
-\mathrm{F}-
$$

Falkland, Islas; vid. Malvinas: 361. Felipe II: 324.

Fernández, Julián: 101.

Fernando VI: 2, 291, 324, 348, 349.

Ferronnays, vizconde de; gobernador interino de la colonia francesa: $362,363$.

Florida, La: 287, 288, 369.

Fontenelle, León de; comisionado del gobernador francés: 159, 349.

Francia: 7, 12, 38, 87, 91, 117, 130, $138,151,153,159,168,175,207$, 229, 304, 308, 341-344, 346, 349, $352,353,361,364,365,371-373$, 375, 378-381, 395, 396, 398, 405.

Frisia, Regimiento de: 298.

Fromesta, Felipe de; comandante de la frontera: 80. 


\section{$-\mathrm{G}-$}

Galicia, Regimiento de: 176, 308, 336.

Gálvez, Bernardo de: 375.

Gálvez, José de: 75.

Gamboa, Francisco de; regente: 309.

Gapy, Sr.: 371.

Garagey, río: 346, 363.

Garaguey. Vid. Garagey.

García, José Gabriel: 293.

García Moreno, Joaquín; gobernador: $6,21,84-87,93,170,155$, 203, 217-219, 309-312, 314-3? 1, 378, 381, 389-392, 403, 405, 406.

Gascúe, Francisco de; contador: 221, 224.

Gelabert, Francisco; contador del tribunal de cuentas: 163 .

Génova: 294.

Gijón: 183.

Godoy: 394.

Gómez Buelta, José; oidor: 296, $300,301$.

González, Manuel; gobernador: 82$85,87,169,170,216,217,222$, 291, 311-313, 315, 318, 319.

Granada: 308.

Gran Bretaña: 349, 371.

Grand Bois: 394.

Grande Riviére: 382.

Gros-Norme: 390.

Guaira, La: 167, 205.

Guanábano, golfo de: 57, 58.

Guaranas, valle de las: 371 .

Guarico: 5, 160, 161, 354, 356, 359, $367,373-375,380,381,383,385$, $390,392,393,396,402-404,407$, 408.

Guayabal: 108.

Guayana, La: 288.

Guayana Francesa: 344.

Guazimal: 108.

Guerra, Domingo de la; Juez de Indias de Canarias: 50.

Gurabo: 101, 108, 110.

Guridi, Nicolás: 101.

Guzmán, José; teniente coronel de milicias y barón de la Atalaya: 62, 169.
$-\mathbf{H}-$

Habana o Havana, La: 50, 105, 106, $109,123,129,180,187,225,228$, $229,240,318,321,372,400,401$, 404, 405.

Haina, Curato del: $35,39-42,133$, 135.

Haina o Hayna, río: 22, 59, 60 , 299, 305, 374, 408.

Haití o Haity: $14,29,45,86,227$, 378, 408.

Hato Mayor: 108.

Havana, La. Vid. Habana.

Hayna, río. Vid. Haina.

Heredia, Andrés de; comandante de la frontera: $347,386$.

Higuey, villa de: $35,39,41,42,62$, 133, 144, 145, 146.

Hincha, villa de: $20,23,35,39,40$ $42,63,132,133,135,143-145$, $152-154,157,171,212,295,296$, $305,332,347,354,364,374,376$, 382.

Holanda: 209, 342.

Honduras, Compañía de comercio: 176, 349.

Howe, general inglés: 372 .

$$
\text { - I - }
$$

India, La: 379.

Indias o Yndias, Las: $176,177,186$, 344, 373.

Ingenios, los: $35,39-42,132,133$, 135.

Inglaterra: 106, 139, 159, 209, 304, $309,321,343,344,348,349,352$, $361,366,371,372,384,388,394$, 398.

Iranda, marqués de: 403.

Isabel la Católica: 14.

Isabela, la: 14.

Italia: 294.

$$
-\mathbf{J}-
$$

Jacagua: 101, 108, 110.

Jacinto, caudillo de color: 387 .

Jacmel: 390. 
Jamaica: 14, 212, 375, 390.

Jatiel, loma de: 364.

Jeremíe: 390.

Jover, Ramón; oidor: 309.

Juan Francisco, caudillo de color: 387, 391-393.

Juana Gives: 390.

Juana Méndez: 385, 389.

\section{$-\mathbf{L}-$}

Laveaux, Esteban; gobernador general del Guarico: 402, 403, 405.

Lecanda. Andrés de: guardalmacen: 107.

Lemos, Conde de; presidente del Consejo. Vid. López de Castro, Pedro: 48.

León, Martín de: 268.

Leoz y Echalas, Gaspar de; teniente coronel de la frontera: 61.

Liaño, Francisco: 304.

Licey: 101, 108, 110, 112.

Limbé: 390.

Limonal: 108, 110

Lisle, Benito; comandante de artillería: 300.

López de Castro, Baltasar: 48.

López de Castro, Pedro. Vid. Conde de Lemos.

López Osorio, Pedro; sargento mayor: 293.

Luís XVI: 344.

Luís, caudillo de color: 391.

Luisiana: 167.

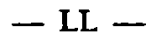

Llanos, Los: 35, 39, 42, 132, 133, $135,146$.

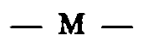

Madrid: 12, 13, 48, 52, 297, 298, 317, 353.

Madrid, Archivo Histórico Nacional: 3.

Madrid, Compañía de los 5 gremios: 176.
Maguana, San Juan de la: 29, 35, 39, 41, 42, 47, 56, 58, 133, 141, 144, 145, 171, 331, 344, 381, 406.

Maguana, valle de San Juan de la: 20, 58, 63, 133, 135, 143, 295.

Málaga: 183, 194, 198.

Malvinas, Islas: Vid. Falkland: 361, 371.

Mallorca: 188, 336.

Maniel, montes del: 79-82, 85, 87.

Manisel, caudillo de color: 398 .

Manzanillo, bahía de: 57, 396.

Maracaibo: 50, 51, 205, 288, 321.

Marat: 377.

Margarita, La: 119, 176-178, 180; 183, 190, 205, 207, 209, 249, 251, 253, 288.

Marmelade: 389.

Massacre, río: 368; vid. Dajabón, río.

Mauleón, Fernando de; tesorero: 222, 223.

México: 52, 56, 95, 106, 112, 115, $207,225,226,228,229,235,236$, $238,240,241,244,245,284,285$. $296,338,379$.

Méndez, Juan Antonio: 101.

Menorca: 188.

Mexía, Silvestre: 268.

Mirebalais o Mirabelé: 345, 394.

Moca: 108.

Moisés, caudillo de color: 408.

Mona, Canal de la: 14.

Monte, Juan: 101.

Montecristi, San Fernando de: 8, 25, $29,35,39,41,42,45,47,56,57$, $133,135,186-188,192,196,205$, 216-218, 221, 244, 274, 294, 298, 305, 332, 341, 374, 380, 407.

Montemar, duque de: 294.

Monteplata: 35, 39, 42, 62, 133, 134, 144,145

Motte, sierra de la: 22.

Moya Pons, Frank: 32, 33.

Mulito, río: 345.

Murcia: 336.

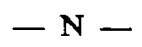

Navarra: 294, 336.

Navarra, regimiento de: 308 
Negro, río: 304.

Neiba, villa de: 35, 39, 41, 42, 60, 79-85, 133, 161, 216, 299, 352, 364.

Neiba, río: 364.

Neiba, Neiva o Neyva; valle de: 20, 133, 135, 143-145, 398.

Neiva, valle de; Vid. Neiba.

Neyva, valle de; vid. Neiba.

Nigua, río: 22.

Nimega, paz de: 342.

Nissao, río; Vid. Nizao.

Niza: 308.

Nizao o Nissao, río: 22, 98, 163.

Nolivos, conde de; gobernador de la parte francesa: $164,358,359,362$, 363.

Normandía, regimiento de: 383 .

Norte América: 110, 344, 371.

Nueva España: 14, 186, 226, 228, 230, 240, 243, 284, 400.

Nueva Granada: 287.

Nueva York: 212.

Núñez, Lorenzo; ingeniero: 81.

$$
-\mathbf{O}-
$$

Ocoa, bahía de: 18 .

Ocoa, río: 22.

Ogé, Vicente; caudillo de color: 378380, 382.

Omán: 294.

Orinoco, río: 304.

Oyarzábal, Juan Bautista de: 120, 121, 187, 403.

Ozama, Curato del: 35, 42.

Ozama, río: 22, 77, 98, 146.

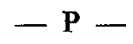

Países Bajos: 93.

Palo del Indio: 364.

Panamá: 236.

Papayo: 108.

Pardo, El: 312.

París: 365, 380, 391, 407.

Paz, Príncipe de la: 400.

Pedernales, río: 364, 367, 368.

Peguero, Luíis Joseph: 3, 13, 17.

Pelona, pico de la: 21.

Pensacola: 376.
Pepín González, Francisco; tesorero: 161.

Peralta y Rojas, Isidro; gobernador: 20, 70, 76, 80, 81, 94, 115, 121, 168, 169, 187, 194, 291, 307-312, $315,318,329,370,371,373,375$, 376.

Pérez y Pérez, Carlos Federico: 33.

Perú: 379.

Petit Riviére, La: 390, 393.

Petit Tomás; caudillo de color: 391, 392.

Pichardo, Francisco: 101.

Pimentel, Luisa: 268.

Pineau, caudillo de color: 398.

Pío, Príncipe: 294.

Plaisence: 390.

Port a Piment: 390.

Port Egmont: 361 .

Portillo, fray Fernando; arzobispo: 84,85

Port Margot: 390, 392, 393.

Portugal: 308, 318, 342, 352.

Prieta, Sierra: 364.

Prusia: 381, 388, 394.

Puerto Cabello: 129.

Puerto Plata, San Felipe de: 8, 25, 29, 35, 39, 41-43, 45, 47, 56, 57, 59, 133, 295, 305, 332, 341, 374, 376.

Puerto Príncipe: 151, 306, 383, 385, 394.

Puerto Rico: 14, 28, 51, 58, 119, $128,176-178,180,183,190,203-$ 207, 229, 236, 249, 251, 253, 288, 290, 292, 318, 320, 383, 392, 399, 401.

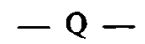

Quinigua: 108.

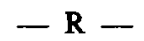

Rabí, Sr.: 347.

Reina, Francisco: 101.

Reino Unido: 371, 397.

República Dominicana: 9.

República Dominicana. Archivo General de la Nación: 2, 3. 
Río de la Plata: 28.

Rodríguez, fray Isidoro; arzobispo: 82-84.

Rodríguez Demorizi, Emilio: 30, 32.

Rohan, Príncipe de; gobernador francés: $162,356$.

Rosas: 294.

Roume, Sr. Comisario francés: 402.

Rubio y Peñaranda, Francisco; gobernador: $6,18,19,57,58,78$, $91,105,146,157,158,291,293-$ 298, 338.

Ryswick, tratado de: 342, 343.

$$
\text { - S - }
$$

Sabana Grande: 108, 110.

Sabana de la Mar: 8, 35, 39, 41, 42, $56,58,59,134,135,374$.

Sacramento, colonia de: 344 .

Saint Domingue: 2, 91, 378-380, 383, 393, 406.

Saint-Mery, M. L., Moreau de: 3, $12,15,22,32,33,63,72,73,98$, $99,102,190$.

Samaná, bahía de: 58, 295, 298.

Samaná, Santa Bárbara de: 35, 39, $41,42,56,58,59,132,295,298$, $305,374$.

San Carlos, villa de: $35,39,41,42$, $56,132,134,332$.

Sánchez Valverde, Antonio: 3, 13, 14, 15, 136, 141.

San Cristóbal, isla de: 29, 341 .

San Eustasio, isla de: 212.

San Felipe de Puerto Plata. Vid. Puerto Plata.

San Fernando de Montecristi. Vid. Montecristi.

San Francisco, convento de: 292.

San Gabriel de las Caobas. Vid. Caobas, las.

San Ildefonso: 397.

San Isidoro de Cambita, hacienda: 108.

San Jerónimo, fuerte de: 374, 408.

San Juan de la Maguana. Vid. Maguana.

San Juan de Puerto Rico: 129, 188.

San Lorenzo de los Minas: 35, 39, $42,77,78,96,132,134$.
San Miguel de la Atalaya. Vid. Atalaya.

San Nicolás, Môle de: 390.

San Rafael de la Angostura. Vid. Angostura.

Santa Bárbara, fuerte de: 296.

Santa Bárbara, parroquia de: 39, 40.

Santa Fé: 288.

Santa Marta: 205.

Santander: 183.

San Telmo, seminario de: 183.

Santhonax, presidente de la comisión de la República Francesa en el Guarico: 404.

Santiago, Pedro J.: 32, 33.

Santiago de los Caballeros: 20, 34, $35,39-43,62,63,101-104,108$, $110,115,132,133,143-145,152$, $153,171,216,218,239,275,304$, $331,332,376,401,408$.

Santiago de Cuba: 111, 129.

Santiago de Govea: 111.

Santo Domingo, ciudad de: 5, 33, $35,39-42,44,47,48,50,52,62$, $66,83,98,101,126,129,136$, $137,142,143,145-150,156,159$, $188,198,205,210,290,294,296$, $299,301,302,305,303,314,325$, $332,359,374,382,383,390,398$, $405,408$.

Santo Domingo, isla de: $1,2,4-8$, $11-14,16,19,21,22,25,27-34$, $36,37,42,44,45,47,49-52,54-$ $57,59,63,64,66-70,72,75-78$, $82,89-93,95-100,102-104,106-$ $125,127,128,130-133,140,141$, $143,151-153,157,161,163,165$, $167-171,175-178,180,181,183$ 193, 195, 196, 199, 201-204, 206, $208,210-215,221,222,224-232$, $234-237,240-247,249,251,253-$ $257,260,262-264,266-268,270$, $275,278,281-284,287-293,298$, $301,302,304,307-309,312,313$, $315, \quad 317-319,321-324,376-3\urcorner 8$, $330,333-336,338,341-346,349$, $351-358,362,365,367-369,372-$ $378,380,381,383-385,387,388$, $395,396,398-401,404,407$. 
Seibo, villa del: $35,39,41,42,62$, 133, 144-146, 332, 376.

Selle, sierra de la: 22.

Sevilla, Archivo General de Indias: 2.

Sevilla, Compañía de Comercio San Fernando: 176.

Sevilla, Reales Fábricas de Tabaco: $105,108,110,111,113,116,201$, 241, 242.

Sevilla, Universidad de: 1, 9.

Siguapo, loma: 363.

Simancas, Archivo General de: 2, 3.

Solano y Bote, José; gobernador: $110,111,113,124,165-167,171$, $211,290,291,302-304,306-308$, $311,318,361-367,369,370$.

Solórzano Pereira, Juan de: 69.

Sucia, loma: 364.

Sunyer y Basteros, José; gobernador interino: 57, 225, 292, 294, 345. Sur, Mar del: 379.

$$
-\mathbf{T}-
$$

Tarifa: 290,308

Toledo, regimiento de: 318 .

Tortuga, isla de la: 29, 49 .

Toussaint L'Ouverture. Caudillo de color: 321, 389-394, 399, 400, 405 408.

Trinidad, isla de: $119,183,288,401$.

$$
-\mathbf{U}-
$$

Urízar, José Antonio de; regente: 316, 320, 379, 390, 392.

Utrecht, Paz de: 344.

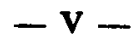

Valencia: 336.

Valencia del Po: 294.
Valliére, Sr. de la; gobernador francés: 363.

Valtiére, Sr.; comisario del príncipe de Rohan: 300, 356, 360.

Vani. Vid. Bani.

Vega, Concepción de la: 20, 34, 35, $39-41,43,63,104,108,112,133$, $144,145,152,153,171,304,332$, 376,408 .

Vega, José de la: 121.

Vega Real, La: 22, 42-44, 47, 99 , $102,108,110,112,132$.

Venezuela: $95,100,186,205,207$, 287, 288, 304.

Veracruz: 205.

Veretes, Los: 390, 393.

Vicent, Sr.; coronel de infantería francés: 359.

Victoria, marqués de la: 304 .

Viento, Canal del: 14.

Villard, Sr.: 347, 355.

Villegas, río: 22.

Virginia: 101,110

Vizcaya: 336.

$$
-\mathrm{Y}-
$$

Yaguana, La: 25, 29, 47, 341.

Yaguesi, fuerte de: 392.

Yane, río. Vid. Yaque, río.

Yaque Pico: 21.

Yaque o Yane, río: 22.

Yaque del Norte, río: 22.

Yaque del Sur, río: 22.

Yndias, las; vid. Indias.

Yucatán: 184.

Yuma o Yuna, río: 112, 304.

Yuna, río; vid. Yuma.

$$
-\mathbf{z}-
$$

Zorrilla de San Martín, Pedro; gobernador: $27,55,132,137,143$, $146,148,152,153,155,156,158$. $160,292,347$. 